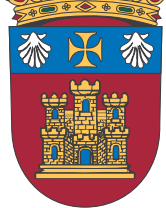

UNIVERSIDAD DE BURGOS

Facultad de Derecho

Departamento de Derecho Público

\title{
TESIS DOCTORAL \\ Las prohibiciones de contratar en el Derecho de la Unión Europea
}

MEMORIA PARA OPTAR AL GRADO DE DOCTOR PRESENTADA POR

Teresa Medina Arnáiz

DIRECTOR

José Manuel Sala Arquer

Burgos, 2015 

El Dr. D. José Manuel Sala Arquer, Catedrático de Derecho Administrativo de la Universidad Rey Juan Carlos,

\section{HACE CONSTAR:}

Que la presente memoria, titulada LAS PROHIBICIONES DE CONTRATAR EN EL DERECHO DE LA UNIÓN EURO$P E A$ ha sido realizada bajo su supervisión por D. ${ }^{a}$ Teresa Medina Arnáiz y constituye la Tesis Doctoral de la interesada para optar al grado de Doctor por la Universidad de Burgos.

Y para que conste, en cumplimiento de la legislación vigente, presenta ante la Escuela de Doctorado de la Universidad de Burgos la referida Tesis, firmando el presente documento.

En Madrid, a 26 de octubre de 2015

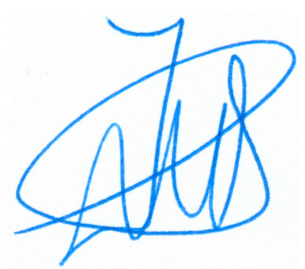

José Manuel Sala Arquer 



\section{Índice general}

$\begin{array}{ll}\text { RESUMEN / ABSTRACT } & 27\end{array}$

$\begin{array}{ll}\text { ABREVIATURAS Y SIGLAS } & 29\end{array}$

INTRODUCCIÓN / INTRODUCTION 33

Capítulo primero

MARCO CONCEPTUAL, CONFIGURACIÓN Y FUNDAMENTOS JURÍDICOS DE LAS PROHIBICIONES DE CONTRATAR 49

I. Planteamiento . . . . . . . . . . . . . . . . . . 49

II. Precisiones conceptuales . . . . . . . . . . . . . . . . 58

III. Aproximación a las prohibiciones de contratar . . . . . . . 67

III.1. Planteamiento del problema . . . . . . . . . . . . . 67

III.2. Las prohibiciones de contratar como parte de un modelo preventivo ................... 81

III.3. Las prohibiciones de contratar como técnica represiva . 88

A. La prohibición de contratar por incumplimiento de las obligaciones por parte del contratista . . . . . 93

B. La prohibición de contratar como sanción administrativa . . . . . . . . . . . . 100

C. La prohibición de contratar como pena aplicable a la comisión de determinados tipos delictivos . . . . . 108

C.1. Concepto y fines de la pena . . . . . . . . . 110

C.2. Responsabilidad penal de las personas jurídicas 112

C.3. Delitos imputables a las personas jurídicas . . . 114

C.4. Clases de penas. Especial referencia a las penas privativas de derechos . . . . . . . . . 121

IV. A modo de conclusión provisional . . . . . . . . . . . . . . 130 
V. Los fundamentos de las prohibiciones de contratar . . . . . . 132

V.1. Su relación con los objetivos de la normativa contractual 135

V.2. La integridad en la contratación pública a través de las prohibiciones de contratar . . . . . . . . . . . . 139

A. Medidas generales de lucha contra la corrupción . . 141

B. La garantía de imparcialidad: Especial referencia a los conflictos de intereses y a la participación previa de candidatos o licitadores . . . . . . . . . . . . . . 144

B.1. Los conflictos de intereses . . . . . . . . . 148

B.1.1. La noción de «conflicto de intereses» . . 149

B.1.2. Identificación de las circunstancias en las que pueden surgir conflictos de intereses 151

B.1.3. La prohibición de contratar motivada por un conflicto de intereses . . . . . . . 154

B.2. La participación previa del operador económico en la preparación de un procedimiento de adjudicación . . . . . . . . . . . . . 155

C. Cumplimiento de los deberes propios de una buena reputación profesional . . . . . . . . . . 158

C.1. Los comportamientos que afectan a la credibilidad profesional del operador económico . . . . 159

C.2. Precisiones conceptuales respecto de la «moralidad profesional» . . . . . . . . . . . . 162

C.3. Listas blancas de operadores económicos "íntegros" . . . . . . . . . . . . . 167

V.3. Las prohibiciones de contratar como instrumentos al servicio de «objetivos secundarios» en la contratación pública ....................... 170

\section{Capítulo segundo}

ANÁLISIS DE LAS PROHIBICIONES DE CONTRATAR DESDE EL DERECHO DE LA UNIÓN EUROPEA (1957-

I. La regulación europea de la contratación pública . . . . . . . 177

II. La contratación pública a la luz del Tratado constitutivo de la Comunidad Económica Europea . . . . . . . . . . . . . . . 186 
II.1. La ausencia de preceptos referidos a la contratación pública ...................... 186

II.2. Alcance de las libertades fundamentales garantizadas por el Tratado CEE en el ámbito de la contratación pública

II.3. La aplicación de los principios generales del Derecho de la Unión . . . . . . . . . . . . . . . . . . . . . . . . . . 192

A. El principio de igualdad de trato . . . . . . . . 194

B. El principio de proporcionalidad . . . . . . . . . 198

C. El principio de concurrencia . . . . . . . . . . 200

D. El principio de seguridad jurídica . . . . . . . . 203

III. La evolución de la normativa de la Unión Europea sobre contratación pública: De la primera a la cuarta generación de Directivas

III.1. Las primeras Directivas sobre contratación pública . . 207

A. Las Directivas de liberalización . . . . . . . . . 211

B. Las Directivas de coordinación . . . . . . . . . . 213

III.2. La segunda etapa de la normativa sobre contratación pública . . . . . . . . . . . . .

A. El mandato del Libro Blanco para la realización del Mercado interior (1985) . . . . . . . . . . .

A.1. Medidas destinadas a mejorar las Directivas entonces vigentes . . . . . . . . . . . . .

A.2. Procedimientos de recurso en materia de adjudicación de los contratos públicos de obras y de suministro . . . . . . . . . . . .

A.3. Extensión del régimen contractual público a los sectores del agua, la energía, los transportes y las telecomunicaciones . . . . . . . . . . . 230

A.4. Medidas para incluir en la regulación de la contratación pública los contratos de servicios . . .

B. La consolidación del régimen sustantivo de la contratación pública (1992-1993) . . . . . . . . . 236

III.3. Las Directivas 2004/17/CE y 2004/18/CE . . . . . . . 247

A. Los objetivos de la reforma de 2004 . . . . . . . 253

B. Su proceso de elaboración . . . . . . . . . 256

B.1. Dictamen del Comité Económico y Social . . . 259 
B.2. Dictamen del Comité de las Regiones . . . . . 261

B.3. Dictamen del Parlamento Europeo - Primera lectura ................ . . 263

B.4. Propuesta modificada de la Directiva . . . . . 268

B.5. Posición Común del Consejo . . . . . . . . . 270

B.6. Dictamen del Parlamento Europeo - Segunda lectura . . . . . . . . . . . . . 274

C. La aprobación de las Directivas 2004/17/CE y 2004/18/CE . . . . . . . . . . . 276

D. Las principales novedades de las Directivas 2004/17/CE y 2004/18/CE que afectan a la regulación de las prohibiciones de contratar . . . . . . . . . . 282

D.1. Prohibiciones de carácter obligatorio . . . . 285

D.2. Prohibiciones de carácter facultativo . . . . 287

IV. El marco jurídico actual: Las Directivas de «cuarta generación» 292

IV.1. El proceso de elaboración y los objetivos de la reforma 295

A. La utilización estratégica de la contratación pública 298

B. La simplificación de la carga burocrática del operador económico . . . . . . . . . . . . . . . 299

C. La integridad de los procedimientos . . . . . . . 301

IV.2. Las principales novedades respecto de las prohibiciones de contratar . . . . . . . . . . . . . 301

A. Nuevas prohibiciones de contratar obligatorias . . . 302

B. Las prohibiciones de contratar facultativas . . . . . 304

B.1. Primera temática. Prohibiciones de contratar por falta de credibilidad profesional . . . . . . 305

B.2. Segunda temática. Prohibiciones de contratar por la existencia de un conflicto de intereses . . . . 306

B.3. Tercera temática. Prohibiciones de contratar por la quiebra de la veracidad documental . . . . . 307

B.4. Cuarta temática. Prohibiciones de contratar por motivos económicos . . . . . . . . . . 308 


\section{Capítulo tercero}

\section{LAS PROHIBICIONES DE CARÁCTER OBLIGATORIO PARA LOS ESTADOS MIEMBROS: SITUACIÓN ACTUAL Y PROPUESTAS DE LEGE FERENDA}

I. Introducción . . . . . . . . . . . . . . . . 311

II. La corrupción en la contratación pública . . . . . . . . . . . . 312

III. La política de la Unión Europea contra la corrupción y otras formas graves de delincuencia . . . . . . . . . . . . . . . . 329

IV. La identificación de los delitos que habilitan una prohibición de contratar de carácter obligatorio . . . . . . . . . . . . . . 337

IV.1. Consideraciones preliminares sobre el Derecho penal sustantivo en la Unión Europea y su importancia en la delimitación de las prohibiciones de contratar obligatorias

IV.2. Delitos relativos a la participación en una organización delictiva . . . . . . . . . . . . . . 351

IV.3. Corrupción . . . . . . . . . . . . . . . . . . . 358

IV.4. Fraude . . . . . . . . . . . . . . . . . . 378

IV.5. Blanqueo de capitales o financiación del terrorismo . . 393

IV.6. Delitos de terrorismo o ligados a actividades terroristas 398

IV.7. Trabajo infantil y otras formas de trata de seres humanos 410

V. $\quad$ El impago de impuestos y cotizaciones a la seguridad social . 416

VI. La regulación de las prohibiciones de carácter obligatorio en los Estados miembros . . . . . . . . . . . . . . . . . 418

VII. La consideración de aspectos sociales y medioambientales entre las prohibiciones de contratar. Algunas propuestas de lege ferenda 446 VII.1. Cuestiones previas . . . . . . . . . . . . . . 446

VII.2. Las prohibiciones de contratar por incumplimiento de las obligaciones en materia medioambiental, social o laboral en las nuevas Directivas . . . . . . . . . . . . .

VII.3. Nuestra propuesta de lege ferenda: dotar de un carácter obligatorio a estas prohibiciones de contratar . . . . .

\section{Capítulo cuarto}

LA DELIMITACIÓN EN LA APLICACIÓN DE LAS PROHIBICIONES DE CONTRATAR

I. Planteamiento de la cuestión 
II. El elemento subjetivo en las prohibiciones de contratar . . . . 462

II.1. Los poderes adjudicadores . . . . . . . . . . . . . . . . 467

II.2. Las entidades adjudicadoras . . . . . . . . . . . . . . 468

II.3. El concepto de «operador económico» . . . . . . . . . . . 471

II.4. El subcontratista . . . . . . . . . . . . . . . . . . 473

III. El elemento objetivo de las prohibiciones de contratar . . . . . 475

III.1. Los contratos públicos y los negocios y contratos excluidos de la aplicación de las Directivas . . . . . . . . . 476

III.2. Los umbrales económicos en la contratación . . . . . . 478

IV. La delimitación temporal de las prohibiciones de contratar . . 480

IV.1. La apreciación de las prohibiciones de contratar . . . . 480

IV.2. El momento a partir del cual la prohibición de contratar despliega efectos jurídicos . . . . . . . . . . . 482

A. Primer escenario. La sentencia o resolución administrativa sancionadora contiene un pronunciamiento expreso sobre la prohibición de contratar . . . . . .

B. Segundo escenario. La sentencia o resolución administrativa guarda silencio respecto de la prohibición de contratar ............... . .

IV.3. La prescripción de la acción para la imposición de la prohibición de contratar . . . . . . . . . . . . . 491

IV.4. La duración de las prohibiciones de contratar . . . . . 492

IV.5. Las prohibiciones sobrevenidas: su incidencia en el contrato . . . . . . . . . . . . . . . 493

V. La delimitación espacial de las prohibiciones de contratar . . . 494

V.1. La petición de exclusión realizada desde otro Estado miembro . . . . . . . . . . . . . . . 496

V.2. El reconocimiento de resoluciones judiciales en materia penal . . . . . . . . . . . . . . . . 496

VI. El intercambio de información acerca de las prohibiciones de contratar . . . . . . . . . . . . . . . . 499

VI.1. El Sistema de Información del Mercado Interior (IMI) . 500

VI.2. El depósito de certificados en línea (e-Certis) . . . . . . 501

VI.3. La base de datos central de exclusión y los sistemas de alerta .................... 502 
VII. La simplificación en los medios de prueba de no estar incurso en una prohibición de contratar . . . . . . . . . . 505

VII.1. Las previsiones sobre simplificación administrativa y la apuesta por reducir la carga burocrática en las nuevas Directivas . . . . . . . . . . . . . 507

VII.2. El documento europeo único de contratación . . . . . 508

A. Su configuración . . . . . . . . . . . 508

B. Su contenido . . . . . . . . . . . . 509

VIII. Los supuestos de inaplicación de una prohibición de contratar 511

VIII.1.La excepción derivada de la existencia de razones imperiosas de interés general . . . . . . . . . . . . . 513

VIII.2.Las excepciones por motivos económicos . . . . . . . . 523

A. Una «segunda oportunidad» para los empresarios en situación de quiebra y/o insolvencia . . . . . . . . . 524

B. Compras de suministros en condiciones especialmente ventajosas para el órgano de contratación . . . . 525

VIII.3. Excepciones que superan el juicio de proporcionalidad .

VIII.4.El levantamiento de la prohibición con motivo de la regularización tributaria del operador económico "incumplidor" . . . . . . . . . . . . . .

VIII.5.La excepción a la aplicación de las prohibiciones de contratar a través de las medidas de «self-cleaning» . . . .

A. Las medidas de self-cleaning son «viejas conocidas» de la legislación contractual . . . . . . . . . .

B. Las acciones del operador económico que posibilitan su "rehabilitación" en la participación en un procedimiento de adjudicación . . . . . . . . . . . . . . 544

B.1. Indemnización por los daños causados . . . . . 545

B.2. Colaboración con el esclarecimiento de los hechos 546

B.3. Adopción de medidas técnicas, organizativas y de personal . . . . . . . . . . . . 547

C. El ámbito de aplicación de las medidas de self-cleaning 551

D. Un posible procedimiento de "rehabilitación" . . . . 557

D.1. Inicio del procedimiento . . . . . . . . . . 560

D.2. La documentación a aportar por parte del operador económico . . . . . . . . . . . . . . 562 
D.3. La valoración de las pruebas aportadas . . . . . 563

D.4. El órgano que entendemos competente para valorar las pruebas y resolver el procedimiento . . 564

D.5. Los efectos de la resolución . . . . . . . . . . 573

E. El derecho del operador económico a que se examinen sus medidas de cumplimiento . . . . . . . . . 574

\section{ANEXO DOCUMENTAL}

\section{A Normativa contractual europea}

Directiva 71/305/CEE del Consejo, de 26 de julio de 1971, sobre coordinación de los procedimientos de adjudicación de los contratos públicos de obras (DOCE L 185, de 16 de agosto de 1971) . .

Directiva 77/62/CEE del Consejo, de 21 de diciembre de 1976, de coordinación de los procedimientos de adjudicación de contratos públicos de suministro (DOCE L 13, de 15 de enero de 1977)

Decisión 3/90 del Consejo de Ministros ACP-CEE, de 29 de marzo de 1990, por la que se aprueban las disposiciones generales, las condiciones generales y las normas de procedimiento para la conciliación y el arbitraje, relativos a los contratos de obras, de suministros y de servicios financiados por el Fondo Europeo de Desarrollo (FED), y sobre su aplicación (DOCE L 382, de 31 de diciembre)

Directiva 90/531/CEE del Consejo, de 17 de septiembre de 1990, relativa a los procedimientos de formalización de contratos en los sectores del agua, de la energía, de los transportes y de las telecomunicaciones (DOCE L 297, de 29 de octubre de 1990) 
Decisión 92/97/CEE del Consejo, de 16 de diciembre de 1991, por la que se aprueban las disposiciones generales, las condiciones generales y las normas de procedimiento para la conciliación y el arbitraje, relativos a los contratos de obras, de suministros y de servicios financiados por el Fondo Europeo de Desarrollo (FED), y sobre su aplicación en el marco de la asociación de los países y territorios de ultramar a la Comunidad Económica Europea (DOCE L 40, de 15 de febrero de 1992) . . . . . . .

Directiva 92/50/CEE del Consejo, de 18 de junio de 1992, sobre coordinación de los procedimientos de adjudicación de los contratos públicos de servicios (DOCE L 209, de 24 de julio de 1992) .

Directiva 93/36/CEE del Consejo, de 14 de junio de 1993, sobre coordinación de los procedimientos de adjudicación de contratos públicos de suministro (DOCE L 199, de 9 de agosto de 1993)

Directiva 93/37/CEE del Consejo, de 14 de junio de 1993, sobre coordinación de los procedimientos de adjudicación de los contratos públicos de obras (DOCE L 199, de 9 de agosto de 1993) . .

Directiva 93/38/CEE del Consejo, de 14 de junio de 1993, sobre coordinación de los procedimientos de adjudicación de contratos en los sectores del agua, de la energía, de los transportes y de las telecomunicaciones (DOCE L 199, de 9 de agosto de 1993) .

Reglamento (CE, Euratom) 1605/2002 por el que se aprueba el Reglamento financiero aplicable al presupuesto general de las Comunidades Europeas (DOCE L 248 de 16 de septiembre de 2002)

Decisión 2/2002 del Consejo de Ministros ACP-CE de 7 de octubre de 2002 relativa a la aplicación de los artículos 28, 29 y 30 del anexo IV del Acuerdo de Cotonú (DOUE L 320, de 23 de noviembre de 2002) . . . . . . . . . . . . .

Reglamento (CE, Euratom) 2342/2002 de la Comisión, de 23 de diciembre de 2002, sobre normas de desarrollo del Reglamento (CE, EURATOM) 1605/2002 del Consejo, por el que se aprueba el Reglamento financiero aplicable al presupuesto general de las Comunidades Europeas (DOUE L 357, de 31 de diciembre

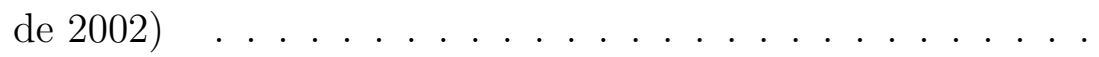


Directiva 2004/17/CE, de 31 de marzo, sobre la coordinación de los procedimientos de adjudicación de contratos en los sectores del agua, la energía, los transportes y los servicios postales (DOUE L 134, de 30 de abril de 2004) . . . . . . . . . . .

Directiva 2004/18/CE, de 31 de marzo, sobre coordinación de los procedimientos de adjudicación de los contratos públicos de obras, de suministro y de servicios (DOUE L 134, de 30 de abril de

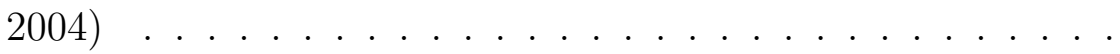

Decisión 2004/658/PESC, de 13 de septiembre, relativa a las disposiciones financieras aplicables al presupuesto general de la Agencia Europea de Defensa (DOUE L 300, de 29 de septiembre de 2004)

Reglamento (CE, EURATOM) 1995/2006 del Consejo de 13 de diciembre de 2006 que modifica el Reglamento (CE, Euratom) $1605 / 2002$ por el que se aprueba el Reglamento financiero aplicable al presupuesto general de las Comunidades Europeas

Decisión del Banco Central Europeo, de 3 de julio de 2007, Decisión BCE/2007/5, por la que se establece su Reglamento de adquisiciones (DOUE L 184, de 14 de julio) ${ }^{* *}$ modificada por la Decisión BCE/2009/2, de 27 de enero de 2009 (DOUE L 51, de 24 de febrero de 2009) . . . . . . . . . . . . . 680

Decisión 2007/643/PESC del Consejo, de 18 de septiembre de 2007, relativa al Reglamento Financiero de la Agencia Europea de Defensa y a las normas sobre contratación pública y sobre contribuciones financieras con cargo al presupuesto operacional de la Agencia Europea de Defensa (DOUE L 269, de 12 de octubre) 681

Reglamento (CE, EURATOM) 478/2007, de la Comisión, de 23 de abril de 2007 por el que se modifica el Reglamento (CE, Euratom) 2342/2002 sobre normas de desarrollo del Reglamento (CE, Euratom) 1605/2002 del Consejo por el que se aprueba el Reglamento financiero aplicable al presupuesto general de las Comunidades Europeas . . . . . . . . . . . . . .

Reglamento (CE) 215/2008 del Consejo, de 18 de febrero de 2008, por el que se aprueba el Reglamento financiero aplicable al décimo Fondo Europeo de Desarrollo (DOUE L 78, de 19 de marzo) 
Decisión de la Comisión 2008/969, de 16 de diciembre de 2008, relativa al sistema de alerta rápida para uso de los ordenadores de la Comisión y de las agencias ejecutivas (DOUE L 344, de 20

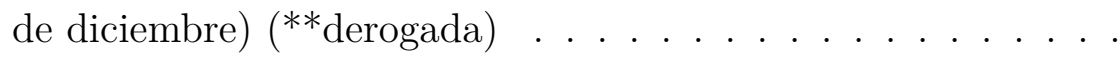

Reglamento (CE, Euratom) 1302/2008 de la Comisión, de 17 de diciembre de 2008, relativo a la base de datos central de exclusión (DOUE L 344, de 20 de diciembre) . . . . . . . . . . . .

Directiva 2009/52/CE del Parlamento Europeo y del Consejo, de 18 de junio de 2009, por la que se establecen normas mínimas sobre las sanciones y medidas aplicables a los empleadores de nacionales de terceros países en situación irregular (DOUE L, 168, de 30 de junio de 2009) . . . . . . . . . . . .

Directiva 2009/81/CE del Parlamento Europeo y del Consejo, de 13 de julio de 2009, sobre coordinación de los procedimientos de adjudicación de determinados contratos de obras, de suministro y de servicios por las entidades o poderes adjudicadores en los ámbitos de la defensa y la seguridad, y por la que se modifican las Directivas 2004/17/CE y 2004/18/CE (DOUE L 216, de 20 de agosto de 2009) . . . . . . . . . . . . . . . .

Decisión del Banco Central Europeo, de 27 de enero de 2009, Decisión BCE/2009/2 (DOUE L 51, de 24 de febrero de 2009) . . . .

Reglamento (UE, Euratom) 966/2012 del Parlamento Europeo y del Consejo, de 25 de octubre de 2012, sobre las normas financieras aplicables al presupuesto general de la Unión y por el que se deroga el Reglamento (CE, Euratom) 1605/2002 del Consejo (DOUE L 298, de 26 de octubre de 2012) . . . . . . . . . . .

Reglamento Delegado (UE) 1268/2012 de la Comisión, de 29 de octubre de 2012, sobre las normas de desarrollo del Reglamento (UE, Euratom) 966/2012 del Parlamento Europeo y del Consejo, sobre las normas financieras aplicables al presupuesto general de la Unión (DOUE L 362, de 31 de diciembre) . . . . . . . . .

Directiva 2014/23/UE del Parlamento Europeo y del Consejo, de 26 de febrero de 2014, relativa a la adjudicación de contratos de concesión (DOUE L 94, de 28 de marzo de 2014) . . . . . . . . 
Directiva 2014/24/UE del Parlamento Europeo y del Consejo, de 26 de febrero de 2014, sobre contratación pública y por la que se deroga la Directiva 2004/18/CE (DOUE L 94, de 28 de marzo de 2014) . . . . . . . . . . . . . . . . . . .

Directiva 2014/25/UE del Parlamento Europeo y del Consejo, de 26 de febrero de 2014 , relativa a la contratación por entidades que operan en los sectores del agua, la energía, los transportes y los servicios postales y por la que se deroga la Directiva 2004/17/CE (DOUE L 94, de 28 de marzo de 2014) . . . . .

Decisión de la Comisión, de 13 de noviembre de 2014, relativa al sistema de alerta rápida para uso de los ordenadores de la Comisión y de las agencias ejecutivas (DOUE L 329, de 14 de noviembre) 722

\section{B Normativa contractual española}

Real órden de 18 de marzo de 1846, por la que se aprueba el Pliego de condiciones generales para las contratas de obras públicas de caminos, canales y puertos . . . . . . . . . .

Real Decreto de 27 de febrero de 1852, estableciendo reglas para la celebración de toda clase de contratos sobre servicios públicos

Real Decreto de 10 de julio de 1861, aprobando el pliego de condiciones generales para las contratas de obras públicas . . . . . .

Real Decreto de 25 de diciembre de 1867 aprobando un pliego adjunto de condiciones generales para los contratos de obras públicas de las provincias de Ultramar (Gaceta de Madrid núm. 9, de 9 de enero de 1868) . . . . . . . . . . . . . . . . . .

Orden del Almirantazgo de 3 de mayo de 1869, aprobando las condiciones generales con arreglo á las que deberán celebrarse las subastas para la contratación de los diferentes servicios de la Marina (Gaceta de Madrid núm. 127, de 7 de mayo) . . . . .

Real Decreto de 4 de enero de 1883, disponiendo que los contratos que celebren las Diputaciones provinciales ó los Ayuntamientos para toda clase de servicios, obras, compras, ventas y arrendamiento, y en general todos aquellos que hayan de producir gastos ó ingresos en los fondos provinciales ó municipales se celebren por remate, previa subasta pública (Gaceta de Madrid núm. 5, de 5 de enero) . . . . . . . . . . . . . . 
Real Decreto de 11 de junio de 1886, aprobando el Pliego de condiciones generales para la contratación de las obras públicas (Gaceta de Madrid núm. 165, de 14 de junio) . . . . . . . . . . . . . 727

Real Orden de 26 de julio de 1888, prohibiendo á los militares representar á casas extranjeras y nacionales en contratos con el Estado (Colección Legislativa del Ejército, núm. 281) . . . .

Real Decreto de 14 de enero de 1892, aprobatorio de la Instrucción para la contrata de los servicios y obras dependientes de la Dirección general de Comunicaciones (Gaceta de Madrid núm. 15 , de 15 de enero) . . . . . . . . . . . . .

Instrucción de 26 de abril de 1900, para la contratación de los servicios provinciales y municipales (Gaceta de Madrid núm. 119, de 29

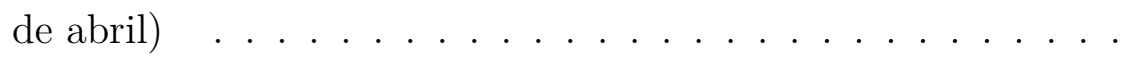

Proyecto de Ley para la contratación de obras y servicios públicos de 15 de noviembre de 1900 (Gaceta de Madrid núm. 331, de 27 de noviembre $\ldots \ldots \ldots \ldots \ldots \ldots$

Real Decreto de 7 de diciembre de 1900 aprobando el Pliego de condiciones generales para la contratación de obras públicas (Gaceta de Madrid núm. 346, de 12 de diciembre) . . . . . . . . . .

Real Decreto de 21 de diciembre de 1900, relativo á las concesiones de ferrocarriles y tranvías disponiendo que en lo sucesivo sólo podrán ser concesionarios de ferrocarriles y tranvías los ciudadanos españoles con domicilio permanente en España y las Sociedades y Compañías que se sujeten á los requisitos que se expresan (Gaceta de Madrid núm. 357, de 23 de diciembre de

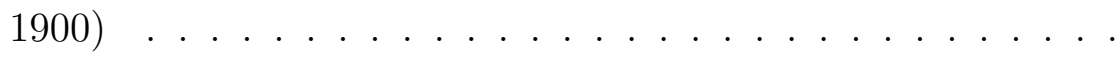

Real Decreto, de 13 de marzo de 1903, aprobatorio del adjunto pliego de condiciones generales para la contratación de obras públicas (Gaceta de Madrid núm. 77, de 18 de marzo) . . . . . . . . .

Real Orden Circular de 29 de diciembre de 1903 aclarando y ampliando la Real Orden de 26 de julio de 1888 prohibiendo á los militares representar á casas extranjeras y nacionales en contratos con el Estado (Colección Legislativa del Ejército, núm. 187) 
Instrucción para la contratación de los servicios provinciales y municipales aprobada por Real Decreto de 24 de enero de 1905 (Gaceta de Madrid núm. 26, de 26 de enero) . . . . . . . . . 732

Ley de 14 de febrero de 1907, de protección á la producción nacional (Gaceta de Madrid núm. 46, de 15 de febrero) . . . . . . . . 733

Real Decreto de 4 de septiembre de 1908, aprobatorio del adjunto pliego de condiciones generales para la contratación de las obras denominadas de Construcciones civiles, que corren á cargo del Ministerio de Instrucción pública y Bellas Artes (Gaceta de Madrid núm. 252, de 8 de septiembre) . . . . . . . . . . .

Real orden de 18 de octubre de 1909 aprobando el Pliego de condiciones generales y económicas al que han de ajustarse las subastas que se celebren para la instalación de colonias (Gaceta de Madrid núm. 298, de 25 de octubre) . . . . . . . . . . . .

Ley de la Hacienda Pública, de 1 de julio de 1911 (Gaceta de Madrid núm. 185, de 4 de julio) . . . . . . . . . . . . . . .

Real Decreto de 22 de diciembre de 1911, aprobando el Pliego general de condiciones para las obras de caminos vecinales (Gaceta de Madrid núm. 365, de 31 de diciembre de 1911) . . . . . . . .

Proyecto de nuevo Pliego de condiciones de contratación de obras y servicios públicos, de 4 de noviembre de 1913 (Gaceta de Madrid núm. 312, de 8 de noviembre) . . . . . . . . . .

Instrucción de 22 de mayo de 1923, para la contratación de los servicios provinciales y municipales, y de los correspondientes a los Cabildos insulares de la provincia de Canarias (Gaceta de Madrid núm. 144, de 24 de mayo) . . . . . . . . . . . . .

Real Orden Circular de 18 de junio de 1923 acerca del alcance de la prohibición impuesta á los militares para ser contratistas con el Estado, excluyendo de la misma á los que se encuentren en situación de reserva, mientras no desempeñen cargo alguno militar (Diario Oficial del Ministerio de la Guerra, núm. 134) .

Reglamento para la contratación de obras y servicios a cargo de las entidades municipales de 2 de julio de 1924 (Gaceta de Madrid núm. 186, de 4 de julio) . . . . . . . . . . . . . . 
Real Orden Circular de 10 de enero de 1931 por la que se aprueba el Reglamento para la contratación administrativa en el ramo del Ejército (Colección Legislativa del Ejército, núm. 14) . . . . .

Orden circular de 9 de agosto de 1933 por la que se modifica el Reglamento para la contratación administrativa en el ramo del Ejército (Colección Legislativa del Ejército, núm. 390) . . . .

Ley de 24 de noviembre de 1939, sobre ordenación y defensa de la industria (BOE núm. 349, de 15 de diciembre) . . . . . . 738

Orden de 16 de enero de 1941 para dar cumplimiento al artículo 14 del Reglamento para la contratación administrativa en el ramo del Ejército (Diario Oficial del Ejército núm. 24) . . . . . . .

Orden de 30 de abril de 1943 por la que se aprueba, con carácter provisional, el pliego de condiciones generales para la contratación de obras de Telecomunicación (BOE núm. 147, de 27 de mayo de 1943) . . . . . . . . . . . . . . . .

Orden de 30 de abril de 1951 sobre Pliego de condiciones generales de las subastas forestales dependientes de la Dirección General de Marruecos y Colonias (BOE núm. 125, de 5 de mayo) . .

Ley de 20 de diciembre de 1952 por la que se sustituye la relación del Capítulo V de la Ley de Administración y Contabilidad de la Hacienda Pública, de 1 de julio de 1911, relativo a los contratos para la ejecución de obras y servicios públicos (BOE núm. 359, de 24 de diciembre) . . . . . . . . . . . . . . . .

Decreto de 9 de enero de 1953 por el que se aprueba el Reglamento de Contratación de las Corporaciones Locales (BOE núm. 44,

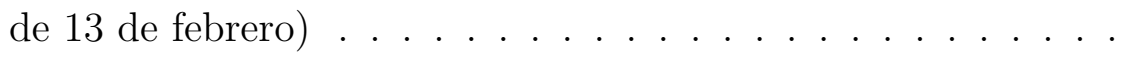

Decreto Ley de 13 de mayo de 1955 sobre incompatibilidades de los cargos de Ministro, Subsecretario, Directores generales y asimilados (BOE núm. 149, de 29 de mayo) . . . . . . . . . . .

Orden de 7 de enero de 1957 por la que se regulan las subastas forestales, y transcribiendo el Pliego de condiciones generales para la explotación forestal en la provincia del Golfo de Guinea (BOE núm. 14, de 14 de enero) . . . . . . . . . . . . . .

Decreto de 12 de diciembre de 1958, por el que se aprueba el Reglamento de contratos de obras y servicios de la Marina (BOE núm. 313, de 31 de diciembre) 
Ley 198/1963, de 28 de diciembre, de Bases de Contratos del Estado (BOE núm. 313, de 31 de diciembre) . . . . . . . . . . . .

Orden de 23 de junio de 1964 por la que se aprueba el Pliego de condiciones generales para la contratación de estudios y servicios técnicos en orden a la elaboración de proyectos de obras en aeropuertos (BOE núm. 162, de 7 de julio) . . . . . . . . .

Decreto 3588/1964, de 5 de noviembre, por el que se aprueba el Reglamento para la aplicación de la Ley del Patrimonio del Estado, texto articulado aprobado por Decreto 1032/1964 de 15 de abril (BOE núm. 276, de 17 de noviembre) . . . . . . . . . 746

Decreto 923/1965, de 8 de abril, por el que se aprueba el texto articulado de la Ley de Contratos del Estado (BOE núm. 97, de 23 de abril de 1965) . . . . . . . . . . . . . . .

Corrección de errores del Decreto 923/1965, de 8 de abril, por el que se aprueba el texto articulado de la Ley de Contratos del Estado (BOE núm. 132, de 3 de junio) . . . . . . . . . . . . 747

Decreto $3637 / 1965$, de 25 de noviembre, por el que se regulan los contratos del Estado y sus Organismos autónomos referente a obras, gestión de servicios o suministros que se celebren en territorio extranjero (BOE núm. 295, de 10 de diciembre) . . .

Decreto 3354/1967, de 28 de diciembre, por el que se aprueba el Reglamento General de Contratación para la aplicación de la Ley de Contratos del Estado (BOE núm. 27, de 31 de enero de

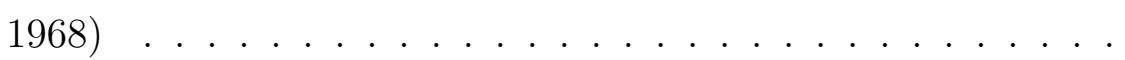

Decreto 916/1968, de 4 de abril, por el que se regula la contratación de estudios y servicios técnicos con sociedades y empresas consultoras por los Departamentos ministeriales (BOE núm. 107, de 3 de mayo) . . . . . . . . . . . . . . . .

Orden de 4 de junio de 1968, por la que se aprueba el pliego de cláusulas generales para la contratación de estudios y servicios técnicos por la Dirección general de carreteras y caminos vecinales (BOE núm. 152, de 25 de junio) . . . . . . . . . . .

Decreto 215/1973, de 25 de enero, por el que se aprueba el pliego de cláusulas generales para la construcción, conservación y explotación de autopistas en régimen de concesión (BOE núm. 41 de 16 de febrero $\quad \ldots \ldots \ldots$. . . . . . . . . . . . 750 
Ley 5/1973, de 17 de marzo, sobre modificación parcial de la Ley de Contratos del Estado (BOE núm. 69, de 21 de marzo) . . . . 750

Decreto 2572/1973, de 5 de octubre, por el que se aprueba el Pliego de Cláusulas administrativas generales para la contratación de equipos y sistemas para el tratamiento de la información y de mantenimiento, arrendamiento y programas (BOE núm. 250, de 18 de octubre) . . . . . . . . . . . . . . . .

Orden de 23 de noviembre de 1973 por la que se fijan las condiciones generales que han de regir en las concesiones y autorizaciones sobre el dominio publico en los aeropuertos nacionales (BOE núm. 289, de 3 de diciembre) . . . . . . . . . . . . . .

Decreto 1005/1974, de 4 de abril, sobre contratos de asistencia con empresas consultoras o de servicios (BOE núm. 97, de 23 de abril) . . . . . . . . . . . . . . .

Decreto 3410/1975, de 25 de noviembre, por el que se aprueba el Reglamento general de Contratación del Estado (BOE núm. 311, de 27 de diciembre) . . . . . . . . . . . .

Real Decreto 609/1982, de 12 de febrero, por el que se dictan las normas para la clasificación de las empresas consultoras y de servicios (BOE núm. 72, de 25 de marzo) . . . . . . . . . .

Ley 50/1984, de 30 de diciembre, de Presupuestos Generales del Estado para 1985 (BOE núm. 313, de 31 de diciembre) . . . . .

Real Decreto 1462/1985, de 3 de julio, por el que se regula a efectos de la contratación administrativa el requisito de hallarse al corriente de las obligaciones tributarias (BOE núm. 204, de 26 de agosto) . . . . . . . . . . . . . . .

Ley 46/1985, de 27 de diciembre, de Presupuestos Generales del Estado para 1986 (BOE núm. 311, de 28 de diciembre) . . . . .

Real Decreto 1465/1985, de 17 de julio, sobre contratación para la realización de trabajos específicos y concretos, no habituales, en la Administración del Estado, sus Organismos autónomos y la Seguridad Social (BOE núm. 205, de 27 de agosto) . . . .

Real Decreto Legislativo 931/1986, de 2 de mayo, por el que se modifica la Ley de Contratos del Estado para adaptarla a las Directivas de la Comunidad Económica Europea (BOE núm. 114, de 13 de mayo) . . . . . . . . . . . . . . . . . 
Real Decreto 2528/1986, de 28 de noviembre, por el que se modifica el Reglamento de Contratación del Estado para adaptarlo al Real Decreto Legislativo 931/1986, de 2 de mayo de 1986, y a las Directivas de la Comunidad Económica Europea (BOE núm. 297, de 12 de diciembre) . . . . . . . . . . . . . . . 757

Ley 4/1990, de 29 de junio, de Presupuestos Generales del Estado para 1990 (BOE núm. 156, de 30 de junio) . . . . . . . . . 760

Ley 9/1991, de 22 de marzo, por la que se modifican determinados artículos de la Ley 25/1983, de 26 de diciembre, de Incompatibilidades de Altos Cargos; de la Ley 7/1985, de 2 de abril, Reguladora de las Bases del Régimen Local; de la Ley de Contratos del Estado y de la Ley 24/1988, de 28 de julio, del Mercado de Valores (BOE núm. 74, de 27 de marzo) . . . . . . . . . .

Orden de 24 abril de 1991, por la que se determina el importe mínimo a partir del cual se exigirá la clasificación de las empresas que concurran a la formalización de contratos de obra con la Administración (BOE núm. 111, de 9 de mayo de 1991) . . 762

Proyecto de Ley de Contratos de las Administraciones Públicas (BOCG, IV Legislatura, Congreso de los Diputados, Serie A núm. 109-1, 26 de octubre 1992) . . . . . . . . . . . . . . . .

Real Decreto 1770/1994, de 5 de agosto, por el que se adecuan a la Ley 30/1992, de Régimen Jurídico de las Administraciones Públicas y del Procedimiento Administrativo Común, las normas reguladoras de los procedimientos de clasificación y de revisión de clasificaciones en materia de contratación administrativa (BOE núm. 198, de 19 de agosto) . . . . . . . . . . . . . .

Ley 13/1995, de 18 de mayo, de Contratos de las Administraciones Públicas (BOE núm. 119, de 19 mayo 1995) . . . . . . . . . .

Ley 9/1996, de 15 de enero, de medidas extraordinarias, excepcionales y urgentes de abastecimiento de aguas como consecuencia de la persistencia de la sequía (BOE núm. 15, de 17 de enero) . . .

Real Decreto 390/1996, de 1 de marzo, de desarrollo parcial de la Ley de Contratos de las Administraciones Públicas (BOE núm. 70, de 21 de marzo $\ldots$. . . . . . . . . . . . . . . . 770 
Ley 48/1998, de 30 de diciembre, sobre procedimientos de contratación en los sectores del agua, la energía, los transportes y las telecomunicaciones, por la que se incorporan al ordenamiento jurídico español las Directivas 93/38/CEE y 92/13/CEE (BOE núm. 313, de 31 de diciembre) . . . . . . . . . . . .

Ley 53/1999, de 28 de diciembre, por la que se modifica la Ley 13/1995, de contratos de las Administraciones Públicas (BOE núm. 311, de 29 de diciembre) . . . . . . . . . . . . . .

Real Decreto Legislativo 2/2000, de 16 de junio, por el que se aprueba el Texto refundido de la Ley de Contratos de las Administraciones Públicas (BOE núm. 148, de 21 de junio) . . . . . . .

Real Decreto 1098/2001, de 12 de octubre, por el que se aprueba el Reglamento General de la Ley de Contratos de las Administraciones Públicas (BOE núm. 257, de 26 de octubre) . . . . . .

Ley 22/2003, de 9 de julio, Ley Concursal (BOE núm. 164, de 10 de julio $\ldots \ldots \ldots \ldots \ldots \ldots$

Ley 5/2006, de 10 de abril, de regulación de los conflictos de intereses de los miembros del Gobierno y de los Altos Cargos de la Administración General del Estado (BOE núm. 86, de 11 de

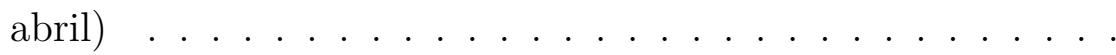

Orden 4247/2006, de 28 diciembre, por la que se aprueba las normas y condiciones generales para la contratación de Puertos del Estado y las Autoridades Portuarias (BOE núm. 17, de 19 de enero de 2007) . . . . . . . . . . . . . . . .

Ley 30/2007, de 30 de octubre, de Contratos del Sector Público (BOE núm. 261, de 31 de octubre) . . . . . . . . . . . .

Ley 31/2007, de 30 de octubre, sobre procedimientos de contratación en los sectores del agua, la energía, los transportes y los servicios postales (BOE núm. 261, de 31 de octubre) . . . . . . . . . .

Orden FOM/4003/2008, de 22 de julio, aprueba las normas y reglas generales de los procedimientos de contratación de Puertos del Estado y Autoridades Portuarias (BOE núm. 21, de 24 de enero de 2009)

Real Decreto-ley 6/2010, de 9 de abril, de medidas para el impulso de la recuperación económica y el empleo (BOE núm. 89, de 13 de abril) 
Real Decreto-ley 5/2011, de 29 de abril, de medidas para la regularización y control del empleo sumergido y fomento de la rehabilitación de viviendas (BOE núm. 108, de 6 de mayo de 2011) 796 Ley 24/2011, de 1 de agosto, de contratos del sector público en los ámbitos de la defensa y de la seguridad (BOE núm. 184, de 2 de agosto) . . . . . . . . . . . . 796

Real Decreto Legislativo 3/2011, de 14 de noviembre, por el que se aprueba el texto refundido de la Ley de Contratos del Sector Público (BOE núm. 276, de 16 de noviembre) . . . . . . . . . 798

Ley 25/2015, de 28 de julio, de mecanismo de segunda oportunidad, reducción de la carga financiera y otras medidas de orden social (BOE núm. 180, de 29 de julio) . . . . . . . . . . . . 804

Ley 40/2015, de 1 de octubre de 2015, de Régimen Jurídico del Sector Público (BOE núm. 236, de 2 de octubre de 2015) . . . . . . 805 Anteproyecto de Ley de Contratos del Sector Público (abril de 2015) 811 Anteproyecto Ley de contratos en sectores del agua, la energía, los transportes y los servicios postales (abril 2015) . . . . . . 823 


\section{Índice de tablas}

1 Gasto total en la contratación pública de obras, suministro y servicios como porcentaje del PIB (\%) en la UE (excluidos los servicios públicos). . . . . . . . . . . . . . . . . 180

2 Los motivos de exclusión en las Directivas de contratación pública de los años 1992 y $1993 \ldots$. . . . . . . . . . . . . 243

3 Puntuación del Índice de Percepción de la Corrupción en los Estados miembros (2012-2014) . . . . . . . . . . . . 321

4 Porcentaje de ciudadanos europeos que opinan que los funcionarios con competencia en procedimientos de contratación pública probablemente sean corruptos . . . . . . . . . . . . . 325

5 La transposición del artículo 45.1 de la Directiva 2004/18/CE respecto de las causas de prohibición de contratar obligatorias en los 28 Estados miembros. . . . . . . . . . . . . . . . . . . . 422 



\section{RESUMEN}

Las Directivas sobre contratación pública prevén, desde el año 2004, dos tipos de motivos de exclusión de los procedimientos de adjudicación de un contrato público por parte del candidato o licitador que se encuentra incurso en ellas.

El primer grupo de prohibiciones se instituye con carácter obligatorio para todos los Estados miembros, de tal manera que su normativa contractual debe recoger necesariamente en el momento de su transposición las prohibiciones de contratar contempladas en el artículo 57.1 de la Directiva 2014/24/UE. Su obligatoriedad deriva de lograr un efecto de sinergia con otras políticas europeas y servir, de esta manera, de instrumento para luchar contra la corrupción, el fraude, el blanqueo de capitales, el terrorismo y/o la trata de seres humanos.

El otro bloque de prohibiciones se establece con carácter potestativo para los legisladores nacionales quedando, por tanto, en manos de los distintos Estados miembros la decisión de incorporar - o no - dichas causas de prohibición de contratar a sus legislaciones internas. Entre estas prohibiciones facultativas merecen ser destacadas aquellas que se refieren a la comisión de faltas profesionales por parte del operador económico que ponen en entredicho su integridad o que prueban que se ha incumplido la legislación en materia medioambiental, social o laboral. Su imprecisión conceptual nos obliga a una labor interpretativa atendiendo a la jurisprudencia del Tribunal de Justicia de la Unión Europea.

Este estudio tiene por objeto analizar la regulación de estos motivos de exclusión y establecer cómo están siendo incorporados en los distintos Estados miembros, aun cuando no ha finalizado el plazo para su transposición. En la realización de esta tarea prestaremos especial atención a la normativa española.

Palabras clave: contratación pública, prohibiciones de contratar, corrupción, conflicto de intereses. 


\section{Grounds for exclusion under European Public Procurement Law}

\section{ABSTRACT}

The public procurement Directives have foreseen since 2004 two types of reasons for the exclusion of a candidate or a tenderer wishing to participate in the award procedures for public contracts (mandatory and discretionary exclusions). The first set of exclusions, of an obligatory nature, are established for all the Member States, in such a way that their contractual regulations should necessarily, at the time of their transposition, include the grounds for exclusion from contracting contemplated under article 57.1 of Directive 2014/24/EU. Their obligatory nature arises from the wish to achieve a synergic effect with other European policies and, by so doing, to serve as an instrument in the fight against corruption, fraud, money laundering, terrorism and/or human trafficking.

The other set of grounds for exclusion, established as optional for national legislators, leave the decision over whether - or not - to incorporate those prohibitive reasons for contracting in their domestic legislations in the hands of the different Member States. Among those optional grounds for exclusion, the ones that deserve to be highlighted refer to serious professional misconduct that raises questions over the integrity of the economic operator or that demonstrates its failure to comply with the legislation on environmental, social and labour matters. Their conceptual imprecision leaves us with little choice but to interpret them in the light of the case-law of the European Court of Justice.

The objective of this study is to analyze the regulation of those grounds for exclusion and to establish the way they are being transposed in the different Member States, even though the deadline for their transposition has yet to elapse. Special attention will be paid to the Spanish regulations in the completion of this task.

Keywords: public procurement, grounds for exclusion, corruption, conflict of interests. 


\title{
ABREVIATURAS Y SIGLAS
}

\author{
AAE Acuerdos de Asociación Económica \\ ACP Grupo de Estados de África, del Caribe y del Pacífico \\ ACP-CEE Acuerdo de asociación entre los Estados de África, del Caribe \\ y del Pacífico, por una parte, y la Comunidad Europea y sus \\ Estados miembros, por otra (Convenio de Lomé) \\ AN Audiencia Nacional \\ art. artículo \\ BCE Banco Central Europeo \\ BEI Banco Europeo de Inversiones \\ BGBl Boletín de la República de Austria Bundesgesetzblatt für die \\ Republik Österreich \\ BOE Boletín Oficial del Estado \\ CCCP Comisión Consultiva de Contratación Pública de Andalucía \\ CE Constitución Española \\ CEE Comunidad Económica Europea \\ CESE Comité Económico y Social Europeo \\ CIS Centro de Investigaciones Sociológicas \\ cit. citado \\ CMLR Common Market Law Review \\ CNUDMI Comisión de las Naciones Unidas para el Derecho Mercantil \\ Internacional (UNCITRAL, en inglés) \\ CPV Vocabulario Común de Contratos Públicos (conocido por sus \\ siglas en inglés Common Procurement Vocabulary) \\ DOCE Diario Oficial de las Comunidades Europeas \\ DOUE Diario Oficial de la Unión Europea \\ EEE Espacio Económico Europeo \\ ELSJ Espacio de libertad, seguridad y justicia
}


EPPL European Procurement 83 Public Private Partnership Law Review

EUROPOL Oficina Europea de Policía

FED Fondo Europeo de Desarrollo

FJ Fundamento jurídico

GAFI Grupo de Acción Financiera Internacional sobre el Blanqueo de Capitales

GATT Acuerdo General sobre Aranceles Aduaneros y Comercio (General Agreement on Tariffs and Trade en inglés)

GRECO Grupo de Estados contra la Corrupción del Consejo de Europa

IFS Índice de Fuentes de Soborno

IMI Sistema de Información del Mercado Interior

INAP Instituto Nacional de Administración Pública

IPC Índice de Percepción de la Corrupción elaborado por Transparencia Internacional

JAI Asuntos de Justicia e Interior

JCCA Junta Consultiva de Contratación Administrativa

JORF Boletín Oficial de la República Francesa (Journal officiel de la République française)

JPP Journal of Public Procurement

NUE Noticias de la Unión Europea

núm. número

OCDE Organización para la Cooperación y el Desarrollo Económico (siglas en inglés OECD Organisation for Economic Cooperation and Development)

OCTA European Organised Crime Threat Assessment

ODM Objetivos de Desarrollo del Milenio

OIT Organización Internacional del Trabajo

OLAF Oficina Europea de Lucha contra el Fraude

OMC Organización Mundial del Comercio

ONG Organización no Gubernamental

op. cit. obra citada

pág. página

PIB Producto Interior Bruto

PPLR Public Procurement Law Review

PPN Public Procurement Network 


\begin{tabular}{|c|c|}
\hline PUCP & $\begin{array}{l}\text { Pontificia Universidad Católica de Perú (Revista Derecho } \\
\text { PUCP) }\end{array}$ \\
\hline PYME & Pequeña y mediana empresa \\
\hline RAAP & Revista Andaluza de Administración Pública \\
\hline RAP & Revista de Administración Pública \\
\hline RArAP & Revista Aragonesa de Administración Pública \\
\hline $\mathrm{RD}$ & Real Decreto \\
\hline REAL & Revista de Estudios de la Administración Local \\
\hline REALA & Revista de Estudios de la Administración Local y Autonómica \\
\hline REDA & Revista Española de Derecho Administrativo \\
\hline REDE & Revista Española de Derecho Europeo \\
\hline REDETI & $\begin{array}{l}\text { Revista de Derecho de las Telecomunicaciones e Infraestruc- } \\
\text { turas en red }\end{array}$ \\
\hline REGAP & Revista Gallega de Administración Pública \\
\hline RELEX & Dirección General de Relaciones Exteriores \\
\hline RJ & Repertorio de Jurisprudencia Aranzadi \\
\hline RVAP & Revista Vasca de Administración Pública \\
\hline SIGMA & $\begin{array}{l}\text { Support for Improvement in Governance and Management in } \\
\text { Central and Eastern European Countries }\end{array}$ \\
\hline STC & Sentencia del Tribunal Constitucional \\
\hline STJUE & Sentencia del Tribunal de Justicia de la Unión Europea \\
\hline STS & Sentencia del Tribunal Supremo \\
\hline STSJ & Sentencia del Tribunal Superior de Justicia \\
\hline TACRC & Tribunal Administrativo Central de Recursos Contractuales \\
\hline TCEE & Tratado constitutivo de la Comunidad Económica Europea \\
\hline TFUE & $\begin{array}{l}\text { Tratado de Funcionamiento de la Unión Europea (desde el } \\
\text { Tratado de Lisboa) }\end{array}$ \\
\hline TJCE & Tribunal de Justicia de las Comunidades Europeas \\
\hline TJUE & $\begin{array}{l}\text { Tribunal de Justicia de la Unión Europea (desde el Tratado } \\
\text { de Lisboa) }\end{array}$ \\
\hline TRLCSP & Texto Refundido de la Ley de Contratos del Sector Público \\
\hline TUE & Tratado de la Unión Europea \\
\hline UCLAF & Unidad de Coordinación de la Lucha contra el Fraude \\
\hline $\mathrm{UE}$ & Unión Europea \\
\hline UE 25 & $\begin{array}{l}\text { Designa a los Estados miembros que formaban parte de la UE } \\
\text { antes del } 1 \text { de enero de } 2007\end{array}$ \\
\hline
\end{tabular}


UE 27 Designa a los Estados miembros que formaban parte de la Unión antes de la adhesión de Croacia el 1 de julio de 2013

UE 28 Designa a los Estados miembros que actualmente forman parte de la UE

UIF Unidades de Inteligencia Financiera

UNCTAD Conferencia de las Naciones Unidas sobre Comercio y Desarrollo

vol. volumen 


\section{INTRODUCCIÓN}

La normativa sobre contratación pública en la Unión Europea tiene por objetivo principal crear las condiciones necesarias para garantizar la efectividad de algunas de las libertades esenciales en la integración europea: la libre circulación de mercancías, de personas y de servicios y, así, promover una competencia efectiva entre operadores económicos de distintos Estados miembros que mejore el funcionamiento del mercado único. Desde sus inicios, el esfuerzo de las Directivas sobre contratación pública se ha centrado en quebrar los rígidos mercados nacionales de las compras públicas y, conforme a la aplicación de los principios básicos del Derecho de la Unión, evitar el riesgo de que se otorgue preferencia a los licitadores o candidatos nacionales en la adjudicación de los contratos que revistan un interés transfronterizo.

A este respecto, la apertura de los contratos a la competencia europea exige garantizar la más amplia participación de operadores económicos en una licitación, y no únicamente en aras del interés por hacer efectivas las citadas libertades fundamentales, sino también en beneficio del propio poder adjudicador que, de esta manera, dispondrá de una mayor posibilidad de elección para optar por la oferta que mejor satisfaga sus necesidades.

Ahora bien, el poder adjudicador cuando contrata no actúa en el mercado público como cualquier particular, ya que no disfruta de libertad en la elección del contratista. Esta elección ha de efectuarse sobre la evaluación de la oferta que resulte económicamente más ventajosa y que haya sido presentada por la persona o entidad que se considere apta para garantizar la ejecución del contrato. De este modo, la normativa contractual supedita el poder contratar con las entidades del sector público al cumplimiento previo de ciertos requisitos de capacidad, de competencia profesional y de solvencia («criterios de selección cualitativa»). 
El establecimiento de estos requisitos obedece a la tradicional preocupación que ha suscitado la elección del contratista y que evidencia una serie de cautelas en base a los intereses en juego. Su finalidad es la de garantizar la idoneidad del contratista para asumir las obligaciones derivadas del contrato y asegurar, de esta manera, que su ejecución se va a llevar a cabo con garantías de éxito.

Estos criterios de selección cualitativa, a la vez que establecen los requisitos positivos que deben cumplir los licitadores o candidatos para poder satisfacer las exigencias del órgano de contratación (que sean capaces, solventes y dispongan de la habilitación necesaria para ejercer la actividad profesional de que se trate), facultan - u obligan, según los casos - a excluir de la participación en un procedimiento de adjudicación a aquellos operadores económicos cuyas cualidades profesionales no sean consideradas suficientes o que hayan dado muestras de no ser fiables.

El objeto de esta memoria doctoral se centra en el estudio de la regulación de las prohibiciones de contratar en el ámbito del Derecho de la Unión Europea y, más concretamente, desde el análisis del marco jurídico que resulta de su Derecho primario y derivado que corresponde aplicar a los Estados miembros.

En la actualidad, el marco normativo que regula la contratación pública en Europa está determinado, además de por las Directivas sobre contratación pública, por las disposiciones de los Tratados en aquellos contratos que presenten un interés transfronterizo cierto, y por cuantos compromisos internacionales en materia de acceso a los mercados públicos han asumido la Unión Europea y sus Estados miembros (por ejemplo, el Acuerdo multilateral sobre Contratación Pública (ACP) de la Organización Mundial del Comercio y las cláusulas sobre contratación recogidas en los Acuerdos de libre comercio y en los Acuerdos de asociación). Asimismo, en virtud de la ejecución de las políticas europeas y en el marco de la ayuda exterior, deben considerarse también las normas sobre contratación pública incluidas en la regulación sobre gestión financiera y presupuestaria, principalmente en el Reglamento Financiero aplicable al presupuesto general de la Unión (Reglamento (UE, Euratom) 966/2012).

Nuestro estudio se enmarca en el análisis de las prohibiciones de contratar que resultan de lo dispuesto en las normas y principios básicos de los Tratados 
(Derecho primario), en las Directivas sobre contratación pública (Derecho derivado) y de la interpretación que de esta materia lleva a cabo la jurisprudencia del Tribunal de Justicia de la Unión Europea. A pesar de centrar nuestro estudio en estos términos, esta opción no puede desconocer el evidente interés que suscita en la actualidad la contratación en un contexto globalizado de la economía que aboga por la pérdida de protagonismo de los ordenamientos nacionales en favor de una creciente armonización normativa. Por esa razón, al hilo de la exposición, nos referiremos también a la regulación financiera y a la regulación internacional para tomar en consideración algunas de las cuestiones allí previstas en cuanto a la selección del contratista y que resulten de interés en el análisis que nos ocupa.

De conformidad con el planteamiento adoptado, y pese al margen de apreciación de que disponen los Estados miembros en esta materia, hemos entendido también necesario prestar atención a cómo estos Estados han incorporado, desde el año 2004, a sus normativas internas la obligación impuesta por las Directivas de incluir los criterios que conllevan obligatoriamente a la exclusión del candidato o licitador de la adjudicación de un contrato. Con todo no se ha llegado a elaborar - ni se ha pretendido - un análisis de Derecho comparado. Nuestro propósito es mucho más limitado en su alcance, ya que atiende a examinar si se sigue una estrategia común por parte de todos los Estados miembros respecto de los motivos de exclusión e identificar diferencias y semejanzas en el entorno europeo.

La elección del tema obedece a varias motivaciones. En primer lugar, aun cuando existen numerosos e importantes estudios que tratan del análisis de la naturaleza jurídica de los contratos que llevan a cabo las entidades del sector público y de la justificación dogmática de su propia existencia, el análisis de la figura del contratista es mucho más limitado y su regulación - en los últimos años - ha sentido como pocas la influencia del Derecho europeo. Por ello, más allá de la construcción jurídica del contrato público, hemos creído oportuno abordar las prohibiciones de contratar como punto de encuentro de los sistemas nacionales de contratación ante la obligación de que los poderes adjudicadores de los distintos Estados miembros apliquen dichas prohibiciones ajustándose a lo dispuesto en la regulación europea. 
En segundo lugar, otra de las razones que justificó, en su momento, la elección de este tema fue el interés que despertaron en el legislador español las prohibiciones de contratar como instrumentos de lucha contra la corrupción y que provocó numerosos cambios normativos - y en distintos sentidos - para acomodar la normativa a las exigencias de tutela judicial efectiva y de respeto a la presunción de inocencia.

En tercer lugar, consideramos que en el actual contexto normativo, los cambios impuestos a favor de una mayor eficiencia económica en la ejecución de los contratos, nos obligan a tratar los objetivos secundarios en la contratación pública en la idea de que los contratos pueden contribuir a la consecución de otros objetivos públicos, en virtud del potencial de sinergia de los fondos destinados a las compras del sector público. De esta manera, la lucha contra distintas manifestaciones de delincuencia económica se materializa en la regulación europea de las prohibiciones de contratar en un intento de servir de instrumento eficaz que impida prácticas comerciales ilícitas en la contratación pública. A nuestro juicio, este objetivo no está bien resuelto - a pesar de los evidentes avances en la materia - y así trataremos de argumentarlo a lo largo de esta memoria doctoral.

Esta memoria doctoral se estructura en torno a cuatro capítulos cada uno de los cuales aborda cuestiones diferenciadas de la materia objeto de estudio: (1) concepto, configuración y fundamentos; (2) marco jurídico; (3) examen de las prohibiciones de contratar obligatorias y (4) ámbito de aplicación.

El Capítulo primero presenta el contexto en el que las prohibiciones de contratar se inscriben. Para una mejor comprensión del texto se efectúan, en primer lugar, algunas observaciones de tipo conceptual que tratan de acotar las distintas expresiones utilizadas por el legislador para referirse a esta materia.

Las peculiares características de las prohibiciones de contratar nos han llevado también a analizar su configuración jurídica desde su adopción normativa por parte del Derecho penal como pena privativa de derechos; del Derecho administrativo sancionador como sanción interdictiva y del ámbito contractual público. Desde la perspectiva contractual - que es la que nos ocupa en esta memoria doctoral - la medida no puede ser calificada de sanción. A este respecto, no sólo nos hemos dejado guiar por las consideraciones de nuestro 
Tribunal Supremo que en su última jurisprudencia ha declarado expresamente que las prohibiciones de contratar no tienen un carácter sancionador, sino que atendemos a sus elementos diferenciadores y, sobre todo, a sus finalidades prevalentes (preventiva y punitiva o represora, según los casos). Su consideración como medidas desfavorables, aunque no sancionadoras, repercute, sin embargo, en el régimen jurídico que les resulta de aplicación.

Como técnicas de intervención en el mercado público su finalidad es, de una parte, disuasoria para obtener el mayor grado de cumplimiento de las obligaciones que derivan del ordenamiento jurídico y de otra, preventiva para asegurar que el contrato no vaya a verse frustrado por haber elegido como contratista a quien no reunía las condiciones necesarias para ello o haya dado muestras de poca fiabilidad. De esta manera, las prohibiciones de contratar además de proteger los intereses financieros de la Unión ante manifestaciones de delincuencia económica - pretenden garantizar el interés público desde la igualdad y la leal competencia entre operadores económicos.

En el segundo Capítulo hemos centrado nuestra investigación en el marco jurídico aplicable a las prohibiciones de contratar. Este análisis comienza con el estudio de los antecedentes históricos retrotrayéndonos, de esta manera, al Tratado Constitutivo de la Comunidad Europea y a las primeras Directivas sobre contratación pública («Directivas de primera y segunda generación»). En nuestra opinión, una correcta comprensión de las prohibiciones de contratar en el momento actual nos obliga a mirar al pasado para encontrar allí elementos de juicio que avalen un examen crítico del actual marco regulador. Esto es así porque una gran parte de las actuales causas de prohibición de contratar obedecen a una tradición heredada a lo largo de los años. Se repiten pautas y modelos a la vez que se reproducen expresiones que se perpetúan en la regulación contractual desde las primeras generaciones de Directivas. Su análisis pormenorizado deviene fundamental puesto que, si bien en los Tratados no existen disposiciones expresas sobre contratación pública, los principios allí recogidos se manifiestan como los pilares básicos del Derecho de la Unión en esta materia, a saber, los principios de no discriminación, de igualdad de trato, de proporcionalidad y de transparencia.

De este examen histórico extraemos la conclusión de que las prohibiciones de contratar son un instrumento dinámico que ha ido adaptándose a los 
actuales requerimientos de utilización más eficiente de los recursos públicos. Estos recientes objetivos se visualizan claramente en el actual marco regulador - las que se han venido a llamarse «la cuarta generación de Directivas» (Directiva 2014/23/UE «concesiones»; Directiva 2014/24/UE «sectores clásicos» y Directiva 2014/25/UE «sectores especiales») - con la incorporación de nuevos supuestos de prohibición de contratar y la "reubicación" de alguno de los ya existentes.

A este respecto, y dado que en el momento actual no ha expirado el plazo de transposición de las nuevas Directivas a los Derechos internos, debemos referirnos también con especial dedicación a las Directivas del año 2004: las Directivas 2004/17/CE y 2004/18/CE. En este contexto, la importancia de la fecha límite del 18 de abril de 2016 es doble: en primer lugar, porque las nuevas Directivas sólo son completamente aplicables en aquellos Estados miembros en los que ya han entrado en vigor las medidas de transposición y, en segundo lugar, porque al día siguiente al vencimiento de este plazo, determinadas disposiciones de las Directivas tendrán un efecto directo.

El Capítulo tercero está centrado de forma específica en las prohibiciones de contratar de carácter obligatorio para los Estados miembros y a las que creemos debieran haberse recogido con tal carácter a tenor de los cometidos que están llamadas a desempeñar en la búsqueda de eficiencia en la selección del contratista. De esta forma, los primeros epígrafes de este capítulo están dedicados a identificar las conductas que habilitan una prohibición obligatoria y cuya calificación parte de su consideración como instrumentos de lucha contra determinadas formas de delincuencia grave y transfronteriza. Cobran así importancia factores vinculados al establecimiento de un espacio de libertad, seguridad y justicia y a la definición de las conductas delictivas que afectan a los intereses financieros de la Unión.

Partiendo de la idea de que la contratación puede favorecer ciertos comportamientos empresariales, se analiza la jurisprudencia del Tribunal de Justicia en este aspecto y se plantea que el incumplimiento de ciertas obligaciones sociales, laborales y medioambientales debiera haberse incluido en la enumeración de las prohibiciones de contratar de carácter obligatorio y ello, principalmente, por dos razones: La primera se refiere a la búsqueda de congruencia de la normativa contractual respecto del cumplimiento de los compromisos interna- 
cionales suscritos en el ámbito social y medioambiental; y la segunda a evitar que el incumplimiento de dicha normativa comporte una ventaja económica que pueda favorecer al operador económico incumplidor con respecto a las empresas competidoras que sí han cumplido.

La delimitación en la implementación de las prohibiciones ha sido objeto de tratamiento en el Capítulo cuarto. En el marco de este capítulo debemos distinguir tres secciones - que aunque no diferenciadas en bloques distintos atienden a aspectos diversos: (i) el ámbito subjetivo y objetivo de aplicación; (ii) las dificultades de orden jurídico y práctico para su aplicación en una dimensión transfronteriza, y por último, (iii) los supuestos de inaplicación de las prohibiciones de contratar.

La normativa de contratación no afecta por igual a todas las entidades del sector público, sino que, de una parte, distingue distintos niveles de sujeción atendiendo a las características propias de cada ente contratante y, por otra, diferencia regímenes jurídicos en atención a la prestación demandada e, incluso, al valor económico del contrato. Así pues, aunque nuestro estudio no trate del ámbito de aplicación de las Directivas, hemos creído oportuno realizar unas observaciones generales relativas al ámbito subjetivo y objetivo para centrar convenientemente a qué contratos y a qué sujetos les resultan de aplicación las prohibiciones de contratar y dar respuesta tanto a quién debe aplicarlas como a quién se le aplican.

En segundo lugar, nos detenemos en el estudio de los mecanismos de que disponen los órganos de contratación para garantizar la efectividad de estas prohibiciones y, más concretamente, en lo que atañe a la cooperación administrativa y al reconocimiento de resoluciones. Asimismo, prestamos especial interés a aquellas novedades de carácter operativo que pretenden mejorar los exiguos datos de la contratación pública transfronteriza (3,7 \% según datos del año 2014), poniendo en valor aquellos instrumentos dirigidos a reducir las cargas burocráticas que deben soportar los operadores económicos que participan en un procedimiento de adjudicación.

El último de los epígrafes de este capítulo - y que pone fin a esta memoria doctoral - versa sobre los supuestos de excepción a la aplicación de una prohibición de contratar. Se trata una de las materias más novedosas en las nuevas Directivas, si bien, tal como veremos, algunos de estos supuestos ya 
encontraban acomodo en la regulación de algún Estado miembro. De los cinco supuestos de excepción previstos actualmente, vamos a centrar nuestra atención en las llamadas medidas autocorrectoras o de «self-cleaning» a través de las cuales los candidatos o licitadores recuperan la posibilidad de participar en la adjudicación de un contrato - aun cuando concurre en ellos un motivo de prohibición de contratar - siempre que hayan adoptado mecanismos eficaces para corregir las consecuencias de su inadecuado comportamiento e impedir de manera efectiva que éste se vuelva a repetir.

Las conclusiones de esta tesis doctoral se presentan tras estos cuatro capítulos. Además, en un documento anexo se incluye la legislación relacionada con esta materia en el que se recogen las normativas contractuales europea y española.

En la elaboración de esta memoria doctoral se ha adoptado un enfoque jurídico enmarcado específicamente en el ámbito administrativo, si bien del contexto en el cual se desarrolla esta materia - y atendiendo a los efectos que ésta causa en otros sectores - también deben ser tenidos en consideración otros elementos más cercanos al ámbito penal, económico, social e incluso tecnológico. Estas referencias resultan necesarias por cuanto en las nuevas Directivas se prevé la transición a un sistema de contratación plenamente electrónico en octubre de 2018 para todos los Estados miembros y sobre la idea de la necesaria interconexión de registros que, por una parte, descargue de carga burocrática a los operadores económicos y, por otra, facilite información actualizada a los órganos de contratación para que las prohibiciones de contratar puedan, realmente, alcanzar los objetivos propuestos. 


\section{INTRODUCTION}

The main aim of the public procurement regulations in the European Union is to uphold the conditions that are necessary to guarantee the effectiveness of some of the freedoms essential to European integration: the free movement of goods, freedom of establishment and the freedom to provide services, likewise, the promotion of effective competition among economic operators from different Member States that will improve the functioning of the Single Market. Since their beginning, the public procurement Directives have centered their efforts on breaking up closed national public-procurement markets. In accordance with the application of the basic principles of European Union Law, they also circumvent the risk of giving preference to national tenderers or candidates in the award of contracts that are of cross-border interest.

In this regard, the opening up of contracts to European competition means taking steps to ensure that the widest range of economic operators participate in a tender. Not only in view of the EU interest in rendering the abovementioned fundamental freedoms effective, but also in the interests of the contracting authority, which will in this way have a greater range of choice when selecting the most advantageous tender that is the most suitable for its needs.

However, the contracting authority is not acting as an individual in the public market when it contracts, as it has no freedom in the selection of the contractor. This choice has to be done following the evaluation of the most economically advantageous tender, which has been presented by the economic operator considered the most suitable to ensure contract fulfillment. In this way, the contracting authorities should require economic operators to be subject to prior compliance with certain criteria on technical and professional ability and economic and financial standing ('criteria for qualitative selection').

The establishment of these requirements responds to the traditional concerns that are raised by the choice of contractor and that highlights a series of concerns based on the interests that are at stake. Their purpose is to gua- 
rantee the suitability of the contractor to meet the obligations arising from the contract, thereby assuring that they will be fulfilled with some degree of success.

These qualitative selection criteria establish the positive requirements that tenderers or candidates should meet to satisfy the demands of the contracting authority (professional ability and financial standing as well as the necessary accreditation to exercise the professional activity in question), at the same time authorizing - or obliging, according to each case - the exclusion of economic operators from participation in an award procedure whose professional qualities are not considered sufficient or that have shown signs of unreliability.

The objective of this doctoral dissertation is to study the regulation of the grounds for exclusion from contracting in the field of European Union Law and, more specifically, from the analysis of the legal framework arising from its primary and secondary legislation that has to be applied to the Member States.

At present, the normative framework that regulates public procurement in Europe is decided by the provisions of the Treaties in those contracts that present a certain cross-border interest, as well as by the public procurement Directives and the international commitments relating to access to public markets which the European Union and its Member States have subscribed (for example, the multilateral Government Procurement Agreement (GPA) of the World Trade Organization and the clauses on contracting covered in the Free Trade Agreements and Association Agreements). Likewise, through the execution of European policies and in the framework of external aid, the norms on public procurement included in the regulation on financial and budgetary management should also be considered, principally in the Financial Rules applicable to the general budget of the Union Regulation (EU, Euratom) 966/2012).

This study analyses the grounds for exclusion from contracting procedures that arise from the provisions of the norms and basic principles of the Treaties (primary Law), in the public procurement Directives (secondary Law) and in the legal interpretations of this material found in the case-law of the European Court of Justice of the European Union. Despite centering this study in these terms, this option can not ignore the evident interest that procurement awakens 
in a globalized economic context that advocates the loss of the leading role of national orders in favor of growing normative harmonization. Hence, I also refer to both financial regulations and to international regulations throughout the presentation, so as to consider some of the questions that they raise in relation to contractor selection, which are of interest to the present study.

In accordance with the approach that I have adopted, and despite the margin of appreciation available to the Member States in this matter, I have also understood that it is necessary to lend attention to the way in which these States have, since 2004, transposed the obligation imposed by the Directives into their national legislation: inclusion of the criteria that entail the obligatory exclusion of the candidate or tenderer from the award of a contract. In spite of this obligation, a comparative legal study was at no stage prepared — nor was it ever intended. The objective is much more limited in scope; with regard to the grounds for exclusion, it sets out to examine whether a common strategy is followed by all the Member States and to identify differences and similarities in the European context.

The selection of this topic is due to various reasons. In the first place, even when there are numerous and important studies that cover the legal nature of the contracts into which public sector bodies enter and the dogmatic justification of their own existence, the analysis of the figure of the contractor is much more limited and its regulation - over recent years - has hardly felt the influence of European Law. Therefore, beyond the legal construction of the public contract, I thought it advisable to approach the exclusions from contracting as a meeting point of the national procurement systems, in view of the obligation on the contracting authorities of the different Member States to apply those grounds for exclusion in accordance with the provisions of the European regulation.

In second place, another of the reasons that justified, in its day, the choice of this topic was the interest of the Spanish legislator in the grounds for exclusion as instruments in the fight against corruption. It provoked numerous legislative changes - in different ways - to include the right to effective judicial protection and respect for the presumption of innocence in the regulation. In third place, I consider that the changes imposed in the present normative context, in favor 
of increased economic efficiency in public expenditure, oblige us to look at the secondary objectives in public procurement, by considering the idea that the contracts can contribute to the achievement of other public objectives, in view of the potential synergy of funds allocated to public sector purchases. In this way, the fight against different sorts of economic crime is visible in the European regulation on the prohibitions on contracting in an effort to serve as an effective instrument that prevents illegal commercial practices in public procurement. In my judgment, this objective is not well defined-despite the evident progress in the matter - and I will seek to argue as much throughout this doctoral dissertation.

This doctoral thesis is structured into four chapters, each of which approaches different questions on the subject matter that is under study: (1) concept, configuration and grounding; (2) legal framework; (3) examination of the mandatory grounds for exclusion; and, (4) scope of application.

The first chapter presents the context in which the exclusions from contracting are situated. In the first place, some observations of a conceptual type are made for a better understanding of the text, which seek to circumscribe the different expressions used by the legislator in reference to this matter.

The peculiar characteristics of the prohibitions on contracting have also led us to analyze their legal configuration from their legislative adoption in criminal Law as a disqualification; as an injunction in administrative sanctioning Law and in the area of public procurement. From the contractual perspectivewhich is what concerns us in this doctoral thesis - the measure can not be qualified as a sanction. In this regard, not only have I been guided by the rulings and views of the Spanish Supreme Court, which in its most recent jurisprudence expressly declared that the exclusions on contracting are not of a sanctioning nature, but respond to different aspects and, above all, to their main (preventive and punitive or repressive) purpose, in each case. Although not sanctioning in nature, their consideration as unfavorable measures has a special impact on the legal regime to which they are applied.

On the one hand, as techniques for intervention in the public market, their aim is dissuasive, to obtain the highest degree of compliance with the obligations that arise from the legal order. On the other hand, they have a preventive 
role to ensure that the contract will not be frustrated, because of having chosen a contractor who has failed to meet the necessary conditions to do so or who has shown signs of unreliability. In this way, the exclusions from contractingas well as protecting the financial interests of the Union from manifestations of economic crime - seek to defend the public interest on the basis of equal treatment and fair competition between economic operators.

In the second Chapter, I have centered my research on the legal framework applicable to the exclusions from contracting. This analysis starts with the study of the historic background, taking us back, in this way, to the Treaty of Rome (Treaty Establishing the European Union) and the initial public procurement Directives ('First'and 'Second Generation' Directives). In my opinion, to gain a correct understanding of the present exclusions from contracting means having to look to the past to find assessable criteria that endorse a critical examination of the present regulatory framework. This is so, because the current grounds for exclusion from contracting respond in large part to a tradition that has been inherited over the years. Patterns and models are repeated at the same time as expressions are reproduced that have been perpetuated in the contractual regulations since the first generations of Directives. Their detailed analysis is fundamental given that, even though the Treaties themselves contain no specific provisions on public procurement, the principles that they contain appear as the basic pillars of Union Law on this matter: the principles of non-discrimination, equal treatment, proportionality and transparency.

From this historical examination, I arrive at the conclusion that the grounds for exclusion from contracting are a dynamic instrument that has been adapting itself to present-day requirements for more efficient use of public resources. These recent objectives are clearly seen in the regulatory framework in force - those that have come to be called the 'fourth generation of Directives' (Directive 2014/23/EU 'concessions'; Directive 2014/24/EU 'public sector' and Directive 2014/25/EU 'utilities sectors') - with the incorporation of new circumstances for exclusion from contracting and the 'reclassification' of some of those already in existence.

In this regard, and given that as of today the time limit for the transposition of the new Directives into domestic law has yet to expire, we should refer to and lay special emphasis on the Directives of 2004: Directives 2004/17/EC and 
2004/18/EC. The importance of the deadline of 18th April, 2016, is twofold: in the first place, because the new Directives will only be fully applicable in those Member States in which the transposition of the measures have already entered into force and, in second place, because on the day following the expiry of this time limit, certain provisions of the Directives will be directly applicable.

The third Chapter is centered in a specific way on the grounds for exclusion from contracting that are mandatory for the Member States and those which I believe should have been included as such, in view of the commitments that the Member States are called on to fulfill in the search for efficiency in the selection of contractors. So, the first sections of this chapter are dedicated to the identification of behaviors that give rise to mandatory exclusion, the qualification of which is based on their consideration as instruments in the fight against certain forms of serious and cross-border crime, security and justice and the definition of criminal behaviors that affect the financial interests of the Union.

The relevant case-law of the Court of Justice is analyzed with a view to understanding contracting as an activity that can favor certain business conducts. It is proposed that non-compliance with certain social, employment and environmental obligations should have been included in the list of mandatory grounds for exclusion, principally for two reasons: the first refers to the search for the congruency of the contractual regulation with regard to compliance with the international undertakings upheld in social and environmental fields; and, the second, to prevent non-compliance with the norm yielding economic advantages that might favor the economic operator who fails to comply, as opposed to its competitors who have themselves complied.

The boundaries to the implementation of exclusion form the subject matter of the fourth Chapter. In the framework of this chapter, we should distinguish three sections - which although not divided into different blocks - respond to various aspects: (i) the subjective (rationae personae) and objective scope of application; (ii) the difficulties of a legal and practical sort for their application in a cross-border dimension and, finally, (iii) the circumstances for nonapplication of the grounds for exclusion (derogations from exclusion).

The norms on public sector contracting do not affect all public sector entities equally. Instead, on the one hand, they distinguish different levels of 
observance in accordance with the specific characteristics of each contracting body and, on the other hand, they differentiate between legal regimes in accordance with the service that is required and, even, the economic value of the contract. So, although this study does not cover the scope of application of the Directives, I considered it advisable to make some general observations on both their subjective and their objective setting, so as to focus on which contracts and on which bodies the grounds for exclusion from contracting are applicable and so as to provide a response to the question of who should apply them and to whom they should be applied.

In second place, I shall dwell on the study of the mechanisms available to the contracting authorities to guarantee the effectiveness of these exclusions and, more specifically, with regard to administrative cooperation and the recognition of decisions. Likewise, I shall lend special attention to those novelties of an operational nature that seek to improve the scarce data on cross-border public procurement (3.7\% according to data from 2014), emphasizing the value of those instruments that serve to reduce the administrative burden for the economic operator.

The last section of this chapter-which draws this doctoral thesis to a conclusion - relates to the circumstances in which an exception to the application of an exclusion may be granted. It is one of the most novel aspects of the new Directives, however, as we have seen, allowance for some of the circumstances had already been written into the regulations of certain Member States. From among the five circumstances for exceptions that are foreseen at present, we shall centre our attention on the so-called 'self-cleaning' measures through which the candidates or bidders recover the possibility of competing for the award of a contract - even when a reason for exclusion from contracting affects them - when they have adopted effective mechanisms to correct the consequences of their inadequate behavior and prevent it from happening again in an effective way.

The general conclusions of this doctoral thesis are presented after these four chapters. Besides, a documental annex containing legislation related to the topic of this thesis is presented. It includes European laws as well as Spanish legislation. 
This thesis is based on traditional legal method, which provides for a reconstruction of the legal system and applicable law. A juridical focus, specifically on administrative matters, was adopted in the preparation of this doctoral thesis. However, from the context in which this subject is developed - and mindful of the effects that this causes in other sectors - other elements closer to the criminal, economic, social and even technological fields should also be taken into account. Above all, if we are to judge by the fact that the new Directives envisage the transition to a fully electronic procurement system by October 2018 for all the Member States. In addition, the idea of the necessary interconnection between registries, on the one hand, relieves the administrative burden of economic operators and, on the other, facilitates up-to-date information on the contracting authorities, so that the exclusions from contracting can, in fact, achieve the proposed objectives. 


\section{Capítulo primero}

\section{MARCO CONCEPTUAL, CONFIGURACIÓN Y FUNDAMENTOS JURÍDICOS DE LAS PROHIBICIONES DE CONTRATAR}

\section{Planteamiento}

Las entidades que integran el sector público no están obligadas a contratar con terceros cuando disponen de los medios suficientes y adecuados para atender la prestación directa de los servicios y actividades de su competencia ${ }^{1}$. Ahora bien, en ocasiones, estos medios materiales y personales se muestran insuficientes a tal propósito y la entidad pública precisa la asistencia de otros sujetos que contribuyan al cumplimiento y realización de sus funciones de servicio público. Esta colaboración puede articularse a través de una relación con otras autoridades - sin que en el supuesto de «cooperación horizontal» podamos hablar propiamente de contratos públicos cuando esta relación se formaliza

\footnotetext{
${ }^{1}$ El principio del "contratista interpuesto", que consagró el liberalismo decimonónico y que se basaba en la desconfianza en las Administraciones para llevar a cabo actividades propias del ámbito empresarial, ya no resulta aplicable. Así lo manifestaba REBOLLO PUIG, M., "Los entes institucionales de la Junta de Andalucía y su utilización como medio propio", $R A P$, núm. 161, mayo - agosto 2003, pág. 379; y así se expone también ahora en la Directiva 2014/24/UE, de 26 de febrero de 2014, sobre contratación pública, en su considerando trigésimo primero: "la aplicación de las normas de contratación pública no debe interferir con la libertades de los poderes públicos para ejercer las funciones de servicio público que le han sido conferidas utilizando sus propios recursos, lo cual incluye la posibilidad de cooperación con otros poderes adjudicadores".
} 
bajo ciertas condiciones ${ }^{2}$ - o bien, puede enmarcarse en una verdadera relación contractual al verse obligada la entidad pública a recurrir a personas externas y ajenas a sus servicios.

En el supuesto de que sean operadores económicos externos los que lleven a cabo dichas funciones, o le provean de los bienes necesarios para afrontar dicho cometido, estos sujetos «cualificados» ${ }^{3}$, necesitarán acreditar que están en condiciones de ejecutar la prestación de que se trate, aportando las garantías necesarias para ello, a efectos de dotar al contrato de la requerida validez.

En este sentido, el Derecho europeo de los contratos públicos no exige que la persona que celebra un contrato con una entidad pública tenga una determinada forma jurídica, ni siquiera que sea capaz de realizar la prestación pactada directamente con sus propios recursos - ya que puede recurrir a medios que pertenecen a otros sujetos - pero sí requiere el cumplimiento y acreditación de ciertas condiciones de solvencia y capacidad, que se refieren a la aptitud de los licitadores al objeto de garantizar su idoneidad para la ejecución de la prestación demandada ${ }^{4}$.

El fundamento que justifica estos requisitos está en garantizar el interés general inherente al contrato, de tal manera que el cumplimiento de los mismos

${ }^{2}$ El Tribunal de Justicia de la Unión Europea (TJUE) nos recuerda en distintos pronunciamientos que una autoridad pública puede realizar tareas de servicio público en colaboración con otras entidades, pero en este supuesto es preciso distinguir a efectos de aplicar o no la normativa sobre contratación pública - entre medidas de naturaleza meramente administrativa y/u organizativa y los contratos públicos. Véase, a título de ejemplo, las sentencias de 11 de enero de 2005, Stadt Halle y RPL Lochau, C-26/03, apartados 48 y 49; de 13 de noviembre de 2008, Coditel Brabant, C324/07, apartado 48; de 9 de junio de 2009, Comisión/Alemania, C-480/06, apartado 45 y de 8 de mayo de 2014, Universität Hamburg, C-15/13, apartado 25.

${ }^{3}$ De "especialmente cualificados" se calificaban por parte de Sebastián MARTÍNRETORTILLO BAQUER en su artículo "La institución contractual en el Derecho administrativo: en torno al problema de la igualdad de las partes", $R A P$, núm. 29, mayo - agosto 1959, pág. 83.

${ }^{4}$ Sentencias del Tribunal de Justicia de 12 de julio de 2001, Ordine degli Architetti delle province di Milano e Lodi y otros, «Scala», C-399/98, apartado 90; de 18 de marzo de 2004, Siemens y ARGE Telekom, C-314/01, apartado 43; de 23 de diciembre de 2009, CoNISMa, C-305/08, apartados 41 y 42, de 18 de octubre de 2012, Hochtief Construction, C-218/11 y el Auto del Tribunal de Justicia, de 4 de octubre de 2012, Vivaio dei Molini, C-502/11. 
constituya un indicio objetivo de la existencia de una base suficiente para la correcta ejecución del mismo. La idea de proteger el interés público y garantizar un buen uso de los fondos públicos va a estar presente en toda la institución contractual - aunque con el contrato no siempre se vaya a satisfacer necesidades de interés general ${ }^{5}$ - de tal manera que, más allá de colmar las pretensiones de las partes, la normativa contractual persigue objetivos de mayor calado entre los que se encuentra el garantizar la libre circulación de bienes y servicios, y la regulación del acceso al mercado de las compras públicas ${ }^{6}$.

La prosecución de estos objetivos generales va a modular la propia institución contractual y justifica, como tendrá ocasión de advertirse más adelante, toda una serie de peculiaridades en su regulación que lo diferencia del régimen jurídico de la contratación entre particulares. Una de estas especialidades es la que hace referencia a la selección, por parte de las entidades del sector público, de la otra parte del contrato, lo cual exige la observancia de determinadas formalidades y requisitos a la hora de seleccionar a la persona física o jurídica más idónea para llegar a ser contratista público ${ }^{7}$.

${ }^{5}$ STJUE de 15 de julio de 2010, Comisión/Alemania, C-271/08, apartado 73.

${ }^{6} \mathrm{El}$ Tribunal de Justicia ya ha reiterado en numerosas ocasiones que el objetivo principal de las normas de la Unión en materia de contratos públicos es la libre circulación de las mercancías y de los servicios y su apertura a la competencia más amplia posible - y no falseada - en todos los Estados miembros. Véanse, en este sentido, las sentencias de 13 de diciembre de 2007, Bayerischer Rundfunk y otros, C-337/06, apartado 39; de 23 de diciembre de 2009, CoNISMa, C-305/08, apartado 37; de 10 de octubre de 2013, Swm Costruzioni, C-94/12, apartado 34; de 10 de julio de 2014, Consorzio Stabile Libor Lavori Pubblici, C-358/12, apartado 29 y de 18 de diciembre de 2014, Data Medical Service, C-568/13, apartado 34.

${ }^{7}$ La premisa de idoneidad de aquél que pretende contratar con la Administración ha sido, por ejemplo, una constante en el Derecho español y, así, se manifiesta desde las primeras normas que rigen esta institución contractual. Véase a este respecto, el artículo 1 de la Real órden (sic) de 18 de marzo de 1846, que aprueba el Pliego de Condiciones Generales para las contratas de obras públicas de caminos, canales y puertos (que puede consultarse en el segundo volumen de esta memoria doctoral): "Ninguno podrá ser admitido en la subasta sin reunir las cualidades necesarias para ejecutar por su cuenta las obras y afianzar la seguridad de su buena construcción. (...) Garantizarán igualmente la buena construcción de las obras, ya sea presentando el título ó la certificación que acredite su capacidad para dirigirlas por sí mismo, ya sea obligándose á confiar su ejecución á personas facultativas prácticas en las de que se trate, ya justificando su buen cumplimiento en otras contratas de la misma 
Las normas de contratación pública en la Unión Europea y en los Estados miembros - con independencia de su modelo de regulación más cercano al Derecho público o al privado - establecen procedimientos específicos para la adjudicación de los contratos por parte de las entidades del sector público. La finalidad de estos procedimientos es satisfacer, en las mejores condiciones posibles, las necesidades de los órganos de contratación respetando la igualdad de acceso a los contratos públicos y los principios de transparencia y no discriminación de todos los operadores económicos interesados en el contrato (que se denominarán licitadores y/o candidatos, según el procedimiento utilizado).

La contratación pública se configura, así, como una institución eminentemente formal que precisa de una serie de trámites, ya que la entidad pública no va a poder contratar con aquel sujeto que discrecionalmente elija, sino únicamente con aquél que cumpla una serie de requisitos y, además de ello, resulte adjudicatario del contrato en virtud del oportuno procedimiento de licitación ${ }^{8}$.

El actual marco regulador de la contratación pública en la Unión Europea está integrado, principalmente, por tres directivas:

- La Directiva 2014/23/UE, del Parlamento Europeo y del Consejo, de 26 de febrero de 2014, relativa a la adjudicación de contratos de concesión («concesiones»);

- La Directiva 2014/24/UE, del Parlamento Europeo y del Consejo, de 26 de febrero de 2014, sobre contratación pública y por la que se deroga la Directiva 2004/18/CE («sectores clásicos»), y

especie."

${ }^{8}$ En nuestro derecho, se ha partido de la consideración del contratista como ejecutor de funciones públicas que sustituye, en las mismas, a la Administración competente para ello. De tal manera que se ha llegado a afirmar que "No estamos únicamente ante un vicario, un colaborador cualificado de la entidad pública contratante. Estamos ante un modo sui generis de realización del interés general", en GOSÁlBEZ PEQUEÑO, H., El contratista de la Administración Pública, Marcial Pons - Cámara de Cuentas de Andalucía, Madrid, 2000, pág. 16. Con anterioridad, ARIÑO ORTIZ ya había manifestado que el contratista debía ser un "fiel colaborador" de la Administración en las finalidades que se le encomiendan, en ARIÑO ORTIZ, G., La reforma de la Ley de Contratos del Estado, Unión Editorial, Madrid, 1984, pág. 61. 
- La Directiva 2014/25/UE, del Parlamento Europeo y del Consejo, de 26 de febrero de 2014, relativa a la contratación por entidades que operan en los sectores del agua, la energía, los transportes y los servicios postales y por la que se deroga la Directiva 2014/17/CE («sectores especiales») ${ }^{9}$.

Estas dos últimas Directivas establecen las condiciones de participación en los procedimientos de contratación bajo el epígrafe general de «selección cualitativa», centrándose en los requisitos de idoneidad de aquellos que quieren tomar parte de un procedimiento de adjudicación y poder, así, resultar elegidos contratistas $^{10}$.

Estos criterios están vinculados, en esencia, a la apreciación de la aptitud de los licitadores/candidatos para ejecutar el contrato y establecen los requisitos positivos que deben cumplir estos operadores económicos (que sean capaces, solventes y honestos), a la vez que facultan a las entidades contratantes para que impidan participar en un procedimiento de contratación pública a aquellos

${ }^{9}$ Estas Directivas entraron en vigor el 17 de abril de 2014, veinte días después de su publicación en el Diario Oficial de la Unión Europea (DOUE L 94, de 28 de marzo de 2014), si bien hasta el 18 de abril de 2016 - fecha límite para su transposición las Directivas 2004/17/CE («sectores especiales») y 2004/18/CE («sectores clásicos») siguen estando vigentes, puesto que las Directivas del año 2014 sólo son aplicables en aquellos Estados miembros en los que ya han entrado en vigor las medidas de transposición. Para completar la regulación europea debemos referirnos también a las disposiciones recogidas en las Directivas en materia de recursos y a la Directiva 2009/81/CE del Parlamento Europeo y del Consejo, de 13 de julio de 2009, sobre los procedimientos de adjudicación contractual en los ámbitos de la defensa y de la seguridad (DOUE L 216, de 20 de agosto).

${ }^{10} \mathrm{El} \mathrm{TJUE} \mathrm{ha} \mathrm{diferenciado,} \mathrm{en} \mathrm{distintas} \mathrm{ocasiones,} \mathrm{entre} \mathrm{los} \mathrm{criterios} \mathrm{denominados}$ de «selección cualitativa» y los criterios de adjudicación de un contrato, aclarando que los denominados criterios de selección cualitativa tienen por cometido la comprobación de la aptitud de los licitadores que es llevada a cabo por las entidades adjudicadoras de conformidad con los criterios de capacidad económica, financiera y técnica, mientras que los criterios de adjudicación están relacionados con el objeto del contrato y sirven para identificar la oferta económicamente más ventajosa. Véase, a este respecto, las sentencias de 19 de junio de 2003, GAT, C-315/01, apartados 59 a 64; de 24 de enero de 2008, Lianakis, C-532/06, apartado 27; de 12 de noviembre de 2009, Comisión/Grecia, C-199/07; de 9 de octubre de 2014, España/Comisión, C-641/13P, apartado 36 (que confirma la sentencia del Tribunal General de 16 de septiembre de 2013, España/Comisión, T-2/07), y de 18 de diciembre de 2014, Ambisig, C-601/03. 
cuyas cualidades profesionales no sean suficientes para la correcta ejecución del contrato o hayan mostrado un comportamiento ímprobo ${ }^{11}$. Es decir, determinan quién puede y quién no puede ser contratista en atención a la situación personal del candidato o licitador, a su capacidad económica y financiera, a sus conocimientos técnicos, a su experiencia, - y más allá de los conocimientos técnicos - a su fiabilidad o "capacidad moral" en denominación utilizada por nuestro Tribunal Supremo ${ }^{12}$, estableciendo los supuestos en los cuales se puede excluir de los procedimientos de adjudicación a determinados sujetos.

Los motivos de exclusión encuentran acomodo en el artículo 38 de la Directiva 2014/23/UE («concesiones»), en el artículo 57 de la Directiva 2014/24/UE y en el artículo 80 de la Directiva 2014/25/UE («sectores especiales») con remisión expresa al contenido de la Directiva en los sectores clásicos, que es también la norma a la que vamos a referirnos principalmente.

Estos preceptos requieren, por una parte, excluir de la participación en un contrato público a aquellos operadores económicos condenados en sentencia judicial firme por determinados tipos delictivos o por haber sido sancionados por incumplir sus obligaciones tributarias o con la seguridad social (artículo 57, apartados 1 y 2 de la Directiva 2014/24/UE); y, por otra, establecen la posibilidad de excluir de la participación en un contrato público a cualquier operador económico que esté incurso en alguno de los diez supuestos contemplados en los apartados 2 - segundo inciso - y 4 del citado artículo 57. Los primeros los vamos a agrupar bajo la consideración de prohibiciones de contra-

\footnotetext{
${ }^{11}$ La calificación de requisitos positivos - en referencia a la capacidad y a la solvencia - y negativos - en alusión a las prohibiciones de contratar - la encontramos en MORELL OCAÑA, L., "Requisitos de los contratos. Capacidad y solvencia de las empresas (arts. 10 a 23 de la Ley)", en la obra colectiva Comentario a la Ley de Contratos de las Administraciones Públicas, Civitas, Madrid, 1996, pág. 141; GIL IBÁÑEZ, J.L., "La capacidad para contratar y la clasificación de los contratistas", Actualidad Administrativa, núm. 46, diciembre 1995, págs. 845 - 879; GOSÁLBEZ PEQUEÑO, H., El contratista (...), op. cit., pág. 76 y VÁLCARCEL FERNÁNDEZ, P., "Promoción de la igualdad de género a través de la contratación pública", en la obra colectiva Contratación pública estratégica, Aranzadi, Cizur Menor (Navarra), 2013, pág. 336.

${ }^{12}$ Sentencias de 24 noviembre de 2004 (RJ 2004\8061); de 2 febrero de 2005 (RJ 2005\1650); de 28 de marzo de 2006 (RJ 2006\5062); de 30 enero de 2007 (RJ 2007\830); de 21 marzo de 2007 (RJ 2007\4043) y de 26 diciembre de 2007 (RJ $2008 \backslash 840)$.
} 
tar de carácter obligatorio y los segundos - dado que se inscriben en un marco dispositivo para los Estados miembros - los veremos bajo la consideración de prohibiciones de contratar de carácter facultativo.

En ambos casos, el legislador europeo encomienda a los Estados miembros las condiciones de aplicación de estas prohibiciones que, en todo caso, deben satisfacer las exigencias requeridas en estos artículos - evitar contratar con quien no es merecedor de la confianza suficiente - desde el respeto a los principios básicos de la contratación pública: transparencia, igualdad de trato, no discriminación, concurrencia y proporcionalidad ${ }^{13}$.

Con carácter general, las prohibiciones son medidas que limitan la actuación de una persona física o jurídica para la realización de ciertas actividades. Aplicadas al ámbito de la contratación pública, y desde la perspectiva del operador económico, se configuran como actos desfavorables en cuanto restringen su posibilidad de participar en un procedimiento de licitación. Así pues, pueden definirse como impedimentos legales para poder contratar con una entidad del sector público al descalificar de los procedimientos de adjudicación a quienes incurran en una serie de supuestos y circunstancias recogidos en la normativa contractual, pero que técnicamente - y en términos civilistas - no suponen una incapacidad de obrar ${ }^{14}$.

\footnotetext{
${ }^{13} \mathrm{El}$ TJUE ha analizado en distintas ocasiones las causas de prohibición de contratar. A lo largo de esta memoria doctoral, vamos a hacer referencia a sus sentencias de 9 de febrero de 2006, La Cascina y otros, C-226/04 y C-228/04; de 16 de diciembre de 2008, Michaniki, C-213/07; de 19 de mayo de 2009, Assitur, C-538/07; de 23 de diciembre de 2009, Serrantoni, C-376/08; de 15 de julio de 2010, Bâtiments y Ponts Construction, C-74/09; de 13 de diciembre de 2012, Forposta SA, C-465/1; de 10 de julio de 2014, Consorzio Stabile, C-358/12; de 6 de noviembre de 2014, Cartiera dell'Adda, C-42/13; de 11 de diciembre de 2014, Croce Amica One Italia, C-440/13 y de 18 de diciembre de 2014, Generali-Providencia Biztosító, C-470/13. Por lo que respecta a los conflictos de intereses, también nos referiremos a la sentencia de 12 de marzo de 2015, eVigilo, C-538/13.

${ }^{14} \mathrm{El}$ Consejo de Estado ha venido sosteniendo que la diferencia entre incapacidades para contratar y prohibiciones legales, es clara. Así, "la prohibición significa la selección normativa de unos valores o intereses jurídicos cuya protección se hace efectiva mediante la privación de efectos jurídicos al actuar contrario a los mismos. La incapacidad exige la definición de supuestos de inhabilidad para actuar jurídicamente mediante la realización de concretos negocios o actos jurídicos en razón de la falta de concurrencia de los requisitos mínimos que permitan discernir la existencia de un consentimiento libre y no viciado de quien tiene reconocida su capacidad
} 
En este primer capítulo vamos a realizar una aproximación a la configuración jurídica de las prohibiciones de contratar desde la distinta calificación jurídica que el ordenamiento les viene otorgando. Para ello hemos de partir de una premisa fundamental que condiciona el debate posterior acerca de su régimen jurídico, puesto que atenderemos a su calificación como técnica de regulación económica con un carácter preventivo o punitivo según la normativa que, en cada caso, les resulte de aplicación.

En este sentido, hay que hacer constar que el tratamiento que han recibido las prohibiciones de contratar en nuestro ordenamiento no se agota en la normativa contractual, y es lo suficientemente extenso como para comprender distintas instituciones sometidas a regímenes diferenciados (especialmente, en lo que respecta a su consideración de pena privativa de derechos y sanción administrativa). Esta realidad - que ya avanza su naturaleza heterogénea nos obliga a delimitar la figura de las prohibiciones de contratar sin que, como veremos, tal distinción resulte siempre nítida ${ }^{15}$.

De esta forma, las consideraciones generales que realicemos acerca de su naturaleza se trasladan al concreto campo de su aplicación y atienden tanto al régimen jurídico propio y específico del marco contractual, como a lo que acontece fuera de él puesto que, tal como hemos avanzado, el contenido de las prohibiciones de contratar tiene proyección ad extra sobre los ciudadanos más allá de la regulación contractual.

jurídica general por el Ordenamiento jurídico" (Dictamen núm. 830/1995, 13 de julio de 1995). En estos mismos términos se expresaba el Informe y Conclusiones de la Comisión de expertos para el estudio y diagnóstico de la situación de la contratación pública en España, Ministerio de Hacienda, Madrid, 2014, pág. 102.

${ }^{15}$ En su sentencia de 17 de febrero de 1992 (RJ 1992 \2491), el Tribunal Supremo ponía de relieve que "la Administración ha de seleccionar a aquel de los contratistas, que sin estar incurso en las prohibiciones, incompatibilidades o incapacidades contenidas en las disposiciones legales y reglamentarias aplicables, más garantías ofrezca" (FJ tercero). Incluso, desde la normativa contractual, se ha puesto en evidencia la diferente naturaleza de los supuestos comprendidos bajo la categoría genérica de prohibiciones de contratar, y muestra de ello son los artículos 4 y 5 del Reglamento de Contratación de las Corporaciones Locales, de 9 de enero de 1953; la Ley Foral 6/2006, de 9 de junio, de Contratos Públicos de Navarra, que en su artículo 20, se refiere a los supuestos de incompatibilidad para contratar diferenciándolos de las causas de prohibición de contratar de su artículo 18. 
Ahora bien, centrado el tema en estos términos, el análisis de esta figura requiere también de una interpretación acorde con las notas características expuestas desde la jurisprudencia y la doctrina ${ }^{16}$, puesto que su concreción permitirá superar posibles disfunciones en la calificación de la prohibición de contratar exclusivamente como medida administrativa de carácter restrictivo.

Con carácter previo al análisis de la naturaleza jurídica y fundamentos de las prohibiciones de contratar, abordaremos una cuestión de carácter terminológico que busca mantener la relación entre las distintas expresiones empleadas por el legislador, tanto europeo como nacional, para referirse a esta

${ }^{16}$ En este sentido, y a título de ejemplo, resultan de interés las aportaciones doctrinales de SALA ARQUER, J. M., "La prohibición de contratar prevista en el art. 20.a) de la nueva Ley de Contratos de las Administraciones Públicas", en la obra colectiva Estudios sobre el ordenamiento jurídico español. Libro conmemorativo del X aniversario de la Facultad de Derecho, Universidad de Burgos, Burgos, 1996, págs. 637 - 654; MARTÍN-RETORTILLO BAQUER, S., "La prohibición de contratar establecida en el artículo 20 a) de la Ley de Contratos de las Administraciones Públicas", La Ley, núm. 4037, de 16 de mayo de 1996; FUERTES LÓPEZ, M., El contratista y el subcontratista ante las Administraciones públicas, Marcial Pons, Madrid, 1997; PISELLI, E., "The scope for excluding providers who have committed criminal offences under the EU Procurement Directives", Public Procurement Law Review, vol. 9 (6), 2000, págs. 267 - 286; FENELLÓS PUIGCERVER, V., "Prohibiciones de contratar", en la obra colectiva Comentarios a la Ley de Contratos de las Administraciones Públicas, Tomo II. La gestación del contrato, Comares, Granada, 2003, págs. 71 - 164; WILLIAMS, S., "The mandatory exclusions for corruption in the new EC Procurement Directives", European Law Review, vol. 31 (5), October 2006, págs. 711 - 734; MEDINA ARNÁIZ, T., "Grounds for exclusion in public procurement: Measures in the fight against corruption in European Union", II International Public Procurement Conference, Roma, 2006; CEA AYALA, Á., "Breves reflexiones acerca de las prohibiciones para contratar", Contratación Administrativa Práctica, núm. 67, septiembre 2007, págs. 26 - 40; BERMEJO VERA, J., "Las prohibiciones de contratar en la Ley de Contratos del Sector Público", Revista Aragonesa de Administración Pública, núm. monográfico El Derecho de los Contratos del Sector Público, 2008, págs. 109-140 y del mismo autor la Voz "Prohibiciones de contratar", en el Diccionario de Contratación Pública, Iustel, Madrid, 2009, págs. 537 - 552; GALLEGO CÓRCOLES, I., "Capacidad y solvencia del empresario", en la obra colectiva Contratación del sector público local, $2^{\mathrm{a}}$ ed., La Ley - El Consultor de los Ayuntamientos, Madrid, 2010, especialmente págs. 404 a 451; FERESIN, E., Le cause di esclusione negli appalti pubblici, Giuffrè Editore, Milán, 2011 y MEDINA ARNÁIZ, T., "La regulación europea de las prohibiciones de contratar y su aplicación según la jurisprudencia del Tribunal de Justicia de la Unión Europea", en la obra colectiva Observatorio de Contratos públicos 2014, Thomson Reuters, Cizur Menor (Navarra), 2015, págs. 173 - 194. 
figura. Una visión panorámica del ordenamiento jurídico nos muestra la variedad de términos y expresiones utilizados, razón que justifica el que a lo largo de esta memoria doctoral usemos determinadas expresiones como sinónimas sin que estrictamente lo sean, ya que - aunque las circunstancias que impiden contratar con el sector público requieren de una interpretación estricta - ello no implica que los términos empleados para su calificación hayan de interpretarse de igual manera.

\section{Precisiones conceptuales}

A través de las prohibiciones de contratar, el ordenamiento jurídico anuda determinadas consecuencias jurídicas - que en el supuesto que estudiamos es la imposibilidad de contratar - originadas en un motivo de desconfianza respecto de quienes proyectan ser contratistas públicos y que, según los diferentes supuestos contemplados en la normativa, evidencian una doble preocupación: de una parte, encontrar al contratista que aporte las garantías necesarias para la correcta ejecución del contrato y, a su vez, no contratar con aquéllos que, de una forma u otra, han violentado la legislación o han incumplido sus obligaciones.

Ahora bien, las expresiones utilizadas por el legislador para referirse a esta imposibilidad de contratar con las entidades del sector público son de lo más dispares, y como hemos avanzado no se encuentran recogidas, exclusivamente, en la legislación contractual.

Así, la normativa europea muestra predilección por aquellos términos que reflejen la contraposición entre los criterios de selección y los de exclusión aplicables al contrato, y que se recogen principalmente en expresiones tales como «motivos de exclusión ${ }^{17} \mathrm{y}$ «criterios de exclusión» ${ }^{18}$, si bien también

${ }^{17}$ Artículo 57 de la Directiva 2014/24/UE y artículo 80 de la Directiva 2014/25/UE.

${ }^{18}$ Por ejemplo, en el Reglamento (UE, Euratom) 966/2012 del Parlamento Europeo y del Consejo, de 25 de octubre de 2012, sobre las normas financieras aplicables al presupuesto general de la Unión (DOUE L 298, de 26 de octubre de 2012) y en la Decisión 2007/643/PESC del Consejo, de 18 de septiembre de 2007, relativa al Reglamento financiero de la Agencia Europea de Defensa y a las normas sobre 
se refiere a las condiciones de participación, «criterios de admisibilidad ${ }^{19}$, «impedimentos a la adjudicación ${ }^{20}$, «criterios de elegibilidad aplicables a la adjudicación del contrato» ${ }^{21}$ e «impedimentos a la adjudicación ${ }^{22}$.

En la normativa contractual de los Estados miembros, los términos empleados para abordar las prohibiciones de contratar aluden mayoritariamente a los criterios en materia de selección cualitativa del contratista ${ }^{23}$, a la situación personal de los licitadores y candidatos ${ }^{24}$ y a las reglas de acceso a los procedi-

contratación pública y sobre contribuciones financieras con cargo al presupuesto operacional de la Agencia Europea de Defensa (DOUE L 269, de 12 de octubre).

${ }^{19}$ Artículo 4.2 de la Decisión del Consejo, de 16 de diciembre de 1991, por la que se aprueban las disposiciones generales, las condiciones generales y las normas de procedimiento para la conciliación y el arbitraje, relativos a los contratos de obras, de suministros y de servicios financiados por el Fondo Europeo de Desarrollo (FED), y sobre su aplicación en el marco de la asociación de los países y territorios de ultramar a la Comunidad Económica Europea (DOCE L 40, de 15 de febrero de 1992).

${ }^{20}$ Artículo 68 de la Propuesta de Directiva relativa a la contratación pública, COM (2011) 896 final, de 20 de diciembre de 2011 y artículo 78 de la Propuesta de Directiva relativa a la contratación por entidades que operan en los sectores del agua, la energía, los transportes y los servicios postales, COM (2011) 895, de la misma fecha.

${ }^{21}$ Decisión 3/90 del Consejo de Ministros ACP-CEE, de 29 de marzo de 1990, por la que se aprueban las disposiciones generales, las condiciones generales y las normas de procedimiento para la conciliación y el arbitraje, relativos a los contratos de obras, de suministros y de servicios financiados por el Fondo Europeo de Desarrollo (FED), y sobre su aplicación (DOCE L 382, de 31 de diciembre) y artículo 8 del Reglamento (UE) 236/2014 del Parlamento Europeo y del Consejo, de 11 de marzo de 2014, por el que se establecen normas y procedimientos de ejecución comunes de los instrumentos de la Unión para la financiación de la acción exterior (DOUE L 77, de 15 de marzo de 2014).

${ }^{22}$ Artículo 68 de la Propuesta de Directiva relativa a la contratación pública, COM (2011) 896 final, de 20 de diciembre de 2011 y artículo 78 de la Propuesta de Directiva relativa a la contratación por entidades que operan en los sectores del agua, la energía, los transportes y los servicios postales, COM (2011) 895, de la misma fecha.

${ }^{23}$ En Malta, el artículo 50 (4) del Reglamento de Contratos Públicos, aprobado por Legal Notice 296/2010, de 1 de junio de 2010 (S.L.174.04), modificado por Legal Notice 68/2015.

${ }^{24}$ Por ejemplo, en la legislación rumana los artículos 180 y 181 del Decreto del Gobierno 34/2006, modificado en junio de 2014 (Ordonanţa de Urgenţă a Guvernului 
mientos de adjudicación de un contrato público ${ }^{25}$. Sin embargo, de la variedad de expresiones hemos de subrayar, en primer lugar, aquellas que se refieren a los motivos de exclusión como sucede, por ejemplo, en el Derecho húngaro «Kizáró okok» ${ }^{26}$, en el Derecho austríaco «Ausschlussgründe» ${ }^{27}$, en la Ley de contratos públicos letona «Kandidātu un pretendentu izslēgšanas noteikumi» (criterios de exclusión de los candidatos y licitadores) ${ }^{28}$, por el Derecho neerlandés «Uitsluitingsgronden» ${ }^{29}$, y en la regulación del Reino Unido «Exclusion grounds» ${ }^{30}$.

En segundo lugar, tenemos igualmente que destacar aquéllas que aluden a los impedimentos para contratar ${ }^{31}$, a las prohibiciones de licitar (Interdictions de soumissionner $)^{32}$ y a la descalificación del contrato que se encuentran más próximas a la terminología utilizada por nuestro legislador.

nr. 34/2006); el artículo 51 de la Ley chipriota 12(I) de 2006 (Personal situation of the candidate or tenderer) o el artículo 26 de la Ley eslovaca de adjudicaciones públicas 25/2006, de 14 de diciembre de 2005 (Zákon č. 25/2006 Z).

${ }^{25}$ Artículo 20.1 de la Ley belga de 15 de junio de 2006, relativa a los contratos públicos y a determinados contratos de obras, suministros y servicios (versión de 15 de mayo 2014) Loi relative aux marchés publics et à certains marchés de travaux, de fournitures et de services (Droit d'accès et sélection qualitative).

${ }^{26}$ Tanto en el artículo 56 de la Ley CVIII de 2011, relativa a la adjudicación de contratos públicos (2011. évi), en su versión consolidada de 1 de julio de 2015, como en el artículo 62 de la Ley CXLIII de 22 de septiembre de 2015 (2015. évi) en vigor desde el 1 de noviembre de 2015.

${ }^{27} \S 68$ de la Ley Federal de adjudicación de contratos públicos 2006 - BverG 2006 (Bundesvergabegesetz 2006). Actualizada BGBl. II Nr. 292/2014.

${ }^{28}$ Artículo 39 (1) de la Ley de contratos públicos (Publisko iepirkumu likums).

${ }^{29}$ Artículo 2.86 de la Ley de adquisiciones públicas (Aanbestedingswet 2012).

${ }^{30}$ Artículo 57 Public Contracts Regulations 2015.

${ }^{31}$ En la legislación portuguesa, el artículo 55 del Código da Contratação Pública.

${ }^{32}$ En la legislación francesa, los artículos 45 (Interdictions de soumissionner obligatoires et générales), 46 (Interdictions de soumissionner obligatoires propres aux marchés publics de défense ou de sécurité) y 48 (Interdictions de soumissionner facultatives) de la Ordenanza 2015-899, de 23 de julio de 2015, sobre contratación pública, cuya entrada en vigor se fija a más tardar para el 1 de abril de 2016. Ordonnance n. ${ }^{\circ} 2015-899$ du 23 juillet 2015 relative aux marchés publics (JORF n. ${ }^{\circ}$ 169, du 24 juillet 2015). 
El examen de la normativa española - tanto vigente como derogada - nos conduce también a hablar de una amplia variedad en el uso de las expresiones que remiten a la intención de impedir la contratación a las personas, físicas o jurídicas, que se hallen comprendidas en alguno de los supuestos contemplados por las distintas normas. Así, nos encontramos locuciones tales como «limitaciones para contratar ${ }^{33}$, «prohibición para celebrar contratos» ${ }^{34}$, «inhabilitación para contratar $»^{35}$, «inhabilitación para ser titular de contra-

${ }^{33}$ Artículo 92.2 de la Ley 13/2003, de 17 de diciembre, de Defensa y Protección de los Consumidores y Usuarios de Andalucía: "La imposición de las sanciones previstas en esta Ley comportará limitaciones para contratar con la Administración en los casos y condiciones que establezca la legislación sobre contratos de las Administraciones Públicas" y artículo 341-8 de la Ley 22/2010, de 20 de julio, del Código de consumo de Cataluña.

${ }^{34}$ A título de ejemplo cabe citar, el artículo 34.3 de la Ley 21/1992, de 16 de julio, de Industria; el artículo 222.2 de la Ley 2/2001, de 25 de junio, de Ordenación Territorial y Régimen Urbanístico del Suelo de Cantabria; el artículo 81 de la Ley de Hacienda de Castilla-La Mancha, aprobada por Decreto legislativo 1/2002, de 19 de noviembre; los artículos 62, 63 y 65 de la Ley 38/2003, de 17 de noviembre, General de Subvenciones; el artículo 35.3 de la Ley 8/2004, de 12 de noviembre, de Industria de la Comunidad Autónoma de Euskadi; el artículo 154.3 de la Ley 11/2006, de 11 de diciembre, de Hacienda de Canarias; el artículo 60.2 de la Ley 9/2007, de 13 de junio, de subvenciones de Galicia; el artículo 55.2 de la Ley 5/2008, de 25 de septiembre, de subvenciones de Castilla y León; el artículo 68.2 de la Ley 6/2011, de 23 de marzo, de subvenciones de Extremadura; el artículo 190 de la Ley 11/2013, de 21 de octubre, de Hacienda Pública de La Rioja; el artículo 160 de la Ley $1 / 2015$, de 6 de febrero, de Hacienda Pública, del Sector Público Instrumental y de Subvenciones de Valencia y los artículos 69 y 70 de la Ley 5/2015, de 25 de marzo, de Subvenciones de Aragón.

${ }^{35}$ Por ejemplo, en los derogados artículos 20.h) de la Ley 13/1995, de 18 de mayo, de Contratos de las Administraciones Públicas y del Real Decreto Legislativo 2/2000, de 16 de junio, por el que se aprueba el texto refundido de la Ley de Contratos de las Administraciones Públicas. Asimismo, en el artículo 33.7.f) del Código Penal al señalar las penas aplicables a las personas jurídicas; en el artículo 44.2 de la Ley Foral $7 / 2006$, de 20 de junio, de defensa de los consumidores y usuarios de Navarra; en el artículo 132.1.f) de la Ley 4/2009, de 11 de junio, de servicios sociales de las Illes Balears y en el artículo 130.2.c) de la Ley 5/2014, de 9 de octubre, de Protección Social y Jurídica de la Infancia y la Adolescencia de Castilla-La Mancha. 
tos $»^{36}$, «inhabilitación para suscribir contratos ${ }^{37}$, «exclusión de la adjudicación $»^{38}$, «circunstancias incapacitantes para contratar $»^{39}$, «imposibilidad de contratar $»^{40}$, «pérdida del derecho a la adjudicación ${ }^{41}$, «casos de excepción ${ }^{42}$,

${ }^{36}$ Artículo 87.1.b) de la Ley 21/2007, de 18 de diciembre, de Régimen Jurídico y Económico de los Puertos de Andalucía; artículo 128.5 de la Ley 5/2011, de 30 de septiembre, del Patrimonio de la Comunidad Autónoma de Galicia al tratar la "inhabilitación del infractor, por un plazo de uno a cinco años, para ser titular de autorizaciones y concesiones o contratar con cualquier administración pública gallega" y el artículo 104 de la Ley 6/2011, de 1 de abril, de movilidad de la Comunidad Valenciana al prever la "inhabilitación del infractor durante un período de tres años, en la Comunitat Valenciana, para ser titular de cualquier clase de contrato, autorización o licencia habilitante"

${ }^{37}$ Artículo 60.2.d) de la Ley 10/1997, de 19 de diciembre, de ordenación del Turismo de Castilla y León.

${ }^{38}$ Artículo 29.4 de la Ley $7 / 2000$, de 23 de noviembre, de ordenación de aprovechamiento de pastos, hierbas y rastrojeras de Castilla-La Mancha al señalar que "En el caso de las infracciones graves y muy graves, además de las multas, podrá imponerse la exclusión de la adjudicación de pastos por un período de hasta tres años y la pérdida del derecho a pastos".

${ }^{39}$ Artículo 41.1 de la Ley 6/2006, de 17 de julio, de Patrimonio de la Comunidad Autónoma de Canarias.

${ }^{40} \mathrm{El}$ artículo 73 de la Ley Foral 13/2000, de 14 de diciembre, General Tributaria de Navarra señala la"imposibilidad de contratar durante el mismo tiempo (periodo máximo de dos años) con la Administración de la Comunidad Foral y otros entes públicos". Además de ello, y aunque propiamente no se trate del mismo supuesto, en el artículo 24.6 del Texto refundido de la Ley de Contratos del Sector Público al tratar de los medios propios se refiere a "la imposibilidad de participar en licitaciones públicas convocadas por los poderes adjudicadores de los que sean medios propios".

${ }^{41}$ Artículo 95 de la Ley 7/2006, de 22 de junio, de protección ambiental de Aragón, y artículos 34 y 35 de la Ley 22/2007, de 18 de diciembre, de Farmacia de Andalucía (modificada por Decreto Ley $3 / 2014$, de 8 de abril).

${ }^{42}$ Artículo 48 de la Ley de 20 de diciembre de 1952 por la que se sustituye la redacción del Capítulo V de la Ley de Administración y Contabilidad de la Hacienda Pública, de 1 de julio de 1911, relativo a los contratos para la ejecución de obras y servicios públicos, que señalaba que "Están facultadas para concertar con la Administración contratos para la ejecución de obras y servicios públicos las personas naturales y jurídicas, nacionales o extranjeras, que hallándose en plena posesión de sus capacidades jurídica y de obrar no estén comprendidas en alguno de los casos de excepción señalados por la presente Ley o por cualquier otra disposición que especialmente los establezca" (ver volumen segundo de esta memoria doctoral). 
«causa de exclusión para contratar»y «causas de exclusión de los licitadores ${ }^{43}$.

No obstante, entre todas estas expresiones destacan - tanto por la frecuencia en su utilización, como por recogerse expresamente en la legislación contractual - dos locuciones: «prohibiciones de contratar» 44 y «prohibiciones para contratar ${ }^{45}$.

Conviene, pues, precisar la conveniencia, o no, de la utilización de una expresión frente a otra y, a su vez, aclarar si la diferente terminología empleada por el legislador condiciona una interpretación distinta según los casos, puesto que la normativa parece utilizar de manera indistinta las dos expresiones para referirse a la misma figura impeditiva ${ }^{46}$.

El Texto refundido de la Ley de Contratos del Sector Público (TRLCSP), recoge en su artículo 60 - bajo el enunciado «prohibiciones de contratar» - una serie de circunstancias que impiden la contratación con los entes, organismos y entidades del sector público. De este título y del tenor de este artículo, se deduce una preferencia del legislador nacional en el uso de la expresión prohibiciones de contratar ${ }^{47}$; sin embargo, pese a lo afirmado, lo cierto es que, sin

${ }^{43}$ Artículos 18 a 20 de la Ley Foral 6/2006, de 9 de junio, de Contratos Públicos.

${ }^{44} \mathrm{Al}$ margen de la legislación contractual, vamos a citar el artículo 177.4.a) de la Ley balear $2 / 2014$, de 25 de marzo, de ordenación y uso del suelo y el artículo 60 de la Ley catalana 17/2015, de 21 de julio, de igualdad efectiva de mujeres y hombres.

${ }^{45}$ También al margen de la normativa contractual, el artículo 186 de la Ley 58/2003, de 17 de diciembre, General Tributaria.

${ }^{46}$ Nos referimos a la normativa vigente, pero las mismas afirmaciones que aquí sostenemos se pueden mantener respecto de la legislación contractual ya derogada y a la futura, a tenor de los Anteproyectos de Ley de Contratos del Sector Público y de Contratos en los sectores específicos del agua, la energía, los transportes y los servicios postales (abril 2015). En este sentido, baste señalar que el Reglamento General de Contratación, aprobado por el Decreto 3410/1975, de 25 de noviembre, en su artículo 23 aludía a las prohibiciones para contratar, mientras que los artículos 23 bis y 23 ter se inclinaban por la locución prohibiciones de contratar. Más novedoso, y a su vez más acertado desde un punto de vista gramatical por la finalidad que la expresión comprende, se mostraba el artículo 286 de este mismo Texto, al indicar "(...) que, teniendo plena capacidad de obrar, no se encuentren incursas en alguna de las prohibiciones que para contratar establece el artículo 23 de este Reglamento".

${ }^{47}$ Esta misma preferencia se manifiesta en la Disposición adicional tercera de la Ley $31 / 2007$, de 30 de octubre, sobre procedimientos de contratación en los sectores 
salir de esta norma, pueden citarse ejemplos donde la expresión empleada es la de prohibición para contratar ${ }^{48}$, refiriéndose incluso a las inhabilitaciones para contratar al fijar los requisitos exigidos al subcontratista y diferenciándolos de los supuestos del artículo 60 (artículo 227.5 del TRLCSP).

De esta forma, para establecer cuál es la expresión más acertada, será necesario acudir a las distintas acepciones que de las proposiciones de y para se nos ofrecen, y de esta manera, hacer un uso más correcto del lenguaje en aras a una mayor claridad expositiva.

En una de las acepciones del Diccionario de la Real Academia Española de la Lengua, la preposición para denota finalidad, "el fin o término a que se encamina una acción", con lo cual, aplicado al supuesto que nos ocupa, su empleo pudiera, en principio, parecer más apropiado que el de la preposición de que no asigna ningún significado que se acerque a la idea de finalidad que encierra la citada prohibición. No obstante, lo cierto es que una singularidad de nuestra lengua radica en el uso desmesurado que, en ocasiones, hacemos de la preposición de seguida de un infinitivo para expresar relaciones que normalmente implican una finalidad y que, por tanto, debieran expresarse con la preposición para $^{49}$.

Con todo, desde un punto de vista gramatical, podemos afirmar que resulta indiferente el empleo de una preposición u otra. Son expresiones equivalentes que no hacen variar su sentido ya que, en último extremo, las dos están acep-

del agua, la energía, los transportes y los servicios postales; en el artículo 12 de la Ley 24/2011, de 1 de agosto, de contratos del sector público en los ámbitos de la defensa y de la seguridad y en el artículo 13 del Reglamento General de Contratación Pública de la Comunidad de Madrid, aprobado por Decreto 49/2003, de 3 de abril.

${ }^{48}$ Por ejemplo, el mismo artículo 60, en su apartado segundo, al señalar las circunstancias que impiden contratar con las Administraciones públicas. También en el artículo 111 de la Ley Foral 6/2006, de 9 de junio, de Contratos Públicos de Navarra, en su modificación por parte de la Ley Foral 32/2013, de 31 de octubre, o en los artículos 33.1 y 35.1 de la Ley $3 / 2007$, de 4 de julio, de la obra pública de Cataluña.

${ }^{49}$ En este sentido, el Diccionario de uso del español, de María MOLINER, 3. ${ }^{\text {a }}$ ed., Gredos, 2007, dentro de los significados de la preposición de, nos señala diferentes ejemplos de lo aquí afirmado, tales como goma de mascar, máquina de escribir, o ¿qué tenemos hoy de cena?, donde sería más apropiado utilizar la proposición para por indicar una finalidad, pero en los cuales el uso de la preposición de está comúnmente aceptado y generalizado. 
tadas por su conexión sintáctica con lo pretendido por la norma.

Mayores dificultades interpretativas, apelando al tenor literal de la norma y al óptimo uso de la lengua castellana, presenta la calificación de estos supuestos impeditivos como «causas de exclusión» ${ }^{50}$. La referencia a los criterios de exclusión no se puede considerar equivalente, en todo caso, a las prohibiciones de contratar, puesto que la exclusión de un procedimiento de adjudicación no siempre procede de la situación personal en la que se encuentra el licitador o el candidato. En ocasiones, dicha exclusión viene motivada por causas que se refieren a la propia oferta, como pudiera ser el (i) no presentar la documentación exigida en plazo y/o en forma ${ }^{51}$; (ii) por una incorrecta presentación de la documentación en los sobres; (iii) que la propuesta del licitador no cumpla con los requerimientos de los pliegos (por ejemplo, por incumplimiento de las especificaciones técnicas en la oferta del licitador), y en todos estos supuestos se produce la exclusión del licitador sin que realmente esté incurso en una

\footnotetext{
${ }^{50} \mathrm{Tal}$ como hemos indicado, el término "exclusión" se encuentra presente en las nuevas Directivas sobre contratos públicos, en la Ley de Contratos Públicos de Navarra y en la normativa de distintos Estados miembros al enumerar los criterios que conllevan la imposibilidad de participar en un procedimiento de adjudicación. En esta línea se manifestaban, BOURGOIN, P., "Les exclusions de marchés publics", RMP, núm. 208, 1985, págs. 27 - 31; BRÉCHON-MOULÈNES, C., Droit des marchés publics. Exclusions (epígrafe III. 410.1), Le Moniteur, París, 1998; HOLLARD, V., L'exclusion des marchés publics, Chambre de commerce et d'industrie de Paris, 6 juillet 1989 (Annexe au rapport sur le projet de réforme du Code penal); y LAUBADĖRE, A., MODERNE, F. y DELVOLVÉ, P., Traité des contrats administratifs, Tomo I, LGDJ, Paris, 1983, págs. 548 y ss. Respecto de las nuevas Directivas, hemos de destacar los trabajos de SÁNCHEZ GRAELLS, A., "Exclusion, Qualitative Selection and Short-Listing in the New Public Sector Procurement Directive 2014/24", en la obra colectiva Modernising Public Procurement: The New Directive, DJØF Publishing, Copenhague, 2014, págs. 97 - 129 y PRIESS, H-J., "The Rules on Exclusion and Self-Cleaning under the 2014 Public Procurement Directive", Public Procurement Law Review, vol. 23 (3), 2014, págs. 112 - 123.

Nuestro Tribunal Supremo también se hizo eco de esta nueva terminología y así, la STS de 30 de octubre de 2001 (RJ 2002\496), en su fundamento jurídico octavo, afirma que "(...) alude como posibles licitadores, a quienes no estén comprendidos en ninguna de las causas de exclusión previstas en las normas de contratación del régimen local (...)".

${ }^{51}$ Por ejemplo, el TJUE analiza en el asunto RegioPost, C-115/14, la exclusión del procedimiento de adjudicación cuando el licitador se niega a aportar una declaración de compromiso relativa al salario mínimo a pagar a sus trabajadores.
} 
prohibición de contratar ${ }^{52}$.

Es así que, en una tarea propia de depuración conceptual, aunque las causas de exclusión no se vinculen únicamente a la falta de aptitud para poder contratar con el sector público, todos los supuestos de prohibiciones de contratar dan origen a la exclusión de la participación en el contrato de todo operador económico que se encuentre incurso en alguno de ellos ${ }^{53}$.

En coherencia con ello, y a pesar de la variedad de términos empleados sin que propiamente se trate de expresiones sinónimas ${ }^{54}$, en esta memoria doctoral se utilizarán con un significado equivalente y compatible con la intención del legislador de concretar los requisitos para participar en un proceso de adjudicación contractual, y de conformidad con lo dispuesto en las Directivas de la Unión que se refieren expresamente a "motivos de exclusión".

\footnotetext{
${ }^{52}$ Así pues, e incidiendo en este particular, nos encontramos con numerosas sentencias del TS y resoluciones de los distintos Tribunales Administrativos de Recursos Contractuales de nuestro país que se refieren a la exclusión de un licitador en un procedimiento de adjudicación sin que exista conexión directa con las prohibiciones de contratar. A título de ejemplo, y acudiendo a la cronología más reciente, cabe señalar las sentencias de 22 de mayo de 2013 (RJ 2013 \5596) y de 30 de abril de 2014 (RJ 2014 \2685); las Resoluciones del Tribunal Administrativo Central 505/2015, de 28 de mayo, 546/2015, de 11 de junio y 661/2015, de 17 de julio; las Resoluciones 58/2015, de 6 de mayo y 79/2015, de 29 de julio, del Tribunal Administrativo de Contratos Públicos de Aragón; la Resolución 171/2015, de 12 de mayo del Tribunal Administrativo de Recursos contractuales de la Junta de Andalucía y la Resolución 74/2015, de 21 de mayo, del Tribunal de Contratación Pública de la Comunidad de Madrid.

${ }^{53}$ En este sentido se manifiesta el artículo 20.1 de la Ley Foral 6/2006, de 9 de junio de Contratos Públicos al indicar que "será causa de exclusión para contratar la concurrencia, en la persona física o en los administradores de la persona jurídica licitadora, de algún supuesto de incompatibilidad para contratar recogido en la legislación específica que resulte aplicable en cada caso".

${ }^{54}$ La variedad de expresiones utilizadas para referirse a esta materia no es exclusiva de nuestro idioma. WILLIAMS-ELEGBE alude a los términos disqualification, debarment, exclusion, suspension, rejection o blacklisting, con sus significados propios dependiendo del ámbito en el que van a ser usados, en WILLIAMS-ELEGBE, S., Fighting Corruption in Public Procurement: A Comparative Analysis of Disqualification Measures, Hart Publishing, Oxford, 2012, pág. 31 y en BOLTON, P., "The Exclusion of Contractors from Government Contract Awards", Law Democracy 8 Development, vol. 10 (1), 2006, pág. 28.
} 
A través de estas expresiones intercambiables, concretaremos las circunstancias que justifican que un licitador o candidato quede excluido de participar en la licitación porque, según los casos, denotan una falta de aptitud profesional, de capacidad económica o de credibilidad necesaria que requiere la adecuada selección del contratista para el buen desarrollo de los cometidos involucrados en la contratación pública.

\section{Aproximación a la configuración jurídica de las prohibiciones de contratar}

\section{III.1. Planteamiento del problema}

Hemos señalado cómo la normativa sobre contratación pública exige el cumplimiento previo de ciertos requisitos de capacidad, de solvencia y de honorabilidad para poder contratar con los distintos poderes adjudicadores con el fin de garantizar la idoneidad del licitador para la ejecución de la prestación demandada. De esta manera, la legislación en materia de contratación pública establece límites a la actuación de las autoridades públicas en lo que respecta a la elección de la otra parte contratante, al requerir unas específicas condiciones personales más allá de una necesaria capacidad genérica para poder contratar $^{55}$.

\footnotetext{
${ }^{55}$ BOQUERA OLIVER nos apuntaba que las normas crean el derecho a ser contratista y se lo niegan o restringen a determinadas categorías de personas, en BOQUERA OLIVER, J. M., La selección de contratistas. Procedimiento de selección y contrato, Instituto de Estudios Políticos, Madrid, 1963, pág. 29. Fuera de nuestras fronteras, resultan de interés, FLAMME, M. A., "Los contratos de obras públicas de la Administración", $R A P$, núm. 21, septiembre - diciembre 1956, pág. 38, al mencionar la honorabilidad civil y comercial como restricciones al principio de concurrencia en los contratos públicos de distintos países y citando, entre otros, la exclusión de los empresarios que han faltado a sus deberes patrióticos en tiempos de guerra. Con referencia igualmente a la honorabilidad, JÈZE, G., Principios generales del Derecho Administrativo, Vol. IV, Teoría general de los contratos de la Administración, (Formación. Ejecución de los contratos), Depalma, Buenos Aires, 1950, (traducción de la $3 .^{\mathrm{a}}$ ed., francesa Les principes généraux du droit administratif), pág. 91 "sólo hay que permitir hacer ofertas a las personas que gocen de plena capacidad jurídica y a las sociedades, válidamente constituidas, honorables, solventes, capaces de ejecutar el contrato y que tengan intenciones serias de contratar". Por su parte, PIÑAR
} 
Una vez explicitados los requisitos esenciales para resultar adjudicatario de un contrato - que sea capaz, solvente y fiable - creemos necesario abordar los elementos que el legislador ha establecido como indicadores de falta de fiabilidad o de carencia de una cualidad del operador económico que lo excluye de ser parte de una relación contractual con las entidades públicas ${ }^{56}$. Así pues, por razones vinculadas a los intereses generales que impregnan las compras públicas se prohíbe acceder a la contratación a quienes estén incursos en determinadas situaciones que presumen un peligro manifiesto para el ejercicio de funciones públicas.

En este apartado de esta memoria doctoral, pretendemos analizar la configuración jurídica de estas restricciones desde el efecto que producen en los sujetos a los que afectan en relación al procedimiento contractual y también desde su consideración legal al margen de la legislación contractual. Reconociendo que la distinción entre las incapacidades, incompatibilidades y prohibiciones puede resultar bizantina ${ }^{57}$ - y más desde el punto de vista del operador

MAÑAS y CANALES GIL, se referían a "determinadas condiciones de moralidad, que no permitan razonablemente poner en duda la honradez y seriedad del contratista", en "Comentarios al artículo 20. Prohibiciones de contratar", en la obra colectiva Comentarios a la Ley de Contratos de las Administraciones Públicas, Tirant lo Blanch, Valencia, 2003, págs. 129 y 149. PLEITE GUADAMILLAS sostiene que los sujetos que pretenden contratar con la Administración "han de reunir no sólo condiciones de índole económica y de índole técnica, sino también moral", en MORENO MOLINA, J.A. y PLEITE GUADAMILLAS, F., La nueva Ley de Contratos del Sector Público. Estudio sistemático, 3. ${ }^{\text {e }}$ ed., La Ley, Las Rozas (Madrid), 2011.

También deben tenerse en cuenta las sentencias del TS de 9 de febrero de 2001 (RJ 2001 \216), de 24 de enero de 1995 (RJ 1995\316) y de 17 de febrero de 1992 (RJ 1992 $\backslash 2491$ ) que, en sus fundamentos jurídicos tercero, sexto y tercero respectivamente, aluden a la moralidad administrativa como criterio definidor de la selección de los contratistas.

${ }^{56}$ Véase, en este sentido, el apartado 32 de la sentencia del TJUE de 10 de julio de 2014, Consorzio Stabile, C-358/12, al indicar que "un impago de cotizaciones de seguridad social por un operador económico tiende a indicar la falta de fiabilidad, de diligencia y de seriedad de éste por lo que respecta al cumplimiento de sus obligaciones legales y sociales".

${ }^{57}$ Así era calificada por VILLAR PALASÍ, J.L. y VILLAR EZCURRA, J.L., Principios de Derecho Administrativo. Tomo III. Contratación Administrativa, Servicio de publicaciones de la Universidad Complutense de Madrid, Madrid, 1983, pág. 129. 
económico excluido, puesto que para él no van a variar las consecuencias jurídicas de su distinta calificación - entendemos necesaria alguna precisión ${ }^{58}$.

Este análisis adquiere importancia en relación al momento en el que aquellas se originan y a los efectos que producen, ya que en clave nacional: (i) la adjudicación del contrato a personas que se hallen incursas en alguna de las prohibiciones de contratar, es causa de nulidad del contrato. - nulidad que es absoluta, imprescriptible, insubsanable e indisponible para el particular - ; (ii) si la causa de prohibición de contratar se produce después de formalizado el contrato, podemos encontrarnos ante un supuesto de resolución contractual si así se ha contemplado expresamente en los pliegos ${ }^{59}$; (iii) si se trata de una causa de incompatibilidad, estaremos ante un supuesto de extinción del contrato con fundamento en la normativa de incompatibilidades con funcionamiento ope legis $^{60}$, mientras que (iv) la incapacidad sobrevenida del contratista es considerada, en todo caso, causa de resolución del contrato (artículo 223.a) del TRLCSP).

Tras esta aclaración, abordamos el estudio de las prohibiciones de contratar desde el análisis de sus elementos comunes. Estas prohibiciones han sido calificadas por la jurisprudencia como:

- Medidas de garantía del interés público (STS de 2 de octubre del 2000, RJ 2000\8598) ${ }^{61}$;

\footnotetext{
${ }^{58}$ Según manifestaba MORELL OCAÑA, la incapacidad es una técnica de protección del propio incapacitado, de su limitación o déficit en las propias aptitudes naturales; las prohibiciones afectan a sujetos capaces, y se establecen para salvar la moralidad general y las inhabilitaciones incluyen los supuestos de sujetos capaces pero cuya conducta antecedente genera un riesgo que se trata de evitar, en MORELL OCAÑA, L., "Requisitos de los contratos (...)", op. cit., pág. 144.

${ }^{59}$ Sobre la pérdida sobrevenida de los requisitos para contratar con la Administración, véase la STS de 4 de octubre de 2005 (RJ 2005\8752). En este sentido, el Dictamen del Consejo de Estado 1084/95, de 1 de junio de 1995, manifestaba que: "Las prohibiciones, al igual que las incapacidades, impiden contratar a quienes están incursas en ellas; pero, frente a las incapacidades y caso de sobrevenir después de celebrado el negocio jurídico, las prohibiciones no determinan su extinción, salvo que expresamente se haya convenido asi".

${ }^{60}$ Informe 5/2013, de 10 de abril, de la JCCA de Aragón.

${ }^{61}$ En la sentencia del TSJ del País Vasco, de 11 de abril de 2003 (RJ 2003\181644)
} 
- Tachas negativas que impiden la contratación (Sentencia AN de 17 de abril de 2006, RJ 2006\152560). Las sentencias del TS de 24 de noviembre de 2004 (RJ 2004\8061), de 28 de marzo de 2006 (RJ 2006\5062) y de 30 de enero de 2007 (RJ 2007 \830) vinculan la lista de tachas al concepto de honorabilidad ${ }^{62}$;

- Medidas restrictivas de derechos (y de las libertades fundamentales de la UE) que, sin embargo, pueden estar justificadas por razones de interés general (Sentencias del TJUE de 23 de diciembre de 2009, Serrantoni, C-376/08, apartado 44 y de 10 de julio de 2014, Consorzio Stabile, C$358 / 12$, apartados 30 y 31 ).

- Remedios que pretenden garantizar la observancia de los principios de transparencia y de igualdad de oportunidades (Sentencia del Tribunal General de la UE, de 13 de octubre de 2015, Intrasoft International SA, T-403/02, apartado 79 .

- Uno de los efectos de reacción del ordenamiento jurídico a determinadas conductas que se estiman atentatorias a la buena fe y confianza que deben presidir las relaciones entre Administración y quienes contratan con ella o aspiran a ser contratistas (STS de 7 de noviembre de 2006, RJ $2006 \backslash 9055)$.

Igualmente, se precisa que:

- Tienen un efecto restrictivo de la capacidad de obrar, es decir, determinan una incidencia negativa en la esfera jurídica de aquellos a quienes se

se señalaba que "las prohibiciones de contratar son medidas de garantía del interés público, en tanto que constituyen uno de los instrumentos fundamentales de regulación de los mercados de contratación administrativa", FJ 6.

62"Concepto éste, como valor a preservar (...) suficientemente extenso como para comprender situaciones en las que no se ha llegado a una sanción, penal o administrativa, pero la conducta del sujeto que incurre en ella evidencia un notable riesgo para el tráfico jurídico que debe evitarse" FJ 4 de la STS de 30 de enero de 2007. En este sentido, RUIZ OJEDA señalaba que se trataba de "evitar que puedan contratar con la Administración empresas sobre las que recaen tachas o prohibiciones legalmente establecidas", en RUIZ OJEDA, A., "Algunos problemas de regulación de mercados en el ámbito de la contratación de obras públicas", NUE, núm. 219, abril 2003, pág. 54. 
imponen, careciendo de un único fundamento fuera del genérico relativo a la protección del interés público (STS de 7 de noviembre de 2006, RJ $2006 \backslash 9055)$;

- Las prohibiciones por supuestos de incompatibilidad tienen por objeto preservar la «moralidad administrativa», evitando en modo absoluto toda sospecha sobre la rectitud y moralidad en la actuación de todas las personas que intervienen en la vida pública (STS de 17 de febrero de 1992, RJ 1992\2491) $)^{63}$;

- La prohibición de contratar no tiene carácter sancionador, aunque al ser un acto limitativo de derechos se deben aplicar ciertos principios y garantías del procedimiento sancionador (STS de 30 de enero de 2007, RJ 2007\830 y STS de 31 de mayo de 2007, RJ 2007\5402) ${ }^{64}$. Entre estas garantías se encuentran - como no puede ser de otro modo - los principios de tutela judicial efectiva y el respeto por el derecho de defensa ${ }^{65}$;

- Tienen un carácter tasado y deben ser interpretadas con un criterio res-

${ }^{63}$ En esta sentencia del año 1992, el TS se refiere a la importancia de la adhesión de España a las entonces denominadas Comunidades Europeas y manifiesta, en su FJ 4, que "la incidencia de las directivas comunitarias, no ha eliminado la necesidad de que en toda actividad de la Administración y en particular, en la contratación, brille siempre la moralidad de las partes contratantes (de la Administración y del contratista), que exige que no haya nunca favoritismos ni pueda sospecharse de ello".

${ }^{64}$ Más reciente es la sentencia de la Audiencia Nacional de 15 de abril de 2013 citando otras sentencias también de la Audiencia Nacional: las de 15 de diciembre de 2011 (RJ 2011 \436010); de 14 de mayo de 2009 (RJ 2010\332048); de 11 de diciembre de 2008 (RJ 2009\34893) y de 18 de enero de 2006 (RJ 2006 243880 ). No obstante, hay que señalar que existen sentencias del TS que reconocen el carácter de sanción a la prohibición de contratar (STS de 30 de octubre de 1995, RJ 1995\7885), mientras que otras se limitan a declarar que no tiene carácter sancionador (STS de 28 de marzo de 2006, RJ 2006\5062).

${ }^{65} \mathrm{~A}$ este respecto, procede recordar que el principio de tutela judicial efectiva es un principio general del Derecho de la Unión (STJUE de 13 de marzo de 2007, Unibet, C-432/05, apartado 37). Asimismo, el Tribunal de Justicia ha declarado que este derecho debe ser respetado en todo procedimiento que pueda dar lugar a sanciones y actos limitativos. Véase, en este sentido, la sentencia de 26 de septiembre de 2013, Texdata Software $G m b H$, C-418/11, apartado 79, con cita expresa a la sentencia de 8 de febrero de 2007, Groupe Danone/Comisión, C-3/06P, apartado 68. 
trictivo (STS de 2 de octubre del 2000, RJ 2000\8598) ${ }^{66}$.

- Constituyen materia reservada a la ley, por lo cual no se pueden establecer ex novo por una norma reglamentaria o por parte del órgano de contratación; es decir, no es posible que los órganos de contratación incorporen a los pliegos de cláusulas administrativas particulares prohibiciones distintas de las recogidas en la normativa ${ }^{67}$;

- La prohibición de contratar ha de imponerse con sumo cuidado tras un exquisito procedimiento administrativo y en función, estrictamente, del resultado, adecuadamente ponderado, que arrojen las pruebas practicadas, ya que no es dable admitir que la Administración pueda ejercitar una potestad, que afecta a la capacidad de una empresa para intervenir en la contratación pública, y que le priva por tanto de un derecho, a su libre decisión y sin una prueba objetivamente convincente (STS de 18 de mayo de 2011, RJ 2011 \4440, confirmando la sentencia del TSJ de Canarias de 19 de octubre de 2007);

- El procedimiento para la declaración de una prohibición de contratar es un procedimiento de oficio (STS de 30 abril 2014, RJ 2014\2685);

${ }^{66}$ También las sentencias del TS de 16 de diciembre de 1988 (RJ 1988\10160) y de 30 de octubre de 1990 (RJ 1990\8400). Como tendremos ocasión de tratar más adelante, los Estados miembros al transponer las Directivas sobre contratación pública podrán prever otras causas de exclusión siempre que tengan por objeto garantizar la observancia de los principios de igualdad de trato entre los licitadores y de transparencia, y "tales medidas no excedan de lo necesario para alcanzar este objetivo", STJUE de 16 de diciembre de 2008, Michaniki, C-213/07, apartado 49.

${ }^{67}$ Entre otras sentencias, la STS de 20 de diciembre de 1995 (RJ 1995\9352) "La capacidad para contratar, y todo lo que sobre ella incide, como son las prohibiciones para contratar, constituyen materia reservada en la ley [por ello] es clara la improcedencia de introducir prohibiciones de contratar mediante normas que tengan rango inferior a la ley, y mucho más si tienen tan ínfima jerarquía normativa como la que corresponde a la examinada: «Pliego de Condiciones Particulares» (...) en materia de prohibiciones contractuales el límite lo establece la ley y no las peculiares relaciones contractuales que en cada caso se establezcan, en virtud de la individualidad de cada contrato. Es decir, en materia de prohibiciones contractuales administrativas el monopolio de su establecimiento corresponde a quien pertenece el poder de dictar normas con rango formal de ley. Las autoridades administrativas carecen de facultad para incorporar prohibiciones contractuales a los contratos que celebren, por muy razonables que puedan parecer éstas" (FJ 6). 
- El acto por el que se impone una prohibición de contratar produce los efectos que le son propios una vez que se cumplen los requisitos previstos en cuanto a su notificación y publicación, y esos efectos sólo podrán cesar cuando recurrido el acto ante la jurisdicción se acuerde la suspensión del mismo si lo considera procedente (STS de 13 de diciembre de 2006, RJ $2006 \backslash 9778)$;

- La prohibición de contratar, cualquiera que sea su naturaleza, por aplicación del principio de seguridad jurídica, ha de tener un plazo de prescripción, si bien no puede aplicarse los plazos de prescripción que la legislación administrativa prevé para las sanciones, ya que no poseen la misma naturaleza jurídica (STS de 7 de noviembre de 2006, RJ 2006\9055);

- La validez del contrato exige unas específicas condiciones personales de los sujetos, fueren personas físicas o personas jurídicas, que pretendan contratar con la Administración a fin de no caer en nulidad de la adjudicación (STS de 30 de enero de 2007, RJ 2007\830);

- La adjudicación del contrato a personas que se hallen incursas en alguna de las prohibiciones de contratar determina la nulidad de pleno derecho de la adjudicación (STS de 4 de octubre de 2005, RJ 2005\8752);

- Las prohibiciones de contratar persiguen una finalidad preventiva: evitar, en aras de la debida tutela de los intereses públicos, la relación con la Administración de quienes hayan demostrado poca seriedad en su actividad empresarial. Tal prevención está justificada ante cualquier práctica empresarial defectuosa o reprochable, bien haya sido intencional, bien negligente (STS de 18 de marzo de 2015, RJ 2015\2796, confirmando la sentencia de la Audiencia Nacional de 10 de febrero de 2014, RJ $2014 \backslash 53718)^{68}$.

Entre las notas características expuestas por los órganos consultivos de

\footnotetext{
${ }^{68}$ Contraria a esta aseveración se muestra, por ejemplo, la STSJ de Murcia, de 10 de octubre de 2014 (RJ 2015 \5368), en la que se trata sobre una prohibición de contratar por resolución contractual "dicha prohibición exige un plus en el incumplimiento, ya que para declararla se impone por la Ley que el contratista haya incurrido en una manifiesta mala fe contractual y además que los daños causados al interés público sean de cierta entidad".
} 
nuestro país (Consejo de Estado y Juntas Consultivas de Contratación ${ }^{69}$ ) destacaremos las siguientes:

- Limitación de la legitimación del interesado para celebrar un negocio jurídico (Informe Consejo de Estado 1084/95, de 1 de junio de 1995);

- Se configuran legalmente como impedimentos para poder contratar (Informe JCCA Estado 52/07, de 24 de enero de 2008; Informe JCCA Cataluña 14/2012, de 30 de noviembre e Informes JCCA Aragón 5/2013, de 10 de abril, 14/2014, de 25 de junio y 11/2015, de 30 de septiembre);

- Circunstancias objetivas que impiden la contratación con el sector público de quien se halle incurso en ellas (Informe JCCA Aragón 6/2013, de 10 de abril);

- La prohibición de contratar afecta a la aptitud del contratista para contratar a partir del momento en que se acuerde y surte efectos desde la fecha en que se inscribe en el Registro Oficial de Licitadores y Empresas Contratistas del Estado (Informe JCCA Estado 45/13, de 26 de febrero de 2015);

- Puede tener su origen, bien en la condición personal - criterio subjetivo como son las causas de incompatibilidad; bien en la conducta del sujeto - criterio objetivo - como son las causas de prohibición previstas en los artículos 60.1.a), b), c), d) y e) del TRLCSP; o bien en las causas contractuales del artículo 60.2 (Informe JCCA Estado 44/13, de 27 de junio de 2014);

${ }^{69}$ A título de ejemplo, vamos a citar los siguientes informes: Informe 9/08, de 31 de marzo de 2009 (JCCA Baleares); Informe 1/09, de 25 de septiembre de 2009 (JCCA Estado - contratos menores); Informe 13/2010, de 26 de noviembre (JCCA Estado); Informe 6/2012, de 7 de junio (JCCA Cataluña); Informe 14/2012, de 30 de noviembre (JCCA Cataluña); Informe 2/2013, de 5 de marzo de 2013 (JCCA Canarias); Informe 7/2013, de 10 de abril (JCCA Aragón); Informe 3/2013, de 28 de noviembre (JCCA Cataluña); Informe 4/2013, de 20 de diciembre (JCCA Madrid); Informe 14/2014, de 25 de junio (JCCA Aragón); Informe 44/13, de 27 de junio de 2014 (JCCA Estado); Informe 16/2014, de 17 de diciembre (JCCA Cataluña); Informe 6/2014, de 28 de abril de 2015 (CCCP Andalucía) e Informe 4/2015, de 28 de julio de 2015 (JCCA Galicia). 
- Se aplican también a los contratos menores porque la capacidad para contratar es uno de los requisitos de todo contrato público, aun cuando en los expedientes referentes a esta tipología contractual no exista un trámite específico para acreditar la inexistencia de tales prohibiciones (Informes JCCA Estado 13/1996, de 7 de marzo de 1996 y 29/2001, de 13 de noviembre).

Y, por último, recogemos algunas de las características expuestas por la doctrina, más allá de su consideración general de requisito para contratar con el sector público:

- Medida que afecta a la capacidad de una persona para intervenir en la contratación. En esta consideración se encuentran quienes sostienen que se trata de restricciones a la capacidad de obrar ${ }^{70}$, incapacidades especiales $^{71}$ y quienes entienden que la limitación es de la capacidad

${ }^{70}$ Entre otros, vamos a destacar a GIL IBÁÑEZ, J.L., "Capacidad para contratar y clasificación de los contratistas", en el volumen colectivo Contratación administrativa, Cuadernos de Derecho Judicial, Consejo General del Poder Judicial, Madrid, 1995, págs. 253 - 300; SALA ARQUER, J.M., "La prohibición de contratar prevista en el art. 20.a) (...)", op. cit., pág. 640 al señalar que las prohibiciones de contratar "se inscriben en la especial capacidad de obrar que, en materia de contratación administrativa, exige el ordenamiento jurídico-administrativo". Por parte de FUERTES LÓPEZ se califican como "limitaciones para poder contratar", FUERTES LÓPEZ, M., El contratista (...), op. cit., pág. 71 .

${ }^{71}$ En referencia al artículo 48 de la Ley de 20 de diciembre de 1952, GARCÍA DE ENTERRÍA aludía a la prohibiciones allí recogidas como supuestos de incapacidad específica para ser contratista de la Administración, en "Dos regulaciones orgánicas de la contratación administrativa", $R A P$, núm. 10, enero - abril 1953, pág. 249. También CARRETERO PÉREZ, A., "El contrato administrativo ante la Ley de Bases de contratos del Estado de 28-XII-1963", RAP, núm. 45, septiembre - diciembre 1964, pág. 136 y PARADA VÁZQUEZ, J. R., "La nueva Ley de Contratos del Estado", RAP, núm. 47, mayo - agosto 1965, pág. 434. BENÍTEZ MORCILLO habla de incapacidades especiales de tipo administrativo, BENÍTEZ MORCILLO, G.J., El contratista en la Ley de Contratos de las Administraciones Públicas, Tesis manuscrita, Universidad Autónoma de Madrid, 1998, págs. 296 y siguientes; FENELLÓS PUIGCERVER, V., "Prohibiciones de contratar, (...)", op. cit., pág. 93 sostiene que se trata de incapacidades específicas de Derecho Administrativo "dirigidas a la finalidad de elegir un contratista que haga viable la obtención del interés público" y BACA ONETO manifiesta que estas prohibiciones "limitan la capacidad especial 
jurídica del sujeto afectado ${ }^{72}$.

- Supuestos de inhabilitación para realizar ciertos actos en general, o respecto de ciertas personas (en este caso la Administración), impuestas por un texto legal ${ }^{73}$;

- Impedimentos, establecidos y previstos en las normas que hacen jurídicamente inviable la participación de ciertas personas, físicas o jurídicas, públicas o privadas en el sistema de la contratación pública ${ }^{74}$;

- Instrumentos de regulación de los mercados de la contratación administrativa de primera magnitud ${ }^{75}$;

- Medidas administrativas a disposición de los Estados que impiden la adjudicación de nuevos contratos - o ampliaciones de los vigentes - para los proveedores por quebrantamiento de la ley o la ética ${ }^{76}$;

de obrar necesaria para participar en un procedimiento administrativo de selección de contratistas", en BACA ONETO, V. S., La invalidez de los contratos públicos, Thomson-Civitas, Cizur Menor (Navarra), 2006, pág. 179.

${ }^{72}$ MARTÍNEZ LÓPEZ MUÑIZ sostiene que la limitación es de la capacidad jurídica del sujeto afectado, al entender que "la prohibición no se dirige al mero obrar, a la capacidad de obrar, sino a la aptitud para ser titular u ostentar un derecho". Al indicar que estamos ante circunstancias reductoras, más o menos temporalmente, de la capacidad jurídica, para este autor ya no resulta de importancia distinguir si se trata de incapacidades especiales, limitaciones de dicha capacidad, inhabilitaciones o, incluso incompatibilidades. MARTÍNEZ LÓPEZ-MUÑIZ, J.L., "Los beneficiarios de subvenciones", en la obra colectiva Comentario a la Ley General de Subvenciones, Thomson - Civitas, Cizur Menor (Navarra), 2005, especialmente págs. 168 a 171.

${ }^{73}$ VILLAR PALASÍ, J.L. y VILLAR EZCURRA, J.L., Principios de Derecho Administrativo (...), op. cit., pág. 129.

${ }^{74}$ BERMEJO VERA, J., "Las prohibiciones de contratar en la Ley de Contratos del Sector Público", Revista Aragonesa de Administración Pública, núm. X monográfico dedicado al Derecho de los Contratos del Sector Público, 2008, pág. 112.

${ }^{75}$ RUIZ OJEDA, A., (Dir.) Derecho de la contratación pública y regulada. Comentario sistemático y concordado de la legislación vigente, Thomson - Civitas, Madrid, 2004, pág. 151.

${ }^{76}$ SCHOONER, S., "The Paper Tiger Stirs: Rethinking Suspension and Debarment", Public Procurement Law Review, vol. 13 (5), 2004, en sus págs. 212 y 213; WILLIAMS-ELEGBE, S., Fighting Corruption (...), op. cit., pág. 31. GIMENO 
- Técnicas que utilizan los organismos gubernamentales para asegurar que establecen un contrato sólo con oferentes "responsables"77; que tratan de garantizar la honorabilidad de las personas que desean contratar con los sujetos sometidos a la legislación contractual ${ }^{78}$ y que pretenden garantizar el interés público reduciendo la discrecionalidad administrativa en la elección del contratista ${ }^{79}$;

- Medidas de policía que limitan la capacidad de obrar de las personas físicas o jurídicas al eliminar de manera absoluta durante cierto tiempo que quienes incurran en ellas gocen del derecho a participar libremente en las licitaciones públicas ${ }^{80}$;

- Situaciones impeditivas para contratar, que condicionan la capacidad general establecida en el Derecho privado para contratar cuando el negocio jurídico tiene como contraparte a una Administración ${ }^{81}$;

FELIÚ señala que "se establece la prohibición de licitar a ciertos contratistas en los que concurran determinadas circunstancias que podríamos calificar de antisociales (actividades fraudulentas o delictivas, fraude de subvenciones, incumplimiento legislación fiscal o laboral)", en GIMENO FELIÚ, J.M.a, Novedades de la Ley de Contratos del Sector Público de 30 de octubre de 2007 en la regulación de la adjudicación de los contratos públicos, Civitas - Thomson Reuters, Cizur Menor (Navarra), 2010, pág. 194, y sin que se llegue a requerir ni una "condición angélica" de los contratistas públicos, ni "una prueba de pureza de sangre" como apuntaba VICENTE LÓPEZ, C., La contratación administrativa. Condiciones generales y eficacia, Comares, Granada, 1996, págs. 212 y 213.

${ }^{77}$ MANUEL, K., Debarment and Suspension of Government Contractors: An Overview of the Law Including Recently Enacted and Proposed Amendments, Congressional Research Service, 2012, disponible en: http://www.safgc.hq.af.mil/shared/media/document/AFD-120315-091.pdf [Fecha de consulta: 15 de octubre de 2015].

${ }^{78}$ MORELL OCAÑA, L., "Requisitos de los contratos (...)", op. cit., págs. 136 a 139 y GIMENO FELIÚ, J. M. ${ }^{a}$., Novedades de la Ley de Contratos del Sector (... ), op. cit., pág. 197.

${ }^{79}$ REBOLLO PUIG, M., "La invalidez de los contratos administrativos", Noticias de la Unión Europea, núm. 136, 1996, pág. 103.

${ }^{80}$ VALCÁRCEL FERNÁNDEZ, P., "Promoción de la igualdad de género (... )", op. cit., pág. 341

${ }^{81}$ MERINO MERCHÁN, J. F. y PALMA FERNÁNDEZ, J. L. "Requisitos para contratar con la Administración (I): Capacidad y solvencia", en la obra colectiva 
- Barreras de entrada al mercado público ${ }^{82}$;

- Obstáculos legales a la participación de los sujetos en la contratación pública $^{83}$, cuyo efecto es vedar directa y expresamente la contratación por determinados motivos tasados, ligados al comportamiento precedente de los aspirantes o a su situación personal actual ${ }^{84}$;

- Instrumentos de lucha contra la corrupción desde la normativa de contratación pública al evitar que algunos empresarios en los que concurren determinadas circunstancias que no sean honorables puedan contratar con las Administraciones públicas ${ }^{85}$;

- Medidas de protección de los intereses públicos ${ }^{86}$;

Habida cuenta del conjunto de elementos expuestos, estamos en disposición de aportar una definición propia de prohibiciones de contratar que es la que vamos a utilizar a lo largo del texto y que se vincula en exclusiva a la normativa de contratos públicos. De esta manera - y completando la definición ya esbozada - entendemos que las prohibiciones de contratar se configuran como limitaciones a la posibildad de resultar contratista de un contrato público, de tal manera que pueden definirse como medidas administrativas, aplicadas por

Derecho de los contratos públicos, Praxis-Wolters Kluwer, Barcelona, 1995, pág. 306.

${ }^{82}$ CADEMARTORI, D., Buena administración y procedimientos de selección de contratistas: Análisis de mecanismos jurídicos e informativos para alcanzar la eficiencia en las licitaciones públicas, Tesis doctoral manuscrita facilitada por el autor, Universidad de Salamanca, 2010, pág. 263. "Las prohibiciones de contratar corresponden a uno de los requisitos de idoneidad moral que Administraciones y Órganos Públicos deben verificar para ver si un determinado agente económico puede ser seleccionado como futuro contratista, constituyendo algunas de ellas, verdaderas indignidades para contratar".

${ }^{83}$ BERMEJO VERA, J., "Las prohibiciones de contratar (...)", op. cit., pág. 114.

${ }^{84}$ GIMENO FELIÚ, J. M.a., Novedades de la Ley de Contratos del Sector (...), op. cit., pág. 194.

${ }^{85}$ CERRILLO I MARTÍNEZ, A., El principio de integridad en la contratación pública. Mecanismos para la prevención de los conflictos de intereses y la lucha contra la corrupción, Aranzadi, Cizur Menor (Navarra), 2014, pág. 233.

${ }^{86}$ BESTEIRO RIVAS, J., "Comentarios al artículo 49 de la LCSP (...)", op. cit., pág. 780. 
los órganos de contratación, que impiden contratar a quienes incurran en una serie de circunstancias que, a juicio, del legislador, presuponen una falta de fiabilidad en el candidato o licitador o de su imparcialidad en la selección del contratista.

Las prohibiciones de contratar restringen el acceso al mercado público y, en la medida que afectan negativamente al ejercicio de actividades privadas, deben ser objeto de control mediante los procedimientos de recursos pertinentes $^{87}$. No se trata, sin embargo, de limitaciones al derecho a ser contratista, ya que a nuestro juicio no existe tal derecho previo ${ }^{88}$. Incluso, y aun cuando del tenor literal de las Directivas se desprende su consideración de impedimentos a la participación en un procedimiento de adjudicación ${ }^{89}$, nos cuestionamos el

\footnotetext{
${ }^{87}$ Recordemos que no se exige ser titular de un derecho para poder recurrir los actos de la fase precontractual, puesto que en la tutela de las posiciones jurídico-subjetivas de los interesados en los procedimientos de adjudicación de contratos la legitimidad es muy amplia y los recursos se pueden interponer por "cualquier persona que tenga o haya tenido interés en obtener un determinado contrato" (Directiva 89/665/CEE). Sobre esta materia puede consultarse, DÍEZ SASTRE, S., La tutela de los licitadores en la adjudicación de contratos públicos, Marcial Pons, Madrid, 2012.
}

${ }^{88}$ Con carácter general, DE LA CUÉTARA al referirse a la prohibición como actividad de policía señala que ésta se mueve "en el ámbito del ejercicio de un derecho en un determinado tiempo y lugar y no en el de la existencia del derecho mismo", DE LA CUÉTARA MARTÍNEZ, J. M., La actividad de la Administración, Tecnos, Madrid, 1983, pág. 255. GOSÁlBEZ PEQUEÑO, H., El contratista (...), op. cit., afirmaba que "el particular no puede exigir a las entidades públicas la adjudicación de algún contrato, por lo que difícilmente puede hablarse de un verdadero derecho subjetivo a ser contratista", pág. 73. Siguiendo a este mismo autor, MANTECA VALDELANDE sostenía que el derecho a optar a la condición de contratista público no es un auténtico derecho subjetivo, sino más bien una facultad integrante de la aptitud contractual jurídico-pública, un contenido de la genérica capacidad de obrar administrativa, en Contratación Administrativa Práctica, núm. 40, marzo 2005, pág. 33 y siguientes.

A este respecto, y en apoyo a lo expuesto, cabe indicarse que la sentencia del Tribunal de Justicia de 16 de septiembre de 1999, Fracasso y Leitschutz, C-27/98, en sus apartados 32 y 33 declaró que "el órgano de contratación no está obligado a adjudicar el contrato al único licitador que haya sido considerado apto para participar", y que el Tribunal General en su sentencia de 9 de julio de 1999, New Europe Consulting y Brown/Comisión, T-231/97, apartado 49 concluía que "ningún licitador tiene derecho a que automáticamente se le adjudiquen contratos".

${ }^{89}$ Artículo 57.1 de la Directiva 2014/24/UE "Los poderes adjudicadores excluirán a un operador económico de la participación en un procedimiento de contratación 
referirnos con carácter general a las prohibiciones de contratar como restricciones a la participación en los procesos de selección de contratista, ya que tras la posibilidad que la norma ofrece de examinar las ofertas antes de comprobar la inexistencia de motivos de exclusión, se está permitiendo participar en la licitación, presentar ofertas y "competir" en un procedimiento abierto a quienes estén incursos en una prohibición de contratar y, por tanto, no podrían llegar a ser contratistas ${ }^{90}$. Por ello, entendemos que son medidas que privan al operador económico de una expectativa de derecho y no del propio derecho ${ }^{91}$.

Los operadores económicos tienen derecho a participar en el procedimiento de contratación cuando cumplen tres requisitos: 1) capacidad de obrar; 2) solvencia y 3) ausencia de prohibiciones de contratar. Tanto de las normas de la Unión como de la jurisprudencia del Tribunal de Justicia se infiere que puede licitar o presentarse como candidato toda persona o entidad que, a la vista de los requisitos previstos en un anuncio de licitación, se considere apta para garantizar la ejecución del contrato público ${ }^{92}$.

El cumplimiento de los requisitos expuestos se aprecia por parte de los poderes adjudicadores en una fase ulterior del procedimiento y si se acredita

$(\ldots) "$

${ }^{90}$ Esta opción se recoge expresamente en el artículo 56.2 de la Directiva 2014/24/UE que permite que en los procedimientos abiertos, los poderes adjudicadores puedan decidir "examinar las ofertas antes de comprobar la inexistencia de motivos de exclusión y el cumplimiento de los criterios de selección" y así sólo examinar los criterios de selección relativos al adjudicatario. Con anterioridad, la jurisprudencia del TJUE ya había declarado que las Directivas en materia de contratos públicos no excluían, en teoría, que "la verificación de la aptitud de los licitadores y la adjudicación del contrato puedan tener lugar simultáneamente", aunque sean operaciones distintas (sentencias de 20 septiembre de 1988, Beentjes, 31/87, apartados 15 y 16; de 24 de enero de 2008, Lianakis y otros, C-532/06, apartado 26 y de 12 de noviembre de 2009, Comisión/Grecia, C-199/07, apartado 51).

${ }^{91}$ En este sentido, HUERGO LORA, A., Las sanciones administrativas, Iustel, Madrid, 2007, pág. 320.

${ }^{92}$ Véanse las sentencias del TJUE de 23 de diciembre de 2009, CoNISMa, C305/08, apartado 42; de 18 de diciembre de 2014, Data Medical Service, C-568/13, apartado 35 y de 6 de octubre de 2015, Consorci Sanitari del Maresme, C-203/14, apartado 34. Así se manifiesta tambien el Abogado General Sr. WATHELET en sus conclusiones presentadas, el 4 de junio de 2015, en el asunto Ostas celtnieks, C-234/14, apartado 38. 
que los operadores económicos no reúnen la aptitud necesaria para contratar - o bien están incursos en alguna de las causas legales de prohibición - deben quedar excluidos de la licitación ${ }^{93}$. Por el contrario, mientras no se demuestre que el operador económico se halle comprendido en alguna de las restricciones a dicha capacidad establecidas por una norma con rango legal, no puede prohibírsele participar en cualquiera de los procedimientos de adjudicación.

Así pues, y completando lo anterior, las prohibiciones de contratar se configuran como requisitos específicos de naturaleza pública que delimitan el contenido esencial del derecho a optar a la condición de contratista en aras a una mayor defensa de los intereses implícitos en las compras públicas.

\section{III.2. Las prohibiciones de contratar como parte de un modelo preventivo}

La distinta clasificación que podamos establecer de todas las situaciones que configuran una prohibición de contratar no impide encontrar una finalidad común a todas ellas, ya que - como hemos señalado y ha reconocido la jurisprudencia - con estas prohibiciones se trata de evitar que cualquier entidad del sector público contrate con personas que, en atención a su comportamiento

\footnotetext{
${ }^{93}$ Desde las primeras líneas de esta memoria doctoral, señalábamos que la normativa contractual de la Unión Europea no exige que la persona que celebra un contrato con una entidad adjudicadora sea capaz de realizar la prestación pactada directamente con sus propios recursos. No es necesario que el licitador tenga la propiedad de los medios técnicos, económicos o financieros, sino sólo que sea capaz de acreditar que dispondrá de ellos durante la ejecución del contrato, aunque pertenezcan a un tercero, en GALLEGO CÓRCOLES, I., "El recurso a las capacidades de otras entidades (o del intento de concretar el régimen jurídico de la integración de la solvencia mediante medios externos)", en la obra colectiva Observatorio de los contratos públicos 2014, Thomson - Aranzadi, Cizur Menor (Navarra), 2015, pág. 208. En ese sentido, véanse las sentencias del TJUE de 2 de diciembre de 1999, Holst Italia, C-176/98, apartado 29; de 18 de marzo de 2004, Siemens y ARGE Telekom, C-314/01, apartados 43 y 44, de 10 de octubre de 2013, Swm Costruzioni, C-94/12, apartados 33 y 35, así como las conclusiones del Abogado General Sr. JÄÄSKINEN presentadas, el 8 de septiembre de 2015, en el asunto PARTNER Apelski Dariusz, C-324/14.
} 
o cualidad, no son merecedoras de la debida confianza ${ }^{94}$.

La importancia de estas medidas de garantía del interés público ${ }^{95}$ se asocia al hecho de que su consagración pretende, en primer lugar, que quienes aspiran a acceder a la condición de contratista público posean ciertas condiciones que aseguren la correcta ejecución del contrato y, en segundo término, que quede garantizada la imparcialidad en la selección del contratista.

En cualquier caso, tal como hemos expuesto, la fiabilidad del operador económico constituye uno de los elementos a tener en consideración en el momento de adjudicar un contrato público («criterios de selección cualitativa»), privándole de la posibilidad de resultar contratista si se encuentra en alguna de las circunstancias que revelan el desvalor de ciertos comportamientos o situaciones $^{96}$. Así, podríamos entender que su finalidad es triple: (i) proteger a la entidad contratante de los "operadores económicos informales y deshonestos"97, (ii) ampliando sus fines preventivos al tráfico jurídico en general

${ }^{94}$ En este sentido, la sentencia del TJUE de 10 de julio de 2014, Consorzio Stabile, C-358/12 hablaba de "falta de fiabilidad y de seriedad" en el operador económico y la STS de 18 de marzo de 2015 (RJ 2015 134770) señalaba que se trata de "evitar, en aras de la debida tutela de los intereses públicos, la relación con la Administración de quienes hayan demostrado poca seriedad en su actividad empresarial", FJ 7.

${ }^{95}$ Como han sido calificadas en la STS de 2 de octubre de 2000 (RJ 2000\8598).

${ }^{96}$ Según FERNÁNDEZ MALLOL en las prohibiciones de contratar subyacen las dudas sobre la honorabilidad del contratista, o bien, posibles conflictos de interés que aconsejan limitar la contratación con esos sujetos, en FERNÁNDEZ MALLOL, A. L., "La integridad del procedimiento de contratación pública en el Derecho de la Unión Europea. El conflicto de interés y su incidencia sobre la regulación de las prohibiciones para contratar, las causas de incompatibilidad y las disposiciones sobre transparencia y buen gobierno", REALA, núm. 2 (nueva época), julio-diciembre 2014, pág. 6.

En este sentido, traemos a colación lo dispuesto en la Exposición de motivos de la Orden de 31 de marzo de 2006, del Consejero de Justicia, Empleo y Seguridad Social del Gobierno Vasco, al propugnar que puede ser una medida preventiva de gran eficacia "excluir de la contratación administrativa a quienes han infringido la normativa social, y dentro de ella la de prevención de riesgos laborales, y han sido sancionados por la comisión de infracciones muy graves" (BOPV núm. 107, de 7 de junio de 2006).

${ }^{97} \mathrm{El}$ primero de estos adjetivos fue utilizado por el Comité de las Regiones en su Dictamen sobre la Propuesta de Directiva sobre coordinación de los procedimientos de adjudicación de los contratos públicos de suministro, de servicios y de obras 
al impedir ventajas inaceptables entre operadores económicos no basadas en la oferta que presentan, (iii) a la vez que, de algún modo, se desincentiva el quebrantamiento de la legalidad vigente.

Su carácter preventivo puede observarse también desde distintos ámbitos: En primer lugar, puede evitar un gran número de infracciones, puesto que para el operador económico la "amenaza" de ser excluido del mercado de las compras públicas puede disuadirle de llevar a cabo ciertas conductas deshonestas si quiere seguir contratando con el sector público ${ }^{98}$. Ahora bien, sólo tendrá un verdadero efecto disuasorio si el sistema de control de la existencia de prohibiciones de contratar es lo suficientemente riguroso como para desanimar a los ya infractores de reincidir, y a otros posibles infractores de llegar a cometer la infracción.

En segundo lugar, para el órgano de contratación - obligado a actuar conforme a unos criterios de objetividad en la selección del contratista y no libremente - las prohibiciones de contratar pueden suponer una especie de medida de seguridad en tanto le permiten excluir de la adjudicación a quien ha demostrado poca seriedad en su actividad empresarial precedente y podría convertirse en contratista si llegase a presentar la oferta económicamente más ventajosa

2000, al manifestar que "no se debe permitir la participación en los procedimientos de adjudicación pública de operadores informales", si bien hay que indicar que en la versión inglesa la expresión que encontramos es bastante más rotunda "dishonest suppliers" (DOCE C 144, de 16 de mayo de 2001, pág. 26). En el Libro Verde sobre la modernización de la política de contratación pública de la UE, la Comisión habla de "la exclusión de los licitadores deshonestos", COM (2011) 15 final, de 25 de enero, pág. 56.

${ }^{98}$ Esta afirmación debe ser matizada cuando se trata de una prohibición impuesta como consecuencia de una condena judicial firme, puesto que, en ese caso, se deduce claramente que no tiene capacidad para prevenir el delito ya cometido, aunque sí quizá para evitar que se vuelva a cometer, hablando entonces de una prevención especial post-delictual. SÁNCHEZ GRAELLS manifiesta que la prohibición de contratar por prácticas colusivas en la contratación es un instrumento importante de prevención o de disuasión en la manipulación de las licitaciones porque los contratistas saben los riesgos que corren de explusión del mercado de las compras públicas, en SÁNCHEZ GRAELLS, A., "Prevention and deterrence of bid rigging: a look from the new EU directive on public procurement", en la obra colectiva Integrity and Efficiency in Sustainable Public Contracts, Bruylant, Brussels, 2014, págs. 171 $-198$. 
en un procedimiento de adjudicación ${ }^{99}$.

Por último, en tercer lugar, las prohibiciones de contratar pueden entenderse como medidas orientadas a la promoción del interés general en tanto que algunas de ellas contribuyen a reforzar la idea de integridad y fortalecen los mecanismos de lucha contra la corrupción y otras conductas ilícitas ${ }^{100}$.

En relación con este último aspecto, cabe indicarse que las Directivas sobre contratación pública desde el año 2004 vienen abordando cuestiones que hasta entonces no habían sido tratadas por el legislador europeo como son la prevención de la corrupción, el favoritismo y otras formas de delincuencia económica a través del establecimiento de prohibiciones de contratar de carácter obligatorio para todos los Estados miembros ${ }^{101}$.

${ }^{99}$ MERINO MERCHÁN, J. F. y PALMA FERNÁNDEZ, J. L., "Requisitos para contratar (...)", op. cit., pág. 328 manifestaban que la prohibición de contratar "produce el efecto de aherrojar jurídicamente aquellos individuos o empresas que, habiendo resultado previamente adjudicatarios de contratos administrativos, han frustrado la confianza en ellos depositada".

${ }^{100}$ Sobre esta materia resulta de interés, GIMENO FELIÚ, J. M.a "La Ley de Contratos del Sector Público: ¿una herramienta eficaz para garantizar la integridad? Mecanismos de control de la corrupción en la contratación pública", REDA, núm. 147, julio - septiembre 2010, págs. 517 - 535, y del mismo autor El nuevo paquete legislativo comunitario sobre contratación pública. De la burocracia a la estrategia. El contrato público como herramienta del liderazgo institucional de los poderes públicos, Aranzadi - Thomson Reuters, Cizur Menor (Navarra), 2014, especialmente las págs. 189 a 196. También, MEDINA ARNÁIZ, T., "EU Directives as Anticorruption Measures: Excluding Corruption-Convicted Tenderers from Public Procurement Contracts", en la obra colectiva International Handbook of Public Procurement, CRC Press (Francis \& Taylor), Boca Raton, Florida, 2008, págs. 105 130, y en "Instrumentos jurídicos frente a la corrupción en la contratación pública: perspectiva europea y su incidencia en la legislación española", en la obra colectiva La contratación pública a debate: presente y futuro, Thomson - Aranzadi, Cizur Menor (Navarra), 2014, págs. 299 - 344.

${ }^{101}$ Sirva poner de ejemplo que hasta la redacción de la Directiva 2004/18/CE no se incorpora a la legislación contractual el término corrupción, si bien, la posibilidad de excluir a un licitador o candidato de un procedimiento de adjudicación ya se preveía desde la Directiva 71/305/CEE del Consejo, de 26 de julio de 1971, sobre coordinación de los procedimientos de adjudicación de los contratos públicos de obras, al tratar las prohibiciones por "cualquier delito que afecte a su moralidad profesional". 
En este sentido, las actuales Directivas establecen la exclusión obligatoria de los procesos de contratación pública de aquellos candidatos y licitadores que hayan sido condenados en sentencia judicial firme por fraude, corrupción, blanqueo de capitales, terrorismo, trabajo infantil y otras formas de trata de seres humanos o bien por participar en una organización delictiva (artículo 57.1 de la Directiva 2014/14/UE sobre contratación pública y el artículo 38.4 de la Directiva 2014/23/UE«concesiones»).

Bajo este tenor, impedir en todos los Estados miembros la participación en las licitaciones públicas a quienes han sido condenados por incurrir en determinadas actividades delictivas, puede entenderse no sólo como un modo de preservar los principios que rigen la contratación pública y asegurar con ello una competencia real en los procedimientos de adjudicación contractual, sino también, y en último extremo, como uno de los instrumentos con los que prevenir distintas manifestaciones de delincuencia económica. En efecto, la importancia de estas prohibiciones de contratar como instrumento para luchar contra la corrupción y el fraude en la contratación pública ha sido puesta de manifiesto por diferentes autores que aludían bien a su naturaleza preventi$\mathrm{va}^{102}$, bien a su carácter aflictivo manifestado, al margen de la propia condena penal, en daños en la reputación de la empresa y en el menoscabo económico que supone dejar de contratar con las entidades del sector público ${ }^{103}$.

Ahora bien, en este momento y sin poner en discusión la relevancia de estas prohibiciones, sí resulta cuestionable - tal y como están concebidas - su eficacia como mecanismos que aporten una plusvalía real al empeño de luchar contra las irregularidades en la contratación, ya que su puesta en práctica se enfrenta

${ }^{102}$ PISELLI, E., "The scope for excluding providers who have committed (...)", op. cit., pág. 274; SCHOONER, S., "The Paper Tiger Stirs: Rethinking (...)", op. cit., pág. 214; DREW, K., "The Challenges Facing Debarment and the European Union Public Procurement Directive", en la obra colectiva Fighting Corruption and Promoting Integrity in Public Procurement, OCDE, París, 2005, pág. 270 y Simone WHITE se refería a las listas negras (blacklisting) como elemento de disuasión en "Exclusion of Tenderers in the European Union: The Only Way Forward against Procurement Fraud?", en la misma obra Fighting Corruption and Promoting Integrity in Public Procurement, pág. 252. En nuestro país, CERRILLO I MARTÍNEZ, A., El principio de integridad (...), op. cit., pág. 233 y MEDINA ARNÁIZ, T., "Instrumentos jurídicos frente a la corrupción (...)", op. cit., pág. 328.

${ }^{103}$ BOURGOIN, P., "Les exclusions de marchés (...)", op. cit., pág. 27. 
a distintos obstáculos que plantean dificultades en su detección y aplicación.

Así pues, aunque es cierto que potencialmente representan un avance formal en cuanto que se incorporan al texto de las Directivas y se obliga a su transposición en las normativas nacionales de los Estados miembros, a lo largo de esta memoria doctoral veremos cómo sus buenas intenciones se desvanecen ante aspectos tan concretos como son: (i) la falta de calificación común respecto de los elementos integradores de las infracciones penales que dan soporte a estas prohibiciones, (ii) la falta de conocimiento de las condenas que habilitan dicha exclusión y, aun conociendo dichas condenas, la inacción por dar inicio al expediente de prohibición de contratar e, incluso, (iii) con respecto a las personas jurídicas, aun reconociendo su responsabilidad penal, por la ausencia de un régimen procesal específico que posibilite su condena.

Por estos motivos, y en nuestra opinión, las prohibiciones de contratar resultan, cuando menos, poco efectivas como medidas disuasorias para la no comisión de los delitos de naturaleza económica, ya que mientras no se superen los inconvenientes apuntados, difícilmente van a poder aplicarse a nivel transnacional, y a veces ni siquiera nacional ${ }^{104}$.

Quizá por razón de su ineficacia o quizá por un cambio en la estrategia de lucha contra la delincuencia desde la contratación pública, lo cierto es que se mantiene el establecimiento de listas negras (blacklists) que niegan el acceso a la contratación pública a quienes se encuentren incluidos en ellas sobre la base de la información registrada ${ }^{105}$, también se avanza en un cambio de criterio a

\footnotetext{
${ }^{104}$ En otras ocasiones ya hemos aludido a estos inconvenientes prácticos en la aplicación de las prohibiciones de contratar, y hemos señalado ejemplos concretos en los que, a pesar de darse el supuesto para ello, no se ha declarado la prohibición de contratar, en MEDINA ARNÁIZ, T., "Las respuestas normativas al fenómeno de la corrupción en la contratación pública", La Ley, núm. 7382, abril 2010. En el caso español, esta aseveración se fundamenta en datos objetivos, puesto que en el periodo comprendido entre los años 1997 y 2008 únicamente se publicaron en el BOE un total de 93 supuestos de declaración de prohibición de contratar.

105 En Malta, por ejemplo, la última modificación de la legislación contractual (en vigor desde el 1 de septiembre de 2015) recoge la obligatoriedad de incorporar a una lista negra a aquellos operadores que han quebrantado la legislación laboral y, de esta manera, impedir que contraten con el sector público durante un periodo máximo de dos años, en el Reglamento de Contratos Públicos, aprobado por Legal Notice 296/2010, de 1 de junio de 2010 (S.L.174.04), modificado por Legal Notice
} 
favor de una política de incentivos - más cercana a las listas blancas (whitelists) - para involucrar al sector privado a reforzar, por ejemplo, su actuación en la lucha contra conductas ilícitas y prácticas comerciales desleales ${ }^{106}$. En este supuesto, la amenaza de exclusión del procedimiento de adjudicación contractual cede ante un modelo de autorregulación, en el cual se utiliza el acceso a la contratación pública como un estímulo para aquellos operadores económicos que logren demostrar que han cumplido con sus obligaciones (programas de cumplimiento), que han asumido pactos de integridad y que han adoptado medidas suficientes para prevenir la comisión de futuras infracciones ${ }^{107}$.

De esta manera, tal como veremos en el último capítulo de esta memoria doctoral, las nuevas Directivas de contratación pública prevén la posibilidad de excepcionar la aplicación de una prohibición de contratar cuando el operador económico ha adoptado medidas de cumplimiento destinadas a reparar las consecuencias de las infracciones cometidas y a prevenir eficazmente que éstas vuelvan a producirse ${ }^{108}$.

68/2015 (de 6 de marzo de 2015). Asimismo, en la República Checa, la Ley 137/2006, de 14 de marzo, de Contratos Públicos - modificada por la Ley 40/2015 - prevé el establecimiento de listas negras de operadores económicos y, como requisito previo para poder contratar establece que el licitador "is not enrolled on the black list of economic operators banned to participe in the performance of public contracts" $(\S 53.1 . \mathrm{j})$.

${ }^{106}$ Una de las primeras referencias a favor de este cambio en la normativa sobre contratación pública la encontramos en EHLERMANN-CACHE, N., "Regulating Access to Public Procurement: Issues for Consideration", en la obra colectiva Fighting Corruption and Promoting Integrity in Public Procurement, OCDE, París, 2005, pág. 222.

${ }^{107}$ En esta materia resultan de cita obligada las referencias a Transparencia Internacional y su guía para la implementación de pactos de integridad Integrity pacts in public procurement: an implementation guide http://www.transparency.org/whatwedo/tools/integrity_pacts/4/ [Fecha de consulta: 15 de octubre de 2015]. También, BERNAL BLAY, M. Á., "Los efectos de los programas de compliance en la contratación pública", en la obra colectiva Las nuevas Directivas de contratación pública, Thomson - Aranzadi, Cizur Menor (Navarra), 2015, págs. 413 a 424, y GÓMEZ-JARA DÍEZ, C., "Responsabilidad penal de las personas jurídicas y contratación pública. A propósito de la nueva Directiva europea sobre contratación pública", Diario La Ley, núm. 8423, 18 de noviembre de 2014.

${ }^{108}$ Artículo 57.6 de la Directiva 2014/24/UE («sectores clásicos») y artículo 38.9 de la Directiva 2014/23/UE («concesiones»). 


\section{III.3. Las prohibiciones de contratar como técnica re- presiva}

Una vez analizadas las prohibiciones de contratar desde la perspectiva preventiva, hemos de centrarnos en aquellos aspectos que concuerdan mejor con un modelo represivo. A este respecto, ahondaremos en la distinción entre sanciones administrativas y otras resoluciones adoptadas por la Administración que restringen derechos aun cuando no deben ser consideradas propiamente sanciones al perseguir otras finalidades alejadas de la idea de castigo, como son por ejemplo, el estímulo para el cumplimiento de la normativa o la disuasión ante posibles incumplimientos.

Avanzamos, sin embargo, que no se trata de una labor sencilla en tanto que, por una parte, prevención y sanción están estrechamente vinculadas y eso dificulta su distinción ${ }^{109}$; además, las disposiciones de la UE contemplan a menudo la adopción de «medidas administrativas» y la imposición de «sanciones» sin que tal diferenciación sea suficientemente clarificadora ${ }^{110} \mathrm{y}$, por último, ciertas

${ }^{109}$ Toda pena o sanción tiende a una doble finalidad represiva y disuasoria, al reprimir una conducta y desalentar a otros eventuales infractores. "Denial of access to public procurement is understood to be a means to prevent, deter and sanction corruption", en EHLERMANN-CACHE, N., "Regulating Access to Public Procurement: (...)", op. cit., pág. 214. En la misma idea de prevenir y sancionar se encuentra el Libro Verde sobre la modernización de la política de contratación pública de la UE "la exclusión de los licitadores que sean culpables de corrupción y, más en general, de falta profesional («inhabilitación»), es un arma poderosa para castigar - y también, en cierta medida, impedir - los comportamientos empresariales ilícitos", COM (2011) 15 final, de 25 de enero, págs. 56 y 58.

${ }^{110} \mathrm{~A}$ este respecto, ponemos como ejemplo, el artículo 1 del Reglamento (CE, Euratom) 2988/95 del Consejo, de 18 de diciembre de 1995, relativo a la protección de los intereses financieros de las Comunidades Europeas, que hace referencia a la adopción de "una normativa general relativa a controles homogéneos y a medidas y sanciones administrativas aplicables a las irregularidades respecto del Derecho [de la Unión]", con el objetivo, según el tercer considerando de ese Reglamento, de "combatir en todos los ámbitos los perjuicios a los intereses financieros". Asimismo, de la jurisprudencia reciente del TJUE se desprende que no procede establecer distinciones entre una sanción administrativa y una medida administrativa al aplicar este Reglamento. En este sentido, véase las sentencias de 11 de junio de 2015, Pfeifer E Langen, C-52/14 y de 3 de septiembre de 2015, Sodiaal International, C-383/14, apartado 27 . 
actuaciones administrativas pueden considerarse sanciones administrativas en algunos Estados miembros y medidas administrativas en otros ${ }^{111}$.

El Tribunal Supremo manifiesta que el ordenamiento jurídico siempre reacciona contra los actos llevados a cabo contra él mismo y esta respuesta también se ejercita a través de actos administrativos que, con base en la normativa contractual, impiden al operador económico acudir a la contratación pública durante un periodo de tiempo. En este sentido el Alto Tribunal afirmaba que "la prohibición de contratar es uno de los efectos de reacción del ordenamiento jurídico a determinadas conductas que se estiman atentatorias a la buena fe y confianza que deben presidir las relaciones entre Administración y quienes contratan con ella o aspiran a serlo"112.

Los actos limitativos de derechos comprenden toda una gama de medidas jurídicas coercitivas al objeto de hacer cumplir el ordenamiento jurídico y entre esas medidas nos encontramos, entre otras, con las sanciones administrativas y con las prohibiciones de contratar ${ }^{113}$. En este apartado, y más allá de una cuestión teórica, tratamos de dilucidar si las prohibiciones de contratar tienen naturaleza sancionadora o no ${ }^{114}$, puesto que de asumir esta calificación

${ }^{111}$ A la dificultad de delimitación conceptual se refieren REBOLLO PUIG, M., "El contenido de las sanciones", Justicia Administrativa número extraordinario dedicado a las Infracciones, sanciones y procedimiento administrativo sancionador, 2001, págs. 151 - 206; HUERGO LORA, A., Las sanciones (...), op. cit., págs. 209 y, con un carácter más general, PEMÁN GAVÍN, I., "Dificultades para la delimitación sustantiva del concepto de sanción. Pautas para un replanteamiento de la cuestión", Revista Aragonesa de Administración Pública, núm. 14, 1999, págs. 131 - 202.

${ }^{112}$ En el FJ 2 de la STS de 7 de noviembre de 2006 (RJ 2006\9055).

${ }^{113} \mathrm{De}$ actos limitativos de derechos se califican las prohibiciones de contratar en la STS de 31 de mayo de 2007 (RJ 2007\5402) FJ 2.

${ }^{114}$ Sobre esta materia, véase GOSÁLBEZ PEQUEÑO, H., El contratista (...), op. cit., pág. 200 y siguientes. GOSÁLBEZ se refiere a distintos autores que expresamente han defendido el carácter sancionador de algunas de las prohibiciones legales para contratar. Entre ellos, se cita a GONZÁLEZ-BERENGUER URRUTIA, quien en referencia al artículo 4 del texto articulado de la Ley de Contratos del Estado manifestaba que este precepto enumeraba "las causas de incapacidad para contratar con la Administración, causas de carácter de sanción y meras incompatibilidades", GONZÁLEZ-BERENGUER URRUTIA, J. L., "El texto articulado de la Ley de Contratos del Estado", Revista de Estudios de la Vida Local, núm. 142, julio - agosto, 1965 , pág. 540. 
se desplegarían una serie de consecuencias vinculadas al catálogo de garantías que deben respetarse en la declaración y aplicación de las prohibiciones de contratar, y que serían coincidentes con las que se predican del procedimiento administrativo sancionador como manifestación del ius puniendi de la Administración ${ }^{115}$.

A este respecto, es necesario señalar la contradicción - más aparente que real, como veremos - entre la jurisprudencia española y alguna de las sentencias del Tribunal General de la UE. Desde hace tiempo, nuestro Tribunal Supremo, después de algunas sentencias contradictorias ${ }^{116}$, viene manteniendo que las prohibiciones de contratar no participan del concepto de sanciones administrativas, "si bien al ser un acto limitativo de derechos deben aplicarse ciertos principios y garantías propios del procedimiento sancionador"117. En

${ }^{115}$ Entre los distintos autores que han tratado sobre el Derecho administrativo sancionador, vamos a destacar en este momento a Alejandro NIETO quien se refiere al Derecho administrativo sancionador como una política pública preventivo-represiva, al destacar que la clave del sistema administrativo sancionador ya no se encuentra tanto en la represión, sino en la prevención. NIETO GARCÍA, A., Derecho administrativo sancionador, $5 .^{\mathrm{a}}$ ed., Tecnos, Madrid, 2012.

${ }^{116}$ Resulta de cita obligada la STS de 30 de octubre de 1995 (RJ 1995 $\backslash 7885$ ) por ser una de las últimas en mantener dicha naturaleza sancionadora al sostener que "Solamente tienen esta naturaleza cuando la sanción impuesta comporta la privación de bienes jurídicos que rebasan el ámbito contractual, por ejemplo prohibición de contratar en lo sucesivo con las Administraciones Públicas" (FJ 3). No obstante, es preciso recordar que en los años ochenta encontramos muchos ejemplos de sentencias en las que se mantenía la idea de un carácter sancionador y punitivo de las prohibiciones de contratar. Sirvan como ejemplos la STS de 12 de julio de 1983 (RJ 1983\5703) "la inhabilitación del contratista tiene un carácter punitivo adicional, no necesariamente ligado al puro hecho del incumplimiento motivador de la resolución contractual" o la STS de 15 de julio de 1988 (RJ 1988\5903) "La inhabilitación del contratista y la pérdida de la garantía definitiva tienen carácter sancionador y punitivo derivado del incumplimiento del contratista".

${ }^{117}$ El mismo Tribunal aplica alguno de los principios del Derecho administrativo sancionador como puede verse en la sentencia de 11 de mayo de 2007 (RJ 2007 55843 ). Las sentencias del TS de 31 de mayo de 2007 (RJ 2007\5402) y de 11 de mayo de 2007 (RJ 2007 \5843) declararon expresamente que a las prohibiciones de contratar no se aplica el régimen de las sanciones administrativas, porque "no estamos ante un acto sancionador". Así se ha pronunciado también, y en reiteradas ocasiones, la Audiencia Nacional, entre otras en sus sentencias de 18 de enero de 2006 (RJ $2006 \backslash 243880$ ), de 11 de diciembre de 2008 (RJ 2009\34893), de 14 de mayo de 2009 (RJ 2010\332048) y de 15 de diciembre de 2011 (RJ 2011\436010). 
cambio, el Tribunal General adopta el nomen iuris de sanción administrativa, para referirse a la decisión de excluir temporalmente a un operador económico de un contrato de la Unión como consecuencia de haber efectuado falsas declaraciones al facilitar la información exigida por el órgano de contratación para participar en el procedimiento de adjudicación ${ }^{118}$.

Así las cosas, no apreciamos, sin embargo, que exista una antinomia irreductible entre las afirmaciones de los dos Tribunales. Es cierto que el Tribunal General califica dicha exclusión como «sanción» ${ }^{119}$, pero del análisis de la propia sentencia se extrae que lo importante no es establecer si se trata - o no de una decisión sancionadora, sino de dilucidar si de la medida implementada resultan actos lesivos para los interesados, es decir, que afectan a sus intereses acarreándoles "graves consecuencias económicas" o, de un modo más genérico, consecuencias que trascienden al contrato en cuestión, como puede ser la lesión de su reputación, porque de ser así, habría que aplicar el principio general de respeto al derecho de defensa ${ }^{120}$.

\footnotetext{
${ }^{118} \mathrm{El}$ apartado 60 de la sentencia de 26 de septiembre del 2014, Flying Holding y otros/Comisión, asuntos acumulados T-91/12 y T-280/12, señala que “(...) medidas como la exclusión temporal de un operador económico del régimen de ayudas de la Unión como consecuencia de falsas declaraciones pueden calificarse de sanciones administrativas" y, en su apartado 63, el Tribunal sostiene que "la decisión de exclusión de las demandantes del contrato controvertido tiene carácter de sanción administrativa".
}

${ }^{119}$ Procede mencionar que el propio TJUE, en el marco del régimen de ayudas agrícolas de la Unión, se refiere al término sanción para aludir al instrumento administrativo específico impuesto en caso de incumplimiento de las exigencias de probidad y fiabilidad "destinado a garantizar la buena gestión económica de los fondos públicos comunitarios", sentencias de 11 de julio de 2002, Käserei Champignon Hofmeister, C-210/00, apartado 41 y 5 de junio de 2012, Bonda, C-489/10, apartado 29. El Abogado General Sr. MENGOZZI alude también al concepto de sanción para referirse a la exclusión del licitador de participar en el procedimiento de adjudicación del contrato, en sus conclusiones presentadas, el 9 de septiembre de 2015, en el asunto RegioPost, C-115/14, apartado 91.

${ }^{120}$ Sentencia de 26 de septiembre del 2014, Flying Holding y otros/Comisión, asuntos acumulados T-91/12 y T-280/12, apartado 65, con cita expresa a la sentencia de 9 de julio de 1999, New Europe Consulting y Brown/Comisión, T-231/97 "el respeto de los derechos de defensa en todo procedimiento incoado contra una persona y que pueda terminar en un acto que le sea lesivo constituye un principio fundamental del Derecho comunitario". 
En este sentido, las dos posiciones se acercan. Su consideración de medida desfavorable es evidente al incidir negativamente en el ejercicio de la actividad profesional del operador económico, pues implica su expulsión del mercado de las compras públicas por el tiempo que dure la prohibición. Ahora bien, a los efectos de precisar su naturaleza sancionadora lo determinante es analizar qué pretende conseguirse a través de la imposición de una prohibición de contratar, ya que la función represiva es la que distingue la sanción de otro tipo de actos administrativos limitadores de derechos, y si careciese de tal función no estaríamos en el ámbito sancionador ${ }^{121}$.

Tal como hemos apuntado, las prohibiciones de contratar desempeñan, principalmente, una función disuasoria que se logra mediante la amenaza de una consecuencia negativa y, aunque en determinadas circunstancias, esta función puede constituir un indicio de su carácter sancionador, lo cierto es que del análisis de su régimen propio - que, por lo que a esta memoria doctoral interesa, es el contractual - debemos mantener que no se impone una prohibición de contratar con un fin represivo o retributivo por la realización de una conducta que se considere administrativa o penalmente ilícita ${ }^{122}$. A nuestro juicio, las prohibiciones de contratar no participan de una función punitiva, o lo que es lo mismo, no suponen un castigo por la realización de una conducta reprochable, sino un estímulo para el cumplimiento de los requisitos de admisibilidad al procedimiento de licitación.

Habida cuenta de estas consideraciones, procede señalar que, en el marco de la legislación de contratos públicos, cuando el legislador establece requisitos de aptitud para la selección del contratista (capacidad, solvencia y ausencia de prohibiciones de contratar), la exclusión de cualquier operador económico por inobservancia de alguno de ellos, no constituye una sanción, aun cuando

\footnotetext{
${ }^{121}$ Así se manifiesta la Audiencia Nacional en sus sentencias de 4 de febrero de 2004 (RJ 2007 209249 , FJ 1) y de 20 de julio de 2004 (RJ 2007 209237 , FJ 4) al indicar que es la función represora y punitiva la que diferencia la sanción de otro tipo de actos administrativos restrictivos de derechos que toman en consideración la conducta de las personas y que cumplen una función de prevención general.

${ }^{122}$ Recordemos que el mismo Tribunal Supremo ha manifestado que la prohibición de contratar no tiene carácter sancionador por estar ausentes las funciones represora y punitiva que presenta toda sanción. En tal sentido, se manifiestan las sentencias de 31 de mayo de 2007 (RJ 2007\5402) y de 11 de mayo de 2007 (RJ 2007\5843).
} 
produce efectos gravosos para los interesados, sino que es la mera consecuencia del incumplimiento de los referidos requisitos legalmente establecidos.

A pesar de lo dicho, creemos de interés examinar si podemos mantener la afirmación de que las prohibiciones de contratar no participan de la función represiva propia de las sanciones en tres ámbitos concretos: (1) cuando la prohibición se impone como consecuencia de un incumplimiento de las obligaciones derivadas de un contrato previo; (2) en el ámbito del Derecho administrativo sancionador al calificarse expresamente por el legislador como sanciones no pecuniarias o accesorias y, por último, (3) en el ámbito penal con referencia a la prohibición de contratar como pena privativa de derechos.

\section{A. La prohibición de contratar por incumplimiento de las obliga- ciones por parte del contratista}

Una vez que el legislador identifica una situación específica que entiende puede afectar gravemente al interés general habilita mecanismos para prohibir las conductas que la configuran. Entre esas conductas se encuentra la de no volver a contratar con aquel operador que en un contrato anterior ha dado muestras de deficiencias significativas en la ejecución del contrato o ha resuelto de manera culpable un contrato anterior ${ }^{123}$. Si no fuera así, el órgano de contratación - sometido al principio de legalidad - estaría obligado a adjudicar un contrato posterior a ese licitador si resultara que es quien presenta la oferta económicamente más ventajosa, aun cuando es perfectamente conocedor de su falta de fiabilidad al no haber respetado los compromisos contractuales anteriores.

El interés del legislador radica, por tanto, en que no puedan resultar adjudicatarios de un nuevo contrato quienes, con anterioridad, ya incumplieron las obligaciones estipuladas en el marco de un contrato anterior, al entender que tales incumplimientos entrañan una conducta contraria a la buena fe que debe regir la ejecución contractual por parte del contratista ${ }^{124}$. Ahora bien,

\footnotetext{
${ }^{123}$ En el TRLCSP éstas son dos de las circunstancias que impiden contratar con las entidades del sector público (artículo 60.2 letras c y d).

${ }^{124}$ Atendiendo a lo dispuesto en la STJUE de 13 de diciembre de 2012, Forposta y $A B C$ Direct Contact, C-465/11, apartado 29 "el incumplimiento de sus obligaciones
} 
esta causa de prohibición de contratar no ha encontrado respaldo normativo autónomo en el Derecho de la Unión hasta la aprobación de las vigentes Directivas $^{125}$, más allá de enmarcarse en la clásica circunstancia impeditiva de haber "cometido una falta grave en materia profesional"126.

La denominada «cuarta generación» de Directivas ${ }^{127}$ considera, sin embargo, que se debe "poder excluir a los candidatos o licitadores cuya actuación en anteriores contratos públicos/concesiones haya mostrado graves deficiencias en lo que se refiere al cumplimiento de los requisitos de fondo, como la no realización de una entrega o prestación, la existencia de deficiencias significativas en el producto entregado o el servicio prestado que los hagan inutilizables para el fin perseguido, o una conducta indebida que haga dudar seriamente de la fiabilidad del operador económico" ${ }^{128}$.

En tal sentido, y a tenor del artículo 57.4.g) de la Directiva 2014/24/UE :

contractuales por parte de un operador económico es una falta cometida en materia profesional".

${ }^{125}$ Debemos matizar, no obstante, que el Acuerdo sobre Contratación Pública de la Organización Mundial del Comercio del que forman parte la UE y sus Estados miembros, sí recogía en su texto revisado en el año 2006 que se pudiera excluir de la adjudicación de un contrato a un proveedor por motivos tales como "deficiencias significativas o persistentes en el cumplimiento de cualquier requisito sustantivo u obligación dimanante de uno o más contratos anteriores" (artículo VIII.3.d).

${ }^{126}$ En el Capítulo segundo de esta memoria doctoral se analiza la evolución en las causas de prohibición de contratar, pero ya podemos avanzar que la calificamos de "clásica" porque esta prohibición ya se encontraba recogida en el artículo 23.d) de la Directiva 71/305/CEE (obras) y en el artículo 20.d) de la Directiva 77/62/CEE (suministro).

${ }^{127}$ Es la denominación utilizada por BENACCHIO, G., "Verso le direttive di quarta generazione", en la obra colectiva Gli appalti pubblici tra regole europee e nazionali, EGEA, Milán, 2012, págs. 3-28; MORENO MOLINA, J. A., "La cuarta generación de Directivas de la Unión Europea sobre contratos públicos", en la obra colectiva $O b$ servatorio de contratos públicos 2012, Thomson Aranzadi, Cizur Menor (Navarra), 2013, págs. 115 - 163 y GIMENO FELIÚ, J. M. a "Las nuevas Directivas - cuarta generación - en materia de contratación pública. Hacia una estrategia eficiente en compra pública", REDA, núm. 159, julio - septiembre 2013, págs. 39 - 105.

${ }^{128}$ Considerando centésimo primero de la Directiva 2014/24/UE y considerando septuagésimo de la Directiva 2014/23/UE («concesiones»). 
"Los poderes adjudicadores podrán excluir a un operador económico de la participación en un procedimiento de contratación, por sí mismos o a petición de los Estados miembros, en cualquiera de las siguientes situaciones:

g) cuando el operador económico haya mostrado deficiencias significativas o persistentes en el cumplimiento de un requisito de fondo en el marco de un contrato público anterior, de un contrato anterior con una entidad adjudicadora o de un contrato de concesión anterior que hayan dado lugar a la terminación anticipada de ese contrato anterior, a indemnización por daños y perjuicios o a otras sanciones comparables." 129

Aun a pesar de la novedad que supone este motivo de exclusión en las nuevas Directivas sobre contratación pública, esta prohibición de contratar ha sido recogida, con algunas variaciones, en la normativa contractual española desde sus orígenes ${ }^{130}$, y ha provocado una notable discusión sobre si esta prohibición puede ser configurada - o no - como una sanción al contratista que incumple sus obligaciones ${ }^{131}$, discusión motivada en parte porque la propia jurispru-

${ }^{129}$ Con una redacción similar, también se plasma en el artículo 38.7 f) de la Directiva de concesiones.

${ }^{130}$ Por ejemplo, en el artículo 1 del Real Decreto, de 10 de julio de 1861, que aprobaba el Pliego de condiciones generales para las contratas de obras públicas ya se disponía que: "No podrán ser contratistas de obras: 7. ${ }^{\circ}$ Los que hayan sido inhabilitados por la Administración para tomar á su cargo servicios públicos por su falta de cumplimiento en contratos anteriores" o en el artículo 4 del Decreto 923/1965, de 8 de abril, por el que se aprueba el texto articulado de la Ley de Contratos del Estado, al prever que "Están facultados para contratar con la Administración las personas naturales o jurídicas, españolas o extranjeras, que teniendo plena capacidad de obrar no se hallen comprendidas en alguna de las circunstancias siguientes: 5. Haber dado lugar por causa de las que se les declare culpables a la resolución o rescisión de dos contratos celebrados con el Estado o con sus Organismos autónomos dentro de un mismo periodo de cinco años", (según la redacción dada tras la corrección de errores publicada en el BOE núm. 132, de 3 de junio). En el Anexo documental de esta memoria doctoral pueden consultarse las referencias normativas españolas sobre esta materia.

${ }^{131}$ Así lo expone BARRERO RODRÍGUEZ, C., La resolución de los contratos administrativos por incumplimiento del contratista, 2. ${ }^{\text {a }}$ ed., Lex Nova, Valladolid, 2011. La discusión traspasa las fronteras y prueba de ello es que JÈZE después de 
dencia respaldaba el carácter sancionador y punitivo de la inhabilitación del contratista $^{132}$.

Respecto de su plasmación en las Directivas, es preciso destacar dos aspectos que van a resultar comunes a lo dispuesto en la normativa española, ya que, por una parte, hemos de distinguir las causas que fundamentan la imposición de esta prohibición de contratar, y por otra, los requisitos para resolver un contrato por causas imputables al contratista y que, es importante recalcar, tiene lugar en un procedimiento diferente.

Así pues, las circunstancias que la Directiva contempla para la aplicación de esta prohibición son tres - y de carácter alternativo a juzgar por el empleo de la conjunción disyuntiva «0»- la terminación anticipada de un contrato anterior, la indemnización por daños y perjuicios y la imposición de "otras sanciones comparables" 133 , si bien todas ellas son consecuencia de la existencia de un previo incumplimiento de las obligaciones contractuales.

Por otra parte, la resolución de un contrato implica la terminación anormal de la relación contractual al existir motivos que inciden en la correcta ejecución del contrato. En el caso que nos ocupa: (i) la causa que ampara la resolución contractual debe entenderse referida a un comportamiento imputable únicamente al contratista; (ii) el comportamiento del contratista debe revelar deficiencias importantes en lo que se refiere al cumplimiento de sus

señalar que en Francia existía una práctica tradicional que consiste en que "cuando un empresario o un proveedor ha ejecutado un contrato en forma muy deficiente, el jefe de servicio declara - a título de penalidad - su exclusión de las adjudicaciones y suministros del servicio", manifiesta que dicha decisión de exclusión es una medida administrativa que no tiene, en ningún grado, el carácter de una condenación penal judicial. "La Administración, teniendo motivos para quejarse de un empresario o proveedor, decide no contratar más con él", en JÈZE, G., Principios generales del Derecho (...), op. cit., págs. 139 y 141.

${ }^{132}$ Además de ya citada sentencia de 30 de octubre de 1995 (RJ 1995 7885 ), cabe destacar las sentencias del TS de 18 de mayo de 1983 (RJ 1983\6078) al tratar de la "imposición de la sanción de prohibición de contratar" y de 8 de junio de 1990 (RJ 1990\5377) al señalar que "la inhabilitación del contratista tiene a todas luces un carácter punitivo adicional".

${ }^{133}$ A nuestro entender, la expresión "otras sanciones comparables" no condiciona la naturaleza jurídica de la prohibición de contratar, ni de la imposición de penalidades que se puedan aplicar por incumplimiento de las obligaciones contractuales. 
obligaciones contractuales esenciales ${ }^{134}$; y, por último, (iii) para la resolución del contrato es exigible la culpabilidad del contratista, ya lo sea en su grado mayor o dolo, o a título de negligencia ${ }^{135}$.

Es evidente que en la inhabilitación del contratista por esta causa podemos encontrar algunos elementos que le confieren un cierto sesgo sancionador, puesto que dicha medida incide negativamente sobre sus intereses al traducirse en la restricción del derecho a volver a participar en un procedimiento de adjudicación durante un plazo de tiempo determinado; además de ello, se aplica como consecuencia de un incumplimiento que está previsto por la normativa y, precisamente, se impone al operador económico que aparece como responsable del mismo. No obstante, entendemos que estos hechos no bastan por sí solos para sostener la consideración de sanción, ya que, como hemos venido manteniendo, el carácter sancionador de un acto depende de la función que a través de la imposición de la medida de gravamen pretende conseguirse ${ }^{136}$.

En efecto, debemos recordar que el concepto de sanción admite que no se comprenda en él toda medida restrictiva de derechos o simplemente desfavorable, sino que sólo tienen naturaleza propiamente sancionadora aquéllas que tienen una finalidad meramente represiva o de castigo ${ }^{137}$. El concepto de

\footnotetext{
${ }^{134}$ Utilizamos la calificación de esenciales por ser la recogida en la legislación española entre las causas de resolución contractual (artículo 223.f del TRLCSP), si bien, conforme a lo dispuesto en las Directivas el incumplimiento se vincula a "requisitos de fondo" (substantive requirements en la versión inglesa y défaillances importantes en la versión francesa) que ejemplificados en los considerandos atienden mejor a la idea de tratarse de incumplimientos de las obligaciones principales del contrato.
}

${ }^{135}$ STS de 18 de marzo de 2015 (RJ 2015 \2796). El TJUE, en su interpretación de la expresión «falta grave», ya manifestaba que debía entenderse referida a un comportamiento que revele dolo o una negligencia de cierta gravedad por parte del operador económico en cuestión, STJUE de 13 de diciembre de 2012, Forposta y $A B C$ Direct Contact, C-465/11, apartado 30.

${ }^{136}$ FUERTES LÓPEZ, M., El contratista y el subcontratista (...), op. cit., pág. 88, mantenía que esta prohibición, a diferencia de otras, "se proyecta hacia una doble finalidad. Por un lado sanciona a los contratistas incumplidores, pero es que también surte efectos como llamada de atención, al advertir de la necesidad de un correcto cumplimiento contractual".

${ }^{137}$ En este sentido se manifiestan las sentencias del Tribunal Constitucional 239/1988, de 14 de diciembre, (FJ 2) y 164/1995, de 13 de noviembre, (FJ 2). 
sanción nos obliga, por tanto, a acudir a los conceptos de mal infligido (que sería la prohibición de contratar) y de conducta irregular (incumplimiento del contrato por parte del contratista) para dilucidar si estamos verdaderamente ante un "castigo previsto por el ordenamiento para ser impuesto por la Administración"138.

En este sentido, la prohibición no supone un castigo por la realización de una conducta considerada ilícita administrativamente ${ }^{139}$. Desempeña, ante todo, una función de disuasión ante posibles incumplimientos, es decir, resulta un medio de presión a fin de lograr que el contratista atienda correctamente las obligaciones dimanantes del contrato y se orienta a asegurar que el contrato, en lugar de verse frustrado, alcance sus objetivos.

Para reforzar su carácter no sancionador, cabe señalarse que tampoco se impone como consecuencia de una infracción administrativa en el estricto sentido de la expresión (acción u omisión antijurídica, tipificada y culpable), puesto que de ser así - y tratándose de una medida restrictiva de derechos - sólo podría justificarse como sanción. La inhabilitación del contratista no resulta del incumplimiento de sus obligaciones esenciales, o lo que es lo mismo, no es consecuencia automática del incumplimiento del contrato por parte de aquél. El acto administrativo firme declarando la resolución de un contrato anterior "se erige en el presupuesto de hecho necesario" para que, una vez constatada la culpabilidad del contratista, se pueda proceder a la declaración de la prohi-

GARCÍA DE ENTERRÍA sostenía que por sanción administrativa entendemos "un mal infligido por la Administración a un administrado como consecuencia de una conducta ilegal. Ese mal (fin aflictivo de la sanción) consistirá siempre en la privación de un bien o de un derecho", en GARCÍA DE ENTERRÍA, E., "El problema jurídico de las sanciones administrativas", REDA, núm. 10, julio - septiembre, 1976, pág. 399. De la misma opinión, REBOLLO PUIG, M., "El contenido (...)", op. cit., págs. 155 y 156.

${ }^{138}$ Es el concepto de sanción acotado por REBOLLO PUIG, M., "El contenido (... )", op. cit., pág. 154 .

${ }^{139}$ Es una opinión compartida con GOSÁLBEZ PEQUEÑO quien se oponía expresamente a la consideración de sanción administrativa en tanto que "las prohibiciones contractuales no pretenden castigar al empresario por la realización de alguna actuación ilegal", sino "prevenir ejecuciones defectuosas o incorrectas de los contratos públicos en orden a los antecedentes inmediatos de los aspirantes", en GOSÁLBEZ PEQUEÑO, H., El contratista (...), op. cit., págs. 202 y 203. 
bición ${ }^{140}$, pero no se trata de un automatismo derivado de una relación causa - efecto.

La exclusión de la posibilidad de contratar tiene lugar tras la declaración sobre la concurrencia de la prohibición de contratar que, en este caso concreto, deriva de la resolución de un contrato por incumplimiento culpable del contratista. El inicio del expediente de declaración de la prohibición queda en manos del órgano de contratación que ha resuelto el contrato y, de hecho, la práctica lo avala al mostrarnos que son más numerosos los casos de resolución contractual culpable del contratista que los supuestos de prohibición de contratar por esta causa ${ }^{141}$. En este contexto, y aunque será objeto de un tratamiento posterior, no podemos pasar por alto referirnos a que es la inactividad de los órganos de contratación respecto de dar inicio del procedimiento una de las razones de ineficacia del sistema de prohibiciones de contratar como "arma de disuasión" ${ }^{\prime 142}$.

En coherencia con lo que hemos expuesto, las prohibiciones de contratar por incumplimiento del contratista no tienen un carácter sancionador, aunque sí - como el resto de prohibiciones - limitan la facultad de ser parte en un contrato público en atención a garantizar la buena ejecución contractual y, como tendremos ocasión de desarrollar más adelante al tratar los fundamentos

${ }^{140}$ BARRERO RODRÍGUEZ, C., "La resolución del contrato por incumplimiento del contratista en la Ley 30/2007, de 30 de octubre, de Contratos del Sector Público", $R A P$, núm. 176, mayo - agosto, 2008, pág. 100 "La prohibición para contratar por tal causa exige, una declaración previa sobre la concurrencia de la prohibición, el alcance y duración de ésta, de acuerdo con el procedimiento que en las normas de desarrollo de esta Ley se establezca atendiendo, en su caso, a la existencia de dolo o manifiesta mala fe en el empresario y a la entidad del daño causado a los intereses públicos".

${ }^{141}$ Resulta ilustrativo que en España, en el periodo comprendido entre los años 1997 y 2008, se publicaron en el BOE sólo 50 supuestos de declaración de prohibición de contratar por este motivo de exclusión, primero, en el artículo 20.c) de la Ley 13/1995, de 18 de mayo, de Contratos de las Administraciones Públicas y, después, en el artículo 20.c) del Real Decreto Legislativo 2/2000, de 16 de junio, por el que se aprobó el Texto Refundido de la Ley de Contratos de las Administraciones Públicas.

${ }^{142}$ El paso del tiempo ha venido a confirmar el vaticinio de GARCÍA DE ENTERRÍA sobre la benevolencia de la Administración respecto de la aplicación de esta prohibición de contratar, en "Dos regulaciones orgánicas (...)", op. cit., págs. $249-250$. 
de las prohibiciones de contratar, para salvaguardia de los propios fines de la contratación pública.

Un supuesto distinto es el que se analiza en los siguientes epígrafes.

\section{B. La prohibición de contratar como sanción administrativa}

Con fundamento en su ius puniendi, el legislador interno se encuentra habilitado para concretar los comportamientos que se tipifican como faltas y fijar las sanciones que resultan aplicables ${ }^{143}$. La libertad del legislador para establecer las sanciones se ve reforzada por el hecho de que ni siquiera tienen que tener alguna clase de relación material con la infracción que la origina ${ }^{144}$. En este sentido, al tratar los aspectos conceptuales, hemos advertido que en distintos sectores de actividad administrativa (subvenciones, defensa de los consumidores y usuarios, patrimonio, hacienda, etc.) se prevé - y se califica - como sanción administrativa la prohibición de contratar por incumplimiento de los deberes $\mathrm{u}$ obligaciones previstos en dicha normativa sectorial, sin que estén vinculados a la legislación contractual ${ }^{145}$.

De esta manera, no podemos desconocer que las prohibiciones de contratar también se han venido calificando normativamente como sanciones - algunas

\footnotetext{
${ }^{143}$ La referencia al ius puniendi del Estado es común para delitos y sanciones administrativas, en cuanto que ambas constituyen manifestaciones del mismo y obedecen a idénticos principios ontológicos; sin embargo, en este epígrafe vamos a referirnos únicamente a las sanciones administrativas.

${ }^{144}$ En opinión de REBOLLO PUIG "no hay una exigencia general de congruencia entre sanciones e infracciones que limite al legislador", en REBOLLO PUIG, M., "El contenido (...)", op. cit., pág. 162.

${ }^{145}$ Vamos a poner tres ejemplos entre muchos otros posibles: (1) la prohibición de contratar obras con la Administración pública por la comisión de infracciones urbanísticas graves y muy graves recogida en el artículo 209.1.a) de la Ley 7/2002, de 17 de diciembre, de Ordenación Urbanística de Andalucía; (2) las sanciones de prohibición de contratar impuestas por la comisión de una infracción grave o muy grave de la Ley 16/2006, de 28 de diciembre, de Protección y Defensa de los Consumidores y Usuarios de Aragón (artículo 92.apartado 1.c) y apartado 2.c), y (3) en la Ley $12 / 2015$, de 8 de abril, de igualdad social de lesbianas, gais, bisexuales, transexuales, transgénero e intersexuales y de políticas públicas contra la discriminación por orientación sexual e identidad de género en la Comunidad Autónoma de Extremadura (artículo 48.2 b) y 3.c).
} 
veces con el adjetivo de accesorias - superando el mero efecto disuasorio y actuando como "castigo" por contravenir dicha legislación sectorial. Así pues, aunque configuradas al margen de la normativa contractual, las prohibiciones de contratar también encuentran acomodo en el contexto del régimen sancionador participando de un carácter aflictivo y represivo ${ }^{146}$. No se trata sólo de llevar a cabo una distinción formal entre categorías jurídicas, puesto que vistas desde este ámbito, las prohibiciones constituyen una manifestación del Derecho administrativo sancionador y, como tal, les serán de aplicación todos los principios y garantías exigibles para la imposición de sanciones (por ejemplo, principios de legalidad, de culpabilidad, presunción de inocencia, prohibición de non bis in idem, etc.), con especial diferenciación respecto de extremos tales como la carga de la prueba en el procedimiento o la posibilidad de moderación de la responsabilidad en aplicación de los criterios de culpa vigentes en materia sancionadora $^{147}$.

Conforme a una visión esquemática, se puede afirmar que la prohibición de contratar es una de las formas de reproche que los ordenamientos jurídicos nacionales han previsto ante la infracción de ciertas conductas en distintos ámbitos de actuación administrativa. Dicho en otros términos, es una de las consecuencias que lleva aparejada la infracción de la normativa y que, en principio, será declarada por la autoridad competente para sancionar dichas infracciones ajustándose al procedimiento sancionador que tenga por objeto depurar las actuaciones contrarias a dicha norma sectorial ${ }^{148}$.

\footnotetext{
${ }^{146}$ Recordemos que ésta es la característica principal de las sanciones y lo que las distingue de otras resoluciones administrativas que restringen derechos individuales con otros fines (STC 132/2001, de 8 de junio, FJ 3). Para ilustrar lo anterior, baste recordar los supuestos recogidos en las notas al pie 33 a 41 de este mismo capítulo (páginas $61-62$ ).

${ }^{147}$ Puede consultarse, con un carácter general, SUAY RINCÓN, J., Sanciones administrativas, Publicaciones del Real Colegio de España, Bolonia, 1989; NIETO GARCÍA, A., Derecho administrativo (...), op. cit., ALARCÓN SOTOMAYOR, L., Procedimiento administrativo sancionador y derechos fundamentales, Cizur Menor (Navarra), Thomson-Aranzadi, 2007 y GÓMEZ TOMILLO, M., Derecho administrativo sancionador. Parte general: teoría general y práctica del Derecho penal administrativo, 3. ${ }^{\mathrm{a}}$ ed., Thomson-Aranzadi, Cizur Menor (Navarra), 2013.

${ }^{148}$ En la mayoría de los supuestos el procedimiento previsto para la imposición de una sanción de prohibición de contratar se regula al margen de la legislación contractual; sin embargo, en ocasiones, la legislación sectorial remite a la norma-
} 
En esta materia, es útil mencionar, que además de las sanciones previstas en los distintos sistemas nacionales como parte del núcleo específico de su soberanía nacional, también las instituciones europeas están facultadas para concretar aquellas sanciones que estimen adecuadas para velar por que se repriman las infracciones del Derecho de la Unión. Dos de los ámbitos claves en los que esto sucede, y que serán objeto de tratamiento posterior, es el de la protección de los intereses financieros de la Unión, con la adopción de una normativa general relativa a controles homogéneos y a medidas y sanciones administrativas en todos los Estados miembros y en las instituciones europeas a través del Reglamento financiero ${ }^{149}$; y en el ámbito del Derecho de la competencia como consecuencia de las sanciones que la Comisión puede imponer para castigar conductas contrarias a la competencia ${ }^{150}$.

tiva de contratos para su imposición. Es el caso, por ejemplo, del artículo 43 bis al Texto Refundido de las Leyes de Ordenación del Territorio y de Espacios Naturales de Canarias, en su redacción dada por la Ley 14/2014, de 26 de diciembre: "El incumplimiento por el equipo redactor de las obligaciones asumidas, o su cumplimiento defectuoso, en la formulación de un instrumento de ordenación del territorio o de planeamiento urbanístico, con independencia de la posible responsabilidad contractual que pueda ser exigida por la administración contratante, podrá determinar, previo expediente con audiencia de los interesados, la desclasificación, en su caso, y la prohibición de contratar con las administraciones públicas de Canarias, en el marco de lo previsto en el artículo 18 del Reglamento General de Contratos de las Administraciones Públicas, aprobado por el Real Decreto 1098/2001, de 12 de octubre, por un plazo máximo de hasta cuatro años".

${ }^{149}$ Por una parte, el artículo 325 del Tratado de Funcionamiento de la Unión Europea (TFUE) exige a los Estados miembros que combatan las actividades ilegales que afecten a los intereses financieros de la Unión mediante medidas disuasorias y efectivas. Por otra, las disposiciones del Reglamento financiero que regulan la contratación pública - aun cuando no obligan a los Estados miembros, pues únicamente resultan aplicables a los contratos adjudicados por las instituciones, órganos y organismos de la Unión - contienen una regulación específica dirigida a hacer efectivo el principio de buena gestión financiera en la adjudicación de contratos con cargo a los fondos públicos europeos, como por ejemplo el artículo 96 del Reglamento (UE, Euratom) 966/2012, del Parlamento Europeo y del Consejo, de 25 de octubre de 2012, sobre las normas financieras aplicables al presupuesto general de la Unión.

${ }^{150}$ Estas sanciones se han llegado, incluso, a calificar de «parapenales» en las conclusiones de la Abogado General Sra. KOKOTT, presentadas el 28 de febrero de 2013, en el asunto Schenker \& Co. y otros, C-681/11, apartado 40, que contiene varias citas en relación con la aplicación por el Tribunal de Justicia, en virtud de reiterada jurisprudencia, de los principios del Derecho penal en el ámbito del Derecho 
Así pues, bajo la exigencia de que "tengan un carácter efectivo, proporcionado y disuasorio" 151 , el legislador europeo puede instar a aplicar sanciones específicas para llevar a cabo la protección de ciertos bienes jurídicos mediante el ejercicio de la potestad sancionadora - que es la que específicamente nos ocupa en el presente epígrafe - a través de la tipificación de conductas cuya infracción conlleve la imposición de la sanción específica de prohibición de contratar.

Ejemplos de lo dicho pueden encontrarse en la Directiva 2009/52/CE, del Parlamento Europeo y del Consejo, de 18 de junio de 2009, por la que se establecen normas mínimas sobre las sanciones y medidas aplicables a los empleadores de nacionales de terceros países en situación irregular, cuyo artículo 7 establece una lista de medidas para sancionar a los empleadores responsables del empleo ilegal, de tal manera que:

\begin{abstract}
"Los Estados miembros dispondrán lo necesario para garantizar que los empleadores también sean, en su caso, objeto de las medidas siguientes: b) exclusión de la participación en licitaciones públicas tales como las mencionadas en la Directiva 2004/18/CE del Parlamento Europeo y del Consejo, de 31 de marzo de 2004, sobre coordinación de los procedimientos de adjudicación de los contratos públicos de obras, de suministro y de servicios durante un período máximo de cinco años" (Artículo 7.1) ${ }^{152}$.
\end{abstract}

Asimismo, de conformidad con lo dispuesto en el artículo 6 de la Directiva 2011/36/UE, del Parlamento Europeo y del Consejo, de 5 abril de 2011, relativa a la prevención y lucha contra la trata de seres humanos y a la pro-

europeo de la competencia.

${ }^{151}$ En este sentido, las sentencias del TJUE de 3 de mayo de 2005, Berlusconi y otros, C-387/02, C-391/02 y C-403/02, apartado 65; de 4 de julio de 2006, Adeneler y otros, C-212/04, apartado 94 y de 3 de julio de 2014, Fiamingo y otros, C-362/13, C-363/13 y C-407/13, apartados 62 y 64.

${ }^{152}$ DOUE L 168, de 30 de junio de 2009. Creemos de interés destacar que todos los Estados miembros, excepto Dinamarca, Irlanda y el Reino Unido, están vinculados por esta Directiva, ya que estos países no se acogieron a la opción de participar en la Directiva 2009/52/CE y, por lo tanto, no están vinculados por ella, ni sujetos a su aplicación. 
tección de las víctimas ${ }^{153}$, el legislador de la Unión ha exigido a los Estados miembros que adopten las medidas necesarias para garantizar que la persona jurídica considerada responsable de estas prácticas sea excluida "del disfrute de ventajas o ayudas públicas" y/o quede inhabilitada "temporal o permanente para el ejercicio de actividades comerciales".

En semejantes términos se expresa el artículo 10 de la Directiva 2011/93/UE, del Parlamento Europeo y del Consejo, de 13 de diciembre de 2011, relativa a la lucha contra los abusos sexuales y la explotación sexual de los menores y la pornografía infantil ${ }^{154}$, al prever que los delincuentes condenados que sean personas físicas queden inhabilitados para ejercer actividades que impliquen contactos directos y regulares con menores, o que, en su artículo 13.1.b), contempla la inhabilitación temporal o permanente para el ejercicio de actividades comerciales como una posible sanción a imponer a las personas jurídicas responsables de estos delitos.

En todas estas disposiciones se alude, de una manera explícita, a la dimensión punitiva de las medidas que los Estados miembros deben adoptar para sancionar las prácticas mencionadas en estas Directivas y que, además de obligar a los Estados miembros a establecer penas, contempla la posibilidad de imponer sanciones en el ámbito administrativo, una de las cuales puede ser la de prohibición de contratar.

Avanzando brevemente en lo que supone una de las principales novedades de las nuevas Directivas de contratación pública respecto de los motivos de exclusión obligatorios, hemos de señalar que en esta materia existe una interconexión entre regulaciones - aunque deficientemente resuelta como analizaremos después - al preverse la exclusión de la participación en un procedimiento de contratación a quienes hayan sido condenados en sentencia judicial firme por "trabajo infantil y otras formas de trata de seres humanos" (artículo 57.1.f) de la Directiva 2014/24/UE), sin que en ningún momento de este mismo artículo se señale una prohibición de contratar por haber sido sancionados por estas

${ }^{153}$ DOUE L 101, de 15 de abril de 2011.

${ }^{154}$ Directiva 2011/93/UE del Parlamento Europeo y del Consejo, de 13 de diciembre de 2011, relativa a la lucha contra los abusos sexuales y la explotación sexual de los menores y la pornografía infantil y por la que se sustituye la Decisión Marco 2004/68/JAI del Consejo (DOUE L 335, de 17 de diciembre de 2011). 
mismas conductas, más allá de la referencia genérica a haber cometido una falta profesional grave que ponga en entredicho su integridad (artículo 57.4.c) de la Directiva 2014/24/UE).

En este último caso ya no nos encontramos ante una prohibición de contratar con un carácter sancionador. De vuelta en el ámbito contractual, el supuesto es de signo inverso: la imposición de una sanción con carácter firme por la comisión de ciertas infracciones conlleva la prohibición de contratar, no constituyendo una sanción por un comportamiento anterior ${ }^{155}$.

En efecto, podemos colegir que alguna de las circunstancias configuradas legalmente como motivos de exclusión por parte de las Directivas de contratación pública tienen como presupuesto la adopción de una resolución administrativa sancionadora por la comisión de una falta profesional grave; es decir, tienen su origen en una sanción previa, pero no comparten su naturaleza jurídica, ni consagran una modalidad adicional de sanción.

A este respecto, y a título de ejemplo, vamos a referirnos a los supuestos del Derecho francés, concretamente en el artículo 45.4 de la Ordenanza 2015-899, de 23 de julio de 2015, sobre contratación pública al establecer la prohibición de contratar por incumplimiento de las obligaciones recogidas en distintos artículos del Código de Trabajo:

«Sont exclues de la procédure de passation des marchés publics: (...)

$4^{\circ}$ Les personnes qui : a) Ont été sanctionnées pour méconnaissance des obligations prévues aux articles L. 8221-1, L. 8221-3, L.

\footnotetext{
${ }^{155}$ De tener la consideración de sanción, nos enfrentaríamos a una posible contravención del principio non bis in idem. Dicho principio prohíbe que se sancione - o se inicie de nuevo un procedimiento sancionador - contra un mismo sujeto por una causa de la cual ya ha sido sancionado o del que se le haya declarado no responsable mediante una decisión anterior que ya no puede ser objeto de recurso (constatación de la triple identidad de hecho, sujeto y fundamento). Ahora bien, teniendo en cuenta su naturaleza de medidas limitadoras, y no de sanciones (ni administrativas, ni penales como seguidamente veremos), no les resulta aplicable el principio non bis in idem. En este mismo sentido se manifiesta la STS de 31 de mayo de 2007 (RJ $2007 \backslash 5402)$ "no estamos ante un acto sancionador, y por tanto asiste la razón a la sentencia en el sentido de que no cabe entender que hubiera podido infringirse el principio de non bis in idem" (FJ 2).
} 
8221-5, L. 8231-1, L. 8241-1, L. 8251-1 et L. 8251-2 du code du travail ${ }^{156}$.

"Son excluidas del procedimiento de adjudicación contractual: (...)

4. ${ }^{\circ}$ Las personas que: a) Han sido sancionadas por incumplimiento de las obligaciones previstas en los artículos 8221-1, 8221-3, 8221-5, 8231-1, 8241-1, 8251-1 y 8251-2 del Código de Trabajo" [Traducción propia]

En Portugal en el artículo 55 apartados c) y g) del Código dos Contratos Públicos, sobre la aplicación de distintas sanciones accesorias e inhabilitaciones $^{157}$ :

Artigo 55. ${ }^{\circ}$ Impedimentos.

Não podem ser candidatos, concorrentes ou integrar qualquer agrupamento, as entidades que:

c) Tenham sido objeto de aplicação de sa ção administrativa por falta grave em matéria profissional, se entretanto não tiver ocorrido a sua reabilita ção, no caso de se tratar de pessoas singulares, ou, no caso de se tratar de pessoas colectivas, tenham sido objeto de aplica ção daquela san ção administrativa os titulares dos órgãos sociais de administra ção, direcção ou gerência das mesmas e estes se encontrem em efectividade de fun ções;

g) Tenham sido objeto de aplica ção da san ção acessória prevista na alínea b) do n.. 2 do artigo 562. ${ }^{\circ}$ do Código de Trabalho;

Artículo 55. Prohibiciones de contratar.

No podrán ser candidatos o licitadores, ni integrar una agrupación de los mismos, las entidades que:

${ }^{156}$ Se trata de supuestos de lucha contra el trabajo ilegal y del empleo de extranjeros sin permiso de trabajo (estamos consultando la versión del Código de trabajo que entrará en vigor el 1 de noviembre de 2015).

${ }^{157}$ Código dos Contratos Públicos, aprobado por Decreto Ley 18/2008, de 29 de enero de 2008 y modificado en distintas ocasiones entre la que destacamos los cambios introducidos por el Decreto Ley 149/2012, de 12 de julio. 
c) Han sido objeto de una sanción administrativa por falta grave en materia profesional, mientras no se produzca su rehabilitación, en caso de tratarse de personas físicas, o, en caso de tratarse de personas jurídicas, han sido objeto de esta misma sanción administrativa los titulares de los órganos rectores de administración, de dirección o gerencias de las mismas y éstos se encuentren en el ejercicio de esas funciones.

g) Han sido objeto de las sanciones accesorias previstas en el apartado b) del párrafo 2. ${ }^{\circ}$ del artículo 562 del Código de Trabajo [Traducción propia]

Y en Bélgica, en la Ley de 15 de junio de 2006, relativa a los contratos públicos y a algunos contratos de obras, suministro y servicios - versión consolidada a 15 de mayo de 2014 - (Loi relative aux marchés publics et à certains marchés de travaux, de fournitures et de services):

\section{Droit d'accès et sélection qualitative}

Article 20 1/1. Sauf exigences impératives d'intérêt général, est exclu de l'accès au marché, à quelque stade que ce soit de la procédure, tout candidat ou soumissionnaire pour lequel il est établi qu'il a occupé, en tant qu'employeur, des ressortissants de pays tiers en séjour illégal au sens de la loi du 11 février 2013 prévoyant des sanctions et des mesures à l'encontre des employeurs de ressortissants de pays tiers en séjour illégal.

Derecho de acceso y selección cualitativa

Artículo 20 §1/1. Salvo razones imperiosas de interés general, es excluido del acceso al contrato, en cualquier etapa del procedimiento, cualquier candidato o licitador para el cual se establece que ha empleado, en calidad de empleador, a nacionales de terceros países que residen ilegalmente en el sentido de la Ley de 11 de febrero de 2013, sobre las sanciones y medidas aplicables a los empleadores de nacionales de terceros países en situación irregular. [Traducción propia] 


\section{La prohibición de contratar como pena aplicable a la comisión de determinados tipos delictivos}

La pena de inhabilitación especial en el supuesto de las personas físicas ${ }^{158}$ y la pena de prohibición de contratar para las personas jurídicas se ha incorporado en algunos ordenamientos como respuesta punitiva a la comisión de determinadas conductas delictivas.

La falta de armonización en esta materia y la variedad de sistemas de imposición de penas en los Derechos nacionales - como parte del núcleo propio de su soberanía nacional ${ }^{159}$ - nos obligan a referirnos a la legislación española, aunque las consideraciones que vamos a realizar se pueden extrapolar también a otros ordenamientos - como el francés - que también contempla la prohibición de contratar como una de las penas a imponer a las personas físicas y jurídicas («peine d'exclusion des marchés publics») $)^{160}$.

A este respecto, y aunque la finalidad de este epígrafe va a centrarse en distinguir la pena de prohibición de contratar impuesta por los tribunales de justicia y la prohibición de contratar establecida desde órganos administrativos

${ }^{158} \mathrm{Al}$ referirnos a la pena de inhabilitación para las personas físicas lo haremos en referencia general a una inhabilitación especial y no únicamente a la inhabilitación especial para el ejercicio de profesión, oficio, industria o comercio, puesto que el Código penal en su redacción actual contempla penas de inhabilitación especial que comprenderán, en todo caso, "el derecho a contratar con las Administraciones públicas" (artículo 262), "la pena de prohibición de contratar con el sector público" o la "prohibición de intervenir en transacciones comerciales de trascendencia pública" (artículo 286 ter).

${ }^{159}$ En esta materia, y a pesar del tiempo transcurrido, es de obligada referencia el Libro Verde sobre la aproximación, el reconocimiento mutuo y la ejecución de penas en la Unión Europea, COM (2004) 334 final, de 30 de abril.

${ }^{160}$ Artículo 131-34 del Código penal francés «La peine d'exclusion des marchés publics emporte l'interdiction de participer, directement ou indirectement, à tout marché conclu par l'Etat et ses établissements publics, les collectivités territoriales, leurs groupements et leurs établissements publics, ainsi que par les entreprises concédées ou contrôlées par l'Etat ou par les collectivités territoriales ou leurs groupements» y el artículo 131-39 (Des peines criminelles et correctionnelles aux personnes morales) «Lorsque la loi le prévoit à l'encontre d'une personne morale, un crime ou un délit peut être sanctionné d'une ou de plusieurs des peines suivantes: 5. L'exclusion des marchés publics à titre définitif ou pour une durée de cinq ans au plus». 
por aplicación de la normativa contractual, debemos iniciar este apartado con dos consideraciones previas.

En primer lugar, debe partirse del concepto de pena, de sus distintas funciones y, en el caso de las personas jurídicas, de unas referencias genéricas al reconocimiento de su responsabilidad penal ${ }^{161}$. En segundo lugar, creemos importante señalar que la obligación que fijan las Directivas sobre contratación pública es la de impedir el acceso a los contratos públicos a aquellos operadores condenados por determinados tipos delictivos (participación en una organización delictiva, corrupción, fraude, delito de terrorismo o ligado a actividades terroristas, blanqueo de capitales o trata de seres humanos), pero las condiciones de su aplicación quedan a la libre disposición de las legislaciones de los distintos Estados miembros ${ }^{162}$. Es decir, nos encontramos ante un supuesto de prohibición de contratar en el ámbito administrativo anudada a la condición de haber sido objeto de una determinada condena mediante sentencia judicial firme - por tanto, vinculada a la previa existencia de dicha condena - sin que esa condena lleve necesariamente aparejada una pena de inhabilitación (que es una decisión que corresponde inicialmente al legislador penal), y sin que estas Directivas contemplen disposiciones relativas al Derecho penal material, ni obliguen a los Estados miembros a establecer una responsabilidad penal por la comisión de estas conductas. No obstante, las Directivas sí contienen una previsión dirigida a concretar en qué medida estas prohibiciones resultan aplicables a las personas jurídicas - aun cuando no fueran responsables penalmente - y, de esta manera, cubrir los posibles vacíos de punibilidad ampliando su ámbito de aplicación cuando determinados sujetos actúan fácticamente en lugar de la persona jurídica (bajo la fórmula del «actuar en lugar de otro»).

Así pues, las Directivas sobre contratación establecen que "la obligación de excluir a un operador económico se aplicará también cuando el condenado

\footnotetext{
${ }^{161}$ Para conocer más sobre la responsabilidad penal de las personas jurídicas en alguno de los Estados miembros (Bélgica, Dinamarca, Países Bajos, Francia, Portugal y Rumanía) puede consultarse el volumen 28 de la Revista Eguzkilore, Cuaderno del Instituto Vasco de Criminología, del año 2014.

${ }^{162}$ El artículo 57.7 de la Directiva 2014/24/UE y el artículo 38.10 de la Directiva 2014/23/UE («concesiones») son del siguiente tenor: "Mediante disposiciones legales, reglamentarias o administrativas y teniendo en cuenta el Derecho de la Unión, los Estados miembros precisarán las condiciones de aplicación del presente artículo".
} 
mediante sentencia firme sea un miembro del órgano de administración, de dirección o de vigilancia del operador económico o tenga poderes de representación, decisión o control en el mismo" (artículo 57.1 in fine de la Directiva 2014/24/UE y artículo 38.4 in fine de la Directiva 2014/23/UE («concesiones»).

\section{C.1. Concepto y fines de la pena}

$\mathrm{Al}$ igual que hemos precisado respecto del Derecho administrativo sancionador, el legislador nacional tiene un amplio margen de apreciación discrecional para concretar el contenido de su Derecho penal en el desarrollo de la política criminal del Estado. Esta libertad de configuración le permite tipificar las conductas punibles, establecer la clasificación y la duración de las penas, así como contemplar circunstancias de agravación o de atenuación de la responsabilidad criminal, si bien, en cualquier caso, se trata de una libertad limitada, puesto que se debe ceñir a ciertos principios como son los de legalidad, tipicidad, culpabilidad y proporcionalidad ${ }^{163}$, y a ciertas garantías procesales como la presunción de inocencia, el non bis in idem o la prohibición de aplicación retroactiva.

De esta manera, el Derecho penal destaca respecto de otras ramas del Derecho por estar provisto del instrumento, en principio, más severo de control social - las penas - trazando los límites de las conductas permisibles y protegiendo, así, los bienes jurídicos que, en cada momento histórico, son seleccionados por el legislador en atención a los valores que una determinada comunidad tiene en mayor aprecio ${ }^{164}$. Tras la determinación de los comportamientos penalmente reprensibles, al legislador le corresponde también fijar los

163"El principio de legalidad penal, en su vertiente material, refleja la especial trascendencia del principio de seguridad jurídica (art. 9.3 CE) y comporta el mandato de taxatividad o de certeza que se traduce en la exigencia de predeterminación normativa de las conductas y de sus correspondientes sanciones lex certa, en virtud del cual el legislador debe promulgar normas concretas, precisas, claras e inteligibles, para que los ciudadanos puedan conocer de antemano el ámbito de lo proscrito y prever, así, las consecuencias de sus acciones" (STC 150/2015, de 6 de julio, FJ 2).

${ }^{164}$ En la Resolución del Parlamento Europeo, de 22 de mayo de 2012, sobre un enfoque de la UE acerca del Derecho penal se advertía que "el Derecho penal debe aplicarse como instrumento de último recurso (ultima ratio) para abordar una conducta bien definida y delimitada que no pueda atajarse con medidas menos severas" [P7_TA (2012) 208]. 
efectos que conlleva su realización y, en este sentido, la pena es la consecuencia jurídica típica asociada a la infracción realizada ${ }^{165}$. Uno de los presupuestos propios del Derecho penal es la retribución, la imposición de un castigo que encuentra su soporte en la culpabilidad delictiva y donde la pena es su máximo exponente $^{166}$.

En las sanciones penales resulta indudable esa naturaleza de castigo y aflictiva, aun cuando debe tenerse presente que la represión no es la única finalidad identificable de las penas. En relación con sus fines debe primar también una función de prevención general que - como hemos advertido con anterioridad debe asegurar el cumplimiento de las normas y, que en el ámbito penal, además sirve para disuadir a potenciales delincuentes de actuar en contra de los más altos valores sociales, lo cual distingue a la pena de otras sanciones, como son las administrativas ${ }^{167}$.

${ }^{165}$ MAPELLI CAFFARENA define la pena como "una institución de derecho público que limita un derecho a una persona imputable como consecuencia de una infracción criminal impuesta en una sentencia firme por un órgano judicial", en Las consecuencias jurídicas del delito, $5 .^{\mathrm{a}}$ ed., Civitas - Thomson Reuters, Cizur Menor (Navarra), 2011, pág. 21.

${ }^{166}$ Véase, con carácter general, ÁLVAREZ GARCÍA, F. J., "Retribución y prevención general negativa como fines de la pena", Cuadernos de Política Criminal, núm. 72, 2000, págs. 563 - 613 y, del mismo autor, Consideraciones sobre los fines de la pena en el ordenamiento constitucional español, Comares, Granada, 2001. También, FEIJOO SÁNCHEZ, B., La legitimidad de la pena estatal. Un breve recorrido por las teorías de la pena, Iustel, Madrid, 2014. Relacionados con los delitos vinculados a la delincuencia económica, véase MARTÍNEZ-BUJÁN PÉREZ, C., Derecho penal económico y de la empresa, Parte especial, $5 .^{\mathrm{a}}$ ed., Tirant lo Blanch, Valencia, $2015 \mathrm{y}$ JAREÑO LEAL, Á., El delito de negociaciones prohibidas a los funcionarios públicos, Thomson Aranzadi, Cizur Menor (Navarra), 2015, especialmente sus páginas 132 a 136.

${ }^{167}$ La sanción de naturaleza penal significa que la conducta reprobada merece el más alto reproche social, y tal como nos recuerda el TC en su sentencia 160/2012, de 20 de septiembre de 2012 (siendo ponente ORTEGA ÁLVAREZ), con la pena se trata de proteger "los bienes jurídicos más importantes del ciudadano y la sociedad (...) el legislador penal, para fijar la relación de proporción que deba guardar un comportamiento penalmente típico con la sanción que se le asigna, ha de atender no sólo al fin esencial y directo de protección al que responde la norma, sino también a otros fines legítimos que puede perseguir con la pena y a las diversas formas en que la misma opera y que podrían catalogarse como sus funciones o fines inmediatos: a las diversas formas en que la conminación abstracta de la pena y su aplicación influyen 
Las penas son también aplicables a las personas jurídicas y así lo reconoce expresamente nuestro ordenamiento jurídico a partir de la reforma del Código penal del año 2010 con la incorporación del estatuto de la responsabilidad penal de las personas jurídicas a través de su artículo 31 bis $^{168}$.

\section{C.2. Responsabilidad penal de las personas jurídicas}

Una vez reconocido que, bajo ciertas condiciones, las personas jurídicas pueden responder penalmente y superado el principio tradicional según el cual sólo las personas físicas podían ser sujeto activo del delito - bajo el aforismo societas delinquere non potest - se puede proceder a la imposición de penas, aunque por su propia naturaleza, la responsabilidad de las personas jurídicas por las infracciones penales no puede ser ni directa, ni principal ${ }^{169}$. De esta manera, las entidades y sociedades con personalidad jurídica (empresas, organizaciones, fundaciones, grupos o cualquier otra clase de entidades o agru-

en el comportamiento de los destinatarios de la norma -intimidación, eliminación de la venganza privada, consolidación de las convicciones éticas generales, refuerzo del sentimiento de fidelidad al ordenamiento, resocialización, etc.-y que se clasifican doctrinalmente bajo las denominaciones de prevención general y de prevención especial" (FJ 4).

${ }^{168}$ Se trató de la reforma operada por la Ley Orgánica 5/2010, de 22 de junio, si bien tradicionalmente ya se establecían «consecuencias accesorias» como restricciones de derechos que afectaban a las personas jurídicas, pero que no podían considerarse penas (artículo 129 del Código Penal en su redacción de 1995).

${ }^{169}$ Una persona jurídica nunca se considerará «autor» directo de la infracción cometida por una persona física. En la doctrina penal se discutía, principalmente, si una persona jurídica era capaz de actuar en sentido penal, puesto que si no son capaces de culpabilidad, no podían ser sujetos activos de delitos. Sobre esta materia existe una abundante bibliografía, lo que nos ha obligado a una selección ejemplificativa de algunas obras, BACIGALUPO SAGGESE, S., La responsabilidad penal de las personas jurídicas, Bosch, Barcelona, 1998; NIETO MARTÍN, A., La responsabilidad penal de las personas jurídicas: Un modelo legislativo, Iustel, Madrid, 2008; ZÚÑIGA RODRÍGUEZ, L., Bases para un modelo de imputación de responsabilidad penal a las personas jurídicas, $3 .^{\mathrm{a}}$ ed., Aranzadi, Cizur Menor (Navarra), 2009; ZUGALDÍA ESPINAR, J. M.a , La responsabilidad criminal de las personas jurídicas, de los entes sin personalidad y de sus directivos. Análisis de los arts. 31 bis y 129 del Código Penal, Tirant lo Blanch, Valencia, 2013 y QUINTERO OLIVARES, G., "La reforma del régimen de responsabilidad penal de las personas jurídicas", en Comentario a la reforma penal de 2015, Thomson Reuters, Cizur Menor (Navarra), 2015. 
paciones) se hace responsable penalmente de los delitos cometidos "en nombre o por cuenta de las mismas, y en su beneficio directo o indirecto" por quienes son sus representantes legales o por aquellos que actuando individualmente o como integrantes de un órgano de la persona jurídica, están autorizados para tomar decisiones en nombre de la persona jurídica u ostentan facultades de organización y control (artículos 31.1 bis y 31 ter del Código penal, de acuerdo con la reforma introducida por la Ley Orgánica 1/2015, en vigor desde el 1 de julio de 2015) ${ }^{170}$.

Ahora bien, el modelo de respuesta a los hechos delictivos cometidos en el seno de una persona jurídica no alude a todo tipo delictivo, ni comprende cualquier pena, pues más allá de la lógica de que no se les aplica penas privativas de libertad, se trata de penas que recaen sobre el factor dinámico de la persona jurídica, bien su patrimonio, mediante la pena de multa, o bien su actividad, mediante penas privativas de derechos que limitan la capacidad de la persona jurídica penada en determinados ámbitos de actuación (penas de inhabilitación profesional) ${ }^{171}$.

Ante esta realidad normativa, nuestro análisis se va a centrar, por una parte, en conocer de qué delitos pueden ser también responsables las personas jurídicas - y saber con ello si existe identidad respecto de los tipos recogidos en la legislación contractual - y, por otra parte, conocer si para dichas conductas delictivas se establece la pena de prohibición de contratar o de inhabilitación especial para profesión, oficio, industria o comercio, puesto que de recogerse

${ }^{170}$ Fuera del orden penal, el legislador ya había admitido la responsabilidad de las personas jurídicas partiendo de la premisa según la cual cuando estos sujetos se apartan de lo dispuesto en el ordenamiento jurídico se exponen, en consecuencia, a tener que soportar en razón de sus actos u omisiones ilícitas las respectivas sanciones de carácter administrativo o las responsabilidades civiles que correspondan. Véase, en esta materia, GÓMEZ TOMILLO, M., Introducción a la responsabilidad penal de las personas jurídicas, Aranzadi, Cizur Menor (Navarra), 2015.

${ }^{171}$ Como bien apunta GUTIÉRREZ CASTAÑEDA, A., las penas privativas de derechos "incapacitan temporalmente al condenado para adquirir o ejercitar válidamente derechos o facultades - fundamentalmente de carácter político, profesional o civil -, (...) dando lugar a restricciones parciales de su capacidad de obrar", en GUTIÉRREZ CASTAÑEDA, A., Las penas privativas de derechos políticos y profesionales. Bases para un nuevo modelo regulatorio, Tirant lo Blanch, Valencia, 2012, pág. 157. 
alguna de estas penas en la sentencia condenatoria tendría dos consecuencias importantes en el ámbito contractual: (i) sería de apreciación y aplicación automática por parte de los órganos de contratación y (ii) vincularía también respecto de la duración de dicha pena ${ }^{172}$.

\section{C.3. Delitos imputables a las personas jurídicas}

El modelo por el que ha optado el legislador español ha sido el de establecer un catálogo cerrado de delitos - un sistema de numerus clausus - respecto de los cuales se prevé la posibilidad de imponer penas cuando la responsable sea una persona jurídica ${ }^{173}$. Una nota común en estos delitos es que se proyectan al ámbito de la criminalidad socio-económica y financiera de la que deriva importantes beneficios para los delincuentes y, más concretamente, tratan de combatir el factor criminógeno de la empresa en el ámbito de la delincuencia económica $^{174}$.

El Código penal español circunscribe la responsabilidad de las personas jurídicas a un total de veintiocho delitos; sin embargo vamos a referirnos con un mayor detalle a aquellos que interesan a esta memoria doctoral, bien por estar comprendidos en los tipos delictivos que habilitan una prohibición de carácter obligatorio, según lo dispuesto en las Directivas o bien porque los

\footnotetext{
${ }^{172}$ Lo trataremos con un mayor detalle en un momento posterior de esta memoria doctoral (págs. 492 y siguientes), pero cabe avanzar que en las Directivas se establece una duración máxima de cinco o de tres años dependiendo de los supuestos de prohibición de contratar y, siempre que "una sentencia firme no haya establecido el período de exclusión" (artículo 57.7 de la Directiva 2014/24/UE).

${ }^{173}$ En esta materia ha resultado de especial interés la Circular $1 / 2011$, de 1 de junio, de la Fiscalía General del Estado, relativa a la responsabilidad penal de las personas jurídicas conforme a la reforma del Código penal efectuada en el año 2010, que si bien no recoge las últimas modificaciones en la materia (Ley Orgánica 1/2015, de 30 de marzo y Ley Orgánica 2/2015, de la misma fecha), nos ayuda a comprender mejor las razones de este importante cambio legislativo.

${ }^{174}$ RAMOS VÁZQUEZ, J. A., "La pena de inhabilitación especial para profesión, oficio, industria o comercio", en la obra colectiva Las penas privativas de derechos y otras alternativas a la privación de libertad, Tirant lo Blanch, Valencia, 2013, págs. 115 - 128 y BAUCELLS LLADÓS, J., "Sistema de penas para la delincuencia económica en Derecho español", en la obra colectiva La delincuencia económica. Prevenir y sancionar, Tirant lo Blanch, Valencia, 2014, págs. 393 - 423.
} 
entendemos incluidos en el concepto de «falta profesional grave» que pone en entredicho la integridad del operador económico ${ }^{175}$. Así pues, resultan de interés las siguientes referencias normativas:

- Tráfico ilegal de órganos (artículo 156 bis) ${ }^{176}$;

- Delitos de trata de seres humanos (artículo 177 bis);

- Delitos relativos a la prostitución y a la explotación sexual (artículos 187 a 189 bis $)^{177}$;

- Delitos relativos a la propiedad intelectual (artículos 270 y 271$)^{178}$;

- Delitos relativos a la propiedad industrial (artículos 273 a 277) ${ }^{179}$;

${ }^{175}$ Además de acudir a lo dispuesto en el considerando centésimo primero de la Directiva 2014/24/UE, vamos a referirnos también a los que entendemos "delitos que afectan a la moralidad profesional del operador económico" en el sentido del considerando cuadragésimo tercero y del artículo 45.2.c) de la todavía vigente Directiva 2004/18/CE.

${ }^{176} \mathrm{El}$ delito relacionado con el tráfico ilegal de órganos tiene entidad propia en el artículo 156 bis del Código penal español y, como vemos, a la persona jurídica responsable se le puede imponer la pena de inhabilitación para contratar con el sector público; no obstante, cabe indicarse que para el Derecho de la Unión es una de las infracciones relacionadas con la trata de seres humanos del artículo 2 de la Directiva 2011/36/UE y, por tanto, también previstas como causas de prohibición de contratar en las nueva Directivas, por vía del artículo 57.1.f) de la Directiva 2014/24/UE y artículo 38.4.f) de la Directiva 2014/23/UE.

${ }^{177}$ La referencia que hacemos a la explotación de la prostitución ajena y a la explotación sexual es consecuencia - al igual que hemos indicado en la nota al pie anterior - de que se dan las condiciones para imponer la pena de prohibición de contratar (artículo 189 bis del Código Penal) y porque es otra de las infracciones relacionadas con la trata de seres humanos del artículo 2 de la Directiva 2011/36/UE, sin que expresamente se contemple en nuestra legislación contractual.

${ }^{178}$ En un momento posterior nos referiremos a las penas que corresponden a estos tipos delictivos y a los relativos a la propiedad industrial, si bien avanzamos que en el caso de llevarse a cabo por personas jurídicas sólo corresponde la pena de multa, según el artículo 288 del Código penal, mientras que de cometerse por una persona física supone la imposición de la pena de inhabilitación especial para el ejercicio de la profesión relacionada con el delito cometido.

${ }^{179} \mathrm{Tal}$ como hemos advertido en la nota anterior, el artículo 288 del Código penal 
- Delitos relativos al mercado y a los consumidores (artículos 278 a 286) ${ }^{180}$;

- Delitos de corrupción en los negocios (artículos 286 bis al 286 quater) ${ }^{181}$;

- Blanqueo de capitales (artículos 301 y 302);

- Delitos de financiación ilegal de los partidos políticos (artículo 304 bis) ${ }^{182}$;

- Delitos contra la Hacienda Pública y contra la Seguridad Social (artículos 305 a 310 bis $)^{183}$;

no contempla para estos tipos delictivos que se pueda imponer la pena de inhabilitación para contratar con el sector público si una persona jurídica es la responsable del delito, excepto en el caso del artículo 277 que se refiere a la divulgación de la "invención objeto de una solicitud de patente secreta, en contravención con lo dispuesto en la legislación de patentes, siempre que ello sea en perjuicio de la defensa nacional".

${ }^{180} \mathrm{Al}$ igual que en los delitos anteriores, y a pesar de reconocerse responsabilidad penal de las personas jurídicas por estos delitos, no a todos ellos se les podrá imponer las penas recogidas en las letras b) a g) del apartado 7 del artículo 33, entre las que se encuentra la de prohibición de contratar.

${ }^{181}$ La Ley Orgánica $1 / 2015$, de 30 de marzo, ha modificado la rúbrica de estos delitos y ha añadido nuevos tipos que, según la Exposición de motivos de la Ley, "vienen a reforzar la punición de los llamados delitos de corrupción en el ámbito de la Administración pública". Así, se incluyen los delitos de pago de sobornos para obtener ventajas competitivas (se trate de corrupción en el sector privado o de la corrupción de un agente público extranjero). Estos nuevos tipos delictivos ya se encuentran recogidos en la redacción del artículo 60.1.a) del TRLCSP, tras su modificación por parte de la Disposición final novena de la Ley 40/2015, de 1 de octubre, de Régimen Jurídico del Sector Público.

${ }^{182}$ Esta nueva figura delictiva se incorpora al Código penal por la Ley Orgánica $1 / 2015$, de 30 de marzo, con la previsión de un nuevo Título XIII bis que lleva por rúbrica «De los delitos de financiación ilegal de los partidos políticos». En la redacción actual del artículo 60 del TRLCSP ya se encuentra recogido como uno de los tipos delictivos cuya condena mediante sentencia firme supone la prohibición de contratar con las entidades del sector público.

${ }^{183}$ Aunque se trate de ello en un momento posterior de esta memoria doctoral, creemos de interés reseñar que, para estos tipos delictivos, el Código penal prevé que al responsable (sea persona física o jurídica) se imponga obligatoriamente - como pena privativa de derechos - la pérdida de la posibilidad de obtener subvenciones o ayudas públicas y del derecho a gozar de los beneficios o incentivos fiscales o de la Seguridad Social durante un tiempo determinado (artículos 305 bis apartado segundo y artículo 307 bis apartado tercero). Sin embargo, el legislador penal guarda 
- Delitos contra los derechos de los ciudadanos extranjeros (artículo 318 bis $)^{184}$;

- Delitos sobre la ordenación del territorio y el urbanismo (artículos 319 y $320)^{185}$;

- Delitos contra los recursos naturales y el medio ambiente (artículos 325 a 328$)^{186}$;

- Cohecho (artículos 419 a 427 bis);

- Tráfico de influencias (artículos 428 a 430);

silencio respecto de la inhabilitación para contratar de las personas físicas, y para las jurídicas lo establece con un carácter potestativo "Podrá imponerse la prohibición para contratar con las Administraciones Públicas" (artículo 310 bis).

${ }^{184}$ Aunque este tipo delictivo no se contempla en la relación del artículo 60.1.a) del TRLCSP, en caso de que una persona jurídica sea responsable de este delito, el Código Penal prevé la posible imposición de una pena de inhabilitación para contratar (artículo 318 bis, apartado 5 in fine). El TRLCSP "relega", sin embargo, la prohibición a "haber sido sancionadas con carácter firme por infracción grave en materia de extranjería" (artículo 60.1.b), cuando a nuestro entender debiera quedar comprendido en su letra a) por cuanto su inclusión en el Código penal viene motivada por una mayor represión de la conducta que en el ámbito administrativo.

${ }^{185} \mathrm{Su}$ incorporación al catálogo de delitos del artículo 60.1.a) del TRLCSP se lleva a cabo con una referencia genérica a todo el Título XVI del Código penal «De los delitos relativos a la ordenación del territorio y el urbanismo, la protección del patrimonio histórico y el medio ambiente», cuando a nuestro parecer hubiera resultado de mayor interés práctico diferenciar los distintos tipos delictivos en él comprendidos en atención a las distintas penas a imponer en unos y otros supuestos. No obstante, cabe indicarse que es una de las novedades destacadas de la modificación de este artículo por parte de la Disposición final novena de la Ley 40/2015, de 1 de octubre, de Régimen Jurídico del Sector Público y conecta con la posibilidad expresada en el Código penal respecto de que los jueces y tribunales podrán imponer la pena de "inhabilitación para contratar con el sector público" (artículo 319.4 in fine).

${ }^{186} \mathrm{La}$ redacción actual de las conductas típicas responden a la modificación del Código penal llevada a cabo por la Ley Orgánica 1/2015, de 30 de marzo. No obstante, cabe indicarse que en la nueva regulación del artículo 60.1.a) del TRLCSP estos tipos delictivos no se identifican adecuadamente, puesto que la referencia concreta es a "delitos relativos a la ordenación del territorio y el urbanismo, la protección del patrimonio histórico y el medio ambiente". 
- Delitos cometidos con ocasión del ejercicio de los derechos fundamentales y de las libertades públicas garantizados por la Constitución (artículos 510 y 510 bis $)^{187}$;

- Delitos de terrorismo (artículos 573 a 576) ${ }^{188}$.

El artículo 318 del Código penal relativo a los delitos contra los derechos de los trabajadores no está incluido en este catálogo de delitos de los que pueden ser responsables las personas jurídicas, si bien este mismo artículo prevé que la autoridad judicial pueda decretar alguna o algunas de las medidas previstas en el artículo 129 del Código (las conocidas como "consecuencias accesorias") ${ }^{189}$.

${ }^{187}$ La posibilidad de responsabilidad penal a las personas jurídicas por estos delitos se contempla a partir de la entrada en vigor de la Ley Orgánica 1/2015, de 30 de marzo. Sorprendentemente, no se contempla, sin embargo, tal responsabilidad en el supuesto delictivo del artículo 511, aun cuando entendemos que hubiera sido lo deseable, máxime cuando se trata de un particular encargado de un servicio público (que también puede ser persona jurídica) "que deniegue a una persona una prestación a la que tenga derecho por razón de su ideología, religión o creencias, su pertenencia a una etnia o raza, su origen nacional, su sexo, orientación sexual, situación familiar, por razones de género, enfermedad o discapacidad". En estos casos - y aun tratándose de personas físicas - tampoco se contempla la pena de inhabilitación para contratar, más allá de la "pena de inhabilitación especial para profesión u oficio educativos, en el ámbito docente, deportivo y de tiempo libre" (artículo 511.4 del Código penal).

${ }^{188}$ Los artículos referentes a los delitos de terrorismo responden a los cambios incorporados a partir de la Ley Orgánica 2/2015, de 30 de marzo, por la que se modifica la Ley Orgánica 10/1995, de 23 de noviembre, del Código Penal, en materia de delitos de terrorismo, para dar cabida, además de a las modalidades de terrorismo ya conocidas, a las amenazas que provienen del fenómeno del terrorismo internacional. Estos tipos delictivos tienen su correlación en la normativa contractual como una de las novedades de la Directiva 2014/24/UE (artículo 57.1.d) y en la Directiva 2014/23/UE (artículo 38.4.d), aunque ya estaban previstos como motivo de prohibición de contratar en el artículo 39.1.d) de la Directiva 2009/81/CE («sectores seguridad y defensa»). Esta misma afirmación se puede realizar de la legislación española, puesto que con anterioridad a la redacción actual del artículo 60.1.a), la condena por delitos de terrorismo o ligado a actividades terroristas ya se contemplaba en el artículo 12.1.a) de la Ley 24/2011, de 1 de agosto, de contratos del sector público en los ámbitos de la defensa y de la seguridad.

${ }^{189}$ Estas consecuencias aplicables a las personas jurídicas "salvaban" el obstáculo de la falta de responsabilidad penal de las personas jurídicas, puesto que se establecían en el supuesto de que los hechos punibles hubieran sido cometidos en el seno de una persona jurídica o utilizándola como instrumento para la comisión del hecho 
Por ello, en este supuesto, cuando la responsable sea una persona jurídica, se contempla la posibilidad de imponer la prohibición de contratar o bien acordar la prohibición definitiva de llevar a cabo cualquier actividad, pero únicamente como consecuencia accesoria a la pena ${ }^{190}$.

Aparte de estas conductas delictivas, nuestro Código penal recoge otra serie de delitos en los que siendo también destinatarias las personas jurídicas les puede resultar igualmente de aplicación la pena de inhabilitación para contratar. En todos estos casos - llevados al extremo - se puede apreciar una falta grave que pone en entredicho la integridad del operador económico que quiere llegar a ser contratista, pero en base al respeto a la exigencia de taxatividad, hemos optado por una interpretación restrictiva y no incluirlos en la lista anterior. A nuestro juicio se percibe una falta de vinculación con la normativa contractual, más allá de que a las personas físicas condenadas por estos delitos se les pudiera inhabilitar, según los casos, para el ejercicio de profesión, oficio, industria o comercio ${ }^{191}$, o que alguno de estos hechos se cometan en el seno de una organización criminal dedicada a estas actividades delictivas.

Estos tipos delictivos son: (i) Delito de descubrimiento y revelación de secretos (delitos comprendidos en los artículos 197, 197 bis y 197 ter); (ii) Estafa (artículos 248 a 251 bis); (iii) Delitos de frustración de la ejecución (artículos 257 a 258 ter) que incluyen, junto al alzamiento de bienes, dos nuevas figuras delictivas: la ocultación de bienes en un procedimiento judicial o administrativo de ejecución y, de otra, la utilización no autorizada por el depositario de bienes embargados por la autoridad; (iv) Insolvencias punibles (artículos 259 a 261 bis); (v) Daños informáticos (artículos 264 a 264 quater); (vi) Delitos relativos a la energía nuclear y a las radiaciones ionizantes (artículos 341 a 345); (vii) Delitos de riesgo provocados por explosivos y otros agentes (artícu-

delictivo.

${ }^{190}$ En la Circular 1/2011, de 1 de junio, de la Fiscalía General del Estado, relativa a la responsabilidad penal de las personas jurídicas ya se advertía de la posible antinomia normativa respecto de este precepto y se manifestaba que no se lograba adivinar "qué razones pueden justificar esta diferencia de trato en unos y otros casos"; no obstante, lo cierto es que la redacción actual del precepto sigue inalterable después de los últimos cambios normativos.

${ }^{191} \mathrm{El}$ artículo 60.1.a) del TRLCSP se refiere expresamente a esta clase de inhabilitación. 
los 348 a 350); (viii) Delitos contra la salud pública (tanto los relacionados con el comercio de sustancias nocivas a la salud, medicamentos, alimentos y productos nocivos o dopantes, como los delitos relativos a drogas, estupefacientes y sustancias psicotrópicas ${ }^{192}$ ); (x) Falsificación de moneda y efectos timbrados (artículo 386); (xi) Falsificación de tarjetas de crédito y débito y cheques de viaje (artículo 399 bis).

Además de analizar los comportamientos delictivos respecto de los cuales se prevé la responsabilidad de las personas jurídicas, para nuestro estudio es importante valorar las penas que les pueden corresponder y, sobre todo - como venimos apuntando - si entre ellas se encuentra recogida la pena de prohibición de contratar u otra pena equiparable en efectos limitativos ${ }^{193}$.

${ }^{192}$ Como trataremos en el Capítulo segundo de esta memoria doctoral, en el trámite legislativo que dio lugar a la aprobación de las Directivas 2004/17/CE y 2004/18/CE, ya se había planteado por parte del Parlamento que la condena por delitos relacionados con el tráfico ilícito de droga fuera considerada una prohibición de contratar de carácter obligatorio: "Por un delito relacionado con la droga, definido en la letra a) del apartado 1 del artículo 3 de la Convención de las Naciones Unidas contra el tráfico ilícito de estupefacientes y de sustancias sicotrópicas, adoptada en Viena el 19 de diciembre de 1998"; no obstante, la Comisión no entró ni siquiera a valorar estas enmiendas del Parlamento Europeo, COM (2003) 503 final, de 14 de agosto de 2003.

${ }^{193}$ Entre otros muchos autores que se refieren a esta materia, véase especialmente FEIJOO SÁNCHEZ, B., Sanciones para empresas por delitos contra el medio ambiente. Presupuestos dogmáticos y criterios de imputación para la intervención del Derecho penal contra las empresas, Civitas, Madrid, 2002; NIETO MARTÍN, A., La responsabilidad penal (...), op. cit., págs. 263 a 322; DÍEZ RIPOLLÉS, J.L., "Las penas de las personas jurídicas y su determinación legal y judicial: regulación española", en la obra colectiva Estudios penales en homenaje al Profesor Rodrigo Fabio Suárez Montes, Constitutio Criminalis Carolina, Oviedo, 2013, págs. 195 217; BAUCELLS LLADÓS, J., "Las penas previstas para la persona jurídica en la reforma penal de 2010. Un análisis crítico", Estudios Penales y Criminológicos, vol. XXXIII, 2013, págs. 175 - 218; NEIRA PENA, A. M. ${ }^{\text {a }}$ "Las penas aplicables a personas jurídicas", en la obra colectiva Las penas privativas de derechos y otras alternativas a la privación de libertad, Tirant lo Blanch, Valencia, 2013, págs. 393 426. 


\section{C.4. Clases de penas. Especial referencia a las penas privativas de derechos}

Conforme a lo dispuesto en el artículo 33.7 del Código penal - y al margen de la pena "reina" de la multa ${ }^{194}$ - se prevé un conjunto de penas interdictivas que restringen o anulan el ejercicio de diferentes derechos y que, en todos los casos, tienen el carácter de grave ${ }^{195}$. De este catálogo de penas vamos a destacar dos:

- La prohibición de realizar en el futuro las actividades en cuyo ejercicio se haya cometido, favorecido o encubierto el delito. Esta prohibición podrá ser temporal o definitiva. Si fuere temporal, el plazo no podrá exceder de quince años (letra e), y

- La inhabilitación para obtener subvenciones y ayudas públicas, para contratar con el sector público y para gozar de beneficios e incentivos fiscales o de la Seguridad Social, por un plazo que no podrá exceder de quince años (letra f) ${ }^{196}$.

Respecto de estas penas privativas de derechos, su imposición supone incidir sobre la capacidad de obrar de quien resulta condenado, privándole temporalmente de alguna de sus concretas manifestaciones y limitando, con ello, su capacidad de actuar en el ámbito que se vea afectado por la pena para asegurar, así, que la persona jurídica no vuelva a delinquir en el mismo contexto ${ }^{197}$.

\footnotetext{
${ }^{194}$ La multa es calificada de "pena reina del derecho penal colectivo" por NIETO MARTÍN, A., La responsabilidad penal (... ), op. cit., pág. 279.

${ }^{195}$ Sobre estas penas, BACIGALUPO SAGGESE, S., "Comentario al artículo 33.7 del Código penal", en la obra colectiva Comentarios al Código Penal, 2. ${ }^{a}$., Lex Nova, Valladolid, págs. 280 - 285 y RAMOS VÁZQUEZ, J. A., "Las «especiales» inhabilitaciones especiales en el Código Penal", Diario La Ley, núm. de 9 de enero de 2013, págs. $1-9$.
}

${ }^{196}$ En realidad, esta pena de inhabilitación para las personas jurídicas contempla tres supuestos distintos entre los que destacamos "la inhabilitación para contratar con el sector público".

${ }^{197}$ Recordemos que a efectos del ya citado Libro Verde sobre la aproximación, el reconocimiento mutuo y la ejecución de penas en la Unión Europea "se entiende por privación de derechos una pena privativa o restrictiva de derechos o una medida preventiva por la cual se prohíbe a una persona física o jurídica, durante un período limitado o ilimitado de tiempo, ejercer algunos derechos, desempeñar una determi- 
Su carácter aflictivo no es el único elemento a destacar. Puede afirmarse que tras su imposición subyace una finalidad preventiva que se proyecta en su vertiente de servir de disuasión a potenciales delincuentes mediante la amenaza de una pena limitativa de derechos ${ }^{198}$.

Estas penas, a nuestro parecer, pueden resultar mucho más intimidatorias que la multa por cuanto el pago de la misma, como única pena a imponer, pudiera estimular la perniciosa praxis de seguir actuando al margen del ordenamiento ante la probabilidad de asumir su coste. En este orden de ideas, con estas penas la valoración de la persona jurídica de actuar conforme a la Ley no se reduce a un cálculo de beneficios y costes ligados a cierta acción, puesto que deben considerarse otros aspectos no exclusivamente de tipo económico - piénsese, por ejemplo, en la imagen de la empresa y en el deterioro de su reputación - que, como efecto colateral, pueden incrementar las medidas de prevención en la propia organización (prevención especial positiva) ${ }^{199}$.

Aun con lo dicho, la imposición de una de estas penas de inhabilitación en lo que respecta a las personas jurídicas se prevé con un carácter potestativo para el juez o tribunal. En este sentido, basta con examinar los tipos penales a

nada función, ejercer una actividad, desplazarse a determinados lugares o realizar ciertos actos" (COM (2004) 334 final, de 30 de abril).

${ }^{198}$ La doctrina penalista clasifica la prevención bajo las denominaciones de prevención general (positiva y negativa) y de prevención especial positiva (resocialización) y negativa (inocuización). GUTIÉRREZ CASTAÑEDA al tratar la idoneidad de esta clase de penas destaca que "en opinión de la doctrina absolutamente mayoritaria (... ) la privación de derechos, cargos o actividades profesionales en cuyo ejercicio se ha cometido el delito constituye una eficaz medida para evitar o al menos reducir notablemente el riesgo de reincidencia”, en GUTIÉRREZ CASTAÑEDA, A., Las penas privativas de derechos (...), op. cit., pág. 404. En sentido contrario a la idea de prevención general, se muestra FEIJOO SÁNCHEZ, B., Sanciones para empresas (...), op. cit., págs. 123 y siguientes.

${ }^{199}$ Según llega a afirmar NIETO MARTÍN, la imposición de sanciones penales a colectivos "tiene por objeto propiciar por parte de la empresa la implantación de controles preventivos y postdelictivos que ayuden tanto a evitar delitos como a descubrir los ya cometidos", NIETO MARTÍN, A., La responsabilidad penal (...), op. cit., pág. 49. En esta misma idea, BAUCELLS LLADÓS, J., "Las penas previstas para la persona jurídica (...)", op. cit., pág. 182 sostiene que "la mejor finalidad en la que fundamentar la pena a las personas jurídicas es la prevención especial positiva o resocialización" entendida como capacidad de desarrollar la actividad corporativa sin cometer hechos delictivos. 
los que nos hemos referido con anterioridad para constatar tal carácter bajo la siguiente fórmula genérica: "los jueces y tribunales podrán asimismo imponer las penas recogidas en las letras b) a g) del apartado 7 del artículo 33". De esta manera, el propio Código penal limita su imposición y extensión a que se tengan en cuenta tres factores: (i) su necesidad para prevenir la continuidad de la actividad delictiva o de sus efectos; (ii) sus consecuencias económicas y sociales, y especialmente los efectos para los trabajadores y (iii) el puesto que en la estructura de la persona jurídica ocupa la persona física u órgano que incumplió el deber de control (artículo 66 bis).

A pesar de ceñirnos en este momento a las penas aplicables a las personas jurídicas, podemos indicar que la inhabilitación para contratar con el sector público no es exclusiva de estas organizaciones. En efecto, la responsabilidad de la persona jurídica no sustituye a la individual y es en el ámbito de la obligatoriedad en su imposición donde se presentan algunas de sus mayores diferencias, tanto en su carácter de penas principales como accesorias. Tal es así que, respecto a las penas destinadas a las personas físicas, la función preventiva a la que nos hemos referido viene marcada por el carácter mayoritariamente imperativo que presentan las penas de inhabilitación ${ }^{200}$.

Así, y circunscritos a los delitos que a esta memoria doctoral interesa, debemos referirnos a algunas de las penas privativas de derechos previstas en la parte especial del Código penal, con base en lo dispuesto en su artículo 39.

(1) La pena de inhabilitación absoluta, está prevista cuando el culpable se hubiera prevalido de su condición de autoridad, agente o funcionario público en delitos tales como relativos a la trata de seres humanos o la prostitución y a la explotación sexual.

(2) La inhabilitación especial para profesión, oficio, industria o comercio ${ }^{201}$, que en atención a los distintos tipos delictivos comprende expresiones

\footnotetext{
${ }^{200}$ Con carácter facultativo se prevé la pena de inhabilitación especial para el ejercicio de su profesión o industria en el delito de blanqueo de capitales. Así pues, "en estos casos, los jueces o tribunales, atendiendo a la gravedad del hecho y a las circunstancias personales del delincuente, podrán imponer también a éste la pena de inhabilitación especial para el ejercicio de su profesión o industria por tiempo de uno a tres años" (artículo 301 del Código penal).

${ }^{201}$ Recordemos nuevamente que el artículo 60.1.a) del TRLCSP se refiere expresa-
} 
de lo más diversas: inhabilitación especial para profesión u oficio/ para industria o comercio/ para el ejercicio de la profesión o actividad/ para el ejercicio de su profesión o industria/ para el ejercicio de su industria o comercio/ especial para ejercer cualquier profesión sanitaria/ para el ejercicio de la profesión, oficio o cargo/ para el ejercicio de la profesión, oficio o cargo/ para cualquier profesión u oficio/ para empleo o cargo público, profesión u oficio/ inhabilitación especial para profesión u oficio educativos, en el ámbito docente, deportivo y de tiempo libre.

(3) La inhabilitación especial para el ejercicio de la profesión relacionada con el delito cometido. Es el supuesto de los delitos relativos a la propiedad intelectual y a la propiedad industrial. Nos referimos a ellos, pues aunque la condena por estos tipos delictivos no se contemple expresamente en la legislación contractual, entendemos que pueden tener incidencia en el ámbito del contrato de servicios con la demanda de prestaciones de carácter intelectual.

(4) La pena de inhabilitación especial para empleo o cargo público, que si bien, por razones evidentes, no es aplicable a delitos cuya responsabilidad también recae en personas jurídicas, tienen interés en la materia contractual por cuanto el artículo 60.1.a) del TRLCSP se refiere a la condena por delitos de prevaricación y negociaciones prohibidas a los funcionarios públicos como causa de prohibición de contratar.

Además de las penas precedentes, merecen una atención especial aquellos tipos delictivos que expresamente contemplan como pena a imponer la inhabilitación especial para contratar, y que - aunque no todos se contemplen expresamente en la relación de delitos del artículo 60.1.a) del TRLCSP202 - en caso de existir una sentencia condenatoria que la impusiera, supondría

mente a esta modalidad de inhabilitación entre las causas de prohibición de contratar y, como bien señala RAMOS VÁZQUEZ, "reténgase la idea de que toda pena de inhabilitación especial para el ejercicio de profesión, oficio, industria o comercio lleva aparejada, administrativamente, la prohibición de contratar con las Administraciones Públicas", a lo que añadiríamos - para ser más exactos - que la prohibición se extiende a todas las entidades del sector público, y no sólo con las Administraciones públicas, en atención al ámbito de aplicación del artículo 60.1 del TRLCSP. RAMOS VÁZQUEZ, J. A., Las «especiales» inhabilitaciones (...), op. cit., págs. 1- 9.

${ }^{202}$ Falta la referencia expresa a los "delitos de alteración de precios en concursos 
un impedimento para llegar a ser contratista, en atención a lo dispuesto en el artículo 54.1 del mismo texto legal sobre las condiciones de aptitud "Sólo podrán contratar con el sector público las personas naturales o jurídicas, españolas o extranjeras, que tengan plena capacidad de obrar, no estén incursas en una prohibición de contratar".

Es el caso del artículo 262 de Código penal relativo a los delitos de alteración de precios en concursos y subastas:

\begin{abstract}
1."Los que solicitaren dádivas o promesas para no tomar parte en un concurso o subasta pública; los que intentaren alejar de ella a los postores por medio de amenazas, dádivas, promesas o cualquier otro artificio; los que se concertaren entre sí con el fin de alterar el precio del remate, o los que fraudulentamente quebraren o abandonaren la subasta habiendo obtenido la adjudicación, serán castigados con la pena de prisión de uno a tres años y multa de 12 a 24 meses, así como inhabilitación especial para licitar en subastas judiciales entre tres y cinco años. Si se tratare de un concurso o subasta convocados por las Administraciones o entes públicos, se impondrá además al agente y a la persona o empresa por él representada la pena de inhabilitación especial que comprenderá, en todo caso, el derecho a contratar con las Administraciones públicas por un período de tres a cinco años". ${ }^{203}$ [El subrayado es nuestro]
\end{abstract}

Del artículo 286 ter, respecto de la nueva regulación de los delitos de

y subastas", pues como trataremos posteriormente, la colusión entre empresas en licitaciones públicas tiene entidad propia también en la normativa contractual desde la aprobación de las nuevas Directivas.

${ }^{203}$ A pesar de su tipificación penal, lo cierto es que su redacción - con la denominación tradicional de concurso y subasta - no se ajusta a la actual normativa contractual que abandonó dichos conceptos como criterios de adjudicación. Sin embargo, se mantiene en las regulaciones sobre autorizaciones y concesiones sobre bienes de dominio público y en los contratos de explotación de bienes patrimoniales (por ejemplo, en los artículos 137 y 138 de la Ley 33/2003, de 3 de noviembre, de Patrimonio de las Administraciones Públicas). Sobre esta materia, BEATO VIBORA, M., "Protección penal de concursos y subastas de naturaleza pública: El artículo 262 del Código Penal", Anuario de la Facultad de Derecho de la Universidad de Extremadura, vol.14 - 15, 1996 - 1997, págs. 167 - 187. 
corrupción en los negocios ${ }^{204}$ :

1. Los que mediante el ofrecimiento, promesa o concesión de cualquier beneficio o ventaja indebidos, pecuniarios o de otra clase, corrompieren o intentaren corromper, por sí o por persona interpuesta, a una autoridad o funcionario público en beneficio de estos o de un tercero, o atendieran sus solicitudes al respecto, con el fin de que actúen o se abstengan de actuar en relación con el ejercicio de funciones públicas para conseguir o conservar un contrato, negocio o cualquier otra ventaja competitiva en la realización de actividades económicas internacionales, serán castigados, salvo que ya lo estuvieran con una pena más grave en otro precepto de este Código, con las penas de prisión de prisión de tres a seis años, multa de doce a veinticuatro meses, salvo que el beneficio obtenido fuese superior a la cantidad resultante, en cuyo caso la multa será del tanto al triplo del montante de dicho beneficio.

Además de las penas señaladas, se impondrá en todo caso al responsable la pena de prohibición de contratar con el sector público, así como la pérdida de la posibilidad de obtener subvenciones o ayudas públicas y del derecho a gozar de beneficios o incentivos fiscales y de la Seguridad Social, y la prohibición de intervenir en transacciones comerciales de trascendencia pública por un periodo de siete a doce años." 205 [El subrayado es nuestro].

Del artículo 310 bis sobre los delitos contra la Hacienda Pública y contra la Seguridad Social:

${ }^{204}$ Este artículo ha sido incorporado al Código penal por la Ley Orgánica 1/2015, de 30 de marzo, en una nueva sección común, en la cual se incluyen los delitos de pago de sobornos para obtener ventajas competitivas (se trate de corrupción en el sector privado o de la corrupción de un agente público extranjero).

${ }^{205}$ La pena de "prohibición de intervenir en transacciones comerciales de transcendencia pública" entendemos que es diferente de la de prohibición de contratar, como lo prueba el hecho de ubicarse en el mismo artículo e imponerse acumulativamente. Con anterioridad a la reforma de la Ley Orgánica 1/2015, esta pena estaba prevista para el delito de corrupción en las transacciones comerciales internacionales (artículo $445)$. 
"Cuando de acuerdo con lo establecido en el artículo 31 bis una persona jurídica sea responsable de los delitos recogidos en este Título, se le impondrán las siguientes penas: (...)

Además de las señaladas, se impondrá a la persona jurídica responsable la pérdida de la posibilidad de obtener subvenciones o ayudas públicas y del derecho a gozar de los beneficios o incentivos fiscales o de la Seguridad Social durante el período de tres a seis años. Podrá imponerse la prohibición para contratar con las Administraciones Públicas. ${ }^{" 206}$ [El subrayado es nuestro].

También del artículo 424 respecto del delito de cohecho activo en sus distintas modalidades ${ }^{207}$ :

1. El particular que ofreciere o entregare dádiva o retribución de cualquier otra clase a una autoridad, funcionario público o persona que participe en el ejercicio de la función pública para que realice un acto contrario a los deberes inherentes a su cargo o un acto propio de su cargo, para que no realice o retrase el que debiera practicar, o en consideración a su cargo o función, será castigado

${ }^{206}$ De nuevo, al igual que en el delito de alteración de precios en concursos y subastas, el ámbito de aplicación de la prohibición de contratar se circunscribe a las Administraciones públicas y no a todas las entidades del sector público. Este artículo está redactado conforme a la Ley Orgánica 7/2012, de 27 de diciembre, por la que se modifica el Código Penal en materia de transparencia y lucha contra el fraude fiscal y en la Seguridad Social.

${ }^{207}$ En función de la cualidad del autor se distinguen dos clases de cohecho: el autor del cohecho pasivo es una autoridad pública o funcionario que solicita o acepta un soborno y el cohecho activo tipifica la conducta del particular en esa relación de corrupción. Entre otros muchos autores que han tratado el delito de cohecho, y a pesar del tiempo transcurrido, VALEIJE ÁLVAREZ, I., El tratamiento penal de la corrupción del funcionario. El delito de cohecho, Editoriales de Derecho Reunidas, Madrid, 1996; OLAIZOLA NOGALES, I., El delito de cohecho, Tirant lo Blanch, Valencia, 1999. Sobre el artículo 424 del Código penal resultan de interés los comentarios realizados por BLANCO CORDERO en la obra colectiva Comentarios al Código Penal, 2.a ed., Lex Nova, Valladolid, 2011, págs. 1591 a 1593 y por VALEIJE ÁLVAREZ, I., "Delito de cohecho activo (artículo 424)", en la obra colectiva Comentarios a la Reforma de Código Penal de 2015, 2. ${ }^{\text {a }}$ ed., Tirant lo Blanch, Valencia, 2015, págs. 1172 - 1176 quien alude al incremento en la duración de las penas que pasan a tener una duración de cinco a diez años. 
en sus respectivos casos, con las mismas penas de prisión y multa que la autoridad, funcionario o persona corrompida.

2. Cuando un particular entregare la dádiva o retribución atendiendo la solicitud de la autoridad, funcionario público o persona que participe en el ejercicio de la función pública, se le impondrán las mismas penas de prisión y multa que a ellos les correspondan.

3. Si la actuación conseguida o pretendida de la autoridad o funcionario tuviere relación con un procedimiento de contratación, de subvenciones o de subastas convocados por las Administraciones o entes públicos, se impondrá al particular y, en su caso, a la sociedad, asociación u organización a que representare la pena de inhabilitación para obtener subvenciones y ayudas públicas, para contratar con entes, organismos o entidades que formen parte del sector público y para gozar de beneficios o incentivos fiscales y de la Seguridad Social por un tiempo de cinco a diez años." [El subrayado es nuestro].

En el delito de tráfico de influencias del artículo $429^{208}$ :

"El particular que influyere en un funcionario público o autoridad prevaliéndose de cualquier situación derivada de su relación personal con éste o con otro funcionario público o autoridad para conseguir una resolución que le pueda generar directa o indirectamente un beneficio económico para sí o para un tercero, será castigado con las penas de prisión de seis meses a dos años, multa del tanto al duplo del beneficio perseguido u obtenido, y prohibición de contratar con el sector público, así como la pérdida de la posibilidad de obtener subvenciones o ayudas públicas y del derecho a gozar de beneficios o incentivos fiscales y de la Seguridad Social por tiempo de seis a diez años. Si obtuviere el beneficio perseguido, estas penas se impondrán en su mitad superior". [El subrayado es nuestro].

${ }^{208}$ Sobre su nueva redacción, VALEIJE ÁLVAREZ, I., "Tráfico de influencias (arts. 428 y ss.)", en la obra colectiva Comentarios a la Reforma de Código Penal de 2015, 2. a ed., Tirant lo Blanch, Valencia, 2015, págs. 1194 a 1203. 
Del artículo 436 respecto de los fraudes y exacciones ilegales ${ }^{209}$ :

"La autoridad o funcionario público que, interviniendo por razón de su cargo en cualesquiera de los actos de las modalidades de contratación pública o en liquidaciones de efectos o haberes públicos, se concertara con los interesados o usase de cualquier otro artificio para defraudar a cualquier ente público, incurrirá en las penas de prisión de dos a seis años e inhabilitación especial para empleo o cargo público y para el ejercicio del derecho de sufragio pasivo por tiempo de seis a diez años. Al particular que se haya concertado con la autoridad o funcionario público se le impondrá la misma pena de prisión que a éstos, así como la de inhabilitación para obtener subvenciones y ayudas públicas, para contratar con entes, organismos o entidades que formen parte del sector público y para gozar de beneficios o incentivos fiscales y de la Seguridad Social por un tiempo de dos a siete años." [El subrayado es nuestro].

Y, de una manera indirecta, en el artículo 570 quater respecto de las organizaciones y grupos criminales:

"1. Los jueces o tribunales, en los supuestos previstos en este Capitulo y el siguiente, acordarán la disolución de la organización o grupo $y$, en su caso, cualquier otra de las consecuencias de los artículos 33.7 y 129 de este Código.

2. Asimismo se impondrá a los responsables de las conductas descritas en los dos artículos anteriores, además de las penas en ellos previstas, la de inhabilitación especial para todas aquellas actividades económicas o negocios jurídicos relacionados con la actividad de la organización o grupo criminal o con su actuación en el seno de los

\footnotetext{
${ }^{209}$ En este caso concreto, creemos que la nueva regulación de las prohibiciones de contratar del artículo 60.1.a) del TRLCSP no identifica adecuadamente este tipo delictivo, ya que únicamente se refiere a "fraudes" y no se refiere a todas las conductas tipificadas en el Código penal. Respecto de este artículo también hay que mencionar que no fue hasta la reforma del Código penal por parte de la Ley Orgánica 5/2010 que no se incorporó de forma expresa la responsabilidad penal del interesado en este tipo de delito.
} 
mismos, por un tiempo superior entre seis y veinte años al de la duración de la pena de privación de libertad impuesta en su caso, atendiendo proporcionalmente a la gravedad del delito, al número de los cometidos y a las circunstancias que concurran en el delincuente." [El subrayado es nuestro].

\section{A modo de conclusión provisional}

Una vez que hemos resaltado las diferencias entre las prohibiciones de contratar según el sector en el que se aplican, debemos apuntar que en el marco de la adjudicación de contratos públicos las prohibiciones no se establecen con un fin represivo o retributivo por la realización de una conducta que se considere administrativa o penalmente ilícita. Por tanto, no pueden considerarse sanciones, de modo que, cuando se aplican por parte de los poderes adjudicadores tras la imposición de una condena penal o resolución administrativa sancionadora tampoco participan de esa naturaleza, ya que sólo son la consecuencia administrativa del acto que las impone.

La consagración en el ámbito contractual público de una serie de prohibiciones legales para contratar se orientan, no al castigo del sujeto afectado por la prohibición, sino a asegurar una adecuada selección del contratista que redunde en beneficio de los fines ínsitos en la contratación y sirva, además, de garantía a la buena gestión de los fondos públicos de la Unión. De esta forma, la participación en un procedimiento de adjudicación se supedita al requisito de que el operador económico - además de tener la capacidad necesaria para contratar - presente garantías suficientes de solvencia, integridad, probidad y fiabilidad.

Como venimos apuntando, en caso de incumplimiento de tales exigencias, la normativa contractual prevé un régimen de prohibiciones que limitan la capacidad de contratar del operador económico, de tal manera que queda excluido del procedimiento de licitación. El carácter taxativo y restrictivo de este régimen atiende a la consideración de las prohibiciones de contratar como instrumentos administrativos que restringen la posibilidad de contratar con una entidad del sector público y - como actos limitativos que son - se les debe 
aplicar ciertos principios y garantías procedimentales ${ }^{210}$.

En este orden de ideas, el legislador identifica una serie de conductas o de situaciones específicas que entiende pueden afectar a los intereses del contrato y prohíbe las conductas que las configuran en base a criterios de política legislativa, por lo cual - y tal como será objeto de estudio - las causas de prohibición de contratar no han permanecido inalterables a lo largo del tiempo.

Llegados a este punto, consideramos que las prohibiciones de contratar no pueden reducirse, ni abarcarse bajo la única perspectiva de las consecuencias adversas que ocasionan para el operador económico, sino que hemos también de tomar en consideración otros elementos más acordes con las finalidades que persiguen y que justifican los efectos desfavorables que se producen en la esfera de los licitadores y candidatos.

A estas otras finalidades que justifican la existencia misma de las prohibiciones de contratar nos referiremos en el epígrafe siguiente. El enfoque adoptado hace que prestemos mayor atención a la idea de que las prohibiciones tienen un carácter defensivo de los intereses generales - no sólo de los intereses económicos del mercado - y que, por tanto, se dirigen también a evitar ciertas

\footnotetext{
${ }^{210}$ No eludimos la tentación de citar las palabras de GARRIDO FALLA en su voto particular formulado a la STC 132/2001, de 8 de junio, en el cual manifestaba que "La doctrina «iuspublicista» viene distinguiendo, desde el último tercio del siglo XIX, entre sanciones administrativas y otras decisiones restrictivas de derechos adoptadas por la Administración en el seno de concretas relaciones jurídico públicas frente al incumplimiento por el particular de los deberes que le incumben. (...) Esta distinción elemental entre sanción y revocación o caducidad, ha sufrido el embate de la «vis expansiva» del art. 25.1 CE. En efecto, dado que sólo las sanciones administrativas están garantizadas por el derecho fundamental a la legalidad sancionadora, y dado también que sólo en estos casos hay amparo ante el Tribunal Constitucional, no es extraño que éste haya ampliado progresivamente los contornos del concepto de sanción administrativa hasta amparar otras medidas restrictivas impuestas por la Administración. El punto de llegada ha sido un amplísimo concepto de sanción administrativa, desconocido en nuestra tradición jurídica y que no diferencia entre realidades jurídicas notoriamente distintas. Nada de lo dicho habría ocurrido, creo, si la libertad de empresa (art. $38 \mathrm{CE}$ ) y el derecho de propiedad (art. $33 \mathrm{CE}$ ) hubieran gozado de la misma tutela constitucional que la que dispensa el art. 25.1 CE. $\mathrm{Si}$ frente a las medidas restrictivas de la actividad empresarial (o del disfrute de la propiedad) los particulares estuviesen protegidos por una reserva de Ley análoga a la del art. 25.1 CE y del amparo constitucional, difícilmente el concepto de sanción administrativa habría llegado a lo que es en la actualidad".
} 
conductas contrarias a los valores de la Unión establecidos en el artículo 2 del Tratado de la Unión Europea (TUE) ${ }^{211}$. De esta manera, las prohibiciones pueden concebirse de manera tan amplia que, en la práctica equivalgan a mandatos en cuanto pueden llegar a dirigir el comportamiento del operador económico para no quedar excluido de los procedimientos de contratación pública durante un periodo de tiempo.

\section{Los fundamentos de las prohibiciones de con- tratar}

La pluralidad de circunstancias que las Directivas señalan como motivos de exclusión de la participación en los procedimientos de adjudicación contractual no permite establecer un único fundamento a todas ellas más allá de la genérica referencia a la protección del interés público ${ }^{212}$. Así pues, la necesidad de garantizar la correcta ejecución de las prestaciones del contrato requiriendo que el contratista posea ciertas cualidades de fiabilidad, diligencia y seriedad constituye un objetivo legítimo de interés general ${ }^{213}$.

Por tanto, y como ya hemos avanzado con anterioridad, la finalidad que se erige, en causa legítima del requisito de una «capacidad reforzada» de quienes pretenden contratar con las entidades públicas se encuentra en la adecuada

${ }^{211}$ La versión consolidada del Tratado de la Unión Europea está publicada en el DOUE C 326, de 26 de octubre de 2012 y, por lo que a su artículo 2 respecta tiene el siguiente tenor: "La Unión se fundamenta en los valores de respeto de la dignidad humana, libertad, democracia, igualdad, Estado de Derecho y respeto de los derechos humanos, incluidos los derechos de las personas pertenecientes a minorías. Estos valores son comunes a los Estados miembros en una sociedad caracterizada por el pluralismo, la no discriminación, la tolerancia, la justicia, la solidaridad y la igualdad entre mujeres y hombres".

${ }^{212}$ STS de 7 de noviembre de 2006, RJ $2006 \backslash 9055$.

${ }^{213}$ En este sentido se ha manifestado el TJUE en su sentencia de 10 de julio de 2014, Consorzio Stabile, C-358/12, apartado 32 al afirmar que "garantizar que un licitador posea dichas cualidades constituye un objetivo legítimo de interés general". Asimismo nuestro TS, en su sentencia de 18 de marzo de 2015, manifestaba que con las prohibiciones de contratar se trata de "evitar, en aras de la debida tutela de los intereses públicos, la relación con la Administración de quienes hayan demostrado poca seriedad en su actividad empresarial" (RJ 2015\770) FJ 7. 
selección de la parte cocontratante ${ }^{214}$. Es, pues, el régimen público de selección del contratista el que justifica la exigencia de unos estándares de conducta superiores a los impuestos para las relaciones privadas, de tal manera que la aptitud del contratista - en forma de ausencia de prohibiciones de contratar se exige como un plus sobre la capacidad de obrar para asegurar la ejecución de las prestaciones contractuales.

Estas exigencias, evidentemente, no surgen con el Derecho europeo - aunque nuestro objeto de estudio se circunscriba a su análisis - pues, lo cierto es que tienen origen en el mismo momento en que un poder público confía en los particulares la realización de actividades de carácter público (como era el caso, en Roma, de las obras públicas, los suministros o la recaudación de impuestos). Según las fuentes que nos remiten a los orígenes de los contratos públicos, en la época de la Roma republicana, las contrataciones eran competencia de los censores y, en menor medida, de magistrados ordinarios y extraordinarios. Entre las atribuciones del censor se encontraban las referidas a la elección del contratista - designado bajo los términos manceps, redemptor y publicanus ${ }^{215}$ - y las condiciones de la adjudicación venían expresadas con gran detalle en las leges censoriae.

De las características del proceso de subasta nos interesa destacar dos aspectos: (i) se adjudicaban al mejor postor y (ii) se excluía como adjudicatarios públicos a "las personas no solventes (minus idonae), tutores, curatores, deudores del Estado y menores de veinticinco años" ${ }^{216}$. Además, los censores podían impedir, mediante un edicto (summovere ab hasta), el acceso a las licitaciones de aquellos contratistas que hubiesen reclamado ante el Senado por disconfor-

${ }^{214}$ Utilizamos excepcionalmente la palabra «cocontratante» para designar al operador económico que va a formar parte del contrato, que, aunque es un término usado con cierta frecuencia en materia civil y mercantil y también por alguna sentencia del TJUE (STJUE de 18 de julio de 2007, Comisión/Alemania, C-503/04, apartado 36 , no se encuentra recogido en la vigésimo tercera edición del Diccionario de la Real Academia Española de la Lengua.

${ }^{215}$ Sobre esta materia, vamos a destacar la obra de MATEO SANZ, A., Manceps, redemptor, publicanus. Contribución al estudio de los contratistas públicos en Roma, Universidad de Cantabria, Santander, 1999.

${ }^{216}$ FERRER MAESTRO, J.J., "Los contratos públicos y el poder privado en la República romana", POTESTAS. Revista del Grupo Europeo de Investigación Histórica, núm. 2, 2009, pág. 16. 
midad con las condiciones de adjudicación de obras o servicios anteriores ${ }^{217}$.

Ahora bien, sin que sea preciso remontarnos tanto en el tiempo, también la legislación española desde la segunda mitad del siglo XIX se ha preocupado por establecer las condiciones necesarias para ser contratista a partir de una formulación genérica acerca de quién podía contratar y quién quedaba exceptuado de tal posibilidad. Así, el legislador centraba, primeramente, su atención en quienes no tenían capacidad de obrar con arreglo a las normas civiles ("No podrán ser contratistas: Los menores de edad / Los que, con arreglo á las leyes civiles, carezcan de capacidad para contratar por sí sin intervención de otra person ${ }^{218}$ ), ni de conformidad con la legislación mercantil ("Quedan exceptuados de la posibilidad de ser contratistas: Los que estuviesen fallidos ó en suspensión de pagos, ó con sus bienes intervenidos $\left.{ }^{219}\right)$.

Frente a esta capacidad de obrar genérica, también se han venido exigiendo

${ }^{217}$ FERRER MAESTRO sostiene que así ocurrió durante la censura de Marco Porcio Catón y Lucio Valerio Flaco en 184 a.C., cuando ambos magistrados excluyeron a quienes, con súplicas y lágrimas, habían provocado con sus dramáticas reclamaciones ante el Senado la anulación y nueva redacción de los contratos: "Además (los censores) adjudicaron en subasta la recaudación de los impuestos al precio más alto y los suministros estatales al más bajo. Como el Senado, dejándose convencer por las súplicas y las lágrimas de los adjudicatarios de las subastas, ordenó cancelar estos contratos y hacerlos de nuevo, los censores, excluyendo de la subasta mediante un edicto a los que se habían sustraído al cumplimiento de los contratos anteriores, hicieron de nuevo todas las adjudicaciones rebajando los precios ligeramente a la baja (Livio, 39, 44, 7-8)". Esta interesante cita del trabajo de FERRER MAESTRO nos llevaría a afirmar que en Roma las prohibiciones de contratar no sólo se sustentaban en una falta de capacidad de quien pretende llegar a ser contratista, sino en el rechazo a contratar con quienes no dan muestras de fiabilidad.

${ }^{218}$ Por ejemplo, en el Real Decreto de 10 de julio de 1861, aprobando el pliego de condiciones generales para las contratas de obras públicas, y en el Real Decreto de 4 de enero de 1883, disponiendo que los contratos que celebren las Diputaciones provinciales ó los Ayuntamientos para toda clase de servicios, obras, compras, ventas y arrendamiento, y en general todos aquellos que hayan de producir gastos ó ingresos en los fondos provinciales ó municipales se celebren por remate, previa subasta pública. Sobre la normativa española puede consultarse el Anexo documental de esta memoria doctoral.

${ }^{219}$ Este ejemplo lo hemos extraído del artículo 1 del Real Decreto de 11 de junio de 1886, que aprueba el Pliego de condiciones generales para la contratación de las obras públicas (Gaceta de Madrid núm. 165, de 14 de junio). 
determinadas aptitudes especiales a quien va a entablar una relación contractual con una entidad pública y, así, se ha tenido en cuenta no sólo la aptitud intrínseca del sujeto para ejercitar derechos y asumir obligaciones, sino la conveniencia - o no - de contratar con él en atención a distintas razones ${ }^{220}$. Las condiciones de idoneidad y solvencia que en cada momento se han considerado adecuadas a los fines del contrato, han ido modificándose al albur de los tiempos, permaneciendo, sin embargo, inalterable el asegurar la adecuada selección del contratista para la ejecución de la prestación demandada ${ }^{221}$.

\section{V.1. Su relación con los objetivos de la normativa con- tractual}

La posición del legislador respecto de restringir el acceso a la contratación pública parece contradecir uno de los principales objetivos de las Directivas de la Unión Europea en esta materia, a saber, la apertura de los contratos públicos a la mayor participación de operadores económicos en todo el mercado interior

${ }^{220}$ ALBALADEJO manifiesta que "como para ser titular de ciertas relaciones, se pueden exigir a la persona determinada aptitudes especiales, se habla de que para ellas se precisa una especial capacidad jurídica, ya que aún teniendo igual la general, la especial puede variar de unos a otros", ALBALADEJO GARCÍA, M., Derecho civil. Introducción y parte general, Tomo I, $15^{\mathrm{a}}$ ed., Bosch, Barcelona, 2002, pág. 227 .

${ }^{221}$ Como se tratará en un momento posterior, cabe indicarse que uno de los cambios más importantes en la legislación española tuvo lugar con ocasión de exigir una condena penal firme para impedir contratar con las Administraciones públicas, puesto que como presupuesto fáctico habilitador de una prohibición de contratar se preveía por ejemplo, hallarse "procesados criminalmente, se hubiere recaído contra ellos auto de prisión, ó los meramente procesados por delitos de falsificación, estafa, robo, hurto y demás que supongan ataque á la propiedad (artículo 11.2 de la Instrucción de 26 de abril de 1900, para la contratación de los servicios provinciales y municipales), o incluso acusados como señalaba el más reciente artículo 20.a) de la Ley 13/1995, de 18 de mayo, de Contratos de las Administraciones Públicas: "a) Haber sido condenadas mediante sentencia firme o estar procesadas o acusadas en el procedimiento a que se refiere el Título III, del Libro IV, de la Ley de Enjuiciamiento Criminal por delitos de falsedad o contra la propiedad o por delitos de cohecho, malversación de caudales públicos, tráfico de influencias, negociaciones prohibidas a los funcionarios, revelación de secretos o uso de información privilegiada o delitos contra la Hacienda Pública". 
y así hacer efectivo el ejercicio de la libre circulación de mercancías, la libertad de establecimiento y la libre prestación de servicios, tal como pone de relieve el primer considerando de las nuevas Directivas y expone la jurisprudencia del TJUE ${ }^{222}$.

En este sentido, las prohibiciones de contratar pueden entenderse contradictorias a tal fin ${ }^{223}$. Sin embargo, como tendremos ocasión de abordar en los siguientes epígrafes, tan sólo se trata de una aparente contradicción que se salva desde una visión más generalista, puesto que aplicado a un caso específico pudiera suceder, efectivamente, que la no adjudicación de un contrato a un operador económico incurso en una prohibición de contratar resultase más costosa al erario público por no poder atender a su oferta.

Ahora bien, a nuestro juicio, se debe hacer abstracción del caso individual - que nos servirá si acaso para justificar alguno de los supuestos que veremos de derogación de una prohibición de contratar - y buscar afianzar la confianza en su más amplia consideración. En primer lugar, para recuperar niveles de confianza pública, en tanto que se perciba por la ciudadanía que los fondos de la contratación no van destinados a quienes han quebrantado la normativa o a quienes se han dejado llevar por intereses espurios ${ }^{224}$. En segundo lugar, para generar certeza entre los operadores económicos "honestos" que participan del

${ }^{222}$ Véanse, en este sentido, las sentencias de 11 de mayo de 2006, Carbotermo y Consorzio Alisei, C-340/04, apartado 58; de 13 de diciembre de 2007, Bayerischer Rundfunk y otros, C-337/06, apartado 39; de 23 de diciembre de 2009, CoNISMa, C-305/08, apartado 37; de 10 de octubre de 2013, Swm Costruzioni, C-94/12, apartado 34; de 10 de julio de 2014, Consorzio Stabile Libor Lavori Pubblici, C-358/12, apartado 29 y de 18 de diciembre de 2014, Data Medical Service, C-568/13, apartado 34 .

${ }^{223}$ La citada STJUE de 10 de julio de 2014, Consorzio Stabile Libor Lavori Pubblici, C-358/12, manifiesta que "la aplicación de una disposición que excluye de la participación en los procedimientos de adjudicación de contratos públicos de obras a las personas culpables de infracciones graves a las normas nacionales aplicables en materia de pago de cotizaciones de seguridad social (...) puede impedir la participación más amplia posible de licitadores en los procedimientos de licitación".

${ }^{224}$ En el Capítulo tercero tendremos ocasión de referirnos a cuestiones tales como la desconfianza que en el ciudadano producen los escándalos de corrupción vinculados a la adjudicación de contratos públicos y, como bien señala el Preámbulo de la Convención de las Naciones Unidas contra la corrupción, pueden llegar a socavar la democracia y la confianza en las instituciones. 
respeto al Estado de Derecho y, por último, y no menos importante, para generar estabilidad en la economía al atemperar los efectos perjudiciales que las prácticas ilícitas causan en la economía legal de un país ${ }^{225}$.

Esta consideración obedece a la idea de defensa de un interés general cuando se adjudica un contrato público - aun cuando con él no se pretendan satisfacer necesidades de interés general ${ }^{226}$ - puesto que, en último término, no podemos olvidar que se manejan fondos públicos que deben ser correctamente gestionados mediante un escrupuloso cumplimiento de la legalidad ${ }^{227}$.

Desde esta perspectiva en favor de una buena gobernanza en los contratos públicos $^{228}$, pero sin desconocer que los motivos económicos son los que mueven

\footnotetext{
${ }^{225}$ Se calcula que la corrupción en Europa tiene un coste anual de 120.000 millones de euros para la economía (un 1\% PIB de la UE), según los datos que aporta el Informe de la Comisión sobre la lucha contra la corrupción en la UE, COM (2014) 38 , de 3 de febrero de 2014, pág. 3 .

${ }^{226}$ En su sentencia de 15 de julio de 2010, Comisión/Alemania, C-271/08, apartado 73, el TJUE manifestaba que las Directivas no "distinguen entre los contratos públicos celebrados por una entidad adjudicadora para cumplir su función de satisfacer necesidades de interés general y los contratos que no guardan relación con dicha función. La falta de esta distinción se explica por el objetivo de estas Directivas, que pretende excluir el riesgo de que se dé preferencia a los licitadores o candidatos nacionales en cualquier adjudicación de contratos efectuada por las entidades adjudicadoras".
}

${ }^{227}$ En contra de lo aquí manifestado respecto de la defensa del interés público, se muestra DE SOLAS RAFECAS quién entiende que "las Directivas Comunitarias prescinden de la finalidad fundamental de la legislación sobre contratación administrativa, que no es otra que la defensa y promoción del interés público, que se considera una cuestión propia y exclusiva de las legislaciones de los diferentes Estados miembros", y manteniendo sus dudas sobre si las Directivas "pueden encuadrarse en un concepto más amplio e impreciso como es el Derecho público que, a fin y al cabo, también está presidido por el principio del interés público", en DE SOLAS RAFECAS, J. Ma ., "La Ley de contratos del sector público: Dos regulaciones de naturaleza distinta en un solo texto legal", en la obra colectiva Derecho administrativo y regulación económica. Liber Amicorum profesor Doctor Gaspar Ariño Ortiz, La Ley, Las Rozas (Madrid), 2011, especialmente en sus págs. 502 y 516.

${ }^{228}$ En las formulaciones recientes sobre el buen gobierno y buena administración suele estar presente la idea de gobernanza incluyendo aspectos tales como el respeto de los derechos humanos, la democracia y el Estado de Derecho. Véase RODRÍGUEZ-ARANA MUÑOZ, J., El buen gobierno y la buena administración de instituciones públicas, Thomson Aranzadi, Cizur Menor (Navarra), 2006. 
el mercado de las compras públicas, hemos de sostener que:

- Las prohibiciones de contratar deben sustentarse en razones de protección de los intereses generales, puesto que si no fuera así, las restricciones al acceso a los procedimientos de adjudicación a quienes se hallen en determinadas situaciones - que en el ámbito privado no limitarían su capacidad de contratar - perderían justificación como medio legítimo para restringir la concurrencia. Es decir, sólo se justifican en la medida en que previamente estén amparadas en razones de interés general.

- Asimismo, debieran contribuir a reforzar una serie de valores compartidos por todos los Estados miembros que, si no ya sustentados en una idea de justicia o ética, al menos sirvan para dar respuesta a los desafíos que tienen un impacto transversal en toda la Unión Europea (delincuencia económica internacional, protección del medio ambiente, fiscalidad, etc. $)^{229}$.

- Aun justificado en aras de la protección del interés público, no se puede restringir la posibilidad de contratar con una entidad del sector público sin título suficiente que lo ampare, ni con una indefinición temporal, puesto que además de quebrar el objetivo fundamental de la apertura del mercado ${ }^{230}$, es necesario encontrar un equilibrio entre la finalidad protectora que promueven las prohibiciones de contratar y las necesarias garantías, derechos y seguridad jurídica del operador económico.

- Por ello, aunque los Estados miembros tienen la facultad de habilitar o no

${ }^{229}$ Aunque cada Estado miembro se esfuerce en mantener la identidad de sus reglas tradicionales de contratación allí donde no llegan los mandatos de las Directivas, convenimos con MEILÁN GIL cuando se refiere al Derecho europeo de los contratos públicos como meeting point de los ordenamientos nacionales, porque en atención a nuestra materia, veremos que constituye un verdadero lugar de encuentro respecto de las prohibiciones de contratar de carácter obligatorio, MEILÁN GIL J.L., La estructura de los contratos públicos, Iustel, Madrid, 2008, pág. 95.

${ }^{230}$ En palabras de DÍEZ SASTRE "las normas europeas sobre contratos públicos siguen pivotando en torno a un objetivo fundamental de buen funcionamiento del mercado y de competencia entre los operadores económicos", en DÍEZ SASTRE, S., "Formas y estructuras organizativas de la Administración de los contratos públicos en el mercado interior", en la obra colectiva Observatorio de los contratos públicos 2014, Thomson-Reuters Aranzadi, Cizur Menor (Navarra), pág. 63. 
a determinadas categorías de operadores económicos para llevar a cabo ciertas prestaciones, no se puede prohibir participar en un procedimiento de adjudicación a quienes cumplan las condiciones de admisión ${ }^{231}$. Las prohibiciones sólo pueden establecerse por virtud de expresa disposición legal.

Todas estas consideraciones serán objeto de un mayor detalle en los siguientes apartados.

\section{V.2. La integridad en la contratación pública a través de las prohibiciones de contratar}

Con un carácter general, las políticas de integridad "serían todo el conjunto de instrumentos, normas, procesos y estructuras de que se vale el buen gobierno para prevenir la corrupción y fomentar un servicio público coherente con los principios y valores que fundamentan su ética profesional en un régimen democrático"232. Las garantías de integridad en los procedimientos de adjudicación contractual responden al deseo de una gestión honesta de los fondos públicos por cuanto supone la abstención de cualquier práctica que conlleve quebrantar alguno de los principios cardinales en la adjudicación contractual, esto es, la igualdad de trato, la objetividad y la no discriminación ${ }^{233}$.

\footnotetext{
${ }^{231}$ Así se manifiesta el TJUE en sus sentencias de 23 de diciembre de 2009, CoNISMa, C-305/08, apartados 47 a 49; de 19 de diciembre de 2012, Ordine degli Ingegneri della Provincia di Lecce y otros, C-159/11, apartado 27; de 18 de diciembre de 2014, Data Medical Service, C-568/13, apartado 35 y de 6 de octubre de 2015, Consorci Sanitari del Maresme, C-203/14, también en su apartado 35 que señala que "En la medida en que determinadas entidades estén habilitadas para ofrecer servicios en el mercado a título oneroso, aunque sea ocasionalmente, los Estados miembros no pueden prohibirles que participen en procedimientos de adjudicación de contratos públicos relativos a la prestación de los mismos servicios".

${ }^{232}$ Hemos seguido lo dicho por VILLORIA MENDIETA, M., "La ética pública y los códigos de conductas administrativos vs. corrupción y escándalos políticos", en la obra colectiva El derecho a una buena administración y la ética pública, Tirant lo Blanch, Valencia, 2011, pág. 191.
}

${ }^{233}$ Sobre esta materia, resultan obligadas las referencias a GIMENO FELIÚ, J. Ma "La Ley de Contratos del Sector Público: ¿una herramienta eficaz para garantizar la 
Así lo recoge el Informe Anticorrupción de la UE 2014, que aboga por una mayor transparencia en el gasto público, en prestar más atención a la integridad en todas las políticas europeas y, en especial, luchar contra la corrupción en aquellas políticas que comprometen un mayor volumen de recursos. Las razones para ello son contundentes: en primer lugar, la corrupción genera pérdidas en la economía de la UE que se estiman en unos 120.000 millones de euros al año (1\% del PIB europeo) y, en segundo lugar, porque su infiltración en la economía legal conlleva la distorsión del funcionamiento del mercado interior ${ }^{234}$.

En atención al perjuicio económico - y también social - que provoca la corrupción, el citado Informe Anticorrupción plantea, entre otras iniciativas, normas de integridad más rigurosas en el ámbito de la contratación pública y acoge favorablemente algunas de las medidas proyectadas en las entonces Propuestas de Directivas sobre contratación ${ }^{235}$. Era el caso de: (i) las consultas preliminares del mercado; (ii) los motivos de exclusión obligatorios y facultativos; (iii) las disposiciones sobre la modificación de los contratos durante su vigencia; (iv) las obligaciones de seguimiento en la aplicación de las normas de adjudicación de las concesiones y (v) el establecimiento de unas normas mínimas relativas a los conflictos de intereses.

De entre todas ellas, en este epígrafe vamos a centrarnos en tres. En primer lugar, en las medidas de lucha contra la corrupción, aunque los aspectos relacionados con las conductas punibles serán objeto de mayor detalle en el Capítulo tercero al identificar los tipos delictivos cuya condena habilitan una prohibición de contratar de carácter obligatorio. En segundo lugar, nos cen-

integridad? (...)", op. cit., y del mismo autor El nuevo paquete legislativo comunitario (...)", op. cit., especialmente las págs. 24 a 31 y CERRILLO I MARTÍNEZ, A., El principio de integridad en la contratación pública (...)”.

${ }^{234}$ Son datos que encontramos reflejados en el ya citado Informe de la Comisión sobre la lucha contra la corrupción en la UE, COM (2014) 38, de 3 de febrero de 2014, pág. 3 y en su Comunicación Lucha contra la corrupción en la UE, COM (2011) 308 final, de 6 de junio.

${ }^{235}$ Estas propuestas recordemos que eran: la Propuesta de Directiva relativa a la contratación pública, COM (2011) 896 final; la Propuesta de Directiva relativa a la contratación por entidades que operan en los sectores del agua, la energía, los transportes y los servicios postales, COM (2011) 895 final y la Propuesta de Directiva relativa a la adjudicación de contratos de concesión, COM (2011) 897 final, todas ellas de fecha 20 de diciembre de 2011. 
traremos en el estudio de los conflictos de intereses, puesto que es la primera ocasión en que las Directivas de contratos públicos se adoptan disposiciones específicas para identificar e impedir dichas conductas y, en tercer y último lugar, aludiremos a la relación que existe entre una buena reputación - vinculado al concepto de moralidad profesional que se recogía en las Directivas del 2004 - y el acceso a la contratación pública. Así concretaremos algunos aspectos que consideramos de interés en esta materia: la autorregulación de las empresas mediante códigos de conducta y los incentivos y desincentivos que suponen para el operador económico su inclusión en una «lista negra»o en una «lista blanca».

\section{A. Medidas generales de lucha contra la corrupción}

Ante estas manifestaciones de corrupción en las adquisiciones del sector público, el ordenamiento jurídico responde con la adopción de distintas medidas tanto para prevenir como para sancionar dichas conductas irregulares ${ }^{236}$. Con anterioridad hemos advertido que el protagonismo en los mecanismos de respuesta punitiva se ha concedido al Derecho penal mediante la tipificación como delitos de aquellos comportamientos que suponen una desviación de los

${ }^{236}$ Sobre esta materia, resulta de interés la lectura de los siguientes documentos: (1) el Documento de trabajo sobre la corrupción, publicado por la Comisión Especial sobre la Delincuencia Organizada, la Corrupción y el Blanqueo de Dinero, del Parlamento Europeo (diciembre de 2012); (2) la Recomendación del Consejo portugués de Prevención de la corrupción, sobre la prevención de los riesgos de corrupción en la contratación pública (enero de 2015) Prevenção de riscos de corrupção na contratação pública, y (3) el Análisis de la contratación pública en España: Oportunidades de mejora desde el punto de vista de la competencia, que publicó la Comisión Nacional de los Mercados y la Competencia (CNMC) PRO/CNMC/001/15 (febrero 2015).

Asimismo, debemos destacar la Resolución del Parlamento Europeo, de 25 de octubre de 2011 [P7_TA (2011) 0454], sobre la modernización de la contratación pública, que señalaba en su apartado 44 que "la lucha contra la corrupción y el favoritismo es uno de los objetivos de las Directivas". Al mismo tenor responde el Dictamen del Comité Económico y Social Europeo (CESE), sobre el Libro Verde de la Comisión al manifestar que "uno de los objetivos de las directivas consiste en combatir el favoritismo, del fraude y la corrupción", apartados 1.14 y 6.1 (DOUE C 318, de 29 de octubre de 2011) y el Documento de trabajo de los servicios de la Comisión sobre las Propuestas de Directivas, SEC (2011) 1585 final, de 20 de diciembre de 2011, pág. 30. 
intereses públicos por afectar al correcto funcionamiento de las Administraciones públicas. De esta manera, la mayor parte de las conductas vinculadas a la corrupción en la contratación pública son susceptibles de integrar alguno de los delitos recogidos en la Parte Especial de cualquier Código penal: prevaricación, revelación de secretos, información privilegiada, cohecho, tráfico de influencias, negociaciones prohibidas a funcionarios públicos, fraudes y exacciones ilegales ${ }^{237}$.

Junto a estas medidas de carácter represivo, el Derecho administrativo nos ofrece respuestas distintas de la sanción penal que se articulan, esencialmente, bien a través de sanciones administrativas ${ }^{238}$, bien a través de instrumentos de carácter preventivo. En alusión a esta última manera de actuar, los mecanismos que se contemplan en las Directivas sobre contratación pública para hacer frente al flagelo de la corrupción son de dos tipos: Los primeros son de carácter general y aluden al propio sistema contractual presidido por los principios de transparencia, objetividad, no discriminación e igualdad de trato; y los segundos, que podríamos calificar como específicos, que se dirigen a promover la probidad entre aquellos operadores económicos que quieren llegar a ser contratistas, pues como señalan los considerandos centésimo de la Directiva 2014/24/UE y el sexagésimo noveno de la Directiva 2014/23/UE («concesiones») "No deben

${ }^{237}$ Además de la bibliografía ya citada en las páginas 125 a 129, debemos añadir las siguiente por tratar de manera más detallada el tema que nos ocupa: IGLESIAS RIO, M. Á y MEDINA ARNÁIZ, T., "Herramientas preventivas en la lucha contra la corrupción en el ámbito de la Unión Europea", Revista penal, núm. 14, julio 2004, págs. 49 - 70; CASTRO CUENCA, C. G., La corrupción en la contratación pública en Europa, Ratio Legis, Salamanca, 2009; JAREÑO LEAL, Á., Corrupción y delincuencia de los funcionarios en la contratación pública, Iustel, Madrid, 2011; JIMÉNEZ FRANCO, E., "Administración pública y corrupción: iniciativas legislativas de lege ferenda para una nueva cultura de integridad", Actualidad administrativa, núm. 5, marzo 2012, págs. 538 - 569 y GALLEGO CÓRCOLES, I., "La prevención de la corrupción en la contratación pública", en la obra colectiva Public Compliance: Prevención de la corrupción en administraciones públicas y partidos políticos, Ediciones de la Universidad de Castilla La Mancha, Cuenca, 2014, págs. 61 - 92.

${ }^{238}$ En España, los ejemplos más claros se han producido en el ámbito del Derecho de la competencia, con el caso «Licitaciones de carreteras» [Resolución de la, entonces, Comisión Nacional de la Competencia (CNC), de 19 de octubre de 2011 (Expte. S/0226/10]; en el caso «Gestión de recursos sanitarios» [Resolución de la CNC, de 18 de enero de 2010 (Expte. S/0014/07)] y en el caso «Gestión de recursos» [Resolución de la ya CNMC, de 8 de enero de 2015 (Expte. S/0429/12)]. 
adjudicarse contratos públicos a operadores económicos que hayan participado en una organización delictiva o hayan sido declarados culpables de corrupción".

A este segundo grupo de medidas se dedica una gran parte del Capítulo tercero de esta memoria doctoral y, por tanto, a ella nos remitimos para dedicarnos, en este momento, a las medidas de carácter general. El objetivo de este tipo de medidas es reducir las posibilidades de corrupción desde la observancia de los principios cardinales de la contratación pública: igualdad de trato, no discriminación y transparencia ${ }^{239}$.

En este sentido, un marco jurídico que contemple procedimientos de adjudicación basados en la publicidad y en la concurrencia, que garantice la imparcialidad en los procedimientos de adjudicación, que excluya de la posibilidad de contratar con las entidades públicas a quienes se encuentren en una situación de conflicto de intereses y que posibilite el control ulterior de las adjudicaciones mediante la instauración de un sistema eficaz de recursos, contribuye a cerrar espacios a las prácticas corruptas y a otras formas de uso ilícito de los recursos públicos ${ }^{240}$.

A este respecto, cabe señalar que la Directiva 2007/66/CE del Parlamento Europeo y del Consejo, de 11 de diciembre de $2007^{241}$, prevé un sistema de

${ }^{239}$ De cita obligada resultan las referencias a MORENO MOLINA, J. A. Los principios generales de la contratación de las Administraciones públicas, Bomarzo, Albacete, 2006; ESTEVES DE OLIVEIRA. R., "Os princípios gerais da contratação pública", en la obra colectiva dirigida por COSTA GONÇALVES, P., Estudos de Contratação Pública I, Coimbra Editora, Coimbra, 2008, págs. 51-113; RODRÍGUEZARANA MUÑOZ, J., "Los principios del Derecho global de la contratación pública", Revista Derecho PUCP, núm. 66, 2011, págs. 29 - 54 y en la obra colectiva Derecho administrativo y regulación económica. Liber Amicorum profesor Doctor Gaspar Ariño Ortiz, La Ley, Las Rozas (Madrid), 2011, págs. 431 - 456 y SÁNCHEZ GRAELLS, A., "The Continuing Relevance of the General Principles of EU Public Procurement Law After the Adoption of the 2014 Concessions Directive", EPPL, vol. 10 (3), 2015, págs. 130 - 139.

${ }^{240}$ Con un mayor detalle, MEDINA ARNÁIZ, T., "Instrumentos jurídicos frente a la corrupción en la contratación pública (...)”, op. cit., págs. 299 - 344.

${ }^{241}$ Directiva 2007/66/CE del Parlamento Europeo y del Consejo, de 11 de diciembre de 2007, por la que se modifican las Directivas 89/665/CEE y 92/13/CEE del Consejo en lo que respecta a la mejora de la eficacia de los procedimientos de recurso en materia de adjudicación de contratos públicos (DOUE L 335, de 20 de diciembre de 2007). 
recursos en materia de adjudicación de contratos públicos que garantiza que las decisiones adoptadas por los poderes adjudicadores puedan ser recurridas de manera eficaz y, en particular, con la mayor celeridad, por cualquier persona que tenga o haya tenido interés en obtener un determinado contrato y que se haya visto o pueda verse perjudicada por una presunta infracción ${ }^{242}$.

Con independencia del modelo que se adopte del sistema de recursos, el establecimiento de vías de recursos eficaces en materia de adjudicación contractual ayuda a prevenir comportamientos corruptos, en tanto que contribuye a la tutela judicial efectiva a los interesados en el contrato ${ }^{243}$. Si bien, en nuestra opinión, también se debiera incidir en el desempeño de un papel disuasorio que haga que la delincuencia no resulte "rentable", incluso desde la exigencia de responsabilidades personales a quienes utilizan - y han utilizado - el dinero público para su propio beneficio o o de la anulación del contrato si se hubiere incurrido en ilegalidad, reforzando, en todo caso, el papel de los organismos de control con el fin garantizar la buena gestión económica de los fondos públicos.

\section{B. La garantía de imparcialidad: Especial referencia a los conflictos de intereses y a la participación previa de candidatos o licita- dores}

El principio de igualdad de trato entre los licitadores y candidatos tiene por objetivo favorecer el desarrollo de una competencia efectiva entre los operadores económicos que participan en un contrato público, de tal manera que se garantice que no exista riesgo alguno de favoritismo y/o de arbitrariedad por parte del poder adjudicador respecto de ciertos operadores o de determinadas ofertas $^{244}$. El respeto a este principio implica para los poderes adjudicadores la

\footnotetext{
${ }^{242}$ MORENO MOLINA, J. A., La reforma de la Ley de Contratos del Sector Público en materia de recursos, La Ley, Madrid (Las Rozas), 2010; DÍEZ SASTRE, S., La tutela de los licitadores (...)", op. cit.

${ }^{243}$ En palabras de GIMENO FELIÚ que compartimos "el sistema de control de la contratación continua siendo el principal eje sobre el que pivota la normativa comunitaria para preservar la integridad", en su obra El nuevo paquete legislativo comunitario (...), op. cit., pág. 196.

${ }^{244}$ Así se manifiesta el TJUE en sus sentencias de 29 de abril de 2004, Comisión/CAS Succhi di Frutta, C-496/99P, apartados 110 y 111; de 6 de noviembre de
} 
obligación de evitar y, en su caso, eliminar aquellas situaciones que pudieran comprometer el ejercicio imparcial y objetivo de sus funciones. De esta manera,

"A fin de combatir el fraude, el favoritismo y la corrupción e impedir los conflictos de interés, los Estados miembros tomarán las medidas pertinentes para garantizar la transparencia del procedimiento de adjudicación y la igualdad de trato de todos los candidatos y licitadores. Dichas medidas deben estar encaminadas, en particular, a eliminar los conflictos de intereses y otras irregularidades graves" (considerando sexagésimo primero de la Directiva 2014/23/UE («concesiones»).

Para garantizar la imparcialidad en la selección del contratista y prevenir cualquier riesgo de que el poder adjudicador público se deje guiar por consideraciones ajenas al contrato, el legislador europeo establece una serie de cautelas generales dirigidas a alejar los peligros de favoritismos. Entre estas cautelas podemos señalar, a título de ejemplo, que no se exija una determinada forma jurídica al operador económico; que la solvencia requerida sea proporcional respecto del contrato; que los procedimientos de contratación sin licitación sean excepcionales; que el arraigo territorial no pueda ser utilizado como criterio de adjudicación.

Además de ello, y con un carácter más específico, se prevén ciertas situaciones susceptibles de poner en riesgo la objetividad del poder adjudicador por tener vínculos con los operadores económicos. Concretamente, las circunstancias que se recogen en las nuevas Directivas son dos: los conflictos de intereses y la participación previa de los operadores económicos en la preparación de un procedimiento de adjudicación, y para evitar ambas situaciones se articulan mecanismos que atemperen sus efectos en caso de que surjan. Por tanto, y tal como veremos seguidamente, la normativa parte de la presunción del daño a la imparcialidad que supone una relación previa entre el órgano de contratación y el operador económico, y se establece la obligación de que se adopten las medidas adecuadas "para prevenir, detectar y poner remedio a los conflictos de intereses" (artículo 24 de la Directiva 2014/24/UE y artículo 35 de la Directiva

2014, Cartiera dell'Adda, C-42/13, apartado 44 y de 12 de marzo de 2015, eVigilo, C-538/13, apartados 33 y 34 . 
$2014 / 23 / \mathrm{UE})$.

Por lo que a esta memoria doctoral interesa, una de estas medidas son las prohibiciones de contratar. Las nuevas Directivas disponen que "cuando no pueda remediarse por medios menos restrictivos" o "por otra medida menos intrusiva", los poderes adjudicadores podrán excluir a un operador económico de la participación en un procedimiento de contratación cuando exista un conflicto de intereses o un falseamiento de la competencia derivado de la participación previa de los operadores económicos en la preparación del procedimiento de contratación (artículo 57.4 letras e y f) de la Directiva 2014/24/UE y artículo 38.7.d) de la Directiva 2014/23/UE («concesiones»).

Estas prohibiciones de contratar son una de las novedades que presentan las Directivas de 2004 que, a partir de la exclusión del licitador o candidato de la adjudicación del contrato, buscan evitar un falseamiento de la competencia y garantizar la igualdad de trato de licitadores y candidatos. Ahora bien, aunque es cierto que estas prohibiciones se presentan como una novedad de las recientes Directivas, no podemos afirmar que sean una verdadera primicia en la regulación contractual europea, puesto que el Reglamento financiero desde su redacción del año 2002 preveía - y anticipándose, por tanto, a la regulación contenida en las Directivas sobre contratación pública - que "con el fin de prevenir las irregularidades, luchar contra el fraude y la corrupción y fomentar una gestión saneada y eficaz, debe excluirse de la adjudicación de contratos a aquellos candidatos o licitadores que hayan sido declarados culpables de tales actos o que se hallen en una situación de conflicto de intereses" (considerando vigésimo quinto del ya derogado Reglamento financiero 1605/2002) ${ }^{245}$.

En el momento actual y con idéntica finalidad preventiva, los artículos 106

${ }^{245}$ Hemos sostenido que aunque las normas financieras no sean de aplicación a los Estados miembros, pues sólo son aplicables a los organismos de la Unión, nos sirven de guía en muchos de los aspectos vinculados a la contratación pública, ya que siempre han mostrado un especial interés en proteger los intereses financieros de la Unión contra el fraude, la corrupción y cualquier otra actividad ilegal, bajo el objetivo de salvaguardar los fondos públicos y garantizar una buena gestión financiera. Así lo indicábamos en nuestro trabajo "Las disposiciones financieras de la Unión Europea y su aplicación a la contratación pública: especial referencia al nuevo Reglamento financiero y sus normas de desarrollo", en la obra colectiva Observatorio de contratos públicos 2012, Civitas - Thomson Reuters, Cizur Menor (Navarra), 2013, págs. 165 $-194$. 
y 107 del vigente Reglamento (UE, Euratom) 966/2012 determinan, respectivamente, los criterios de exclusión aplicables a la participación en procedimientos de contratación pública y los supuestos de exclusión aplicables durante el procedimiento de adjudicación ${ }^{246}$. Sus disposiciones, más allá del momento procedimental en el que son aplicables, expresamente obligan a excluir de la adjudicación de contratos a aquellos candidatos o licitadores que se encuentren incursos en una situación de conflicto de intereses (artículo 107.1.a) del Reglamento 966/2012):

\begin{abstract}
"Quedarán excluidos de la adjudicación de un contrato aquellos candidatos o licitadores que, durante el procedimiento de contratación correspondiente a ese contrato: se hallen en una situación de conflicto de intereses". [El subrayado es nuestro para enfatizar su carácter obligatorio]
\end{abstract}

A la luz de estas consideraciones previas, vamos a analizar estas prohibiciones de contratar desde la concreción de la noción de «conflicto de intereses» y la identificación de las circunstancias en las que pueden surgir conflictos de intereses.

${ }^{246}$ Desde el 1 de enero de 2013 se encuentran en vigor el Reglamento (UE, Euratom) 966/2012, del Parlamento Europeo y del Consejo, de 25 de octubre de 2012, sobre las normas financieras aplicables al presupuesto general de la Unión (DOUE L 298, de 26 de octubre) y el Reglamento Delegado (UE) 1268/2012 de la Comisión, de 29 de octubre de 2012, sobre sus normas de desarrollo (DOUE L 362, de 31 de diciembre). Desde el 1 de enero de 2014, también resulta aplicable el Reglamento Delegado (UE) 1271/2013 de la Comisión, de 30 de septiembre de 2013, relativo al Reglamento financiero marco de los organismos a que se refiere el artículo 208 del Reglamento (UE, Euratom) 966/2012 del Parlamento Europeo y del Consejo (DOUE L 328, de 7 de diciembre de 2013).

De conformidad con la propuesta de modificación del Reglamento financiero para adaptar sus disposiciones a las Directivas de 2014, se prevé una nueva redacción de los artículos 106 y 107 respecto de los criterios de exclusión que se proyectan más allá de lo dispuesto en las citadas Directivas y que entrarían en vigor el 1 de enero de 2016, COM (2014) 358 final, de 18 de junio de 2014.

De conformidad con la propuesta de modificación del Reglamento financiero para adaptar sus disposiciones a las Directivas de 2014, se prevé una nueva redacción de los artículos 106 y 107 respecto de los criterios de exclusión que se proyectan más allá de lo dispuesto en las citadas Directivas y que entrarían en vigor el 1 de enero de 2016, COM (2014) 358 final, de 18 de junio de 2014. 


\section{B.1. Los conflictos de intereses}

La preocupación por los conflictos de intereses ha ido en paralelo con el creciente interés internacional en el establecimiento de medidas contra la corrupción, puesto que la atención sobre esta materia se vincula a ciertos comportamientos corruptos ${ }^{247}$. De esta manera, tanto las Directrices de la OCDE como la propia Convención de las Naciones Unidas contra la corrupción, constituyen algunos de los instrumentos de referencia para formular y aplicar una política global en materia de conflicto de intereses desde el establecimiento de principios, valores y estándares éticos "destinados a promover la transparencia y a prevenir conflictos de intereses" (artículo 7.4 de la Convención de las Naciones Unidas contra la corrupción) ${ }^{248}$.

${ }^{247} \mathrm{~A}$ juicio de GARCÍA MEXÍA, los comportamientos que derivan en conflictos de intereses son una manifestación atenuada de corrupción, GARCÍA MEXÍA, P., Los conflictos de intereses y la corrupción contemporánea, Aranzadi, Elcano (Navarra), 2001, pág. 34. En opinión de la OCDE manifestada en sus Directrices para la gestión de conflictos de intereses en el servicio público (Managing Conflict of Interests in the Public Service. OECD Guidelines and Country experiences, 2003), un conflicto de intereses no es considerado ipso facto un acto de corrupción, pero existe la creencia de que si los conflictos entre los intereses privados y públicos de los empleados públicos no se manejan adecuadamente, pueden convertirse en corrupción. En opinión de ROSE-ACKERMAN, dentro del concepto de conflicto de intereses, la corrupción y el fraude forman un subconjunto cuando los beneficios para el funcionario son financieros, en ROSE-ACKERMAN, S., "Corruption and Conflicts of Interest", en la obra colectiva Corruption and Conflicts of Interest. A Comparative Law Approach, Edward Elgar Publishing, United Kingdom, 2014, págs. 3 - 11. CERRILLO I MARTÍNEZ sostiene que "los conflictos de interés pueden ser un indicador, un precursor o, incluso, un motor que acabe generando un caso de corrupción si no se hace nada al respecto", en El principio de integridad (...)", op. cit., pág. 30.

Con arreglo a los datos presentados en el Flash Eurobarómetro número 374 Businesses' attitudes towards corruption in the EU (febrero 2014), una de las irregularidades más mencionadas por las empresas en los procedimientos de adjudicación es la existencia de conflictos de intereses en el momento de la valoración de las ofertas. Así lo hemos recogido en MEDINA ARNÁIZ, T., "Los conflictos de intereses llegan a las Directivas sobre contratación pública", en la obra colectiva Observatorio de los contratos públicos 2013, Thomson - Aranzadi, Cizur Menor (Navarra) 2014, págs. 278 y 279.

${ }^{248}$ La Convención de las Naciones Unidas contra la Corrupción entró en vigor en diciembre de 2005, y la UE se adhirió a ella en septiembre de 2008, concretamente en virtud de la Decisión 2008/801/CE del Consejo, de 25 de septiembre (DOUE L 287 , de 29 de octubre). 
Para cumplir con estos estándares, debe partirse de una definición que esboce los rasgos generales de las situaciones de conflictos de intereses susceptibles de poner en riesgo la objetividad en la actuación pública, y así articular los mecanismos que los eviten.

\section{B.1.1. La noción de «conflicto de intereses»}

En el ámbito de la actuación administrativa, debe entenderse que existe un conflicto de intereses cuando concurren en un cargo o funcionario público dos intereses contrapuestos: uno de carácter público - en cuya defensa se ha de ejercitar la función pública - y otro de carácter privado que impide o puede impedir el estricto cumplimiento de sus deberes y que compromete o puede comprometer su imparcialidad. De esta manera, el conflicto puede ser «real» si efectivamente se produce, o «aparente»y/o «potencial» si son susceptibles de convertirse en conflictos reales si llegan a darse ciertas circunstancias ${ }^{249}$.

Más centrados en el ámbito contractual, la Comisión en su Libro Verde sobre la modernización de la política de contratación pública de la UE (2011) adoptó una noción de conflicto de intereses caracterizada por una "situación en la que las personas participantes en la decisión de adjudicación de un contrato tienen obligaciones profesionales o personales o intereses personales o económicos contrapuestos que podrían hacer que les resultase difícil cumplir con su deber justa e imparcialmente, o en la que una persona está en condiciones de influir en el proceso de toma de decisiones del poder adjudicador para favorecer sus propios intereses" 250 .

${ }^{249} \mathrm{El}$ Tribunal de Cuentas Europeo se hace eco de esta diferenciación en el glosario de términos del Informe Especial del Tribunal de Cuentas núm. 15/2012, Gestión de los conflictos de intereses en varias agencias de la UE seleccionadas. No podemos olvidar que, en principio, un conflicto de intereses únicamente puede concretarse durante la ejecución del contrato. Antes de la conclusión del contrato, el conflicto de intereses sólo puede ser potencial

${ }^{250}$ Libro Verde sobre la modernización de la política de contratación pública de la UE. Hacia un mercado europeo de la contratación pública más eficiente, COM (2011) 15 final, de 25 de enero de 2011, pág. 53. Recordemos que la Comisión en su Libro Verde señalaba que la prevención de estos conflictos ayudaría a asegurar la integridad en los procedimientos de adjudicación contractual, puesto que localizar y resolver los conflictos de intereses es clave para prevenir el fraude. Ante la posibilidad de incluir un artículo en las Propuestas de Directivas referido a los conflictos de 
En todo caso - y tal como reconoce la jurisprudencia europea - el conflicto de intereses en la contratación pública supone la quiebra de uno de sus principios básicos cual es el de igualdad, puesto que implica el riesgo de que el poder adjudicador "se deje guiar por consideraciones ajenas al contrato en cuestión y se dé preferencia a un licitador por ese mero hecho" ${ }^{251}$. En este sentido, el concepto de conflicto de intereses tiene un carácter objetivo y se requiere, para caracterizarlo, hacer abstracción de las intenciones de los interesados ${ }^{252}$, es decir, la facultad de un licitador de influir en las condiciones de licitación en un sentido que le sea favorable, aun cuando no sea voluntaria, constituye una situación de conflicto de intereses ${ }^{253}$.

Para que la imparcialidad quede garantizada es preciso, en primer lugar, determinar las situaciones que pueden comportar el riesgo de menoscabar realmente la objetividad en el proceso de selección del contratista y, seguidamente, establecer mecanismos para su prevención (entre otros, recordemos que está la prohibición de contratar). En esta línea argumental, más allá de una definición operativa de conflicto de intereses, lo que interesa es identificar las circunstancias - o los intereses privados y/o personales - que, de confluir en aquellas personas que participan en la toma de decisiones, pudieran provocar

intereses, la Comisión planteaba las siguientes preguntas: ¿¿Estaría a favor de introducir una definición de la UE del conflicto de intereses en la contratación pública? y ¿Qué actividades o situaciones que contengan un riesgo potencial deberían estar contempladas (relaciones personales, intereses empresariales, como la participación en el capital, incompatibilidades con actividades externas, etc.)?".

${ }^{251}$ STJUE de 12 de marzo de 2015, eVigilo, C-538/13, apartado 35.

252"Un conflicto de intereses constituye en sí mismo y de forma objetiva una disfunción grave, sin que sea preciso tener en cuenta, para su calificación, las intenciones de los interesados y su buena o mala fe, ni demostrar que haya causado un perjuicio material cuantificable", sentencia del entonces Tribunal de Primera Instancia de 15 de junio de 1999, Ismeri Europa/Tribunal de Cuentas, T-277/97, apartado 123, confirmada por la sentencia del Tribunal de Justicia de 10 de julio de 2001, C-315/99 $\mathrm{P}$, apartados 44 a 48.

${ }^{253}$ Sentencia del Tribunal de Justicia de 3 de marzo de 2005, Fabricom, C-21/03 y C-34/03, apartados 29 y 30, y las sentencias del Tribunal General de 17 de marzo de 2005, AFCon Management Consultants y otros/Comisión, T-160/03, apartado 74; de 20 de marzo de 2013, Nexans France/Empresa Común Fusion for Energy, T-415/10, apartado 114 y de 13 de octubre de 2015, Intrasoft International SA, $\mathrm{T}-403 / 12$. 
un conflicto de intereses.

Asimismo, es necesario realizar un razonamiento en términos de riesgo, puesto que no toda situación de conflicto de intereses va a posibilitar la exclusión del candidato o licitador del procedimiento de adjudicación. Ello implica que no existe una obligación absoluta de los poderes adjudicadores de excluir sistemáticamente a los operadores económicos en situación de conflicto de intereses, dado que tal exclusión no se justifica en aquellos casos en que puede probarse que tal situación no ha tenido ninguna incidencia en su comportamiento en el marco del procedimiento de licitación y que no supone un riesgo real de que surjan prácticas que puedan falsear la competencia entre los licitadores. En cambio, la prohibición de contratar por la existencia de un conflicto de intereses resulta indispensable cuando no se dispone de un remedio más adecuado para evitar cualquier vulneración de los principios de igualdad de trato y de transparencia ${ }^{254}$.

\section{B.1.2. Identificación de las circunstancias en las que pueden sur- gir conflictos de intereses}

Las Líneas directrices de la OCDE recomiendan que toda política sobre conflictos de intereses tenga en cuenta el riesgo específico asociado a determinadas categorías de personas y que, además de un interés personal directo, se preste también atención a los intereses derivados de sus vínculos afectivos y familiares, de sus afinidades políticas, nacionales y de afiliación. Entiende que los intereses privados no se limitan a aquellos de contenido exclusivamente económico e incluso, enlaza con los casos de «puerta giratoria» cuando los funcionarios y cargos dejan el servicio público, pero aprovechan su saber y conocimiento para favorecer a los grupos privados a los que se incorporan ${ }^{255}$.

\footnotetext{
${ }^{254}$ Sentencia del Tribunal General de 13 de octubre de 2015, Intrasoft International $S A$, T-403/12, apartado 76, con cita expresa en la sentencia del mismo Tribunal de 20 de marzo de 2013, Nexans France/Empresa Común Fusion for Energy, T-415/10, apartados 116 y 117.

${ }^{255} \mathrm{OCDE}$, La gestión de los conflictos de intereses en el servicio público. Líneas directrices de la OCDE y experiencias nacionales, Ministerio de Administraciones Públicas, Madrid, 2005, págs. 18 y 29; OCDE, Post-Public Employment. Good Practices for preventing Conflict of Interest, OECD, Paris, 2010.
} 
En las nuevas Directivas sobre contratación pública, los elementos comunes respecto de los conflictos de intereses se perfilan en el artículo 24 de la Directiva 2014/24/UE sobre contratación pública, en el artículo 42 de la Directiva sobre contratación en los sectores especiales y en el artículo 35 de la Directiva 2014/23/UE sobre concesiones.

Estos artículos incorporan al texto de las Directivas el concepto de conflicto de intereses e instauran una regulación de mínimos, puesto que se prevé que la normativa nacional que transponga estas disposiciones contemple, al menos, “(...) cualquier situación en la que los miembros del personal del poder adjudicador /entidad adjudicadora/ o de un proveedor de servicios de contratación que actúe en nombre del poder adjudicador, que participen en el desarrollo del procedimiento de contratación o puedan influir en el resultado de dicho procedimiento tengan, directa o indirectamente, un interés financiero, económico o particular/personal que pudiera parecer que compromete su imparcialidad e independencia en el contexto del procedimiento de contratación".

Del nuevo marco normativo debemos destacar cinco aspectos:

- Desde esta regulación de mínimos, delimita la categoría de personas que se hallan expuestas a un conflicto de intereses. Estos sujetos son: (i) los miembros del personal de un poder adjudicador, (ii) los miembros del personal de una entidad adjudicadora, (iii) los miembros del personal de un proveedor de servicios que actúa en nombre del poder adjudicador y que se refiere a los organismos públicos o privados que proponen actividades de compra auxiliares en el mercado ${ }^{256}$.

- El concepto de conflicto de intereses tiene un carácter objetivo y para caracterizarlo se requiere - insistimos en ello - abstraernos de las intenciones de las personas a las que se refiere. No se exige, por tanto, un "abuso de cargo o posición", tan sólo que los sujetos se encuentren en situación de intervenir en el procedimiento o influir en él, puesto que las acciones de estos sujetos susceptibles de incurrir en un conflicto de intereses se concreta sobre los términos «actuar», «participar»e «influir»

${ }^{256}$ Es la definición de «proveedor de servicios de contratación» que nos ofrece el artículo 2, apartado primero, numeral 17 de la Directiva 2014/24/UE del Parlamento Europeo y del Consejo, de 26 de febrero de 2014, sobre contratación pública. 
en el procedimiento de contratación.

- No se requiere que el conflicto sea «real» en cuanto que el interés particular influya de facto en el desempeño de la actividad pública, sino que pueda ser «percibido» como comprometedor de la objetividad, la imparcialidad y la independencia requerida en el procedimiento de contratación ${ }^{257}$. Es decir, aunque en principio, un conflicto de intereses únicamente puede concretarse durante la ejecución del contrato, deben adoptarse medidas para disipar las dudas sobre la corrección de la actuación administrativa con anterioridad a la adjudicación. En este sentido, las nuevas Directivas hacen hincapié en que, siendo los Estados miembros los competentes para adoptar las medidas que garanticen la igualdad de trato de los licitadores y candidatos, la identificación de las situaciones de conflicto deben atender al riesgo de parcialidad.

- Los intereses que pueden comprometer la ejecución imparcial de las funciones públicas pueden ser directos o indirectos; esto es, referidas a la obtención de ventajas para uno mismo (directas) o para terceros (indirectas). En todo caso, comprende intereses financieros, económicos o particulares de cualquier otra índole, de tal manera que la obtención de esos beneficios privados influyen indebidamente en las decisiones de compra pública. Al no limitar la relación de intereses particulares, tal conflicto de intereses podría plantearse como consecuencia de afinidades políticas o nacionales, de vínculos familiares o afectivos o por meros intereses compartidos.

- A pesar de poder comprometer la imparcialidad en la selección del contratista, no se considera un conflicto de intereses las situaciones por las cuales un operador económico intenta influir indebidamente en un procedimiento de adjudicación u obtener información confidencial que pueda conferirle ventajas indebidas en el procedimiento de contratación (artículo 57.4 i) de la Directiva 2014/24/UE y artículo 38.7 h) de la Directiva 2014/23/UE).

${ }^{257}$ La Propuesta de Directiva sobre contratación pública, COM (2011) 896 final, y la Propuesta de Directiva relativa a la contratación por entidades que operan en los sectores especiales, COM (2011) 895 final, se referían a situaciones de "conflicto de intereses reales, posibles o percibidos". 
El hecho de ser la primera vez que los conflictos de intereses se regulan en la contratación pública convierte en positivo el intento de lograr una aproximación conceptual de qué se entiende por conflicto de intereses, aunque hemos de destacar que su contenido resulta más limitado que el que se preveía en las Propuestas de Directivas. Los artículos finalmente aprobados no precisan qué se entiende por «intereses particulares o personales» ${ }^{258}$, tampoco plantean soluciones orientadas a evitar la aparición del conflicto de intereses, no resuelven los conflictos de intereses que se puedan presentar, ni adoptan medidas correctoras. La única medida concreta se refiere a las prohibiciones de contratar y eso sí, entendida como ultima ratio.

\section{B.1.3. La prohibición de contratar motivada por un conflicto de intereses}

Como ya hemos avanzado, la única medida que se contempla en las Directivas para resolver los conflictos de intereses es de carácter potestativo y responde a eliminar los conflictos detectados a partir de la exclusión del licitador o candidato de la adjudicación del contrato. De esta manera, las nuevas Directivas prevén que cuando el conflicto de interés no pueda resolverse de otra manera, el candidato o el licitador vinculado al órgano de contratación pueda ser excluido del procedimiento de adjudicación.

"Los poderes adjudicadores podrán excluir a un operador económico de la participación en un procedimiento de contratación, por sí mismos o a petición de los Estados miembros, en cualquiera de las siguientes situaciones: e) cuando no pueda resolverse por medios menos restrictivos un conflicto de intereses en el sentido del artículo 24" (artículo 57.4.e) de la Directiva 2014/24/UE); "Los poderes adjudicadores o entidades adjudicadoras podrán excluir, o los Estados miembros podrán pedirles que excluyan, de la participación en un procedimiento de adjudicación de concesión a cualquier ope-

\footnotetext{
${ }^{258}$ En las Propuestas de Directivas se indicaba expresamente que se entenderá por intereses particulares "Los intereses familiares, afectivos, económicos, políticos u otros intereses compartidos con los candidatos o los licitadores, incluidos los conflictos de intereses profesionales" (artículo 21.1 de la Propuesta de Directiva sobre contratación pública y artículo 36.1 de la Propuesta de Directiva sectores especiales).
} 
rador económico si se da cualquiera de las siguientes situaciones: d) si un conflicto de intereses en el sentido del artículo 35, párrafo segundo, no se puede subsanar con eficacia por ninguna otra medida menos intrusiva (artículo 38.7.d) de la Directiva 2014/23/UE («contratos de concesión»).

Por eso, ante evidentes conflictos de intereses, las Directivas prevén restringir el derecho a contratar de aquellas personas cuyas vinculaciones con alguno/s de los miembros del órgano de contratación pudiera poner en entredicho la debida imparcialidad.

En este sentido, y bajo la debida relación de proporcionalidad, estas disposiciones posibilitan a los poderes y entidades adjudicadoras excluir del procedimiento de adjudicación a los licitadores que ocasionan el conflicto de intere$\operatorname{ses}^{259}$. Ahora bien, sólo se permite excluir a un licitador de un procedimiento de adjudicación si la situación de conflicto de intereses a que se refiere es real y no hipotética. Esto significa que el riesgo de un conflicto de intereses no es suficiente para excluir una oferta, puesto que - en atención a garantizar la máxima apertura posible a la competencia - es preciso que el riesgo de conflicto de intereses sea efectivamente constatado, tras una valoración en concreto de la oferta y de la situación del licitador ${ }^{260}$. En cualquier caso, las condiciones en su aplicación y el periodo en el que dicha prohibición de contratar opera quedan a la determinación de las legislaciones nacionales de los Estados miembros.

\section{B.2. La participación previa del operador económico en la prepa- ración de un procedimiento de adjudicación}

\footnotetext{
${ }^{259}$ La proporcionalidad implica que las actividades deben limitarse exclusivamente a aquello que sea estrictamente necesario. De esta manera, se exige que los motivos de exclusión no excedan de lo que resulta apropiado y necesario para lograr los objetivos propuestos por las Directivas y en este sentido se pronuncian las sentencias del TJCE de 9 de febrero de 2006, La Cascina y otros, C-226/04 y C-228/04; de 16 de diciembre de 2008, Michaniki, C-213/07; de 19 de mayo de 2009, Assitur, C-538/07; de 15 de julio de 2010, Bâtiments et Ponts Construction, C-74/09 y de 13 de diciembre de 2012, Forposta SA, C-465/11.

${ }^{260}$ En este sentido, puede consultarse la sentencia del Tribunal de Primera Instancia de 18 de abril de 2007, Deloitte Business, T-195/05, apartados 66 a 68.
} 
La segunda de las situaciones que pueden poner en peligro la objetividad del poder adjudicador es la que se refiere a la participación previa del operador económico en la preparación de un procedimiento de adjudicación y que se encuentra regulada en el artículo 41 de la Directiva 2014/24/UE ${ }^{261}$.

"Cuando un candidato o licitador, o una empresa vinculada a un candidato o a un licitador, haya asesorado al poder adjudicador, sea o no en el contexto del artículo 40, o haya participado de algún otro modo en la preparación del procedimiento de contratación, el poder adjudicador tomará las medidas adecuadas para garantizar que la participación de ese candidato o licitador no falsee la competencia".

En tanto que esta situación puede comportar para el operador implicado una serie de ventajas frente al resto de futuros licitadores, también se prevé su posible exclusión del procedimiento de adjudicación "cuando no pueda remediarse por medios menos restrictivos" (artículo 57.4.f) Directiva 2014/24/UE). $\mathrm{Su}$ fundamento es el mismo al que hemos aludido con anterioridad, esto es, garantizar el cumplimiento del principio de igualdad de trato y evitar falseamientos de la competencia ${ }^{262}$. Se parte de la presunción de que el operador económico goza de una ventaja competitiva que deriva de la información que ha podido obtener sobre un concreto contrato público, es decir, partiría de un

${ }^{261}$ En la legislación española este supuesto se encuentra recogido en el artículo 56 del TRLCSP bajo el título de condiciones especiales de compatibilidad, de tal manera que "no podrán concurrir a las licitaciones empresas que hubieran participado en la elaboración de las especificaciones técnicas o de los documentos preparatorios del contrato siempre que dicha participación pueda provocar restricciones a la libre concurrencia o suponer un trato privilegiado con respecto al resto de las empresas licitadoras". Sobre esta materia se pronuncian, entre otras, la STS de 24 de noviembre de 2004; la JCCA del Estado en sus Informes 25/2003, de 17 de noviembre; 22/06, de 20 de junio; 2/2008, de 28 de julio de 2008 y 38/2012, de 7 de mayo de 2013; la JCCA de Cataluña en su Informe de 10 de mayo de 1996; la JCCA Aragón en el Informe 9/2010, de 15 de septiembre de 2010 o el TACRC en sus resoluciones $527 / 2013$, de 20 de noviembre y 706/2015, de 24 de julio de 2015 .

${ }^{262}$ FERNÁNDEZ MALLOL, A. L., "La integridad del procedimiento de contratación pública en el Derecho de la Unión Europea. El conflicto de interés (...)", op. cit., SEMPLE, A. y ANDRECKA, M., "Classification, Conflicts of Interest and Change of Contractor: A Critical Look at the Public Sector Procurement Directive", EPPL, vol. 10 (3), 2015, especialmente sus págs. 181 y siguientes. 
conocimiento previo mucho más exhaustivo de las características, peculiaridades y requisitos técnicos de dicho contrato.

A este respecto, hay que poner de relieve que tanto el legislador europeo como la jurisprudencia establecen las condiciones para la exclusión del operador de participar en el procedimiento de adjudicación del contrato ${ }^{263}$. De esta manera, y al igual que veíamos para el supuesto anterior:

- El candidato o el licitador en cuestión sólo será excluido cuando no exista otro medio de garantizar el cumplimiento del principio de igualdad de trato.

- Antes de proceder a su exclusión, se dará a los candidatos o licitadores la oportunidad de demostrar que su participación en la preparación del procedimiento de contratación no falsea la competencia, ya que la exclusión debe basarse en un riesgo real - y no hipotético -, por lo que debe valorarse según las circunstancias particulares de cada caso.

- La prohibición de contratar no se justifica en aquellos casos en que puede probarse que tal participación no ha tenido ninguna incidencia en el marco del procedimiento de licitación, que no supone un riesgo de que surjan prácticas que puedan falsear la competencia entre los operadores económicos, ni un trato privilegiado ${ }^{264}$.

- Por todo ello, no se puede considerar automáticamente que la experiencia adquirida como consecuencia de la participación en un procedimiento de

${ }^{263}$ Las referencias jurisprudenciales son las mismas que hemos utilizado anteriormente: la sentencia del Tribunal de Justicia de 3 de marzo de 2005, Fabricom, C21/03 y C-34/03 y las sentencias del Tribunal General de 17 de marzo de 2005, AFCon Management Consultants y otros/Comisión, T-160/03; de 18 de abril de 2007, Deloitte Business, T-195/05; de 20 de marzo de 2013, Nexans France/Empresa Común Fusion for Energy, T-415/10 y de 13 de octubre de 2015, Intrasoft International SA, T-403/12.

\footnotetext{
${ }^{264}$ Según ha señalado la reciente sentencia de 13 de octubre de 2015, Intrasoft International SA, T-403/12, apartado 82 "no puede aceptarse que el riesgo de conflicto de intereses pueda basarse en el mero hecho de que la demandante haya tenido acceso, antes que los demás licitadores, a documentos propios de otro procedimiento de licitación, como consecuencia de su pertenencia al consorcio que redactó esos documentos, que se conservaron luego para ser usados como referencia para actividades vinculadas a la licitación controvertida en el caso de autos".
} 
licitación anterior pueda falsear la competencia. Es decir, la mera participación de un operador económico en la elaboración de las especificaciones técnicas o de los documentos preparatorios del contrato no determina por sí misma y de forma automática su exclusión del procedimiento, sino que ha de acreditarse que dicha participación puede provocar restricciones a la libre concurrencia o suponer un trato de favor para con respecto al resto de licitadores, circunstancia que deberá ser adecuadamente motivada en la resolución de exclusión.

\section{Cumplimiento de los deberes propios de una buena reputación profesional}

En la selección del contratista público, hemos observado que el legislador establece los requisitos esenciales para contratar desde la relación de los atributos específicos que deben tener los sujetos que quieren ser contratistas, puesto que para la correcta consecución del interés público se impone un celo especial en su elección («criterios de selección cualitativa») ${ }^{265}$. Así, se exige que los operadores económicos demuestren su idoneidad para ejecutar la prestación objeto del contrato y que no estén incursos en alguna de las circunstancias que - al entender del legislador - indican una falta de fiabilidad que lo excluye de poder ser parte de una relación contractual con las entidades públicas ${ }^{266}$.

En el marco de este examen, resulta evidente el juicio de indignidad que ciertas conductas merecen, como es el caso que ampara la prohibición de con-

\footnotetext{
${ }^{265}$ Véase, a este respecto, las sentencias de 19 de junio de 2003, GAT, C-315/01, apartados 59 a 64; de 24 de enero de 2008, Lianakis, C-532/06, apartado 27; de 12 de noviembre de 2009, Comisión/Grecia, C-199/07; de 9 de octubre de 2014, España/Comisión, C-641/13P, apartado 36 y de 18 de diciembre de 2014, Ambisig, C-601/03.

${ }^{266}$ Claudia VIANA también se refiere a la falta de idoneidad como uno de los criterios que pueden determinar la exclusión del operador económico del procedimiento de adjudicación y nos indica que era la expresión utilizada por el legislador portugués en el artículo 55 del Decreto - Lei n. ${ }^{\circ}$ 59/99, de 2 de Março, aprova o novo regime jurídico das empreitadas de obras públicas, que llevaba por título «Idoneidade dos concorrentes», anterior, por tanto, a la aprobación del Código dos Contratos Públicos, en VIANA, C., Os Princípios Comunitários na Contratação Pública, Coimbra Editora, Coimbra, 2007, pág. 493 y nota al pie 1480.
} 
tratar por haber sido condenado por un delito de trata de seres humanos; por contraposición, otros comportamientos que afectan a la credibilidad profesional del candidato o licitador no quedan tan claramente delimitados en la normativa de la Unión. Las conductas que erosionan la credibilidad profesional del operador económico se contemplan bajo una serie de términos profusos que aluden bien a la condena por sentencia firme en delitos relativos a la «moralidad profesional», «honestidad profesional» $\mathrm{y}$ «ética profesional» del operador económico ${ }^{267}$, bien a la comisión de una "falta profesional grave que pone en entredicho su integridad" o a carecer de "la fiabilidad necesaria para descartar los riesgos para la seguridad del Estado miembro", en el caso de concesiones en los ámbitos de la seguridad y la defensa (artículo 38.7.i) de la Directiva 2014/23/UE, de («contratos de concesión»).

Habida cuenta de estas consideraciones, creemos conveniente referirnos siquiera brevemente porque serán objeto de un tratamiento posterior - a distintas cuestiones que, a nuestro entender, constituyen la parte esencial de la integridad en la contratación pública y cuyo desarrollo va a venir de la mano de su transposición, o no, a los ordenamientos nacionales, ya que en todo caso se tratan de prohibiciones de contratar de carácter potestativo para los Estados miembros.

\section{C.1. Los comportamientos que afectan a la credibilidad profesional del operador económico}

Como ya hemos tenido ocasión de señalar, los poderes adjudicadores podrán excluir a un operador económico de la participación en un procedimiento de contratación cuando puedan demostrar por medios apropiados que el operador económico ha cometido una "falta profesional grave que ponga en entredicho

\footnotetext{
${ }^{267}$ Son términos empleados en el Reglamento 966/2012, de 25 de octubre de 2012, sobre las normas financieras aplicables al presupuesto general de la Unión (DOUE L 298, de 26 de octubre de 2012); en el Reglamento de adquisiciones del Banco Central Europeo (DOUE L 184, de 14 de julio de 2007; en la Decisión 2004/658/PESC, de 13 de septiembre, relativa a las disposiciones financieras aplicables al presupuesto general de la Agencia Europea de Defensa (DOUE L 300, de 29 de septiembre de 2004); en el artículo 45, apartado 2, letra c), de la Directiva 2004/18/CE o en el artículo 39.2.c) de la Directiva 2009/81/CE, relativa a la contratación en los sectores de la defensa y seguridad. Esta regulación puede consultarse en detalle en el anexo documental.
} 
su integridad" (artículo 57.4.c) de la Directiva 2014/24/UE).

Ahora bien, aun tratándose de una competencia nacional, y en virtud del principio de seguridad jurídica, hubiera resultado de utilidad haber delimitado las conductas consideradas reprobables a la luz de la normativa europea, más allá de las referidas al falseamiento de la competencia, a facilitar información engañosa para verificar la inexistencia de motivos de exclusión o para justificar el cumplimiento de los criterios de adjudicación o el intentar influir indebidamente en el procedimiento que, a nuestro entender, también estarían incluidas bajo el concepto genérico de «falta grave» cometida «en materia profesional» ${ }^{268}$.

Esta crítica se debe a que la imprecisión conceptual sobre la comisión de una «falta en materia profesional», se ha venido reproduciendo en algunas normativas nacionales al transponer los dictados del artículo 45 de la Directiva 2004/18/CE como sucede, por ejemplo, en el caso de las legislaciones belga o luxemburguesa:

En Bélgica, el artículo 61 del Real Decreto, de 15 de julio de 2011, sobre la adjudicación de contratos públicos en los sectores clásicos - Arrêté royal relatif à la passation des marchés publics dans les secteurs classiques (versión de 7 de febrero de 2014):

§2 Conformément à l'article 20 de la loi, peut être exclu de l'accès au marché, à quelque stade que ce soit de la procédure, le candidat ou le soumissionnaire:

$3^{\circ}$ qui a fait l'objet d'une condamnation prononcée par une décision judiciaire ayant force de chose jugée pour tout délit affectant sa moralité professionnelle; $4^{\circ}$ qui, en matière professionnelle, a commis une faute grave;

De conformidad con el artículo 20 de la Ley, puede ser excluido de

\footnotetext{
${ }^{268}$ La expresión «falta profesional grave» fue objeto de interpretación en la sentencia del Tribunal de Justicia de 13 de diciembre de 2012, Forposta SA, C-465/11. Sobre su significado, véase VIEIRA QUINTA NOVA, A.R., A Exclusão de Operadores Económicos à Luz da Nova Directiva sobre Contratos Públicos - o artigo $57^{\circ}$ $n^{o}$ 4, $1^{\circ}$ parágrafo, alínea g), Publicações CEDIPRE Online - 22, Coimbra, 2014 http://www.fd.uc.pt/cedipre/publicacoes/online/public_22.pdf [Fecha de consulta: 20 de octubre de 2015].
} 
acceso al contrato, en cualquier etapa del procedimiento, el candidato o licitador:

$3^{\circ}$ que sea objeto de una condena impuesta por una decisión judicial con fuerza de cosa juzgada por un delito que afecte a su moralidad profesional; $4^{\circ}$ que, en materia profesional, haya cometido una falta grave [Traducción propia].

En Luxemburgo, el artículo 223 del Reglamento de ejecución de la Ley de Contratos Públicos -Règlement grand-ducal du 3 août 2009 portant exécution de la loi du 25 juin 2009 sur les marchés publics (versión modificada a 9 de febrero de 2015):

«Art. 223. Peut être exclu de la participation au marché, tout opérateur économique :

c) qui a fait l'objet d'un jugement ayant autorité de chose jugée selon les dispositions légales du pays et constatant un délit affectant sa moralité professionnelle; d) qui, en matière professionnelle, a commis une faute grave constatée par tout moyen dont les pouvoirs adjudicateurs pourront justifier»

Artículo 223

Podrá ser excluido de la participación en el contrato, cualquier operador económico:

c) que ha sido condenado por una sentencia con fuerza de cosa juzgada según las disposiciones legales del país por un delito que afecte a su moralidad profesional; d) ha sido declarado culpable de mala conducta profesional comprobada por cualquier medio que los poderes adjudicadores puedan justificar [Traducción propia].

Se reproduce también en la normativa del Reino Unido que transpone literalmente el contenido del artículo 57.4.c) de la Directiva 2014/24/UE (artículo 57.8.c) Public Contracts Regulations 2015), sin que a priori se conozcan con exactitud las conductas comprendidas bajo tal consideración. 
"Contracting authorities may exclude or may be required by Member States to exclude from participation in a procurement procedure any economic operator:

c) Where the contracting authority can demonstrate by appropriate means that the economic operator is guilty of grave professional misconduct, which renders its integrity questionable".

Los poderes adjudicadores podrán excluir o ser requeridos por los Estados miembros para excluir a un operador económico de la participación en un procedimiento de contratación:

c) Cuando el poder adjudicador pueda demostrar por medios apropiados que el operador económico ha cometido una falta profesional grave que pone en entredicho su integridad". [Traducción propia]

\section{C.2. Precisiones conceptuales respecto de la «moralidad profesio- nal»}

El concepto de «moralidad profesional» está ausente en las nuevas Directivas, aunque no desterrado de la normativa contractual, puesto que, además de sus referencias en las - por el momento todavía vigentes - Directivas 2004/18/CE y 2004/17/CE, la Directiva 2009/81/CE («sectores seguridad y defensa») sigue refiriéndose a él en su artículo 39.2 al enumerar los supuestos de prohibición de contratar por los que un operador económico puede ser excluido de la participación en el contrato

“c) que haya sido condenado por sentencia con autoridad de cosa juzgada según las disposiciones legales del país y en la que se constate un delito que afecte a su moralidad profesional, como por ejemplo, la violación de la legislación vigente en materia de exportación de equipos de defensa y/o seguridad sensibles".

La dificultad para su precisión se agrava aún más si bajo el concepto de «moralidad profesional»s se pueden entender comprendidas diferentes acciones en función de la versión lingüística que estemos manejando, puesto que los términos utilizados en estas disposiciones carecen de un significado unívoco en 
todas sus versiones y, en consecuencia, no permiten determinar con claridad su alcance exacto.

En efecto, según reiterada jurisprudencia del Tribunal de Justicia, la formulación utilizada en una de las versiones lingüísticas de una disposición de Derecho de la Unión no puede constituir la única base de interpretación de dicha disposición ${ }^{269}$. Además, ninguna versión tiene carácter prioritario frente a otras en materia de interpretación, pues tal enfoque sería incompatible con la exigencia de uniformidad en la aplicación del Derecho de la Unión. La necesidad de una aplicación y, por lo tanto, de una interpretación uniforme de las disposiciones de Derecho de la Unión excluye la posibilidad de que, en caso de duda, el texto de una disposición sea considerado aisladamente en una de sus versiones, exigiendo, en cambio, que sea interpretado y aplicado a la luz de las versiones redactadas en las demás lenguas oficiales ${ }^{270}$. Es así que, en caso de divergencia entre versiones lingüísticas, la disposición de que se trata debe interpretarse en función del contexto, de la estructura general y de la finalidad de la normativa en que se integra ${ }^{271}$.

Una visión comparativa de distintas versiones lingüísticas, nos permite señalar, por ejemplo, que en la versión francesa e italiana se emplean, res-

${ }^{269}$ Véase, a título de ejemplo, las sentencias de 3 de abril de 2008, Endendijk, C-187/07, apartado 23; de 3 de marzo de 2011, Comisión/Países Bajos, C-41/09, apartado 44; de 15 de noviembre de 2012, SIA Kurcums Metal, C-558/11, apartado 48 y de 15 de octubre de 2015, C-168/14, Grupo Itevelesa SL, apartado 42. La Abogado General Sra. KOKOTT, en sus conclusiones presentadas el 21 de junio de 2012 en el asunto C-566/10-P, recordaba que "las instituciones europeas no disponen hasta la fecha del pez de Babel, que acabaría con las barreras lingüísticas", y dado el reconocimiento del principio del plurilingüismo, esta cuestión resulta muy delicada".

${ }^{270}$ Así se manifiesta el Tribunal de Justicia en su sentencia de 19 de abril de 2007, Profisa, C 63/06, apartado 13, y así también lo declara la Abogado General Sra. Julianne KOKOTT, en sus conclusiones presentadas el 7 de febrero de 2013 en el asunto Toftgaard, C-546/11, apartados 30 y 31.

${ }^{271}$ Sobre la importancia de las traducciones, Lorenzo MARTÍN-RETORTILLO BAQUER recordaba en su artículo "Honorabilidad y buena conducta como requisitos para el ejercicio de profesiones y actividades", $R A P$, núm. 130, enero - abril 1993, pág. 94, que estando tras las huellas de la sentencia Delkvist, encontró en un libro de ALONSO GARCÍA una cita, que hacía referencia a la distinta connotación que un mismo vocablo tenía en las versiones de los diversos idiomas oficiales de la UE, de modo que el mismo criterio sustantivo se vertía en dos vocablos bien diferentes. 
pectivamente, las expresiones «moralité professionnelle» $\mathrm{y}$ «moralità professionale» que son coincidentes con la española. En la versión portuguesa se acuña el término «honorabilidade profissional» ${ }^{272}$, en la versión rumana se alude a «eticii profesionale», en la versión alemana se maneja el vocablo seriedad profesional «berufliche Zuverlässigkeit» ${ }^{273}$, en la húngara se refiere únicamente a la conducta profesional «szakmai magatartásával»y, en este mismo sentido, la versión en inglés también utiliza una fórmula más neutra al estar desprovista de un sentido ético cual es "delito referente a su conducta profesional", ya que sus palabras concretas se refiere a que el licitador o candidato "has been convicted by a judgment which has the force of res judicata in accordance with the legal provisions of the country of any offence concerning its professional conduct".

Las divergencias lingüísticas resultan significativas respecto de la expresión "delito que afecte a su moralidad profesional", aun cuando los considerandos de las citadas Directivas se encargan de ejemplificar - sin un valor jurídico vinculante - algunas de las conductas que quedan comprendidas en estos supuestos de prohibición de contratar. Por ello, para determinar el significado y el alcance de los términos no definidos por el Derecho de la Unión, la jurisprudencia del Tribunal de Justicia viene sustentando que deben determinarse conforme a su sentido habitual en el lenguaje corriente, teniendo también en cuenta el contexto en el que se utiliza y los objetivos perseguidos por la normativa de la que forma parte ${ }^{274}$.

${ }^{272} \mathrm{El}$ artículo 55 del Código dos Contratos Públicos portugués al regular los impedimentos para ser candidatos, licitadores o para integrar una agrupación de los mismos, se refiere a "haber sido condenados por sentencia judicial por algún delito que afecte a su honorabilidad profesional, mientras no se haya producido su rehabilitación" [Traducción propia].

${ }^{273} \mathrm{La}$ expresión berufliche Zuverlässigkeit a la que alude el $\S 68$ apartado 1 de la Ley Federal austriaca de adjudicación de contratos públicos (Bundesvergabegesetz 2006 BVergG) al referirse a los motivos de exclusión, es traducido como solvencia profesional por parte de GARCÍA LUENGO en su estudio sobre "El Derecho de la contratación pública en Austria", en SÁNCHEZ MORÓN, M., Derecho de los contratos públicos en la Unión Europea y sus Estados miembros (...), op. cit., pág. 469, si bien la visualización bilingüe de documentos en la base EUR-Lex lo traduce por ética profesional.

${ }^{274}$ Véanse las sentencias de 22 de diciembre de 2008, Wallentin Hermann, C-549/07, apartado 17; de 21 de diciembre de 2011, Ziolkowski, C-424/10 y C-425/10, apartado 
Por lo que respecta al sentido que deba darse al concepto de «moralidad profesional», procede señalar que, si bien la definición de moralidad es una materia de alcance sensible, caracterizada por múltiples tradiciones y sistemas de valores, no vamos a abordar su estudio desde elementos de naturaleza ética, puesto que las distintas versiones lingüísticas de este artículo nos indican que no es ese el sentido pretendido por la norma ${ }^{275}$. En esta memoria doctoral, nos vamos a limitar a una interpretación jurídica de las disposiciones de la Directiva que resultan de aplicación para conformar la idoneidad del candidato o licitador y que aluden a su comportamiento profesional dada la adjetivación como profesional de la moralidad requerida para poder contratar.

Así pues, el carácter profesional de las conductas incluidas en la prohibición de contratar delimita el propio concepto de «moralidad» al dejarlo desprovisto de connotaciones cercanas a la moralidad pública como elemento que autoriza a los Estados a modular o restringir derechos ${ }^{276}$. Por el contrario, nos acerca a su naturaleza de requisito de acceso a la contratación pública dadas las cualidades subjetivas y profesionales del operador económico en atención a los estándares morales que se aplican a su comportamiento en los negocios y que son más acordes al concepto actual de "integridad" 277.

34; de 25 de octubre de 2012, Anssi Ketelä, C-592/11, apartado 51; de 3 de septiembre de 2014, Deckmyn y Vrijheidsfonds, C-201/13, apartado 19 y de 24 de junio de 2015, Hotel Sava Rogaška, C-207/04, apartado 25.

${ }^{275}$ Baste como ejemplo citar que la versión inglesa de las Directivas 2009/81/CE y 2004/18/CE utilizaban una fórmula desprovista de un sentido ético o moral cual es haber sido condenado el licitador o candidato por sentencia firme por delitos relativos a su conducta profesional.

${ }^{276}$ Véase MARTÍNEZ LÓPEZ-MUÑIZ, J. L., "La moralidad pública como límite de las libertades públicas", en la obra colectiva Los derechos fundamentales y libertades públicas (Vol. I), XII Jornadas de Estudio sobre la Constitución, Centro de Publicaciones del Ministerio de Justicia, Madrid, 1992, págs. 1003 - 1021 (también publicado en la Revista argentina de Derecho Administrativo, núms. 15 - 16, 1994) y PRIETO ÁLVAREZ, T., La dignidad de la persona: núcleo de la moralidad y el orden público, límite al ejercicio de libertades públicas, Thomson-Civitas, Cizur Menor (Navarra), 2005, págs. 191 y ss.

${ }^{277}$ Sobre la moralidad, la honorabilidad y la buena conducta como presupuesto para el ejercicio de actividades, puede consultarse GONZÁLEZ PÉREZ, J., Corrupción, ética y moral en las Administraciones públicas, $2^{\mathrm{a}}$ ed., Thomson Reuters-Civitas, Cizur Menor (Navarra), 2014; MARTÍN-RETORTILLO BAQUER, L., "Honorabi- 
En el ámbito de la empresa estos estándares atienden a las cualidades y actitudes en la conducta del profesional, es decir a sus normas profesionales, incluidas las deontológicas y se pueden referir - por lo que a esta memoria doctoral interesa - al acatamiento de la legalidad vigente, a garantizar los derechos de los trabajadores, a combatir las prácticas de morosidad e, incluso, a respetar las reglas del mercado, abarcando tanto las dirigidas a proteger la libre competencia como la defensa de los consumidores y usuarios ${ }^{278}$.

lidad y buena conducta (...)", op. cit., e IRURZUN MONTORO, F., Honorabilidad como requisito para el ejercicio de profesiones financieras y otras actividades, Thomson-Civitas, Cizur Menor (Navarra), 2007. En relación con la contratación pública, SAITTA, F., "Moralità professionale e partecipazione alle gare (Note a margine dell'art. 12, comma 1, lett. b), d.lgs. n. 157 del 1995", Rivista trimestrale degli appalti, vol. 1, 2004, págs. 229 - 247; BALDI, M., "Il previgente regime delle cause di esclusione per reati incidenti sulla moralità professionale negli appalti di lavori e servizi", Urbanistica e appalti, vol. 11 (2), 2007, págs. 234 - 243; ABRATE, S., "Il requisito della moralità professionale delle imprese negli appalti pubblici. Prassi operativa e giurisprudenza", Appalti \& Contratti, vol. 4 (8 y 9), 2009, págs. 8 -24; CONTALDI LA GROTTERIA, C., "I requisiti soggettivi di moralità professionale", en la obra colectiva Gli appalti pubblici tra regole europee e nazionali, Egea, Milán, 2012, págs. 181 - 201 y SPAGNOLO, G., "Reputation, Competition, and Entry in Procurement", Stockholm Institute of Transition Economics, Working Paper núm. 14, 2012, disponible en: http://ssrn.com/abstract $=1988818$ [Fecha de consulta: 23 de octubre de 2015].

${ }^{278}$ Incluir la defensa de los consumidores y usuarios entre las conductas cuya infracción pudiera conllevar una prohibición de contratar proviene de la propia normativa sectorial. En España, por ejemplo, encontramos referencias a ello en la Ley gallega $2 / 2012$, de 28 de marzo, de protección general de las personas consumidoras y usuarias, al establecer en su artículo 86.2 que "Aquellas empresas que hayan sido sancionadas por la comisión de infracciones graves o muy graves incurrirán, además, de conformidad con la Ley de contratos del sector público, en la prohibición establecida en la misma para las empresas sancionadas en materia de disciplina del mercado". Asimismo, en el artículo 92.2 de la Ley 13/2003, de 17 de diciembre, de Defensa y Protección de los Consumidores y Usuarios de Andalucía; en el artículo 44.2 de la Ley Foral 7/2006, de 20 de junio, de defensa de los consumidores y usuarios de Navarra; en los artículo 92.apartado 1.c) y apartado 2.c) de la Ley 16/2006, de 28 de diciembre, de Protección y Defensa de los Consumidores y Usuarios de Aragón y en el artículo 341-8, primer apartado, de la Ley 22/2010, de 20 de julio, del Código de consumo de Cataluña, al manifestar que "La imposición de sanciones graves y muy graves comporta limitaciones para contratar con la Administración en los casos y condiciones establecidos por la legislación sobre contratos". 


\section{C.3. Listas blancas de operadores económicos "íntegros"}

La falta de integridad profesional del operador económico se documenta de distintas maneras siendo las más habituales las condenas que constan en los registros de antecedentes penales, en los sistemas de información de inhabilitaciones, la publicación de condenas por delitos fiscales o por la inclusión de un operador económico en una «lista negra» con dispositivos de alerta para denegarle el acceso a ayudas, subvenciones y también a los contratos públicos 279 .

Las Directivas sobre contratación públicas no prevén disposiciones específicas respecto de la puesta en práctica de «listas negras» de operadores económicos excluidos de la contratación por actividades relacionadas con el fraude y la corrupción, como se sí ha previsto por algunos Estado miembros (Malta y República Checa) ${ }^{280}$ o por organismos como el Banco Mundial. Estas listas constituyen un instrumento que permite conocer las empresas que han sido condenadas por haber cometido alguna irregularidad, pudiéndose, en este sentido, utilizarse para impedir que participen en la adjudicación de nuevos contratos o "simplemente para advertir a los interesados de los posibles riegos que supone una transacción con este tipo de empresas"281.

${ }^{279}$ Por ejemplo, en el ámbito de las ayudas agrarias, el Reglamento (CE) 1469/95 del Consejo, de 22 de junio de 1995, instauró un sistema de identificación (denominada «lista negra») de determinados agentes económicos que representan un riesgo elevado para el presupuesto de la Unión por las irregularidades cometidas (DOCE L 145, de 29 de junio de 1995). El Reglamento financiero también prevé la existencia de una base de datos central en la que figuran los datos relativos a los candidatos y licitadores "deshonestos" encaminada a excluir de la participación en un contrato público a los operadores que están incluidos en la misma, y que dada su importancia, será objeto de tratamiento posterior en el Capítulo cuarto de esta memoria doctoral (pág. 502).

${ }^{280}$ Véase lo dicho en la nota al pie núm. 105 en la pág. 86 al referirnos al establecimiento de listas negras de operadores económicos en estos dos Estados miembros. También VYMĚTAL, P., "Blacklisting and Public Procurement", en la obra colectiva Blacklisting in the Public Procurement System, Transparency International Czech Republic, Prague, 2007, págs. 21 - 59, especialmente sus págs. 36 a 43 que se refieren a la Unión Europea y a dos de sus Estados miembros (Alemania y Reino Unido).

${ }^{281}$ En palabras de la Comisión en su Comunicación sobre Una política de la Unión en materia de lucha contra la corrupción, COM (97) 192 final, de 21 de mayo de 
Su puesta en práctica se enfrenta a distintos inconvenientes ya destacados por la doctrina - como son la protección de datos de carácter personal y su dudosa compatibilidad con ciertos derechos fundamentales como el derecho a la tutela judicial ${ }^{282}$. Para salvar los obstáculos advertidos, una buena opción es dejar de centrarnos en el aspecto menos amable del operador económico (por su falta de integridad profesional) y apostar por la elaboración de «listas blancas», es decir, listas de licitadores y candidatos honestos que presentan unos elevados niveles de transparencia y de integridad en la participación en procedimientos de licitación pública ${ }^{283}$.

En el ámbito de la contratación pública, las «listas blancas» podrían ser consideradas como un mecanismo para que el operador económico probara su integridad - entendida como buena reputación - para con respecto al cumplimiento de las normas y a ciertos valores añadidos de responsabilidad (por ejemplo, a través de programas de cumplimiento, pactos de integridad, códigos éticos y/o de conducta). En nuestra opinión, este sistema se debiera reflejar en el Documento europeo único de contratación y se tendría que vincular a los sistemas de etiquetado y certificación.

1997, pág. 12.

${ }^{282}$ En relación a esta materia, pueden consultarse los trabajos de JACOBS, J. B., y ANECHIARICO, F., "Blacklisting of Public Contractors as an Anti-Corruption and Racketeering Strategy", Criminal Justice Ethics, vol. 11 (2), 1992, págs. 64 76; IGLESIAS RIO, M. Á. y MEDINA ARNÁIZ, T., "Herramientas preventivas en la lucha (...)", op. cit., pág. 62; OLAYA, J. "Blacklisting corrupt companies", en la obra colectiva Global Corruption Report 2005, Transparency International, Berlín, 2005, págs. 72 - 73; BENGOETXEA CABALLERO, J., "Las listas Negras: un agujero negro en la Europa de los derechos fundamentales", RVAP, núm. 82 (II) septiembre - diciembre 2008, págs. 27 - 47; SIGMA, Use of Official Automatic Exclusion Lists in Public Procurement, julio 2013 y BLANCO CORDERO, I., "La admisibilidad de las listas de evasores fiscales sustraídas en el extranjero como prueba para acreditar la comisión de delitos", InDret. Revista para el análisis del Derecho, núm. 3, julio 2015, págs. 1 - 34 .

${ }^{283}$ VYMĚTAL, P., se refiere a las listas blancas en términos opuestos a las negras para aludir a entidades fiables, confiables y aceptables, que no quebrantan la normativa y que actúan éticamente. Asimismo, menciona las «listas grises» (greylisting) en las que se encuentran quienes levantan sospechas de quebrantar las normas y las «listas verdes» (greenlisting) en relación con aquellas empresas que producen bienes bajo estándares medioambientales, en "Blacklisting and Public Procurement (...)", op. cit., págs. 29 y 30. 
Aunque volveremos a considerar las «listas blancas» al referirnos a las medidas de self-cleaning y su reconocimiento por parte de la normativa contractual, un ejemplo de lo dicho lo encontramos en Italia. En el ordenamiento jurídico italiano se ha establecido un régimen de documentación («protocolos de legalidad antimafia») que persiguen el objetivo de prevenir y luchar contra este fenómeno, sobre todo en el sector de las obras públicas. Así, se ha optado por el establecimiento de una lista de operadores económicos que no son sospechosos de actuaciones criminales ${ }^{284}$.

Su regulación se contempla en el artículo 4, apartado 1.g) y apartado 13 del Decreto-Ley 70/2011, de 13 de mayo (Decreto-Legge convertito con modificazioni dalla Legge 12 luglio 2011, $n^{o}$ 106) que se refiere a una lista de proveedores de obras y servicios no sujetos a riesgo de contaminación por la mafia y que se conecta con la normativa anticorrupción a través del artículo 1 , apartado 52 de la Ley 190/2012, de 6 de noviembre, de disposiciones para la prevención y la represión de la corrupción y de la ilegalidad en la administración pública (Legge 6 novembre 2012, n. 190 Disposizioni per la prevenzione e la repressione della corruzione e dell'illegalità nella pubblica amministrazione)

\section{“(...) di apposito elenco di fornitori, prestatori di servizi ed esecu- tori di lavori non soggetti a tentativi di infiltrazione mafiosa ope- ranti nei medesimi settori" \\ Una lista especial de proveedores de suministro, prestadores de servicios y contratistas de obras no sujetos a intentos de infiltrarse en la mafia que opera en los mismos campos [Traducción propia].}

La duda que se puede plantear es si la ausencia de estos protocolos de legalidad o la no aceptación de pactos de integridad puede establecerse en las legislaciones nacionales como causa legal de prohibición de contratar ${ }^{285}$. El

\footnotetext{
${ }^{284}$ DI LASCIO, F., "La transposición de las nuevas Directivas de contratación pública en Italia", Instituto de Derecho Local, UAM, Madrid, 2014 que puede consultarse en: http://www.idluam.es/images/stories/Convocatorias/DiLasci_seminario.pdf [Fecha de consulta: 15 de octubre de 2015].

${ }^{285} \mathrm{El}$ artículo 1, apartado 17, de la citada Ley 190/2012, para la prevención y la represión de la corrupción y de la ilegalidad en la administración pública contempla
} 
TJUE ha despejado esta incertidumbre recientemente en su sentencia de 22 de octubre de 2015, al indicar que las normas fundamentales y los principios generales del TFUE, "no se oponen a una disposición del Derecho nacional en virtud de la cual un poder adjudicador puede establecer que un candidato o licitador quedará automáticamente excluido del procedimiento de licitación de un contrato público si no presenta, junto con su oferta, una aceptación por escrito de los compromisos y declaraciones contenidos en un protocolo de legalidad cuyo objetivo es luchar contra la infiltración de la delincuencia organizada en el sector de los contratos públicos" 286 .

\section{V.3. Las prohibiciones de contratar como instrumentos al servicio de «objetivos secundarios» en la contra- tación pública}

El objetivo principal en cualquier normativa sobre contratación pública es lograr que las entidades públicas lleven a cabo sus obras y adquirieran sus bienes y servicios en las mejores condiciones posibles. Su función primordial consiste, por tanto, en garantizar la máxima rentabilidad en el uso de los fondos públicos destinados a la compra pública en función de las necesidades que debe cubrir el órgano de contratación, pues, en último extremo, cualquier contrato público busca una satisfacción de tipo funcional, esto es, la consecución de la prestación demandada: el suministro de un bien, la realización de una obra o la gestión de un servicio ${ }^{287}$.

que "Los poderes adjudicadores podrán disponer en los anuncios o convocatorias de licitación o cartas de invitación que el incumplimiento de las cláusulas recogidas en los protocolos de legalidad o en los pactos de integridad constituirá una causa de exclusión de la licitación".

${ }^{286}$ STJUE de 22 de octubre de 2015, Impresa Edilux y SICEF, C-425/14.

${ }^{287}$ ARROWSMith, S., LINARELLI, J. y WALlACE, D., Regulating Public Procurement: National and International Perspectives, Kluwer Law International, The Hague (Netherlands), 2000, págs. 28 a 30, al referirse a los objetivos pretendidos a través de la regulación sobre contratación pública aluden a la expresión «Value for Money» (Mejor relación calidad-precio). Bajo este concepto ponen de relieve la necesidad de que los bienes que se adquieran a través de los contratos públicos sean los adecuados para cubrir las necesidades públicas, pero también que el contratista esté capacitado para cumplir las condiciones del contrato en los términos previstos. 
Esta finalidad obedece a una motivación comercial que requiere poner el acento en la utilización de los procedimientos de selección del contratista con criterios de eficiencia en un sentido estrictamente económico. Sin embargo, a lo largo de este epígrafe vamos a observar cómo el marco jurídico vigente sobre contratación pública en la UE no se circunscribe en exclusiva a las preocupaciones económicas inherentes al contrato, sino que también aspira a obtener un valor añadido de su contratación más allá de una rentabilidad en términos económicos.

Como hemos avanzado a lo largo de este Capítulo, las Directivas sobre contratación pública, cada una dentro de su ámbito de actuación, tratan de asegurar unas condiciones de competencia reales entre los operadores económicos en la adjudicación de los contratos que lleven a cabo los poderes adjudicadores. En este sentido, es palmario que la acción principal de la Unión Europea en la materia de contratación pública trata de fomentar una política de compras transparente, imparcial y de carácter competitivo que permita obtener a los poderes adjudicadores la mejor relación calidad/precio en sus adquisiciones y que garantice la mayor participación de operadores económicos en la licitación 288

A este respecto, en el Capítulo segundo analizaremos cómo las normas

El Abogado General Sr. F.G. JACOBS en sus conclusiones presentadas, el 10 de mayo de 2001, en el asunto SIAC Construction, C-19/00, apartado 33 manifestaba que "la finalidad principal de la regulación de la adjudicación de contratos públicos en general es garantizar que los fondos públicos se gasten con honestidad y eficiencia, sobre la base de una valoración seria y sin ningún género de favoritismo ni contrapartida, ya sea financiera o política. El fin primordial de la armonización comunitaria es garantizar además la supresión de los obstáculos y la igualdad de las condiciones de competencia, mediante exigencias de transparencia y objetividad entre otras".

${ }^{288}$ Nos hemos referido a ello en alusión a las sentencias del TJUE de 11 de mayo de 2006, Carbotermo y Consorzio Alisei, C-340/04, apartado 58; de 13 de diciembre de 2007, Bayerischer Rundfunk y otros, C-337/06, apartado 39; de 23 de diciembre de 2009, CoNISMa, C-305/08, apartado 37; de 10 de octubre de 2013, Swm Costruzioni, C-94/12, apartado 34; de 10 de julio de 2014, Consorzio Stabile Libor Lavori Pubblici, C-358/12, apartado 29 y de 18 de diciembre de 2014, Data Medical Service, C-568/13, apartado 34, que manifiesta que "uno de los objetivos de las normas de la Unión en materia de contratos públicos es la apertura a la competencia lo más amplia posible $(. .$.$) apertura que es también en interés de la propia entidad adjudicadora$ implicada, que dispondrá así de más opciones en cuanto a la oferta más ventajosa y mejor adaptada a las necesidades de la colectividad pública de que se trate". 
europeas relativas a la adjudicación de contratos públicos se adoptaron en el marco de la realización del mercado interior para garantizar las libertades fundamentales $^{289}$. Ahora bien, sin abandonar los objetivos marcados, hemos asistido a su evolución a partir de la consideración de la contratación pública como un elemento clave para alcanzar propósitos públicos más ambiciosos de forma que, desde la entrada en vigor de las Directivas de 2004, se viene propiciando la utilización de la contratación pública con el fin de orientar y afianzar comportamientos empresariales beneficiosos para el interés general sin que, necesariamente, estén conectados con el objetivo funcional del contrato ${ }^{290}$.

La persecución de estos otros propósitos avalan la idea, manifestada entre otros por GIMENO FELIÚ, de que la contratación pública no constituye únicamente una forma de abastecimiento, sino que es también una poderosa herramienta al servicio de los poderes públicos para el cumplimiento efectivo de otros fines o políticas públicas. Utilizando sus mismas palabras, la contratación debiera ser "una técnica que permitiera conseguir objetivos sociales, ambientales o de investigación, en la convicción de que los mismos comportan una adecuada comprensión de cómo deben canalizarse los fondos públicos" ${ }^{291}$.

${ }^{289}$ STJUE de 19 de mayo de 2009, Assitur, C-538/07, apartado 26 "En el contexto de un mercado interior único y de competencia efectiva, redunda en interés del Derecho comunitario que se garantice la participación más amplia posible de licitadores en una licitación"

${ }^{290}$ Con anterioridad a las Directivas del año 2004, FERNÁNDEZ MARTín tras exponer las dos ideologías que informan los sistemas de contratación pública - libre mercado e intervencionismo - señalaba que la teoría intervencionista aboga por el uso instrumental de la contratación para perseguir objetivos generales que pueden incluir, por ejemplo, mejorar las normas de comportamiento en el sector privado, promover salarios justos o potenciar la incorporación al mercado laboral de grupos desfavorecidos o marginados, en FERNÁNDEZ MARTÍN, J. M ${ }^{\mathrm{a}}$.: The EC Public Procurement Rules: A Critical Analysis, Clarendon Press, Oxford, 1996, págs. 41 a 48. También MESTRE DELGADO constataba la existencia de un interés público al emplear mecanismos de refuerzo - o fomento - para forzar a los empresarios al cumplimiento de previsiones contempladas en normativas sectoriales, en MESTRE DELGADO, J. F., "Contratos públicos y políticas de protección social y medioambiental", REAL, núm. 291, enero - abril 2003, pág. 707.

${ }^{291}$ Acerca de esta visión instrumental de la contratación pública, GIMENO FELIÚ, J. $\mathrm{M}^{\mathrm{a}}$., La nueva contratación pública europea y su incidencia en la legislación española. La necesaria adopción de una nueva Ley de contratos públicos y propuestas de reforma, Thomson-Civitas, Cizur Menor (Navarra), 2006, págs. 16 y 17. También 
Resulta pues evidente que la compra pública, en atención al elevado volumen de recursos que moviliza, puede resultar un potente instrumento para la realización de otros cometidos públicos, entre los que cabe destacar la protección al medio ambiente, la promoción de políticas sociales y el impulso de la innovación y competitividad por parte de las empresas ${ }^{292}$.

Esta visión instrumental de la contratación pública es la que nos permite diferenciar los objetivos principales y secundarios en los procedimientos de contratación pública - o colaterales si se emplea la terminología norteamericana - para distinguir los distintos niveles de adecuación a las necesidades que pretenden cubrirse con el contrato.

En la mayor parte de las ocasiones, los objetivos de los que estamos tratando serán considerados de carácter secundario, que es la expresión que vamos a utilizar en esta memoria doctoral y no por entender que éstos manifiestan un menor rango de importancia o rebajan su categoría, ya que bajo esta locución nos referimos a aquellos objetivos que no justifican la contratación, pero que, sin embargo, conllevan aparejada una mejora con respecto a la situación preexistente $^{293}$. Existen, no obstante, otras expresiones que aluden a la mis-

en su obra Novedades de la Ley de Contratos del Sector Público de 30 de octubre de 2007 en la regulación de la adjudicación de los contratos públicos, Civitas Thomson Reuters, Cizur Menor (Navarra), 2010, págs. 21 y 22. Esta misma opinión es defendida por RODRÍGUEZ ESCANCIANO, S., "Trabajo y exclusión social en el nuevo sistema de contratación del sector público", Revista de Trabajo y Seguridad Social CEF, núm. 305 -306, 2008, pág. 7; también por MEDINA ARNÁIZ, T., "Comprando para asegurar nuestro futuro: La utilización de la contratación pública para la consecución de los objetivos políticos de la Unión Europea", en la obra colectiva Observatorio de contratación pública 2010, Civitas - Thomson Reuters, Cizur Menor (Navarra), 2011, págs. 43 - 101 y por CARANTA, R., "Sustainable Procurement", en la obra colectiva EU Public Contract Law: Public Procurement and beyond, Bruylant, Brussels, 2014, págs. 165 - 190.

${ }^{292}$ Dado que la innovación y la competitividad fueron temas centrales en la Estrategia de Lisboa (2000) y lo son ahora en la actual Estrategia Europa 2020, la Comisión ha lanzado diversas iniciativas a fin de examinar cómo fomentar la innovación y la competitividad desde la contratación pública. Entre otras en la Comunicación Iniciativa emblemática de Europa 2020 Unión por la innovación, COM (2010) 546 final, de 6 de octubre de 2010, se habla del "uso estratégico de nuestros enormes presupuestos de contratación".

${ }^{293}$ La expresión «objetivos secundarios» es empleada por SCHOONER en su artícu- 
ma idea de instrumentalización de la contratación pública como son las de objetivos indirectos, objetivos exógenos, políticas horizontales ${ }^{294}$ o el término «linkage» que es utilizado para referirse a la contratación pública como instrumento de política social ${ }^{295}$.

Este epígrafe pretende únicamente aludir a alguno de los objetivos secundarios en la normativa contractual y remarcar que las compras públicas pueden contribuir a la consecución de dichos objetivos en el contexto de la denominada «contratación pública responsable». Bajo esta locución nos referimos al hecho de que la inversión pública que acompaña la contratación tenga en cuenta o impulse objetivos beneficiosos para toda la sociedad - principalmente de carácter medioambiental y/o social - desde un planteamiento que aboga por una uti-

lo "Desiderata: Objectives for a System of Government Contract Law", Public Procurement Law Review, vol. 11 (2), 2002, págs. 103 - 110, si bien goza también de gran aceptación entre otros autores como ARNOULD, J., "Secondary Policies in Public Procurement: The Innovations of the New Directives", Public Procurement Law Review, vol. 13 (4), 2004, págs. 187 -197 y BOLTON, P., "The Use of Government Procurement as an Instrument of Policy", South African Law Journal, núm. 121, 2004, especialmente la pág. 619 donde señala que los gobiernos utilizan la contratación pública para promocionar objetivos secundarios o colaterales que están desconectados con el inmediato objetivo de la contratación que es la adquisición de bienes y servicios en los mejores términos posibles. Asimismo, GONZÁLEZ GARCÍA alude a los «elementos secundarios» de la contratación pública en GONZÁLEZ GARCÍA, J. V., Colaboración público-privada e infraestructuras de transporte. Entre el contrato de colaboración entre el sector público y el sector privado y la atipicidad de la gestión patrimonial, Marcial Pons - CEDIT, Madrid, 2010, pág. 65 y en "Sustainability and Public Procurement in the Spanish Legal System", en la obra colectiva The Law of Green and Social procurement in Europe, Djøf Publishing, Copenhague, 2010, pág. 235.

${ }^{294}$ ARROWSMITH alude al concepto «políticas horizontales» para referirse a la consecución de objetivos de este tipo con las adquisiciones públicas en ARROWSMITH, S., "Application of the EC Treaty and directives to horizontal policies: a critical review", en la obra colectiva Social and Environmental Policies in EC Procurement Law. New Directives and New Directions, Cambridge University Press, Cambridge, 2009, págs. 147 - 248 y en "Horizontal Policies in Public Procurement: A Taxonomy", Journal of Public Procurement, vol. 10 (2), 2010, págs. 149 - 186.

${ }^{295}$ McCRUDDEN, C., Buying Social Justice. Equality, Government Procurement and Legal Change, Oxford University Press, Oxford, 2007 y en "EC public procurement law and equality linkages: foundations for interpretation", en la obra colectiva Social and Environmental Policies in EC Procurement (...), op. cit., especialmente en la pág. 271. 
lización estratégica de la contratación pública sin atender exclusivamente a factores de tipo económico y que se integra por tres elementos: «compra verde o ecológica», «compra pública ética» $\mathrm{y}$ «compra social» ${ }^{296}$.

De esta manera, las posibilidades de actuación responsable en la contratación pública pueden lograrse a través de diversas medidas y en distintas fases del procedimiento de adjudicación. Por lo que a esta memoria interesa, nos vamos a centrar en aquellas que se refieren a la posibilidad de excluir de los procedimientos de adjudicación contractual a los operadores económicos que han infringido la normativa en materia social, laboral o medioambiental.

Abordaremos su estudio detallado en el Capítulo tercero al entender que el legislador europeo debiera haber sido más ambicioso en su regulación buscando avanzar en un conjunto de políticas públicas que garanticen un crecimiento sostenible en sintonía con los propósitos de la Estrategia Europa 2020297.

${ }^{296}$ Según BERNAL BLAY la responsabilidad social en la contratación pública significa establecer un nivel de compromiso con la protección de los intereses sociales más allá de los mínimos legalmente exigibles, en BERNAL BLAY, M. Á., "Hacia una contratación pública socialmente responsable: Las oportunidades de la Ley 30/2007, de 30 de octubre, de Contratos del Sector Público", Revista Aragonesa de Administración Pública, monográfico sobre el Derecho de los contratos del Sector Público, 2008, especialmente págs. 215 y 216. Sobre esta materia resultan de interés, PERNAS GARCÍA, J. J., Contratación pública verde, La Ley, Las Rozas (Madrid), 2011; VALCÁRCEL FERNÁNDEZ, P., "Impulso decisivo en la consolidación de una contratación pública responsable. Contratos verdes: de la posibilidad a la obligación", Actualidad Jurídica Ambiental, núm. 3, marzo 2011, págs. 1-11; GALLEGO CÓRCOLES, I., "Cláusulas sociales, contratación pública y jurisprudencia del TJUE", Contratación Administrativa Práctica, núm. 133, noviembre 2011; MEDINA ARNÁIZ, T., "La contratación pública socialmente responsable a través de la jurisprudencia del Tribunal de Justicia de la Unión Europea”, REDA, núm. 153, enero - marzo 2012, págs. 213 - 240 y las distintas aportaciones que podemos encontrar en el libro colectivo Contratación Pública Estratégica, Thomson-Aranzadi, Cizur Menor (Navarra), 2013.

${ }^{297}$ EU2020 Una estrategia para un crecimiento inteligente, sostenible e integrador, COM (2010) 2020 final, de 3 de marzo 2010. Esta Estrategia diseña una serie de medidas que pretenden un crecimiento inteligente basado en el conocimiento y la innovación; un crecimiento sostenible que promueva una economía que haga un uso más eficaz de los recursos, que sea más verde y competitiva, y por último, un crecimiento integrador que aumente el nivel de empleo y que garantice la cohesión social y territorial. 



\section{Capítulo segundo}

\section{ANÁLISIS DE LAS PROHIBICIONES DE CONTRATAR DESDE EL DERECHO DE LA UNIÓN EUROPEA (1957- 2014)}

\section{La regulación europea de la contratación pú- blica}

El origen de las Comunidades Europeas tiene una raíz de carácter históricopolítico al pretender el restablecimiento de la paz en el continente europeo tras las dos Guerras Mundiales. El proceso de integración europea comenzó a ser una realidad a partir de la Declaración de Schuman en $1950^{298}$ hasta

\footnotetext{
${ }^{*}$ Con la entrada en vigor del Tratado de Lisboa, el 1 de diciembre de 2009, el Derecho comunitario pasó a denominarse Derecho de la Unión; sin embargo, a lo largo del texto mantendremos las referencias al Derecho comunitario en cuanto se utilicen para aludir al Derecho anterior a esta fecha. Con efecto a partir del 1 de diciembre de 2009, el Tratado de Funcionamiento de la Unión Europea ( «TFUE») ha introducido también ciertos cambios, tales como la sustitución de «Comunidad» por «Unión» interior». En toda la decisión se utilizará la terminología del TFUE.

${ }^{298}$ El 9 de mayo de 1950, el entonces ministro francés de Asuntos Exteriores Robert SCHUMAN, pronunció un discurso en el que proponía poner en común el conjunto de la producción de carbón y de acero de Francia y de la República Federal de Alemania en una nueva organización abierta a la participación de los demás países de Europa. El propósito perseguía poner fin al antagonismo franco-alemán y evitar con ello el riesgo de una nueva guerra, sin olvidar otro importante objetivo como era el de reconstruir una economía que estaba en ruinas después de la II Guerra Mundial. La relevancia de esta fecha es tal que, de hecho, cada 9 de mayo se celebra el Día de Europa. Sobre los antecedentes de la integración europea, además
} 
concretarse definitivamente con la firma el 18 de abril de 1951, en París, del Tratado constitutivo de la Comunidad Europea del Carbón y del Acero (CECA) y años más tarde con la firma el 25 de marzo de 1957, en Roma, de los Tratados constitutivos de la Comunidad Económica Europea (CEE) y de la Comunidad Europea de la Energía Atómica (EURATOM) entre seis países: Bélgica, la República Federal de Alemania, Francia, Italia, Luxemburgo y los Países Bajos. De esta manera, desde el año 1958 quedaron constituidas las tres Comunidades Europeas, si bien, y debido principalmente a la entidad de los aspectos económicos, la idea de la integración europea comenzó a asociarse con la CEE y bajo la denominación de Comunidad Europea se designaba a todas ellas.

Con la firma del Tratado constitutivo de la CEE (TCEE) se pretendía un desarrollo armonioso de las actividades económicas en el conjunto de la Comunidad mediante el establecimiento de un «mercado común» (artículo 2). Para lograr la realización del que sería denominado de esta forma en un primer momento, los países signatarios se comprometían a suprimir las barreras arancelarias entre ellos y a establecer un arancel exterior común respecto de terceros Estados (artículos 3.a y b). Asimismo, acordaban remover los obstáculos a la libre circulación de personas, servicios y capitales y aproximar sus legislaciones nacionales para el funcionamiento de dicho mercado común (artículos 3.c y h).

En este sentido, y anticipando materia que será objeto de tratamiento posterior, el interés de las instituciones europeas en la contratación pública deriva, principalmente, de su consideración como uno de los instrumentos necesarios

pueden consultarse las obras de TRUYOL Y SERRA, A., La integración europea: análisis histórico-institucional con textos y documentos. Génesis y desarrollo de la Comunidad Europea (1951-1979), Tecnos, Madrid, 1999; DE QUADROS, F., Droit de l'Union européenne («European Union Law»), Bruylant, Bruselas, 2008, págs. 9 21; SAMANIEGO BONEU, M., "Antecedentes del proceso de integración europea. La idea de Europa hasta 1950", en la obra colectiva Tratado de Derecho y Políticas de la Unión Europea (Tomo I. Desarrollo histórico y caracteres básicos de la Unión Europea. Naturaleza, valores, principios y competencias), Civitas - Thomson Reuters, Cizur Menor (Navarra), 2009, págs. 17 a 91. También resultan de interés, el Capítulo I sobre el proceso histórico de la integración europea redactado por MANGAS MARTÍN en la obra MANGAS MARTÍN, A. y LIÑÁN NOGUERAS, D. J., Instituciones y Derecho de la Unión Europea, $8^{\mathrm{a}}$ ed., Tecnos, Madrid, 2014, págs. 27 a 46 y DÍEZ MORENO, F., Manual de Derecho de la Unión Europea, 5a ed., Civitas-Thomson, Cizur Menor (Navarra), 2009. 
para el establecimiento y el correcto funcionamiento del mercado interior ${ }^{299}$. La importancia de la contratación pública como elemento clave para lograr el mercado interior fue ya puesta de manifiesto en 1985 por el Libro Blanco sobre la realización del Mercado interior ${ }^{300}$. En él, la Comisión Europea enumeraba una serie de medidas destinadas a dar un mayor impulso al proceso de integración europea propugnando la eliminación de cualquier tipo de barreras. Entre las que impedían la consecución de un espacio económico único, figuraban las restricciones de acceso a los contratos públicos de un Estado para los proveedores y contratistas de otros Estados miembros.

${ }^{299}$ El Acta Única Europea (1986), que entró en vigor el 1 de julio de 1987, incorporó el concepto de mercado interior al TCEE como ese espacio sin fronteras interiores, en el que la libre circulación de mercancías, personas, servicios y capitales está garantizada (DOCE L 169, de 29 de junio de 1987), si bien ya con anterioridad el entonces TJCE, en su sentencia de 5 de mayo de 1982, Schul, C-15/81, apartado 33, hablaba de mercado interior al manifestar que el concepto de mercado común "tiene por objeto la eliminación de todos los obstáculos a los intercambios comunitarios con el fin de fundir los mercados nacionales en un mercado único estableciendo condiciones lo más próximas posibles a las de un auténtico mercado interior". Sin embargo, parece haber tomado fuerza la expresión «mercado único», y en este sentido véase la nota al pie 1 del Informe Una nueva estrategia para el mercado único. Al servicio de la economía y la sociedad de Europa, elaborado en mayo de 2010 por el antiguo comisario de la UE - y quien fuera también Primer Ministro italiano Mario MONTI. Según la Comunicación de la Comisión Hacia un Acta del Mercado Único, COM (2010) 608 final de 27 de octubre de 2010, pág. 2, la evolución de las denominaciones «mercado común», «mercado único», «mercado interior»a lo largo del tiempo "traduce un doble fenómeno de desarrollo y enriquecimiento del gran mercado europeo".

${ }^{300}$ Libro Blanco de la Comisión sobre la realización del Mercado interior Completing the Internal Market, COM (85) 310 final, de 14 de junio, págs. 23 y 24. Dos años más tarde en la Comunicación Vademécum sobre los contratos públicos en la Comunidad, la Comisión volvía a poner de manifiesto el papel fundamental que la apertura de los contratos públicos podía desempeñar en favor de la creación de un espacio económico único (DOCE C 358, de 31 de diciembre de 1987). Asimismo, en 1988, el Informe del proyecto de investigación El coste de la no Europa conocido como «Informe Cecchini» - por el nombre de su ponente Paolo CECCHINI - cuantificó en unos 22.000 millones de ecus el beneficio previsto de un aumento de la apertura de la contratación pública si desaparecieran las "compras públicas protegidas nacionalmente" (Capítulo 5 The "cost of non-Europe" in public-sector Procurement). CECCHINI, P., Europa 1992: Una apuesta de futuro, Alianza Editorial, Madrid, 1988. 
Tabla 1: Gasto total en la contratación pública de obras, suministro y servicios como porcentaje del PIB (\%) en la UE (excluidos los servicios públicos).

\begin{tabular}{l|c|c|c|c}
\hline \multicolumn{1}{c|}{ ESTADO MIEMBRO } & 2010 & 2011 & 2012 & 2013 \\
\hline Alemania & 14,68 & 14,46 & 14,45 & 14,67 \\
Austria & 11,32 & 10,99 & 11,10 & 11,24 \\
Bélgica & 13,19 & 13,43 & 13,75 & 13,59 \\
Bulgaria & 12,18 & 11,08 & 10,85 & 12,03 \\
Croacia & 11,97 & 11,88 & 11,67 & 12,29 \\
Chipre & 9,53 & 8,91 & 7,42 & 6,63 \\
Dinamarca & 13,72 & 13,47 & 14,06 & 13,58 \\
Eslovaquia & 12,74 & 12,43 & 11,81 & 11,76 \\
Eslovenia & 13,48 & 12,64 & 12,40 & 12,60 \\
España & 12,94 & 11,83 & 10,18 & 9,74 \\
Estonia & 13,03 & 12,85 & 14,30 & 13,14 \\
Finlandia & 16,66 & 16,66 & 17,20 & 17,81 \\
Francia & 14,87 & 14,52 & 14,74 & 14,90 \\
Grecia & 11,59 & 9,85 & 9,77 & 8,91 \\
Hungría & 13,83 & 13,18 & 13,28 & 14,02 \\
Irlanda & 11,92 & 10,36 & 9,67 & 9,47 \\
Italia & 10,90 & 10,61 & 10,33 & 10,08 \\
Letonia & 11,71 & 12,22 & 11,68 & 11,38 \\
Lituania & 12,85 & 11,58 & 10,51 & 9,87 \\
Luxemburgo & 12,78 & 12,18 & 12,34 & 12,02 \\
Malta & 8,53 & 9,38 & 10,29 & 9,63 \\
Países Bajos & 22,93 & 22,30 & 22,76 & 22,62 \\
Polonia & 14,05 & 13,55 & 12,50 & 12,05 \\
Portugal & 13,79 & 11,89 & 10,68 & 10,43 \\
Reino Unido & 15,43 & 14,34 & 14,46 & 14,46 \\
Republica Checa & 16,29 & 15,40 & 14,73 & 14,37 \\
Rumanía & 12,64 & 12,98 & 12,00 & 11,24 \\
Suecia & 16,25 & 16,14 & 16,23 & 16,32 \\
\hline UE 28 & 14,33 & 13,81 & 13,69 & 13,67 \\
\hline Fus & 029 \\
\hline
\end{tabular}

Fuente: Elaboración propia a partir de los datos obtenidos del Documento de trabajo de la Comisión Europea Public procurement indicators 2013, de 17 de junio de 2015. Puede consultarse en: http://ec.europa.eu/growth/singlemarket/public-procurement/studies-networks/index_en.htm [Fecha de consulta: 15 de octubre de 2015] 
Por esa razón, la apertura de los contratos públicos a la competencia europea constituía, una premisa decisiva en la consecución del mercado interior al entender que la contratación pública era - y sigue siendo aun a pesar de las restricciones en el gasto público - uno de los motores que impulsan la economía de los Estados en atención a los recursos que compromete y, que según los últimos datos publicados por la Comisión Europea, en el año 2013 se cifraron en 1.786.610 millones de euros que equivalen a un 13,6\% del Producto Interior Bruto (PIB) europeo (excluyendo los servicios públicos - utilities) ${ }^{301}$.

En atención a las implicaciones económicas asociadas a las compras públicas, y tal como se ha puesto de manifestado en los numerosos estudios que versan sobre esta materia, la regulación de la contratación pública en la UE se encuentra claramente condicionada por el objetivo de la realización del mercado interior $^{302}$. Así pues, a través de la apertura de los contratos públicos a

\footnotetext{
${ }^{301}$ Son datos del documento de trabajo de la Comisión Europea Public Procurement Indicators 2013, de 17 de junio de 2015. Hasta el año 2011 los indicadores comprendían también los servicios públicos y, por esa razón, los datos que aparecían reflejados eran cercanos al $20 \%$, concretamente el $19,9 \%$ de media en la UE en el año 2009 y el $19,7 \%$ en el año 2010.
}

${ }^{302}$ En el ámbito español, hemos de destacar los trabajos de OJEDA MARÍN, A., "Hacia un sistema de contratación pública acorde con el mercado interior", Revista de Instituciones Europeas, vol. 15 (3), septiembre-diciembre 1988, págs. 821-844; SANTÍAS VIADA, J.A., LÓPEZ BLANCO, C. y SANTAMARÍA DE PAREDES CASTILLO, V., El Derecho comunitario de la contratación pública, Escuela de Hacienda Pública, Madrid, 1991; VINYOLES I CASTELLS, M., La adjudicación de los contratos públicos: la nueva Ley de Contratos de las Administraciones Públicas y normativa comunitaria, Civitas, Madrid,1 995; MORENO MOLINA, J.A., Contratos públicos: Derecho comunitario y Derecho español, McGraw-Hill, Madrid, 1996; RAZQUÍN LIZARRAGA, M.Ma ., Contratos públicos y Derecho comunitario, Aranzadi, Pamplona, 1996; PIÑAR MAÑAS, J.L.,"El Derecho comunitario como marco de referencia del Derecho español de contratos públicos", en la obra colectiva Comentario a la Ley de Contratos de las Administraciones Públicas, $2^{\mathrm{a}}$ ed., Thomson-Civitas, Madrid, 2004, págs .27-79; GONZÁLEZ-VARAS IBÁÑEZ, S.,"La contratación de las Comunidades Europeas", RAP, núm. 142, enero-abril 1997, págs. 195-223 y El contrato administrativo, Civitas, Madrid, 2003; ORDÓÑEZ SOLÍS, D., La contratación pública en la Unión Europea, Aranzadi, Cizur Menor (Navarra), 2002; GIMENO FELIÚ, J.M ${ }^{\mathrm{a}}$., Contratos públicos: ámbito de aplicación y procedimiento de adjudicación. La incidencia de las Directivas comunitarias en el ordenamiento jurídico español, Civitas, Madrid, 2002 y La nueva contratación pública europea y su incidencia en la legislación española. La necesaria adopción de una nueva ley de contratos públicos y propuestas de reforma, Thomson-Civitas, Madrid, 2006; FERNÁNDEZ 
una competencia transfronteriza, las instituciones europeas muestran, por una parte, su interés en garantizar la participación más amplia posible de operadores económicos en un procedimiento de adjudicación y, por otra, tratan de evitar que los órganos de contratación favorezcan a sus nacionales mediante actuaciones con una clara motivación proteccionista que van en detrimento de los principios de competencia y de igualdad de trato.

Éstas son, a grandes rasgos, las razones que justifican una acción específica en materia de contratación pública desde el Derecho de la Unión, aunque a este respecto, y como acertadamente ha señalado el TJUE, es necesario señalar que dicha apertura a la competencia no se pretende únicamente en aras del interés europeo en la realización del mercado interior, sino también en interés del poder adjudicador implicado, que ante un mayor número de licitadores dispondrá de una elección más amplia en cuanto a las posibilidades de encontrar la oferta que mejor se adapte a sus necesidades y que - al menos desde la teoría - le posibilite un ahorro en sus gastos y, con ello, un mejor aprovechamiento de sus

GARCÍA, M ${ }^{\mathrm{a}}$ Y., "La nueva regulación de la contratación pública en el Derecho comunitario europeo", RAP, núm.166, enero-abril 2005, págs. 281-320; HUERGO LORA, A., "El Derecho español de contratos públicos y el Derecho comunitario", REDA, núm. 126, abril-junio 2005, págs. 217-246, y más recientemente, SÁNCHEZ MORÓN, M. (Director) Derecho de los contratos públicos en la Unión Europea y sus Estados miembros, Lex Nova, Valladolid, 2011 y Public procurement in the European Union and its Member States, Lex Nova -Thomson Reuters, Valladolid, 2012.

En el ámbito europeo destacan las obras de LAGUERRE, A., Concurrence dans les marchés publics, Berger-Levrault, Paris, 1989; GOHON, J.-P., Les marchés publics européens, Presses Universitaires de France, Collection Que sais-je?, núm.2625, Paris, 1991; WINTER , J.A., "Public Procurement in the EEC", CMLR, vol. 28 (4), 1991, págs. 741-782; WEISS, F., Public procurement in European Community Law, Athlone Press, London, 1993; COX, A., Public Procurement in the EC (Vol. 1). The Single Market Rules and the Enforcement Regime after 1992, Earlsgate Press, Boston, 1993; FERNÁNDEZ MARTÍN, J.Ma., The EC Public Procurement Rules: A Critical Analysis, Clarendon Press, Oxford, 1996; BOVIS, Ch., EC Public Procurement Law, Longman, London, 1997, también del mismo autor EC Public procurement: Case law $\mathcal{E}$ regulation, Oxford University Press, Oxford, 2006; TREPTE, P.A., Public Procurement in the EU: A Practitioner's Guide, $2^{\mathrm{a}}$ ed., Oxford University Press, Oxford, 2007; NOGUELLOU, R., y STELKENS, U., (Dirs) Droit comparé des Contrats Publics/Comparative Law on Public Contracts, Bruylant, Brussels, $2010 \mathrm{y}$ ARROWSMITH, S., The Law of public and utilities procurement, $3^{\mathrm{a}}$ ed., Sweet \& Maxwell, London, 2014. 
recursos $^{303}$.

El bloque normativo de la Unión Europea en materia de contratos públicos se fundamenta en dos tipos de fuentes: el Derecho originario o primario que lo conforman los Tratados constitutivos de los cuales se derivan los grandes principios que cimentan la normativa contractual, y el Derecho derivado, integrado, principalmente, por las Directivas de la Unión que aspiran a una aproximación de los ordenamientos nacionales de los Estados miembros en esta materia ${ }^{304}$.

En la conformación de este marco jurídico, es preciso también poner de relieve que la jurisprudencia del TJUE está desempeñando un papel fundamental en el desarrollo de la regulación europea sobre contratos públicos contribuyendo a formar un verdadero corpus iuris en esta materia ${ }^{305}$. En particular, el

${ }^{303}$ Sentencias del TJUE de 15 de mayo de 2008, SECAP y Santorso, C-147/06 y C-148/06, apartado 29; de 19 de mayo de 2009, Assitur, C-538/07, apartado 26; de 23 de diciembre de 2009, CoNISMa, C-305/08, apartado 37 y de 18 de diciembre de 2014, Data Medical Service, C-568/13, apartado 34. En este mismo sentido se manifestaba la Comisión Europea en el recurso interpuesto el 16 de noviembre de 2010, Comisión/República Eslovaca, C-531/10, al señalar que al no ser objeto de licitación un contrato para la prestación de servicios de asesoría se "renunció a las ventajas que habrían podido derivarse $(. .$.$) de la existencia del mercado interior y$ gracias a las cuales habría podido obtener una oferta más conveniente (...) debido al mayor número de empresas procedentes de la Unión Europea".

Sobre el objetivo y alcance del Derecho europeo de los contratos públicos, puede consultarse CHINCHILLA MARÍN, C., "La jurisprudencia del TJUE sobre contratos públicos (I). Ámbito subjetivo y objetivo de aplicación de las Directivas", en la obra colectiva El Derecho de los contratos públicos en la Unión Europea y sus Estados miembros, Lex Nova, Valladolid, 2011, págs. 33 - 79.

${ }^{304}$ Aunque nos vayamos a referir esencialmente a las Directivas, hay que señalar que el Derecho derivado es el que alberga todos los actos jurídicos de la Unión, tal y como los califica el TFUE. Estos actos jurídicos como expresión formal de la producción por parte de las instituciones de la Unión se califica en actos jurídicos vinculantes (reglamentos, directivas y decisiones) y no vinculantes (recomendaciones y dictámenes). El artículo 288 TFUE - antiguo artículo 249 TCE - manifiesta que "para ejercer las competencias de la Unión, las instituciones adoptarán reglamentos, directivas, decisiones, recomendaciones y dictámenes". Para profundizar sobre el Derecho institucional de la Unión Europea, nos remitimos a las obras de ALONSO GARCÍA, R., Sistema jurídico de la Unión Europea, $4^{\mathrm{a}}$ ed., Civitas - Thomson Reuters, Cizur Menor (Navarra), 2014 y MANGAS MARTÍN, A. y LIÑÁN NOGUERAS, D. J., Instituciones y Derecho (...), op. cit., págs. 344 y ss.

${ }^{305}$ MORENO MOLINA, J. A., "La reciente jurisprudencia del Tribunal de Justicia 
Tribunal de Justicia insiste en la necesidad de que las entidades que tienen la condición de poderes adjudicadores respeten las obligaciones que derivan del Derecho primario en el momento de celebrar sus contratos, aun cuando dichos contratos no estén comprendidos en el ámbito de aplicación de las Directivas sobre contratación pública ${ }^{306}$.

A lo largo de este Capítulo expondremos la regulación europea desde el Derecho originario, remontándonos al Tratado CEE por resultar la fuente principal de las libertades fundamentales del mercado interior y de sus principios,

de las Comunidades Europeas en materia de contratos públicos", RAP, núm. 151, 2000, pág. 319 y "La influencia del Derecho Comunitario de la contratación pública en el Derecho español. Los principios generales de la contratación del sector público", NUE, núm. 298, noviembre 2009, págs. 7 - 19 y RAZQUIN LIZARRAGA, M. Ma ., Contratos públicos (...), op. cit., pág. 172 y en "La jurisprudencia del Tribunal de Justicia de las Comunidades Europeas sobre contratación pública", Justicia Administrativa, núm. 6,2000 , págs. 5 - 32. Sobre esta materia, y además de la referencia anterior a CHINCHILLA MARÍN, destaca también las aportaciones doctrinales de BOVIS, Ch., "Developing public procurement regulation: Jurisprudence and its influence on law making", CMLR, vol. 43 (2), 2006, págs. 461-495; VIANA, C., "A jurisprudência "principialista" do Tribunal de Justiça da União Europeia relativa à contratação pública", en la obra colectiva Direito da União Europeia e Transnacionalidade - Acção Jean Monnet, Quid Iuris, Lisboa, 2010, págs. 63 - 84; de SÁNCHEZ MORÓN, M., "La jurisprudencia del TJUE sobre contratos públicos (II). Adjudicación de los contratos y recursos en materia de contratación pública", en la obra colectiva El Derecho de los contratos públicos en la Unión Europea (...), op. cit., págs. 81 - 101; de COZZIO, M., "La función de la jurisprudencia en el proceso de europeización de las reglas de contratación pública", en la obra colectiva Observatorio de Contratos Públicos 2012, Civitas - Thomson Reuters, Cizur Menor (Navarra), 2013, págs. 87 - 111 y de MORENO MOLINA, J. A. y DOMÍNGUEZ ALONSO, A. P., "El nuevo derecho de la Unión Europea sobre contratación pública", en el libro colectivo La contratación pública a debate: presente y futuro, Civitas-Thomson, Cizur Menor (Navarra), 2014, pág. 139.

${ }^{306}$ Véanse, en este sentido, la Comunicación interpretativa de la Comisión sobre el Derecho comunitario aplicable en la adjudicación de contratos no cubiertos o sólo parcialmente cubiertos por las Directivas sobre contratación pública (DOCE C 179, de 1 de agosto de 2006, págs. 2 a 7) - impugnada sin éxito en el asunto en que recayó la sentencia de 20 de mayo de 2010, Alemania/Comisión (T-258/06) - y las sentencias del Tribunal de Justicia de 7 de diciembre de 2000, Telaustria y Telefonadress, C-324/98, apartados 60 a 62; de 21 de julio de 2005, Coname, C-231/03, apartados 16 a 19; de 13 de octubre de 2005, Parking Brixen, C-458/03, apartados 46 a 49; de 13 de noviembre de 2008, Coditel Brabant, C-324/07, apartado 25, así como de 13 de abril de 2010, Wall, C-91/08, apartado 33. 
y conoceremos la evolución que se ha registrado en las Directivas sobre esta materia. Así pues, y bajo el hilo conductor de examinar cronológicamente la normativa de la UE, es nuestra intención llegar a comprender los cambios operados en el Derecho positivo actual centrándonos fundamentalmente en el examen de los criterios de selección cualitativa del contratista y en las novedades que se han producido en la regulación de las prohibiciones de contratar.

Ahora bien, antes de proceder a este análisis, hemos de destacar que más de cuarenta años después de las primeras Directivas sobre contratación pública el objetivo de crear un mercado europeo para las compras públicas aún está por conseguir. Los datos nos muestran que las transacciones transfronterizas directas únicamente suponen un 3,5\% del valor de los contratos adjudicados en la UE - cifra que se eleva a un $13.4 \%$ en el caso de contratación indirecta a través de filiales - y que, en el caso de los contratos que superan los umbrales de las Directivas, el $50 \%$ se adjudica a operadores económicos en un radio de $100 \mathrm{~km}^{307}$.

\footnotetext{
${ }^{307}$ Son datos extraídos de los documentos de trabajo de la Comisión que acompañan a la Propuesta de Directiva relativa a la facturación electrónica, SWD (2013) 222 final, de 26 de junio de 2013, pág. 16 y a la Propuesta de Directivas sobre contratación pública, SEC (2011) 1585 final, de 20 de diciembre de 2011, págs. 13 y 25, con cita en el trabajo RAMBØLL MANAGEMENT, Cross-border public procurement above EU thresholds, mayo 2011, págs. 38 y 80. En el año 2014, los datos muestran una ligera mejoría respecto de la contratación transfronteriza directa elevándola al 3,7\% del valor de los contratos, KUTLINA-DIMITROVA, Z., y LAKATOS, C., Determinants of direct cross-border public procurement in EU Member States, julio 2014 en: http://trade.ec.europa.eu/doclib/docs/2014/july/tradoc_152700.pdf [Fecha de consulta: 18 de octubre de 2015]
} 


\section{La contratación pública a la luz del Trata- do constitutivo de la Comunidad Económi- ca Europea}

\section{II.1. La ausencia de preceptos referidos a la contrata- ción pública}

El Tratado constitutivo de la Comunidad Económica Europea (TCEE), adoptado en 1957 (Tratado de Roma), se ocupaba principalmente de establecer un mercado común a partir del establecimiento de cuatro libertades fundamentales en todo el territorio de la Comunidad: la libre circulación de personas, de mercancías, de capitales y la libre prestación de servicios.

Este Tratado, sin embargo, no contiene previsiones específicas sobre contratación pública más allá de las referencias hechas a las condiciones de participación en los contratos financiados por la Comunidad en los países y territorios de Ultramar (artículo 132.4 TCEE) y del artículo 130.f .2), introducido por el Acta Única Europea (1986), relativo a la cooperación de las empresas en materia de investigación y desarrollo tecnológico ${ }^{308}$.

Acerca de la falta de previsiones específicas sobre contratación pública en el Tratado CEE se manifiestan la práctica totalidad de autores que han tratado esta materia, aunque se esgrimen distintos argumentos acerca del porqué de dicha ausencia: (i) bien porque inicialmente no se preveía la importancia económica que iba a tener el sector de la contratación pública ${ }^{309}$, (ii) porque

\footnotetext{
${ }^{308}$ Artículo 132.4 TCEE: "Para las inversiones financiadas por la Comunidad, la participación en las convocatorias para la adjudicación de obras, servicios y suministros quedará abierta, en igualdad de condiciones, a todas las personas físicas y jurídicas que tengan la nacionalidad de los Estados miembros o de los países y territorios".

Artículo 130.f .2) TCEE: "A tal fin, estimulará a las empresas, incluyendo las pequeñas y medianas empresas, centros de investigación y universidades en sus esfuerzos de investigación y desarrollo tecnológico; apoyará sus esfuerzos de cooperación fijándose, en especial, como objetivo permitir a las empresas la plena utilización de las potencialidades del mercado interior de la Comunidad, en particular por medio de la contratación pública nacional (...)” (DOCE L 169, de 29 de junio de 1987).

${ }^{309}$ PIÑAR MAÑAS, J. L., "El sistema de garantías para la efectiva implantación
} 
la complejidad de la materia y las diferencias entre los distintos ordenamientos nacionales impedían llegar a un acuerdo sobre el tema ${ }^{310}$, (iii) o bien porque la filosofía de los Tratados constitutivos era rehuir de todo pronunciamiento categórico respecto de la actividad económica de los poderes públicos ${ }^{311}$.

Sea como fuere, y a pesar de esta falta de mención explícita al régimen aplicable a los contratos que celebren las autoridades públicas, es un hecho cierto, y confirmado por la jurisprudencia del TJUE, que en este Tratado se recogen los principios que sirven de base a las Directivas sobre contratación pública y que, el acatamiento a estos principios resulta una obligación para los poderes adjudicadores - siempre que el contrato revista un interés transfronterizo cierto - con independencia de que estos contratos estén o no incluidos en el ámbito de aplicación de las citadas Directivas por razón de objeto o cuantía ${ }^{312}$.

En este contexto, y conforme a esta jurisprudencia del Tribunal de Justicia, las autoridades públicas que celebren tales contratos están obligadas a respetar las normas fundamentales del hoy conocido como Tratado de Funcionamiento de la Unión Europea $(\mathrm{TFUE})^{313}$ y, en particular, la libre circu-

de la apertura de la contratación pública comunitaria", en la obra colectiva $L a$ protección jurídica del ciudadano. Estudios en homenaje al profesor Jesús González Pérez, Civitas, Madrid, 1993, pág. 774.

${ }^{310}$ WEISS, F., Public procurement (...), op. cit., pág. 19.

${ }^{311}$ BASSOLS COMA, M., "Aproximación a la normativa comunitaria europea sobre contratación administrativa", Noticias CEE, núm. 21, octubre 1986, págs. 27.

${ }^{312}$ En palabras del Abogado General Sr. RUIZ-JARABO COLOMER, presentadas el 27 de noviembre de 2007, en el asunto SECAP, C-147/06 y C-148/06, "los procedimientos de adjudicación de los contratos públicos que, por diferentes causas (cuantitativas o conceptuales), quedan al margen de las Directivas sobre la materia no escapan a la disciplina del ordenamiento jurídico de la Unión Europea, de suerte que sus principios fundamentales y, en especial, las libertades básicas de circulación, se erigen en barreras infranqueables" (apartado 20). Además de las sentencias antes citadas, resultan también de interés las sentencias de 19 de diciembre de 2012, Ordine degli Ingegneri della Provincia di Lecce y otros, C-159/11, apartado 23 y de 16 de abril de 2015, Enterprise Focused Solutions, C-278/14, apartado 16 al indicar que "la adjudicación de contratos que, por su valor, no están incluidos en el ámbito de aplicación de dicha Directiva está sujeta a las normas fundamentales y a los principios generales del Tratado FUE".

${ }^{313}$ El Tratado de Roma, constitutivo de la Comunidad Económica Europea (TCEE), se firmó en esa ciudad el 25 de marzo de 1957 y entró en vigor el 1 de 
lación de mercancías, la libertad de establecimiento y la libre prestación de servicios, así como de los principios que de estas libertades se derivan, como son el principio de igualdad de trato, no discriminación, reconocimiento mutuo, proporcionalidad y transparencia, tal como recoge el considerando primero de la Directiva 2014/24/UE, el considerando cuarto de la Directiva 2014/23/UE («concesiones») y el considerando segundo de la Directiva 2014/25/UE («sectores especiales»).

\section{II.2. Alcance de las libertades fundamentales garanti- zadas por el Tratado CEE en el ámbito de la con- tratación pública}

Las obligaciones que derivan del Derecho primario, y en particular de la libertad de establecimiento y de libre prestación de servicios, son esencialmente dos. Por un lado, los poderes adjudicadores deben respetar los principios de no discriminación por razón de la nacionalidad y de igualdad de trato. Por otra parte, con el fin de permitir que se respeten dichos principios, deben cumplir con la obligación de transparencia ${ }^{314}$.

Como veremos en el siguiente apartado de esta memoria doctoral, las Directivas sobre contratación pública proporcionan soporte jurídico a la libertad

enero de 1958. Este Tratado fue modificado por el Acta Única Europea (1986). Con el Tratado de la Unión Europea, firmado en Maastricht el 7 de febrero de 1992 y que entró en vigor el 1 de noviembre de 1993, el Tratado CEE pasó a denominarse Tratado constitutivo de la Comunidad Europea (TCE) y la Unión Europea sustituyó oficialmente a la Comunidad Europea, aunque no se atribuía a la UE el carácter de sujeto internacional. El Tratado de Ámsterdam, firmado el 2 de octubre de 1997 y en vigor desde el 1 de mayo de 1999, modificó el texto y la numeración de los Tratados UE y CE, estableciendo una versión consolidada de ambos. Las reformas nacidas del Tratado de Niza (2001), en vigor desde el 1 de febrero de 2003, pivotaron sobre los aspectos institucionales con el fin de adaptar las instituciones comunitarias a la adhesión de nuevos Estados miembros en los años 2004 y 2007. Desde el 1 de diciembre de 2009, fecha de la entrada en vigor del Tratado de Lisboa, se modifican el Tratado de la Unión Europea y el Tratado constitutivo de la Comunidad Europea que desde entonces ha pasado a denominarse Tratado de Funcionamiento de la Unión Europea (TFUE). Su versión consolidada se encuentra publicada en el DOUE C 326, de 26 de octubre de 2012.

${ }^{314}$ STJCE de 13 de octubre de 2005, Parking Brixen, C-458/03, apartados 47 a 49. 
de establecimiento y a la libre prestación de servicios en el ámbito de los contratos públicos, puesto que su finalidad de coordinar a escala europea los procedimientos de adjudicación contractual tiene por objeto suprimir las trabas a la libre circulación de servicios y de mercancías y, por tanto, proteger los intereses de los operadores económicos establecidos en un Estado miembro que deseen ofrecer bienes o servicios a los poderes adjudicadores de cualquier otro Estado ${ }^{315}$.

Esta finalidad se oponía a la práctica habitual de los Estados miembros que con anterioridad, e incluso con posterioridad a la firma del Tratado CEE, mantenían restricciones en sus contratos a favor de sus nacionales o establecían exigencias de utilización de productos y materiales de fabricación nacional ${ }^{316}$.

${ }^{315}$ En este sentido puede consultarse las sentencias del TJCE de 3 de octubre de 2000, University of Cambridge, C-380/98, apartado 16; de 18 de octubre de 2001, SIAC Construction, C-19/00, apartado 32; de 13 de noviembre de 2007, Comisión/Irlanda, C-507/03, apartado 27; de 24 de enero de 2008, Lianakis, C-532/06, apartado 39 y de 21 de diciembre de 2011, Chambre de commerce y d'industrie de l'Indre, C-465/10, apartado 56.

${ }^{316}$ Algunos de los Estados miembros fundadores de la CEE reconocían regímenes preferenciales en su normativa de contratación pública a favor de sus regiones menos favorecidas. Por ejemplo, en Alemania a favor de las regiones de la antigua Alemania del Este o en Italia se trataba de favorecer a las empresas del sur de Italia - Mezzogiorno - que son los supuestos enjuiciados por las sentencias del TJCE Du Pont de Nemours y Laboratori Bruneau sobre la reserva del $30 \%$ de los contratos de suministros a las empresas situadas en el sur de Italia. Sobre estos regímenes preferenciales, puede consultarse la Comunicación de la Comisión Aspectos regionales y sociales de la contratación pública, COM (89) 400 final, de 22 de septiembre de 1989. También COX, A. y FURLONG, P., "European procurement rules and national preference: Explaining the local sourcing of public works contracts in the EU in 1993", Journal of Construction Procurement, vol. 1 (2) 1995, págs. 87 - 99; MORENO MOLINA, J.A., Contratos públicos: Derecho comunitario (...), op. cit., págs. 58 y ss.; RAZQUIN LIZARRAGA, M. M ${ }^{\mathrm{a}}$., Contratos públicos y Derecho (...), op. cit., págs. 99 - 101, ARROWSMITH, S., The Law of public and (...), op. cit., págs. 186 y 187 y ORDÓÑEZ SOLÍS, D., La contratación pública (...), op. cit., págs. 169 - 171.

En España, por ejemplo, la legislación contractual de principios del siglo XX recogía expresamente que "en los contratos por cuenta del Estado para toda clase de servicios y obras públicas serán admitidos únicamente los artículos de producción nacional" y, excepcionalmente, se podía recurrir a la industria extranjera por imperfección del producto nacional, por notable diferencia del coste del producto nacional, por reconocida urgencia o por no existir la producción nacional respectiva (artículo 1 de la Ley de 14 de febrero de 1907, de protección á la producción nacional 
Estas prácticas confrontaban con dos de las libertades que constituyen la esencia del mercado interior: la libre circulación de mercancías (Título II del TFUE, especialmente artículo 34 TFUE - antiguo artículo 28 TCE) y la libre prestación de servicios (artículo 56 TFUE - antiguo artículo 49 TCE).

Las disposiciones relativas a la libre prestación de servicios y a la libre circulación de mercancías comportan en el ámbito de la contratación pública la necesidad de aplicar la regla de «tratamiento nacional», esto es, que las condiciones que se apliquen a los bienes y a los prestadores de servicios de otros Estados miembros no sean diferentes a las que ese Estado imponga a sus nacionales o a sus empresas ${ }^{317}$. Se prohíbe con ello cualquier medida o requisito que implique una discriminación, o que favorezca a los productos y contratistas nacionales en detrimento de los nacionales de otros Estados miembros ${ }^{318}$.

(Gaceta de Madrid núm. 46, de 15 de febrero). Véase a este respecto, BAENA DEL ALCÁZAR, M., "Contratistas extranjeros y productos de fabricación extranjera en la legislación vigente sobre contratos de la Administración", $R A P$, núm. 57, septiembre - diciembre 1968, págs. 407 - 426. Por su parte, OJEDA MARÍN manifiesta que "ya desde antiguo la Administración aprovecha cualquier ocasión para mostrar sus preferencias a favor del licitador español. Reinaba una especie de «mercantilismo administrativo» en perjuicio del empresario extranjero", en OJEDA MARÍN, A., "Contratos públicos en la Comunidad Europea: La Ley de Contratos del Estado y su adecuación al ordenamiento jurídico comunitario", RAP, núm. 112, enero - abril 1987, pág. 133.

${ }^{317}$ Según manifiesta BORRAJO INIESTA, "la correlación entre Directivas de contratación pública, por una parte, y la libertad de circulación por la otra, no admite dudas. La libertad comunitaria forma el título habilitador de la intervención comunitaria en la materia: constituye por ende, el punto de referencia obligado para la interpretación de las legislaciones, comunitaria derivada y nacionales, en la materia", en BORRAJO INIESTA, I., "Las Directivas sobre contratación pública como manifestación de la libertad comunitaria de circulación", Noticias CEE, núm. 21, octubre 1986, pág. 42.

${ }^{318}$ Algunas de las sentencias del TJCE que se refieren a estas libertades en el ámbito de la contratación pública han sido la sentencia de 22 de junio de 1993, Comisión/Dinamarca, conocida como «Storebaelt», C-243/89, en la que el Tribunal mantuvo que no se ajustaba al TCE que una entidad contratante incluyese, como requisito de adjudicación, la utilización, en todo lo posible, de materiales, bienes de consumo, mano de obra y bienes de equipo daneses para la construcción de un puente en Dinamarca. En las sentencias Du Pont de Nemours y Laboratori Bruneau, el Tribunal de Justicia declaró la incompatibilidad con el Derecho comunitario de la normativa nacional que reservaba una proporción de los contratos públicos de suministro a las empresas establecidas en determinadas regiones del sur de Italia 
Del mismo modo, al referirnos a la selección de contratistas y atendiendo a la misma regla de tratamiento nacional, no constituiría una restricción a la libre prestación de servicios una medida por la cual los poderes adjudicadores de un Estado miembro impongan a los licitadores de otros Estados miembros las mismas condiciones de licitación que prevé su legislación nacional como requisitos para participar en sus procedimientos de adjudicación contractual.

Dicho esto, y a pesar de lo contundente que resulta esta afirmación, para que estos requisitos aplicables indistintamente a los licitadores nacionales y a los de los otros Estados miembros sean conformes al Derecho de la Unión, no tienen que resultar desproporcionados con los objetivos que pretenden alcanzar, ni generar una excesiva carga burocrática que ocasione en los licitadores y candidatos un efecto disuasorio que afecte a su deseo de acceder al mercado de la contratación pública. Es decir, aunque un requisito nacional de acceso a la condición de contratista no resultase discriminatorio al aplicarse por igual a todos los operadores económicos sin distinguir entre nacionalidades o lugares de establecimiento, podría resultar contrario a las libertades fundamentales si éste desincentivara a los licitadores o candidatos establecidos en un Estado miembro distinto de aquel del destinatario de la prestación contractual ${ }^{319}$.

A esta conclusión llega también el TJUE en su sentencia Bâtiments y Ponts Construction, al señalar que el Derecho de la Unión "no se opone a una normativa nacional que impone al contratista establecido en otro Estado miembro,

(STJCE de 20 de marzo de 1990, Du Pont de Nemours Italiana, C-21/88 y de 11 de julio de 1991, Laboratori Bruneau, C-351/88). Asimismo, en la sentencia de 27 de octubre de 2005, Contse y otros, C-234/03, el Tribunal se oponía a que una entidad adjudicadora incluyese en el pliego de condiciones de un contrato público de prestación de servicios sanitarios de terapias respiratorias domiciliarias un requisito de admisión que obligaba a la empresa licitadora a disponer, en el momento de la presentación de la oferta, de una oficina abierta al público en la capital de la provincia en la que debe prestarse el servicio.

${ }^{319}$ Recordemos que según reiterada jurisprudencia del TJUE, el concepto de «restricción», en el sentido de los artículos 49 TFUE y 56 TFUE, se refiere a las medidas que prohíben, obstaculizan o restan interés al ejercicio de la libertad de establecimiento o de la libre prestación de servicios. Así se pronuncian las sentencias del TJUE de 28 de abril de 2009, Comisión/Italia, C-518/06, apartados 62 y 64; de 21 de octubre de 2010, Idryma Typou, C-81/09, apartado 54; de 7 de marzo de 2013, DKV Belgium, C-577/11, apartado 31 o la más reciente de 15 de octubre de 2015, Grupo Itevelesa y otros, C-168/14, apartado 67. 
para la adjudicación de un contrato en el Estado miembro del poder adjudicador, la obligación de estar registrado en este último Estado miembro, siempre que dicha obligación no obstaculice ni retrase la participación del contratista en la licitación pública en cuestión, ni genere cargas administrativas excesivas, y siempre que sólo tenga la finalidad de comprobar las aptitudes profesionales del interesado" $" 320$.

\section{II.3. La aplicación de los principios generales del Dere- cho de la Unión}

Los principios generales derivados del Derecho primario de la Unión en materia de adjudicación de contratos públicos se nos muestran como el elemento que sirve de soporte a las exigencias derivadas de las libertades garantizadas por el Tratado de Funcionamiento de la Unión Europea (TFUE) y son una referencia obligada para conformar el sistema de contratación pública a nivel europeo ${ }^{321}$. A este respecto hay que señalar que, según reiterada juris-

${ }^{320}$ STJUE de 15 de julio de 2010, Bâtiments y Ponts Construction, C-74/09. Esta sentencia trae causa en la petición de decisión prejudicial por la cual la Cour de cassation belga cuestiona si es compatible con la Directiva $93 / 37 / \mathrm{CEE}$ y con el principio de libre circulación exigir también a los contratistas extranjeros el registro fiscal en Bélgica para poder participar en los procedimientos de adjudicación en este país.

${ }^{321}$ Sobre esta materia resultan de interés BERMEJO VERA, J., "Objetivos, principios y prospectiva de la política comunitaria de contratos públicos", REGAP, núm. 29, septiembre - diciembre 2001, págs. 141 - 163; ESCUIN PALOP, C., "Principios inspiradores del procedimiento de contratación pública", Contratación Administrativa Práctica, núm. 46, octubre 2005, págs. 29 - 41; MORENO MOLINA, J. A., Los principios generales de la contratación de las Administraciones públicas, Bomarzo, Albacete, 2006; GIMENO FELIÚ, J. M ${ }^{\mathrm{a}}$., Contratos públicos: ámbito de aplicación y procedimiento (...), op. cit., págs. 135 a 153; OLLER RUBERT, M., "El procedimiento de contratación pública como garantía de la transparencia", en la obra colectiva Derecho administrativo de la información y administración transparente, Marcial Pons, Madrid, 2010, págs. 261 a 266; MORENO MOLINA, J. A., "El sometimiento de todos los contratos públicos a los principios generales de contratación", en la obra colectiva Liber amicorum Tomás-Ramón Fernández, Civitas - Thomson, Pamplona, 2012, págs. 3429 - 3454 y CODINA GARCÍA-ANDRADE, X., "La doctrina de las obligaciones positivas del Tratado en la contratación pública", $R E D E$ $\mathrm{n}^{\mathrm{o}}$ 50, abril-junio 2014, págs. $73-101$. 
prudencia del TJUE, los principios de igualdad de trato, no discriminación, reconocimiento mutuo, proporcionalidad y transparencia constituyen la base de las Directivas de la Unión en materia de procedimientos de adjudicación de contratos públicos - como señala el citado considerando primero de la Directiva 2014/24/UE - y, volvemos a insistir, en que son de aplicación a todos los contratos que tengan un interés transfronterizo, aun cuando éstos se encuentren excluidos del ámbito de aplicación de las Directivas por razón de su objeto o de su cuantía ${ }^{322}$.

Los principios del TFUE aplicables a la contratación pública son el principio de concurrencia, de igualdad de trato, el principio de reconocimiento mutuo, el principio de proporcionalidad y el principio de transparencia ${ }^{323}$. Estos principios pueden considerarse, como acertadamente manifiestan GIMENO FELIÚ y MORENO MOLINA, el fundamento o la piedra angular sobre el que pivota todo el sistema de contratación pública a nivel europeo ${ }^{324}$, y por lo que

\footnotetext{
${ }^{322}$ Como trataremos a lo largo de esta memoria doctoral, el valor económico del contrato resulta determinante respecto de la aplicación de las Directivas sobre contratación pública, puesto que el legislador europeo ha optado expresamente por dejar al margen de la aplicación a aquellos contratos que sean inferiores a un determinado umbral económico, sin imponer, por tanto, ninguna obligación específica por lo que a ellos respecta, más allá del respeto a las normas del Derecho primario. Estos umbrales, así como su contravalor en las monedas nacionales de los Estados miembros cuya moneda no es el euro, se revisan cada dos años siguiendo un método puramente matemático establecido en las propias Directivas sobre contratación pública. La próxima revisión tendrá lugar a partir del 1 de enero de 2016.
}

${ }^{323}$ Sobre estos principios resulta de interés consultar el apartado 3.1 de la Comunicación interpretativa de la Comisión sobre las concesiones en el Derecho comunitario, de 12 de abril de 2000, pág. 14 (DOCE C 121, de 29 de abril de 2000, pág. 6).

${ }^{324}$ GIMENO FELIÚ, J. M ${ }^{\mathrm{a}}$., La nueva contratación pública europea y su incidencia en la legislación española (...), op. cit., pág. 56 "el principio de igualdad de trato es de tal relevancia que bien puede considerarse la piedra angular sobre la que se hace descansar las Directivas relativas a los procedimientos de adjudicación de contratos públicos" y MORENO MOLINA, J. A., Los principios generales de la contratación (...), op. cit., pág. 33 y del mismo autor "La influencia del Derecho (...)", op. cit., pág. 10 con cita expresa a la STJCE de 22 de junio de 1993, Comisión/Dinamarca «Storebaelt», C-243/89, en la cual el Tribunal de Justicia exponía en relación a la Directiva 71/305/CEE que, "si bien la Directiva no menciona expresamente el principio de igualdad de trato de los licitadores, no es menos cierto que el deber de respetar dicho principio responde a la esencia misma de la Directiva, que, según su noveno considerando, se propone, en particular, el desarrollo de una 
a esta memoria doctoral interesa, podemos afirmar que el régimen de las prohibiciones de contratar previsto por parte del Derecho derivado es consecuencia de la aplicación de estos principios, y la razón última por la cual los Estados miembros tienen la facultad de establecer, además de las causas de exclusión explícitamente recogidas en las Directivas, otras prohibiciones de contratar siempre que tengan por objeto garantizar la observancia de los principios de igualdad de trato, proporcionalidad y transparencia ${ }^{325}$.

\section{A. El principio de igualdad de trato}

El principio de igualdad de trato y de no discriminación, que actualmente se encuentra consagrado en el artículo 20 de la Carta de los Derechos Fundamentales, exige que no se traten de manera diferente situaciones comparables y que no se traten de manera idéntica situaciones diferentes, a no ser que esta disparidad se justifique objetivamente ${ }^{326}$.

De otra parte, el respeto del principio de igualdad de trato en el ámbito de la contratación pública tiene por objetivo favorecer el desarrollo de una

competencia efectiva en el sector de los contratos públicos". También en MORENO MOLINA, J. A. y PLEITE GUADAMILLAS, F., La nueva Ley de Contratos del Sector Público. Estudio sistemático, $3^{a}$ ed., La Ley, Las Rozas (Madrid), 2011. Por su parte, ESTEVES DE OLIVEIRA considera estos principios como el paraguas de la contratación pública, en ESTEVES DE OLIVEIRA. R., "Os princípios gerais da contratação pública", en la obra colectiva dirigida por COSTA GONÇALVES, P., Estudos de Contratação Pública I, Coimbra Editora, Coimbra, 2008, págs. 66 y 67.

${ }^{325}$ Los Estados miembros pueden fijar otros criterios de selección cualitativa que se añadan a los ya recogidos en las Directivas, siempre que no se basen en aspectos relativos a su aptitud profesional y respeten el principio de proporcionalidad. En este sentido se manifiestan las sentencias del Tribunal de Justicia de 16 de diciembre de 2008, Michaniki, C-213/07, apartados 43, 44 y 47; de 19 de mayo de 2009, Assitur, C538/07, apartados 20 y 21; de 15 de julio de 2010, Bâtiments y Ponts Construction, C-74/09, apartado 43; de 13 de diciembre de 2012, Forposta, C-465/11, apartado 38 y de 22 de octubre de 2015, Impresa Edilux y SICEF, C-425/14, apartado 41.

${ }^{326}$ Sentencias del TJCE de 19 de octubre de 1977, Ruckdeschel y otros, C-117/76 y 16/77, apartado 7; de 12 de julio de 2001, Jippes, C-189/01, apartado 129; de 10 de enero de 2006, IATA y ELFAA, C-344/04, apartado 95 y de 14 de septiembre de 2010, Akzo Nobel Chemicals y Akcros Chemicals/Comisión y otros, C-550/07 P, apartado 55 . 
competencia efectiva entre los operadores económicos en la adjudicación de un contrato que permita garantizar una comparación objetiva de las ofertas ${ }^{327}$. Como ya ha declarado el Tribunal de Justicia, el deber de respetar el principio de igualdad de trato responde a la esencia misma de las Directivas en materia de contratos públicos, que tienen por objeto, en particular, "favorecer el desarrollo de una competencia efectiva y enuncian los criterios de adjudicación del contrato tendentes a garantizar dicha competencia"328.

Para cumplir con tal finalidad se requiere cumplir con determinadas condiciones. Primera, que todos los interesados en dicha adjudicación dispongan de las mismas oportunidades en el momento de formular el contenido de sus ofertas; en segundo lugar, es preciso que éstas se sometan a las mismas condiciones de valoración para todos los licitadores y candidatos ${ }^{329}$; en tercer lugar, es necesario que todas las proposiciones sean conformes a las prescripciones del pliego de cláusulas administrativas particulares ${ }^{330} \mathrm{y}$, por último, no se puede descartar una oferta que reúna los requisitos del anuncio de licitación fundándose en motivos no previstos en el citado anuncio ${ }^{331}$. Además de ello, el respeto del principio de igualdad de trato implica no sólo la fijación de condiciones no discriminatorias para acceder a una actividad económica,

\footnotetext{
${ }^{327}$ Sentencia del TJUE de 10 de mayo de 2012, Comisión/Países Bajos, C-368/10, apartado 87 "el respeto de los principios de igualdad, no discriminación y transparencia exige que los criterios de adjudicación sean objetivos, lo que garantiza que la comparación y la evaluación de las ofertas se hagan de manera objetiva y, por tanto, en condiciones de competencia efectiva".

${ }^{328}$ En este sentido, las sentencias de 17 de septiembre de 2002, Concordia Bus Finland, C-513/99, apartado 81 y de 3 de marzo de 2005, Fabricom, C-21/03 y C-34/03, apartados 26 y 27.

${ }^{329}$ Sentencias del Tribunal de Justicia de 18 de octubre de 2001, SIAC Construction, C-19/00, apartado 34; de 12 de diciembre de 2002, Universale-Bau y otros, C-470/99, apartado 93 y de 13 de octubre de 2005, Parking Brixen, C-458/03, apartado 48.

${ }^{330}$ STJCE de 22 de junio de 1993, Comisión/Dinamarca «Storebaelt», C-243/89, apartado 37 "el respeto del principio de igualdad de trato de los licitadores exige que todas las proposiciones sean conformes a las prescripciones del pliego de cláusulas administrativas particulares, con el fin de garantizar una comparación objetiva entre las proposiciones presentadas por los diferentes licitadores".
}

${ }^{331}$ Sentencias de 14 de junio, Medipac - Kazantzidis, C-6/05, apartado 54 y de 16 de abril de 2015, C-278/14, Enterprise Focused, apartado 28. 
sino también que las autoridades públicas adopten las medidas necesarias para garantizar el ejercicio de dicha actividad ${ }^{332}$.

De esta exigencia de igualdad de trato y de la prohibición de discriminación por razón de nacionalidad se infiere, asimismo, una obligación de transparencia que consiste en asegurar, en beneficio de cualquier licitador potencial, una publicidad adecuada que permita exponer a una competencia real la adjudicación de los contratos públicos y que posibilite controlar la imparcialidad de los procedimientos de adjudicación para garantizar que no existen riesgos de favoritismos y/o arbitrariedades por parte de los órganos de contratación ${ }^{333}$.

A fin de concretar esa imparcialidad, y para asegurar de esta manera una adecuada selección del contratista, las Directivas sobre contratación pública establecen la facultad de excluir de la participación en un procedimiento de adjudicación a aquellos licitadores o candidatos que pueden distorsionar la competencia bien por formalizar acuerdos ilícitos entre ellos a fin de proceder a un reparto del mercado o a la fijación de precios («bid-rigging»), bien por vulnerar la igualdad de oportunidades al disfrutar de una posición de ventaja frente al resto de sus competidores, tal como ocurre, por ejemplo, en caso de haber obtenido información confidencial "que pueda conferirle ventajas indebidas en el procedimiento de contratación" o en el supuesto de aquellos licitadores que no han cumplido con el pago de las cotizaciones a la Seguridad Social, o con sus obligaciones tributarias ${ }^{334}$.

${ }^{332}$ STJCE de 7 de julio de 1992, Parlamento/Consejo, C-295/90, apartado 15, con cita expresa en la sentencia de 26 de febrero de 1992, Raulin, C-357/89, apartado 34 .

${ }^{333}$ Sobre este particular, cabe citar entre otras, las sentencias de 7 de diciembre de 2000, Telaustria y Telefonadress, C-324/98, apartados 61 y 62; de 29 de abril de 2004, Comisión/CAS Succhi di Frutta, C-496/99, apartado 111; de 13 de octubre de 2005, Parking Brixen, C-458/03, apartado 49; de 6 de abril de 2006, ANAV, C-410/04, apartado 21; de 13 de noviembre de 2008, Coditel Brabant, C-324/07, apartado 25; de 15 de octubre de 2009, Acoset, C-196/08, apartado 49.

${ }^{334}$ Artículo 57 de la Directiva 2014/24/UE y artículo 38 de la Directiva 2014/23/UE («concesiones»). Según indica el Informe Anual 2010 sobre la protección de los intereses financieros de la UE, la causa más frecuente para la exclusión de la participación en un procedimiento de adjudicación contractual es el impago de las cotizaciones sociales e impuestos recogidas en el artículo 45.2.letras e) y f) de la Directiva 2004/18/CE, COM (2011) 595 final, de 29 de septiembre de 2011, pág. 25. 
Esta última prohibición de contratar está recogida expresamente en las Directivas sobre contratación pública desde el inicio de su regulación (artículos 23.e) y f) de la Directiva 71/305/CEE y 20.e) y f) de la Directiva 77/62/CEE) y, como bien señalara la Abogado General Sra. Juliane KOKOT, "se trata de evitar que, en detrimento del interés general, «ovejas negras» que, por ejemplo, no paguen sus impuestos y cotizaciones a la seguridad social, acaben presentado ofertas más ventajosas que sus competidores y que de esa manera consigan contratos públicos usando métodos desleales, máxime cuando esos contratos se financian normalmente con ingresos fiscales" ${ }^{335}$.

Asimismo, y como apuntábamos anteriormente, los Estados miembros en atención a este principio están facultados para incorporar a sus normativas nacionales otras causas de exclusión, además de las previstas en las Directivas, siempre que éstas tengan por objeto garantizar el cumplimiento del principio de igualdad de trato entre todos los licitadores, puesto que, según ha manifestado el TJUE, son los Estados miembros los que mejor pueden determinar, a la luz de sus propias consideraciones históricas, jurídicas, económicas o sociales, las situaciones más proclives a la aparición de comportamientos que pueden suponer un menoscabo del principio de igualdad de trato y de la obligación de transparencia ${ }^{336}$. Ésta es, por ejemplo, la situación que se produce si concurre en el licitador alguna de las incompatibilidades o conflictos de intereses previstos en la normativa nacional y que, de existir, pudiera comprometer la imparcialidad en la elección del contratista y, con ello, quebrantar la compe-

\footnotetext{
${ }^{335}$ Conclusiones de la Abogado General Sra. KOKOT presentadas el 15 de abril de 2010 en el asunto Bâtiments y Ponts Construction, C-74/09, apartado 50. CADEMARTORI considera que las causas de prohibición de contratar por no cumplir el licitador o candidato con sus obligaciones fiscales y con la Seguridad Social son un buen ejemplo de barreras artificiales innecesarias en la regulación de contractual al no guardar una razonable relación con los elementos del contrato, CADEMARTORI, D., Buena administración y procedimientos de selección (...), op. cit., pág. 263.

${ }^{336}$ A este respecto véanse las conclusiones del Abogado General Sr. M. POIARES MADURO presentadas el 8 de octubre de 2008, en el asunto Michaniki, C-213/07, apartado 23, donde asegura que "debe admitirse que los Estados miembros pueden establecer casos de exclusión distintos de los que figuran en la lista del artículo 24 de la Directiva 93/37, siempre que sea necesario para prevenir eventuales conflictos de intereses y, por lo tanto, para garantizar la transparencia y la igualdad de trato". Sobre esta causa de prohibición de contratar nos remitimos a lo dicho en el Capítulo primero (págs. 148 y ss.).
} 
tencia deseable entre los operadores económicos ${ }^{337}$.

Este margen de apreciación que tienen los Estados miembros para prever causas de prohibición de contratar distintas de las recogidas en las Directivas sobre contratación pública requiere, sin embargo, de una interpretación restrictiva en atención a otro de los principios generales del Derecho de la Unión, el principio de proporcionalidad.

\section{B. El principio de proporcionalidad}

El principio de proporcionalidad, que como hemos indicado forma parte de los principios generales del Derecho de la Unión, exige que toda medida que se adopte para aplicar una disposición europea debe ser apta para alcanzar el objetivo previsto y no vaya más allá de lo necesario para alcanzarlo. A su vez que, cuando exista la posibilidad de elegir entre varias medidas adecuadas, deberá recurrirse a la menos gravosa y que las desventajas ocasionadas no deben ser desproporcionadas con respecto a los objetivos perseguidos ${ }^{338}$.

Este principio se recoge en el artículo 5.4 TUE por el cual "En virtud del principio de proporcionalidad, el contenido y la forma de la acción de la Unión no excederán de lo necesario para alcanzar los objetivos de los Tratados". Sin embargo, no debe aplicarse únicamente a la acción propia de las instituciones europeas, sino también a los Estados miembros en su ámbito de actuación, aun cuando éstos dispongan de un amplio margen de actuación discrecional ${ }^{339}$.

\footnotetext{
${ }^{337}$ Sobre la consideración de este principio como uno de los principios generales del Derecho de la Unión se pronuncian, entre otras, las sentencias del Tribunal de Justicia de 14 de julio de 2005, Países Bajos/Comisión, C-180/00, apartado 103; de 8 de julio de 2010, Afton Chemical, C-343/09, apartado 45 y de 21 de julio de 2011, Etimine SA, C-15/10, apartado 124.

${ }^{338}$ Sobre la consideración de este principio como uno de los principios generales del Derecho de la Unión se pronuncian, entre otras, las sentencias del Tribunal de Justicia de 14 de julio de 2005, Países Bajos/Comisión, C-180/00, apartado 103; de 8 de julio de 2010, Afton Chemical, C-343/09, apartado 45 y de 21 de julio de 2011, Etimine SA, C-15/10, apartado 124.

${ }^{339}$ MORENO MOLINA, J. A., Los principios generales (... ), op. cit., págs. 66 y 67, y GIMENO FELIÚ, J. Ma ., La nueva contratación pública europea y su incidencia en la legislación (...), op. cit., págs. 61 y 62. Sobre este principio también resulta de interés CARLÓN RUIZ, M., "El principio de proporcionalidad", en la obra colectiva
} 
En el contexto de la contratación pública, y concretamente referido a la selección del contratista, este principio presenta dos vertientes. La primera se refiere a que un Estado miembro, si quiere ajustarse a los parámetros de legalidad impuestos para el efectivo cumplimento de las libertades de la Unión, no debe exigir a los licitadores y candidatos unas cualidades profesionales relativas a sus capacidades o solvencia que resulten desproporcionadas en relación con el objeto contractual ${ }^{340}$. La segunda alude a la calificación de las prohibiciones de contratar como medida restrictiva del derecho a participar en un procedimiento de adjudicación que, como tal, exige que una interpretación estricta de las circunstancias que determinan las causas legales de prohibición de contratar para no ir más allá de lo necesario para alcanzar el objetivo de seleccionar al mejor contratista. Asimismo, para garantizar el cumplimiento del principio de proporcionalidad, el órgano de contratación al pronunciarse sobre la exclusión del operador económico y fijar la duración de la prohibición de contratar, debiera tener en consideración aspectos tales como la gravedad de los hechos, su impacto, el tiempo transcurrido desde la comisión de la infracción, su reiteración, o la intención o el grado de negligencia mostrado por el operador económico.

Además, para no infringir el principio de proporcionalidad, los requerimientos de pruebas y de información a los operadores económicos no pueden implicar una excesiva carga burocrática que llegue de facto a obstaculizar, disuadir o hacer menos atractivo el ejercicio de las libertades fundamentales, puesto que los artículos 49 TFUE y 56 TFUE se oponen a cualquier medida nacional de este tipo, aun cuando sea impuesta sin discriminación alguna por razón de la nacionalidad al aplicarse también a los propios nacionales ${ }^{341}$.

Los principios jurídicos del Derecho Administrativo, La Ley, (Las Rozas) Madrid, 2010, concretamente las págs. 209 a 215 que se refieren específicamente al principio de proporcionalidad.

${ }^{340} \mathrm{El}$ apartado 29 de la STJUE 22 de octubre de 2015, Impresa Edilux y SICEF, C$425 / 14$, en relación a un motivo de exclusión de un procedimiento de adjudicación dice así: "conforme al principio de proporcionalidad, que constituye un principio general del Derecho de la Unión, tal medida no debe ir más allá de lo necesario para alcanzar el objetivo perseguido".

${ }^{341}$ Esta aseveración debe ponerse en relación con el ejercicio de la libertad de establecimiento y de circulación de servicios, pues recordemos que según reiterada jurisprudencia del Tribunal de Justicia, se consideran restricciones a la libertad de 
Así pues, sería necesario determinar si las pruebas documentales exigidas al operador económico están justificadas o si resultan excesivas.

\section{El principio de concurrencia}

Como venimos señalando desde el inicio de esta memoria doctoral, la apertura de los contratos públicos a la competencia es uno de los objetivos principales de la normativa europea en esta materia. Así, se garantiza la facultad de participar en el procedimiento de adjudicación a todos los que - a la vista de los requisitos previstos en un anuncio de licitación - se consideren aptos para garantizar la ejecución del contrato ${ }^{342}$.

Ahora bien, las restricciones a dicha concurrencia pueden estar justificadas por razones de interés general y, en este sentido, dado que las prohibiciones de contratar constituyen una restricción a una participación lo más amplia posible de licitadores en una licitación - lo que se entiende como «favor participationis» - es preciso comprobar si cumplen, o no, con los objetivos propuestos.

establecimiento y a la libre prestación de servicios todas las medidas que "prohíban, obstaculicen o hagan menos interesante el ejercicio de dichas libertades". Véase, entre otras, las sentencias de 25 de julio de 1991, Säger, C-76/90, apartado 12; de 14 de octubre de 2004, Comisión/Países Bajos, C-299/02, apartado 15; de 18 de noviembre de 2010, Comisión/Portugal, C-458/08, apartado 83 y de 26 de septiembre de 2013, Texdata Software, C-418/11, apartado 64.

Por su parte, CARLÓN RUIZ señala que "el principio de proporcionalidad comunitario juega un papel fundamental a la hora de valorar si pueden estar justificadas las medidas adoptadas por los Estados miembros que resulten restrictivas de las libertades comunitarias", en "El principio de proporcionalidad", en la obra colectiva Los principios jurídicos (...), op. cit., pág. 213. En este mismo sentido, resultan de interés las observaciones de VIANA, C.. Os Princípios Comunitarios (...), op. cit., págs. 165 y siguientes, así como las de Tomás DE LA QUADRA-SALCEDO acerca del ejercicio de la libertad de establecimiento y de servicios en "Libertad de establecimiento y de servicios: ¿Reconocimiento mutuo o país de origen?", REDA, núm. 146, abril - junio 2010, págs. 221 - 263. También la obra colectiva dirigida por VICENTE BLANCO, D. J. y RIVERO ORTEGA, R., Impacto de la transposición de la Directiva de Servicios en Castilla y León, Colección de Estudios del Consejo Económico y Social de Castilla y León, núm. 13, Valladolid, 2010.

${ }^{342}$ Véase las sentencias del TJUE de 23 de diciembre de 2009, CoNISMa, C-305/08, apartado 42; de 18 de diciembre de 2014, Data Medical Service, C-568/13, apartado 35 y 6 de octubre de 2015, Consorci Sanitari del Maresme, C-203/14, apartado 34. 
En particular, en las prohibiciones de contratar corresponde buscar el difícil equilibrio entre: (i) garantizar el interés del órgano de contratación en no contratar con quienes, en atención a su comportamiento, no son merecedores de la debida confianza; (ii) tutelar el cumplimiento del principio de igualdad a la hora de aplicar tales prohibiciones y, por último, (iii) asegurar que no van más allá de lo necesario para cumplir con las finalidades previstas en las Directivas a fin de eliminar las restricciones a la competencia y velar por las libertades fundamentales establecidas en los Tratados.

En este orden de cosas, las actuales Directivas sobre contratación pública contienen una enumeración exhaustiva de las causas por las cuales un licitador o candidato debe, en unos casos, y puede en otros ser excluido de un procedimiento de licitación (artículo 38 de la Directiva 2014/23/UE («concesiones»), en el artículo 57 de la Directiva 2014/24/UE y en el artículo 80 de la Directiva 2014/25/UE («sectores especiales»). Estas causas, que se refieren a la honestidad profesional, a la solvencia y a la fiabilidad de quienes pretenden llegar a ser contratistas cumplen, a juicio de las instituciones europeas, con el cometido de mediar entre el principio de concurrencia y el interés por evitar que se adjudiquen contratos públicos a aquellos operadores económicos que se encuentren en determinadas situaciones consideradas contrarias al interés general ${ }^{343}$. Por tanto, y en un principio, cualquier otra restricción al principio de libre concurrencia estaría vedada por la normativa sobre contratación pública.

El establecimiento, por parte de las normativas nacionales de los Estados miembros, de otras prohibiciones de contratar distintas de las previstas en las Directivas, sólo es posible para asegurar que se respete el principio de transparencia y la igualdad de trato entre todos los licitadores y siempre que, habida cuenta del principio de proporcionalidad, estas nuevas prohibiciones se concilien con la exigencia de no ir más allá de lo necesario para alcanzar el objetivo de garantizar la aplicación de dichos principios.

En efecto, en la medida en que la exclusión de la participación en un pro-

\footnotetext{
${ }^{343}$ Véase, en este sentido, el apartado 33 de la sentencia del TJUE de 10 de julio de 2014, Consorzio Stabile, C-358/12, al señalar que "un impago de cotizaciones de seguridad social por un operador económico tiende a indicar la falta de fiabilidad, de diligencia y de seriedad de éste por lo que respecta al cumplimiento de sus obligaciones legales y sociales".
} 
cedimiento de adjudicación contractual constituye una restricción al ejercicio de un derecho, debe recordarse que, cuando un Estado miembro establece nuevas prohibiciones de contratar se encuentra obligado a respetar el principio de proporcionalidad, que exige que estas prohibiciones no constituyan una intervención desmesurada e intolerable que afecte a la esencia misma del derecho al acceso a la contratación pública.

A esta conclusión llega el Tribunal de Justicia en sus sentencias Michaniki, Assitur e Impresa Edilux Srl ${ }^{344}$. En la sentencia Michaniki, el TJUE concluye que: "el Derecho comunitario debe interpretarse en el sentido de que se opone a una disposición nacional que, en aras de la consecución de los objetivos legítimos de igualdad de trato entre los licitadores y de transparencia en los procedimientos de adjudicación de los contratos públicos, establece una presunción absoluta de incompatibilidad entre la condición de propietario, socio, accionista principal o directivo de una empresa activa en el sector de los medios de comunicación y la condición de propietario, socio, accionista principal o directivo de una empresa a la que el Estado o una persona jurídica del sector público en sentido amplio confía la ejecución de contratos de obras, suministros o servicios".

Por su parte, en la sentencia Assitur manifiesta que "el Derecho comunitario se opone a una disposición nacional que, a pesar de perseguir objetivos legítimos de igualdad de trato de los licitadores y de transparencia en el marco de los procedimientos de adjudicación de contratos públicos, establece una prohibición absoluta de participar de manera simultánea y en competencia en una misma licitación a aquellas empresas entre las que exista una relación de control o que estén vinculadas entre sí, sin dejarles la posibilidad de demostrar que dicha relación no ha influido en su comportamiento respectivo en el marco de dicha licitación".

En su sentencia Impresa Edilux Srl, el Tribunal de Justicia vuelve a manifestarse contrario a las prohibiciones de contratar automáticas que van más allá de lo necesario para prevenir los comportamientos colusorios en la contratación. Así, entiende que una presunción iuris et de iure de interferencia

\footnotetext{
${ }^{344}$ Sentencias de 16 de diciembre de 2008, Michaniki, C-213/0\%; de 19 de mayo de 2009, Assitur, C-538/07 y de 22 de octubre de 2015, Impresa Edilux y SICEF, C-425/14.
} 
recíproca en las ofertas presentadas para un mismo contrato público por empresas vinculadas, sin ofrecerles la oportunidad de demostrar lo contrario, "es contraria al interés de la Unión de garantizar que la participación de los licitadores en la licitación sea lo más amplia posible".

\section{El principio de seguridad jurídica}

El principio de seguridad jurídica constituye otro de los principios fundamentales del Derecho de la Unión que exige que todo acto de la Unión, en particular si impone o permite la imposición de sanciones o medidas restrictivas, debe ser claro y preciso, para que las personas afectadas puedan conocer sin ambigüedad los derechos y obligaciones que nacen de esa resolución y, en consecuencia, tomar las medidas que consideren oportunas ${ }^{345}$.

En el contexto que ahora nos ocupa, el principio de seguridad jurídica lo relacionamos, en primer lugar, con el hecho de requerir la firmeza de la resolución administrativa o sentencia que habilita una prohibición de contratar, ya que, evidentemente, el carácter firme contribuye a la seguridad, además de garantizar la presunción de inocencia y, vinculado a ello, con el principio de tutela judicial efectiva de los derechos que el ordenamiento de la Unión confiere a los operadores económicos, por cuanto existen una serie de garantías procesales aplicables en el momento de adoptar una prohibición de contratar.

Estas garantías incluyen, entre otros aspectos, las siguientes:

- Al margen de los supuestos de prohibición de contratar como consecuencia de la aplicación de una sentencia judicial o resolución administrativa previa, la prohibición de contratar ha de imponerse tras un procedimiento administrativo en el que se valoren los hechos o comportamientos que constituyen la causa de prohibición de contratar para determinar su existencia y, en su caso, establecer la duración de la misma. Asimismo, y como trataremos posteriormente, el operador económico podría aportar pruebas de que ha adoptado medidas "para demostrar su fiabilidad

\footnotetext{
${ }^{345}$ En este sentido, véase las sentencias de 13 de febrero de 1996, Van es Douane Agenten, C-143/93, apartado 27; de 14 de abril de 2005, Bélgica/Comisión, C110/03, apartado 30 y de 23 de octubre de 2012, Nelson y otros, C-581/10 y C$629 / 10$, apartado 66 .
} 
pese a la existencia de un motivo de exclusión pertinente" (artículo 57.6 de la Directiva 2014/24/UE y artículo 38.9 de la Directiva 2014/23/UE («concesiones»).

- Debe garantizarse la aplicación de unos plazos de prescripción, para que no se socaven, en su conjunto, la efectividad y el carácter disuasorio de las prohibiciones de contratar.

- Existe un deber para el poder adjudicador de motivar la resolución de prohibición de contratar y ésta deber ser lo suficientemente clara para permitir al operador económico utilizar las vías de recurso a su alcance para impugnar la validez de dicha decisión.

- Los operadores económicos tienen la posibilidad de interponer los recursos (administrativos o judiciales) que consideren pertinentes contra la resolución de prohibición de contratar, pues aunque corresponda al ordenamiento jurídico interno de cada Estado miembro regular las acciones dirigidas a garantizar la salvaguardia de los derechos de los operadores económicos, éstos deben quedar garantizados por la aplicación de las Directivas de recursos ${ }^{346}$.

- En este sentido, hay que hacer constar que la anulación posterior de una resolución de prohibición de contratar no implica automáticamente el reconocimiento de una indemnización por los daños y perjuicios ocasionados al operador económico. Así, sólo tendrá derecho a dicha indemnización cuando la imposición de la prohibición de contratar se haya efectuado de manera no "razonada y razonable"347.

\footnotetext{
${ }^{346}$ Directiva 89/665/CEE del Consejo, de 21 de diciembre de 1989, relativa a la coordinación de las disposiciones legales, reglamentarias y administrativas referentes a la aplicación de los procedimientos de recurso en materia de adjudicación de los contratos públicos de suministros y de obras, en su versión modificada por la Directiva 2007/66/CE. Véase lo dicho por el TJUE en su sentencia de 4 de julio de 2013, Fastweb, C-100/12.

${ }^{347} \mathrm{~A}$ este respecto, hemos de destacar la sentencia de nuestro Tribunal Supremo de 17 de marzo de 2015 (RJ 2015\1956).
} 


\section{La evolución de la normativa de la Unión Europea sobre contratación pública: De la primera a la cuarta generación de Directi- vas}

La apertura efectiva de la contratación pública para la realización de un mercado común en el ámbito de los contratos públicos era un imposible desde la exclusiva aplicación de los principios generales establecidas en el Tratado $\mathrm{CEE}^{348}$. Por ello, era necesario que, mediante disposiciones de Derecho derivado, se establecieran unas reglas que al ser transpuestas a los Derechos nacionales, asegurasen unas condiciones de igualdad en la participación de los contratos públicos y garantizasen, en definitiva, la efectividad de los principios y derechos reconocidos por el TCEE ${ }^{349}$.

Este cometido no fue factible en un primer momento, si bien los primeros pasos se dieron con la aprobación, en diciembre del año 1961, del Programa General para la supresión de las restricciones a la libertad de establecimiento y el Programa General para la supresión de las restricciones a la libre prestación de servicios ${ }^{350}$. Estos dos Programas preveían la desaparición de todo

\footnotetext{
${ }^{348}$ PIÑAR MAÑAS califica de ingenuo el pretender que los preceptos del TCEE eran por sí solos suficientes para conseguir los objetivos de no discriminación, transparencia y objetividad que son imprescindibles para alcanzar la apertura de la contratación pública, en PIÑAR MAÑAS, J. L., "El sistema de garantías para la efectiva implantación (...)", op. cit., pág. 776, "El Derecho comunitario como marco de referencia (...)", op. cit., pág. 35 y también en "Origen y fundamentos del Derecho europeo de contratos públicos", en la obra colectiva dirigida por CASSAGNE, J.C., y RIVERO YSERN, E., La contratación pública, (vol. I), Hammurabi, Buenos Aires, 2006, pág. 281.

${ }^{349}$ Según el artículo 54.3.d) TCEE "El Consejo y la Comisión ejercerán las facultades que les atribuyen las disposiciones precedentes: d) eliminando aquellos procedimientos y prácticas administrativas que resulten de la legislación nacional o de acuerdos celebrados con anterioridad entre los Estados miembros, cuyo mantenimiento suponga un obstáculo para la libertad de establecimiento". De la necesidad de garantizar la aplicación de las disposiciones del TCEE trata en sus primeros apartados el Vademécum sobre los contratos públicos en la Comunidad, elaborado por la Comisión y publicado en el DOCE C 358, de 31 de diciembre de 1987.
}

${ }^{350}$ En el TCEE ya se preveía la aprobación de estos Programas, concretamente en 
trato discriminatorio por razón de nacionalidad en materia de establecimiento y de prestación de servicios y declaraban que sus beneficiarios tenían derecho "a presentar ofertas o participar como contratante o subcontratista en los contratos del Estado o de otras personas jurídicas de Derecho público". En consecuencia indicaban que constituían restricciones incompatibles con el Derecho comunitario "las disposiciones y prácticas que, con relación solamente a los extranjeros, excluyan, limiten o subordinen a condiciones" la facultad de ejercer este derecho (Título III A, párrafo 3, letra b) en ambos Programas) ${ }^{351}$.

Al referirse expresamente al ámbito de la contratación pública, estos Programas pueden considerarse el precedente inmediato de la intervención comunitaria en esta materia, y ello a pesar de su transitoriedad y de la falta de eficacia vinculante para los Estados miembros, pues únicamente vinculaban a las instituciones europeas en la medida en que se trataba de programas de acción que debían ser puestos en práctica a través de directivas ${ }^{352}$. Aun con

el artículo 54.1 respecto del Programa General para la supresión de las restricciones a la libertad de establecimiento y en el artículo 63.1 en relación con el Programa General para la supresión de las restricciones a la libre prestación de servicios "(...) el Consejo, por unanimidad, a propuesta de la Comisión y previa consulta al Comité Económico y Social y a la Asamblea, establecerá un programa general para la supresión de las restricciones a la libertad de establecimiento/libre prestación de servicios existentes dentro de la Comunidad". Estos Programas se encuentran publicados en el DOCE núm. 2, de 15 de enero de 1962.

${ }^{351}$ Los beneficiarios de estos Programas eran los prestadores de servicios que bien sean nacionales de los Estados miembros establecidos en la Comunidad o bien sean empresas constituidas de acuerdo con la legislación de un Estado miembro y tengan su sede social, su administración central o su centro de actividad principal en la Comunidad. En el caso de la libertad de establecimiento los beneficiarios del Programa son, por una parte, los nacionales de los Estados miembros y de los países y territorios de Ultramar y también las empresas constituidas con arreglo a la legislación de un Estado miembro o de un país o territorio de Ultramar.

${ }^{352}$ Sobre estos Programas puede consultarse, CLIMENT BARBERÁ, J., "La selección de contratistas en los contratos de las Administraciones Públicas en el Derecho comunitario y en el Derecho español", Noticias CEE, núm. 21, octubre 1986, pág. 50; BORRAJO INIESTA, I., "Las Directivas sobre contratación pública (...), op. cit., pág. 42; SANTÍAS VIADA, J. A., LÓPEZ BLANCO C. y SANTAMARÍA DE PAREDES CASTILlO, V., El Derecho comunitario de la (...), op. cit., pág. 33; MORENO MOLINA, J.A., Contratos públicos: Derecho comunitario (...), op. cit., págs. 113 y 114; RAZQUIN LIZARRAGA, M. M ${ }^{\mathrm{a}}$., Contratos públicos (...), op. cit., pág. 40 y 41. También TURPIN, C., "Public contracts in the EEC", CMLR, 
todo, estos Programas delimitaban rasgos esenciales en la conformación de un mercado común y legitimaban a las instituciones para que interviniesen sobre los contratos públicos.

\section{III.1. Las primeras Directivas sobre contratación pú- blica}

La elección de la directiva como la disposición del Derecho derivado más pertinente para regular el sistema europeo aplicable a la adjudicación de contratos públicos proviene del propio TCEE que establece este mecanismo para disciplinar las cuestiones relacionadas con la libertad de establecimiento, con la libre circulación de servicios y con el funcionamiento del mercado común ${ }^{353}$, pero también se justifica en atención a la naturaleza de este acto jurídico.

Al optar por las directivas - que únicamente obligan al Estado miembro en cuanto al resultado ${ }^{354}$ - se deduce que por parte de las instituciones comuni-

vol. 9 (4) November, 1972, págs. 411 - 424 y TREPTE, P. A., Public Procurement in the EU: a Practitioner's Guide, Oxford University Press, Oxford, 2007, págs. 27 y 28 .

${ }^{353}$ Artículo 57, apartado 2 TCEE “(...) el Consejo, a propuesta de la Comisión y previa consulta de la Asamblea, adoptará, antes de la expiración del período transitorio, directivas para la coordinación de las disposiciones legales, reglamentarias y administrativas de los Estados miembros relativas al acceso y ejercicio de las actividades no asalariadas" y el artículo 100 TCEE "El Consejo adoptará por unanimidad, a propuesta de la Comisión y previa consulta al Parlamento Europeo y al Comité Económico y Social, directivas para la aproximación de las disposiciones legales, reglamentarias y administrativas de los Estados miembros que incidan directamente en el establecimiento o funcionamiento del mercado común".

${ }^{354}$ Artículo 288 TFUE (antiguo artículo 249 TCE) tercer apartado "La directiva obligará al Estado miembro destinatario en cuanto al resultado que deba conseguirse, dejando, sin embargo, a las autoridades nacionales la elección de la forma y de los medios". Una reiterada jurisprudencia del TJCE declara que la adaptación del Derecho interno a una directiva no exige necesariamente una reproducción formal y textual de sus disposiciones en una disposición legal específica, siendo suficiente la existencia de un contexto jurídico general, cuando éste garantiza efectivamente la plena aplicación de la directiva de forma suficientemente clara y precisa. A este respecto, las sentencias de de 7 de enero de 2004, Comisión/España, C-58/02, apartado 26 y de 9 de septiembre de 1999, Comisión/Alemania, C-217/97, apartado 31. 
tarias no se valoró la posibilidad de llevar a cabo una unificación jurídica en la contratación pública, sino únicamente una aproximación legislativa entre los distintos ordenamientos nacionales ${ }^{355}$.

La heterogeneidad de regímenes jurídicos que regulaban los contratos públicos en los Estados miembros hacía difícil articular un régimen común para todos ellos ${ }^{356}$. Este hecho, unido a la resistencia que mostraban en eliminar de su legislación contractual las prácticas proteccionistas que favorecían a sus nacionales ${ }^{357}$, impidió la adopción de un marco legislativo comunitario en materia de contratación pública hasta la década de los años setenta, es decir, más de diez años después de la entrada en vigor del Tratado de Roma.

${ }^{355}$ BRUNELLI, P., Marchés publics et Union européenne: nouvelles règles communautaires, Ed. Continent Europe, Paris, 1995, pág. 15 y DIRICKX, N., Línfluence du Droit Communautaire des marchés publics sur les éléments de définition du marché public en France, Atelier National de reproduction des thèses, Lille, 2005, pág. 18.

${ }^{356} \mathrm{El}$ TCEE únicamente contenía un mandato de coordinación, y no de unificación, lo que permitía a los Estados miembros mantener ciertas particularidades nacionales derivadas de su propia concepción de la figura del contrato público. Estas diferencias - como nos recordaba BASSOLS COMA - presentaban connotaciones específicas más allá de la tradicional bipolaridad entre los países del common law y del régimen administrativo, pues dentro de los países del régimen administrativo puede distinguirse, a su vez, aquellos que admiten la sustantividad de los contratos administrativos, sometidos a una disciplina exorbitante del Derecho común y al control de la jurisdicción contencioso-administrativa, y la de aquellos otros que de manera absoluta o con modulaciones singulares remiten la regulación sustantiva y jurisdiccional al Derecho común (civil o mercantil), en BASSOLS COMA, M., "Aproximación a la normativa comunitaria europea (...)", op. cit., pág. 28.

Sobre la existencia de distintas posturas acerca de la posibilidad de diseñar un bloque uniforme de normas con aplicación en todos los Estados miembros, véase OJEDA MARÍN, A., "La Comunidad Europea y el GATT en el moderno sistema de contratación pública", RAP, núm. 116, mayo - agosto 1988, págs. 410 - 411. Acerca de los distintos regímenes de contratación pública en los Estados miembros, resulta de interés ARIÑO ORTIZ, G., "Contrato del Estado y Common Law", EstudioPrólogo a la obra de MONEDERO GIL, J.I., Doctrina del Contrato del Estado, Instituto de Estudios Fiscales, Madrid, 1977, y en su Estudio introductorio a la obra Comentarios a la Ley de Contratos de las Administraciones Públicas, Granada, Comares, 2002, especialmente págs. 1 - 33.

${ }^{357}$ BASSOLS COMA, M., "Aproximación a la normativa (...)”, op. cit., pág. 29; PIÑAR MAÑAS, J. L., "El Derecho comunitario como marco (...)", op. cit., págs. 35 y 36; MEILÁN GIL, J. L., La estructura de los contratos públicos, Iustel, Madrid, 2008, pág. 95. 
No obstante, debe señalarse que en el año 1964 ya se habían adoptado distintas Directivas que, en ejecución de los Programas de supresión de restricciones anteriormente citados, establecían, en esencia, un sistema de reconocimiento mutuo de los certificados relativos a la capacidad técnica y profesional adquirida en el país de origen para buscar su eficacia y reconocimiento en otro Estado miembro, y que, en opinión de ARROWSMITH y TREPTE, prohibían imponer condiciones a los extranjeros en cuanto a la presentación de las ofertas o solicitudes de participación, ya sea como contratista o subcontratistas, en los contratos adjudicados por el Estado o las demás personas jurídicas de Derecho público $^{358}$.

Los aludidos textos son: la Directiva 64/427/CEE del Consejo, de 7 de julio de 1964, relativa a las modalidades de medidas transitorias en el ámbito de las actividades por cuenta propia de transformación correspondientes a las clases 23 - 40 de la CITI $^{359}$ (industria y artesanía); la Directiva 64/428/CEE del Consejo, de 7 de julio de 1964, relativa a la realización de la libertad de establecimiento y de la libre prestación de servicios en las actividades por cuenta propia de las industrias extractivas, clases 11 a 19 de la CITI (minería) y la Directiva 64/429/CEE del Consejo, de 7 de julio de 1964, relativa a la realización de la libertad de establecimiento y de la libre prestación de servicios en las actividades por cuenta propia de transformación correspondientes a las clases 23 a 40 de la CITI (industria y artesanía).

En ese contexto, estas Directivas se centraban en una serie de certifica-

${ }^{358}$ ARROWSMITH, S., The Law of public and utilities (...), op. cit., pág. $141 \mathrm{y}$ TREPTE, P. A., Public Procurement in the EU (...), op. cit., págs. 28 y 29. El primer considerando de la Directiva 71/304/CEE, nos recuerda que con arreglo a las Directivas 64/427/CEE y 64/429/CEE, las autoridades adjudicadoras no pueden imponer a las personas físicas o jurídicas de derecho privado a las que se adjudique un contrato ninguna discriminación por razón de la nacionalidad de los subcontratistas, en LÓPEZ-FONT MÁRQUEZ, J. F., "La apertura de los procedimientos nacionales de adjudicación de contratos públicos a las empresas de otros Estados miembros de la Unión Europea (Sentencia de 17 de noviembre de 1993 del Tribunal de Justicia de las Comunidades Europeas)", RAP, núm. 133, enero - abril 1994, pág. 313.

${ }^{359} \mathrm{La}$ abreviatura CITI se refiere a la nomenclatura de la clasificación internacional por industrias de todas las ramas de la actividad económica («Classification internationale type, par industrie, de toutes les branches dáctivité économique») (DOCE L 117, de 23 de julio de 1964). 
dos y documentos justificativos cuyo cometido consistía en probar de manera suficiente que se estaba en posesión de los conocimientos, las aptitudes y los requisitos necesarios para poder ejercer las actividades previstas en sus respectivos ámbitos de aplicación, es decir, actividades industriales y artesanales, o bien para ser titulares de derechos mineros.

Abundando en lo anterior, cuando para acceder a una de estas actividades o al ejercicio de las mismas, se exigía por parte del Estado miembro receptor una prueba de honorabilidad y/o la prueba de no haber sido declarado anteriormente en quiebra, se debía aceptar como prueba suficiente, respecto a los nacionales de los otros Estados miembros, la presentación de un certificado de antecedentes penales o, en su defecto, de un documento equivalente, expedido por la autoridad judicial o administrativa competente del país de origen o de procedencia, del que se infiriera el cumplimiento de dichas exigencias. Si en el país de origen o de procedencia no se expidiese el documento referido a la inexistencia de quiebra, se preveía que el mismo podría sustituirse por una declaración jurada hecha por el interesado ante la autoridad judicial o administrativa, un notario o un organismo profesional competente del país de origen o de procedencia.

En caso de que se debiera comprobar la solvencia económica y financiera en el Estado miembro receptor, se señalaba la equiparación de los certificados expedidos por los bancos del país de origen o de procedencia a los expedidos en su propio territorio. Asimismo, y en caso de tener que probar su capacidad técnica, se establecía un trato igualitario entre las actividades realizadas fuera de su territorio que las efectuadas en el suyo propio.

El único límite era de naturaleza temporal, puesto que los certificados y los documentos justificativos que se expidiesen en cumplimento de estas condiciones no podían tener, en el momento de su presentación, una fecha anterior a tres meses. Estas condiciones se señalan expresamente en los artículos 6 de la Directiva 64/428/CEE y en el artículo 7 de la Directiva 64/429/CEE:

"1. Cuando un Estado miembro receptor exija a sus nacionales, para el acceso a alguna de las actividades mencionadas en el artículo 2, una prueba de honorabilidad y de no haber sido declarados en quiebra anteriormente, o una sola de ellas, el Estado aceptará como prueba suficiente, respecto a los nacionales de los demás Estados 
miembros, la presentación de un certificado de antecedentes penales o, en su defecto, de un documento equivalente expedido por la autoridad judicial o administrativa competente del país de origen o de procedencia, del que se desprenda que se cumple dichas exigencias. 2. Cuando el país de origen o de procedencia no expida el mencionado documento, en relación con la inexistencia de quiebra, el documento podrá ser sustituido por una declaración jurada hecha por el interesado ante la autoridad judicial o administrativa, un notario o un organismo profesional competente del país de origen o de procedencia. 3. Los documentos que se expidan en cumplimiento de lo dispuesto en los apartados 1 y 2 no podrán, en el momento de su presentación, tener fecha anterior a tres meses. (...) 5. Siempre que la expedición de la autorización esté subordinada a la presentación de una prueba de capacidad técnica, el Estado miembro receptor concederá a las actividades realizadas fuera de su territorio un trato igual que el que da a las efectuadas en el suyo propio. Asimismo, cuando se haya de probar la solvencia financiera en el país receptor, éste equiparará los certificados expedidos por los bancos de país de origen o de procedencia a los expedidos en su propio territorio".

\section{A. Las Directivas de liberalización}

Al margen de las citadas Directivas, y siguiendo la estela de los objetivos de liberalización fijados por el TCEE y por los Programas generales, en los primeros años de la década de los años setenta se adoptaron las primeras Directivas referidas específicamente al ámbito de la contratación pública. Éstas se conocen con el sobrenombre de «Directivas de liberalización» en atención a los objetivos que persiguen ${ }^{360}$ y son la Directiva 70/32/CEE de la Comisión, de

\footnotetext{
${ }^{360}$ Las Directivas de liberalización se adoptaron en base a los artículos 33.7 y 54 del TCEE para la consecución de los objetivos señalados en su artículo 30 (supresión de las restricciones cuantitativas entre los Estados miembros), artículo 52 (libertad de establecimiento) y artículo 59 (libre prestación de servicios). Véase, BASSOLS COMA, M., "Aproximación a la normativa comunitaria europea (...)", op. cit., págs. 29 y 30; SANTÍAS VIADA, J. A., LÓPEZ BLANCO, C. y SANTAMARÍA DE PAREDES CASTILLO, V., El Derecho comunitario (...), op. cit., págs. 33 a
} 
17 de diciembre de 1969, sobre suministros de productos al Estado, a sus entes territoriales y a las personas jurídicas de Derecho Público ${ }^{361}$, y la Directiva 71/304/CEE del Consejo, de 26 de julio de 1971, relativa a la supresión de las restricciones a la libre prestación de servicios en el sector de los contratos administrativos de obras y a la adjudicación de contratos administrativos de obras por medio de agencias o sucursales ${ }^{362}$.

Su atención se concentraba en evitar todo trato discriminatorio entre los contratistas nacionales y los pertenecientes al resto de los países de la UE proporcionando a los Estados miembros unas pautas de actuación sobre qué prácticas y medidas podían considerarse contrarias a la libertad de establecimiento y de prestación de servicios. Es por ello que, su adopción supuso un importante avance respecto de la adjudicación de los contratos públicos en cuanto que preveían la supresión de las discriminaciones basadas en la nacionalidad y obligaban a los Estados miembros a eliminar de sus normativas nacionales aquellas restricciones, así como todas las medidas de efecto equivalente, que se refieran al acceso, la adjudicación, la ejecución o la participación en la ejecución de los contratos de suministro y de obras por cuenta del Estado, de los entes territoriales y de las personas jurídicas de Derecho público ${ }^{363}$.

38; MORENO MOLINA, J.A., Contratos públicos: Derecho comunitario (...), op. cit., págs. 113 a 117; FERNÁNDEZ MARTÍN, J.Mª., The EC Public (...), op. cit., págs. 4 a 29; TREPTE, P. A., Public Procurement in the EU (...), op. cit., págs. 28 a 30; ORDÓÑEZ SOLÍS, D., La contratación pública en la Unión (. . .), op. cit., pág. 53 y CARBONERO GALLARDO, J. M., La adjudicación de los contratos públicos. Procedimientos para la adjudicación de los contratos administrativos y otros contratos del sector público, La Ley - El Consultor de los Ayuntamientos y de los Juzgados, Las Rozas (Madrid), 2010, págs. 174 y 175.

${ }^{361}$ DOCE L 13, de 19 de enero de 1970.

${ }^{362}$ DOCE L 185, de 16 de agosto de 1971, pág. 129. Esta Directiva ha sido expresamente derogada por la Directiva 2007/24/CE del Parlamento Europeo y del Consejo, de 23 de mayo de 2007 (DOUE L 154, de 14 de junio de 2007, pág. 22).

${ }^{363}$ MOREnO MOLINA, J.A., Contratos públicos: Derecho (...), op. cit., págs. 115 y 116, respecto de la Directiva 70/32/CEE y LÓPEZ-FONT MÁRQUEZ, J. F., "La apertura de los procedimientos nacionales de adjudicación (...)", op. cit., págs. 313 y 314 respecto de la Directiva 71/304/CEE. Según SANTÍAS VIADA, J. A., LÓPEZ BLANCO, C. y SANTAMARÍA DE PAREDES CASTILLO, V., "las «Directivas de liberalización» desempeñan, a la vez, una importante función en la interpretación y aplicación de normas posteriores, de la Comunidad, de los Estados 
Con todo, y pese a garantizar las citadas libertades en el ámbito de los contratos públicos, estas Directivas no fijaban un régimen común en cuanto a los procedimientos de adjudicación contractual y ni siquiera definían las reglas para la participación de licitadores y candidatos en dichos procedimientos. De estos cometidos se encargarían las «Directivas de coordinación» ${ }^{364}$.

\section{B. Las Directivas de coordinación}

Conforme a lo anteriormente afirmado, la supresión de las restricciones a las libertades de establecimiento y de prestación de servicios establecidas en las Directivas de liberalización supuso un significativo avance en cuanto se referían al ámbito de los contratos públicos; pese a ello, se precisaba complementar estas medidas a fin de asegurar unas condiciones de igualdad en la fase de selección de los contratistas ${ }^{365}$.

No era suficiente con prohibir prácticas contrarias a los principios y a las libertades fundamentales porque, para hacerlos efectivos, se debían establecer también unas reglas a las que ajustar los procedimientos de adjudicación de los contratos públicos, de tal manera que, mediante la incorporación de su contenido a los ordenamientos jurídicos nacionales, se construyese un Derecho

miembros, cuando estos últimos transponen a sus legislaciones internas la normativa comunitaria e, incluso de las prácticas administrativas utilizadas en la contratación pública", en El Derecho comunitario de la contratación (...), op. cit., págs. 37 y 38.

También resaltan el valor interpretativo de la Directiva 71/304/CEE, el Vademécum sobre los contratos públicos en la Comunidad y ARROWSMITH, quien considera que la Directiva es únicamente pertinente para interpretar el Tratado CEE, en ARROWSMITH, S., The Law of public and utilities (...), $2^{\mathrm{a}}$ ed., op. cit., págs. 141 con cita expresa a la sentencia del TJCE de 14 de abril de 1994, Ballast Nedam Groep, C-389/92.

${ }^{364}$ En palabras de OJEDA MARÍN durante un primer momento la Comunidad quiso liberalizar y más tarde coordinar los diferentes regímenes de contratación, en OJEDA MARÍN, A., "Hacia un sistema de contratación (...), op. cit., pág. 831.

${ }^{365}$ BASSOLS COMA, M., "Aproximación a la normativa comunitaria europea (... )", op. cit., pág. 30; SANTÍAS VIADA, J. A., LÓPEZ BLANCO, C. y SANTAMARÍA DE PAREDES CASTILLO, V., El Derecho comunitario de la contratación (... ), op. cit., pág. 38; MORENO MOLINA, J.A., Contratos públicos: Derecho (...), op. cit., pág. 118 y MEILÁN GIL, J. L., La estructura de los (...), op. cit., pág. 95. 
común que fuera aplicable en todos los Estados miembros ${ }^{366}$.

Esta necesidad de coordinar la acción de los Estados miembros en materia contractual propició la adopción de dos Directivas: la Directiva 71/305/CEE del Consejo, de 26 de julio de 1971, sobre coordinación de los procedimientos de adjudicación de los contratos públicos de obras ${ }^{367}$ y la Directiva 77/62/CEE, de 21 de diciembre de 1976, sobre coordinación de los procedimientos de adjudicación de contratos públicos de suministro ${ }^{368}$.

El objetivo de estas Directivas, tal como indican sus enunciados, era coordinar los procedimientos nacionales para la adjudicación de los contratos públicos de obras y de suministro mediante la técnica de la aproximación legislativa, de manera que sus textos no contenían una regulación completa de las normas comunitarias en la materia ${ }^{369}$. Es por ello que, en el marco de las normas comunes

\footnotetext{
${ }^{366}$ En los primeros años de la década de los setenta, la entonces CEE estaba integrada por los seis Estados fundadores, es decir, Bélgica, Alemania, Francia, Italia, Luxemburgo y los Países Bajos; no obstante, recordemos que la adhesión de nuevos Estados supone que éstos acepten el acervo comunitario y que ajusten sus normativas nacionales a la legislación de la Unión, ya que sus disposiciones vinculan al Estado miembro desde el momento de su adhesión.
}

${ }^{367}$ DOCE L 185, de 16 de agosto de 1971, pág. 5. Esta Directiva fue modificada por la Directiva 72/277/CEE del Consejo, de 26 de julio de 1972, relativa a las modalidades y condiciones de publicación de los anuncios de contratos y de concesiones de obras públicas en el Diario Oficial de las Comunidades Europeas (DOCE L 176, de 3 de agosto de 1972, pág. 12) y por la Directiva 78/669/CEE del Consejo, de 22 de agosto de 1978, para determinar el importe estimado en unidades de cuenta de los contratos de obras públicas a los que dicha Directiva sería aplicable (DOCE L 225, de 16 de agosto de 1978).

${ }^{368}$ DOCE L 13, de 15 de enero de 1977. En el año 1977 ya formaban parte de la CEE Dinamarca, Irlanda y el Reino Unido que se habían integrado como Estados miembros en 1973.

${ }^{369}$ Según la sentencia del TJCE de 9 de julio de 1987, CEI y Bellini, 27/86 a 29/86, apartado 14 "El objetivo de la Directiva 71/305/CEE es garantizar que la realización efectiva en el interior de la Comunidad de la libertad de establecimiento y de la libre prestación de servicios en la adjudicación de los contratos públicos de obras suponga, a la vez que la eliminación de las restricciones, una coordinación de los procedimientos nacionales de adjudicación de los contratos públicos de obras. Esta coordinación debe respetar, en la medida de lo posible, los procedimientos y las prácticas en vigor en cada uno de los Estados miembros (segundo considerando de la Directiva). El artículo 2 prevé de modo expreso que los poderes adjudicadores (léase, 
que establecen, "los Estados miembros conservan su libertad para mantener o dictar reglas materiales y procesales en materia de contratos públicos, siempre que se respeten todas las disposiciones aplicables del Derecho comunitario y, concretamente, las prohibiciones que derivan de los principios consagrados por el Tratado en materia de derecho de establecimiento y de libre prestación de servicios" $" 370$.

$\mathrm{Ni}$ en este primer momento de la regulación de la contratación pública, ni tampoco posteriormente, se proyectó unificar todas las disposiciones de los Estados miembros en materia de contratación pública, puesto que estas Directivas estaban principalmente diseñadas para armonizar la fase de preparación y adjudicación de los contratos públicos de obras y suministro.

Por lo tanto, y según se desprende de sus considerandos, pretendían desarrollar una competencia efectiva en dichos sectores mediante la prohibición de aquellas especificaciones técnicas que tuvieran un efecto discriminatorio, garantizando unas normas comunes en cuanto a la publicidad de los anuncios de los contratos realizados por los poderes adjudicadores de los distintos Estados miembros, elaborando un procedimiento que permitiera velar por el cumplimiento de los principios generales del Derecho de la Unión y, estableciendo idénticas condiciones de participación en estos contratos a través de criterios comunes para la selección del contratista.

De esta forma, bajo el título de «Criterios de selección cualitativa», estas Directivas señalan, por una parte, los supuestos en virtud de los cuales los poderes adjudicadores permitían excluir a un contratista y/o proveedor de la participación en la adjudicación de un contrato público de obras y suministro por causas relativas a su situación personal y profesional, así como la forma y los medios en que estos contratistas y proveedores podían aportar la prueba de que se ajustaban a dichos criterios (artículos 23 a 28 de la Directiva 71/305/CEE para el contrato de obras y artículos 20 a 24 de la Directiva

órganos de contratación) aplicarán sus propios procedimientos nacionales adaptados a las disposiciones de la Directiva".

${ }^{370}$ Sentencias del TJCE de 20 de septiembre de 1988, Beentjes, 31/87, apartado 20, y de 9 de julio de 1987, CEI y Bellini, 27/86 a 29/86, apartado 15, que al referirse a la Directiva $71 / 305 / \mathrm{CEE}$, afirmaron que ésta no establecía una normativa uniforme y exhaustiva sobre los contratos públicos de obras. 
77/62/CEE para el contrato de suministro) ${ }^{371}$.

Estos criterios - a juicio de MESTRE DELGADO - podían ser calificados en tres grupos: los que se refieren a la capacidad económica y financiera; aquellos que atienden a la capacidad técnica, y por último, los que aluden a la «capacidad moral» de quien pretende ser contratista ${ }^{372}$.

Así, conforme a los artículos 23 de la Directiva 71/305/CEE (obras) y al artículo 20 de la Directiva 77/62/CEE (suministro) - en términos esencialmente idénticos - los criterios de exclusión aplicables a estos tipos contractuales se encuentran vinculados a la honestidad profesional, la solvencia y la fiabilidad de quien es licitador o candidato en un procedimiento de adjudicación contractual, a pesar de que la literalidad de estos artículos nos hable del contratista

${ }^{371}$ Como expone el Abogado General Sr. POIARES MADURO en sus conclusiones presentadas el 8 de octubre de 2008, en el asunto Michaniki, C-213/07, apartado 21 "el Tribunal de Justicia ha declarado que los artículos 17 a 25 de la anterior Directiva sobre contratos públicos de suministro, Directiva 77/62/CEE, enumeraban «exhaustiva e imperativamente» los criterios de selección cualitativa - entre los que figuraban, en su artículo 20, los vinculados a la honestidad profesional del candidato".

${ }^{372}$ MESTRE DELGADO utiliza la denominación de capacidad moral para referirse a una serie de criterios de exclusión que, según este autor, difícilmente se podrían aglutinar bajo otra categoría, puesto que aluden a los supuestos por los que un contratista ha sido condenado en sentencia con fuerza de cosa juzgada por cualquier delito que afecte a su moralidad profesional; que haya cometido una falta grave en materia profesional y que se le considere culpable de hacer falsas declaraciones al proporcionar las informaciones exigidas en la aplicación de estas Directivas. No obstante, manifiesta abiertamente que este concepto no le complace, en "La normativa comunitaria europea sobre contratación administrativa: una visión general", Noticias CEE, núm. 21, octubre 1986, págs. 60 y 61, especialmente en la nota al pie núm. 23. De capacidad moral hablan también otros autores como VINYOLES I CASTELLS, M., La adjudicación de los contratos públicos. La nueva Ley de Contratos de las Administraciones Públicas y normativa comunitaria, Civitas - Escola dÁdministració Pública de Catalunya, Madrid, 1995, pág. 39 y PARADA VÁZQUEZ que señala que la capacidad moral se asegura negativamente estableciendo determinadas prohibiciones de contratar, en PARADA VÁZQUEZ, R., Derecho Administrativo. Parte general, Tomo I, 19a ed., Marcial Pons, Madrid, 2012, pág. 252. En el Capítulo primero de esta memoria doctoral ya avanzábamos que nuestro Tribunal Supremo también utiliza la denominación de «capacidad moral» para referirse a estos mismos supuestos en sus sentencias de 24 de noviembre de 2004 (RJ 2004\8061); de 2 de febrero de 2005 (RJ 2005\1650), de 28 de marzo de 2006 (RJ 2006\5062), de 11 de julio de 2006 (RJ 2006\8471) y de 21 de marzo de 2007 (RJ 2007\4043). 
o proveedor ${ }^{373}$.

Atendiendo a su tenor, los criterios de exclusión que se recogen en estos artículos no tienen un carácter obligatorio para los Estados miembros, dado que el legislador de la Unión atribuye un amplio margen de discrecionalidad respecto de las prohibiciones de contratar que pueden recoger las legislaciones nacionales al utilizar la expresión «podrá ser excluido». De esta manera, y según lo dispuesto en los mencionados artículos, podrá ser excluido de la participación en un contrato de obras y suministro todo contratista/proveedor:

\footnotetext{
${ }^{373}$ Bajo el término contratista se designa a la persona física o jurídica que celebra un contrato con una entidad del sector público formalmente distinta de ella. En atención a esta definición, para hablar propiamente de contratista resulta necesario aguardar hasta el momento de la perfección del contrato con su formalización. No obstante, hasta la Directiva 2004/18/CE, va a resultar una constante que se siga empleando el término «contratista» para referirse a la persona que desea participar en un contrato público y que puede ser excluida de dicha participación por encontrarse incursa en alguna de las causas de prohibición de contratar.
} 
Artículo 23 Directiva 71/305/CEE (obras)

a) que se encuentre en estado de quiebra, de liquidación, de cese de actividades, de intervención judicial o de convenio con los acreedores, o en cualquier situación análoga a resultas de un procedimiento de la misma naturaleza que exista en las legislaciones y reglamentaciones nacionales;

b) que sea objeto de una declaración de quiebra, de intervención judicial, de convenio con los acreedores o de cualquier otro procedimiento de la misma naturaleza que exista en las regulaciones y legislaciones nacionales;

c) que haya sido condenado en sentencia con fuerza de cosa juzgada por cualquier delito que afecte a la moralidad profesional del contratista;

d) que haya cometido una falta grave en materia profesional, que pueda ser comprobada por algún medio que los poderes adjudicadores puedan justificar;

e) que no esté en regla con sus obligaciones relativas al pago de la cotización de la Seguridad Social, según las disposiciones legales del país en el que esté establecido o las del país del poder adjudicador;

f) que no esté en regla con sus obligaciones relativas al pago de sus impuestos y tasas según las disposiciones legales del país del poder adjudicador;

g) que se le considere culpable de hacer falsas declaraciones al proporcionar los informes exigidos en aplicación del presente capítulo.
Artículo 20 Directiva 77/62/CEE (suministro)

a) que se encuentre en estado de quiebra, de liquidación, de cese de actividades, de intervención judicial, de convenio con los acreedores, con sus actividades comerciales suspendidas, o que se encuentre en cualquier situación análoga a resultas de un procedimiento de la misma naturaleza que exista en sus respectivas legislaciones y regulaciones nacionales;

b) que sea objeto de un procedimiento de declaración de quiebra, de intervención judicial, de convenio con los acreedores o de cualquier otro procedimiento similar existente en sus respectivas legislaciones y regulaciones nacionales;

c) que haya sido condenado en sentencia con fuerza de cosa juzgada por cualquier delito que afecte a su moralidad profesional;

d) que haya cometido una falta grave en materia profesional que el poder adjudicador está en condiciones de probar por cualquier medio;

e) que no haya normalizado su situación en lo referente al pago de las cotizaciones de la seguridad social en cumplimiento de las normas legales del país en el que esté establecido o de las del poder adjudicador;

f) que no haya cumplido sus obligaciones relativas al pago de impuestos y tasas en cumplimiento de las disposiciones legales del país en el que esté establecido o de las del país del poder adjudicador;

g) que sea culpable de declaraciones falsas graves al proporcionar las informaciones exigidas en cumplimiento de lo dispuesto en el presente capítulo. 
Los primeros años de aplicación de estas Directivas se encuentran condicionados por distintos acontecimientos entre los que cabe destacar las difíciles circunstancias económicas de principios de los años setenta y la aprobación del Acuerdo sobre Compras del Sector Público, adoptado en el seno del Acuerdo General sobre Aranceles Aduaneros y Comercio (GATT), en 1979.

Es indudable que en el contexto de recesión económica surgido tras la crisis del petróleo de 1973, los Estados miembros percibieron la contratación pública como un instrumento de política económica y mostraron su inclinación en favorecer a sus nacionales en las compras públicas. Este hecho suponía un trato discriminatorio contrario al espíritu y a la letra de las Directivas sobre contratación pública ${ }^{374}$.

Los efectos de la crisis de 1973 también se dejaron sentir al omitirse la aplicación de las reglas relativas a la publicidad de las licitaciones, así como en la utilización abusiva de las excepciones al procedimiento abierto por motivos que no estaban realmente justificados. Si a estos hechos se añade que estas primeras Directivas no contenían disposiciones específicas que permitieran garantizar su aplicación y excluían de su ámbito de aplicación los contratos celebrados en los sectores del agua, de la energía, de los transportes y de las telecomunicaciones, causaba cierta consternación el constatar una falta de ejecución generalizada de la normativa comunitaria sobre contratación pública ${ }^{375}$.

${ }^{374}$ MARTÍN BURGOS habla de una escasa interpenetración de los mercados en el ámbito de la contratación pública puesto que los Estados miembros se mostraron más sensibles a los proveedores nacionales como consecuencia de la crisis económica, en MARTÍN BURGOS, J. A., "El Derecho comunitario y la contratación pública. Situación y perspectivas", Gaceta Jurídica de la CEE, núm. 59, 1989, págs. 3 y 4. Según datos que aportan DÍEZ MORENO, F. y LÓPEZ-IBOR MAYOR, V., "La contratación administrativa en la UE y el ordenamiento español", Política exterior, núm. 43 (IX), febrero-marzo 1995, pág. 147 "sólo uno de cada cuatro contratos celebrados por las Administraciones públicas se ajustaban a lo regulado por el legislador europeo". En el documento de la Comisión La apertura de los contratos públicos en la Comunidad, enero-febrero 1989, pág. 3 se indica que "sólo el $20 \%$ del total de los contratos públicos europeos estarían adjudicados conforme a las Directivas comunitarias".

${ }^{375}$ La explicación a esta falta de aplicación de las primeras Directivas sobre contratación pública la podemos encontrar en una serie de Comunicaciones de la Comisión relativas a la transposición de estas normas: COM (84) 717 final, de 14 de diciembre de 1984, la Comunicación La contratación pública en la Comunidad, COM (86) 375 
El segundo hecho importante en esta primera etapa de la normativa de la Unión sobre contratación pública viene dado por la aprobación del Acuerdo sobre Compras del Sector Público que fue suscrito en Ginebra el 29 de abril de 1979, que entró en vigor el 1 de enero de 1981 y, posteriormente, fue modificado el 2 de febrero de $1987^{376}$.

El objetivo de este Acuerdo era establecer un marco internacional en materia de derechos y obligaciones sobre la adjudicación de los contratos públicos con el fin de llevar a cabo una liberalización y una expansión del comercio en el sector de los suministros. El Consejo europeo, mediante su Decisión 80/271/CEE, de 10 de diciembre de 1979, aprobó en nombre de la CEE los Acuerdos multilaterales resultantes de las negociaciones comerciales de 19731979, entre los que se encontraba este Acuerdo. Ello suponía que las disposiciones de este Acuerdo eran aplicables también a las relaciones entre los Estados miembros e implicaba, por tanto, que la normativa comunitaria en vigor en aquel momento estaba obligada a incorporar a sus textos las disposiciones de este Acuerdo ${ }^{377}$.

Las modificaciones tuvieron lugar a través de la Directiva 80/767/CEE, de 22 de julio de 1980, que adapta y completa la Directiva 77/62/CEE, en lo que relativo a determinados poderes adjudicadores ${ }^{378}$ y la Directiva 88/295/CEE, de 22 de marzo de 1988, ya que este Acuerdo en su redacción original y después

final, de 10 de febrero de 1987 y en el Sexto Informe anual al Parlamento Europeo sobre el control de la aplicación del Derecho comunitario - 1988, COM (89) 411 final, de 21 de diciembre de 1989 (DOCE C 330, de 30 de diciembre).

${ }^{376} \mathrm{El}$ texto original se encuentra publicado en el DOCE L 71, de 17 de marzo de 1980 y el Protocolo de modificación en el DOCE L 345, de 9 de diciembre de 1987.

${ }^{377}$ Para profundizar en cuestiones generales relacionadas con este Acuerdo puede consultarse OJEDA MARÍN, A., "La Comunidad Europea y el GATT en el moderno sistema de contratación pública", RAP, núm. 116, mayo - agosto 1988, págs. 409 446; DÍEZ MORENO, F. y LÓPEZ-IBOR MAYOR, V., "La contratación administrativa en la UE (...)", op. cit., págs. 161 a 163; WIDMER, M. y DELBOS, M., "El nuevo acuerdo sobre la contratación pública del GATT", en la obra colectiva La contratación pública en los llamados sectores excluidos. Agua, Energía, Transportes y Telecomunicaciones, Civitas, Madrid, 1997, págs. 383 - 403 y ARROWSMITH, S. y ANDERSON R. (Eds.), The WTO Regime on Government Procurement: Challenge and Reform, Cambridge University Press, New York, 2011.

${ }^{378}$ DOCE L 215, de 18 de agosto de 1980. 
de su revisión en 1987, creaba condiciones más favorables para las empresas licitadoras que las previstas en la Directiva $77 / 62 / \mathrm{CEE}^{379}$.

\section{III.2. La segunda etapa de la normativa sobre contra- tación pública}

Como se ha destacado anteriormente, las carencias en la construcción de un mercado común de la contratación pública se evidenciaron a mediados de los años ochenta. Consciente, pues, de lo insatisfactorio de los resultados obtenidos hasta ese momento, la Comisión emprendió una segunda etapa en la normativa sobre contratación pública con el impulso indiscutible que para esta materia supuso la aprobación del Libro Blanco sobre la realización del Mercado interior en $1985^{380}$.

\section{A. El mandato del Libro Blanco para la realización del Mercado interior (1985)}

El Libro Blanco sobre la realización del Mercado interior planteó, de manera general, la necesidad de una estrategia decidida para la conclusión del objetivo de un mercado interior eliminando los obstáculos y las barreras ya fueran físicas, técnicas o fiscales que impedían su consecución ${ }^{381}$.

El Libro Blanco comenzaba diciendo que "conseguir la unidad de ese gran mercado (de 320 millones de consumidores) supone que los Estados miembros de la Comunidad lleguen a un acuerdo en lo que se refiere a la abolición de las barreras de cualquier naturaleza, la armonización de las normas, la apro-

\footnotetext{
${ }^{379}$ DOCE L 127, de 20 de mayo de 1988.

${ }^{380} \mathrm{El}$ Libro Blanco de la Comisión sobre la realización del Mercado interior fue aprobado en el Consejo Europeo de junio de 1985 celebrado en Milán, Completing the Internal Market: White Paper from the Commission to the European Council (Milan, 28-29 June 1985), COM (85) 310 final, de 14 de junio. Puede consultarse en: http://ec.europa.eu/white-papers/index_es.htm [Fecha de consulta: 20 de octubre de 2015].

${ }^{381}$ VIANA, C., Os Princípios Comunitários na Contratação (...), op. cit., págs. 329 y siguientes.
} 
ximación de las legislaciones y las estructuras fiscales, el reforzamiento de la cooperación monetaria y las medidas conexas necesarias para lograr la cooperación de las empresas europeas. Este proyecto está a nuestro alcance siempre que saquemos provecho de las enseñanzas del pasado y, en particular, de los fracasos y retrasos producidos. Por ello, la Comisión solicitará del Consejo Europeo que éste haga suyo el objetivo de la unificación total del mercado interior a más tardar en 1992 y que, a tal fin, apruebe un programa acompañado de un calendario realista y vinculante".

Dentro del apartado dedicado a la supresión de las barreras técnicas se incluía un epígrafe referido a la contratación pública (apartados 81 a 87) al entender la Comisión que, representando los contratos públicos una parte importante del PIB comunitario, la propensión de las autoridades públicas en mantener sus compras públicas en su propio país se apreciaba como una de las barreras más evidentes para la consecución de un verdadero mercado interior $(\text { apartado } 81)^{382}$.

Ratificando esta posición, tanto el Vademécum sobre los contratos públicos

\footnotetext{
${ }^{382}$ La importancia de la contratación pública como un elemento clave para lograr ese espacio sin fronteras interiores que conlleva el Mercado interior ha sido recordado en distintas ocasiones por el TJUE al señalar, por ejemplo, que "la coordinación comunitaria de los procedimientos de adjudicación de contratos públicos tiene por objeto suprimir las trabas a la libre circulación de servicios y de mercancías y, por tanto, proteger los intereses de los operadores económicos establecidos en un Estado miembro que deseen ofrecer bienes o servicios a las entidades adjudicadoras establecidas en otro Estado miembro" (Sentencias de 3 de octubre de 2000, University of Cambridge, C-380/98 y de 1 de febrero de 2001, Comisión/Francia C-237/99, apartados 41 y 42). Más cercano en el tiempo vuelve a ser objeto de interés la importancia del buen funcionamiento del mercado de contratación pública como parte esencial del Mercado interior "a fin de estimular la competencia transfronteriza, fomentar la innovación, promover una economía con bajas emisiones de carbono y alcanzar las mayores ventajas para las autoridades públicas", en la Resolución del Parlamento Europeo, de 18 de mayo de 2010, sobre nuevos aspectos de la política de contratación pública [P7_TA (2010) 0173], DOUE C 161E, de 31 de mayo de 2011, pág. 38. En parecido sentido, la STJUE de 19 de mayo de 2009, Assitur, C-538/07, apartado 25 nos recordaba que "las normas comunitarias relativas a la adjudicación de contratos públicos se adoptaron en el marco de la realización del mercado interior, en el que esté garantizada la libre circulación y se eliminen las restricciones de la competencia".
} 
en la Comunidad (1987) como el denominado Informe Cecchini en $1988^{383}$, volvían a incidir en el gran potencial que supone la contratación pública para el desarrollo del mercado interior en atención a su valor económico, pero también por razones vinculadas a la innovación y a la competitividad de las empresas europeas. Por todo ello, y a partir de ese momento, la apertura a la competencia de la contratación pública va a establecerse como una prioridad en la agenda comunitaria dentro de la estrategia de la realización del mercado interior con el horizonte puesto en el 31 de diciembre de 1992.

Así, en el marco de la política de contratación pública, las principales medidas adoptadas tras la publicación del citado Libro Blanco y la posterior modificación del TCEE por parte del Acta Única Europea ${ }^{384}$, pueden agruparse en torno a cuatro categorías:

1. Medidas destinadas a reformar las Directivas entonces vigentes;

2. El establecimiento de unos procedimientos de recurso en materia de adjudicación contractual para velar por el cumplimiento de las disposiciones sobre contratos públicos;

\footnotetext{
${ }^{383}$ Recordemos que el «Informe Cecchini» había cuantificado en unos 22.000 millones de ecus el beneficio previsto de un aumento de la apertura de la contratación pública si desaparecieran las "compras públicas protegidas nacionalmente". Este Informe añadía que "los costes de las prácticas de compras cerradas, casi herméticamente, son importantes y diversos. Por no alentar la competencia dentro de la CE - sino rechazarla deliberadamente - el sector público paga más de lo necesario por los bienes que precisa y, al hacerlo así, apoya a empresas subóptimas de la Comunidad", en The cost of Non-Europe in publicsector Procurement (Cap. 5). En septiembre de 2014 este Informe ha sido revisado The Cost of Non-Europe in the Single Market. 'Cecchini Revisited' An overview of the potential economic gains from further completion of the European Single Market y sus conclusiones avanzan en la idea del ahorro de conseguir un mercado único de contratos públicos (entre un $5 \%$ y un $8,6 \%$ del PIB europeo por año). http://www.europarl.europa.eu/RegData/etudes/STUD/2014/510981/EPRS_STU(2014)510981_REV1_EN.pdf [Fecha de consulta: 20 de octubre de 2015].

${ }^{384} \mathrm{El}$ Acta Única Europea fue suscrita el 17 de febrero de 1986 y entró en vigor después de la ratificación por parte de los Estados miembros el 1 de julio de 1987. Este texto incorporó el concepto de mercado interior al TCEE como ese espacio sin fronteras interiores, en el que la libre circulación de mercancías, personas, servicios y capitales está garantizada (DOCE L 169, de 29 de junio de 1987).
} 
3. Medidas para proceder a la apertura de la contratación pública en los sectores del agua, la energía, los transportes y las telecomunicaciones, y por último,

4. Medidas para incluir en la regulación de la contratación pública los contratos de servicios.

\section{A.1. Medidas destinadas a mejorar las Directivas entonces vigentes}

A finales del año 1986, la Comisión presentó ante el Consejo sendas propuestas de modificación de las Directivas 71/305/CEE y 77/62/CEE, relativas a los contratos públicos de obras y de suministro, con el objetivo de subsanar las deficiencias que presentaban estas Directivas en su redacción original y, de esta forma, lograr más transparencia en los procedimientos y asegurar una mayor concurrencia en las licitaciones intercomunitarias; sin embargo, en aquel momento no se contemplaba establecer un texto consolidado con las disposiciones aplicables a los contratos de obra y de suministro.

Las modificaciones tuvieron lugar a través de dos Directivas: La Directiva 88/295/CEE, de 22 de marzo de 1988, sobre contratos públicos de suministro, que además incorporaba al Derecho comunitario las modificaciones del Acuerdo sobre contratación pública del GATT de diciembre de 1986 y la Directiva 89/440/CEE, de 18 de julio de $1989^{385}$.

Estas Directivas aclaraban aquellos términos que provocaban confusión en la redacción original, como el concepto de contrato de suministro o de organismo de derecho público. Además de ello, incluyeron un nuevo procedimiento de adjudicación, el procedimiento negociado para designar la contratación directa; ampliaron los plazos para la presentación de las ofertas; se impusieron determinadas obligaciones estadísticas y se modificaron las normas sobre las

${ }^{385}$ Directiva 88/295/CEE del Consejo, de 22 de marzo de 1988, por la que se modifica la Directiva 77/62/CEE de coordinación de los procedimientos de adjudicación de contratos públicos de suministro y por la que se derogan determinadas disposiciones de la Directiva 80/767/CEE (DOCE L 127, de 20 de mayo de 1988) y la Directiva 89/440/CEE del Consejo, de 18 de julio de 1989, que modifica la Directiva 71/305/CEE sobre coordinación de los procedimientos de celebración de los contratos públicos de obras (DOCE L 210, de 21 de julio). 
especificaciones técnicas de los contratos en el sentido de convertir en obligatoria la referencia a normas técnicas europeas ${ }^{386}$.

Respecto de los candidatos y licitadores, se mantiene intacta la redacción de los artículos correspondientes a los motivos de exclusión de la participación en una licitación (artículo 23 Directiva 71/305/CEE y artículo 20 Directiva 77/66/CEE), si bien, se incorpora al texto de estas Directiva la obligación de poner en conocimiento de los candidatos o licitadores que hubieren sido rechazados, los motivos de la desestimación de su candidatura u oferta, así como que se levante acta sobre el desarrollo de cada procedimiento de adjudicación en el que se haga constar expresamente los nombres de los candidatos o licitadores excluidos y los motivos de su rechazo ${ }^{387}$.

Estas garantías conferidas por la normativa europea en relación con los procedimientos de adjudicación contractual revisten una gran importancia, ya que - como hemos señalado con anterioridad - el órgano de contratación al motivar sus decisiones relativas a la adjudicación del contrato, posibilita que los interesados conozcan las razones que, por ejemplo, han conducido a su exclusión del procedimiento, ofrece la posibilidad de que éstos puedan hacer valer sus derechos en caso de disconformidad y, permite un control judicial respecto a la legalidad del acto de que se trate ${ }^{388}$.

${ }^{386}$ SANTÍAS VIADA, J. A., LÓPEZ BLANCO, C. y SANTAMARÍA DE PAREDES CASTILLO, V., El Derecho comunitario (...), op. cit., págs. 47 a 49; SANTÍAS VIADA, J. A., "La normativa comunitaria sobre contratación pública en el período 1985-1990", Noticias CEE, núm. 75, abril 1991, págs. 67 - 77.

${ }^{387}$ En la Directiva 88/295/CEE (suministro) esta obligación de motivación se señala para los procedimientos restringidos y negociados, es decir para con respecto a quien es candidato (artículo 6.6); sin embargo, en la Directiva 89/440/CEE la exigencia de motivación se amplía a todo candidato o licitador rechazado que lo solicite (artículo 5 bis).

${ }^{388}$ Según reiterada jurisprudencia tanto del Tribunal de Justicia como del Tribunal General, la exigencia de motivación debe apreciarse en función de las circunstancias de cada caso, en particular del contenido del acto, la naturaleza de los motivos invocados y el interés que los destinatarios u otras personas afectadas directa e individualmente por dicho acto puedan tener en recibir explicaciones. Véase, la sentencia del Tribunal de Justicia de 14 de febrero de 1990, Delacre y otros/Comisión, C-350/88, apartados 15 y 16, y del Tribunal de Primera Instancia de 18 de abril de 2007, Deloitte Business Advisory/Comisión, T-195/05, apartado 45 y de 9 de septiembre de 2010, Evropaïki Dynamiki/Comisión, T-300/07, apartado 46. Sobre 


\section{A.2. Procedimientos de recurso en materia de adjudicación de los contratos públicos de obras y de suministro}

Uno de los argumentos que se esgrimían para justificar la falta de cumplimiento de las Directivas sobre contratación pública de los años 1971 y 1977 era la ausencia de mecanismos efectivos de control que permitieran garantizar su aplicación. Por esa razón, el segundo tipo de medidas que se adoptaron tenían por objeto velar por el cumplimiento de dichas normas a través del establecimiento de recursos eficaces contra las infracciones de las disposiciones aplicables en materia de los contratos públicos de obras y de suministro ${ }^{389}$. Pues, como nos indica GIMENO FELIÚ la normativa sobre contratación pública, a fin de ser realmente eficaz, debe estar apoyada por mecanismos de control fiables, ya que una auténtica apertura a la concurrencia en esta materia exige la existencia de recursos rápidos y eficaces para solventar posibles deficiencias ${ }^{390}$.

La obligatoriedad de dicho sistema de recursos se impuso a través de la Directiva 89/665/CEE del Consejo, de 21 de diciembre de 1989, también conocida como «Directiva de recursos» ${ }^{391}$. De conformidad con su artículo 1 ,

el principio de motivación de las decisiones véase también MORENO MOLINA, J. A., Los principios generales (...), op. cit., págs. 67 y 68 .

${ }^{389}$ Sobre esta materia resulta de interés la consulta a MESTRE DELGADO, J. F., "El control de la adjudicación de los contratos públicos a tenor del Derecho comunitario europeo: Una nueva ordenación de las medidas cautelares", Noticias CEE, núm. 74, marzo 1991, págs. 35 - 40, y del mismo autor "El control de la adjudicación de los contratos públicos", en la obra colectiva Nuevas perspectivas del Régimen local. Estudios en homenaje al Profesor José $M^{a}$ Boquera Oliver, Tirant lo Blanch, Valencia, 2002, págs. 291-330. Asimismo, HERNÁNDEZ Y FERNÁNDEZ DEL VALLE, $\mathrm{M}^{\mathrm{a}} \mathrm{I}$., "Los procedimientos de recurso en materia de adjudicación de los contratos públicos de suministros y de obras", NUE, núm. 89, 1992, págs. 43 50 .

${ }^{390}$ GIMENO FELIÚ, J. Ma ., La nueva contratación pública europea y su incidencia en la legislación española (...), op. cit., pág. 251 y en Novedades de la Ley de Contratos del Sector Público de 30 de octubre de 2007 en la regulación de la adjudicación de los contratos públicos, Civitas - Thomson Reuters, Cizur Menor (Navarra), 2010, pág. 299. Esta opinión es compartida por PIÑAR MAÑAS, J. L., "El sistema de garantías para la efectiva (... )", op. cit., pág. 782 .

${ }^{391}$ Directiva 89/665/CEE del Consejo, de 21 de diciembre de 1989, relativa a la coordinación de las disposiciones legales, reglamentarias y administrativas referentes a la aplicación de los procedimientos de recurso en materia de adjudicación de 
apartado primero, los Estados miembros están obligados a garantizar que las decisiones ilícitas emanadas de los órganos de contratación puedan ser recurridas de manera eficaz y lo más rápidamente posible cuando sus contenidos hayan infringido el Derecho de la Unión en materia de contratos públicos o las normas nacionales de incorporación de dicha normativa ${ }^{392}$, al señalar que:

"Los Estados miembros tomarán, en lo relativo a los procedimientos de adjudicación de contratos públicos comprendidos en el ámbito de aplicación de las Directivas 71/305/CEE y 77/62/CEE, las medidas necesarias para garantizar que las decisiones adoptadas por los poderes adjudicadores puedan ser recurridos de manera eficaz y, en particular, lo más rápidamente posible".

Por ende, tal como se desprende del tercer apartado de este mismo artículo,

"los Estados miembros están obligados a garantizar que los procedimientos de recurso sean accesibles, como mínimo, a cualquier persona que tenga o haya tenido interés en obtener un determina-

los contratos públicos de suministros y de obras (DOCE L 395, de 30 de diciembre de 1989, pág. 33). Posteriormente esta Directiva fue modificada por la Directiva 92/50/CEE del Consejo, de 18 de junio de 1992 (servicios), con lo que amplío su ámbito de aplicación para incluir también los contratos públicos de servicios. Asimismo, la última modificación de esta Directiva, todavía en vigor, se ha llevado a cabo por la Directiva 2007/66/CE del Parlamento Europeo y del Consejo, de 11 de diciembre de 2007, por la que se modifican las Directivas 89/665/CEE y 92/13/CEE del Consejo en lo que respecta a la mejora de la eficacia de los procedimientos de recurso en materia de adjudicación de contratos públicos (DOUE L 335, de 20 de diciembre de 2007, pág. 31).

${ }^{392}$ Según la sentencia de 28 de enero de 2010, Uniplex, C-406/08, apartado 26, con cita expresa en la sentencia de 12 de diciembre de 2002, Universale-Bau y otros, C470/99, apartado 71 "La Directiva 89/665 tiene por objeto garantizar la existencia de recursos eficaces en caso de infracción del Derecho comunitario en materia de contratos públicos o de las normas nacionales de adaptación a dicho Derecho, con el fin de garantizar la aplicación efectiva de las directivas sobre coordinación de los procedimientos de adjudicación de los contratos públicos".

A este respecto, procede también recordar que el principio de tutela judicial efectiva es otro de los principios general del Derecho de la Unión. En este sentido se manifiesta la sentencia del TJUE de 13 de marzo de 2007, Unibet, C-432/05, apartado 37 . 
do contrato público de suministros o de obras y que se haya visto o pueda verse perjudicada por una presunta infracción".

A mayor abundamiento, el concepto «decisiones» empleado por esta Directiva - entendido como actos recurribles - debe someterse a una interpretación amplia $^{393}$; es decir, debe aplicarse a todas las decisiones adoptadas por las entidades adjudicadoras, comprendiendo incluso aquéllas que han sido tomadas antes del inicio del procedimiento de adjudicación, como pueden ser las referidas a las prohibiciones de contratar, puesto que la Directiva 89/665/CEE no prevé restricciones en lo que atañe a la naturaleza y el contenido de estas decisiones $^{394}$.

En efecto, según se desprende de la jurisprudencia del Tribunal de Justicia, la decisión mediante la cual el órgano de contratación descarta la oferta de un licitador en el momento de la verificación de su aptitud, constituye una actuación contra la cual debe ser posible la interposición de un recurso ${ }^{395}$. En esta materia, no podemos perder de vista que la razón de ser de la Directiva 89/665/CEE es permitir, mediante la instauración de procedimientos de recurso adecuados, la correcta aplicación de las reglas de fondo del Derecho de la Unión en materia de contratos públicos, las cuales pretenden garantizar a favor de los operadores económicos establecidos en los Estados miembros la apertura

\footnotetext{
${ }^{393}$ En atención a lo señalado por la sentencia de 18 de junio de 2002, HI, C-92/00, apartado 49 "una interpretación restrictiva del concepto de decisiones con respecto a las cuales los Estados miembros deben garantizar la posibilidad de recursos sería incompatible con lo dispuesto en el artículo 2, apartado 1, letra a), de la misma Directiva, que obliga a los Estados miembros a establecer procedimientos de medidas provisionales con respecto a toda decisión que adopten las entidades adjudicadoras".

${ }^{394}$ Ésta es la línea jurisprudencial que ha mantenido el Tribunal de Justicia en sus sentencias de 28 de octubre de 1999, Alcatel Austria y otros, C-81/98, apartado 35; de 23 de enero de 2003, Makedoniko Metro y Michaniki, C-57/01, apartado 68 y de 19 de junio de 2003, GAT, C-315/01, apartado 52.

${ }^{395}$ STJCE de 19 de junio de 2003, Hackermüller, C-249/01, apartado 25 "si la oferta del licitador hubiera sido descartada por la entidad adjudicadora en una fase anterior a la de la selección de la mejor oferta, debería habérsele permitido impugnar la legalidad de la decisión de exclusión de su oferta mediante los procedimientos de recurso previstos por la Directiva 89/665, como persona que se ha visto perjudicada o que puede verse perjudicada por dicha decisión".
} 
de los contratos a una competencia no falseada y lo más amplia posible ${ }^{396}$.

Asimismo, en el marco de esta Directiva, la protección jurídica destinada a garantizar la salvaguardia de los derechos de los operadores económicos implica, al igual que veíamos anteriormente, la obligación de informar de la decisión de adjudicación del contrato público. Esta protección jurídica exige que se prevea la posibilidad de que el licitador excluido examine en tiempo oportuno la validez de la decisión de adjudicación. Ello supone que debe transcurrir un plazo razonable entre el momento en que se comunica la decisión de adjudicación a los licitadores excluidos y la firma del contrato, ya que la posibilidad real de recurrir contra las decisiones del órgano de contratación conlleva que tanto los candidatos como los licitadores sean conocedores de la decisión a recurrir, muy en concreto en la fase en la que las infracciones aún pueden corregirse ${ }^{397}$.

En el contexto de las prohibiciones de contratar, esta exigencia de comunicación de los motivos de exclusión de un licitador o candidato obedece al empeño de asegurar un nivel mínimo de transparencia en los procedimientos de adjudicación contractual, y con ello garantizar también la observancia del principio de igualdad de trato al que antes aludíamos.

${ }^{396}$ En este sentido se manifiestan las ya citadas sentencias del Tribunal de Justicia las sentencias de 11 de mayo de 2006, Carbotermo y Consorzio Alisei, C-340/04, apartado 58; de 13 de diciembre de 2007, Bayerischer Rundfunk y otros, C-337/06, apartado 39; de 23 de diciembre de 2009, CoNISMa, C-305/08, apartado 37; de 10 de octubre de 2013, Swm Costruzioni, C-94/12, apartado 34; de 10 de julio de 2014, Consorzio Stabile Libor Lavori Pubblici, C-358/12, apartado 29 y de 18 de diciembre de 2014, Data Medical Service, C-568/13, apartado 34.

${ }^{397}$ La STJUE de 3 de marzo de 2005, Fabricom, C-21/03 y C-34/03, apartado 43, señala que las disposiciones de la Directiva 89/665/CEE "destinadas a proteger a los licitadores contra la arbitrariedad de la entidad adjudicadora, tienen por objeto reforzar los actuales mecanismos para garantizar la aplicación efectiva de las normas comunitarias en materia de adjudicación de los contratos públicos, en particular en la fase en la que las infracciones aún pueden corregirse. Esta protección queda desvirtuada si el licitador no se halla en condiciones de invocar tales normas frente a la entidad adjudicadora".

Véanse también en este mismo sentido, las sentencias de 24 de junio de 2004, Comisión/Austria, C-212/02, apartado 21; de 3 de abril de 2008, Comisión/España, C 444/06; de 23 de diciembre de 2009, Comisión/Irlanda, C-455/08, apartado 26 y de 28 de enero de 2010, Comisión/Irlanda, C-456/08, apartado 30. 


\section{A.3. Extensión del régimen contractual público a los sectores del agua, la energía, los transportes y las telecomunicaciones}

El Libro Blanco sobre la realización del Mercado interior se hacía eco de que cuatro sectores claves en la economía, como son el del agua, la energía, los transportes y las telecomunicaciones - los conocidos entonces como «sectores excluidos» 398 o «sectores especiales» - se encontraban al margen de la regulación comunitaria de la contratación pública y fijaba para ellos la obligatoriedad de someterse a un régimen público de contratación antes del 31 de diciembre de 1992 (apartado 86 del Libro Blanco) ${ }^{399}$.

El principal motivo de la exclusión de estos sectores en la aplicación de las Directivas sobre los contratos de obras y suministro trae causa en la diversidad del estatuto jurídico - público o privado - de las entidades que operan en estos

\footnotetext{
${ }^{398}$ Con carácter general se hablaba de sectores excluidos por quedar éstos al margen de la regulación contractual o bien, como apuntan MARTÍNEZ LÓPEZ-MUÑIZ y GIMENO FELIÚ, porque los sectores de actividad a los que se aplican estaban excluidos de la aplicación de las Directivas generales, esto es, de las Directivas sobre los sectores clásicos. En MARTÍNEZ LÓPEZ-MUÑIZ, J. L., "Examen de la contratación de los Entes Instrumentales. Estudio especial del Derecho Comunitario", en la obra colectiva Eficacia, discrecionalidad y control judicial en el ámbito administrativo, Consejo General del Poder Judicial, Madrid, 1994, pág. 385 y en GIMENO FELIÚ, J. Ma ${ }^{\mathrm{a}}$, Contratos públicos: ámbito de aplicación (...), op. cit., pág. 114. A pesar de estos argumentos hay autores que muestran su preferencia por la denominación de sectores especiales, reservados o dirigidos como es el caso de GARCÍA DE COCA, J. A., "Regulación comunitaria sustantiva sobre los contratos celebrados en los sectores especiales y su repercusión sobre los contratos entre empresas de titularidad privada", RVAP, núm. 59, enero - abril 2001, pág. 122 al manifestar que la expresión excluidos puede inducir a error toda vez que después de su regulación se tratan ya de sectores sometidos a la normativa contractual.

Asimismo, PIÑAR MAÑAS y HERNÁNDEZ CORCHETE opinan que después de la aprobación de la Directiva 90/531/CEE "ya no es rigurosamente correcta la expresión «sectores excluidos» (...), pues si bien siguen fuera del ámbito general de aplicación de las Directivas generales de contratación pública, ahora sí tienen una regulación, aunque menos intensa" por lo que sería más apropiado hablar de «sectores especiales», en PIÑAR MAÑAS, J. L. y HERNÁNDEZ CORCHETE, J. A., "El contrato de obras en el ámbito de los sectores excluidos", en la obra colectiva $L a$ contratación pública en los llamados sectores excluidos. Agua, Energía, Transportes, Telecomunicaciones, Civitas, Madrid, 1997, pág. 106.

${ }^{399}$ Esta exclusión venía establecida en los artículos 3, apartados 4 y 5 , de la Directiva 71/305/CEE y en el artículo 2, apartado 2, de la Directiva 77/62/CEE.
} 
sectores, ya que gran parte de las entidades que prestan sus servicios en los sectores señalados son empresas privadas beneficiarias de derechos especiales o exclusivos expedidos por una autoridad competente de un Estado miembro. Habida cuenta de estas singularidades, las normas reguladoras de los procedimientos de adjudicación contractual no podían aplicarse a estas empresas sin acomodarlo a sus características ${ }^{400}$.

Teniendo en consideración todo lo dicho, y con el doble objetivo de dar cumplimiento al mandato emanado del citado Libro Blanco y atender a las peculiaridades propias de estos sectores, se aprobaron la Directiva 90/531/CEE del Consejo, de 17 de septiembre de 1990, relativa a los procedimientos de formalización de contratos en los sectores del agua, de la energía, de los transportes y de las telecomunicaciones ${ }^{401}$, y la Directiva 92/13/CEE, de 25 de febrero de 1992, relativa a los procedimientos de recurso en dichos sectores ${ }^{402}$.

\footnotetext{
${ }^{400}$ Sobre los motivos que llevaron a esta exclusión y acerca de las singularidades de la contratación en estos sectores se ocupan DÍEZ MORENO, F., "Las dificultades de la incorporación al ordenamiento español de las Directivas comunitarias sobre contratación de los sectores excluidos", Noticias CEE, núm. 71, diciembre 1990, págs. 49 - 63; SAMANIEGO BORDIÚ, G., "La normativa comunitaria de los contratos de las empresas que actúan en los sectores del agua, la energía, los transportes y las telecomunicaciones", REDA, núm. 71, julio - septiembre 1991, págs. 357 - 374 y TORRICELLI, S., "Utilities Procurement", en la obra colectiva EU Public Contract Law: Public Procurement and beyond, Bruylant, Brussels, 2014, págs. 222 - 248.
}

${ }^{401}$ DOCE L 297, de 29 de octubre de 1990.

${ }^{402}$ Directiva 92/13/CEE, de 25 de febrero de 1992, relativa a la coordinación de las disposiciones legales, reglamentarias y administrativas referentes a la aplicación de las normas comunitarias en los procedimientos de formalización de contratos de las entidades que operen en los sectores del agua, de la energía, de los transportes y de las telecomunicaciones (DOCE L 76, de 23 de marzo, págs. 14 a 20). Esta Directiva, al igual que la otra Directiva de recursos, se encuentra todavía en vigor tras las modificaciones efectuadas por la Directiva 2007/66/CE del Parlamento Europeo y del Consejo, de 11 de diciembre de 2007, a la que nos referíamos en el epígrafe anterior y por la cual se modifica también la Directiva 89/665/CEE en lo que respecta a la mejora de la eficacia de los procedimientos de recurso en materia de adjudicación de contratos públicos (DOUE L 335, de 20 de diciembre de 2007, pág. 31).

Sobre esta Directiva, puede consultarse DÍEZ MORENO, F. y OLIVÉ MARTÍNEZ-PENALVER, L., "La Directiva de recursos para la contratación de los sectores del agua, energía, transportes y telecomunicaciones", Noticias CEE, núm. 97, febrero 1993, págs. 61 - 68 y GIMENO FELIÚ, J, Ma ., El control de la contratación pública. Las normas comunitarias y su adaptación en España, Civitas, Madrid, 
Con la aprobación de la Directiva 90/531/CEE, como señala LÓPEZIBOR, se homogeniza la contratación en estos sectores al esquema seguido desde la década de los años sesenta para el régimen contractual en los sectores clásicos ${ }^{403}$. Desde ese momento se establece un régimen "ex novo" que supone un cambio radical en cuanto que obliga a las empresas que operan en estos sectores a modificar sus tradicionales prácticas contractuales y les impone, con independencia de su calificación jurídica, adoptar un sistema de contratación basado en los principios de publicidad y concurrencia con el fin de garantizar la transparencia en sus procedimientos de adjudicación contractual ${ }^{404}$. A partir de entonces se instauran normas para la formalización de los contratos perfeccionados en estos sectores, lo cual implica que la selección del contratista se va a realizar con arreglo a criterios objetivos y no discriminatorios ${ }^{405}$.

De esta manera, el artículo 25.1 de la Directiva 90/531/CEE disponía que las entidades contratantes que seleccionen los candidatos para un procedimiento de formalización de contratos restringido o negociado, deberán hacerlo de acuerdo con los criterios y normas objetivos que hayan definido previamente.

1995, págs. 105 a 113 quien destaca los problemas de transposición de esta Directiva en atención a los sujetos a los que se aplica, es decir, a toda persona pública y privada titular de derechos exclusivos o especiales.

${ }^{403}$ LÓPER-IBOR MAYOR, en la presentación del monográfico "La contratación pública en los sectores excluidos", NUE, núm. 301, enero 2010, pág. 5.

${ }^{404}$ SAMANIEGO BORDIÚ utiliza la expresión «revolución jurídica» para referirse a este cambio en las modalidades de contratación en estos sectores de actividad económica, en SAMANIEGO BORDIÚ, G., "La normativa comunitaria de los contratos de las empresas (...), op. cit., pág. 359. Asimismo, LÓPEZ-IBOR MAYOR y GIMENO FELIÚ califican de capital importancia esta regulación en cuanto suponen la aplicación de procedimientos públicos no sólo a Administraciones públicas, sino también a empresas privadas que ejercen actividades en alguno de los campos comprendidos en las mismas, en "Los denominados sectores excluidos: agua, transporte, energía y telecomunicaciones (Disposición adicional undécima LCAP)", en la obra colectiva dirigida por GÓMEZ-FERRER MORANT, Comentario a la Ley de Contratos de las Administraciones Públicas, $2^{\mathrm{a}}$ ed., Thomson - Civitas, Madrid, 2004, pág. 1678.

${ }^{405}$ Según LÓPEZ-FONT MÁRQUEZ con la Directiva 90/531/CEE "se prohíbe a las entidades contratantes imponer a determinados proveedores obligaciones que no se hayan exigido al resto de los proveedores y exigirles pruebas o comprobaciones suplementarias", en LÓPEZ-FONT MÁRQUEZ, J. F., "La apertura de los procedimientos nacionales de adjudicación de contratos públicos (...), op. cit., pág. 324 . 
Este mismo artículo alude a las prohibiciones de contratar al señalar que entre los criterios empleados por las entidades contratantes se "podrán incluir los de exclusión enumerados en el artículo 23 de la Directiva 71/305/CEE y en el artículo 20 de la Directiva 77/62/CEE".

Esta remisión normativa - que a partir de este momento va a ser una constante en la regulación de la contratación en los sectores especiales, incluso en la actual Directiva 2014/25/UE ${ }^{406}$ - suponía que las entidades contratantes sometidas a esta Directiva podían utilizar las mismas causas de exclusión de la participación en una licitación por hallarse el candidato en alguno de los supuestos contemplados en las entonces Directivas clásicas sobre contratos públicos de obras y de suministro; esto es, por encontrarse en estado de quiebra, de liquidación, de cese de actividades, por haber sido condenado por cualquier delito que afecte a su moralidad profesional, por haber sido sancionado en materia profesional, por falta de pago de sus obligaciones tributarias y con la Seguridad social y, por último, porque se le considere culpable de hacer declaraciones falsas al proporcionar la información respecto de su aptitud para contratar.

\section{A.4. Medidas para incluir en la regulación de la contratación pú- blica los contratos de servicios}

El sector de los servicios tampoco se encontraba comprendido en el ámbito de aplicación de las Directivas 71/305/CEE (obras) y 77/62/CEE (suministro) dada la dificultad que conllevaba encontrar una definición de servicios válida para todos los Estados miembros. Hubo que esperar al año 1992 para que, finalmente, se aprobara la Directiva 92/50/CEE del Consejo, de 18 de junio, sobre coordinación de los procedimientos de adjudicación de los contratos públicos de servicios ${ }^{407}$.

Esta Directiva afirmaba explícitamente en sus considerandos segundo, sexto y vigésimo su finalidad de contribuir a la consecución de un mercado interior,

\footnotetext{
${ }^{406}$ Véase el artículo 80 de la Directiva 2014/25/UE, de 26 de febrero de 2014, relativa a la contratación por entidades que operan en los sectores del agua, la energía, los transportes y los servicios postales y por la que se deroga la Directiva 2004/17/CE (DOUE L 94, de 28 de marzo de 2014).
}

${ }^{407}$ DOCE L 209, de 24 de julio de 1992. 
ya que su objetivo no era otro que evitar las trabas a la libre circulación de servicios para con ello, proteger los intereses de los operadores económicos establecidos en un Estado miembro que desearan ofrecer servicios a las entidades adjudicadoras establecidas en otro Estado miembro ${ }^{408}$.

Para lograr estos propósitos la Directiva 92/50/CEE determinaba, por un lado, los contratos de servicios que debían someterse a un procedimiento de adjudicación, distinguiendo dos niveles de aplicación en atención al servicio concertado y, por otra parte, establecía las normas que debían observar los órganos de contratación para adjudicar un contrato que tuviera por objeto servicios considerados prioritarios ${ }^{409}$.

Entre las normas relativas a los criterios de selección cualitativa se señalaban los motivos de exclusión de la participación en la adjudicación de un contrato público de servicios. Y así, el artículo 29, párrafo primero, de la Directiva 92/50/CEE disponía que: "podrá ser excluido de la participación en un contrato todo prestador de servicios:

a) Que se encuentre en estado de quiebra o de liquidación, cuyos negocios se encuentren bajo administración judicial, que haya negociado un convenio con sus acreedores, que haya cesado en sus actividades empresariales o se encuentre en cualquier situación análoga de resultas de un procedimiento

${ }^{408}$ En este sentido, véase las sentencias del Tribunal de Justicia de 3 de octubre de 2000, University of Cambridge, C-380/98, apartado 16 y de 24 de enero de 2008, Lianakis y otros, C-532/06, apartado 39.

${ }^{409}$ La Directiva 92/50/CEE diferenciaba, en sus artículos 8 a 10, entre servicios prioritarios y no prioritarios. Los primeros se enumeraban en su Anexo I A y los no prioritarios se recogían en el Anexo IB. La causa de esta distinción residía en que los contratos relativos a servicios no prioritarios no presentaban a priori un interés transfronterizo que pudiera justificar que su adjudicación se llevara a cabo mediante un procedimiento de licitación. Por ello, y desde la perspectiva del doble régimen de aplicación previsto en esta Directiva, sólo los servicios prioritarios estaban plenamente sujetos a la aplicación de la Directiva (artículo 8). En cambio, los servicios no prioritarios - si bien quedan sometidos a los principios consagrados por el Tratado CEE en materia de derecho de establecimiento y de libre prestación de servicios - sólo están sujetos a la Directiva de manera parcial, puesto que únicamente les resultaban de aplicación las normas sobre especificaciones técnicas y las relativas a la notificación de los resultados de los procedimientos de adjudicación, es decir, la Directiva 92/50/CEE se limitaba, para esta categoría de servicios, a imponer una publicidad a posteriori (artículo 9 ). 
de la misma naturaleza que exista en las legislaciones y reglamentaciones nacionales;

b) Que esté sujeto a un procedimiento de quiebra o sea objeto de una orden de liquidación obligatoria, de administración judicial, de concurso de acreedores o de cualquier otro procedimiento de la misma naturaleza que exista en las legislaciones y reglamentaciones nacionales;

c) Que haya sido condenado en sentencia firme por cualquier delito que afecte a su moralidad profesional;

d) Que haya cometido una falta profesional grave comprobada por cualquier medio que las entidades adjudicadoras puedan justificar;

e) Que no haya cumplido sus obligaciones en lo referente al pago de la cotización a la Seguridad Social, según las disposiciones legales del país en el que esté establecido o del país de la entidad adjudicadora;

f) Que no haya cumplido sus obligaciones fiscales según las disposiciones legales del país de la entidad adjudicadora; y

g) Que oculte o falsee gravemente la información exigible en virtud de lo dispuesto en el presente capítulo.

En cuanto a la acreditación de no concurrir en el licitador o candidato alguna de las circunstancias que posibilitaban su exclusión del procedimiento de adjudicación, este mismo artículo 29 preveía distintos medios de prueba dependiendo de la causa impeditiva. Así, en los tres primeros supuestos - quiebra, concurso de acreedores y condena por delitos contra la moralidad profesional - se aceptaba como prueba suficiente "la presentación de un certificado del registro de antecedentes penales o, en su defecto, un documento equivalente expedido por una autoridad judicial o administrativa competente del país de origen o de procedencia". Para justificar el cumplimiento de las obligaciones fiscales y con la Seguridad Social bastaba, sin embargo, con un certificado expedido por la autoridad competente del Estado miembro de que se tratara. Para el supuesto de que estos documentos o certificados no fueran expedidos por el país en cuestión, éstos podrían sustituirse por "una declaración jurada efectuada por el interesado ante una autoridad judicial o administrativa, 
un notario o una organización profesional o mercantil cualificada del país de origen o procedencia".

Como puede comprobarse, esta disposición está redactada en términos semejantes a lo expresado anteriormente por parte de las Directivas sobre adjudicación de los contratos públicos de obras y de suministro; ya que, adelantando materia futura, tanto la inmutabilidad en las causas que posibilitan una prohibición de contratar, como su carácter potestativo para los órganos de contratación van a configurarse como elementos caracterizadores de la normativa contractual pública en los sectores clásicos hasta la aprobación de la Directiva 2004/18/CE.

Este carácter potestativo, según fue interpretado por el Tribunal de Justicia en sus sentencias La Cascina y Assitur, supone que "el artículo 29 de la Directiva 92/50/CEE no contempla en la materia una aplicación uniforme de las causas de exclusión que en ella se mencionan a escala comunitaria, en la medida en que los Estados miembros están facultados para no aplicar en absoluto dichas causas de exclusión (... ) o bien para integrarlas en la normativa nacional con un grado de rigor que podría variar según el caso, en función de consideraciones de carácter jurídico, económico o social" ${ }^{410}$.

Además de ello, este mismo artículo "debe interpretarse en el sentido de que no se opone a que un Estado miembro establezca, además de las causas de exclusión incluidas en dicha disposición, otras causas de exclusión con el fin de garantizar el respeto de los principios de igualdad de trato y de transparencia, siempre que tales medidas no vayan más allá de lo necesario para alcanzar dicho objetivo" 411 .

\section{B. La consolidación del régimen sustantivo de la contratación públi- ca (1992-1993)}

Concluido el plazo dado por el Libro Blanco sobre la realización del Mercado interior para lograr una efectiva apertura de la contratación pública en el

${ }^{410}$ STJCE de 9 de febrero de 2006, La Cascina y otros, C-226/04 y C-228/04, apartados 21 a 23.

${ }^{411}$ STJCE de 19 de mayo de 2009, Assitur, C-538/07, apartado 23. 
ámbito de la UE, ya se habían adoptado medidas suficientes como para hablar de cumplimiento de los objetivos previstos ${ }^{412}$.

Tal y como hemos analizado en el epígrafe anterior, en el año 1992 se había completado el marco regulador en esta materia. Este marco normativo comprendía, de una parte, las Directivas que podríamos denominar sustantivas en cuanto que su objeto era la coordinación de los procedimientos nacionales para la adjudicación de los contratos públicos tanto en los sectores clásicos (obras, suministro y servicios) [Directivas 71/305/CEE; 77/62/CEE y 92/50/CEE] como en los sectores especiales (agua, energía, transportes y telecomunicaciones) [Directiva 90/531/CEE]. De otra parte, también se habían adoptado Directivas de garantías que posibilitaban, mediante la instauración de procedimientos de recurso, la correcta aplicación de las reglas de fondo del entonces Derecho comunitario en materia de contratos públicos ${ }^{413}$ [Directivas 89/665/CEE y 92/13/CEE].

${ }^{412}$ Así se manifiesta el Séptimo Informe de la Comisión al Consejo y al Parlamento Europeo relativo a la aplicación del Libro Blanco de la Comisión sobre la plena realización del mercado interior, COM (92), 383 final, de 2 de septiembre de 1992, pág. 33. En contra de esta opinión se muestran COX, A. y FURLONG, P., "Cross-border trade and contract awards: The intellectual myopia at the heart of the EU procurement rules", European Journal of Purchasing $\&$ Supply Management, vol. 3(1), 1997, págs. 9 - 20, quienes mantienen que son pocas posibilidades reales de alcanzar los objetivos propuestos ya que la normativa parte de erróneos planteamientos neoliberales acerca de que una mayor competencia conlleva precios más bajos y una mayor calidad en los productos.

${ }^{413}$ La distinción conceptual entre Directivas sustantivas o materiales y adjetivas o de garantías jurisdiccionales es sugerida por MARTÍNEZ LÓPEZ-MUÑIZ al indicar que las Directivas que podríamos denominar materiales o sustantivas lo son "por constituir su objeto la regulación sustantiva de diversos aspectos básicos para la válida celebración de los contratos públicos" y de otra parte las Directivas adjetivas o de garantías jurisdiccionales los son "porque su objeto es, en efecto, el sistema de tutela efectiva del ordenamiento contractual sustantivo bajo suficientes garantías de objetividad, independencia y eficacia", en MARTÍNEZ LÓPEZ-MUÑIZ, J. L., "Examen de la contratación de los Entes Instrumentales (...), op. cit., págs. 384 y 385. También FERNÁNDEZ GARCÍA, M ${ }^{\mathrm{a}}$ Y., "La nueva regulación de la contratación pública (...), op. cit., pág. 284. Asimismo, RAZQUIN LIZARRAGA alude a esta distinción entre Directivas sustantivas y Directivas "procesales" sobre recursos, en RAZQUIN LIZARRAGA, J. A., "El sistema especial de recursos en la contratación pública tras la reforma de la Ley de Contratos del Sector Público", Revista General de Derecho Administrativo, núm. 25, octubre 2010, pág. 2. 
Las Directivas 71/305/CEE y 77/62/CEE, con las que se inició la coordinación de las legislaciones de los Estados miembros en materia de contratación pública, fueron objeto de sucesivas y distintas modificaciones que aconsejaban su codificación ${ }^{414}$. Tal y como han indicado MORENO MOLINA y PIÑAR MAÑAS, era necesario, por tanto, elaborar unos textos refundidos que proporcionaran una mayor seguridad jurídica al marco normativo entonces vigente en materia de contratación pública ${ }^{415}$.

Esta codificación se llevó a cabo, en lo que a los contratos de obra y suministro se refiere, por parte de la Directiva 93/37/CEE del Consejo, de 14 de junio de 1993, sobre coordinación de los procedimientos de adjudicación de los contratos públicos de obras, y la Directiva 93/36/CEE del Consejo, sobre coordinación de los procedimientos de adjudicación de contratos públicos de suministro, de la misma fecha ${ }^{416}$.

Asimismo, la Directiva 90/531/CEE cuyo ámbito objetivo se circunscribía únicamente a los contratos de obras y de suministro en los sectores del agua, de la energía, de los transportes y de las telecomunicaciones, tuvo que extender su regulación a los contratos de servicios adjudicados en estos sectores especiales como consecuencia de la aprobación de la Directiva 92/50/CEE, razón por la cual fue sustituida por la Directiva 93/38/CEE, de 14 de junio, sobre coordinación de los procedimientos de adjudicación de contratos en los sectores del

\footnotetext{
${ }^{414}$ Sobre la necesidad de codificar las Directivas de los años setenta se manifiestan las Propuesta de Directiva del Consejo sobre coordinación de los procedimientos de adjudicación de contratos públicos de obras, SEC (91) 2360 final, de 9 de enero de 1992 (DOCE C 46, de 20 de febrero de 1992) y la Propuesta de Directiva del Consejo sobre coordinación de los procedimientos de adjudicación de contratos públicos de suministro, COM (92) 346 final, de 7 de septiembre de 1992 (DOCE C 277, de 26 de octubre de 1992).

${ }^{415}$ MORENO MOLINA, J. A., "Las nuevas Directivas sobre contratos públicos", NUE, núm. 135, 1996, págs. 31 y 32. PIÑAR MAÑAS, J. L., "El Derecho comunitario como marco de referencia (...)", op. cit., pág. 41 y en "Origen y fundamentos del Derecho europeo", op. cit., págs. 286 y 287 con cita expresa en el anterior artículo de MORENO MOLINA también publicado bajo el título "Las nuevas Directivas de la Comunidad Europea sobre contratos públicos (93/36, 93/37 y 93/38/CEE, de 14 de junio de 1993)", Revista Estado 8 Direito, núm. 13, 1994, pág. 65.

${ }^{416}$ Estas Directivas se encuentran publicadas en el DOCE L 199, de 9 de agosto de 1993.
} 
agua, de la energía, de los transportes y de las telecomunicaciones ${ }^{417}$.

Una vez aprobados estos textos, podemos indicar que desde el año 1993 y hasta el 2004, el marco regulador de la UE para la armonización de las normas sustantivas sobre contratación pública ha estado formado principalmente por las siguientes disposiciones de Derecho derivado:

- La Directiva 92/50/CEE del Consejo, de 18 de junio de 1992, sobre coordinación de los procedimientos de adjudicación de los contratos públicos de servicios;

- La Directiva 93/36/CEE del Consejo, de 14 de junio de 1993, sobre coordinación de los procedimientos de adjudicación de contratos públicos de suministro;

- La Directiva 93/37/CEE del Consejo, de 14 de junio de 1993, sobre coordinación de los procedimientos de adjudicación de los contratos públicos de obras;

- La Directiva 93/38/CEE del Consejo, de 14 de junio de 1993, sobre coordinación de los procedimientos de adjudicación de contratos en los sectores del agua, de la energía, de los transportes y de las telecomunicaciones;

Estos textos, como venimos señalando, se adoptaron en el marco de la realización del mercado interior con el objetivo centrado en la apertura de los contratos públicos a la concurrencia a fin de crear las condiciones de competencia necesarias que eviten discriminaciones en la adjudicación de los contratos y así hacer efectivas la libre circulación de mercancías, personas, servicios y capitales en los términos que resultaban del Tratado $\mathrm{CE}^{418}$. No obstante lo

${ }^{417}$ DOCE L 199, de 9 de agosto de 1993, pág. 84. A tenor de lo dispuesto en el artículo 45, apartado 3, de la Directiva 93/38/CEE, la Directiva 90/531/CEE fue sustituida por la Directiva 93/38/CEE y dejó de surtir efectos a partir de la fecha de puesta en aplicación de la Directiva de 1993. Dicha disposición precisaba además, en su apartado 4, que las referencias hechas a la Directiva 90/531/CEE se entenderían realizadas a la Directiva 93/38/CEE.

${ }^{418}$ Como señala el apartado 16 de la sentencia de 3 de octubre de 2000, University of Cambridge, C-380/98, "en lo que atañe al objetivo de las Directivas 92/50, 93/36 y $93 / 37$, el Tribunal de Justicia ha declarado que la coordinación comunitaria de 
anterior, estas Directivas no agotaron aquí su finalidad, ya que también pretendieron unificar la normativa sobre contratación tal y como parece advertirse de la intención manifestada abiertamente en el considerando segundo de la Directiva 93/36/CEE de crear "un cuerpo único y coherente de normas sobre contratación pública".

Por lo que se refiere al objeto de estas Directivas, de la lectura de sus títulos y considerandos, se desprende que tampoco preveían una regulación completa de los contratos públicos a escala europea, sino que su objeto quedaba circunscrito a la coordinación de los procedimientos nacionales de adjudicación de los citados contratos $^{419}$. En este contexto de coordinación, estas Directivas disponían el establecimiento de reglas comunes de participación en los contratos públicos que debían incluir, tanto criterios de selección cualitativa relativos a la idoneidad de quien pretende llegar a ser contratista, como criterios de adjudicación del contrato.

En cuanto a la selección del contratista, las citadas Directivas se detenían en la aptitud de los licitadores y candidatos en el ámbito profesional, en el económico y en el técnico. La proscripción de cualquier conducta o práctica discriminatoria se conseguía obligando a los órganos de contratación a predefinir y dar publicidad tanto a las condiciones que debían guiar la elección, como a los medios que los interesados podían aportar como prueba a fin de acreditar el cumplimiento de tales requisitos.

Asimismo, y adoleciendo de una total falta de originalidad, estas disposi-

los procedimientos de adjudicación de contratos públicos tiene por objeto suprimir las trabas a la libre circulación de servicios y de mercancías y, por tanto, proteger los intereses de los operadores económicos establecidos en un Estado miembro que deseen ofrecer bienes o servicios a las entidades adjudicadoras establecidas en otro Estado miembro". Los datos, sin embargo, nos mostraban un volumen bajo de operaciones transfronterizas, pues según cifras extraídas del informe $A$ report on the functioning of public procurement markets in the EU: benefits from the application of EU directives and challenges for the future (2010) tan sólo un $3 \%$ del total de una muestra de empresas contratistas afirmaba haber llevado a cabo transacciones transfronterizas directas. VIANA, C., Os Princípios Comunitários na Contratação (...), op. cit., pág. 38 .

${ }^{419}$ Sentencias del TJCE 27 de noviembre de 2001, Lombardini y Mantovani, C285/99 y C-286/99, apartado 33 y de 12 de diciembre de 2002, Universale-Bau y otros, C-470/99, apartado 88. 
ciones utilizaron los mismos criterios de exclusión ya mencionados en las Directivas precedentes, puesto que enumeraban idénticas circunstancias por las cuales un operador económico interesado en una licitación podía ser excluido de la participación en un procedimiento de adjudicación.

El tenor de estas disposiciones es prácticamente idéntico - salvo pequeñas diferencias en su redacción (Tabla 2) - no sólo entre sí, sino también con respecto a los preceptos de las Directivas que codifican [artículo 23 de la Directiva 71/305/CEE (obras) y artículo 20 de la Directiva 77/62/CEE (suministro)]. Tanto es así que incluso el apartado segundo del artículo 31 de la Directiva 93/38/CEE, durante sus años de vigencia, mantuvo las mismas referencias a las Directivas de los años 70 que su predecesora, la Directiva 90/531/CEE, a pesar de que los dos artículos a los que se refiere fueron recogidos, respectivamente, en los artículos 24 y 20 de las Directivas 93/37/CEE y 93/36/CEE al codificar las Directivas 71/305/CEE y 77/62/CEE ${ }^{420}$.

Nuevamente cabe destacarse que el lenguaje utilizado en estos artículos apunta con claridad a que los criterios de exclusión que en ellos se mencionan no tienen un carácter obligatorio para los Estados miembros, ya que les concede un amplio margen de discrecionalidad respecto de los criterios de exclusión que pueden llegar a aplicar bajo la expresión "podrá ser excluido"421.

${ }^{420} \mathrm{En}$ su redacción original las referencias a los artículos 23 de la Directiva 71/305/CEE y 20 de la Directiva 77/62/CEE puede entenderse dado que la tramitación de la Directiva 93/38/CEE fue paralela a las Directivas 93/36/CEE y 93/37/CEE e incluso se aprobaron el mismo día. Sin embargo, resulta llamativo que ni siquiera las modificaciones de la Directiva 93/38/CEE realizadas por la Directiva 98/4/CE, de 16 de febrero de 1998 y por la Directiva 2001/78/CE, de 13 de septiembre, alterasen la literalidad de este artículo 31.2 para actualizar las referencias a las Directivas derogadas. Sobre los criterios de selección cualitativa y las causas de exclusión recogidas en estas Directivas, véase BOVIS, Ch., "Qualitative Selection Criteria for Enterprises Participating in the Award of Public Procurement Contracts", European Business Law Review, vol. 5 (1), 1994, págs. 9 - 12; MARDAS, D. y TRIANTAFYLLOU, D., "Selection criteria and the award procedure in public procurement", International Advances in Economic Research, vol. 3 (1), 1997, págs. 91 - 112 y PISELLI, E., "The scope for excluding providers (...)", op. cit., págs. $267-286$.

${ }^{421} \mathrm{El}$ Tribunal de Justicia se ha referido en distintas ocasiones a las causas de prohibición de contratar. Concretamente, del artículo 29 de la Directiva 92/50/CEE tratan las sentencias del TJCE de 9 de febrero de 2006, La Cascina y otros, C-226/04 y C-228/04 y de 19 de mayo de 2009, Assitur, C-538/07. Sobre el artículo 24 de la 
En relación con los medios de prueba, y tal como se desprende de los mismos preceptos que establecen las prohibiciones de contratar, cuando el poder adjudicador solicite al candidato o licitador la prueba de no encontrarse incurso en alguno de los supuestos anteriormente mencionados, aceptará como prueba suficiente la presentación de un certificado del registro de antecedentes penales o, en su defecto, de un documento equivalente expedido por una autoridad judicial o administrativa competente en los supuestos de quiebra, de intervención judicial, de concurso de acreedores o de condena por delitos relacionados con su moralidad profesional. Para acreditar el cumplimiento de sus obligaciones fiscales y con la Seguridad social, el interesado debía presentar un certificado expedido por la autoridad competente de su Estado miembro de establecimiento. Cuando estos documentos o certificados no se expidiesen en dicho Estado, se aceptaba como prueba una declaración jurada o, en los Estados miembros donde no exista dicho juramento, una declaración solemne efectuada por el interesado ante una autoridad judicial o administrativa, un notario o un organismo profesional cualificado del país de origen o de procedencia.

Directiva 93/37/CEE se pronuncian las sentencias de 16 de diciembre de 2008, $M i$ chaniki, C-213/07 y de 15 de julio de 2010, Bâtiments y Ponts Construction, C-74/09. Por último, la sentencia de 12 de noviembre de 2009, Comisión/Grecia, C-199/07, se refiere a los criterios de selección del artículo 31 de la Directiva 93/38/CEE. 
Tabla 2: Los motivos de exclusión en las Directivas de contratación pública de los años 1992 y 1993

\begin{tabular}{|c|c|c|c|c|c|c|c|c|}
\hline 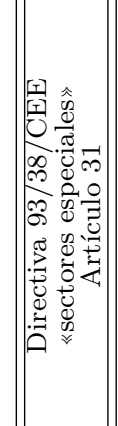 & 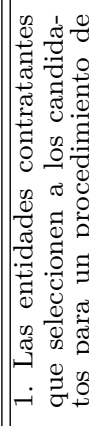 & 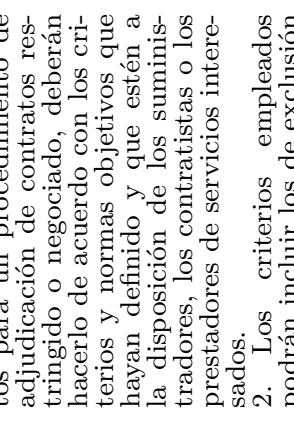 & 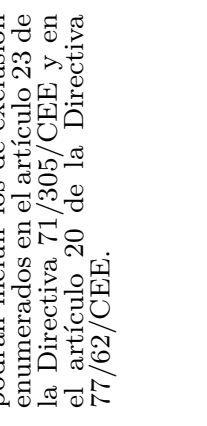 & & & & & \\
\hline 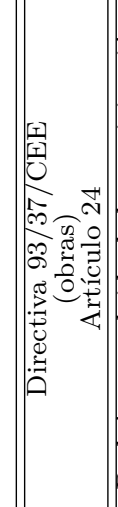 & 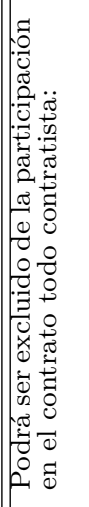 & 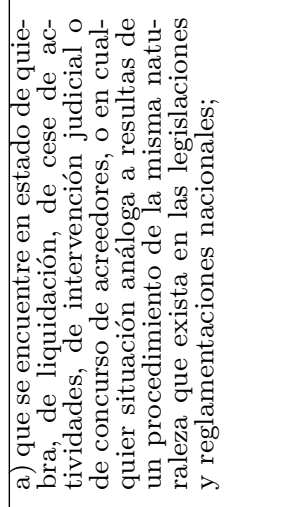 & 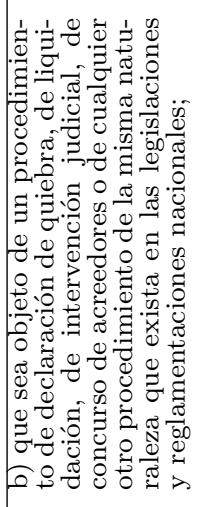 & 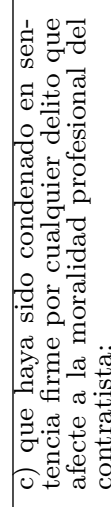 & 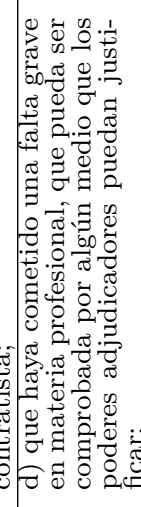 & 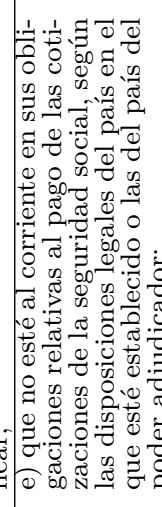 & 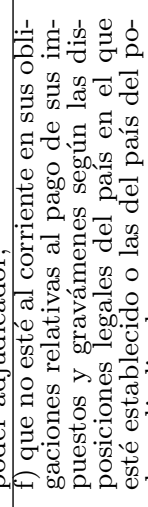 & 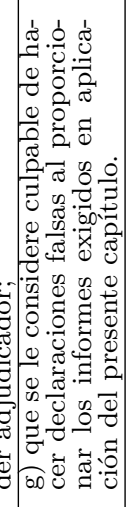 \\
\hline 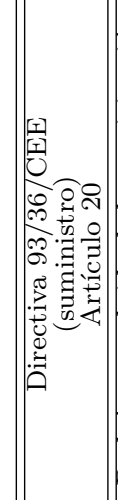 & 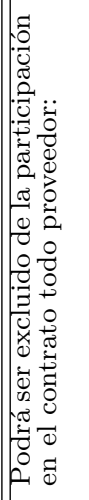 & 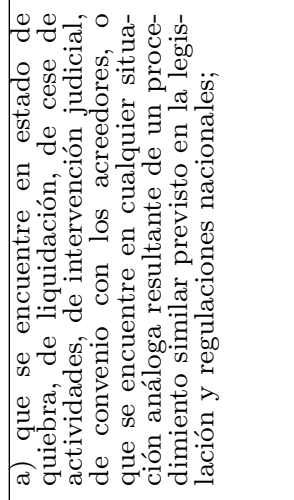 & 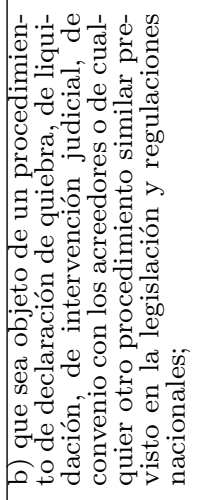 & 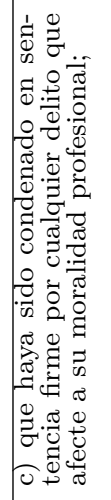 & 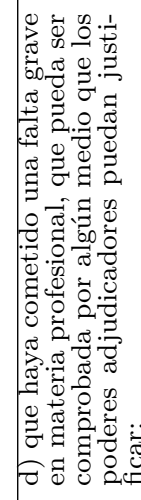 & 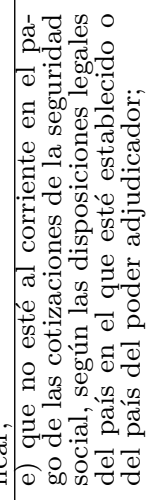 & 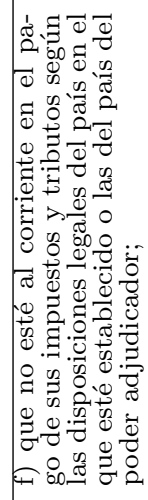 & 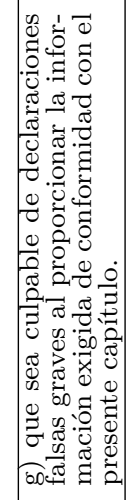 \\
\hline 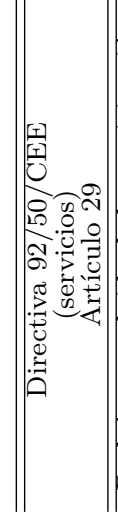 & 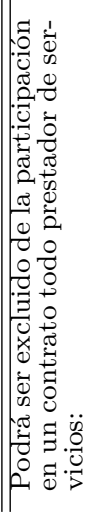 & 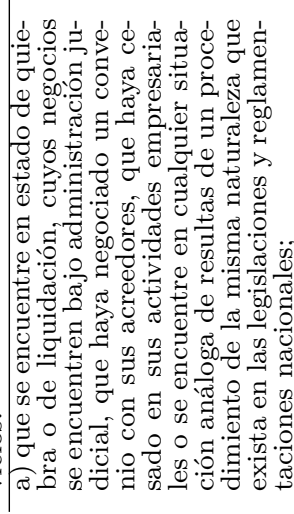 & 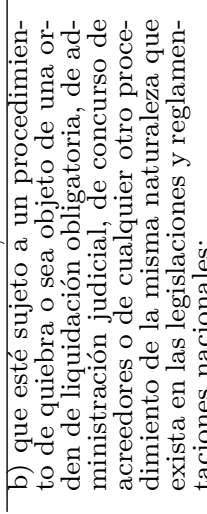 & 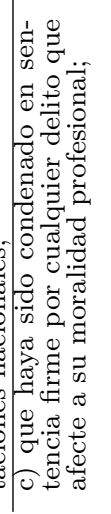 & 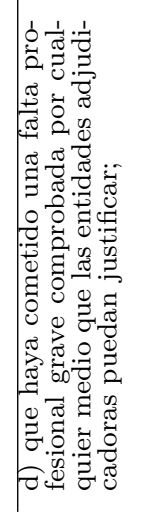 & 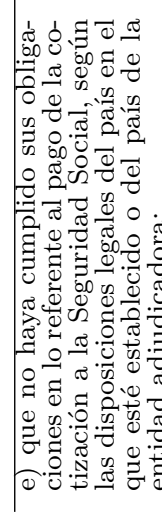 & 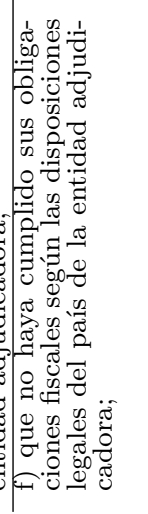 & 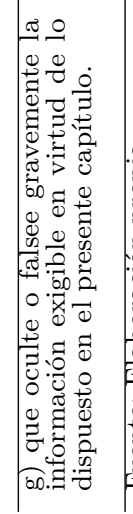 \\
\hline
\end{tabular}


Además de lo anterior, estas Directivas exhortan a los poderes adjudicadores a que comuniquen a todo candidato o licitador rechazado los motivos por los que se ha desestimado su solicitud o su oferta y, en el caso de la presentación de la oferta, el nombre del adjudicatario. Este deber de información, que permite a los interesados conocer la justificación de su rechazo y, de esta forma ver ampliadas sus posibilidades de control vía recurso, se complementa con la obligación que tienen los poderes adjudicadores de levantar un acta por cada contrato adjudicado en el que harán constar, entre otros "los nombres de los candidatos o licitadores excluidos y los motivos de su rechazo" 422 .

De lo anteriormente expuesto se desprende que el marco comunitario sobre contratación pública vigente en el año 1993 no incorporaba modificaciones sustanciales en relación con las prohibiciones de contratar, ya que contemplaba las mismas causas de exclusión de la participación en un contrato que las mencionadas Directivas al basarse en los mismos motivos relacionados tanto con la falta de capacidad y honradez profesional, como con la insuficiencia de medios económicos y financieros de quien quiere ser contratista ${ }^{423}$. Ni siquiera las modificaciones introducidas por las Directivas 97/52/CE y 98/4/CE cambiaron este panorama de inamovilidad en la determinación de los motivos de exclusión, al no incorporar cambio alguno en la regulación de las prohibiciones de contratar ${ }^{424}$.

Estas Directivas 97/52/CE y 98/4/CE que modificaron tanto las Directivas «clásicas» como la de «sectores especiales» se adoptaron con el propósito de

\footnotetext{
${ }^{422}$ Esta obligación deriva de los artículos 12 de la Directiva 92/50/CEE («servicios»), artículo 7 de la Directiva 93/36/CEE («suministro»), artículo 8 de la Directiva 93/37/CEE («obras»).

${ }^{423}$ PISELLI, E., "The scope for excluding providers (...)", op. cit., pág. 269.

${ }^{424}$ Se trata de la Directiva 97/52/CE, del Parlamento Europeo y del Consejo, de 13 de octubre de 1997, por la que se modifican las Directivas 92/50/CEE, 93/36/CEE y 93/37/CEE sobre coordinación de los procedimientos de adjudicación de los contratos públicos de servicios, de los contratos públicos de suministros y de los contratos públicos de obras, respectivamente (DOCE L 328, de 28 de noviembre de 1997) y la Directiva 98/4/CE del Parlamento Europeo y del Consejo, de 16 de febrero de 1998, por la que se modifica la Directiva 93/38/CEE del Consejo sobre coordinación de los procedimientos de adjudicación de contratos en los sectores del agua, de la energía, de los transportes y de las telecomunicaciones (DOCE L 101, de 1 de abril de 1998).
} 
asumir los compromisos internacionales que para la entonces Comunidad se derivaban de las negociaciones multilaterales de la Ronda Uruguay (1986-1994) y de la creación de la Organización Mundial del Comercio (OMC) el 15 de abril de $1994^{425}$.

Como parte integrante del Acuerdo por el que se establecía la OMC se aprobaron también una serie de Acuerdos calificados como plurilaterales por vincular únicamente a aquellos miembros de la OMC que los han aceptado. Entre dichos Acuerdos plurilaterales figura el Acuerdo sobre Contratación Pública que entró en vigor el 1 de enero de 1996 y del que forma parte la UE incluidos sus 28 Estados miembros ${ }^{426}$.

Este Acuerdo tiene por finalidad la liberalización de las compras públicas mediante el acceso recíproco, transparente y no discriminatorio a las adquisiciones que lleven a cabo las entidades sujetas a su cumplimiento. Al amparo de las obligaciones que se imponen, este Acuerdo contribuye al fenómeno de la «mundialización ${ }^{427}$ de la contratación pública al establecer una normativa de derechos y obligaciones internacionales respecto de la adjudicación de

\footnotetext{
${ }^{425}$ En esta fecha, en una reunión celebrada en Marrakech (Marruecos), el Presidente del Consejo y el Comisario encargado de las relaciones exteriores procedieron a la firma, en nombre de la Comunidad y condicionada a su aprobación posterior, del Acta Final por la que se cerraban las negociaciones comerciales multilaterales de la Ronda Uruguay, del Acuerdo por el que se establece la Organización Mundial del Comercio, así como del conjunto de Acuerdos y de Entendimientos que figuran en los anexos 1 a 4 de dicho Acuerdo. Como consecuencia de dicha firma, el Consejo adoptó la Decisión 94/800/CE, de 22 de diciembre de 1994 (DOCE L 336, de 23 de diciembre de 1994). El Instrumento de ratificación por parte de España del Acuerdo por el que se establece la OMC se encuentra publicado en el BOE núm. 20, de 24 de enero de 1995.
}

${ }^{426}$ El Acuerdo sobre Contratación Pública está recogido en el Anexo 4 b) del Acuerdo por el que se establece la OMC (DOCE L 336, de 23 de diciembre de 1994, págs. 273 - 289). Su texto revisado puede consultarse en el DOUE L 68, de 7 de marzo de 2014 .

${ }^{427}$ Es la expresión que utiliza el Libro Verde de la Comisión, de 27 de noviembre de 1996 La contratación pública en la Unión Europea: reflexiones para el futuro, COM (96) 583 final, pág. III apartado 9. También es la acepción empleada por CLERC, E., "La mondialisation des marchés publics: Bilan et perspectives de l'accord OMC sur les marchés publics", en la obra colectiva Les marchés publics à l'aube du XXIe siècle, Bruylant, Brussels, 2000, pág. 143 al manifestar que "les marchés publics participent au phénomène du mondialisation". 
contratos públicos cuando éstos superan ciertos umbrales económicos ${ }^{428}$.

Con arreglo al antiguo artículo VIII.h) de este Acuerdo referente a la calificación de los proveedores y a las condiciones de su participación en un contrato público, se excluiría del procedimiento de adjudicación a cualquier proveedor "por motivos tales como la quiebra o declaraciones falsas, a condición de que tal medida sea compatible con las disposiciones del presente Acuerdo sobre el trato nacional y la no discriminación" ${ }^{429}$.

Como hemos podido comprobar, las Directivas 92/50/CEE, 93/36/CEE y 93/37/CEE - con anterioridad a su versión modificada por la Directiva 97/52/CE - así como la redacción inicial de la Directiva 93/38/CEE, ya recogían tales causas de exclusión, incluso de manera más detallada que lo explicitado en este Acuerdo, y por esa razón, no necesitaron incorporar cambios en relación a esta materia ${ }^{430}$.

\footnotetext{
${ }^{428}$ Para un mayor detalle sobre el Acuerdo sobre Contratación Pública y su influencia en las Directivas de la UE, nos remitimos a los trabajos de MORENO MOLINA, J.A., Derecho global de la contratación pública, Ubijus, Asociación Internacional de Derecho Administrativo, México, 2011 y "La influencia del Acuerdo de Contratación Pública de la OMC sobre la Directiva 2014/24/UE", en la obra colectiva Observatorio de los Contratos Públicos 2013, Thomson-Reuters Aranzadi, Cizur Menor (Navarra), págs. 123 - 164.

${ }^{429}$ Por Decisión del Consejo, de 2 de diciembre de 2013, se modificó el Acuerdo sobre Contratación Pública, si bien su entrada en vigor se pospuso al 6 de abril de 2014. El artículo VIII del texto revisado - que lleva por título condiciones de participación - contempla en su apartado 4, que "cuando haya pruebas que lo justifiquen, una Parte, incluidas sus entidades contratantes, podrá excluir a un proveedor por motivos tales como los siguientes: a) quiebra; b) declaraciones falsas; c) deficiencias significativas o persistentes en el cumplimiento de cualquier requisito sustantivo $\mathrm{u}$ obligación dimanante de uno o más contratos anteriores; d) sentencias firmes por delitos graves $\mathrm{u}$ otras infracciones graves; e) falta profesional o actos $\mathrm{u}$ omisiones que pongan en entredicho la integridad comercial del proveedor; o f) impago de impuestos".
}

${ }^{430}$ Estas Directivas tampoco requirieron cambios después de su versión modificada por la Directiva 2001/78/CE de la Comisión, de 13 de septiembre de 2001, sobre la utilización de formularios normalizados en la publicación de los anuncios de contratos públicos (DOCE L 285, de 29 de octubre de 2004). 


\section{III.3. Las Directivas 2004/17/CE y 2004/18/CE}

Tras un breve lapso temporal desde la aprobación de las Directivas de principios de los años noventa se planteó el debate sobre la conveniencia de conjugar la política sobre contratación pública con otras políticas de la UE, de tal manera que la normativa contractual pudiera contribuir al cumplimiento de objetivos propios de la política social, del medio ambiente o de la lucha contra la corrupción y la delincuencia organizada.

Las Directivas de «segunda generación» no contenían referencias explícitas a la posibilidad de instrumentalizar la contratación pública para conseguir otros objetivos más allá de los estrictamente económicos ${ }^{431}$. De igual forma, estas Directivas tampoco resolvían las dudas que se habían empezado a plantear por parte de algunos Estados miembros acerca de incorporar aspectos sociales en los procedimientos de adjudicación contractual, aun cuando el Tribunal de Justicia, con anterioridad a la aprobación de las citadas Directivas, ya se había pronunciado sobre la posibilidad de atender a objetivos sociales en la adjudicación de contratos públicos en sus sentencias Gebroeders Beentjes, Du Pont de Nemours y Laboratori Bruneau ${ }^{432}$.

\footnotetext{
${ }^{431}$ A lo largo de este epígrafe, el concepto de objetivos económicos se va a emplear para describir las políticas que buscan promover una eficiencia económica directa de la contratación pública, y no para referirnos a políticas que pueden tener unos objetivos macroeconómicos más amplios, como son las que se refieren al apoyo a las economías regionales o a sectores desfavorecidos y que pudiera demostrarse que también resultan económicamente eficientes.
}

\footnotetext{
${ }^{432}$ Sentencias del TJCE de 20 de septiembre de 1988, Gebroeders Beentjes, C31/87; de 20 de marzo de 1990, Du Pont de Nemours Italiana, C-21/88 y de 11 de julio de 1991, Laboratori Bruneau, C-351/88. En la primera de estas sentencias, el Tribunal consideró aceptable una condición vinculada al empleo de trabajadores en paro prolongado, calificándola de condición específica adicional, siempre que "no incida de forma discriminatoria directa o indirectamente por lo que respecta a los licitadores de otros Estados miembros". En las otras dos sentencias, el Tribunal de Justicia declaró la incompatibilidad con el Derecho comunitario de la normativa nacional que reservaba una proporción de los contratos públicos de suministro a las empresas establecidas en determinadas regiones del territorio nacional, ya que algunos Estados miembros reconocían regímenes preferenciales en su normativa de contratación pública a favor de sus regiones menos favorecidas.

Por ejemplo, en Alemania a favor de las regiones de la antigua Alemania del Este; en Grecia estos regímenes se aplican a más del $90 \%$ del territorio nacional para
} 
En este contexto de cierta confusión, y ante las dudas sobre la viabilidad y conveniencia de perseguir objetivos no comerciales con la adjudicación de contratos públicos, la Comisión en su Libro Verde La contratación pública en la Unión Europea: reflexiones para el futuro, se propuso aclarar estos aspectos a través de distintas Comunicaciones interpretativas ${ }^{433}$, tras afirmar que la reglamentación sobre contratación pública puede contribuir a cumplir objetivos de política social y medioambiental, o que "las adquisiciones públicas pueden constituir un importante medio de orientar la actuación de los operadores económicos" 434 .

A partir de las reflexiones obtenidas con este Libro Verde, la Comisión pretendió, en un primer momento, mejorar la aplicación de las disposiciones sobre contratos públicos para luchar contra la corrupción ${ }^{435}$, aunque posteriormen-

evitar una excesiva concentración de actividades económicas en el área del Gran Atenas; en el Reino Unido sus preferencias afectan a las empresas establecidas en Irlanda del Norte, y en Italia se trata de favorecer a las empresas del sur de Italia Mezzogiorno - que son los supuestos enjuiciados por las sentencias del Tribunal de Justicia Du Pont de Nemours y Laboratori Bruneau. Véase, MEDINA ARNÁIZ, T., "La contratación pública socialmente responsable a través de la jurisprudencia del Tribunal de Justicia de la Unión Europea”, REDA, núm. 153, enero - marzo 2012, págs. $213-240$.

${ }^{433}$ Estas Comunicaciones tardarían cinco años en llegar y se trata de la Comunicación sobre la legislación comunitaria de contratos públicos y las posibilidades de integrar aspectos medioambientales en la contratación pública, COM (2001) 274 final, de 4 de julio de 2001, y la Comunicación sobre la legislación comunitaria de contratos públicos y las posibilidades de integrar aspectos sociales en dichos contratos, COM (2001) 566 final, de 15 de octubre de 2001.

${ }^{434}$ Libro Verde de la Comisión, de 27 de noviembre de 1996, COM (96) 583 final, págs. 43 y 44.

${ }^{435}$ Véase en este sentido la Comunicación de la Comisión al Consejo y al Parlamento Europeo sobre una política de la Unión en materia de lucha contra la corrupción, COM (97) 192 final, de 21 de mayo de 1997, págs. 10 y 11. En esta Comunicación la Comisión manifiesta que las Directivas sobre contratación pública entonces vigentes ya recogían la posibilidad de excluir a un licitador o candidato condenado por corrupción al incluir entre las causas de prohibición de contratar el que haya sido condenado en sentencia firme por cualquier delito que afecte a la moralidad profesional del contratista; no obstante, sugería la elaboración del «listas negras» de licitadores condenados por corrupción para evitar contratar con ellos. Asimismo, el Plan de Acción para luchar contra la delincuencia organizada, adoptado por el Consejo el 28 de abril de 1997, en su apartado decimotercero, planteaba tomar 
te consideró más adecuado modificar el marco jurídico contractual entonces vigente a fin de simplificarlo y hacerlo más flexible. De esta manera, en su Comunicación, de 11 de marzo de 1998, La contratación pública en la Unión Europea, tras realizar un diagnóstico de la situación de la contratación pública en el ámbito europeo ${ }^{436}$, propuso la adaptación de las Directivas a las exigencias de un mercado en constante evolución, a la vez que destacaba la necesidad de que la contratación pública alcanzase un efecto de sinergia con otras políticas de interés para la UE, y por esa razón, animaba a los Estados miembros a que utilizasen su influencia, en cuanto compradores públicos, para perseguir objetivos distintos a los estrictamente comerciales ${ }^{437}$.

Respecto de las prohibiciones de contratar, la Comisión en esta Comunicación de 1998 expresaba su voluntad de comprometerse en la lucha contra las irregularidades en la contratación pública y, en este sentido, retomaba la idea manifestada en su Comunicación sobre Una política de la Unión en materia de lucha contra la corrupción de explorar la posibilidad de establecer un sistema de «listas negras» - blacklists - de las empresas que hubieran sido acusadas de fraude o de corrupción a fin de impedir la contratación con ellas ${ }^{438}$.

otras medidas que permitieran la exclusión de las organizaciones delictivas o de sus miembros de la participación en los procedimientos de contratación pública (DOCE C 251, de 15 de agosto de 1997).

${ }^{436}$ En noviembre de 1997, el Cuadro de indicadores del Mercado interior de la Comisión Europea mostraba que la contratación pública era uno de los ámbitos en los que existía un mayor déficit en la transposición y aplicación de las Directivas por parte de los entonces quince Estados miembros.

${ }^{437}$ Comunicación de la Comisión La contratación pública en la Unión Europea, COM (1998) 143, de 11 de marzo de 1998, págs. 25 y ss. En este mismo sentido nos hemos manifestado en las últimas páginas del Capítulo primero de esta memoria doctoral al tratar sobre las prohibiciones de contratar como instrumento al servicio de los objetivos secundarios de la contratación pública, págs. 170 y siguientes.

${ }^{438}$ Sobre las «listas negras» resulta de interés la aportación doctrinal de JACOBS, J.B. y ANECHIARICO, F., "Blacklisting of Public Contractors (...), op. cit., y OLAYA, J., "Blacklisting corrupt companies", (...), op. cit., pág. 72 quien se refiere a la "confección de una lista negra o de inhabilitación como un proceso por el cual, sobre bases preestablecidas, una empresa o individuo no puede participar de ofertas de contratos por un cierto período de tiempo".

La elaboración de estas listas negras ha sido, no obstante, criticada por ser cerradas y poco publicitadas, así como por no incluir las grandes empresas con participación demostrada en actos corruptos al utilizar «hombres de paja»-men of straw - o 
En tal sentido, consideraba que estas listas negras podían ser una herramienta útil para ayudar a superar la generalizada falta de cooperación entre las autoridades de los diferentes Estados miembros con respecto al intercambio de información relativa a la comisión de determinados delitos que suponen la exclusión del licitador o candidato de los procedimientos de adjudicación contractual $^{439}$.

Asimismo, esta Comunicación destacaba la conveniencia de garantizar el cumplimiento de la legislación social y ambiental a través de la contratación pública y alegaba que las Directivas sobre contratación pública ya permitían excluir bajo determinadas condiciones, "a los candidatos que violen las normativas nacionales en materia de medioambiente" y a los que "violan la legislación en materia social, incluyendo las relacionadas con la promoción de la igualdad de oportunidades" 440 .

Las opiniones favorables a simplificar el marco jurídico contractual como parte de las medidas encaminadas a mejorar el funcionamiento del mercado interior $^{441}$, así como la jurisprudencia del Tribunal de Justicia que proyectaba luz sobre aspectos esenciales en la aplicación de las Directivas sobre contratación

empresas pantalla. En este sentido, WHITE, S., Procurement and organised crime: an EU wide study, Institute of Advanced Legal Studies, London, 2000, pág. 33 y SCHOONER, S., "The Paper Tiger Stirs: Rethinking Suspension and Debarment", PPLR, vol. 13 (5), 2004, págs. 215 quien se refiere al «Excluded Party Listing System» (EPLS).

${ }^{439}$ PISELLI, E., "The scope for excluding providers (...)", op. cit., pág. 285 e IGLESIAS RIO, M. Á. y MEDINA ARNÁIZ, T., "Herramientas preventivas en la lucha, (...)", op. cit., pág. 62 .

${ }^{440}$ La contratación pública en la Unión Europea, (...)”, op. cit., págs. 27 y 28.

${ }^{441}$ Estas opiniones se manifestaron, por ejemplo, en la Comunicación de la Comisión Programa de trabajo de la Comisión para 2000, COM (2000) 155, de 9 de febrero (DOCE C 81, de 21 de marzo, pág. 13) y en el Programa de trabajo establecido en el Consejo Europeo de Lisboa de los días 23 y 24 de marzo de 2000 y confirmado por el Consejo Europeo de Barcelona de los días 15 y 16 de marzo de 2002. Asimismo, la Comunicación de la Comisión Estrategia para el mercado interior - Prioridades del período de 2003-2006, COM (2003) 238 final, de 7 de mayo de 2003, pág .18 afirmó que "el mercado de los contratos públicos de la Unión Europea sigue siendo poco abierto y competitivo" y que "la contratación pública todavía implica la realización de numerosas formalidades administrativas y desconoce los enormes beneficios de las licitaciones electrónicas". 
pública $^{442}$, preconizaban una reforma en la normativa sustantiva contractual que se completó en el año 2004 con la aprobación de dos Directivas:

- La Directiva 2004/17/CE del Parlamento Europeo y del Consejo, de 31 de marzo de 2004, sobre la coordinación de los procedimientos de adjudicación de contratos en los sectores del agua, de la energía, de los transportes y de los servicios postales («sectores especiales»), y

- La Directiva 2004/18/CE del Parlamento Europeo y del Consejo, de 31 de marzo de 2004, sobre coordinación de los procedimientos de adjudicación de los contratos públicos de obras, de suministro y de servicios («sectores clásicos» $)^{443}$.

${ }^{442}$ A título de ejemplo, y sin ánimo de exhaustividad, baste citar las sentencias de 15 de enero de 1998, Mannesmann Anlagenbau Austria y otros, C-44/96, que se refiere al concepto de «organismo de Derecho público»; de 18 de noviembre de 1999, Teckal, C-107/98, sobre los contratos «in house providing»; de 7 de diciembre de 2000, Telaustria y Telefonadress, C-324/98, acerca de la sujeción a los principios del Tratado CE en todas las adjudicaciones de contratos públicos con independencia de si están excluidos del ámbito de aplicación de las Directivas; también de 7 de diciembre de 2000, ARGE, C-94/99, en la que el Tribunal de Justicia declaró, entre otras cosas, que la legislación sobre contratos públicos es aplicable incluso en los supuestos en que el propio contratista sea una entidad adjudicadora, o la sentencia de 17 de septiembre de 2002, Concordia Bus Finland, C-513/99, que se refiere a la posibilidad de que el poder adjudicador utilice como criterio de adjudicación un criterio relacionado con la protección del medio ambiente.

Para un análisis más detallado de la influencia de la jurisprudencia en la codificación de las Directivas clásicas, puede consultarse BOVIS, Ch., "Recent case law relating to public procurement: A beacon for the integration of public markets", CMLR, vol. 39 (5), 2002, págs. 1025 - 1056 y DRIJBER, B. J. y STERGIOU, H., "Public procurement law and internal market law", $C M L R$, vol. 46 (3), 2009, págs. $805-846$.

${ }^{443} \mathrm{La}$ entrada en vigor de estas Directivas se produjo el mismo día de su publicación en el DOUE, es decir el 30 de abril de 2004 (DOUE L 134, págs. 1- 240), sin perjuicio de las obligaciones de los Estados miembros en lo que se refiere al plazo para adoptar las disposiciones necesarias para dar cumplimiento a lo dispuesto en dichas Directivas. TRYBUS, M., "The morning after the deadline: the State of implementation of the new EC Public Procurement Directives in the Member States on 1st February 2006", PPLR, vol. 15 (3), 2006, NA 82-89. También resulta de interés la documentación preparada por Andrea RENDA para el Parlamento Europeo The Public Procurement Directives: Transposition in the EU Member States, Bruselas, mayo 2006 (IP/A/IMCO/0F/2006-071). 
Estas Directivas tenían como fecha límite para su transposición a los derechos nacionales el 31 de enero de $2006^{444}$, y si bien al vencimiento de este plazo, sólo ocho de los entonces veinticinco Estados miembros habían cumplido con esa obligación, a partir de la publicación de estas Directivas existe un nuevo marco jurídico sobre contratación pública que debe completarse con las disposiciones recogidas en las Directivas en materia de recursos ${ }^{445}$ y en la Directiva sobre los procedimientos de adjudicación contractual en los ámbitos de la defensa y de la seguridad ${ }^{446}$.

Al estudio del proceso de gestación de las Directivas del 2004 se dedica este epígrafe. Para ello, analizaremos los objetivos generales que plantean y las modificaciones que se llevan a cabo respecto del régimen jurídico anterior. $\mathrm{Su}$

\footnotetext{
${ }^{444}$ Sobre la transposición de las Directivas del 2004 en los Estados miembros puede consultarse TRYBUS, M. y MEDINA, T., "Unfinished Business: The State of Implementation of the New EC Public Procurement Directives in the Member States on February 1, 2007", PPLR, vol. 16 (4) 2007, pp. NA89 - NA97; MEDINA ARNÁIZ, T. y TRYBUS, M., "La transposición de las Directivas comunitarias sobre contratación pública en los Estados miembros", NUE, núm. 298, noviembre 2009, págs. 83 - 94 y los libros colectivos dirigidos por SÁNCHEZ MORÓN, M., Derecho de los contratos públicos en la Unión Europea y sus Estados miembros, Lex Nova - Thomson Reuters, Valladolid, 2011 y Public procurement in the European Union and its Member States, Lex Nova - Thomson Reuters, Valladolid, 2012.

${ }^{445}$ Se trata de la Directiva 89/665/CEE, de 21 de diciembre de 1989, relativa a la coordinación de las disposiciones legales, reglamentarias y administrativas referentes a la aplicación de los procedimientos de recurso en materia de adjudicación de los contratos públicos de suministros y de obras; la Directiva 92/13/CEE, de 25 de febrero de 1992, relativa a la coordinación de los disposiciones legales, reglamentarias y administrativas referentes a la aplicación de las normas comunitarias en los procedimientos de formalización de contratos de las entidades que operen en los sectores del agua, de la energía, de los transportes y de las telecomunicaciones y, por último, la Directiva 2007/66/CE, de 11 de diciembre de 2007, por la que se modifican las Directivas 89/665/CEE y 92/13/CEE en lo que respecta a la mejora de la eficacia de los procedimientos de recurso en materia de adjudicación de contratos públicos (DOUE L 335, de 20 de diciembre de 2007, pág. 31).

${ }^{446}$ La Directiva 2009/81/CE del Parlamento Europeo y del Consejo, de 13 de julio de 2009, sobre coordinación de los procedimientos de adjudicación de determinados contratos de obras, de suministro y de servicios por las entidades o poderes adjudicadores en los ámbitos de la defensa y la seguridad, y por la que se modifican las Directivas 2004/17/CE y 2004/18/CE (DOUE L 216, de 20 de agosto de 2009, pág. 76). Esta Directiva también contempla motivos de exclusión del candidato o licitador en un procedimiento de adjudicación contractual en su artículo 39.
} 
examen detallado obedece a distintas razones, pero sin duda tres son las que destacan: En primer lugar, y a nuestro entender, es a partir de estas Directivas que tiene cabida la idea de una utilización estratégica de la contratación pública como instrumento político. En segundo lugar, vamos a diferenciar, por primera vez, las prohibiciones de contratar obligatorias de las potestativas para los Estados miembros y, por último, aunque se trate de un motivo temporal, estas Directivas siguen siendo aplicables en aquellos Estados miembros en los que no han entrado en vigor las medidas de transposición de las Directivas del año 2014, por lo que serán de aplicación hasta el 18 de abril de 2016, fecha en que será efectiva su derogación ${ }^{447}$.

\section{A. Los objetivos de la reforma de 2004}

La aplicación del bloque normativo sobre contratación pública adoptado en 2004, tanto en los sectores clásicos (Directiva 2004/18/CE) como en el de los sectores especiales (2004/17/CE), intenta simplificar y modificar las Directivas que entonces estaban vigentes y adaptarlas a las necesidades de una gestión administrativa moderna en un entorno económico cambiante ${ }^{448}$.

Es así que las modificaciones emprendidas por las Propuestas de Directivas (2000) descansaban sobre un triple objetivo: modernización, simplificación y flexibilidad. Modernización para tener en cuenta las nuevas tecnologías; simplificación para aligerar normas demasiado detalladas y complejas; y flexibilidad

\footnotetext{
${ }^{447} \mathrm{El}$ artículo 90 de la Directiva 2014/24/UE titulado Transposición y disposiciones transitorias prevé en su apartado 1 que "los Estados miembros pondrán en vigor las disposiciones legales, reglamentarias y administrativas necesarias para dar cumplimiento a lo establecido en la presente Directiva a más tardar el 18 de abril de 2016. Comunicarán inmediatamente a la Comisión el texto de dichas disposiciones". Las nuevas Directivas entraron en vigor a los veinte días de su publicación en el DOUE, que se produjo el 28 de marzo de 2014.

${ }^{448} \mathrm{~A}$ los objetivos de simplificación y modernización se refieren expresamente los considerandos primeros de las Directivas 2004/18/CE y 2004/17/CE. A estos propósitos se ha vuelto a referir el Parlamento Europeo en su Resolución de 18 de mayo de 2010, sobre nuevos aspectos de la política de contratación pública y en el Libro Verde sobre la modernización de la política de contratación pública de la UE. Hacia un mercado europeo de la contratación pública más eficiente, COM (2011) 15 final, de 27 de enero, al insistir en que las Directivas de contratación pública deben simplificar, modernizar y flexibilizar los procedimientos de adjudicación.
} 
para responder a las críticas sobre la excesiva rigidez de los procedimientos contractuales.

Para la consecución de estos objetivos planteaban, entre otras medidas, adaptar las prácticas de la contratación pública al desarrollo del comercio electrónico y, de esta manera, facilitar la implantación de la contratación pública electrónica (e-procurement $)^{449}$; codificar las tres Directivas «clásicas» refundiéndolas en un único texto; incorporar un nuevo procedimiento de adjudicación - el diálogo competitivo - que posibilite que el poder adjudicador entable un diálogo con los candidatos seleccionados para explorar las mejores soluciones que satisfagan de forma óptima sus necesidades y permitir el empleo de técnicas de compra más flexibles mediante la utilización de acuerdos marco ${ }^{450}$.

Asimismo, en este nuevo escenario, y debido a la aplicación de medidas liberalizadoras en el sector de las telecomunicaciones, se consideró que ya no era necesario reglamentar las compras por parte de las entidades que operan en este ámbito. La competencia real existente hacía innecesario mantener por más tiempo las telecomunicaciones en el ámbito de aplicación de la Directiva de los sectores especiales, mientras que, al mismo tiempo, se incluían los servicios postales $^{451}$.

\footnotetext{
${ }^{449}$ Según el Libro Verde sobre la generalización del recurso a la contratación pública electrónica en la UE, COM (2010) 571 final, de 18 de octubre, el término contratación pública electrónica designa "la utilización de medios electrónicos en el tratamiento de las operaciones y en la comunicación por parte de las instituciones gubernamentales y demás organismos del sector público a la hora de adquirir bienes y servicios o licitar obras públicas". A este respecto, puede consultarse, BICKERSTAFF, R., "The new directives' rules e-communication mechanisms in public and utilities procurement", PPLR, vol. 13 (6), 2004, págs. 277-284.

${ }^{450}$ Acerca de las novedades relativas a dotar de mayor flexibilidad a los procedimientos de adjudicación contractual puede consultarse ARROWSMITH, S., The Law of public and utilities (...), op. cit., págs. 152 y 153. Respecto de estas Propuestas de Directivas resulta de interés la consulta de la obra de HEBLY, J., European Public Procurement: Legislative History of the Classic Directive 2004/18/EC, Kluwer Law International, Alpen aan den Rijn (The Netherlands), 2007, y del mismo autor, European Public Procurement: Legislative History of the Utilities Directive 2004/17/EC, Kluwer Law International, Alpen aan den Rijn (The Netherlands), 2008. También, WAINWRIGHT, R., "Marchés publics-Refonte des Directives", Revue du Marché Commun et de l'Union Européenne, vol. 449, juin 2001, págs .394-399.

${ }^{451}$ Sobre este extremo ORDÓÑEZ SOLIS manifiesta que la Directiva 2004/17/CE
} 
En cuanto a la selección del contratista, en el proceso de elaboración de las Directivas surgieron distintas opiniones en cuanto a la utilización de la contratación pública como instrumento para la consecución de objetivos secundarios a las compras públicas y, en lo que a esta memoria doctoral interesa, sobre la posibilidad de incorporar estos objetivos secundarios a los criterios de selección cualitativa del contratista. De esta manera, se propuso incorporar criterios de exclusión por motivos relacionados con la realización de prácticas corruptas, con la vulneración de los convenios internacionales en materia laboral, por incumplir la normativa relativa a la protección del empleo o por perjuicios causados al medio ambiente.

La importancia que adquieren estos pronunciamientos durante el proceso de gestación de las Directivas del año 2004 merece ser destacada por dos motivos. En primer lugar, porque presentan diferencias sustanciales respecto del texto que finalmente fue aprobado. En segundo lugar, porque en las nuevas Directivas sobre contratación pública se mantienen como objetivos de la legislación contractual combatir el favoritismo, el fraude y la corrupción, y vuelve a proponerse que los poderes adjudicadores puedan excluir de los contratos a los operadores económicos que no cumplan con las obligaciones establecidas por la legislación de la Unión en materia social, laboral o medioambiental (artículo 57.4.a) de la Directiva 2014/24/UE y artículo 38.7.a) de la Directiva 2014/23/UE («concesiones»).

Con la mirada en el pasado para entender mejor el presente, en este apartado nos centraremos en los trámites anejos a la elaboración de las Directivas del año 2004, si bien cabe indicarse que la mayor parte de las cuestiones a las que vamos a referirnos provienen del procedimiento de elaboración de la

presenta dos importantes novedades: por una parte, la exclusión del sector de las telecomunicaciones de su regulación y, por otra, la incorporación de los servicios postales, en ORDÓÑEZ SOLÍS, D., "Las nuevas Directivas sobre la contratación pública en la Unión Europea: renovación formativa y experiencia judicial", $R E D E$, núm. 18, abril - junio 2006, págs. 166 y 167. Véase también ARROWSMITH, S., "The past and future evolution of EC Procurement Law: From framework to Common Code?", Public Contract Law Journal, vol. 35 (3), 2006, págs. 345 y 346 quien opina que esta reforma era necesaria a la luz de la liberalización que se había llevado a efecto en el sector de las telecomunicaciones desde que se adoptara la primera Directiva sobre la contratación en los sectores especiales «Utilities Directive» en los años noventa. 
Directiva 2004/18/CE ya que, en este extremo, la Directiva 2004/17/CE se refiere a las prohibiciones de contratar como lo hiciera su predecesora, la Directiva 93/38/CEE, es decir, por remisión a las disposiciones adoptadas en la Directiva clásica ${ }^{452}$.

\section{B. Su proceso de elaboración}

La Propuesta de Directiva sobre coordinación de los procedimientos de adjudicación de los contratos públicos de suministro, de servicios y de obras $(2000)^{453}$, además de refundir la normativa relativa a la contratación pública en un único texto, presentaba novedades importantes en distintos aspectos de su regulación ${ }^{454}$.

Por lo que respecta a las prohibiciones de contratar, esta Propuesta, en su artículo 46 relativo a la situación personal del candidato o licitador, pretendía acometer una revisión ambiciosa en esta materia. De esta forma, y como novedad más destacada, a través de la selección del contratista perseguía reforzar los instrumentos para combatir la delincuencia organizada, la corrupción y el fraude. Para lograrlo incorporaba al texto de las Directivas un nuevo apartado según el cual los poderes adjudicadores estaban obligados a excluir de la participación en la adjudicación contractual, por un periodo de cinco años, a todo licitador y candidato que haya sido condenado en una sentencia firme por

${ }^{452}$ De conformidad con el artículo 53.4 de la Propuesta de Directiva del Parlamento Europeo y del Consejo sobre coordinación de los procedimientos de adjudicación de contratos en los sectores del agua, de la energía y de los transportes, COM (2000) 276 final, de 31 de agosto de 2000 "Los criterios contemplados en los apartados 1 y 2 podrán incluir los criterios de exclusión enumerados en el artículo 46 de la Directiva .././CE [sobre coordinación de los procedimientos de adjudicación de los contratos públicos de suministro, de servicios y de obras]" (DOCE C 29E, de 30 de enero de 2001, pág. 112).

${ }^{453}$ Propuesta de Directiva del Parlamento Europeo y del Consejo sobre coordinación de los procedimientos de adjudicación de los contratos públicos de suministro, de servicios y de obras, COM (2000) 275 final, de 30 de agosto de 2000 (DOCE C $29 \mathrm{E}$, de 30 de enero de 2001).

${ }^{454}$ Sobre las novedades que presenta la Propuesta de Directiva, BERMEJO VERA, J., "Objetivos, principios y prospectiva de la política comunitaria (...)", op. cit., págs. 153 a 162. 
delitos relacionados con la delincuencia organizada, la corrupción o el fraude en detrimento de los intereses económicos de la Comunidad, definiendo qué conductas están comprendidas en cada uno de estos tipos delictivos.

Por otra parte, ampliaba los supuestos en los que se admitía la facultad de excluir a licitadores y candidatos. Así, la Propuesta preveía en su artículo 46, apartado 2, letra h), la posibilidad de prohibir contratar a todo operador económico que hubiera sido juzgado, por sentencia incluso no firme, por su implicación en un fraude o actividad ilegal a tenor del antiguo artículo 280 del Tratado $\mathrm{CE}^{455}$, con excepción de las previstas en la letra c) del apartado 1 que, como ya se ha indicado, se refieren a una exclusión de carácter obligatorio. De la misma manera, esta facultad de excluir a los participantes en un contrato por delitos relacionados con su moralidad profesional extendía su ámbito de aplicación a los supuestos de condenas por sentencias no firmes.

Artículo 46, apartado 1 (exclusiones obligatorias)

"Quedará excluido de la participación en el contrato todo aquel operador económico que, durante el período de cinco años anterior al inicio del procedimiento de adjudicación del contrato, haya sido condenado en sentencia firme por los siguientes motivos:

a) Haber cometido infracciones graves participando en las actividades de una organización delictiva, entendiendo por tal una asociación estructurada, establecida durante un cierto tiempo, y que actúe de manera concertada con el fin de obtener beneficios patrimoniales $y$, en su caso, de influir de manera indebida en el funcionamiento de la autoridad pública;

b) Por corrupción, a saber, por haber prometido, ofrecido o dado, directamente o por medio de terceros, una ventaja del tipo que sea a un funcionario o agente público de un Estado miembro, de un tercer país o de un organismo internacional o a cualquier otra persona,

\footnotetext{
${ }^{455} \mathrm{El}$ antiguo artículo 280 TCE se corresponde con el actual artículo 325 TFUE que se refiere a la lucha contra el fraude "1. La Unión y los Estados miembros combatirán el fraude y toda actividad ilegal que afecte a los intereses financieros de la Unión mediante medidas adoptadas en virtud de lo dispuesto en el presente artículo, que deberán tener un efecto disuasorio y ser capaces de ofrecer una protección eficaz en los Estados miembros y en las instituciones, órganos y organismos de la Unión".
} 
para ésta o para un tercero, con el fin de que dicha persona realice o se abstenga de realizar un acto incumpliendo sus obligaciones profesionales;

c) Por fraude, a efectos del artículo 1 del Convenio relativo a la protección de los intereses financieros de las Comunidades Europeas, establecido por Acto del Consejo de 26 de julio de 1995".

Artículo 46, apartado 2 (exclusiones facultativas)

"Podrá ser excluido de la participación en el contrato todo operador económico:

a) Que se encuentre en estado de quiebra, de liquidación, de cese de actividades, de intervención judicial o de concurso de acreedores, o en cualquier situación análoga a resultas de un procedimiento de la misma naturaleza que exista en las legislaciones y reglamentaciones nacionales;

b) Que sea objeto de un procedimiento de declaración de quiebra, de liquidación, de intervención judicial, de concurso de acreedores o de cualquier otro procedimiento de la misma naturaleza que exista en las legislaciones y reglamentaciones nacionales;

c) Que haya sido juzgado mediante una sentencia en la que se aprecie un delito que afecte a su moralidad profesional;

d) Que haya cometido una falta grave en materia profesional, que pueda ser comprobada por cualquier medio que los poderes adjudicadores puedan justificar;

e) Que no esté al corriente en sus obligaciones relativas al pago de las cotizaciones de la seguridad social, según las disposiciones legales del país en el que esté establecido o las del país del poder adjudicador;

f) Que no haya cumplido sus obligaciones fiscales según las disposiciones legales de los países pertinentes;

g) Que haya incurrido en culpabilidad grave por hacer declaraciones falsas al proporcionar la información exigida en aplicación de la presente Sección; 
h) Que haya sido juzgado mediante una sentencia en la que se aprecie un fraude o cualquier otra actividad ilegal a efectos del artículo 280 del Tratado, distinta de las contempladas en la letra c) del apartado 1".

A pesar de lo novedosa que resulta esta Propuesta con respecto al texto que entonces estaba vigente, guarda silencio en cuanto a la falta de aplicación efectiva de estos criterios de exclusión obligatorios, ya que su efectiva puesta en práctica necesitaría de la creación de un mecanismo común de intercambio de información entre los Estados miembros sobre los motivos que habilitan una prohibición de contratar ${ }^{456}$.

Esta Propuesta de Directiva - al igual que el texto finalmente aprobado - se limitaba a mantener los mismos medios de prueba que las Directivas de las que traen causa. De tal manera que, cuando un poder adjudicador solicitara del operador económico la prueba de que no está incurso en alguno de los supuestos de exclusión obligatoria a los que se refieren el apartado 1 del artículo 46, admitiría como prueba suficiente un certificado de antecedentes penales o, en su defecto, un documento equivalente expedido por una autoridad judicial o administrativa competente del país de origen o de procedencia que acreditase el cumplimiento de todos los requisitos. Cuando el país de que se trate no expidiera este certificado o documento, éstos podrán ser sustituidos por una declaración jurada o, en los Estados miembros en los que no exista tal declaración, por una declaración solemne hecha por el interesado ante una autoridad judicial o administrativa competente, un notario o un organismo profesional competente del país de origen o de procedencia.

\section{B.1. Dictamen del Comité Económico y Social}

El Dictamen del Comité Económico y Social se inicia con el reconocimiento de que las Directivas entonces vigentes habían tenido un impacto muy limitado en la apertura de la contratación pública y, para cambiar esa dinámica, se

\footnotetext{
${ }^{456}$ Sobre este particular y en relación con la Propuesta de Directiva, véase IGLESIAS RIO, M. Á. y MEDINA ARNÁIZ, T., "Herramientas preventivas en la lucha contra la corrupción en el ámbito (...)", op. cit., págs. 60 a 62 y DREW, K., "A Critical Analysis of the EC's Public (...)", op. cit., págs. 9 y 10.
} 
muestra favorable ante la «fusión simplificadora» que lleva a cabo la Propuesta de la Comisión ${ }^{457}$. No obstante, considera que el texto puede ser mejorado y, por ello, formula comentarios constructivos con esa idea.

Así, el Comité Económico y Social ponía de relieve la ausencia, en el texto propuesto, de referencias a cuestiones medioambientales y de carácter social, si bien era consciente de la dificultad de tratar estos aspectos con detalle, máxime cuando aún no se habían publicado las Comunicaciones interpretativas que versarían sobre estas materias ${ }^{458}$. En este sentido, recomendaba la redacción de un manual social de contratación a fin de orientar a los poderes públicos en este ámbito y, respecto de las prohibiciones de contratar, proponía que el texto de la Directiva recogiese expresamente que "se puede excluir a un licitador en caso de infracción grave probada de la legislación social o medioambiental" (apartado 4.9.3 del Dictamen).

Consideraba que esta exclusión era ya posible con arreglo a las Directivas entonces en vigor al entenderse comprendida en la prohibición de contratar por estar el licitador o candidato condenado por cualquier delito que afectase a su moralidad profesional o por falta grave en materia profesional, si bien declaraba que una mención específica en el texto de la futura Directiva reforzaría y aportaría claridad a esta posibilidad.

En particular, el Comité estimaba que se debía excluir de la participación en un contrato a cualquier agente económico que hubiera infringido la legislación laboral de los Estados miembros, incluidas las disposiciones relativas a la

${ }^{457}$ Dictamen del Comité Económico y Social de 26 de abril de 2001 (DOCE C 193, de 10 de julio de 2001, págs. 7-15). Recordemos que, respecto del impacto económico de la normativa sobre contratación pública durante el periodo 1995-2002, la Comisión publicó en febrero de 2004 un estudio A report on the functioning of public procurement markets in the EU: benefits from the application of EU directives and challenges for the future, según el cual únicamente un $3 \%$ del total de una muestra de empresas contratistas afirmaba haber llevado a cabo contrataciones transfronterizas directas.

${ }^{458}$ Meses más tarde de la aprobación del Dictamen del Comité Económico y Social se publicaron la Comunicación sobre la legislación comunitaria de contratos públicos y las posibilidades de integrar aspectos medioambientales en la contratación pública, COM (2001) 274 final, de 4 de julio de 2001 y la Comunicación sobre la legislación comunitaria de contratos públicos y las posibilidades de integrar aspectos sociales en dichos contratos, COM (2001) 566 final, de 15 de octubre de 2001. 
igualdad de trato. De este modo, "las agencias de contratación podrían excluir a licitadores que no respeten la reglamentación nacional y regional encaminada a obtener determinados objetivos sociales" (apartado 4.9.3.1 del Dictamen).

La aprobación de este apartado del Dictamen fue especialmente debatido en el seno del Comité a juzgar por el resultado de la votación que pretendía la supresión de este apartado al entender que la redacción del punto 4.9.3 era ya suficiente para contrarrestar infracciones graves ${ }^{459}$. No obstante, las enmiendas presentadas fueron rechazadas y el texto propuesto por el Comité Económico y Social abogaba por incorporar al texto de la Directiva una prohibición de contratar que tuviera por objeto excluir a un licitador que hubiera infringido la legislación laboral de los Estados miembros.

\section{B.2. Dictamen del Comité de las Regiones}

Por lo que se refiere a las prohibiciones de contratar, el Comité de las Regiones consideró muy positiva la Propuesta de la Comisión respecto de endurecer la lucha contra las actividades delictivas de los operadores económicos que tienen lugar en el ámbito de la contratación pública, pues en palabras del Comité, "no se debe permitir la participación en los procedimientos de adjudicación pública de operadores informales" 460 . Sin embargo, en relación con la puesta en práctica de las exclusiones de carácter obligatorio consideraba que debían concretarse con mayor detalle algunos aspectos en su aplicación.

\footnotetext{
${ }^{459}$ Véase el anexo al Dictamen donde se recogen las enmiendas que obtuvieron más de la cuarta parte de los votos emitidos, pero que fueron rechazadas en el debate para la elaboración del Dictamen. Concretamente, nos referimos a la enmienda presentada al apartado 4.9.3.1 que solicitaba la supresión de la petición de excluir indefinidamente a un licitador que "haya infringido la legislación laboral de los Estados miembros", puesto que, en opinión de quienes presentan la enmienda, "esta exclusión tendría un efecto discriminatorio completamente incontrolable, y posiblemente también arbitrario, particularmente de los competidores extranjeros. Incluso las infracciones de poca monta contra la legislación nacional podrían llevar a la exclusión de licitadores o a complicados procedimientos de control y conflictos judiciales". Esta enmienda de supresión fue rechazada por 53 votos a favor, 71 en contra y 1 abstención (DOCE C 193, de 10 de julio de 2001, pág. 15).

${ }^{460}$ Dictamen del Comité de las Regiones a la Propuesta de Directiva sobre coordinación de los procedimientos de adjudicación de los contratos públicos de suministro, de servicios y de obras (DOCE C 144, de 16 de mayo de 2001, pág. 26).
} 
En primer lugar, el Comité de las Regiones cuestionaba cómo aplicar estas prohibiciones de contratar en aquellos Estados miembros en los que una persona jurídica no puede ser condenada por corrupción al no reconocerse responsabilidad penal a las personas jurídicas. Del mismo modo, se preguntaba si la prohibición debía persistir aun cuando por parte de la empresa se hubieran adoptado medidas de prevención para impedir la reiteración del hecho delictivo o, por ejemplo, que hubieran despedido de inmediato a los directivos que cometieron estos delitos sin la complicidad del operador económico en cuestión (medidas de self-cleaning) ${ }^{461}$. Por último, planteaba la hipótesis de la provisión de un medicamento único y vital que no pudiera ser suministrado por ningún otro proveedor que aquél que estuviera condenado por alguno de los delitos que daban lugar a una exclusión de carácter obligatorio. Para hacer frente a estas cuestiones, el Comité de las Regiones recomendaba una nueva formulación de las causas de exclusión obligatorias que tuvieran en cuenta estos supuestos para tratar de buscar un equilibrio entre las prohibiciones de contratar y una visión pragmática del interés general (apartados 2.5.2 y 2.5.3 del Dictamen).

Asimismo, y en este mismo apartado dedicado a los criterios de selección cualitativa, el Comité de las Regiones consideraba muy importante que los poderes adjudicadores pudieran imponer a los licitadores exigencias para que respetasen la normativa nacional en el ámbito social de cada Estado miembro. En este sentido, entendía comprensible que un órgano de contratación no se viera en la obligación de aceptar en la licitación a un operador económico que incumpliese, por ejemplo, las normas sobre creación de empleo, entorno laboral, salario mínimo o trabajo infantil, siempre que estos requisitos figurasen en el anuncio de la licitación y no fueran discriminatorios (apartado 2.5.4 del Dictamen).

\footnotetext{
${ }^{461}$ Estos "antecedentes" de las medidas de self-cleaning en la regulación contractual serán tratados con mayor detenimiento en las páginas 541 y siguientes del Capítulo cuarto de esta memoria doctoral con cita expresa al trabajo de ARROWSMITH, S., PRIESS, H.J. y FRITON, P., "Self-Cleaning as a Defence to Exclusions for Misconduct - an Emerging Concept in EC Public Procurement Law?", PPLR, vol. 18 (6), 2009, pág. 262.
} 


\section{B.3. Dictamen del Parlamento Europeo - Primera lectura}

La Posición del Parlamento Europeo, adoptada en primera lectura el 17 de enero de 2002, modificó la Propuesta de la Comisión en diferentes aspectos conectados con las prohibiciones de contratar, ya que, se aprobaron distintas enmiendas en relación con el artículo 46 de la Propuesta y con la incorporación de un nuevo considerando al texto de la Directiva. Este considerando tenía por finalidad aclarar la situación jurídica de los licitadores que "pueden verse excluidos cuando hayan sido condenados por delitos relacionados particularmente con infracciones de Derecho laboral o por delito ecológico. También pueden verse excluidos si han sido sancionados por acuerdos ilícitos en relación con licitaciones o por falta profesional grave" 462 .

En lo que concierne a los criterios de exclusión, las enmiendas presentadas se referían tanto a las exclusiones de carácter obligatorio como a las facultativas.

Respecto de la primera categoría, la justificación de las enmiendas pivotaba sobre la definición de los tipos delictivos cuya condena iba a ocasionar la exclusión obligatoria del licitador o candidato de los procedimientos de adjudicación contractual. Se proponía que estos delitos se definieran por remisión a los instrumentos jurídicos incardinados en el ámbito de cooperación intergubernamental propios del «tercer pilar» ${ }^{463}$ y no por acepciones autónomas recogidas en la Directiva sobre contratos. En este sentido, hemos de recordar

${ }^{462}$ Enmienda número 16 que incorpora al texto de la Directiva el considerando 33 bis presentado por el Informe del Parlamento Europeo, de 29 de octubre de 2001, elaborado por la Comisión de Asuntos Jurídicos y Mercado Interior siendo ponente Stefano ZAPPALÀ (A5-0378/2001) (DOCE C 271E, de 7 de noviembre de 2002, pág. 176).

${ }^{463} \mathrm{El}$ concepto de pilares se utilizaba en el TUE para definir la arquitectura de la Unión. El primer pilar, relativo a las tres Comunidades (CEE, EURATOM y CECA) tenía carácter comunitario o de integración y estaba formado por los Tratados constitutivos. Los otros dos pilares eran de carácter intergubernamental correspondiendo al segundo pilar la política exterior y de seguridad común (PESC), y al tercer pilar los aspectos relativos a la cooperación policial y judicial en materia penal (denominado inicialmente de cooperación en materia de justicia y asuntos de interior (JAI). Con la entrada en vigor del Tratado de Lisboa, la estructura en pilares desaparece y se generaliza la aplicación del método comunitario, es decir, la aprobación por mayoría cualificada de las propuestas que haga la Comisión, en el campo de la justicia, la libertad y la seguridad. 
que la potestad legislativa penal no ha sido transferido a las instituciones europeas, y que aun a pesar de los avances actuales en esta materia, el Derecho penal sigue reservado a la competencia exclusiva de cada Estado ${ }^{464}$. Es por ello que los Estados miembros son los únicos con competencia, tanto para la creación de normas penales como para la imposición de sanciones de esta misma naturaleza. Debido a la ausencia de atribución competencial de la UE para la calificación de los tipos penales, no se consideraba adecuado que en las Directivas sobre contratación pública se incluyesen definiciones propias del Derecho Penal, pues ello hubiera podido generar debates inútiles sobre el fundamento jurídico que posibilitaba la armonización de conceptos jurídicos como son el de organización delictiva o corrupción.

Además de estos cambios nominativos, también se propusieron algunas enmiendas en el sentido de incluir en el apartado primero del artículo 46 relativo a las exclusiones de carácter obligatorio, la condena en sentencia firme por otros tipos delictivos como el blanqueo de capitales y los delitos relacionados con el tráfico ilícito de droga, o por mostrar el licitador o candidato un comportamiento fraudulento o desleal en relación con la adjudicación de contratos público contrario a la competencia, así como por incumplir los convenios colectivos y otras normas y leyes en materia laboral y social (enmiendas 80 a 83). También se preveía que quedase excluido automáticamente de la participación en el contrato todo operador económico que se encontrase en estado de quiebra o en cualquier situación análoga que suponga el cese en el pago de sus obligaciones.

De igual manera, fueron varias las enmiendas que se referían a las exclusiones facultativas. En primer lugar, y para el supuesto de condena por un delito que afectase a la moralidad del licitador o candidato, se aludía a la exigencia de que la condena se haya pronunciado mediante sentencia judicial firme. En segundo lugar, se incluía en el concepto de falta grave en materia profesional el quebrantamiento de los principales Convenios de la Organización Internacional del Trabajo (OIT) y de las principales Directivas en el ámbito de la política

${ }^{464} \mathrm{El}$ avance lo constituye principalmente el artículo 83.2 del TFUE que expresa el reconocimiento de la competencia de la Unión en materia penal en una serie de nuevos sectores armonizados y que, a diferencia de los que antes se reconocían en el antiguo «tercer pilar» (artículo 29 TUE), no están subordinados a la exigencia de cooperación judicial. 
social. Por último, las enmiendas 87 y 89 pretendían que se garantizasen las disposiciones sobre protección y condiciones de trabajo en la selección del contratista $^{465} \mathrm{y}$, por ello, requieren que un operador económico sea excluido de la participación en un procedimiento de licitación pública si éste ha sido condenado por no cumplir sus obligaciones en lo que respecta a la protección del trabajo y a la seguridad y salud de los trabajadores (enmiendas 84 a 90).

Artículo 46, apartado 1 (exclusiones obligatorias)

"Quedará excluido de la participación en el contrato todo aquel operador económico que, durante el período de cinco años anterior al inicio del procedimiento de adjudicación del contrato, haya sido condenado en sentencia firme por los siguientes motivos:

a) Haber cometido el delito, que se define en el apartado 1 del artículo 2 de la Acción Común 98/733/JAI, de participación en una organización delictiva, que en el artículo 1 de la mencionada Acción Común se define como una asociación estructurada de más de dos personas, establecida durante un cierto tiempo, y que actúe de manera concertada con el fin de cometer delitos sancionables con una pena privativa de libertad o una medida de seguridad privativa de libertad de un máximo de cuatro años o con una pena aún más severa, con independencia de que esos delitos constituyan un fin en sí mismos o un medio de obtener beneficios patrimoniales $y$, en su caso, de influir de manera indebida en el funcionamiento de la autoridad pública;

b) Por corrupción, a saber, por haber prometido, ofrecido o dado, directamente o por medio de terceros, una ventaja del tipo que sea a un funcionario o agente público de un Estado miembro, de un tercer país o de un organismo internacional o a cualquier otra persona,

\footnotetext{
${ }^{465}$ La justificación de la enmienda número 87 estribaba en que "debe establecerse con claridad que para excluir a una empresa de un procedimiento de licitación no bastará una infracción menor cometida en el pasado (por ejemplo, un empresario que en una ocasión se haya retrasado dos días en el pago del sueldo de sus trabajadores a causa de un fallo en el sistema informático de contabilidad de su empresa). La exclusión constituye una injerencia en el derecho al libre ejercicio de una profesión (derecho garantizado por la jurisprudencia del Tribunal de Justicia) y, por ello, debe ser proporcionada".
} 
para ésta o para un tercero, con el fin de que dicha persona realice o se abstenga de realizar un acto incumpliendo sus obligaciones profesionales;

c) Por fraude, a efectos del artículo 1 del Convenio relativo a la protección de los intereses financieros de las Comunidades Europeas, establecido por Acto del Consejo de 26 de julio de 1995;

c.bis) Por el delito de blanqueo de bienes procedentes de actividades ilícitas, definido en el artículo 1 de la Directiva 91/308/CEE del Consejo, de 10 de junio de 1991, relativa a la prevención de la utilización del sistema financiero para el blanqueo de capitales;

c.ter) Por comportamiento engañoso o cualquier comportamiento ilícito que falsee la competencia en relación con la adjudicación de contratos públicos en el mercado común;

c.quater) Por incumplimiento de convenios colectivos y otras normas y leyes en materia laboral y social vigentes en el país en el que esté establecido u otro país pertinente;

c.quinquies) Por un delito relacionado con la droga, definido en la letra a) del apartado 1 del artículo 3 de la Convención de las Naciones Unidas contra el tráfico ilícito de estupefacientes y de sustancias sicotrópicas, adoptada en Viena el 19 de diciembre de 1998. "

Artículo 46, apartado 2 (exclusiones facultativas)

"Podrá ser excluido de la participación en el contrato todo operador económico:

c) Que haya sido juzgado mediante una sentencia firme, de conformidad con la legislación del Estado miembro en cuestión, en la que se aprecie un delito que afecte a su moralidad profesional;

d) Que haya cometido una falta grave en materia profesional, incluida la violación de las normas laborales internacionales básicas tal y como se definen en el Anexo XII ${ }^{466}$ y la violación de la legislación comunitaria básica relativa a la protección del empleo y a

${ }^{466}$ La normativa laboral básica, en atención a lo dispuesto en el Anexo XII de este Dictamen estaba constituida por los siguientes Convenios de la OIT: Convenio 87 relativo a la libertad sindical y a la protección del derecho de sindicación; Convenio 
las condiciones de trabajo, que pueda ser comprobada por cualquier medio que los poderes adjudicadores puedan justificar;

e) Que no esté al corriente en sus obligaciones relativas al pago de las cotizaciones de la seguridad social, según las disposiciones legales del país en el que esté establecido o las del país del poder adjudicador;

e bis) (nueva) No haber cumplido sus obligaciones con los trabajadores en lo relativo a la protección del trabajo y a los representantes de los trabajadores de conformidad con las normas vigentes, incluidas las disposiciones contenidas en leyes, convenios colectivos y contratos de trabajo. Para poder ser invocada como causa de exclusión en un procedimiento de licitación, una infracción de esta naturaleza deberá haber sido constatada mediante sentencia firme de un tribunal ordinario. La exclusión y su duración deberán guardar proporción con la importancia de la infracción;

f) Que no haya cumplido sus obligaciones fiscales según las disposiciones legales de los países pertinentes;

g) Que haya incurrido en culpabilidad grave por hacer declaraciones falsas al proporcionar la información exigida en aplicación de la presente Sección;

h) $(\text { Suprimido) })^{467}$;

$h$ bis) (nueva) Que haya sido condenado por un tribunal por no haber cumplido sus obligaciones en lo que respecta a la seguridad y la salud de los trabajadores de conformidad con el Derecho comunitario o con las disposiciones legales de los correspondientes países,

98, relativo a la aplicación de los principios del derecho de sindicación y de negociación colectiva; Convenio 29, relativo al trabajo forzoso u obligatorio; Convenio 105, relativo a la abolición del trabajo forzoso; Convenio 138, relativo a la edad mínima; Convenio 111, relativo a la discriminación (empleo y ocupación) y Convenio 100, relativo a la igualdad de remuneración.

${ }^{467}$ La letra h) disponía que los operadores económicos puedan ser excluidos de la participación en el contrato en caso de que hayan cometido un fraude o hayan participado en otras actividades delictivas a efectos del artículo 280 del Tratado sin la debida precisión y sin que la condena se haya pronunciado en sentencia firme. 
o en relación con el cual la autoridad nacional competente haya demostrado dicho incumplimiento."

Artículo 46, apartado 2 bis (nuevo)

"Quedará excluido de la participación en el contrato todo operador económico que se encuentre en estado de quiebra, de liquidación, de cese de actividades, de intervención judicial o de concurso de acreedores, o en cualquier situación análoga a resultas de un procedimiento de la misma naturaleza que exista en las legislaciones y reglamentaciones nacionales". "

\section{B.4. Propuesta modificada de la Directiva}

Las numerosas enmiendas planteadas provocaron la presentación por parte de la Comisión de una Propuesta modificada de Directiva en la que se aceptaban algunas de las modificaciones sugeridas por el Parlamento Europeo ${ }^{468}$.

Así, la Propuesta modificada de Directiva se plegaba a la exigencia de que la exclusión por un delito relativo a la moralidad profesional del licitador o candidato no se produjese hasta que éste no hubiera sido condenado por sentencia firme conforme a las disposiciones legales nacionales que le fueran aplicables. Igualmente, se mostraba receptiva a suprimir la posibilidad de excluir a un operador económico que hubiera sido condenado por fraude o cualquier otra actividad ilegal, en el sentido del artículo 280 del Tratado CE.

En cuanto a las exclusiones de carácter obligatorio, esta Propuesta modificada introdujo tres importantes cambios respecto de la Propuesta original. En primer término, suprimió la referencia temporal al periodo de cinco años anterior al inicio del procedimiento de adjudicación del contrato. En segundo lugar, completó la relación de delitos del apartado 1 del artículo 46 añadiendo el delito de blanqueo de capitales procedentes de una actividad ilícita y, finalmente, dio una nueva redacción al resto de los tipos delictivos acorde con el debate planteado acerca de las definiciones que debían contemplarse en la nor-

${ }^{468}$ Propuesta modificada de Directiva del Parlamento Europeo y del Consejo sobre coordinación de los procedimientos de adjudicación de los contratos públicos de suministro, de servicios y de obras, COM (2002) 236 final, de 6 de mayo de 2002 (DOCE C 203E, de 27 de agosto de 2002, págs. 210 - 240). 
mativa contractual, de tal manera que las acepciones empleadas para habilitar una prohibición de contratar lo fuesen por remisión a instrumentos propios de la cooperación intergubernamental ${ }^{469}$.

Entre las enmiendas descartadas por la Comisión se encuentran aquellas que pretendían incorporar al texto de la Directiva la exclusión obligatoria por motivos anejos a los comportamientos ilícitos que falseen la competencia, por incumplimiento de los convenios colectivos u otras normas en materia sociolaboral y por delitos relacionados con el tráfico de estupefacientes. La justificación en estos casos se amparaba en que, en el ámbito de la UE, no se habían armonizado los tipos penales vinculados a estos fenómenos, ni existían regímenes de sanciones aplicables en todos los Estados miembros. Estos motivos se consideraban suficientes como para no aplicarse un régimen de prohibiciones de contratar de carácter obligatorio en tales situaciones.

También quedó fuera de consideración la enmienda que pretendía incluir como obligatoria la exclusión de cualquier operador económico que se encontrase en estado de quiebra, de liquidación, de cese de actividades, de intervención judicial o de concurso de acreedores, o en cualquier situación análoga a las anteriores. En este caso se aducía que, de admitirse esta enmienda, se dejaba al licitador o candidato sin la menor oportunidad de modificar su precaria situación económica, y por esa razón, parecía más conveniente dejar que cada Estado miembro decidiera sobre la posibilidad de excluir a los operadores que se encontrasen en dichas situaciones.

Tampoco se admitieron, las enmiendas relacionadas con la posibilidad de excluir a un operador económico por quebrantamiento de los convenios internacionales en materia laboral, por incumplimiento de la normativa básica relativa a la protección del empleo y las condiciones de trabajo, o por haber desatendido sus obligaciones de protección hacia los trabajadores y en materia de normativa laboral respecto a los representantes de éstos. El argumento esgrimido para justificar estos rechazos se basaba en que no era necesario con-

\footnotetext{
${ }^{469}$ Como hemos comentado anteriormente, el desacuerdo lo provocaba la búsqueda del mecanismo jurídico adecuado para encuadrar la exclusión de los licitadores como una materia propia del mercado interior o del Derecho penal, puesto que estas dos áreas de la legislación europea se rigen por procesos legislativos diferentes, adoptan instrumentos jurídicos distintos y asignan competencias desiguales a la Comisión, al Consejo y al Parlamento.
} 
templar explícitamente estos supuestos en el articulado de la Directiva, porque la normativa entonces vigente ya preveía dichos motivos de exclusión. Es así que, apoyándose en su Comunicación sobre la legislación comunitaria de contratos públicos y las posibilidades de integrar aspectos sociales en dichos contratos $^{470}$, la Comisión manifestaba que estas prohibiciones podían ser aplicadas por parte de los Estados miembros siempre que, en sus respectivas legislaciones nacionales, dichas infracciones constituyesen bien una falta grave en materia profesional, bien un delito que afectase a la moralidad profesional del licitador o candidato ${ }^{471}$.

\section{B.5. Posición Común del Consejo}

El 20 de marzo de 2003, el Consejo adoptó su Posición Común con vistas a la adopción de la Directiva sobre coordinación de los procedimientos de adjudicación de los contratos públicos de obras, de suministros y de servicios $^{472}$. Respecto de su contenido, cabe indicarse que, con carácter general, perviven los mismos objetivos de simplificación y modernización contemplados en la propuesta inicial de la Comisión, al tiempo que se acogen algunas de las reivindicaciones presentadas por el Parlamento Europeo en sus enmiendas y por el Comité de las Regiones en su Dictamen.

Por lo que se refiere a las exclusiones obligatorias, esta Posición Común completa el apartado primero del artículo 46 de la Propuesta modificada con

\footnotetext{
${ }^{470}$ Comunicación interpretativa de la Comisión sobre la legislación comunitaria de contratos públicos y las posibilidades de integrar aspectos sociales en dichos contratos, COM (2001) 566 final, de 15 de octubre de 2001 (DOCE C 333, de 28 de noviembre de 2001, págs. 27 - 41).

${ }^{471}$ En esta Comunicación, la Comisión había aclarado en qué medida la normativa existente contemplaba estos motivos de exclusión, y señalaba expresamente que el no respeto de determinadas obligaciones sociales podía conllevar la exclusión de los licitadores en algunos casos, correspondiendo a cada Estado miembro determinar en cuáles. Por ejemplo, por quebrantar la prohibición del trabajo clandestino o por incumplimiento de las disposiciones en materia de igualdad de trato.

${ }^{472}$ Posición Común (CE) 33/2003, aprobada por el Consejo el 20 de marzo de 2003, con vistas a la adopción de la Directiva del Parlamento Europeo y del Consejo sobre coordinación de los procedimientos de adjudicación de los contratos públicos de obras, de suministro y de servicios (DOCE C 147E, de 24 de junio de 2003).
} 
la incorporación de distintos párrafos que buscan clarificar el modo en que han de aplicarse estas prohibiciones de contratar.

En este sentido, el segundo párrafo del renumerado artículo 45 precisa que serán los Estados miembros quienes establezcan las condiciones de aplicación de las exclusiones obligatorias, en particular cuando ésta se refiera a cuestiones relativas al Derecho penal, cuya armonización - como venimos señalando - no es objeto de las Directivas sobre contratación pública. El tercer párrafo posibilita excepcionar la aplicación de las prohibiciones de contratar cuando razones imperativas de interés general así lo aconsejen, tal y como sugería el Comité de las Regiones en su Dictamen y, por último, el cuarto párrafo concreta los mecanismos mediante los cuales los poderes adjudicadores pueden obtener la información necesaria para poner en práctica las exclusiones obligatorias; así puede verse cómo contempla, en particular, la cooperación con las autoridades competentes de los otros Estados miembros.

Respecto de las exclusiones facultativas, el apartado segundo de este artículo 45 se ha completado, mediante la inserción de un nuevo párrafo. Este párrafo indica, igualmente, que serán los Estados miembros los que precisarán, de conformidad con su Derecho nacional, las condiciones de aplicación de estas prohibiciones de contratar. También se han despejado dudas en el texto de la Propuesta modificada, en relación con la exclusión de los operadores condenados mediante sentencia judicial, al precisarse que el carácter firme de las sentencias deberá corresponder a la autoridad de cosa juzgada y que sólo puedan excluirse a los operadores económicos sobre la base de una sentencia de carácter firme.

$\mathrm{Al}$ detenernos en la consideración de aspectos sociales y medioambientales en la selección del contratista, podemos observar cómo se ha ampliado el texto de la Propuesta modificada. La ampliación se refiere al cumplimiento de la normativa social y en materia de medio ambiente, con la formulación de los considerandos trigésimo segundo y cuadragésimo primero que recogen expresamente la posibilidad de excluir - con arreglo a las letras c) y d) del apartado 2 del artículo 45 - del procedimiento de adjudicación de un contrato público a los operadores considerados culpables de incumplir dichas normas ${ }^{473}$.

\footnotetext{
${ }^{473} \mathrm{El}$ considerando trigésimo segundo señala que "Las leyes, reglamentaciones y convenios colectivos, tanto nacionales como comunitarios, vigentes en materia social
} 
La incorporación de estas modificaciones ha permitido culminar el trámite legislativo con el siguiente texto, que va a mantenerse básicamente incólume hasta la aprobación final de la Directiva 2004/18/CE, salvo por ligeros retoques habidos en la redacción de sus considerandos y en su letra d).

Artículo 45, apartado 1 (exclusiones obligatorias)

"Quedará excluido de la participación en un contrato público todo aquel candidato o licitador que haya sido condenado en sentencia firme, de la que tenga conocimiento el poder adjudicador, por uno o varios de los motivos que a continuación se enumeran:

a) Participación en una organización delictiva, tal y como se define en el apartado 1 del artículo 2 de la Acción Común de 21 de diciembre de 1998.

b) Corrupción, tal y como se define, respectivamente, en el artículo 3 del Acto del Consejo de 26 de mayo de 1997 y en el apartado 1 del artículo 3 de la Acción Común de 22 de diciembre de 1998.

c) Fraude, según el artículo 1 del Convenio relativo a la protección de los intereses financieros de las Comunidades Europeas, establecido por Acto del Consejo de 26 de julio de 1995.

d) Blanqueo de capitales, tal como se define en el artículo 1 de la Directiva 91/308/CEE del Consejo, de 10 de junio de 1991, relativa a la prevención de la utilización del sistema financiero para el blanqueo de capitales, modificada por la Directiva 2001/97/CEE del Parlamento Europeo y del Consejo de 4 de diciembre de 2001.

y de seguridad del trabajo, se aplicarán durante la ejecución de un contrato público, siempre que dichas normas, así como su aplicación, se ajusten al Derecho comunitario (... ). Si el Derecho nacional contemplare disposiciones a tal efecto, el incumplimiento de dichas obligaciones se podrá considerar una falta grave o un delito que afecta a la moralidad profesional del operador económico, pudiendo acarrearle su exclusión del procedimiento de adjudicación de un contrato público".

Por su parte, el considerando cuadragésimo primero en su último párrafo recoge que "Si el Derecho nacional contemplare disposiciones a tal efecto, el incumplimiento de la legislación en materia de medio ambiente o de contratos públicos por acuerdos ilícitos se podrá considerar un delito que afecta a la moralidad profesional del operador económico o una falta grave si ha dado lugar a una sentencia firme o a una decisión de efectos equivalentes". 
Los Estados miembros precisarán, de conformidad con su Derecho nacional y respetando el Derecho comunitario, las condiciones de aplicación del presente apartado.

Podrán establecer una excepción respecto a la obligación contemplada en el párrafo primero por necesidades imperativas de interés general.

Para la aplicación del presente apartado, los poderes adjudicadores solicitarán, en su caso, a los candidatos o licitadores que presenten los documentos a que se refiere el apartado 3 y, cuando tengan dudas sobre la situación personal de éstos, podrán dirigirse a las autoridades competentes para obtener la información que consideren necesaria sobre la situación personal de dichos candidatos o licitadores. Cuando la información se refiera a un candidato o licitador establecido en un Estado distinto del Estado del poder adjudicador, éste podrá solicitar la cooperación de las autoridades competentes. Con arreglo a la legislación nacional del Estado miembro en el que estén establecidos los candidatos o licitadores, dichas solicitudes se referirán a personas jurídicas y físicas, incluidos, en su caso, los jefes de empresa o cualquier persona que ejerza poderes de representación, decisión o control en el seno de las empresas del candidato o licitador".

Artículo 45, apartado 2 (exclusiones facultativas)

"Podrá ser excluido de la participación en el contrato todo operador económico:

a) Que se encuentre en estado de quiebra, de liquidación, de cese de actividades, de intervención judicial o de concurso de acreedores, o en cualquier situación análoga a resultas de un procedimiento de la misma naturaleza que exista en las normas legales y reglamentarias nacionales;

b) Que sea objeto de un procedimiento de declaración de quiebra, de liquidación, de intervención judicial, de concurso de acreedores o de cualquier otro procedimiento de la misma naturaleza que exista en las normas legales y reglamentarias nacionales;

c) Que haya sido condenado por sentencia con autoridad de cosa 
juzgada según las disposiciones legales del país y en la que se aprecie un delito que afecte a su moralidad profesional;

d) Que haya cometido una falta grave en materia profesional, que pueda ser comprobada por cualquier medio que los poderes adjudicadores puedan justificar;

e) Que no esté al corriente en sus obligaciones relativas al pago de las cotizaciones de la seguridad social, según las disposiciones legales del país en el que esté establecido o las del país del poder adjudicador;

f) Que no haya cumplido sus obligaciones tributarias impuestas por las disposiciones legales del país en el que esté establecido o las del país del poder adjudicador;

g) Que se le considere gravemente culpable de hacer declaraciones falsas al proporcionar la información exigida en aplicación de la presente Sección o que no haya proporcionado dicha información.

Los Estados miembros precisarán, de conformidad con su Derecho nacional y respetando el Derecho comunitario, las condiciones de aplicación del presente apartado".

\section{B.6. Dictamen del Parlamento Europeo - Segunda lectura}

Si bien en los párrafos precedentes se ha indicado que, en lo que respecta a los criterios de exclusión, el texto aprobado por parte del Consejo en su Posición Común se mantuvo intacto hasta la aprobación de la Directiva 2004/18/CE, lo cierto es que el Parlamento Europeo, intentó de nuevo, en el trámite de segunda lectura, presentar alguna de las enmiendas que habían sido aprobadas en su primera lectura ${ }^{474}$.

$\mathrm{Su}$ firme, aunque infructuosa insistencia, recaía sobre la incorporación al catálogo de las prohibiciones de contratar obligatorias de aquellas circunstan-

${ }^{474}$ Dictamen del Parlamento Europeo, de 2 de julio de 2003, respecto de la Posición común del Consejo con vistas a la adopción de la Directiva del Parlamento Europeo y del Consejo relativa a la coordinación de los procedimientos de adjudicación de los contratos públicos de suministro, de servicios y de obras [A5-0242/2003 - P5_TA(2003) 0312]. 
cias relacionadas con la quiebra o el cese de actividades del operador económico, por su comportamiento engañoso o desleal que falseara la competencia, por el incumplimiento de los convenios colectivos y otras normas y leyes en materia sociolaboral, y finalmente, por haber sido condenado el licitador o candidato un delito relacionado con la droga ${ }^{475}$.

Mayor suerte tuvo la enmienda de modificación del considerando trigésimo segundo. La propuesta pretendía - y así lo consiguió - la incorporación al texto de la referencia a las condiciones de trabajo basándose en la formulación de la Directiva sobre desplazamiento de los trabajadores. Tras el cambio mencionado, la redacción de este considerando se consolidó bajo en siguiente tenor:

"Las leyes, reglamentaciones y convenios colectivos, tanto nacionales como comunitarios, vigentes en materia de condiciones de trabajo y empleo y de seguridad del trabajo, se aplicarán durante la ejecución de un contrato público, siempre que dichas normas, así como su aplicación, se ajusten al Derecho comunitario. Para las situaciones transfronterizas, en las que los trabajadores de un Estado miembro prestan sus servicios en otro Estado miembro para la realización de un contrato público, en la Directiva 96/71/CE del Parlamento Europeo y del Consejo, de 16 de diciembre de 1996, sobre el desplazamiento de trabajadores efectuado en el marco de una prestación de servicios, se enuncian las condiciones minimas que han de respetarse en el país de acogida en relación con dichos trabajadores desplazados. Si el Derecho nacional contemplare disposiciones a tal efecto, el incumplimiento de dichas obligaciones se podrá considerar una falta grave o un delito que afecta a la moralidad profesional del operador económico, pudiendo acarrearle su exclusión del procedimiento de adjudicación de un contrato público".

\footnotetext{
${ }^{475}$ El Dictamen de la Comisión sobre las enmiendas del Parlamento Europeo a la Posición común del Consejo no entró ni siquiera a valorar a estas enmiendas, COM (2003) 503 final, de 14 de agosto de 2003.
} 


\section{La aprobación de las Directivas 2004/17/CE y $2004 / 18 / \mathrm{CE}$}

Tal y como hemos avanzado al principio de este epígrafe, desde el año 2004 en la UE existe una tercera generación de Directivas sobre contratación pública: la Directiva 2004/17/CE del Parlamento Europeo y del Consejo, de 31 de marzo de 2004, sobre la coordinación de los procedimientos de adjudicación de contratos en los sectores del agua, de la energía, de los transportes y de los servicios postales («Directiva sobre sectores especiales») y la Directiva 2004/18/CE, de 31 de marzo, que refunde en un único texto las disposiciones relativas a la adjudicación de los contratos públicos de obras, de suministro y de servicios («Directiva clásica»).

Tras la lectura de sus considerandos se deduce que estas Directivas pretenden "responder a las exigencias de simplificación y modernización formuladas tanto por los poderes adjudicadores como por los operadores económicos", pero sin modificar el objetivo de las Directivas precedentes que era la coordinación de los procedimientos nacionales de adjudicación contractual cuando los importes de los contratos superen unos determinados umbrales económicos ${ }^{476}$. Este propósito, sin embargo, tal y como también se infiere de la jurisprudencia emanada del Tribunal de Justicia, no es más que una herramienta para alcanzar una finalidad de mayor calado, esto es, implantar una competencia objetiva en la contratación pública, en aras de la realización de las libertades

${ }^{476}$ Recordemos que como ya referimos en la Introducción de esta memoria doctoral, el Derecho de la Unión aplicable a los contratos públicos no está constituido únicamente por las disposiciones específicas contenidas en las Directivas sobre esta materia, ya que la jurisprudencia del Tribunal de Justicia ha insistido en la importancia del Derecho originario en este ámbito. De esta manera, las reglas sobre la adjudicación de los contratos públicos se supeditan al acatamiento de los principios recogidos en los Tratados constitutivos y, en particular, a los de la libre circulación de mercancías, la libertad de establecimiento, la libre prestación de servicios y a los más generales de igualdad de trato, de no discriminación, de reconocimiento mutuo, de proporcionalidad y de transparencia con independencia de los umbrales económicos. Sin embargo, para asegurar la apertura a la competencia, se impone, en los contratos públicos por importes superiores a una determinada cantidad, "elaborar a escala comunitaria disposiciones de coordinación de los procedimientos nacionales de adjudicación [...] basadas en dichos principios [...]" (considerando segundo de la Directiva 2004/18/CE y considerandos primero a tercero de la Directiva 2004/17/CE). 
esenciales para la plena integración europea (libre circulación de mercancías, personas, servicios y capitales) ${ }^{477}$.

Para asegurar el ejercicio de estas libertades, las citadas Directivas sobre contratación pública tratan de suprimir las trabas a la libre circulación de servicios y mercancías, protegiendo los intereses de los operadores económicos de un Estado miembro que desean vender bienes o servicios a las entidades adjudicadoras de otros Estados miembros. Consecuentemente con ello, se pretende eliminar el riesgo de que se otorgue preferencia a los licitadores o candidatos nacionales en cualquier adjudicación de contratos públicos que tenga un interés transfronterizo (buy national $)^{478}$.

A este respecto, procede señalar que aun cuando estas Directivas - al igual que las anteriores - no contemplan una armonización exhaustiva del régimen de la contratación pública en los Estados miembros, sí establecen una serie de normas específicas que abarcan distintas obligaciones relativas a la preparación y adjudicación de los contratos comprendidos en sus respectivos ámbitos de aplicación por razón de materia y de umbrales económicos y que se celebran por parte de las entidades que tienen la condición de poderes adjudicadores.

Estos compromisos, que se presentan como el reflejo del principio de no discriminación garantizado por el Derecho primario, son los siguientes: en primer lugar, los poderes adjudicadores están obligados a adjudicar sus contratos públicos utilizando alguno de los procedimientos recogidos en las Directivas

\footnotetext{
${ }^{477}$ Como se ha indicado al tratar las Directivas 92/50/CEE, 93/36/CEE y 93/37/CEE, la coordinación a escala de la Unión de los procedimientos de adjudicación de contratos públicos trata de garantizar una verdadera apertura del mercado único. Así lo venía manifestando el Tribunal de Justicia en distintas ocasiones, por ejemplo, en sus sentencias de 18 de octubre de 2001, SIAC Construction, C-19/00, apartado 32; de 18 de junio de 2002, HI, C-92/00, apartado 43 y de 13 de noviembre de 2007, Comisión/Irlanda, C-507/03, apartado 27.

${ }^{478}$ Así se manifiesta, por ejemplo, la STJUE de 18 de noviembre de 2010, Comisión/Irlanda, C-226/09, apartado 30 y de 15 de julio de 2010, Comisión/Alemania, C-271/08, apartado 73, con cita expresa en la sentencia de 15 de enero de 1998, Mannesmann Anlagenbau Austria y otros, C-44/96, apartados 32 y 33. También las conclusiones del Abogado General RUIZ-JARABO COLOMER presentadas, respectivamente, el 22 y 27 de noviembre de 2007 en el asunto C-393/06, Ing. Aigner, apartado 31, y en los asuntos acumulados C-147/06 y C-148/06, SECAP, apartados 29 y 30.
} 
sobre contratos públicos, puesto que los Estados miembros no tienen libertad para adoptar procedimientos de adjudicación distintos de los enumerados taxativamente en dichas Directivas ${ }^{479}$. En segundo lugar, es preciso publicitar a nivel europeo los contratos que superen determinados umbrales económicos. Asimismo, la proscripción de cualquier discriminación en la adjudicación de un contrato público conlleva, no sólo, la equivalencia en cuanto a las especificaciones técnicas empleadas para identificar el objeto del contrato ${ }^{480}$, sino también la homologación respecto de las aptitudes exigidas a los contratistas. Finalmente, las mencionadas Directivas contienen también una obligación de objetividad respecto de la valoración de los criterios que sirven de base para la adjudicación de un contrato, de tal manera que se admiten únicamente la aplicación de dos criterios de adjudicación, a saber, el del precio más bajo y el de la oferta económicamente más ventajosa ${ }^{481}$.

${ }^{479}$ Cabe indicarse que los poderes adjudicadores están obligados a utilizar, como procedimientos comunes, el procedimiento abierto o el restringido; no obstante, bajo determinadas condiciones y circunstancias específicas recogidas en las Directivas, podrán utilizar el diálogo competitivo, o bien, el procedimiento negociado. En este sentido, como señaló el Abogado General MAZÁK en sus conclusiones de 22 de septiembre de 2009 en el asunto Comisión/Francia, C-299/08, apartado 14 y 16, y que posteriormente confirmó el Tribunal de Justica en su sentencia de 10 de diciembre de 2009, Comisión/Francia, C-299/08, apartados 28 y 29, la enumeración de los procedimientos de adjudicación de contratos contenida en la Directiva 2004/18 es taxativa, ya que "esta Directiva no autoriza la adjudicación de contratos públicos por otros procedimientos".

${ }^{480}$ Para que esas especificaciones técnicas garanticen la apertura de los contratos públicos a la competencia, deben, en primer lugar, ser definidas previamente a la selección del contratista; igualmente, han de ser comunicadas o facilitadas a los potenciales licitadores y, por último, deben permitir el acceso en condiciones de igualdad de todos los licitadores sin que puedan tener por efecto la creación de obstáculos injustificados a la competencia. En principio, y según indica la Abogado General SHARPSTON en sus conclusiones presentadas, el 21 de noviembre de 2006, en el asunto Medipac, C-6/05, apartado 78 "cualquier oferta que cumpla las especificaciones técnicas previstas en el anuncio de licitación debe ser admitida como idónea para cumplir el objetivo del contrato por el poder adjudicador".

${ }^{481}$ Considerando 46 y artículo 53 de la Directiva 2004/18/CE y considerando 55 y artículo 55 de la Directiva 2004/17/CE. Procede recordar que, según jurisprudencia del Tribunal de Justicia anterior a la aprobación de las Directivas del 2004, la elección de la oferta económicamente más ventajosa dejaba al poder adjudicador la elección de los criterios de adjudicación que pretendía aplicar, siempre que dichos criterios vayan dirigidos a identificar la oferta más ventajosa económicamente y no confiriesen 
La actitud perseverante respecto al logro de los objetivos pretendidos con esta regulación, esto es, la apertura de los contratos públicos a la competencia europea en condiciones de transparencia y de no discriminación, no debe hacer pensar que las Directivas del 2004 no han incorporado novedades para modernizar y flexibilizar el marco jurídico entonces existente, puesto que, como veremos a continuación, han introducido nuevos instrumentos que suponen importantes cambios en la normativa sobre contratación pública en la $\mathrm{UE}^{482}$.

En efecto, además de refundir en un único texto las Directivas «clásicas», dejar fuera del ámbito de aplicación de la Directiva 2004/17/CE los contratos celebrados en el sector de las telecomunicaciones e incluir, por el contrario, los contratos adjudicados por las entidades adjudicadoras que oferten servicios postales, las Directivas de 2004 presentan como novedades más destacables las siguientes ${ }^{483}$ :

a la entidad adjudicadora una libertad incondicional de elección. Por ejemplo, en las sentencias de 20 de septiembre de 1988, Beentjes, C-31/87, apartados 19 y 26 ; de 18 de octubre de 2001, SIAC Construction, C-19/00, apartados 36 y 37 y de 17 de septiembre de 2002, Concordia Bus Finland, C-513/99, apartados 59 y 61.

${ }^{482}$ No parece, sin embargo, que estos cambios hayan resultado exitosos a tenor de lo expresado por el Parlamento Europeo en su Resolución de 18 de mayo de 2010, sobre nuevos aspectos de la política de contratación pública [P7_TA (2010) 0173] (DOUE C 161E, de 31 de mayo de 2011). El Parlamento Europeo lamenta que hasta el momento "no se hayan alcanzado los objetivos de la revisión efectuada en 2004 de las Directivas de contratación pública, en particular en lo relativo a la simplificación de las normas de licitación y la creación de una mayor seguridad jurídica" e insiste en que las Directivas de contratación pública deben simplificar, modernizar y flexibilizar los procedimientos de adjudicación. Asimismo, la Comisión, en su Programa de Trabajo para el 2011, prevé presentar propuestas para la modernización del marco legislativo de la contratación pública en el UE, COM (2010) 623 final, de 27 de octubre de 2010 .

${ }^{483}$ Acerca de las principales novedades que presentan estas Directivas, véase con carácter general, ARROWSMITH, S., "An assessment of the new legislative package on public procurement", Common Market Law Review, vol. 41 (5), 2004, págs. 1277 - 1325; ORDÓÑEZ SOLÍS, D., "Las nuevas Directivas sobre (...)", op. cit., pág. 182; NIELSEN, R. y TREUMER, S., (Eds.) The new EU Public Procurement Directives, Djøf Publishing, Copenhague, 2005; BOVIS, Ch., "The New Public Procurement Regime: A Different Perspective on the Integration of Public Markets of the European Union", European Public Law, vol. 12, (1) March 2006, págs. 73 - 109; FERNÁNDEZ GARCÍA, Ma . Y., "La nueva regulación de la contratación (...)", op. cit., págs. 309 a 314; ALLAIN, Y., "The new European Directives on Public Pro- 
- Proporcionan a los Estados miembros el marco jurídico para facilitar la utilización de los medios electrónicos en los procedimientos de contratación pública ${ }^{484}$

- Simplifican los umbrales económicos aplicables a los distintos tipos contractuales $^{485}$;

- Clarifican las disposiciones relativas a las especificaciones técnicas para que no ocasionen obstáculos injustificados a la competencia, de tal manera que se establecen los requisitos que deben incluirse en los documentos del contrato para garantizar que todos los licitadores disponen de las mismas oportunidades en la selección de las ofertas idóneas para cubrir las necesidades del contrato.

- Utilizan la nomenclatura del Vocabulario Común de Contratos Públicos - Common Procurement Vocabulary - (CPV) para identificar el objeto del contrato $^{486}$

curement: Change or continuity?", Public Contract Law Journal, vol. 34 (3), 2006, págs. 517 - 536; ESTORNINHO, M. J., "A transposição das Directivas 2004/17/CE e 2004/18/CE, de 31 de Março, e a elaboração de um Código de Contratos Públicos", Cadernos de Justiça Administrativa, vol. 58, 2006, págs. 10 - 20 y VARA ARRIBAS, G., "Novedades en el Debate Europeo sobre la Contratación Pública", Revista Española de Derecho Europeo, núm. 26, 2008, págs. 115 - 150.

${ }^{484}$ Sobre las novedades referidas al uso de la llamada contratación pública electrónica, puede consultarse, entre otros, GALLEGO CÓRCOLES, I., "Contratación pública electrónica", en la obra colectiva Administraciones públicas y nuevas tecnologías, Lex Nova, Valladolid, 2005, págs. 219 - 272 y en "La contratación electrónica y su impulso por el Derecho Europeo", NUE, núm 298, noviembre 2009, págs. 43 - 53; MEDINA ARNÁIZ, T., "La contratación pública electrónica: balance actual de su regulación en Europa", en la obra colectiva Gobierno, Derecho y Tecnología: las actividades de los poderes públicos, Thomson - Civitas, Cizur Menor, 2006, págs. 527 - 556; PUNZÓN MORALEDA, J. y RODRÍGUEZ SÁNCHEZ, F., "El uso de las nuevas tecnologías en la Administración Pública: la contratación pública electrónica prevista en la Directiva 2004/18/CE", REDETI, núm. 24, septiembre - diciembre 2005, págs. 63 - 96 y GIMENO FELIÚ, J. Mª ., La nueva contratación pública europea y su incidencia en la legislación española (...), op. cit., págs. 228 - 250 y en Novedades de la Ley de Contratos del Sector (... ), op. cit. págs. 261- 296.

${ }^{485}$ Estos umbrales estaban previstos en el artículo 16 de la Directiva 2004/17/CE y en el artículo 7 de la Directiva 2004/18/CE.

${ }^{486}$ La Recomendación de la Comisión 96/527/CE, de 30 de julio de 1996, relativa 
- Autorizan y regulan la posibilidad de celebrar acuerdos marco entre uno o varios poderes adjudicadores y uno o varios operadores económicos (listas de contratistas autorizados), entendiendo que estos acuerdos son una forma de contratos regulados por disposiciones específicas y no son nuevos procedimientos para la adjudicación de los contratos públicos ${ }^{487}$;

- Establecen un nuevo procedimiento de adjudicación diseñado para introducir una mayor flexibilidad en los contratos especialmente complejos. Este procedimiento especial es el diálogo competitivo cuya aplicación y condiciones se precisan en el artículo 29 de la Directiva 2004/18/CE ${ }^{488}$;

- Esclarecen las posibilidades con las que cuentan los poderes adjudicadores para incorporar aspectos sociales y medioambientales a las distintas fases del procedimiento de adjudicación de un contrato público ${ }^{489}$. Así,

al empleo del Vocabulario Común de Contratos Públicos para la descripción del objeto del contrato se encuentra en el origen de esta necesidad de armonizar las referencias a las distintas nomenclaturas utilizadas por los poderes adjudicadores para describir el objeto de los contratos que deben publicarse según lo dispuesto en las Directivas. Estos códigos deberán figurar en el anuncio de licitación y en el pliego de cláusulas administrativas para posibilitar la identificación del objeto de un contrato, de forma precisa, en cualquiera de las lenguas oficiales de la UE. El sistema CPV ha sido revisado por el Reglamento (CE) 213/2008, de 28 de noviembre de 2007 (DOUE L 74, de 15 de marzo de 2008). Véase a este respecto, RUIZ DE CASTAÑEDA Y DE LA LLAVE, A., "La nomenclatura CPV en la contratación", en la obra colectiva Administración Local. Estudios en homenaje a Ángel Ballesteros, La Ley - El Consultor de los Ayuntamientos, Las Rozas (Madrid), 2011, págs. 197 204.

${ }^{487}$ Como manifestó el Abogado General MAZÁK en sus conclusiones de 22 de septiembre de 2009 en el asunto Comisión/Francia, C-299/08, apartado 18.

${ }^{488} \mathrm{El}$ diálogo competitivo no se prevé expresamente en la Directiva 2004/17/CE porque las entidades adjudicadoras en los sectores especiales ya tenían la posibilidad de entablar negociaciones con los licitadores y candidatos siempre que ello no impidiera la competencia, GIMENO FELIÚ, J. M ${ }^{\mathrm{a}}$., La nueva contratación pública europea y su incidencia en la legislación española (...), op. cit., págs. 219 a 223 y CARBONERO GALLARDO, J. M., La adjudicación de los contratos públicos. (... ), op. cit., págs. 227 a 229.

${ }^{489} \mathrm{El}$ considerando quinto de la Directiva 2004/18/CE específicamente se refiere a esta posibilidad al señalar que "La presente Directiva clarifica pues de qué modo pueden contribuir los poderes adjudicadores a la protección del medio ambiente y al fomento del desarrollo sostenible al tiempo que se garantiza que los poderes 
por ejemplo, regulan los supuestos en los que es posible incluir consideraciones de tipo social y medioambiental como criterios de adjudicación o como condiciones de ejecución contractual, o bien permiten tener en cuenta consideraciones sociales en el marco de los contratos reservados;

- Fortalecen las previsiones relativas a garantizar el respeto a los principios de igualdad de trato y de transparencia al imponer a los poderes adjudicadores la obligación de dar a conocer en la fase de publicación del anuncio de licitación la ponderación relativa de cada uno de los criterios que consideran más adecuados para adjudicar el contrato a la oferta económicamente más ventajosa ${ }^{490}$;

- Precisan las reglas aplicables a la selección del contratista reconociendo la posibilidad de que los poderes adjudicadores exijan niveles mínimos de capacidad a los licitadores y candidatos siempre que estén vinculados y sean proporcionados al objeto del contrato;

- Y, por último, establecen nuevos requisitos para el acceso a la contratación pública al incrementar la casuística de los criterios de exclusión.

A continuación, nos centraremos en el análisis de las novedades que se refieren a las prohibiciones de contratar.

\section{Las principales novedades de las Directivas 2004/17/CE y 2004/18/CE que afectan a la regulación de las prohibiciones de contratar}

Como hemos indicado con anterioridad, las Directivas sobre contratación pública de 2004, al igual que las distintas Directivas en la materia anteriores a

adjudicadores puedan obtener para sus contratos la mejor relación calidad/precio".

${ }^{490}$ En la regulación anterior se contemplaba la obligación de mencionar en el pliego de cláusulas administrativas particulares, o en el anuncio de licitación, todos los criterios de adjudicación que el poder adjudicador fuera a utilizar para adjudicar el contrato, y "si fuera posible" el orden decreciente de la importancia que les sea atribuida, con lo cual, el uso de la expresión «si ello es posible» no constituía una verdadera obligación que incumbiese al órgano de contratación. 
esta fecha, establecen las condiciones de participación en los procedimientos de adjudicación bajo el epígrafe general de «criterios de selección cualitativa ${ }^{491}$.

Estos criterios señalan los requisitos positivos que deben cumplir los licitadores y candidatos para llegar a ser contratista, a la vez que facultan a los poderes adjudicadores para excluir del procedimiento de contratación a aquellos operadores económicos cuyas capacidades no resultan suficientes para la ejecución del contrato. Es decir, evalúan a los operadores económicos para determinar quién puede y quién no puede ser contratista en atención a su situación personal, a su capacidad económica y financiera, a sus conocimientos técnicos, a su experiencia profesional, e incluso a la honradez comercial de su conducta, estableciendo los supuestos por los que se puede excluir de los procedimientos de adjudicación a determinados sujetos ${ }^{492}$.

De esta manera, el TJUE ha diferenciado, en distintas ocasiones, entre los «criterios de selección cualitativa» y los «criterios de adjudicación» de un contrato, manifestando que los primeros se refieren a la verificación de la aptitud de los candidatos y licitadores, mientras que los criterios de adjudicación se ocupan de seleccionar la oferta más acorde a las necesidades del órgano de contratación. De esta manera, los criterios de selección cualitativa se centran en las cualidades personales y capacidades del futuro contratista, frente a los

\footnotetext{
${ }^{491}$ Sobre los criterios de selección cualitativa, véase BOVIS, Ch., "Qualitative Selection Criteria (...)", op. cit., págs. 9 - 12; MARDAS, D. y TRIANTAFYLLOU, D., "Selection criteria and the award procedure (...)", op. cit., págs. 91 a 94; PISELLI, E., "The scope for excluding providers who have committed criminal offences (...)", op. cit., págs. $267-286$ y, en relación con la jurisprudencia que trata este tema, TREUMER, S., "The Distinction between Selection and Award Criteria in EC Public Procurement Law: A Rule without Exception?", PPLR, vol. 18 (3), Special Issue of the Public Procurement Law Review on the Application and Implications of the ECJ's Decision in Lianakis on the Separation of Selection and Award Criteria in EC Procurement Law 2009, págs. 103 - 111 y PETERSEN, Z., "Refining the Rules on the Distinction between Selection and Award criteria - Evropaïky Dynamiki v Commission (T-589/08)", PPLR, vol. 20 (6), 2011, págs. NA246 - 249.

${ }^{492}$ Bajo este epígrafe se posibilita que los órganos de contratación excluyan del procedimiento de adjudicación a un operador económico por no disponer de la habilitación necesaria para ejercer una determinada profesión o bien por no estar inscrito en un concreto registro profesional o mercantil (artículo 46 Directiva 2004/18/CE). También, por no acreditar una capacidad económica, financiera, técnica o profesional adecuada para ejecutar el contrato que se quiere adjudicar (artículos 47 y 48 Directiva 2004/18/CE).
} 
criterios de adjudicación del contrato que se refieren a las calidades de la obra, prestación o servicio que se requiere o se pretende efectuar ${ }^{493}$.

Así, dentro del contexto de la celebración de un contrato público, la verificación de la aptitud de los operadores económicos para ejecutar el contrato es independiente de la fase de evaluación de las ofertas. Se trata de operaciones distintas que se rigen por normas diferentes aunque no se excluye que la verificación de la aptitud de los licitadores y la adjudicación del contrato puedan tener lugar simultáneamente. En todo caso, una vez que comprobada la idoneidad del candidato o licitador, la adjudicación se lleva a cabo sobre la base de criterios objetivos que permitan determinar la oferta económicamente más ventajosa ${ }^{494}$.

Conforme a los criterios de selección cualitativa, el artículo 45 de la Directiva 2004/18/CE enumera las causas que justifican la exclusión de un licitador o candidato en un procedimiento de adjudicación contractual. Por su parte, el artículo 54.4 de la Directiva 2004/17/CE, si bien no enumera las prohibiciones de contratar, establece los motivos de exclusión por referencia a la Directiva clásica. De esta manera:

"Los criterios contemplados en los apartados 1 y 2 podrán incluir los criterios de exclusión enumerados en el artículo 45 de la Directiva 2004/18/CE en las condiciones que en él se estipulan"

La principal novedad en esta materia reside en el hecho de que estos artículos contemplan dos categorías de prohibiciones de contratar: las de carácter

${ }^{493}$ Entre otras, la STJCE de 20 de septiembre de 1988, Beentjes, C-31/87, apartados 15 y 16; de 19 de junio de 2003, GAT, C-315/01, apartados 59 a 64; de 24 de enero de 2008, Lianakis, C-532/06, apartados 26 y 27; de 12 de noviembre de 2009, Comisión/Grecia, C-199/07; de 9 de octubre de 2014, España/Comisión, C-641/13P, apartado 36 (que confirma la sentencia del Tribunal General de 16 de septiembre de 2013, España/Comisión, T-2/07), y de 18 de diciembre de 2014, Ambisig, C-601/03.

${ }^{494}$ En esta materia, las Directivas del año 2014 presentan dos novedades: 1. Se apuesta por una terminología distinta para abarcar la «mejor relación calidadprecio», de tal manera que la oferta económicamente más ventajosa se evaluase sobre la base de la mejor relación calidad-precio, que ha de incluir siempre un elemento de precio o coste, y 2. Se posibilita examinar las ofertas antes de comprobar la inexistencia de algún motivo de exclusión (artículo 56.2 de la Directiva 2014/24/UE). 
obligatorio y las de carácter potestativo o facultativo. Así, el artículo 45 de la Directiva 2004/18/CE establece un doble catálogo de causas de exclusión que compelen en el primer caso y facultan en el segundo, a excluir de la adjudicación de un contrato a un operador económico en atención a su situación personal y profesional.

\section{D.1. Prohibiciones de carácter obligatorio}

Por lo que respecta a las prohibiciones de carácter obligatorio, el párrafo primero del artículo 45 de la Directiva 2004/18/CE establece, bajo determinadas circunstancias, la obligatoriedad de excluir de la participación de un procedimiento de adjudicación a aquellos licitadores o candidatos que han sido condenados mediante sentencia firme por delitos de corrupción, fraude, blanqueo de capitales o por participación en una organización delictiva ${ }^{495}$.

\section{Quedará excluido de la participación en un contrato público cual-}

quier candidato o licitador que haya sido condenado mediante sen-

\footnotetext{
${ }^{495}$ Acerca de estas prohibiciones de carácter obligatorio - mandatory exclusions - puede consultarse WHITE, S., "Exclusion of tenderers in the European Union: The only way forward against procurement fraud?, en la obra colectiva Fighting Corruption and Promoting Integrity in Public Procurement, OECD Publishing, París, 2005, págs. 251-254 y en la misma obra colectiva DREW, K., "The Challenges Facing Debarment and the European Union Public Procurement Directive" págs. 267 - 276. Asimismo resultan de interés, MEDINA ARNÁIZ, T., "Grounds for exclusion in public procurement: Measures in the fight against corruption in European Union", Comunicación presentada en II International Public Procurement Conference, Roma, 21 - 23 September 2006 y publicado en las actas del Congreso http://www.ippa.ws/IPPC2/PROCEEDINGS/Article_12_Amaiz.pdf [Fecha de consulta: 20 de octubre de 2015] y también en "EU Directives as an Anticorruption Measures: Excluding Corruption-Convicted Tenderers from Public Procurement Contracts", en la obra colectiva International Handbook of Public Procurement, CRC Press (Francis \& Taylor), Boca Raton, 2008, págs. 105 - 130; WILLIAMS, S., "The mandatory exclusions for corruption in the new EC Procurement Directives", European Law Review, vol. 31 (5) October, 2006, págs. 711 - 734; "Coordinating public procurement to support EU objectives - a first step? The case of exclusions for serious criminal offences", en la obra colectiva Social and Environmental Policies in EC Procurement Law, Cambridge University Press, Cambridge, 2009, págs. 479 - 498 y ARROWSMITH, S., PRIESS, H.-J. y FRITON, P., "Self-Cleaning as a Defence to Exclusions for Misconduct - An Emerging Concept in EC Public Procurement Law?", PPLR, vol. 18 (6), 2009, págs. 257 - 282.
} 
tencia firme, de la que tiene conocimiento el poder adjudicador, por uno o varios de los motivos que a continuación se enumeran:

a) participación en una organización delictiva, tal y como se define en el apartado 1 del artículo 2 de la Acción Común 98/r773/JAI del Consejo;

b) corrupción, tal y como se define, respectivamente, en el artículo 3 del acto del Consejo de 26 de mayo de 1997 y en el apartado 1 del artículo 3 de la Acción Común 98/742/JAI del Consejo;

c) fraude, según el artículo 1 del Convenio relativo a la protección de los intereses financieros de las Comunidades Europeas;

d) blanqueo de capitales, tal y como se define en el artículo 1 de la Directiva 91/308/CEE del Consejo, de 10 de junio de 1991, relativa a la prevención de la utilización del sistema financiero para el blanqueo de capitales.

En la práctica legislativa este carácter obligatorio implica que estas prohibiciones de contratar deberán ser incorporadas en todas las legislaciones nacionales de los Estados miembros en el momento de transponer estas Directivas, correspondiendo al ordenamiento jurídico interno de cada Estado miembro determinar las condiciones de aplicación necesarias para garantizar su cumplimiento y efectividad, pero estableciendo también como obligatorias estas causas de prohibición de contratar para sus poderes adjudicadores.

Esta misma exigencia, en cuanto a la ineludible transposición de estas causas de exclusión obligatorias a los derechos nacionales, se encuentra también recogida en el artículo 54.4, segundo párrafo, de la Directiva 2004/17/CE («sectores especiales»). No obstante, hay que señalar que en esta Directiva dicha obligación se encuentra limitada por razón de los sujetos que deben aplicar tales prohibiciones, pues sólo resulta obligatoria para los órganos de contratación que tienen la condición de poderes adjudicadores,

"Cuando la entidad adjudicadora sea un poder adjudicador (...) los criterios y las normas contemplados en los apartados 1 y 2 del presente artículo incluirán los criterios de exclusión enumerados en el apartado 1 del artículo 45 de la Directiva 2004/18/CE". 
La explicación de esta limitación por razón del sujeto contratante se justifica en atención a la especificidad de los sectores cubiertos por la Directiva 2004/17/CE y por la diversidad del estatuto jurídico de las entidades que operan en estos sectores. Esto es debido a que, en el ámbito de aplicación subjetivo de esta Directiva se distinguen tres tipos de entidades a las que son aplicables sus normas: las entidades adjudicadoras que son poderes adjudicadores, las empresas públicas sobre las cuales los poderes adjudicadores puedan ejercer, directa o indirectamente, una influencia dominante y, por último, las empresas privadas que tienen derechos especiales o exclusivos concedidos por una autoridad competente de un Estado miembro, en la medida en que estas entidades ejerzan alguna de las actividades contempladas por dicha Directiva en los sectores del agua, de la energía, del transporte y de los servicios postales.

Las prohibiciones de carácter obligatorio sólo se van a aplicar, necesariamente, por parte de las entidades que son poderes adjudicadores - definidos de igual manera que en la Directiva 2004/18/CE - ya que el resto de entidades pudieran no tener acceso a las pruebas que habilitan esta prohibición de contratar, máxime si tenemos en cuenta que tal obligación supone forzosamente conocer las condenas por sentencia judicial firme en casos de corrupción, fraude, blanqueo de capitales o participación en una organización delictiva. Por ese motivo, el artículo 54.4 de la Directiva 2004/17/CE permite la opción de aplicar, o no, los criterios de exclusión obligatorios para los órganos de contratación que no son poderes adjudicadores (considerando quincuagésimo cuarto de la Directiva 2004/17/CE) ${ }^{496}$.

\section{D.2. Prohibiciones de carácter facultativo}

El segundo grupo de prohibiciones de contratar, recogido en el apartado segundo del artículo 45 de la Directiva 2004/18/CE, deja la aplicación de los casos de exclusión que menciona a la apreciación de los Estados miembros, como atestigua la expresión "podrá ser excluido de la participación en el contrato (... ") que figura al inicio de esta disposición.

A este respecto, procede señalar que este artículo 45.2 reproduce, en térmi-

${ }^{496}$ WILLIAMS, S., "The mandatory exclusions for corruption in the new EC (...)", op. cit., págs. 721 y 722; MEDINA ARNÁIZ, T., "EU Directives as an Anticorruption Measures: Excluding Corruption-Convicted (...)", op. cit., págs. 113 y 114. 
nos esencialmente idénticos, el artículo 29 de la Directiva 92/50/CEE («servicios»), del artículo 20 de la Directiva 93/36/CEE («suministro») y del artículo 24 de la Directiva 93/37/CEE («obras») en cuanto a las causas de exclusión, después de haber resultado fallidos los intentos de incorporar a este listado, durante el proceso de elaboración de la Directiva 2004/18/CE, una serie de prohibiciones de contratar relacionadas con el incumplimiento, por parte del licitador o candidato, de la normativa sociolaboral.

De esta manera, enumera con un carácter exhaustivo los motivos que pueden justificar la exclusión de un operador económico de la participación en una licitación por razones que se basan en elementos objetivos que dependen de sus cualidades profesionales. Este apartado es del siguiente tenor:

"Podrá ser excluido de la participación en el contrato todo operador económico:

a) que se encuentre en estado de quiebra, de liquidación, de cese de actividades, de intervención judicial o de concurso de acreedores, o en cualquier situación análoga a resultas de un procedimiento de la misma naturaleza que exista en las normas legales y reglamentarias nacionales;

b) que sea objeto de un procedimiento de declaración de quiebra, de liquidación, de intervención judicial, de concurso de acreedores o de cualquier otro procedimiento de la misma naturaleza que exista en las normas legales y reglamentarias nacionales;

c) que haya sido condenado por sentencia con autoridad de cosa juzgada según las disposiciones legales del país y en la que se aprecie un delito que afecte a su moralidad profesional;

d) que haya cometido una falta grave en materia profesional, que pueda ser comprobada por cualquier medio que los poderes adjudicadores puedan justificar;

e) que no esté al corriente en sus obligaciones relativas al pago de las cotizaciones de la seguridad social, según las disposiciones legales del país en el que esté establecido o las del país del poder adjudicador;

f) que no haya cumplido sus obligaciones tributarias impuestas por 
las disposiciones legales del país en el que esté establecido o las del país del poder adjudicador;

g) que se le considere gravemente culpable de hacer declaraciones falsas al proporcionar la información exigida en aplicación de la presente Sección o que no haya proporcionado dicha información.

Los Estados miembros precisarán, de conformidad con su Derecho nacional y respetando el Derecho comunitario, las condiciones de aplicación del presente apartado.

El carácter voluntario de las prohibiciones de contratar contenidas en este artículo supone, en la práctica, otorgar a los Estados miembros un amplio margen de apreciación para que decidan acerca de incorporar o no, estas causas de exclusión a sus legislaciones nacionales, puesto que la Directiva no pretende una aplicación uniforme de estas prohibiciones de contratar a escala europea. Así pues, los Estados miembros están facultados para no aplicar en absoluto dichas causas de exclusión o bien integrarlas en la normativa nacional "con un grado de rigor que podría variar según el caso, en función de consideraciones de carácter jurídico, económico o social que prevalezcan en el plano nacional"497.

De la falta de armonización en esta materia se deduce, por tanto, que es a los Estados miembros a quienes incumbe decidir, conforme a un criterio nacional, si implantan dichas prohibiciones de contratar, si aplican sólo alguna de ellas, o por el contrario, si se inclinan por rechazar dichas causas de exclusión de su normativa contractual, optando por la participación más amplia posible en los procedimientos de formalización de contratos públicos ${ }^{498}$.

En cualquier caso, no debemos olvidar que esta facultad de los Estados

\footnotetext{
${ }^{497} \mathrm{El}$ TJUE se ha manifestado en estos términos en sus sentencias de 9 de febrero de 2006, La Cascina y otros, C-226/04 y C-228/04, apartado 22; de 16 de diciembre de 2008, Michaniki, C- 213/07, apartado 56; de 23 de diciembre de 2009, Serrantoni, C-376/08, apartados 31 y 32; de 13 de diciembre de 2012, Forposta SA, C-465/1; de 10 de julio de 2014, Consorzio Stabile, C-358/12, apartados 35 y 36 y de 22 de octubre de 2015, Impresa Edilux y SICEF, C-425/14, apartado 26.

${ }^{498}$ Las sentencias del Tribunal de Justicia 9 de febrero de 2006, La Cascina y otros, C-226/04 y C-228/04 y de 10 de julio de 2014, Consorzio Stabile, C-358/12 manifiestan que "los Estados miembros pueden moderar o hacer más flexibles los requisitos establecidos en dicha disposición".
} 
miembros queda circunscrita al cumplimiento de los principios del Derecho de la Unión relativos a la igualdad, proporcionalidad y no discriminación. Además de ello, y también como novedad en la regulación de las prohibiciones de contratar, si los Estados miembros optasen por contemplar estas causas de exclusión, la Directiva 2004/18/CE les exige, al igual que sucede en los supuestos de prohibiciones obligatorias, que especifiquen las condiciones de aplicación de estas prohibiciones de conformidad con su Derecho nacional y respetando, en cualquier caso, el Derecho de la Unión.

En definitiva, de acuerdo con lo expuesto, y como consecuencia de las exigencias derivadas de las Directivas sobre contratación pública, la novedad más significativa en esta materia estribaba en que los Estados miembros están obligados a incorporar a sus legislaciones nacionales las prohibiciones de contratar por la condena firme al licitador o candidato en atención a las conductas punibles recogidas en el artículo 45.1 de la Directiva 2004/18/CE.

Tal como veremos en el siguiente capítulo, con el establecimiento de estas prohibiciones de carácter obligatorio se pretende, entre otros cometidos, avanzar en la lucha contra el fraude, contra la corrupción y contra cualquier otra actividad ilegal que pueda ir en detrimento de los intereses financieros de la Unión con el objetivo declarado de evitar "la adjudicación de contratos públicos a operadores económicos que hayan participado en una organización delictiva o que hayan sido declarados culpables por corrupción o fraude contra los intereses financieros de las Comunidades Europeas o por blanqueo de capitales" (considerandos cuadragésimo tercero de la Directiva 2004/18/CE y quincuagésimo cuarto de la Directiva 2004/17/CE).

Esta finalidad se encuentra en línea con lo establecido desde algunas instituciones de la Unión - Parlamento, Comisión y Consejo Europeo - en cuantos documentos se han hecho eco de la estrategia transversal contra la corrupción y contra la delincuencia organizada ${ }^{499}$, puesto que, como bien señalan, para

${ }^{499}$ Las propuestas de la Comisión se han recogido en la Comunicación al Consejo y al Parlamento Europeo Una política de la Unión en materia de lucha contra la corrupción, COM (97) 192 final, de 21 de mayo de 1997, pág. 10 y en su Comunicación Una política global de la UE contra la corrupción, COM (2003) 317 final, de 28 de mayo de 2003, págs. 17 y 18. Asimismo, en el Plan de Acción para luchar contra la delincuencia organizada, adoptado por el Consejo Europeo celebrado en Ámsterdam en junio de 1997, se planteaba tomar otras medidas que permitieran la exclusión de las 
prevenir la delincuencia es fundamental desarticular las redes delictivas, pero también combatir cualquier incentivo financiero que las motive, para proteger, de esta forma la economía contra la infiltración de la delincuencia ${ }^{500}$.

La obligatoriedad de excluir de un contrato público a quienes han sido condenados por estos delitos es consecuente con esa lucha, puesto que no se puede mantener la misma contundencia desde parámetros de mera opcionalidad. Así, si nos retrotraemos a las primeras Directivas sobre contratación pública, se observa que ya desde la Directiva 71/305/CEE (obras) y la Directiva 77/62/CEE (suministro) se ofrecía a los Estados miembros la posibilidad de excluir de los procedimientos de contratación pública a aquellos candidatos o licitadores que hubieran sido condenados por delitos relacionados con su falta de «moralidad profesional $»^{501}$.

Entre estos tipos delictivos podríamos entender implícitos, en cierta manera, los relacionados con las distintas modalidades de fraude, cohecho o tráfico de influencias propios de una actuación corrupta; sin embargo, no fue hasta la redacción de la Directiva 2004/18/CE que los términos «corrupción» y «fraude» se incorporaron a las Directivas de la UE, incluyendo la obligato-

organizaciones delictivas o de sus miembros de la participación en los procedimientos de contratación pública (DOCE C 251, de 15 de agosto de 1997). Asimismo, el documento de trabajo del Parlamento Europeo Working Paper Measures to Prevent Corruption in EU Member States (Legal Affairs Series JURI 101 EN 03-1998) y su anexo relativo a combatir la corrupción en los contratos públicos Combating corruption in public procurement contracts, se refieren a este tipo de medidas como uno de los instrumentos a adoptar, entre otros muchos, para luchar contra la corrupción y el fraude http://www.europarl.europa.eu/workingpapers/juri/101/default2_en.htm [Fecha de consulta: 20 de octubre de 2015].

${ }^{500}$ En la Comunicación La Estrategia de Seguridad Interior de la UE en acción: cinco medidas para una Europa más segura, la Comisión incidía en que "deberán desarrollarse políticas por las que los órganos administrativos y reguladores responsables de la concesión de licencias, autorizaciones, contratos públicos y subvenciones («enfoque administrativo») se comprometan a proteger la economía contra la infiltración de las redes delictivas", COM (2010) 673 final, de 22 de noviembre de 2010, pág. 6.

${ }^{501}$ Artículo 23 c) de la Directiva 71/305/CEE y artículo 20.c) de la Directiva 77/62/CEE. También se recogía esta posibilidad en los derogados artículos 29.1.c) de la Directiva 92/50/CEE (servicios), 20.1.c) Directiva 93/36/CEE (suministro) y 24.1.c) Directiva 93/37/CEE (obras). 
riedad de excluir de los procedimientos de contratación a aquellos operadores económicos condenados por estas actividades ilegales ${ }^{502}$.

Este cambio de perspectiva en la regulación de las prohibiciones de contratar a nivel europeo viene, sin duda, condicionado por la idea de instrumentalizar la contratación pública para la consecución de objetivos políticos en el seno de la Unión, aunque, en el caso concreto de las prohibiciones de contratar, y en atención a alguno de los tipos delictivos a los que se refiere el artículo 45.1 de la Directiva 2004/18/CE, podemos señalar que también sirven a los objetivos cardinales de la contratación pública en cuanto que garantizan la igualdad de trato de todos los licitadores o candidatos.

\section{El marco jurídico actual: Las Directivas de «cuarta generación»}

La pretendida revisión, simplificación y modernización del marco normativo de los contratos públicos ha llegado con una «cuarta generación» ${ }^{503}$ de directivas en esta materia que afronta los cambios desde objetivos complemen-

\footnotetext{
${ }^{502}$ Consideramos, no obstante, preciso matizar esta aseveración en tanto que en el Reglamento (CE, Euratom) 1605/2002 del Consejo, de 25 de junio de 2002, por el que se aprueba el Reglamento financiero aplicable al presupuesto general de las Comunidades Europeas, ya se mencionaba el fraude y la corrupción como motivos de exclusión de los procedimientos de adjudicación, señalando expresamente su considerando vigesimoquinto que "con el fin de prevenir las irregularidades, luchar contra el fraude y la corrupción (...) debe excluirse de la adjudicación de contratos a aquellos candidatos o licitadores que hayan sido declarados culpables de tales actos o que se hallen en una situación de conflicto de intereses" (DOCE L 248, de 16 de septiembre de 2002).

${ }^{503}$ Adoptamos la expresión utilizada por BENACCHIO, G., "Verso le direttive di quarta generazione", op. cit., págs. 3-28; MORENO MOLINA, J. A., "La cuarta generación de Directivas de la Unión Europea sobre contratos públicos", op. cit., págs. 115 - 163 y GIMENO FELIÚ, J. Ma ., "Las nuevas Directivas - cuarta generación en materia de contratación pública. Hacia una estrategia eficiente en compra pública", op. cit., págs. 39 - 105 y en El nuevo paquete comunitario sobre contratación pública (...), op. cit., págs. $31-37$.
} 
tarios con los presentados en la Estrategia Europa 2020 004 y en el Acta del Mercado Único ${ }^{505}$. Entre sus objetivos se encuentran los de corregir las deficiencias detectadas en su aplicación, clarificar conceptos de conformidad con la jurisprudencia del TJUE y garantizar una utilización más eficiente de los fondos públicos.

Este nuevo marco normativo de la contratación pública está integrado por tres directivas, con la salvedad ya hecha respecto de las Directivas en materia de recursos y a la Directiva 2009/81/CE del Parlamento Europeo y del Consejo, de 13 de julio de 2009, sobre los procedimientos de adjudicación contractual en los ámbitos de la defensa y de la seguridad. Estas Directivas son:

- La Directiva 2014/23/UE, del Parlamento Europeo y del Consejo, de 26 de febrero de 2014, relativa a la adjudicación de contratos de concesión («concesiones»);

- La Directiva 2014/24/UE, del Parlamento Europeo y del Consejo, de 26 de febrero de 2014, sobre contratación pública y por la que se deroga la Directiva 2004/18/CE («sectores clásicos»), y

- La Directiva 2014/25/UE, del Parlamento Europeo y del Consejo, de 26 de febrero de 2014, relativa a la contratación por entidades que operan

${ }^{504}$ EU2020 Una estrategia para un crecimiento inteligente, sostenible e integrador, COM (2010) 2020 final, de 3 de marzo 2010. Esta Estrategia enuncia tres prioridades que se refuerzan mutuamente: un crecimiento inteligente basado en el conocimiento y la innovación; un crecimiento sostenible que promueva una economía que haga un uso más eficaz de los recursos, que sea más verde y competitiva, y por último, un crecimiento integrador que aumente el nivel de empleo y que garantice la cohesión social y territorial.

${ }^{505} \mathrm{El}$ Acta del Mercado Único II fijó doce nuevas intervenciones prioritarias concretas para reactivar el Mercado Único, COM (2012) 573 final, de 3 de octubre de 2012, y una de ellas se refería a la contratación pública partiendo de una idea clara: el mercado interior no está liberando todo su potencial en el ámbito de la contratación pública. Véase también la Comunicación Hacia un Acta del Mercado Único. Por una economía social de mercado altamente competitiva. Cincuenta propuestas para trabajar, emprender y comerciar mejor todos juntos, COM (2010) 608 final, de 27 de octubre de 2010, pág. 16 y la Comunicación Acta del Mercado Único. Doce prioridades para estimular el crecimiento y reforzar la confianza «Juntos por un nuevo crecimiento», COM (2011) 206 final, de 13 de abril de 2011. 
en los sectores del agua, la energía, los transportes y los servicios postales y por la que se deroga la Directiva 2014/17/CE («sectores especiales»).

Estas Directivas entraron en vigor el 17 de abril de 2014 - veinte días después de su publicación en el DOUE - aunque el plazo de su transposición a los Estados miembros finalizará el 18 de abril de abril de $2016^{506}$. En esta fecha se hará efectiva, por tanto, la derogación de las Directivas 2004/17/CE («sectores especiales») y 2004/18/CE, puesto que antes las Directivas del año 2014 sólo son aplicables en aquellos Estados miembros en los que han entrado en vigor las medidas de transposición ${ }^{507}$.

Antes de analizar los objetivos de la reforma, vamos a destacar dos importantes novedades respecto de la nueva regulación. La primera es que las nuevas Directivas no inciden únicamente en los procedimientos de adjudicación contractual, ya que pretenden actuar sobre la totalidad de las fases de la contratación pública (también en la fase de ejecución con cuestiones vincu-

\footnotetext{
${ }^{506} \mathrm{El}$ artículo 90 de la Directiva 2014/24/UE prevé en su apartado 1 que "los Estados miembros pondrán en vigor las disposiciones legales, reglamentarias y administrativas necesarias para dar cumplimiento a lo establecido en la presente Directiva a más tardar el 18 de abril de 2016. Comunicarán inmediatamente a la Comisión el texto de dichas disposiciones". En estos mismos términos, pero con palabras diferentes, se manifiestan el artículo 51.1 de la Directiva 2014/23/UE y el artículo 106.1 de la Directiva 2014/25/UE («sectores especiales»).

${ }^{507}$ Véase lo dicho en el artículo 91 de la Directiva 2014/24/UE "Queda derogada la Directiva 2004/18/CE con efecto a partir del 18 de abril de 2016" y en el artículo 107 de la Directiva 2014/25/UE "Queda derogada la Directiva 2004/17/CE con efecto a partir del 18 de abril de 2016". Por lo que respecta al estado de transposición en los Estados miembros, cabe indicarse que Reino Unido y Francia ya han notificado medidas de transposición que modifican por completo su anterior regulación contractual (Public Contracts Regulations 2015 y Ordonnance $n^{\circ}$ 2015-899, du 23 juillet 2015 relative aux marchés publics). En Hungría, la Ley 2015 CXLIII, de 22 de septiembre, sobre contratación pública, entrará en vigor el 1 de noviembre de 2015; Italia Austria, Malta, Irlanda, República Checa y España han modificado recientemente su regulación con un distinto grado de adaptación a las nuevas Directivas; Alemania y Países Bajos tienen adelantado su proceso de transposición y, por lo que respecta al resto de Estados miembros, además de remitirnos a la Tabla 5 de esta memoria doctoral, debemos mencionar que existe un estudio que avanza posibles reformas Public Procurement Network Italian Presidency 2014: Comparative survey on the transposition of the new EU Public Procurement package, 2014, que puede consultarse en: http://www.publicprocurementnetwork.org/docs/ItalianPresidency/documento \%206.pdf [Fecha de consulta: 24 de octubre de 2015].
} 
ladas a la modificación, a la resolución y a la subcontratación) y, por ello, el cambio en la denominación de las Directivas que abandona la clásica referencia a la coordinación de los procedimientos de adjudicación. La segunda novedad es que se completa el marco jurídico de la contratación con la regulación de las concesiones (Directiva 2014/23/UE), puesto que hasta este momento, los contratos de concesión de servicios no se disciplinaban por ninguna de las Directivas anteriores, aunque - siempre que revistieran un interés transfronterizo cierto - les resultaba de aplicación las normas fundamentales de los Tratados $y$, en especial, los principios de igualdad de trato y de no discriminación por razón de la nacionalidad, así como la obligación de transparencia que de ellos se deriva ${ }^{508}$.

\section{IV.1. El proceso de elaboración y los objetivos de la reforma}

A partir del anuncio de revisión de las Directivas del 2004 a través del Programa de Trabajo de la Comisión para el año $2011^{509}$, se abrió un proceso

${ }^{508} \mathrm{La}$ Comunicación interpretativa de la Comisión sobre las concesiones en el Derecho comunitario, de 29 de abril de 2000, aclaró el marco jurídico relativo a los contratos de concesión de servicios (DOCE C 121, de 29 de abril de 2000). La aplicación de los principios cardinales de la contratación pública deriva de la propia jurisprudencia del Tribunal de Justicia, concretamente se refieren a ello las sentencias de 7 de diciembre de 2000, Telaustria y Telefonadress, C-324/98, apartados 60 y 61, de 21 de julio de 2005, Coname, C-231/03, apartado 17; de 13 de octubre de 2005, Parking Brixen, C-458/03, apartado 46; de 13 de abril de 2010, Wall, C-91/08, apartado 33; de 3 de junio de 2010, Sporting Exchange, C-203/08, apartados 39 y 40; de 10 de marzo de 2011, Privater, C-274/09; de 14 de noviembre de 2013, Belgacom, C-221/12, apartado 28 y de 6 de noviembre de 2014, Cartiera dell'Adda, C-42/13, apartado 47. Sobre la nueva regulación, HERNÁNDEZ GONZÁLEZ, F.L., "La nueva Directiva de concesiones. Un largo viaje con final esperado", en la obra colectiva Las nuevas Directivas de contratación pública, Thomson Reuters-Aranzadi, Cizur Menor (Navarra), 2015, págs. 169 - 237.

${ }^{509}$ Programa de Trabajo de la Comisión para 2011, COM (2010) 623 final, de 27 de octubre de 2010 (Volumen I y II). La Comisión expuso a los Estados miembros en las reuniones del Comité Consultivo para los Contratos Públicos, celebradas el 13 de octubre y el 15 de diciembre de 2010, los fines perseguidos en ambas acciones entre los que destacó el anuncio de la adopción de una iniciativa legislativa dirigida al Parlamento Europeo y al Consejo a finales del año 2011, en la que se modificarían 
de consultas con la publicación del Libro Verde de la Comisión sobre la modernización de la política de contratación pública de la UE. Hacia un mercado europeo de la contratación pública más eficiente (2011), para debatir acerca de los principales cambios pretendidos con la reforma ${ }^{510}$. La finalidad de este Libro Verde era determinar una serie de ámbitos fundamentales que podrían ser objeto de reforma y recabar las opiniones de las partes interesadas sobre las opciones concretas de cambio legislativo. Se recibieron un total de 623 respuestas que versaban - entre otros aspectos - sobre: (i) la simplificación y flexibilización de los procedimientos; (ii) el uso estratégico de la contratación pública para promover otros objetivos políticos; (iii) la mejora del acceso de las PYMEs a los contratos públicos y (iv) la lucha contra el favoritismo, la corrupción y los conflictos de intereses ${ }^{511}$.

Tras la consulta y siguiendo el procedimiento legislativo ordinario con la intervención del Parlamento Europeo ${ }^{512}$ como colegislador junto con el Consejo, se publicaron tres propuestas de Directivas: la Propuesta de Directiva relativa a la contratación pública, COM (2011) 896 final; la Propuesta de Directiva relativa a la contratación por entidades que operan en los sectores del agua, la energía, los transportes y los servicios postales, COM (2011) 895 final y la Propuesta de Directiva relativa a la adjudicación de contratos de concesión, COM (2011) 897 final, todas ellas de fecha 20 de diciembre de 2011.

Como objetivos principales de la reforma se planteaba la flexibilización de los procedimientos, la simplificación de las normas y el incremento de la

las Directivas sobre contratos públicos con el fin de simplificar el sistema regulador del procedimiento de adjudicación de los contratos. Véase, la noticia de la Comisión, de 20 de diciembre de 2011 (IP/11/1580) y el documento MEMO/11/931 de la misma fecha. En este sentido, RUIZ DE CASTAÑEDA DE LA LLAVE, A. y BERNAL BLAY, M. Á., "La contratación pública y del Derecho comunitario. Cuestiones pendientes", en la obra colectiva Observatorio de contratos públicos 2010, Civitas Thomson Reuters, Cizur Menor (Navarra), 2011, págs. 23 - 41.

${ }^{510} \mathrm{COM}$ (2011) 15 final, de 25 de enero de 2011.

${ }^{511}$ Para proceder a una valoración de las 623 respuestas recibidas al Libro Verde puede consultarse: http://ec.europa.eu/internal_market/consultations/2011/public_procurement_en.htm [Fecha de consulta: 20 de octubre de 2015]. pública (2011/2048 [INI]) (DOUE C 131E, de 8 de mayo de 2013).

${ }^{512}$ El Parlamento Europeo había aprobado la Resolución de 25 de octubre de 2011, sobre la modernización de la contratación. 
eficiencia del gasto público para garantizar los mejores resultados posibles de la contratación en términos de relación calidad/precio ${ }^{513}$. Ahora bien, en relación a esos objetivos principales, se presentaban otra serie de propósitos a lograr con la nueva regulación que se articulan en torno a determinados núcleos temáticos clave (clusters) para posibilitar transacciones entre las instituciones y encontrar un espacio de entendimiento sobre una serie de cuestiones esenciales.

Estos núcleos temáticos fueron diez:

1. Flexibilización de los procedimientos;

2. Utilización estratégica de la contratación pública;

3. Reducción de la carga burocrática respecto de los requisitos de documentación a presentar por los operadores económicos;

4. Contratación pública electrónica;

5. Acceso de las PYMEs a la contratación;

6. Contratación conjunta (agregación de la demanda);

7. Otros requisitos procedimentales (publicaciones, variantes, concursos de proyectos);

8. Integridad de los procedimientos;

9. Gobernanza y

10. Definiciones y ámbito de aplicación.

De estos núcleos temáticos a esta memoria doctoral interesan especialmente tres: la utilización estratégica de la contratación pública; la simplificación de la carga burocrática exigida a los operadores económicos para participar en un procedimiento de adjudicación contractual y la integridad de los procedimientos ${ }^{514}$.

${ }^{513}$ TREUMER, S., "Evolution of the EU Public Procurement Regime: The New Public Procurement Directive", en la obra colectiva Modernising Public Procurement. The New Directive, Djøf Publishing, Copenhagen, 2014, págs. 9 y 10.

${ }^{514}$ Con carácter general, sobre las nuevas Directivas vamos a remitirnos a los tra- 


\section{A. La utilización estratégica de la contratación pública}

La Propuesta de Directiva sobre contratación pública enuncia una serie de medidas orientadas al uso estratégico de las compras públicas respecto de «cómo comprar»y «qué comprar». Así pues, se avanzaba en la idea de que la futura política de contratación pública incorporase una relación de objetivos orientados a la utilización de los contratos públicos en apoyo a las prioridades políticas de la Unión y, especialmente, respecto de aquellas en las que se garantice un uso más eficiente de los fondos públicos en un momento económico de austeridad presupuestaria y de presión sobre las finanzas públicas ${ }^{515}$.

De esta manera, se incide en la importancia de tener en cuenta aspectos innovadores, ambientales y sociales en las compras públicas. Las posibilidades de actuación responsable en la contratación pública puede lograrse a través de distintas medidas, entre las que debemos destacar tres: (i) emprendiendo acciones de apoyo hacia la compra de bienes y servicios que den satisfacción a objetivos

bajos de BENACCHIO, G., "Verso le direttive di quarta (...) op. cit., págs. 3-28; MORENO MOLINA, J. A., "La cuarta generación de Directivas (... ), op. cit., págs. 115 - 163; GIMENO FELIÚ, J. Mª "Las nuevas Directivas (...), op. cit., MORENO MOLINA, J. A. y DOMÍNGUEZ ALONSO, A. P., "El nuevo derecho de la Unión Europea sobre contratación pública", en la obra colectiva La contratación pública a debate: presente y futuro, Civitas-Thomson, Cizur Menor (Navarra), 2014, págs. 139 - 164; GIMENO FELIÚ, J. M ${ }^{\mathrm{a}}$., El nuevo paquete legislativo comunitario sobre contratación pública. (...), op. cit., LICHÈRE, F., CARANTA, R. y TREUMER, S., (Eds.) Modernising Public Procurement. The New Directive, Djøf Publishing, Copenhagen, 2014; CARANTA, R., "The changes to the Public Contract Directives and the story they tell about how EU law works", CMLR, vol. 52 (2), 2015, págs. $391-460$.

${ }^{515}$ Sobre estas cuestiones véase, CARANTA, R. y TRYBUS, M., (Eds.) The Law of Green and Social Procurement in Europe, Djøf Publishing, Copenhague, 2010; MEDINA ARNÁIZ, T.: "Comprando para asegurar nuestro futuro (...)", op. cit., págs. 43 - 101; KAHLENBORN, W., et al. (ADELPHI), Strategic Use of Public Procurement in Europe- Final Report to the European Commission (MARKT/2010/02/C), Berlin, 2011; PERNAS GARCÍA, J. J., Contratación pública verde, La Ley, Las Rozas (Madrid), 2011 y PERNAS GARCÍA, J. J., (Dir), Contratación pública estratégica, Aranzadi, Cizur Menor (Navarra), 2013; DRAGOS, D., y NEAMTU, B., "Sustainable Public Procurement in the EU: Experiences and Prospects", en la obra colectiva Modernising Public Procurement. The New Directive, Djøf Publishing, Copenhagen, 2014 y que puede consultarse en SSRN: http://ssrn.com/abstract=2488047 [Fecha de consulta: 20 de octubre de 2015]. 
medioambientales y de política social - como parte integrante del concepto de «oferta económicamente más ventajosa»-; (ii) estableciendo condiciones de ejecución contractual de carácter social o medioambiental, de tal manera que el operador económico al que se adjudique el contrato estará obligado a cumplir con los requisitos que se hayan establecido por parte de la entidad pública; y por último, (iii) excluyendo de los procedimientos de adjudicación contractual a los operadores económicos que no cumplan con las obligaciones establecidas por la legislación de la Unión en materia social, laboral o medioambiental, o por las disposiciones internacionales de Derecho social y medioambiental.

Asimismo, y con arreglo a la Propuesta de Directiva, un poder adjudicador podrá excluir del procedimiento a operadores económicos si detecta infracciones de las obligaciones establecidas por la legislación de la Unión en materia social, laboral o medioambiental o de las disposiciones internacionales de Derecho laboral. Además, cuando los poderes adjudicadores constaten que una oferta es anormalmente baja debido a infracciones de la legislación de la Unión en materia social, laboral o medioambiental, estarán obligados a rechazarla.

A estos últimos aspectos dedicaremos los últimos de los epígrafes del Capítulo tercero - que trata sobre las prohibiciones de contratar de carácter obligatorio - puesto que, a pesar de su reconocimiento normativo, consideramos que hubiera resultado más adecuado concretar las prohibiciones de contratar por infracciones en materia social, laboral o medioambiental con un carácter obligatorio para todos los Estados miembros. Así pues, en el marco de dicho Capítulo, procederemos a analizar la inclusión de aspectos medioambientales y sociales entre los criterios de selección cualitativa del contratista en tanto que pretenden servir de soporte a la consecución de los objetivos de la Estrategia Europa 2020 para un crecimiento inteligente, sostenible e integrador.

\section{B. La simplificación de la carga burocrática del operador econó- mico}

En el contexto de mejora regulatoria propiciado por los programas estratégicos «Legislar mejor» $\mathrm{y}$ «Normativa inteligente», la reducción de las cargas administrativas para las empresas, ha sido un propósito constante desde que, en el año 2007, la Comisión pusiera en marcha el Programa de Acción para 
la reducción de las cargas administrativas en la Unión Europea con el objetivo global de reducir en un $25 \%$ las cargas administrativas innecesarias que recaen sobre las empresas ${ }^{516}$.

En el sector de la contratación pública, las PYMEs y los operadores económicos transfronterizos se ven perjudicados por requisitos administrativos de tipo burocrático como son los referidos a las pruebas documentales del cumplimiento de los criterios de selección cualitativa, problemas en la obtención de información y, a veces incluso, requisitos desproporcionados por parte de los órganos de contratación. Estos obstáculos han sido considerados unos los mayores obstáculos para mejorar los porcentajes de participación transfronteriza en las compras públicas.

Es por ello que uno de los esfuerzos actuales de la normativa contractual se concentra en simplificar los requisitos de documentación a presentar por parte de los operadores económicos interesados en la adjudicación. Sus iniciativas se plantean, por una parte, en aceptar las declaraciones responsables de los licitadores y candidatos respecto del cumplimiento de los requisitos para contratar y que únicamente el adjudicatario de un contrato presente al órgano de contratación la documentación exigida, y por otra, que se pueda eximir al operador económico de la obligación de presentar documentos e información que el poder adjudicador pueda obtener por sí mismo sin dificultad a partir de bases de datos o registros (Depósito de certificados en línea E-certis; Documento europeo único de contratación - en las Propuestas denominado Pasaporte

${ }^{516}$ El Plan de acción Simplificar y mejorar el marco regulador, COM (2002) 278 final, de 5 de junio de 2002 fue actualizado y completado con la Comunicación Legislar mejor para potenciar el crecimiento y el empleo en la Unión Europea, COM (2005) 97, de 16 de marzo de 2005, que considera que la simplificación debe ser una acción prioritaria para la UE. Sobre esta materia, entre otros, VILLAREJO GALENDE, H., "Simplificación administrativa al servicio del Mercado Interior Europeo", en el Libro Marrón: Retos y oportunidades para la transposición de la Directiva de Servicios, Círculo de Empresarios, Madrid, 2009, págs. 433 - 495; ARROWSMITH, S., "Modernising the European Union's public procurement regime: A blueprint for real simplicity and flexibility", PPLR, vol. 21 (3), 2012, págs. 71 - 82 y GIMENO FELIÚ, J. $\mathrm{M}^{\mathrm{a}}$. (Dir.), Observatory of Public Procurement "Towards efficiency in Public Procurement: Simplifying procedures and reducing the administrative burden", Ponencia presentada en 5th International Public Procurement Conference, Seattle 2012 que puede consultarse en: http://www.ippa.org/IPPC5/Proceedings/Part4/PAPER48.pdf [Fecha de consulta: 20 de octubre de 2015]. 
europeo de contratación pública - y la utilización del Sistema de Información del Mercado Interior (IMI).

\section{La integridad de los procedimientos}

Los intereses financieros en juego y la estrecha interacción entre los sectores público y privado hacen de la contratación pública un ámbito expuesto a prácticas comerciales deshonestas, como el conflicto de intereses, el favoritismo y la corrupción. La Propuesta pretende mejorar las salvaguardias existentes contra tales riesgos y ofrece una protección suplementaria a través de distintos instrumentos. De esta manera, las Propuestas de Directivas plantean diversas medidas para garantizar la integridad de los procedimientos de contratación pública, y así se regulan - como ya hemos señalado - los denominados conflictos de intereses, las conductas ilícitas, los impedimentos a la adjudicación, las ofertas anormalmente bajas, las consultas preliminares del mercado, las modificaciones de los contratos durante su vigencia y también las prohibiciones de contratar de carácter obligatorio para quienes hayan sido condenados por sentencia judicial firme por delitos vinculados a la corrupción, al fraude, a la trata de seres humanos, por delitos de terrorismo, blanqueo de capitales y participación en una organización delictiva.

En atención a su importancia - tanto desde el punto de vista económico, como de descrédito para las instituciones - dedicaremos una parte del Capítulo tercero de esta memoria doctoral a analizar estas causas de prohibición de contratar.

\section{IV.2. Las principales novedades respecto de las prohi- biciones de contratar}

Las nuevas Directivas impulsan muchos y numerosos cambios en la regulación de las prohibiciones de contratar. Estos cambios se refieren tanto: (i) a las causas - puesto que el elenco de prohibiciones varía respecto de las prohibiciones obligatorias y de las potestativas para los Estados miembros -, (ii) al momento de su apreciación, al referirse "a cualquier momento del procedimiento, como (iii) a los sujetos sobre los que se proyectan, ya que por primera 
vez existe una previsión expresa sobre los subcontratistas.

Así pues, en absoluta coherencia con las disposiciones aplicables a los contratistas principales, se plantea la necesidad de "exigir a los poderes adjudicadores que verifiquen que los subcontratistas no se encuentran en ninguna de las situaciones en las que se justificaría la exclusión de operadores económicos". De este modo, si el subcontratista estuviera incurso en un supuesto de prohibición de contratar obligatorio, éste debe ser sustituido y cuando incurra en una causa de prohibición potestativa los poderes adjudicadores pueden solicitar su sustitución (considerando centésimo quinto de la Directiva 2014/24/UE en relación con su artículo 71.6.b) y considerando septuagésimo segundo en relación con su artículo 42.4.b) de la Directiva 2014/23/UE («concesiones») ${ }^{517}$.

\section{A. Nuevas prohibiciones de contratar obligatorias}

Se amplía el catálogo de delitos que habilitan una prohibición de contratar de carácter obligatorio a los delitos de terrorismo o delitos ligado a las actividades terroristas - aunque ya estaban recogidos en la Directiva 2009/81/CE («sectores seguridad y defensa») - y a los delitos vinculados al trabajo infantil y otras formas de trata de seres humanos. Por tanto, las regulaciones nacionales que transpongan estas Directivas deben recoger expresamente estas conductas como un supuesto de prohibición de contratar.

Hay que hacer notar que la obligación de excluir a un operador económico de un procedimiento de adjudicación por haber sido condenado por su participación en una organización delictiva, por corrupción, por fraude, por delito de terrorismo, blanqueo de capitales o financiación del terrorismo, por trabajo infantil y otras formas de trata de seres humanos atañe tanto a los contratos en los sectores clásicos (Directiva 2014/24/UE), en los sectores especiales cuando el órgano de contratación es un poder adjudicador (Directiva 2014/25/UE) como a los contratos de concesión (Directiva 2014/23/UE) aun cuando el tenor

${ }^{517}$ Aunque ya hemos indicado que los considerandos de una Directiva carecen en sí mismos de valor jurídico vinculante, la Exposición de motivos de un acto de la Unión ofrece elementos de interés a fin de precisar el contenido del mismo. Véanse, en este sentido, las sentencias del TJUE de 2 de abril de 2009, Tyson Parketthandel, C134/08, apartado 16 y de 25 de febrero de 2010, C-562/08, Müller Fleisch, apartado 40. 
literal del artículo 38.4 parece indicar lo contrario ${ }^{518}$.

En efecto, la versión española de este artículo - y sin que exista una corrección de errores al respecto - indica que "Los poderes adjudicadores y entidades adjudicadoras a que se refiere el artículo 7, apartado 1, letra a), podrán excluir a un operador económico de la participación en un procedimiento de adjudicación de concesión (...)".

Más allá de su tenor literal, no podemos mantener su carácter potestativo por dos motivos: En primer lugar, de la lectura de este mismo artículo se deduce su carácter preceptivo al contemplar que "la obligación de excluir a un operador económico se aplicará también cuando el condenado mediante sentencia firme sea miembro del órgano de administración (...)" o en su considerando sexagésimo noveno al conminar a que "no deben adjudicarse concesiones a operadores económicos que hayan participado en una organización delictiva o hayan sido declarados culpables de corrupción o fraude contra los intereses financieros de la Unión, de delitos terroristas, de blanqueo de dinero o de financiación del terrorismo, ni de trata de seres humanos. No obstante, los Estados miembros deben poder establecer excepciones a dichas exclusiones obligatorias en circunstancias excepcionales" (los subrayados son nuestros).

En segundo lugar, distintas versiones lingüísticas de este mismo artículo permiten mantener sin ambigüedades su carácter obligatorio. Así, la versión en inglés se refiere a"shall exclude an economic operator", la francesa a "excluent un opérateur économique", en la versión portuguesa se alude a "devem excluir um operador económico" y en la italiana "escludono un operatore económico". Por todo ello, y dado que el Tribunal de Justicia exige uniformidad en la interpretación de las disposiciones del Derecho de la Unión, hemos de mantener su carácter de prohibiciones de contratar obligatorias ${ }^{519}$.

\footnotetext{
${ }^{518}$ La deficiente redacción del primer párrafo del artículo 38.4 ya había sido advertida por HERNÁNDEZ GONZÁLEZ, F.L., "La nueva Directiva de concesiones (...), op. cit., pág. 197.

${ }^{519}$ Recordemos que según reiterada jurisprudencia del Tribunal de Justicia, se exige, en caso de divergencia entre las diferentes versiones lingüísticas de ésta, que la disposición considerada se interprete en función del contexto y de la finalidad de la normativa en la que se integra. Entre otras en sus sentencias de 15 de octubre de 2015, Nike European Operations Netherlands, C-310/14, apartado 17 y de 26 de febrero de 2015, Christie's France, C-41/14, apartado 26. Sobre la importancia de
} 
Asimismo, deben concretarse como prohibiciones de contratar obligatorias los supuestos en los que el operador económico ha quebrantado sus obligaciones fiscales y con la seguridad social; no obstante, para su consideración como obligatoria dicho quebrantamiento debe estar acreditado por una sentencia o resolución administrativa firme, puesto que de no ser así, no se contempla como una prohibición de carácter obligatorio, aunque sí potestativa (artículo 57.2 in fine Directiva 2014/24/UE y artículo 38.5 de la Directiva 2014/23/UE («concesiones»).

Ahora bien, tal como tendremos ocasión de analizar en un momento posterior de esta memoria doctoral, a la vez que se incrementa el rigor de exigencia para contemplar nuevas prohibiciones de contratar obligatorias se posibilita su excepción - ya no únicamente por razones imperiosas de interés general - si no a través de distintas medidas que, en último extremo, se vinculan al cumplimiento posterior de sus obligaciones de pago.

\section{B. Las prohibiciones de contratar facultativas}

El catálogo de prohibiciones de contratar facultativas es el que mayor número de novedades presenta y se encuentra recogido en el artículo 57.4 de la Directiva 2014/24/UE y en el artículo 38.7 de la Directiva sobre concesiones. De la lectura de estos artículos vamos a poner de relieve la existencia de cuatro grandes temáticas, todas ellas presididas por la búsqueda de un contratista fiable y por el respeto al principio de igualdad de trato que debe presidir la selección del contratista ${ }^{520}$.

las traducciones, MARTÍN-RETORTILLO BAQUER, L., "Honorabilidad y buena conducta (...), op. cit., pág. 94.

${ }^{520}$ Con carácter general, puede consultarse PRIESS, H-J., "The Rules on Exclusion and Self-Cleaning under the 2014 Public Procurement Directive", PPLR, vol. 23 (3), 2014, págs. 112 - 123 y SÁNCHEZ GRAELLS, A., "Exclusion, Qualitative Selection and Short-Listing in the New Public Sector Procurement Directive 2014/24", en la obra colectiva Modernising Public Procurement: The New Directive, DJØF Publishing, Copenhague, 2014, págs. 97 - 129. 


\section{B.1. Primera temática. Prohibiciones de contratar por falta de cre- dibilidad profesional}

Por un lado, y como consecuencia de la jurisprudencia del TJUE en relación a esta materia, se ha abierto el «cajón de sastre» que englobabn las prohibiciones de contratar por motivos relacionados a la moralidad profesional del operador económico y se han concretado algunas de las conductas específicas que comprendían el haber cometido una falta grave en materia profesional. De esta manera, entre las conductas que, en este momento, pueden habilitar una prohibición de contratar por falta de idoneidad profesional suficiente, tendremos que entender incluidas las siguientes:

- Incumplimientos de las obligaciones aplicables en los ámbitos del Derecho medioambiental, social y laboral, si bien a nuestro parecer - y como manifestaremos con posterioridad - se debieran haber recogido con el carácter de prohibiciones de contratar obligatorias por servir de soporte a la consecución de los propósitos de la Estrategia Europa 2020 y por perseguir objetivos compatibles con los valores de la Unión.

- Aquellas que confirman judicialmente o en vía administrativa la infracción de las normas sobre competencia por formalizar acuerdos ilícitos entre operadores económicos a fin de proceder a un reparto del mercado o a la fijación de precios, lo que se conoce como «bid-rigging» (STJUE de 18 de diciembre de 2014, Generali-Providencia Biztositó, C-470/13);

- Deficiencias significativas o persistentes en el cumplimiento de un requisito de fondo en el marco de un contrato público anterior (STJUE de 13 de diciembre de 2012, Forposta SA, C-465/11). Se posibilita excluir a los candidatos o licitadores cuya actuación en anteriores contratos públicos haya mostrado graves deficiencias en lo que se refiere al cumplimiento de los requisitos de fondo, como la no realización de una entrega o prestación, la existencia de deficiencias significativas en el producto entregado o el servicio prestado que los hagan inutilizables para el fin perseguido, o una conducta indebida que haga dudar seriamente de la fiabilidad del operador económico (considerando centésimo primero de la Directiva 2014/24/UE y considerando 70 de la Directiva 2014/23/UE) ${ }^{521}$;

\footnotetext{
${ }^{521}$ En este sentido, LÓPEZ MIÑO, A., y VALCÁRCEL FERNÁNDEZ, P., des-
} 
- Cualquier incumplimiento grave de las obligaciones contractuales imputables al contratista previa apreciación del comportamiento culposo que se le imputa, puesto que el concepto de «falta grave» debe entenderse referido a un comportamiento que revele dolo o una negligencia de cierta gravedad por parte del operador económico en cuestión (STJUE de 13 de diciembre de 2012, Forposta SA, C-465/11).

\section{B.2. Segunda temática. Prohibiciones de contratar por la existencia de un conflicto de intereses}

Como ya hemos expuesto con anterioridad, la preocupación por el respeto al principio de igualdad y el control de la imparcialidad de los procedimientos de adjudicación quedan confirmadas en el texto de las Directivas con dos prohibiciones de contratar diferentes:

- Por conductas que vulneran la igualdad de oportunidades entre licitadores al disfrutar de una posición de ventaja frente al resto de sus competidores, tal como ocurre, por ejemplo, en el supuesto un falseamiento de la competencia derivado de la participación previa de los operadores económicos en la preparación del procedimiento de contratación, y siempre que no pueda remediarse por medios menos restrictivos (STJUE de 3 de marzo de 2005, Fabricom, C-21/03 y C-34/03);

- Por conflicto de intereses. En este supuesto, debemos tener en cuenta que no existe una obligación absoluta de los poderes adjudicadores de excluir

tacaban la novedad de la Directiva 2014/24/UE en encomendar a los poderes adjudicadores la persecución del bid rigging en la contratación pública habilitándoles incluso para prohibir su participación en un procedimiento de adjudicación, en LÓPEZ MIÑO, A., y VALCÁRCEL FERNÁNDEZ, P., "Colusión en la contratación pública (bid rigging): propuestas para combatirla eficazmente y posibilidades que ofrece la Directiva 2014/14/UE sobre contratación pública", en la obra colectiva Observatorio de los contratos públicos 2013, Thomson-Aranzadi, Cizur Menor, 2014, págs. 458 y 459. Sobre esta materia resulta de interés, SÁNCHEZ GRAELLS, A., Public Procurement and the EU Competition Rules, $2^{\mathrm{a}}$ ed., Hart Publishing, Oxford, 2014, especialmente sus págs. 296 a 301 y del mismo autor "Prevention and deterrence of bid rigging: a look from the new EU directive on public procurement", en la obra colectiva Integrity and Efficiency in Sustainable Public Contracts, Bruylant, Brussels, 2014, págs. 171 - 198 que puede consultarse también en SSRN: http://ssrn.com/abstract=2053414 [Fecha de consulta: 24 de octubre de 2015]. 
sistemáticamente a los operadores económicos en situación de conflicto de intereses, dado que tal exclusión no se justifica en aquellos casos en que puede probarse que tal situación no ha tenido ninguna incidencia en su comportamiento en el marco del procedimiento de licitación y que no supone un riesgo real de que surjan prácticas que puedan falsear la competencia entre los licitadores. En cambio, la exclusión de un licitador en situación de conflicto de intereses resulta indispensable cuando no se dispone de un remedio más adecuado para evitar cualquier vulneración de los principios de igualdad de trato entre los licitadores y de transparencia (STJUE de 12 de marzo de 2015, eVigilo, C-538/13 y sentencia del Tribunal General de 13 de octubre de 2015, Intrasoft International/Comisión, $\mathrm{T}-403 / 02)^{522}$;

\section{B.3. Tercera temática. Prohibiciones de contratar por la quiebra de la veracidad documental}

Esta temática responde también a garantizar la seriedad y credibilidad profesional del operador económico; sin embargo, hemos optado por su diferenciación en cuanto que la nueva regulación favorece la simplificación documental eximiendo a los operadores económicos de la obligación de presentar la documentación que acredita el cumplimiento de las condiciones de participación en los procedimientos de adjudicación de un contrato público, pero sin que se supriman los requisitos para poder contratar.

En este contexto de simplificación, la descarga burocrática que supone la aceptación del documento europeo único de contratación es posible porque se parte de la confianza en el operador económico. Por ello, a una mayor confianza del órgano de contratación debiera corresponder un mayor compromiso a favor

\footnotetext{
${ }^{522}$ Recordemos nuevamente que la Directiva 2014/23 establece en su artículo 35 bajo el título «Lucha contra la corrupción y prevención de los conflictos de interés» - que "los Estados miembros exigirán a los poderes adjudicadores y a las entidades adjudicadoras que tomen las medidas adecuadas para luchar contra el fraude, el favoritismo y la corrupción y prevenir, detectar y solucionar de modo efectivo los conflictos de intereses que puedan surgir en los procedimientos de adjudicación de concesiones a fin de evitar cualquier distorsión de la competencia y garantizar la transparencia del procedimiento de adjudicación y la igualdad de trato de todos los candidatos y licitadores".
} 
de la lealtad documental - integridad, exactitud y veracidad - por parte del operador económico, de tal manera que si ésta quiebra se fractura el equilibrio de esta ecuación y el licitador o candidato puede incurrir en alguno de los siguientes supuestos de prohibición de contratar:

- Por haber sido declarado culpable de falsedad grave al proporcionar la información exigida para verificar la inexistencia de motivos de exclusión o el cumplimiento de los criterios de selección;

- Por haber retenido dicha información;

- Por no poder presentar los documentos justificativos requeridos por el órgano de contratación;

- Por proporcionar negligentemente información engañosa que pueda tener una influencia importante en las decisiones relativas a la exclusión, selección o adjudicación.

\section{B.4. Cuarta temática. Prohibiciones de contratar por motivos eco- nómicos}

En este último bloque temático vamos a referirnos a las prohibiciones de contratar que tratan de evitar que el contrato se vea frustrado por la falta de solvencia económica del candidato o licitador y que, en definitiva, expresan la desconfianza del legislador ante las situaciones de dificultad económica por las que puede atravesar el operador económico (quiebra, insolvencia, liquidación, suspensión) $)^{523}$.

\footnotetext{
${ }^{523}$ Esta materia ha sido tratada en profundidad por CHINCHILLA MARÍN, C., "La insolvencia del contratista de las Administraciones públicas", RVAP, núm. 69 (I), mayo - agosto 2004, págs. 33 - 88; CARLÓN RUIZ, M., "Las Administraciones Públicas ante el fenómeno concursal: algunas reflexiones al hilo de la nueva Ley", $R A P$, núm. 164, mayo - agosto 2004, págs. 95 - 143; DEL GUAYO CASTIELLA, I., Contratos del sector público y concurso de acreedores, La Ley, Madrid, 2011, especialmente sus páginas 31 a 50 que tratan del concurso de acreedores como causa de prohibición de contratar; PUNZÓN MORALEDA, J. y PUERTA SEGUIDO, F., "Procesos concursales y contratación pública", REDA, núm. 161, enero-marzo 2014, págs. 223-259 y FERNÁNDEZ TORRES, I., El concurso de las entidades del sector público y sus contratistas, Civitas - Thomson Reuters, Cizur Menor (Navarra), 2015, especialmente págs. 110 a 123.
} 
"Los poderes adjudicadores podrán excluir a un operador económico de la participación en un procedimiento de contratación, por sí mismos o a petición de los Estados miembros, en cualquiera de las siguientes situaciones: b) si el operador económico ha quebrado o está sometido a un procedimiento de insolvencia o liquidación, si sus activos están siendo administrados por un liquidador o por un tribunal, si ha celebrado un convenio con sus acreedores, si sus actividades empresariales han sido suspendidas o se encuentra en cualquier situación análoga resultante de un procedimiento de la misma naturaleza vigente en las disposiciones legales y reglamentarias nacionales" (artículo 57.4 b) de la Directiva 2014/24/UE y artículo 38.7 b) de la Directiva 2014/23/UE («concesiones»).

En las Directivas de 2014, esta "clásica" prohibición de contratar - puesto que se encuentra recogida en la legislación contractual desde sus inicios ${ }^{524}$ cede en intensidad a favor de mantener las relaciones contractuales con los operadores económicos incursos en alguno de estos supuestos de insolvencia, ya que expresamente - y como novedad legislativa - se contempla que no se "excluya a un operador económico que se encuentre en una de las situaciones contempladas en dicha letra si ha comprobado que ese operador económico va a estar en condiciones de ejecutar el contrato, teniendo en cuenta las normas y medidas nacionales aplicables en materia de continuación de la actividad empresarial" ${ }^{25}$. Este motivo de inaplicación de una prohibición de contratar será objeto de tratamiento posterior al tratar los diferentes supuestos de excepción que contemplan las nuevas Directivas.

\footnotetext{
${ }^{524}$ Véase el artículo 23.a) de la Directiva 71/305/CEE («contrato de obras») y el artículo 20.a) de la Directiva 77/62/CEE («contrato de suministro»).

${ }^{525} \mathrm{El}$ artículo 38.7 b) in fine de la Directiva 2014/23/UE es del siguiente tenor: "No obstante, el poder o entidad adjudicador podrá decidir no excluir ni estar obligado por el Estado miembro a excluir a un operador económico que se encuentre en una de las situaciones anteriores si se ha establecido que el operador económico de que se trata puede llevar a cabo la concesión, teniendo en cuenta las normas nacionales aplicables y las medidas sobre la continuación de los negocios en el caso de las situaciones anteriores".
} 



\section{Capítulo tercero}

\section{LAS PROHIBICIONES DE CARÁCTER OBLIGATORIO PARA LOS ESTADOS MIEMBROS: SITUACIÓN ACTUAL Y PROPUESTAS DE LEGE FERENDA}

\section{Introducción}

Del amplio elenco de objetivos que pueden perseguirse a través de la contratación pública, la lucha contra determinadas conductas delictivas ocupa un lugar destacado entre ellos. A este respecto, y como venimos apuntando desde los capítulos anteriores, las Directivas del año 2014 - siguiendo la estela de la regulación anterior - establecen la exclusión obligatoria de los procesos de contratación pública de aquellos candidatos y licitadores que hubieran sido condenados en sentencia judicial firme por fraude, corrupción, blanqueo de capitales, delitos de terrorismo, trata de seres humanos o participación en organización delictiva (artículo 57.1 de la Directiva 2014/24/UE y artículo 38.4 de la Directiva 2014/23/UE («concesiones»).

Estamos ante una de las medidas que se dirigen a promover la probidad entre aquellos operadores económicos que quieren llegar a ser contratistas, pues como ya hemos indicado, en los considerandos de estas Directivas se señala que "no deben adjudicarse contratos públicos a operadores económicos que hayan participado en una organización delictiva o hayan sido declarados culpables de corrupción o fraude contra los intereses financieros de la Unión, de delitos terroristas, de blanqueo de dinero o de financiación del terrorismo, ni de trata de seres humanos" (considerando centésimo de la Directiva 2014/24/UE y 
sexagésimo noveno de la Directiva 2014/23/UE).

Bajo este tenor, la exclusión obligatoria derivada de la previa condena penal por estos delitos supone, de una parte, un importante mecanismo en la estrategia de lucha contra las prácticas delictivas que plantean una mayor amenaza para la Unión, y de otra, contribuye a proteger al mercado de estas conductas punibles al tratar de garantizar una competencia justa entre todos los licitadores y candidatos. La UE sabedora de la existencia de sectores más proclives a la delincuencia económica, ha intensificado sus acciones para evitar y combatir estas conductas en aquellas áreas que, por conllevar un mayor empleo de recursos públicos, pudieran poner en entredicho tanto el funcionamiento eficaz del mercado único como el cumplimiento de los principales objetivos previstos en la normativa en materia de adjudicación de contratos públicos, es decir, la apertura de los contratos a una competencia transfronteriza en condiciones de igualdad, transparencia y no discriminación.

\section{La corrupción en la contratación pública}

Entre los tipos delictivos que habilitan una prohibición de contratar y que, en mayor medida, pueden comprometer los citados objetivos, se encuentran aquellos relacionados con el fenómeno de la corrupción ${ }^{526}$. En este sentido, si bien la corrupción se manifiesta en distintos ámbitos, la reiteración de escándalos relacionados con la adjudicación de contratos públicos ha puesto de mani-

\footnotetext{
${ }^{526}$ Hay autores que defienden la idea de que la mejora en la integridad y la lucha contra la corrupción en la contratación pública debe entenderse como una finalidad integrada en el objetivo global de optimización de recursos, como por ejemplo, BERTOK, J., "Promoting transparency and integrity in public procurement: the work of the OECD", PPLR, vol. 15 (6), 2006, pág. NA190. La Resolución del Parlamento Europeo, de 25 de octubre de 2011 [P7_TA (2011) 0454], sobre la modernización de la contratación pública, también se manifiesta en este sentido al señalar en su apartado 44 que "la lucha contra la corrupción y el favoritismo es uno de los objetivos de las Directivas". Al mismo tenor responde el Dictamen del CESE sobre el Libro Verde de la Comisión al señalar que "uno de los objetivos de las directivas consiste en combatir el favoritismo, del fraude y la corrupción", apartados 1.14 y 6.1 (DOUE C 318, de 29 de octubre de 2011) y el documento de trabajo de los servicios de la Comisión sobre las Propuestas de Directivas, SEC (2011) 1585 final, de 20 de diciembre de 2011, pág. 30.
} 
fiesto que ésta es una de las áreas más fértiles para la proliferación de prácticas corruptas, ya que pocas actividades económicas crean mayores tentaciones y ofrecen más oportunidades a la corrupción que las licitaciones en el sector público ${ }^{527}$. Tanto es así que el Parlamento Europeo ha llegado a afirmar que "el sector de la contratación pública es el más expuesto a los riegos de gestión irregular, fraude y corrupción y que estas conductas ilícitas distorsionan el mercado, provocan un aumento de los precios y de las tarifas abonadas por los consumidores para la adquisición de bienes y servicios, y siembran la desconfianza con respecto a la Unión Europea" ${ }^{28}$.

Por lo que respecta a los tipos contractuales potencialmente más expuestos

${ }^{527}$ Ésta es la opinión manifestada por MARTÍN-RETORTILLO BAQUER, L., "Lo público y la acción administrativa: el fantasma de la corrupción" en la obra Don Luis Jordana de Pozas, creador de ciencia administrativa, Servicio de Publicaciones de la Facultad de Derecho y Fundación BSCH, Madrid, 2000, pág. 82; POPE, J., "Public Procurement: Where the Public and Private Sectors Do Business", en la obra colectiva TI Sourcebook 2000. Confronting Corruption: The Elements of a National Integrity System, Transparency International, Washington, 2000, pág. 205; RIVERO ORTEGA, R., "Corrupción y contratos públicos: las respuestas europea y latinoamericana", en la obra colectiva La corrupción en un mundo globalizado: Análisis interdisciplinar, Ratio Legis, Salamanca, 2004, pág. 110; DOMÍNGUEZ-BERRUETA DE JUAN, M. Á., "Sobre la Ley de Contratos de las Administraciones Públicas. Factores de la reforma de la normativa reguladora de la contratación pública", en la obra colectiva La contratación pública, (vol. I), Hammurabi, Buenos Aires, 2006, pág. 157; MEDINA ARNÁIZ, T., "Las respuestas normativas al fenómeno de la corrupción (... )", op. cit., pág. 3 y GIMENO FELIÚ, J. Mª., "La Ley de Contratos del Sector Público: ¿una herramienta eficaz (...)”, op. cit., pág. 524.

A este respecto, cabe mencionarse, que la respuestas dadas a la pregunta 100 del Libro Verde "¿Comparte la opinión de que los mercados de la contratación pública están expuestos a un riesgo de corrupción y favoritismo?" coinciden mayoritariamente en el hecho de que las compras públicas se encuentran expuestas al riesgo de corrupción, si bien existen diferencias respecto a la idea de si las Directivas sobre contratación son el instrumento adecuado para contrarrestar estos riesgos o sería más adecuado que fuera la normativa nacional quien se encargara de neutralizar estas amenazas. Sobre las respuestas al $L i$ bro Verde sobre modernización de la política de contratación pública de la UE, puede consultarse: http://ec.europa.eu/internal_market/consultations/docs/2011/public_procurement/synthesis_document_en.pdf [Fecha de consulta: 20 de octubre de 2015].

${ }^{528}$ Apartado 27 de la Resolución del Parlamento Europeo, de 6 de mayo de 2010, sobre la protección de los intereses financieros de las Comunidades y la lucha contra el fraude, P7_TA (2010) 0155 (DOUE C 81E, de 15 de marzo de 2011). 
a la corrupción, huelga decir que son los contratos de obras los que han dejado al descubierto los escándalos más flagrantes de casos de corrupción. Los grandes proyectos de obras o infraestructuras, las telecomunicaciones o los relacionados con el sector energético y el de la defensa, se consideran igualmente como propensos a prácticas corruptas, ya que la complejidad tecnológica de dichos sectores ofrece una mayor oportunidad para ocultar sobornos a través de precios inflados que pueden achacarse a otros factores ${ }^{529}$. No obstante, aquellos contratos de menor envergadura económica, como son los relativos a la adquisición de bienes de uso corriente se presentan, a juicio de ROSE-ACKERMAN, como los principales objetivos sobre los que cometer irregularidades, lo que nos lleva a afirmar que las prácticas corruptas se extiende a todas las modalidades contractuales, aunque sean más habituales en ciertas categorías de contratos que en otras ${ }^{530}$.

Una de las razones que explican el avance de estas conductas punibles se encuentra en el volumen de recursos que mueve la contratación del sector público, puesto que, la realización de obras, el suministro de bienes y la gestión de servicios que demandan las entidades públicas representan una parte considerable del PIB de un país.

A nivel mundial los porcentajes en la compra pública oscilan entre un 15 y un 20 por ciento dependiendo de los países $^{531}$, aunque en el caso de la UE, y

${ }^{529}$ KENNY, C. y SØREIDE, T., Grand Corruption in Utilities, Policy Research Working Paper núm. 4805, December 2008 y SØREIDE, T., Risks of Corruption and Collusion in the Awarding of Concession Contracts, European Parliament's Committee on Internal Market and Consumer Protection, Bruselas, 2012.

${ }^{530}$ ROSE-ACKERMAN, S., "Corruption and the Global Economy", en la obra colectiva Corruption and Integrity Improvement Initiatives in Developing Countries, United Nations Programme Development, New York, 1998, pág. 27.

${ }^{531}$ Los datos varían dependiendo de los estudios, pero según datos ofrecidos por la OCDE, la proporción del total de adquisiciones públicas en todos los niveles del gobierno en los países de la OCDE suponía un promedio de un $12 \%$ de su PIB en la contratación pública (excluyendo las compras realizadas por sus propios servicios públicos estatales), según se recoge en Government at a Glance 2011, OECD Publishing, Paris, 2011, págs. 148. No obstante, existen autores que manifiestan que en economías en vía de desarrollo las compras públicas pueden llegar a representar un $80 \%$ del PIB de un país. En este sentido se manifiestan, TELGEN, J., HARLAND, Ch., y KNIGHT, L., "Public procurement in perspective", en la obra colectiva $P u$ blic Procurement: International Cases and Commentary, Routledge, London, 2007, 
según los datos aportados por la Comisión Europa, en el año 2013 se han fijado en un valor superior al 13 por ciento del PIB europeo - concretamente en un $13,6 \%$ - excluyendo los servicios públicos (Tabla 1) ${ }^{532}$. Estos porcentajes en el volumen de gasto público destinado a la contratación pública constituyen un incentivo para que las empresas, mediante el uso de prácticas corruptas, pretendan obtener posiciones más favorables que sus competidores en este mercado y, también, para que los titulares de los órganos de contratación utilicen su poder de compra en beneficio propio $^{533}$.

pág. 19.

${ }^{532}$ Según los datos publicados en el Documento de trabajo de la Comisión Public Procurement Indicators 2013, de 17 de junio de 2015 que puede consultarse en: http://ec.europa.eu/growth/single-market/public-procurement/studiesnetworks/index_en.htm [Fecha de consulta: 20 de octubre de 2015].

${ }^{533}$ Así se manifiesta STAPENHURST, F. y LANGSETH, P., "The role of the public administration in fighting corruption", The International Journal of Public Sector Management, vol. 10 (5), 1997, pág. 312. En este mismo sentido, un gran número de los estudios sobre corrupción aluden a los estímulos económicos que ésta provoca en los distintos operadores implicados en los procedimientos de contratación. A título de ejemplo, baste señalar BUEB, J. P., "Fraudes et Corruption dans les Marchés Publics", Revue du Marché Unique Européen, núm. 1, 1997, págs. 27 - 68; FENECH, G., La moralisation des marchés publics, Presses Universitaires de France, Col. Que sais je?, Paris, 1998; ROSE-ACKERMAN, S., Corruption and government: causes, consequences, and reform, Cambridge University Press, Cambridge, 1999; SØREIDE, T., Corruption in public procurement: causes, consequences and cures, Chr. Michelsen Institute, Bergen, 2002; ARIEL REZZOAGLI, B., Corrupción y contratos públicos: una visión desde la fiscalización del Tribunal de Cuentas, Ratio Legis, Salamanca, 2005 y CASTRO CUENCA, C. G., La corrupción en la contratación pública en Europa, Ratio Legis, Salamanca, 2009.

Asimismo, resultan de gran interés los estudios de la OCDE Integrity in Public Procurement: Good Practice from A to $Z$ (Buenas prácticas para la integridad en la contratación pública "de la A a la Z”), OECD Publishing, París, 2007, que también se encuentra publicado por el Instituto Nacional de Administración Pública (INAP), Bribery in Public Procurement: Methods, Actors and Counter-Measures, OECD Publishing, París, 2007 (El cohecho en las adquisiciones del sector público. Métodos, actores y medidas para combatirlo), cuya traducción al castellano ha sido realizada por la Secretaría de la Función Pública del Gobierno de México y Principles of Integrity in Public Procurement, 2009. También el documento Collusion and Corruption in Public Procurement, DAF/COMP/GF (2010) 6, de 15 de octubre de 2010, que en sus págs. 137 a 140 se refiere al papel de las Directivas sobre contratación en la lucha contra la corrupción. 
El hecho que la adjudicación venga precondicionada por un acuerdo previo adoptado en función de una dádiva o en atención a ciertos intereses personales espurios, adultera el procedimiento de selección del contratista, ya que se prescinde de la objetividad necesaria en toda adjudicación contractual. Esta falta de objetividad es la que nos lleva a pensar que el contrato no será presumiblemente adjudicado a quien ofrezca la oferta económicamente más ventajosa, sino a quien resulte más hábil a la hora de utilizar estos canales y prácticas corruptas $^{534}$.

El resultado es una pérdida de eficiencia en el proceso contractual. Sin una competencia real, la ejecución de obras, la adquisición de bienes o la prestación de servicios resulta más costosa para el erario público y deja al descubierto una importante desviación de recursos para fines privados, de tal manera que el resultado final de la licitación no garantiza una adecuada relación calidadprecio («value for money») $)^{535}$.

Los costes añadidos al contrato pueden llegar a ser de un 20 a un 25 por ciento, pudiendo alcanzar incluso un 50 por ciento del monto total del contrato $^{536}$. La razón de este sobrecoste es evidente: las empresas revierten en el

${ }^{534}$ Alejandro NIETO manifestaba que "el fraude es gusano que vive en casi todas las manzanas de contratación pública. Con unos artificios o con otros, es el caso que los contratos terminan adjudicándose no a la oferta más beneficiosa, sino al que se ha concertado con quienes van a decidir, de tal manera que la obra o servicio resultan de peor calidad y desde luego más caros", en NIETO, A., Corrupción en la España democrática, Ariel, Barcelona, 1997, pág. 117. También GIMENO FELIÚ, J. Ma ; "La Ley de Contratos del Sector Público: ¿una herramienta (...)", op. cit., pág. 524; CERRILLO I MARTÍNEZ, A., El principio de integridad (...)", op. cit., págs. 37 y siguientes y MEDINA ARNÁIZ, T., "Instrumentos jurídicos frente (... )", op. cit., pág. 314 .

${ }^{535}$ MEDINA ARNÁIZ, T.: "EU Directives as an Anticorruption Measures: Excluding Corruption-Convicted (...)", op. cit., págs. 105 - 130. Véase también el estudio elaborado por PRICEWATERHOUSECOOPERS y ECORYS Identifying and Reducing Corruption in Public Procurement in the EU - Development of a methodology to estimate the direct costs of corruption and other elements for an EU-evaluation mechanism in the area of anti-corruption, de 30 de junio de 2013.

${ }^{536}$ STROMBOM, D., "Corruption in Procurement", Economic Perspectives, vol. 3 (5) 1998, pág. 22. Este autor se hace eco del ejemplo citado por TANZI y DAVOODI a raíz de un escándalo de corrupción destapado en la ciudad de Milán (conocida con el sobrenombre de Tangentopolis «la ciudad del soborno») ya que, después de 
contrato los pagos realizados en concepto de sobornos a los funcionarios, técnicos o políticos que, directa o indirectamente, intervienen en la adjudicación contractual ${ }^{537}$.

Como bien ha reseñado CASTRO CUENCA, el mecanismo de los sobrecostes en la contratación pública es doblemente lesivo ${ }^{538}$. Al revertir en el importe final del contrato los pagos realizados en concepto de sobornos, no sólo se daña al erario público por el sobrecoste que acumula ese contrato, sino que constituye un fraude al principio de selección objetiva del contratista, puesto que al final el precio pagado por la prestación demandada resulta ser más onerosa que las ofertas presentadas por el resto de licitadores a la adjudicación del contrato.

que se dejara al descubierto una sofisticada y compleja red de corrupción políticoempresarial que supuso el procesamiento de la élite política del país, los costes en los contratos se redujeron en más de un 50 por ciento, TANZI, V. y DAVOODI, H., Corruption, Public Investment, and Growth, IMF Working Papers 97/139, 1997, y que en castellano se puede consultar bajo el título "Corrupción, inversión pública y crecimiento", Gestión y Análisis de Políticas Públicas, núm. 21, mayo - agosto, 2001, págs. 73 - 82. Igualmente, en el trabajo de EVENETT y HOEKMAN se alude a la cifra del 50 por ciento como la cuantía que puede suponer el sobrecoste en un contrato en el que medien prácticas corruptas, EVENETT, S. y HOEKMAN, B., "Government procurement: market access, transparency, and multilateral trade rules", European Journal of Political Economy, vol. 21 (1), 2005, pág. 178. Por su parte, KENNY estima que entre el 5 y el 20 por ciento de los costes de los gastos de construcción se destinan al pago de sobornos, KENNY, C., Measuring and Reducing the Impact of Corruption in Infrastructure, World Bank Policy Research Working Paper núm. 4099, December 2006, Washington, pág. 4.

${ }^{537}$ Resulta innecesario precisar que no todos los sobrecostes en un contrato derivan de prácticas corruptas, ya que existen otro tipo de ineficiencias que ocasionan este aumento indebido del coste del contrato como ha puesto de manifiesto GANUZA FERNÁNDEZ. Este autor muestra cómo la corrección de los defectos en los proyectos presentados por la Administración es el factor de mayor peso a la hora de analizar las causas de estos sobrecostes, en GANUZA FERNÁNDEZ, J. J., "Los sobrecostes en las obras públicas: un análisis económico del caso español", Economía Industrial, núm. 318 (Ejemplar dedicado a: Competencia y regulación de mercados), 1997, págs. 116 y 117.

${ }^{538}$ CASTRO CUENCA, C. G., La corrupción en la contratación pública (...), op. cit., pág. 89 "los sobrecostos implican la pérdida de millonarias cantidades de dinero público pagadas para que las empresas desembolsen sobornos y se apropien del valor restante". 
Además de ello, es importante también referirnos al coste no económico que suponen los casos de corrupción en las adquisiciones del sector público, sobre todo cuando éstos van asociados a la delincuencia organizada. La repercusión en los medios de comunicación de acusaciones de corrupción vinculados a la contratación pública por parte de representantes y altos cargos de la Administración en distintos Estados miembros ${ }^{539}$ muestra, de una parte, la debilidad del sistema contractual, y por otra, reduce la confianza en las instituciones públicas impidiendo, precisamente, el avance de la institucionalidad. Es así que, debido a estos numerosos escándalos nacionales e internacionales, se acentúa la percepción de los ciudadanos sobre la corrupción y, aunque no siempre los mecanismos de responsabilidad electoral y política funcionen eficazmente para reprobar estas conductas, lo cierto es que estos escándalos menoscaban la credibilidad en la gestión pública. De hecho, uno de los instrumentos normativos más importantes en la lucha contra la corrupción, la Convención de las Naciones Unidas contra la Corrupción, alude en su Preámbulo a los efectos destructores de este fenómeno al transmitir su preocupación por "la gravedad de los problemas y las amenazas que plantea la corrupción para la estabilidad y seguridad de las sociedades al socavar las instituciones y los valores de la democracia, la ética y la justicia y al comprometer el desarrollo sostenible y el imperio de la ley" ${ }^{540}$.

${ }^{539}$ Una relación de los principales escándalos de corrupción vinculados a la adjudicación de contratos públicos en el entorno europeo puede consultarse en DELLA PORTA, D. y VANNUCCI, A., Corrupt exchanges: actors, resources, and mechanisms of political corruption, Walter de Gruyter, New York, 1999; EIGEN, P., Las redes de la corrupción: la sociedad civil contra los abusos de poder, Planeta, Barcelona, 2004; MEDINA ARNÁIZ, T., "Las respuestas normativas al fenómeno de la corrupción (...)", op. cit., págs. 2 y 3, y SØREIDE, T., Risks of Corruption and Collusion in the Awarding (...)", op. cit., pág. 11. Más centrado en el caso español, véase VILLORIA MENDIETA, M., "Corrupción: la amarga verdad", en el Informe sobre la Democracia en España 2010. La erosión de la confianza y el bienestar. Contra la desafección ciudadana, Marcial Pons - Fundación Alternativas, Madrid, 2010, págs. 81 - 105, y en VILLORIA, M. y JIMÉNEZ, F., “¿Cuánta corrupción hay en España?. Los problemas metodológicos de la medición de corrupción", Revista de Estudios Políticos, núm. 156, abril - junio 2012, págs. 34 a 39.

${ }^{540}$ La Convención de las Naciones Unidas contra la Corrupción se aprobó en Mérida (México) en diciembre de 2003 y entró en vigor el 14 de diciembre de 2005. La UE y sus 28 Estados miembros son Partes en esta Convención, véase la Decisión 2008/801/CE del Consejo, de 25 de septiembre de 2008 (DOUE L 287, de 29 de octubre de 2008). El instrumento de ratificación, por parte de España, se encuentra 
Es por ello que el interés por medir y cuantificar los niveles de corrupción de un país adquiere una dimensión global que permite describir el fenómeno de manera más acotada y, por tanto, mucho más fácil de comparar y de aprehender de cara a instrumentalizar medidas eficaces y efectivas en su prevención y lucha. A nuestro entender, los índices que miden los niveles de corrupción pueden utilizarse para establecer prioridades políticas al posibilitar conocer dónde se producen las mayores fallas del sistema y, de hecho, por lo que a la contratación pública se refiere, es uno de los factores a tener en consideración para analizar su influencia en la consecución de una contratación pública transfronteriza, y ello aunque su contribución no parece resultar significativa a juzgar por las conclusiones presentadas en algún estudio ${ }^{541}$.

Basándonos en las percepciones sobre la corrupción, se han elaborado diferentes índices que nos acercan, si bien no a su dimensión real, incuantificable por la naturaleza clandestina del propio fenómeno, sí a su repercusión social. Uno de los instrumentos de medición más conocidos y consolidados es el Índice de Percepción de la Corrupción (IPC) que anualmente, y desde el año 1995, publica la ONG Transparencia Internacional. Este índice establece un ranking de países según el grado en el que se percibe la corrupción basándose en las opiniones de expertos y analistas del propio país recogidas a partir de encuestas. En el momento actual, el Índice clasifica a los países y territorios en una escala de 0 a 100, de tal manera que una calificación de 100 indica un país totalmente honesto, mientras que una clasificación de 0 revela que el país es percibido como altamente corrupto ${ }^{542}$.

publicado en el BOE núm. 171, de 19 de julio de 2006 y los últimos Estados en ratificarla han sido República Checa (29 de noviembre de 2013) y Alemania (12 de noviembre de 2014).

${ }^{541}$ Así se señala en el informe elaborado por MANAGEMENT RAMBØLL, Crossborder procurement above EU thresholds, Copenhague, 2011, págs. 13 y 76.

${ }^{542}$ Hay que indicar, sin embargo, que con anterioridad al año 2012 los valores oscilaban entre el 0 (percepción de altos niveles de corrupción) y el 10 (percepción de bajos niveles de corrupción). Las encuestas utilizadas para calcular el IPC se centran, por una parte, en las percepciones respecto del mal uso del poder público por parte de funcionarios y servidores públicos y, por otra, en la percepción sobre la eficacia de sistemas de control de la corrupción política y administrativa; así, contienen preguntas relacionadas, por ejemplo, con sobornos aceptados por funcionarios públicos en contrataciones públicas. 
Los resultados del IPC correspondientes a los Estados miembros durante el periodo 2012-2014 $4^{543}$ ponen de manifiesto que la corrupción es un problema que compromete a toda la Unión Europea. De los 28 Estados que en el momento actual conforman la UE, más de un 20 por ciento de ellos (de 5 a 8 dependiendo de los años) se sitúan por debajo de una puntuación óptima de 50, lo que supone un elevado porcentaje si consideramos que estamos hablando de Estados con un dilatado bagaje democrático. No obstante, estos resultados muestran ligeras mejorías en el último año e importantes diferencias entre países, pues aunque la corrupción parece perpetuarse en algunos Estados miembros como Grecia, Bulgaria, Italia o Rumanía hay que destacar que otros lideran la puntuación de este Índice, como es el caso de Dinamarca, Finlandia y Suecia ${ }^{544}$.

Otro de los instrumentos elaborados por Transparencia Internacional es el Índice de Fuentes de Soborno (IFS) que aborda el problema del soborno de funcionarios públicos durante el transcurso de actividades comerciales en el extranjero ${ }^{545}$. Las puntuaciones se obtienen a partir de las respuestas ofrecidas por ejecutivos de empresas internacionales a la pregunta de con qué frecuencia las compañías de un determinado país, con las cuales mantienen una relación comercial, participan en sobornos $(0=$ siempre, $10=$ nunca $)$.

Acerca de otros indicadores que también miden los niveles de corrupción, véase HELLER, N., "Definiendo y midiendo la corrupción. ¿De dónde venimos, dónde estamos ahora y qué importa para el futuro?", Revista del CLAD Reforma y Democracia, núm. 45, octubre 2009, págs. 5 - 30.

${ }^{543}$ Se ha elegido el año 2012 como el primero a analizar porque a partir de ese año se ha actualizado y modificado la metodología del IPC, por lo que los resultados obtenidos en años anteriores no resultan totalmente comparables y es esa la razón por la cual hemos descartado su análisis.

${ }^{544}$ Una valoración de estos datos la podemos encontrar en el documento $E U$ anticorruption reporting mechanism for periodic assessment of Member States ('EU Anti-Corruption Report'), SEC (2011) 661, de 6 de junio y en el Primer Informe sobre la lucha contra la corrupción de 2014, que incluye un capítulo dedicado a la corrupción en la contratación pública. El informe analiza la manera en que cada Estado miembro hace frente a la corrupción, examina cómo se aplican en la práctica las leyes y las políticas y ofrece sugerencias sobre la forma en que cada país puede mejorar sus actividades de lucha contra la corrupción, COM (2014) 38 final, de 3 de febrero de 2014.

${ }^{545}$ Los últimos datos correspondientes al año 2011 pueden consultarse en http://www.transparency.org/bpi2011 [Fecha de consulta: 20 de octubre de 2015]. 
Tabla 3: Puntuación del Índice de Percepción de la Corrupción en los Estados miembros (2012-2014)

\begin{tabular}{l|c|c|c}
\hline \multicolumn{1}{c|}{ Estado miembro } & $\mathbf{2 0 1 2}$ & $\mathbf{2 0 1 3}$ & $\mathbf{2 0 1 4}$ \\
\hline \hline Alemania & 79 & 78 & 79 \\
\hline Austria & 69 & 69 & 72 \\
\hline Bélgica & 75 & 75 & 76 \\
\hline Bulgaria & 41 & 41 & 43 \\
\hline Croacia & 46 & 48 & 48 \\
\hline Chipre & 66 & 63 & 63 \\
\hline Dinamarca & 90 & 91 & 92 \\
\hline Eslovaquia & 46 & 47 & 50 \\
\hline Eslovenia & 61 & 57 & 58 \\
\hline España & 65 & 59 & 60 \\
\hline Estonia & 64 & 68 & 69 \\
\hline Finlandia & 90 & 89 & 89 \\
\hline Francia & 71 & 71 & 69 \\
\hline Grecia & 36 & 40 & 43 \\
\hline Hungría & 55 & 54 & 54 \\
\hline Irlanda & 69 & 72 & 74 \\
\hline Italia & 42 & 43 & 43 \\
\hline Letonia & 49 & 53 & 55 \\
\hline Lituania & 54 & 57 & 58 \\
\hline Luxemburgo & 80 & 80 & 82 \\
\hline Malta & 57 & 56 & 55 \\
\hline Países Bajos & 84 & 83 & 83 \\
\hline Polonia & 58 & 60 & 61 \\
\hline Portugal & 63 & 62 & 63 \\
\hline Reino Unido & 44 & 76 & 78 \\
\hline República Checa & 88 & 48 & 51 \\
\hline Rumanía & & 89 & 43 \\
\hline Suecia & & & 87 \\
\hline & 49 & & \\
\hline
\end{tabular}

Fuente: Elaboración propia a partir de los datos publicados por Transparencia Internacional http://www.transparency.org/research/cpi/overview [Fecha de consulta: 20 de octubre de 2015]. 
Según los datos presentados en el año 2011, se percibe que se producen sobornos en mayor o menor medida en todos los sectores de actividad económica, si bien éstos resultan más frecuentes en relación con los contratos de obras públicas y construcción (public works contracts and construction). Este sector es considerado el más propenso a todos los tipos de soborno; es decir, sobornos pagados a funcionarios de bajo rango (corrupción menor), contribuciones indebidas a funcionarios públicos y políticos de alto nivel (corrupción a gran escala) y sobornos entregados a otras empresas del sector privado (corrupción entre particulares). Estos elocuentes datos se constatan a pesar de la existencia de varias convenciones internacionales que incluyen disposiciones contra el soborno transnacional, como es el caso de la Convención de la OCDE contra el Soborno de Funcionarios Públicos Extranjeros en Transacciones Comerciales Internacionales, que exige a cada uno de los 34 países miembros de la OCDE - además de Argentina, Brasil, Bulgaria, Rusia y Sudáfrica, que también han adoptado la Convención - tipificar penalmente el soborno transnacional ${ }^{546}$.

A estos elementos de análisis pueden añadirse otras herramientas de medición de la corrupción como son los Indicadores de Gobernanza Mundial del Instituto del Banco Mundial (Worldwide Governance Indicators, conocidos por sus siglas WGI) o, de carácter más general, como los Eurobarómetros que recogen información de la población sobre diversas cuestiones para la UE. Y es que, ante la imposibilidad de observar directamente la corrupción, se ha avanzado en el análisis y la cuantificación de otros mecanismos vinculados con la gobernanza en la idea de que un enfoque basado en sus distintos componentes podría aportar información de cuándo la corrupción es más o menos prevalente en un determinado país. Estos instrumentos atienden tanto a la existencia y calidad de las instituciones, normas y procedimientos ("inputs" de gobernanza o de medidas anti-corrupción), como a los resultados que éstas provocan ${ }^{547}$.

\footnotetext{
${ }^{546}$ Por razones lingüísticas, derivadas de los procesos de traducción, este Convenio experimenta distintas variaciones en su denominación dependiendo de la versión que utilicemos. Por lo que se refiere a nuestro país, y según su Instrumento de ratificación, se conoce como Convenio de lucha contra la corrupción de agentes públicos extranjeros en las transacciones comerciales internacionales (BOE núm. 46, de 22 de febrero de 2002).

${ }^{547}$ Véase HELLER, N., "Definiendo y midiendo (... )", op. cit., pág. 7. Los autores de ambos índices (IPC y WGI) argumentan que, en la medida que la corrupción no puede ser vista directamente ni observada empíricamente, lo único que se puede hacer
} 
Por lo que se refiere a los últimos Eurobarómetros que muestran la opinión de los europeos acerca del fenómeno de la corrupción - Attitudes of Europeans towards Corruption (2011, 2009 y 2007) ${ }^{548}$ - y en el Flash Eurobarómetro número 374 Businesses' attitudes towards corruption in the EU (febrero 2014) - sus datos nos confirman: (i) que la corrupción en los Estados miembros se percibe con gran preocupación, (ii) que la corrupción es un problema importante en la mayor parte de los Estados miembros ${ }^{549}$ y, quizá uno de los datos más preocupantes, (iii) que dos de cada tres encuestados considera que la corrupción es inevitable y que forma parte de la cultura empresarial de su país.

Por lo que a esta memoria doctoral interesa, un significativo porcentaje de los encuestados relaciona directamente corrupción con contratación pública, ya que la corrupción en la contratación pública se percibe muy extendida en los procesos de adjudicación gestionados tanto por las autoridades regionales o locales ( $60 \%$ en la media europea) como por las autoridades nacionales ( $56 \%$ en la media europea $)^{550}$. Tampoco la inclinación de los sujetos responsables de la adjudicación de contratos públicos a dejarse seducir por actuaciones contrarias a los principios de objetividad e imparcialidad no pasa desapercibida en estos

son observaciones indirectas que, al agregarlas, puedan sugerir valores respecto de las variables deseadas. Sobre estos índices de medición de la corrupción, VILLORIA, M. y JIMÉNEZ, F., “¿Cuánta corrupción (... )”, op. cit., págs. 26 a 33. En este sentido, KAUFMANN, D., KRAAY, A. y MASTRUZZI, M., "The Worldwide Governance Indicators: A Summary of Methodology, Data and Analytical Issues", World Bank Policy Research, Working Paper núm. 5430, 2010.

${ }^{548}$ Los Eurobarómetros a los que nos estamos refiriendo son el Eurobarómetro especial núm. 374 publicado en febrero 2012 con datos de septiembre de 2011; el Eurobarómetro especial núm. 325, cuyo trabajo de campo se llevó a cabo entre septiembre y octubre de 2009 y que fue publicado en noviembre 2009 y el Eurobarómetro especial núm. 291, cuyo trabajo de campo se realizó entre noviembre y diciembre 2007 y se publicó en abril de 2008.

http://ec.europa.eu/public_opinion/archives/ebs/ebs_325_en.pdf http://ec.europa.eu/public_opinion/archives/ebs/ebs_291_en.pdf http://ec.europa.eu/public_opinion/archives/ebs/ebs_374_en.pdf

${ }^{549}$ En el caso de Grecia, Rumanía, Bulgaria, la República Checa, Chipre, Hungría y Portugal el porcentaje de respuestas que manifiestan que la corrupción es un grave problema en su país supera el $90 \%$ en todos los Eurobarómetros referenciados.

${ }^{550}$ Son datos extraídos del Flash Eurobarómetro número 374 Businesses' attitudes towards corruption in the EU (febrero 2014) http://ec.europa.eu/public_opinion/flash/fl_374_en.pdf [Fecha de consulta: 20 de octubre de 2015]. 
estudios. De hecho, según los porcentajes arrojados por estos Eurobarómetros citados, a la pregunta: "En su país, ¿cree usted que la entrega y aceptación de sobornos o el abuso de posiciones de poder para beneficio personal están ampliamente extendidos entre las siguientes actividades?", casi la mitad de los europeos encuestados considera que la corrupción se encuentra extendida entre los funcionarios y los agentes encargados de la adjudicación de contratos públicos (Officials awarding public tenders) [Tabla 4] $]^{551}$.

Estos datos confirman la creencia de la población europea con respecto a que la contratación pública genera los máximos incentivos para los comportamientos corruptos ${ }^{552}$. Asimismo, y a juzgar por los datos ofrecidos por la OCDE, parece un hecho constatable que el empleo de sobornos es más frecuente en la adjudicación de contratos públicos que en otras actividades como son las relacionadas con la fiscalidad o el poder judicial ${ }^{553}$.

\footnotetext{
${ }^{551}$ No existen datos de Croacia, puesto que su incorporación la Unión Europea tuvo lugar en el año 2013

${ }^{552}$ Porcentajes similares aparecen también recogidos en el Especial Eurobarómetro núm. 245 Opinions on organised, cross-border crime and corruption, publicado en marzo de 2006, págs. 16 y 18, en el cual uno de cada dos ciudadanos encuestados (50\%) manifestaban que los funcionarios con competencias en la adjudicación de contratos públicos probablemente fueran corruptos.

${ }^{553}$ Se trata del estudio Foreign Bribery Report. An Analysis of the Crime of Bribery of Foreign Public Officials, OECD Publishing, Paris, 2014, pág. 35 que revela que en el $57 \%$ de los casos examinados el pago de dádivas tenía el objetivo de obtener contratos públicos. En este mismo sentido puede consultarse el gráfico "Frecuencia de los sobornos en el ámbito de la contratación" publicado en el estudio de la OCDE Integrity in Public Procurement: Good Practice from A to $Z$ (...) op. cit., realizado por Daniel KAUFMANN del Banco Mundial (pág. 9).
} 
Tabla 4: Porcentaje de ciudadanos europeos que opinan que los funcionarios con competencia en procedimientos de contratación pública probablemente sean corruptos

\begin{tabular}{|c|c|c|c|}
\hline Estado miembro & $\begin{array}{c}\text { Eurobarómetro } \\
2011\end{array}$ & $\begin{array}{c}\text { Eurobarómetro } \\
2009\end{array}$ & $\begin{array}{c}\text { Eurobarómetro } \\
2007\end{array}$ \\
\hline Alemania & $\overline{47 \%}$ & $60 \%$ & $54 \%$ \\
\hline Austria & $54 \%$ & $47 \%$ & $39 \%$ \\
\hline Bélgica & $52 \%$ & $57 \%$ & $49 \%$ \\
\hline Bulgaria & $57 \%$ & $64 \%$ & $34 \%$ \\
\hline Chipre & $71 \%$ & $76 \%$ & $60 \%$ \\
\hline Dinamarca & $25 \%$ & $27 \%$ & $24 \%$ \\
\hline Eslovaquia & $50 \%$ & $46 \%$ & $42 \%$ \\
\hline Eslovenia & $68 \%$ & $66 \%$ & $53 \%$ \\
\hline España & $47 \%$ & $45 \%$ & $20 \%$ \\
\hline Estonia & $52 \%$ & $55 \%$ & $40 \%$ \\
\hline Finlandia & $35 \%$ & $41 \%$ & $29 \%$ \\
\hline Francia & $50 \%$ & $56 \%$ & $49 \%$ \\
\hline Grecia & $62 \%$ & $55 \%$ & $53 \%$ \\
\hline Hungría & $49 \%$ & $56 \%$ & $48 \%$ \\
\hline Irlanda & $47 \%$ & $49 \%$ & $31 \%$ \\
\hline Italia & $59 \%$ & $56 \%$ & $48 \%$ \\
\hline Letonia & $57 \%$ & $54 \%$ & $40 \%$ \\
\hline Lituania & $52 \%$ & $55 \%$ & $34 \%$ \\
\hline Luxemburgo & $32 \%$ & $31 \%$ & $42 \%$ \\
\hline Malta & $53 \%$ & $61 \%$ & $42 \%$ \\
\hline Países Bajos & $46 \%$ & $56 \%$ & $47 \%$ \\
\hline Polonia & $36 \%$ & $42 \%$ & $40 \%$ \\
\hline Portugal & $39 \%$ & $49 \%$ & $39 \%$ \\
\hline Reino Unido & $33 \%$ & $38 \%$ & $28 \%$ \\
\hline República Checa & $66 \%$ & $74 \%$ & $66 \%$ \\
\hline Rumanía & $43 \%$ & $46 \%$ & $51 \%$ \\
\hline Suecia & $51 \%$ & $45 \%$ & $40 \%$ \\
\hline UE 27 & $47 \%$ & $52 \%$ & $43 \%$ \\
\hline
\end{tabular}

Fuente: Elaboración propia a partir de las respuestas positivas a la pregunta "In (OUR COUNTRY), do you think that the giving and taking of bribes, and the abuse of positions of power for personal gain, are widespread among any of the following?", con múltiples respuestas posibles: People working in the police service, the people working in the customs service, the people working in the judicial services, Politicians at national level, Politicians at regional level, Politicians at local level, Officials awarding public tenders, Officials issuing buildings permits, People working in the public health sector, People working in the public education sector, Inspectors (health, construction, food quality, sanitary control and licensing). 
Un análisis apresurado de todos estos datos nos llevaría a una doble conclusión: de una parte, a defender que la corrupción se manifiesta claramente en el sector de la contratación pública en Europa y, de otra, que se ha fracasado en el desafío que supone la expansión de la delincuencia con una dimensión transnacional en un espacio sin fronteras como es el europeo. Sin embargo, e independientemente de la incuestionable importancia de los datos que se recogen en estos estudios, no debemos olvidar que tales resultados están condicionados por una pluralidad de factores, especialmente por las informaciones de que se hacen eco los medios de comunicación al destapar casos de corrupción y que puede alterar de manera sustancial la percepción ciudadana sobre este fenómeno de un año a otro, sin que, en realidad, quede probada la existencia de un mayor nivel de corrupción ${ }^{554}$.

Lo que en cualquier caso se pone de manifiesto - y es lo que queremos manifestar - es la preocupación de los ciudadanos europeos ante los distintos casos de corrupción, crimen organizado y fraude que han aparecido vinculados a la adjudicación de contratos públicos ${ }^{555}$. Todos estos acontecimientos,

\footnotetext{
${ }^{554}$ Uno de los ejemplos más significativo de lo expuesto lo encontramos en España y los resultados de los barómetros del Centro de Investigaciones Sociológicas (CIS) de estos últimos años. En estos barómetros, y después de destaparse algunos de los más conocidos casos de corrupción en nuestro país (Caso Gürtel - Caso Palma Arena Brugal - Pokemón - Púnica - Enredadera), la corrupción y el fraude aparecen en un lugar destacado entre los problemas considerados más importantes por los españoles solo por detrás de los relacionados con los problemas económicos y el desempleo.

Como expone VILLORIA MENDIETA, desde marzo de 1996 no había existido un porcentaje tan elevado de personas que citaran el fraude y la corrupción entre los tres problemas más importantes del país. VILLORIA MENDIETA, M., "La ética pública y los códigos de conducta administrativos vs. Corrupción y escándalos políticos", en la obra colectiva El derecho a una buena administración y la ética pública, Tirant lo Blanch - Fundación General de la Universidad de Málaga, Valencia, 2011, pág. 186; y en VILLORIA, M. y JIMÉNEZ, F., “¿Cuánta corrupción hay en España (...)”, op. cit., págs. 33 a 35. De hecho, durante más de 13 años, no habían sido citados por más del $3 \%$ de los encuestados; sin embargo, en noviembre de 2009 ya se llegó al 10,4\% de respuestas que incluían este ítem, en marzo de 2013 al 44,5\%, en diciembre de 2014 al $60 \%$ y en julio de 2015 al $43,7 \%$.

${ }^{555}$ Además de en los Eurobarómetros anteriormente citados, la vinculación entre corrupción y crimen organizado aparece recogida en distintos documentos de la UE entre los que cabe citarse, a título de ejemplo, el Plan de Acción de Viena (diciembre 1998) - Plan de acción del Consejo y de la Comisión sobre la mejor manera de aplicar las disposiciones del Tratado de Ámsterdam relativas a la creación de un espacio de
} 
susceptibles de encajar en alguna de las categorías tipificadas como delito en cualquier Código penal (prevaricación, revelación de secretos, aprovechamiento de secreto o información privilegiada, cohecho, tráfico de influencias, fraudes y exacciones ilegales, negociaciones prohibidas a funcionarios públicos o delito de corrupción en las transacciones comerciales internacionales) confirman, de una parte, que la globalización en los intercambios económicos favorece la transmisión de los modelos corruptos y, asimismo, que las técnicas para corromper se proyectan más allá de las fronteras nacionales ${ }^{556}$.

Es necesario, por tanto, articular mecanismos de cooperación para poner freno a estos fenómenos e intensificar la coordinación entre los Estados

libertad, seguridad y justicia - donde se incluía a la corrupción como uno de las conductas delictivas en el ámbito de la delincuencia organizada (DOCE C 19, de 23 de enero de 1999) y el Documento de trabajo de la Comisión An examination of the links between organised crime and corruption, SEC (2008) 196, de 8 de febrero de 2008.

En el ámbito doctrinal, la estrecha relación que existe entre blanqueo de capitales - como una de las modalidades de delito económico -, corrupción y crimen organizado ha sido puesta de manifiesto, entre otros, por CACIAGLI, M., Clientelismo, corrupción y criminalidad organizada. Evidencias empíricas y propuestas teóricas a partir de los casos italianos, Centro de Estudios Constitucionales, Madrid, 1996 y FERRÉ OLIVÉ, J., "Corrupción, crimen organizado y blanqueo de capitales en el mercado financiero", en el vol. 2 de la obra colectiva Blanqueo de dinero y corrupción en el sistema bancario de la obra Delitos financieros, fraude y corrupción en Europa, Servicio de publicaciones de la Universidad de Salamanca, Salamanca, 2002, págs. 16 y ss. En 2003, BUSCAGLIA y VAN DIJK confirmaron el vínculo entre el crecimiento de la delincuencia organizada y la corrupción del sector público mediante el análisis cualitativo y cuantitativo en una gran muestra de países con el fin de aislar los factores determinantes y los vínculos entre ambos fenómenos delictivos, en BUSCAGLIA, E. y VAN DIJK, J., "Controlling organized crime and corruption in the public sector", Forum on Crime and Society, vol. 3 (1 y 2) December 2003, págs. $3-34$.

${ }^{556}$ Entre los ejemplos que ilustran los casos más sonados de corrupción en relación con la contratación pública, caben citarse algunos de los recogidos en JAREÑO LEAL, A., (Dir.), Corrupción pública: Cuestiones de Política Criminal (I) y (II), Iustel, Madrid, 2014; SØREIDE, T., Risks of Corruption and Collusion in the Awarding of Concession Contracts, European Parliament's Committee on Internal Market and Consumer Protection, Bruselas, 2012; BENITO SÁNCHEZ, D., El delito de corrupción en las transacciones comerciales internacionales, Iustel, Madrid, 2012; MEDINA ARNÁIZ, T., "Las respuestas normativas al fenómeno de la corrupción (... )", op. cit.,. págs. 2 y 3, y en EIGEN, P., Las redes de la corrupción (...), op. cit., 2004. 
miembros en el marco de la Convención de las Naciones Unidas contra la Corrupción, del Grupo de Estados contra la Corrupción del Consejo de Europa (GRECO $)^{557}$ y de las labores de la OCDE en materia de lucha contra la corrupción $^{558}$.

${ }^{557}$ El GRECO es el mecanismo de control de las medidas de lucha contra la corrupción más completo de los existentes a escala europea, en el que participan todos los Estados miembros de la UE. En la actualidad cuenta con un total de 49 miembros (48 Estados europeos y los Estados Unidos de América). El Acuerdo por el que se estableció GRECO fue aprobado por el Comité de Ministros del Consejo de Europa el 1 de mayo de 1999 [Resolución 99 (5)] con el propósito de "mejorar la capacidad de sus miembros para luchar contra la corrupción, velando por el cumplimiento de los compromisos adquiridos en la materia, a través de un procedimiento dinámico de evaluación y de presión mutua" (artículo 1). Véase el Informe de la Comisión al Consejo sobre las modalidades de participación de la Unión Europea en el Grupo de Estados contra la Corrupción (GRECO), COM (2011) 307 final, de 6 de junio de 2011.

${ }^{558}$ En este sentido es importante tener en cuenta alguno de los principales instrumentos jurídicos internacionales en la lucha contra la corrupción: los Veinte principios rectores de la lucha contra la corrupción, aprobados por la Resolución (97) 24, del Comité de Ministros del Consejo de Europa; la Convención de las Naciones Unidas contra la Corrupción, adoptada por la Asamblea General de las Naciones Unidas por Resolución 58/4, del 31 de octubre de 2003; el Convenio relativo a la lucha contra la corrupción en la que estén implicados funcionarios de las Comunidades Europeas o funcionarios de los Estados miembros de la Unión Europea, firmado en Bruselas el 26 de mayo de 1997 y que entró en vigor el 28 de septiembre de 2005 (DOCE C 195, de 25 de junio de 1997); el Convenio de la OCDE de lucha contra la corrupción de agentes públicos extranjeros en las transacciones comerciales internacionales, firmado en Paris el 17 de diciembre de 1997; el Convenio penal sobre la corrupción (Convenio núm. 173 del Consejo de Europa), hecho en Estrasburgo, el 27 de enero de 1999, que entró en vigor de forma general el 1 de julio de 2002 y para España el 1 de agosto de 2010 después de su ratificación publicada en el BOE núm. 182, de 28 de julio de 2010 y, por último, el Convenio civil sobre la corrupción (Convenio núm. 174 del Consejo de Europa), hecho en Estrasburgo, el 4 de noviembre de 1999, que entró en vigor de forma general el 1 de noviembre de 2003 y para España el 1 de abril de 2010 después de su ratificación publicada en el BOE núm. 78, de 31 de marzo de 2010. 


\section{La política de la Unión Europea contra la corrupción y otras formas graves de delin- cuencia}

El desvanecimiento de los límites geográficos a raíz de la supresión de las fronteras entre los Estados miembros de la UE supuso la consolidación de un espacio único. Este espacio común permite, como ya hemos señalado con anterioridad, la realización efectiva de las libertades fundamentales en todo el territorio de la UE: libre circulación de personas, de mercancías, de capitales y libertad de establecimiento y de prestación de servicios; sin embargo, este espacio sin fronteras interiores a la vez que favorece la integración económica entre los Estados miembros, también facilita la movilidad de los delincuentes que se aprovechan de la permeabilidad de las fronteras en el espacio Schengen.

La consideración de la delincuencia económica como un fenómeno de dimensiones transfronterizas supuso para las instituciones europeas cambios significativos en los medios para combatirla. De las declaraciones programáticas de los primeros años se pasó a un modelo de lucha más activo y así, junto a las actuaciones propias de cada Estado, han proliferado las iniciativas para desarrollar una Estrategia europea de seguridad global en un espacio de libertad, seguridad y justicia (ELSJ) ${ }^{559}$, incluso con órganos creados al efecto como es el caso de la Oficina Europea de Lucha contra el Fraude (OLAF) ${ }^{560}$;

${ }^{559}$ Tradicionalmente, la lucha contra cualquier tipo de delincuencia correspondía a cada Estado siendo éste el único actor con competencia para implementar las medidas necesarias para su neutralización. El concepto de «Espacio de libertad, seguridad y justicia» aparece recogido por primera vez en el Tratado de Ámsterdam, firmado el 2 de octubre de 1997 y en vigor desde el 1 de mayo de 1999, como consecuencia del funcionamiento de un espacio europeo sin fronteras interiores y el surgimiento de determinadas formas de delincuencia con una dimensión transnacional. Todo ello llevó a la necesidad de articular mecanismos de ámbito europeo destinados a facilitar, intensificar y mejorar la cooperación policial y judicial en materia penal entre los diferentes Estados miembros a fin de garantizar la libertad, la seguridad y la justicia a los ciudadanos de la Unión.

${ }^{560} \mathrm{La}$ OLAF fue creada por la Comisión Europea en 1999 por Decisión 1999/352/CE, CECA, Euratom, de 28 de abril, con la misión de proteger los intereses financieros de la UE, combatir el fraude, la corrupción y cualquier otra actividad irregular, incluidas las que puedan sucederse dentro de las instituciones europeas (DOCE L 136, de 31 de mayo de 1999). En el momento actual, existe una pro- 
las Unidades de Información Financiera (UIF) de los Estados miembros ${ }^{561}$; la creación de una Fiscalía Europea, en colaboración con Europol, para combatir las infracciones que afecten a los intereses financieros de la Unión, tal como establece el artículo 86.1 del TFUE ${ }^{562}$, y la constitución, en el seno del Parlamento Europeo, de una Comisión Especial sobre la Delincuencia Organizada, la Corrupción y el Blanqueo de Dinero con la finalidad de analizar y evaluar la magnitud de la delincuencia organizada, la corrupción y el blanqueo de dinero y su impacto en la Unión y en los Estados miembros ${ }^{563}$.

Y si bien una de las mejores maneras de reducir la cifra de delitos consiste en adoptar medidas directas, de naturaleza coercitiva, que impidan que éstos

puesta de la Comisión para modificar su marco jurídico al objeto de aumentar la eficacia y rapidez de sus investigaciones, reforzar las garantías procesales, reforzar su cooperación con los Estados miembros y mejorar su gobernanza preservando su independencia como órgano investigador, COM (2011) 135 final, de 17 de marzo de 2011.

${ }^{561}$ Estas Unidades - que en la versión en lengua inglesa se conocen como Unidades de Inteligencia Financiera (Financial Intelligence Units) y así se las denomina también en distintos documentos de la UE - han sido creadas por la Decisión 2000/642/JAI, de 17 de octubre de 2000, para recabar y analizar la información financiera a efectos de la lucha contra el blanqueo de capitales y la financiación del terrorismo (DOCE L 271, de 24 de octubre de 2000).

${ }^{562} \mathrm{El}$ artículo 86.1 TFUE señala que "Para combatir las infracciones que perjudiquen a los intereses financieros de la Unión, el Consejo podrá crear, mediante reglamentos adoptados con arreglo a un procedimiento legislativo especial, una Fiscalía Europea a partir de Eurojust". En este sentido, debe recordarse que mediante la Decisión 2002/187/JAI del Consejo, de 28 de febrero de 2002, se crea Eurojust para reforzar la lucha contra las formas graves de delincuencia (DOCE L 63, de 6 de marzo de 2002) y que la Oficina Europea de Policía (Europol) tiene por objetivo ayudar a los Estados miembros a prevenir y combatir la delincuencia organizada, el terrorismo y otras formas de delincuencia grave que afecten a dos o más Estados miembros, según recoge la Decisión 2009/371/JAI del Consejo, de 6 de abril de 2009 (DOUE L 121, de 15 de mayo de 2009, pág. 37).

A este respecto, resulta de interés ORDÓÑEZ SOLÍS, D., "La lucha europea contra el fraude en la gestión de fondos y contra la corrupción en la contratación pública", Gaceta Jurídica de la Unión Europea y de la Competencia, núm. 16, julio - agosto 2010, págs. 12 a 16.

${ }^{563}$ Decisión del Parlamento Europeo, de 14 de marzo de 2012, sobre la constitución, el establecimiento de las competencias, la composición numérica y la duración del mandato de la Comisión Especial sobre la Delincuencia Organizada, la Corrupción y el Blanqueo de Dinero, P7_TA(2012)0078. 
se perpetren, una estrategia ambiciosa en la lucha contra ciertos tipos de delincuencia transfronteriza requiere de un enfoque pluridisciplinar que precisa integrar las medidas destinadas principalmente a prevenir y controlar dicha delincuencia con otras políticas de la Unión a fin mantener la necesaria coherencia entre todas ellas.

Así, junto a acciones de carácter represivo, resulta de crucial importancia establecer medidas en distintos sectores de actividad pública que incorporen a esta lucha un efecto disuasorio y que puedan contribuir también a reducir las oportunidades para que se lleven a cabo estas conductas delictivas. Se trata, en definitiva, de formular un planteamiento de lucha transversal y aprovechar las sinergias entre todas las políticas de la Unión para combatir el incentivo que supone la comisión de estos delitos ${ }^{564}$.

En este sentido, desde que 1999 se creara el ELSJ, el Consejo ha aprobado tres programas quinquenales cuya finalidad ha sido - y aún lo es - ofrecer a los ciudadanos un alto grado de seguridad mediante la prevención y lucha contra la delincuencia en un espacio sin fronteras interiores: el Programa de

${ }^{564}$ El Parlamento Europeo, en su Resolución de 15 de diciembre de 1995, sobre la lucha contra la corrupción en Europa, A4-0314/95 (Ponente: H. SALISCH), instó a la Comisión a que emprendiera acciones en una amplia variedad de sectores para luchar contra la corrupción. Así, pedía expresamente a la Comisión y a los Estados miembros que tomaran medidas "con vistas a excluir de la participación en las licitaciones y del derecho a cualquier forma de subvención, durante un período determinado, a los agentes del mercado corruptos" (DOCE C 17, de 22 de enero de 1996, pág. 443). La Comisión respondió a esta petición con la Comunicación Una política de la Unión en materia de lucha contra la corrupción que señalaba determinadas áreas de riesgo en las que se hacía necesario un enfoque común de cara a la aplicación de medidas anticorrupción. Entre estas medidas, como ya hemos señalado con anterioridad, se encontraba el establecimiento de «listas negras» de licitadores condenados por corrupción y un mayor control sobre los procedimientos de contratación pública, COM (1997) 192 final, de 21 de mayo de 1997. Con posterioridad, en la Estrategia del Milenio sobre la prevención y el control de la delincuencia organizada (2000), el Consejo invitaba a los Estados miembros y a la Comisión a garantizar que la legislación aplicable estableciera que las personas que hubieran perpetrado delitos relacionados con la delincuencia organizada quedasen excluidas de la participación en procedimientos de licitación organizados por los Estados miembros y la Comunidad y que no pudiesen obtener subvenciones, ni licencias de la Administración (DOCE C 124, de 3 de mayo de 2000, pág. 6). 
Tampere (1999-2004) $)^{565}$, el Programa de La Haya (2004-2009) ${ }^{566}$ y el Programa de Estocolmo (2010-2014) ${ }^{567}$ puesto en práctica con arreglo al nuevo marco jurídico definido tras el Tratado de Lisboa y, en especial, sus disposiciones relativas al espacio de libertad, seguridad y justicia (artículos 67 y siguientes del TFUE $)^{568}$.

Entre las prioridades políticas que presenta este último Programa se encuentra la de elaborar una Estrategia de Seguridad Interior a fin de hacer

${ }^{565}$ El Programa de Tampere, de acuerdo con las conclusiones del Consejo Europeo de Tampere, de 15 y 16 de octubre de 1999, abarcaba determinados aspectos del Derecho penal y civil. La Comisión evaluó sus resultados en su Comunicación Espacio de Libertad, Seguridad y Justicia: balance del programa de Tampere y futuras orientaciones, COM (2004) 401 final, de 2 de junio de 2004.

${ }^{566}$ El Programa de La Haya, adoptado por el Consejo Europeo de 4 y 5 de noviembre de 2004, se recoge en el Programa de La Haya: consolidación de la libertad, la seguridad y la justicia en la Unión Europea (DOUE C 53, de 3 de marzo de 2005) y en el Plan de acción para ejecutar dicho Programa adoptado conjuntamente por la Comisión y el Consejo (DOUE C 198, de 12 de agosto de 2005). Durante este periodo se aprobó el Programa «Prevención y lucha contra la delincuencia», integrado en el Programa marco «Seguridad y defensa de las libertades (2007-2013)», que se refiere a la prevención y lucha contra la delincuencia, organizada o no, y en particular al terrorismo, la trata de seres humanos y los delitos contra la infancia, el tráfico ilícito de armas, la corrupción y el fraude. Véase la Decisión del Consejo 2007/125/JAI, de 12 de febrero de 2007 (DOUE L 58, de 24 de febrero de 2007.

${ }^{567}$ El Programa de Estocolmo fue adoptado por el Consejo Europeo celebrado los días 10 y 11 de diciembre de 2009, Programa de Estocolmo - Una Europa abierta y segura que sirva y proteja al ciudadano (DOUE C 115, de 4 de mayo de 2010). El Plan de acción por el que se aplica este Programa y se esbozan a grandes rasgos las acciones futuras de la UE se encuentran recogido en la Comunicación Garantizar el espacio de libertad, seguridad y justicia para los ciudadanos europeos COM (2010) 171 final, de 20 de abril de 2010.

${ }^{568} \mathrm{El}$ artículo 67 TFUE (antiguo artículo 29 TUE) después de reconocer que la Unión constituye un espacio de libertad, seguridad y justicia, señala que la Unión se esforzará por garantizar un nivel elevado de seguridad mediante medidas de prevención de la delincuencia. También hay que tener presente el nuevo marco jurídico para la protección de los derechos humanos y la consolidación de la ciudadanía de la Unión, los artículos 2, 6 y 7 del TUE en su versión modificada, el Protocolo núm. 8 del TFUE, relativo a la adhesión de la Unión al Convenio Europeo para la Protección de los Derechos Humanos y de las Libertades Fundamentales (CEDH) y la Carta de los Derechos Fundamentales de la Unión Europea, que tiene el mismo valor jurídico que los Tratados. 
frente a la delincuencia organizada, al terrorismo y demás amenazas transnacionales en la seguridad de los ciudadanos de la Unión, centrada en la ejecución y su integración en distintas políticas (apartado 4.4 del Programa de Estocolmo dentro de la prioridad Una Europa que protege). Respecto de la delincuencia económica y la corrupción, la Comunicación La Estrategia de Seguridad Interior de la UE en acción (2010) señalaba que, desde un enfoque administrativo, debieran desarrollarse políticas "por las que los órganos administrativos y reguladores responsables de la concesión de licencias, autorizaciones, contratos públicos y subvenciones se comprometan a proteger la economía contra la infiltración de las redes delictivas" 569 .

En consecuencia, la UE ha desarrollado un enfoque que combina instrumentos a distinto nivel administrativo para evitar la infiltración de la delincuencia organizada en el sector público o en la economía ${ }^{570}$. Los mecanismos que se establecen para hacer frente al flagelo de la corrupción y el fraude en la contratación pública se basan en dos tipos de medidas. Las primeras son de carácter general y se consideran esenciales por cuanto intentan reducir las oportunidades para que se produzca el hecho delictivo en lugar de actuar a resultas de su concurrencia. Estas medidas se basan principalmente, en una normativa contractual presidida por los principios de integridad, transparencia e igualdad de $\operatorname{trato}^{571}$.

${ }^{569}$ La Estrategia de Seguridad Interior de la UE en acción: cinco medidas para una Europa más segura, COM (2010) 673 final, de 22 de noviembre de 2010, pág. 6. Las conclusiones sobre la Estrategia de Seguridad Interior de la Unión Europea, COM (2014) 154 final, de 11 de marzo de 2014.

${ }^{570}$ La Comunicación de la Comisión Agenda Europea de Seguridad trata alguno de estos instrumentos, COM (2015) 185 final, de 28 de abril de 2015.

${ }^{571}$ En la Resolución del Consejo de la UE, de 21 de diciembre de 1998, sobre prevención de la delincuencia organizada y adopción de una estrategia global para combatirla, ya se subrayaba la idea de que la transparencia y el control en la atribución de contratos públicos constituía un elemento esencial para la prevención de la corrupción y la delincuencia organizada (DOCE C 408, de 29 de diciembre). Igualmente, en la Comunicación de la Comisión Desarrollo de un concepto estratégico para hacer frente a la delincuencia organizada se manifestaba que el desarrollo y la aplicación de una política anticorrupción global de la UE debía incluir la promoción de los principios éticos y de integridad en la Administración pública, COM (2005) 232 final, de 2 de junio de 2005 , pág. 5 . 
De esta manera - y tal como ya hemos señalado - un marco jurídico que contemple procedimientos de adjudicación basados en los principios de publicidad y concurrencia, que verifique el cumplimiento de la legalidad en todas las fases contractuales, que promueva la imparcialidad de las autoridades que intervienen en los procedimientos de adjudicación y, finalmente, que posibilite el control ulterior de las adjudicaciones mediante la instauración de un sistema eficaz de recursos, contribuye a cerrar espacios a las prácticas corruptas, ya que todas estas medidas suponen un obstáculo para la corrupción, el fraude y otras formas de uso ilícito de los recursos públicos ${ }^{572}$.

Ésta es la idea que subyace en las Directivas sobre contratación pública y también en el artículo 9.1 de la Convención de las Naciones Unidas contra la Corrupción al requerir a cada Estado parte adoptar "las medidas necesarias para establecer sistemas apropiados de contratación pública, basados en la transparencia, la competencia y criterios objetivos de adopción de decisiones, que sean eficaces, entre otras cosas, para prevenir la corrupción".

Además de estas medidas generales, la normativa contractual europea contempla, asimismo, un instrumento específico para combatir ciertas formas de delincuencia. Tal y como venimos adelantando desde el principio de esta memoria doctoral, a partir del año 2004, las Directivas sobre contratación pública imponen a los Estados miembros establecer salvaguardias frente a la adjudicación de contratos públicos a aquellos operadores económicos que hayan pertenecido a una organización delictiva o que hayan sido declarados culpables en sentencia judicial firme por corrupción, blanqueo de capitales o por fraude en detrimento

${ }^{572}$ Véase a este respecto, MORENO MOLINA, J. A., Los principios generales de la contratación (...), op. cit., págs. 44 a 46. Sobre los mecanismos de control, SÁNCHEZ MORÓN, M., "La corrupción y los problemas del control de las Administraciones públicas", en la obra colectiva La corrupción política, Alianza Editorial, Madrid, 1997, págs. 189-210 y NEVADO-BATALLA MORENO, P. T., "Cumplimiento de la legalidad en la nueva cultura de gestión pública: propuestas y realidades en la lucha contra la corrupción", en la obra colectiva La corrupción en un mundo globalizado: análisis interdisciplinar, Ratio Legis, Salamanca, 2004, págs. 87107. Asimismo, ARROWSMITH, S., LINARELLI, J. y WALLACE, D., Regulating Public Procurement: National (...), op. cit., págs. 38 a 40, se refieren a las medidas para combatir la corrupción en la adjudicación de contratos públicos - transparencia, normas sobre conflicto de intereses y privaciones de derechos (exclusion debarment) - aun cuando manifiestan expresamente que la completa eliminación de la corrupción es probablemente imposible. 
de los intereses financieros de la UE, ya que los licitadores o candidatos incursos en alguna de estas circunstancias quedarán excluidos de la participación en un contrato público (Prohibiciones de carácter obligatorio recogidas en el artículo 45.1 de la Directiva 2004/18/CE y en los vigentes artículos 57 de la Directiva 2014/24 UE y artículo 38.4 de la Directiva 2014/23/UE). Por otra parte, no debemos olvidar que con anterioridad al año 2004 ya se contemplaba, y aún se contempla, la posibilidad de excluir de la adjudicación de un contrato a cualquier operador económico que hubiera cometido de una falta grave en materia profesional (Prohibiciones de carácter facultativo) ${ }^{573}$. Se puede hablar entonces de la utilización de la contratación pública como soporte a los objetivos políticos de la UE a fin de aumentar la eficacia de las medidas adoptadas en el ámbito del espacio de libertad, seguridad y justicia ${ }^{574}$.

Desde esta perspectiva, las prohibiciones de contratar de carácter obligatorio vinculadas a una condena penal podrían desempeñar un importante papel para reforzar una estrategia global y coordinada contra la delincuencia organizada, el fraude, la corrupción y otros delitos graves que representan un riesgo importante, tanto para la seguridad de los ciudadanos, como para los intereses financieros de la UE. Se calcula que la corrupción tiene un coste anual de 120.000 millones de euros para la economía de la Unión (un 1\% PIB de la $\mathrm{UE})^{575}$, que los presuntos fraudes financieros ascienden a unos 538 millones de

${ }^{573}$ Véase, PISELLI, E., "The scope for excluding providers who have committed criminal offences (...)", op. cit., págs. 267 - 286 y MEDINA ARNÁIZ, T., "EU Directives as an Anticorruption Measures (...)", op. cit., pág. 113. También WILLIAMS, S., "The mandatory exclusions (... )", op. cit., pág. 721 y en "Coordinating public procurement to support (...)", op. cit., pág. 481.

${ }^{574}$ Durante el año 2011, la Comisión ha incidido en aquellas medidas que impiden que los delincuentes se aprovechen del sistema económico de la UE, de tal manera que se han elaborado distintas Comunicaciones que han tenido por objeto la protección de los intereses financieros de la Unión Europea a través del Derecho penal y de las investigaciones administrativas, Una politica para salvaguardar el dinero de los contribuyentes, COM (2011) 293 final, de 26 de mayo de 2011; Una política global contra la corrupción, COM (2011) 308 final, de 6 de junio y la adopción de una Estrategia de lucha contra el fraude, COM (2011) 376 final, de 24 de junio de 2011. En el año 2012, destacamos la Propuesta de Directiva sobre la lucha contra el fraude que afecta a los intereses financieros de la Unión a través del Derecho penal, COM (2012) 363 final, de 11 de julio de 2012.

${ }^{575}$ Estos datos se encuentran recogidos en el Informe Anticorrupción de la UE 2014, 
euros al año en concepto de ingresos y gastos ${ }^{576}$, y que el volumen de negocios de las organizaciones criminales de carácter mafioso que actúan en Europa se estiman, a la baja, en torno a 135.000 millones de euros, siendo ésta una cifra superior a la suma del PIB de seis Estados miembros ${ }^{577}$.

Asimismo, en este apartado cabe recordar que en el trámite de elaboración de la Directiva 2004/18/CE, concretamente, entre las enmiendas presentadas por el Parlamento Europeo se propuso incorporar al texto de esta Directiva otras prohibiciones de contratar de carácter obligatorio que tuvieran por objeto excluir a aquellos licitadores o candidatos que hubieran sido condenados por un delito relacionado con el tráfico ilícito de drogas, si bien, esta enmienda no prosperó al entender la Comisión que no se habían armonizado los tipos penales vinculados a este fenómeno ${ }^{578}$.

COM (2014) 38 final, de 3 de febrero de 2014 y en la Comunicación Lucha contra la corrupción en la UE, COM (2011) 308 final, de 6 de junio de 2011, pág. 3.

${ }^{576}$ Según recoge el Informe anual sobre la lucha contra el fraude 2014, COM (2015) 386 final, de 31 de julio de 2015, pág. 5 .

${ }^{577}$ Son datos que podemos encontrar en la Resolución del Parlamento Europeo, de 25 de octubre de 2011, sobre la delincuencia organizada en la Unión Europea (P7_TA(2011)0459). Esta Resolución aporta otra elocuente cifra: los beneficios anuales estimados de la «Ndrangheta», la mafia más arraigada en los países de la UE, se calculan en 44.000 millones de euros, como mínimo.

${ }^{578}$ Se trataba de la enmienda núm. 83 presentada por el Parlamento Europeo, adoptada en primera lectura el 17 de enero de 2002, con la que se pretendía la incorporación como prohibición de contratar de una nueva letra, la c. quinquies), que tenía la siguiente redacción: "Por un delito relacionado con la droga, definido en la letra a) del apartado 1 del artículo 3 de la Convención de las Naciones Unidas contra el tráfico ilícito de estupefacientes y de sustancias sicotrópicas, adoptada en Viena el 19 de diciembre de 1998". Véase la página 266 de esta memoria doctoral. 


\section{La identificación de los delitos que habili- tan una prohibición de contratar de carácter obligatorio}

Desde el planteamiento integrador que se ha adoptado, impedir la participación en las licitaciones públicas a quienes han sido condenados por incurrir en determinadas actividades delictivas, puede verse no sólo como un modo de preservar los principios que rigen la contratación pública y asegurar con ello una competencia real en los procedimientos de adjudicación contractual, sino también, y en último término, como uno de los instrumentos con los que prevenir la delincuencia y luchar contra sus distintas manifestaciones ${ }^{579}$.

No obstante, y sin poner en cuestión la importancia de apostar por un enfoque horizontal y transversal en la adopción de medidas para luchar contra estos fenómenos, sí resulta cuestionable - tal y como están concebidas - la eficacia de estas prohibiciones de contratar como mecanismos que aporten una

${ }^{579}$ En esta misma línea, el Libro Verde sobre la modernización del mercado europeo de la contratación pública. Hacia un mercado europeo de la contratación pública más eficiente, COM (2011) 15 final, de 25 de enero de 2011, pág. 56, manifestaba que "la exclusión de los licitadores que sean culpables de corrupción y, más en general, de falta profesional ( «inhabilitación»), es un arma poderosa para castigar - y también, en cierta medida para impedir - los comportamientos empresariales ilícitos".

Con anterioridad a la publicación de este Libro Verde, la misma idea sobre la importancia de las prohibiciones de contratar como instrumento para prevenir la corrupción en la contratación pública ya había sido puesta de manifiesto por diferentes autores, si bien todos ellos manifiestan sus dudas acerca de cuán efectivas resultan estas prohibiciones en la práctica. Por ejemplo, SCHOONER, S., "The Paper Tiger Stirs: (...)", op. cit., págs. 214 y 215; SHAW, S. A., "Access to Information: The Key Challenge to a Credible Suspension and Debarment Programme", PPLR, vol. 13 (5), 2004, págs. 230 - 234; YUKINS, Ch., "Suspension and Debarment: Re-examining the Process", PPLR, vol. 13 (5), 2004, págs. 255 - 259; KRAMER, R., "Awarding Contracts to Suspended and Debarred Firms: Are Stricter Rules Necessary?", Public Contract Law Journal, vol. 34 (3), 2005, pág. 550; WILLIAMS, S., "The mandatory exclusions for corruption (...)", op. cit., págs. 729 a 734; DREW, K., "A Critical Analysis of the EC's Public (...)", op. cit., pág. 16 y en "The Challenges Facing Debarment (...)", op. cit., pág. 270; WHITE, S., "Exclusion of Tenderers in the European Union (...)", op. cit., pág 253; BOLTON, P., "The Exclusion of Contractors from Government Contract Awards", Law Democracy \&3 Development, vol. 10 (1), 2006, pág. 19 y MEDINA ARNÁIZ, T., "EU Directives as an Anticorruption Measures: (...)", op. cit., págs. 126 y 127. 
plusvalía real en este empeño, ya que su puesta en práctica se enfrenta a distintos obstáculos que plantean dificultades en su aplicación. Así pues, aunque ya hemos señalado que estas prohibiciones de contratar de carácter obligatorio para los Estados miembros potencialmente representan un avance para reducir, por ejemplo, la corrupción y el fraude vinculados a la contratación pública, su efecto disuasorio se desvirtúa ante un aspecto tan concreto como es la falta de calificación común respecto de los elementos integradores de las infracciones penales que dan soporte a estas prohibiciones. Es decir, resultan, cuando menos, poco efectivas mientras no exista consenso respecto de qué se entiende por participación en una organización delictiva, por corrupción, por fraude, por blanqueo de capitales, por terrorismo o por trata de seres humanos.

Por esa razón, y en nuestra opinión, es necesario clarificar conceptos y buscar los elementos comunes que identifican las conductas punibles que configuran una prohibición de contratar tanto por parte de las Directivas de 2014 como por la Directiva 2009/81/CE (artículo 39.1).

Uno de los principales obstáculos a su eficacia alude, por tanto, a las dificultades de precisión normativa, pues todavía - en la mayor parte de los tipos delictivos a los que se refieren las Directivas contractuales - la potestad para concretar los contenidos sustantivos del Derecho penal y las normas de esa naturaleza está reservada a los poderes legislativos nacionales, formando parte de las denominadas «competencias exclusivas» de los Estados miembros. El cambio se puede llegar a producir al amparo del Tratado de Lisboa, ya que, tal como se tratará con posterioridad, la UE cuenta en la actualidad con base jurídica suficiente para la adopción de directivas de Derecho penal en virtud del artículo 83.2 del TFUE que posibilita el establecimiento de "normas mínimas relativas a la definición de infracciones penales y sanciones" 580 .

\footnotetext{
${ }^{580}$ Sirva como ejemplo de ello, la adopción de la Directiva 2011/92/UE, del Parlamento y del Consejo, de 13 de diciembre de 2011, relativa a la lucha contra los abusos sexuales y la explotación sexual de los menores y la pornografía infantil (DOUE L 335, de 17 de diciembre de 2011) o la Directiva 2014/62/UE del Parlamento Europeo y del Consejo, de 15 de mayo de 2014, relativa a la protección penal del euro y otras monedas frente a la falsificación (DOUE L 151, de 21 de mayo de 2014). Véase también la Comunicación de la Comisión Hacia una política de Derecho penal de la UE: garantizar la aplicación efectiva de las políticas de la UE mediante el Derecho penal, COM (2011) 573 final, de 20 de septiembre de 2011.
} 
Sin embargo, hasta la total adopción de Directivas en esta materia, la exclusividad del ámbito penal bajo la soberanía nacional tiene como efecto que los Estados miembros pueden definir, de manera autónoma, qué conductas están sometidas a sanción penal y determinar, con ello, los perfiles de los delitos a través de los cuales se busca prevenir y reprimir las conductas que se consideran punibles. Sus plurales circunstancias históricas, culturales o jurídicas dotan de un carácter propio la valoración de dichos ilícitos, causando una pluralidad de regulaciones en atención a un mismo hecho. Tal circunstancia, desde la perspectiva que nos ocupa, dificulta la aplicación uniforme de estas prohibiciones de contratar en todos los Estados miembros, disminuyendo con ello su eficacia.

\section{IV.1. Consideraciones preliminares sobre el Derecho pe- nal sustantivo en la Unión Europea y su impor- tancia en la delimitación de las prohibiciones de contratar obligatorias}

Ante la ausencia de un espacio penal de la UE, el Derecho de la Unión emprendió, a partir de la entrada en vigor del Tratado de Maastricht (1992) y con el objetivo del establecimiento del ELSJ por el Tratado de Ámsterdam (1997), la aproximación de los ordenamientos penales de los distintos Estados miembros respecto de la tipificación penal de determinadas conductas en el marco del denominado «tercer pilar» de acuerdo con el clásico método de la cooperación intergubernamental - cooperación entre los Estados miembros y las instituciones (cooperación política) - que se caracterizaba, esencialmente, por la utilización de instrumentos jurídicos carentes de efecto directo ${ }^{581}$.

\footnotetext{
${ }^{581}$ Este tercer pilar aspiraba a proporcionar a los ciudadanos, sin perjuicio de las competencias de la Comunidad, un alto grado de seguridad, elaborando políticas de prevención y de lucha contra la delincuencia, mediante una mayor cooperación entre las autoridades judiciales y de la aproximación, cuando procediese, de las normas penales nacionales (artículo 31 TUE). Recordemos que el nuevo marco jurídico establecido por el Tratado de Lisboa ha eliminado la estructura de pilares de la Unión que hasta entonces se asentaba sobre una estructura de tres pilares, correspondiendo al tercer pilar aquellos aspectos relativos al ámbito de la cooperación policial y judicial en materia penal. Desde el 1 de diciembre de 2014, esta cooperación se incluye en el ordenamiento jurídico de la UE y el control del TJUE y la función de
} 
En atención a estas consideraciones, y debido a la comentada ausencia de atribución competencial de la UE para la calificación de los tipos penales, no se entendió adecuado que en las Directivas sobre contratación pública se incluyesen conceptos autónomos propios del Derecho Penal, como la definición de corrupción, y de organización delictiva que sí se incorporaban a las Propuestas de Directivas del año $2000^{582}$. Por ello, la precisión de las infracciones penales cuya condena habilitan la exclusión obligatoria del licitador o candidato del procedimiento de adjudicación contractual, se materializa en estas Directivas a través de la remisión a distintos instrumentos jurídicos comprendidos en el ámbito del citado tercer pilar (acciones comunes, decisiones marco y convenios) que tratan de establecer unas normas mínimas en relación con la definición de

la Comisión como guardiana de los Tratados se aplican ahora íntegramente.

Sobre el espacio de libertad, seguridad y justicia en la configuración del Tratado de Lisboa, véase con carácter general, CARRERA, S. y GEYER, F., "El Tratado de Lisboa y un Espacio de Libertad, Seguridad y Justicia: Excepcionalismo y fragmentación en la Unión Europea", Revista de Derecho Comunitario Europeo, núm. 29, enero - abril 2008, págs. 133 - 162; DONAIRE VILLA, F. J., "El espacio de libertad, seguridad y justicia tras el Tratado de Lisboa: entre supranacionalidad e integración diferenciada", Revista Española de Derecho Europeo, núm. 35, julio - septiembre 2010, págs. 337 - 364 y MUÑOZ DE MORALES ROMERO, M., El legislador penal europeo: Legitimidad y racionalidad, Civitas - Thomson Reuters, Cizur Menor (Navarra), 2011, especialmente su Capítulo IV, págs. 265 a 311.

${ }^{582}$ Recordemos lo dicho en las páginas 257-259 del Capítulo segundo, que en el trámite de elaboración de la Directiva 2004/18/CE, la Propuesta de Directiva sobre coordinación de los procedimientos de adjudicación de los contratos públicos de suministro, de servicios y de obras, sí se procedía a una definición autónoma de las conductas que estaban comprendidas en cada uno de estos tipos delictivos, COM (2000) 275 final, de 30 de agosto de 2000 (DOCE C 29E, de 30 de enero de 2001). No obstante, este concreto apartado fue cuestionado por parte del Parlamento Europeo al entender que esta tipificación penal por parte de las Directivas sobre contratación pública suscitaba debates inútiles sobre el fundamento jurídico que posibilitaba dicha tipificación. Por ello, la Propuesta modificada de Directiva cambió las definiciones propias por la remisión a instrumentos propios del tercer pilar, COM (2002) 236 final, de 6 de mayo de 2002 (DOCE C 203E, de 27 de agosto). La misma idea de inadecuación de las directivas como instrumento normativo para recoger definiciones propias del Derecho penal se encuentra en la supresión de la definición de terrorismo y organización delictiva que se incluían en el artículo 2 de la Propuesta de Directiva del Parlamento Europeo y del Consejo sobre coordinación de los procedimientos de adjudicación de determinados contratos públicos de obras, de suministro y de servicios en los ámbitos de la defensa y la seguridad, COM (2007) 766 final, de 5 de diciembre de 2007. 
dichas conductas delictivas, según señalaba el antiguo artículo 31.1 TUE ${ }^{583}$.

Esta remisión, sin embargo, suscita dificultades en cuanto a su transposición a las normas contractuales de los Estados miembros a efectos de aplicar estas prohibiciones de contratar obligatorias de forma homogénea en todos ellos y, sobre todo, con independencia de la nacionalidad del licitador o candidato. Las contrariedades derivan, principalmente, de que tales instrumentos resultan inadecuados por no ajustarse al objetivo de armonización respecto de las normas punitivas, ni establecen obligaciones positivas para los Estados miembros en el ámbito del Derecho penal ${ }^{584}$. La transcendencia de este aserto se justifica en que sobre las definiciones allí recogidas se concretan las prohibiciones de contratar en la normativa contractual de cada Estado miembro.

En este sentido, tras examinar cómo los Estados miembros han transpuesto el artículo 45.1 de la Directiva 2004/18/CE a su Derecho interno - que es sobre el que tenemos constancia, ya que las Directivas de 2014 están aun en proceso de transposición - podemos afirmar la existencia de diferencias significativas respecto de los criterios adoptados para concretar las conductas delictivas que originan una prohibición de contratar de carácter obligatorio. El único aspecto común resulta de la no formulación de definiciones autónomas respecto de estos

\footnotetext{
${ }^{583}$ De la lectura conjunta de los artículos 29 y 31.1 TUE se desprendía que el "alto grado de seguridad en la Unión" debía alcanzarse mediante la prevención la lucha contra la delincuencia incluyendo medidas de aproximación de las disposiciones penales de los Estados miembros en el marco de la cooperación judicial penal.
}

${ }^{584}$ No obstante, el Tribunal de Justicia en su sentencia de 16 de junio de 2005, Pupino, C-105/03, reconoció efecto indirecto a las Decisiones marco y, poco después en su sentencia de 13 de septiembre de 2005, Comisión/Consejo, C-176/03, estableció que el legislador europeo está facultado para adoptar medidas que obliguen expresamente a los Estados miembros a establecer sanciones penales contra determinadas conductas.

A nivel doctrinal, destacan los trabajos de SARMIENTO RAMÍREZESCUDERO, D., "Un paso más en la constitucionalización del Tercer Pilar de la Unión Europea: La sentencia Maria Pupino y el efecto directo de las Decisiones Marco", Revista Electrónica de Estudios Internacionales, núm. 10, 2005, págs. 1 - 32; WEYEMBERGH, A., "Approximation of criminal laws, the Constitutional Treaty and the Hague Programme", CMLR, vol. 42 (6), 2005, págs. 1567 - 1597 y CASTILLO GARCÍA, J. F., "La comunitarización del Tercer Pilar: un paso necesario para la consolidación del Espacio penal europeo", Revista General de Derecho Europeo, núm. 11, octubre 2006, págs. 1 - 49. 
tipos delictivos [Tabla 5] $]^{585}$.

Así, en atención a la delimitación de tales comportamientos punibles, podemos clasificar a los Estados miembros en cuatro grupos: Un primer grupo de países se remiten a los mismos instrumentos jurídicos que la Directiva, tal como ha sucedido en la legislación contractual de Chipre, Grecia, Italia, Malta, Portugal y Suecia. Un segundo grupo lo conforman aquellos Estados miembros que se refieren a sus propias normas penales para la calificación de los tipos delictivos que habilitan una prohibición de contratar obligatoria (Alemania, Austria, Bulgaria, Dinamarca, Luxemburgo, Países Bajos y Reino Unido). A un tercer grupo pertenecen aquellos Estados que no remiten a norma alguna y se limitan a enumerar los delitos sin ofrecernos un concepto operativo de cada uno de ellos (Bélgica, Croacia, Eslovaquia, Eslovenia, España, Estonia, Francia, Irlanda, Letonia, Lituania, Polonia, República Checa y Rumanía); y por último, Hungría y Finlandia que diferencian las normas aplicables en atención a si se destinan a sus nacionales - se remiten entonces a sus respectivos Códigos penales - o si se trata de licitadores y candidatos establecidos en cualquiera de los demás Estados miembros, en cuyo caso acuden a los mismos instrumentos normativos que la Directiva 2004/18/CE.

Esta clasificación por países tiene una significación evidente más allá de las importantes diferencias que pueden observarse en cuanto a la criminalización nacional de estas conductas en atención a sus distintos sistemas y tradicio-

${ }^{585}$ La Tabla 5 incluida al final de este capítulo se dedica a la transposición formal en los Estados miembros del artículo 45 de la Directiva 2004/18/CE en cuanto a las prohibiciones de contratar de carácter obligatorio. Sobre esta materia resulta de interés MESSINE, J., "Marchés publics et crime organisé - le droit pénal" y XANTHAKI, H., "First Pillar Analysis", publicados en la obra colectiva dirigida por WHITE, S., Procurement and organised crime: an EU wide study, Institute of Advanced Legal Studies, London, 2000. Respecto de la transposición de las Directivas sobre contratación pública en los Estados miembros, puede consultarse TRYBUS, M. y MEDINA, T., "Unfinished Business: The State of Implementation of the New EC Public Procurement Directives in the Member States on February 1, 2007", PPLR, vol. 16 (4), 2007, págs. NA89 - NA97; MEDINA ARNÁIZ, T. y TRYBUS, M., "La transposición de las Directivas comunitarias sobre contratación pública en los Estados miembros", NUE, núm. 298, noviembre 2009, págs. 83 - 94 y, más recientemente, la obra colectiva dirigida por SÁNCHEZ MORÓN, M., Derecho de los contratos públicos en la Unión Europea y sus Estados miembros, Lex Nova, Valladolid, 2011 (su versión en inglés está publicada en el año 2012). 
nes jurídicas ${ }^{586}$, pues, debido a que en los Estados miembros conviven diversas fórmulas de tipificación de los delitos abordados, no existe una protección equivalente en todos los Estados respecto de las conductas punitivas que conducen a una prohibición de contratar.

A nuestro entender, tales divergencias restan poder disuasorio a estas medidas que, incluso, pueden quedar sin efecto en el momento de aplicarse por la falta, en la práctica, de un reconocimiento mutuo. Es por ello que, para evitar discrepancias en atención a los distintos ordenamientos penales nacionales, y dado que los conceptos de corrupción, fraude, organización delictiva y terrorismo a los que remiten las Directivas sobre contratación pública se forjaron sobre la base jurídica del tercer pilar y ésta ha quedado obsoleta tras la entrada en vigor del Tratado de Lisboa (2009), podría haberse evaluado la conveniencia de ajustar las definiciones de estos delitos a la metodología comunitaria y proceder a su «comunitarización» en todas las políticas sectoriales conexas, lo que incluye también la contratación pública ${ }^{587}$.

Esta propuesta a favor del establecimiento de unos criterios comunes respecto de los elementos constitutivos de los delitos que habilitan una prohibición de contratar de carácter obligatorio en todos los Estados miembros no se ajusta, sin embargo, al contenido de las Directivas. Las nuevas Directivas siguen apostando por referirse a los delitos de corrupción, crimen organizado, fraude, terrorismo y blanqueo de capitales por remisión a otros instrumentos jurídicos de la Unión, aunque - como novedad destacada - en el supuesto de los delitos

\footnotetext{
${ }^{586}$ En toda la UE, se han identificado al menos 52 sistemas distintos, según manifiesta la Comunicación de la Comisión La delincuencia en la UE en cifras: Plan de acción para las estadísticas 2011-2015, COM (2011) 713 final, de 18 de enero de 2012, pág. 4. A este respecto resulta de un gran interés la obra de CASTRO CUENCA en tanto que nos muestra las diferencias en la tipificación de estos delitos en los Códigos penales de los Estados miembros. CASTRO CUENCA, C. G., La corrupción en la contratación pública en Europa, Ratio Legis, Salamanca, 2009.

${ }^{587}$ La necesidad de armonizar las disposiciones jurídicas de los Estados miembros en relación con los delitos de corrupción, ya se había puesto de manifiesto en la Resolución del Parlamento Europeo de 15 de diciembre de 1995 sobre la lucha contra la corrupción en Europa (A3-0314/95) (DOCE C 17, de 22 de enero de 1996, pág. 443). Las cuestiones que antes estaban incluidas en el Título VI del Tratado UE (el antiguo «tercer pilar») se integran ahora en los Capítulos 4 («Cooperación judicial en materia penal») y 5 («Cooperación policial») del Título V del TFUE relativo al Espacio de libertad, seguridad y justicia (artículo 67 y ss.).
} 
de corrupción se refieren a la corrupción "tal como se defina en la legislación nacional del poder adjudicador o del operador económico" (artículo 57.1.b) de la Directiva 2014/24/UE y artículo 38.4.b) de la Directiva 2014/23/UE («concesiones»).

Ante la falta de una definición autónoma, entendemos pues recomendable que se exija a los Estados miembros la aproximación de sus legislaciones en materia penal y se adopten técnicas de integración a través de mecanismos de Derecho derivado (reglamentos, directivas y decisiones) que aseguren una armonización de los tipos penales comprendidos bajo estos conceptos y de las sanciones a aplicar. Esta recomendación, que excede nuestra materia de estudio, está en línea con los cambios acontecidos en el Derecho de la UE tras la desaparición del sistema de pilares, la nueva distribución de poderes y también en atención a lo dispuesto en el artículo 83 TFUE que, como ya hemos señalado, se refiere a la competencia de la Unión en armonizar las legislaciones penales de los distintos Estados miembros mediante el establecimiento de normas mínimas adoptadas con arreglo al procedimiento de codecisión en ámbitos delictivos que sean de especial gravedad y con un carácter transfronterizo (los denominados «delitos europeos») $)^{588}$.

La propuesta que planteamos se sustenta en el hecho de que, tras el Tratado de Lisboa, la UE dispone de mayores competencias en el ámbito de la cooperación judicial en materia penal, incluido el Derecho penal sustantivo, de tal manera que Parlamento y Consejo tienen potestad para establecer a través de directivas los elementos constitutivos de los delitos de terrorismo, blanqueo de capitales, corrupción y delincuencia organizada, pues éstos figuran expre-

${ }^{588}$ Según MUÑOZ DE MORALES ROMERO, el artículo 83 TFUE tiene la peculiaridad de reconocer dos tipos de armonización legislativa: armonización autónoma y armonización accesoria, "La autónoma implica el reconocimiento a la Unión, por primera vez en su historia, de competencias expresas stictu sensu penales-materiales indirectas que las instituciones europeas van a ejercer por el método comunitario" no estando subordinadas a la exigencia de cooperación judicial, en MUÑOZ DE MORALES ROMERO, M., El legislador penal europeo (...)", op. cit., pág. 267. Conforme al artículo 289.1 TFUE el procedimiento legislativo ordinario se identifica con el procedimiento de codecisión, es decir, con la adopción conjunta por el Parlamento y el Consejo, a propuesta de la Comisión de un reglamento, una directiva o una decisión, lo que supone una ampliación de los poderes del Parlamento. 
samente entre los delitos a los que se refiere el artículo 83.1 TFUE $^{589}$ :

\begin{abstract}
"El Parlamento Europeo y el Consejo podrán establecer, mediante directivas adoptadas con arreglo al procedimiento legislativo ordinario, normas mínimas relativas a la definición de las infracciones penales y de las sanciones en ámbitos delictivos que sean de especial gravedad y tengan una dimensión transfronteriza derivada del carácter o de las repercusiones de dichas infracciones o de una necesidad particular de combatirlas según criterios comunes. Estos ámbitos delictivos son los siguientes: el terrorismo, la trata de seres humanos y la explotación sexual de mujeres y niños, el tráfico ilícito de drogas, el tráfico ilícito de armas, el blanqueo de capitales, la corrupción, la falsificación de medios de pago, la delincuencia informática y la delincuencia organizada".
\end{abstract}

Reconociendo, pues, que se trata de ámbitos delictivos de especial gravedad, que tienen una dimensión transfronteriza y que se deben combatir conforme a criterios comunes, el legislador de la Unión debe considerar, como paso previo, la necesidad de garantizar una armonización mínima de las legislaciones nacionales por lo que respecta a la definición de dichas actividades y las sanciones que les resultan de aplicación, no limitándose a obligar a los Estados miembros a tipificar determinadas conductas y a que establezcan, al respecto, sanciones penales efectivas, proporcionadas y disuasorias ${ }^{590}$.

${ }^{589}$ En atención a los principios de subsidiariedad y proporcionalidad, la Directiva es el instrumento apropiado para establecer disposiciones de Derecho penal armonizadas en el ámbito de la protección de los intereses financieros de la Unión, dejando a los Estados miembros un cierto margen de flexibilidad en cuanto a aplicar o no disposiciones más estrictas.

${ }^{590}$ Este trabajo no tiene por objeto el análisis del Derecho penal europeo, pero en cuanto que es una materia que afecta a la determinación de las prohibiciones de contratar de carácter obligatorio, creemos conveniente profundizar en esta importante cuestión a través de la remisión a la Comunicación de la Comisión Hacia una política de Derecho penal de la UE: garantizar la aplicación efectiva de las políticas de la UE mediante el Derecho penal, COM (2011) 573 final, de 20 de septiembre de 2011, y a los Dictámenes de los órganos consultivos que se refieren a esta materia, como es el caso del Dictamen del Comité Económico y Social Europeo publicado en el DOUE C 191, de 29 de junio de 2012. También resulta de interés, el Informe del 
La conformación de los elementos que van a constituir la tipificación del hecho delictivo en estas conductas supone una medida indispensable en cuanto a la protección contra estas formas graves de delincuencia por su aplicación de forma equivalente en todos los Estados miembros, pero de manera conexa - y por lo que a esta memoria doctoral interesa - puede también contribuir a mejorar la necesaria coordinación y cooperación que garantice la plena efectividad de las prohibiciones de contratar de carácter obligatorio en todo el territorio de la Unión.

En este sentido, y dado que para el ordenamiento jurídico de la UE existe un interés manifiesto en que toda disposición del Derecho de la Unión reciba una interpretación uniforme, consideramos necesario superar los obstáculos que suponen tanto los enfoques nacionales divergentes como las imprecisiones existentes en torno a estos tipos delictivos, incorporando en las Directivas sobre contratación pública - aunque, evidentemente, no se traten de directivas penales - la delimitación de los elementos constitutivos de las conductas típicas que van a habilitar una futura prohibición de contratar. Con ello, la propuesta formulada pretende poner fin a las remisiones normativas amparadas en la inadecuación de estas Directivas para acuñar definiciones penales por falta de base jurídica, puesto que además, como veremos con ejemplos concretos, las actuales remisiones quedarán obsoletas tras la derogación de las normas reenviadas, sin que las nuevas Directivas resuelvan totalmente estas deficiencias, y

Parlamento Europeo, de 24 de abril de 2012, sobre un enfoque de la UE acerca del Derecho Penal A7-0144/2012 (2010/2310 (INI).

Sobre la «europeización» del Derecho penal de acuerdo con lo dispuesto en el Tratado de Maastricht, véase VERVAELE, J. A., "La europeización del Derecho penal y la dimensión penal de la integración europea", Revista Penal, núm. 15, enero 2005, págs. 169 - 183, especialmente sus págs. 175 y siguientes; ARROYO ZAPATERO, L. y NIETO MARTÍN, A. (Directores)., El derecho penal de la Unión Europea: situación actual y perspectivas de futuro, Ediciones de la Universidad de Castilla - La Mancha, Cuenca, 2007; SANZ MORÁN, Á. J., "Presente y futuro de la armonización del derecho penal material", en la obra colectiva El proceso penal en la Unión Europea: garantías esenciales, Lex Nova, Valladolid, 2008, págs. 285305; NIETO MARTÍN, A., "La armonización del Derecho penal ante el Tratado de Lisboa y el Programa de Estocolmo", Revista General de Derecho Penal, núm. 13, mayo 2010 y MUÑOZ DE MORALES ROMERO, M., El legislador penal europeo (... "), op. cit., 2011 y PÉREZ MARÍN, M A., La lucha contra la criminalidad en la Unión Europea. El camino hacia la jurisdicción penal común, Atelier, Barcelona, 2013. 
lo que consideramos más importante, sin que clarifiquen el marco conceptual referido a estos tipos delictivos respecto de la contratación pública ${ }^{591}$.

En todo caso, y antes de adentrarnos en el estudio de los instrumentos a los que se refieren las actuales Directivas sobre contratación, es preciso reflexionar sobre distintas cuestiones de esta regulación. En primer lugar, las conductas delictivas que conducen a una prohibición de contratar obligatoria para los Estados miembros obedecen al objetivo común, aunque como hemos indicado no exclusivo, de evitar que actividades económicas legales - como es el caso de la contratación pública - puedan proporcionar cobertura a actividades delictivas que suponen una amenaza para el bienestar ciudadano y la seguridad interior de los Estados. El propio Parlamento Europeo parece avalar esta idea al señalar que "los grupos de la delincuencia organizada se están convirtiendo en organizaciones empresariales cada vez más complejas y estructuradas, capaces de penetrar los mercados económicos y financieros y de provocar su distorsión en busca de espacios económicos lícitos con el fin de canalizar, con frecuencia mediante sofisticadas operaciones de blanqueo de dinero, los beneficios acumulados ilícitamente" ${ }^{592}$. Así pues, y a efectos de la consecución de este objetivo, es que venimos defendiendo que debieran definirse con mayor precisión los comportamientos y las actividades ilegales que justifican una prohibición de contratar.

En segundo lugar, si consideramos que la lucha contra los ámbitos delictivos de especial gravedad y con un carácter transfronterizo («delitos euro-

\footnotetext{
${ }^{591}$ A nuestro entender, podría servir de modelo de trabajo los distintos documentos/guías elaborados desde la Comisión Europea para determinar las correcciones financieras que deben aplicarse a las irregularidades detectadas respecto de las inversiones financiadas con cargo a fondos de la UE, pues en estos documentos se señalan comportamientos y prácticas indicadoras de fraude y corrupción en la contratación pública. Véase a este respecto, Guidelines for determining financial corrections to be made to expenditure co-financed by the Structural Funds or the Cohesion Fund for non-compliance with the rules on public procurement (COCOF 07/0037/03-EN), versión final de 29 de noviembre de 2007, e Information Note on fraud indicators for the ERDF, ESF and CF (COCOF 09/0003/00-EN) versión final de 18 de febrero de 2009, referido al Fondo Europeo de Desarrollo Regional (FEDER), al Fondo Social Europeo (FSE) y al Fondo de Cohesión.

${ }^{592}$ Recomendación del Parlamento Europeo, de 24 de mayo de 2007, destinada al Consejo sobre el desarrollo de un concepto estratégico para hacer frente a la delincuencia organizada [2006/2094(INI)] (DOUE 102E, de 24 de abril de 2008).
} 
peos») debe afrontarse desde distintas perspectivas, como por ejemplo, desde el demandado «enfoque administrativo» ${ }^{593}$, una primera opción del legislador europeo es plantearse la conveniencia de atajar el carácter lucrativo de estas actividades ilegales mediante el desarrollo de un modelo común en todos los ámbitos cubiertos por las políticas de la Unión ${ }^{594}$.

Este modelo común debiera incluir el establecimiento de medidas que comprendieran, por una parte, la inhabilitación temporal para el ejercicio de actividades comerciales y/o la exclusión del disfrute de ventajas públicas y, por otra, desde la perspectiva del Derecho administrativo, una prohibición de contratar en similar sentido. Así pues, y dado que la incriminación penal de una conducta debe ser el último mecanismo que la Unión imponga a los Estados miembros en atención al respeto a los principios de subsidiariedad y proporcionalidad (la «ultima ratio»), esta opción nos obligaría a incluir en el catálogo de prohibiciones de contratar obligatorias una serie de supuestos, ahora ausentes, en los que el operador económico no va a poder concurrir a un procedimiento de adjudicación contractual por haberse contemplado esta conducta en el ámbito punitivo penal, sin que propiamente, y como ya hemos señalado en el Capítulo primero, podamos hablar de una vulneración del principio non bis in $i_{\text {dem }}^{595}$.

Cabría pensar entonces en incorporar a una futura «quinta generación» de Directivas sobre contratación pública - como nuevas prohibiciones de contratar

\footnotetext{
${ }^{593}$ Recordemos que en la Estrategia de Seguridad Interior se incide en este «enfoque administrativo» que supone involucrar a todos los órganos de la Administración pública - y no sólo a los órganos con funciones coercitivas - en la labor de protección de la economía contra el delito y la corrupción. COM (2010) 673 final, de 22 de noviembre.

${ }^{594}$ Por lo que hace a la seguridad interior y a los delitos europeos, la base jurídica de esta propuesta es el artículo 83, apartado 1, del TFUE, que se limita a las infracciones en los ámbitos enumerados en dicho artículo, a saber: el terrorismo, la trata de seres humanos y la explotación sexual de mujeres y niños, el tráfico ilícito de drogas, el blanqueo de capitales, la corrupción, la falsificación de medios de pago, la delincuencia informática y la delincuencia organizada.

${ }^{595} \mathrm{~A}$ este respecto, procede recordar que el Tribunal de Justicia ya ha declarado que las sanciones que tienen por objeto la exclusión temporal de un agente económico del beneficio de un régimen de ayudas, no tienen carácter penal, véase lo dicho en la STJUE de 5 de junio de 2012, Bonda, C-489/10, apartado 28.
} 
- los supuestos contemplados en el artículo 7.1.b) de la Directiva 2009/52/CE, del Parlamento Europeo y del Consejo, de 18 de junio de 2009, por la que se establecen normas mínimas sobre las sanciones y medidas aplicables a los empleadores de nacionales de terceros países en situación irregular, que expresamente contempla como sanción "la exclusión de la participación en licitaciones públicas tales como las mencionadas en la Directiva 2004/18/CE del Parlamento Europeo y del Consejo, de 31 de marzo de 2004, sobre coordinación de los procedimientos de adjudicación de los contratos públicos de obras, de suministro y de servicios, durante un período máximo de cinco años"596.

Una segunda opción, complementaria de la anterior, es limitar las conductas que habilitan una prohibición de contratar de carácter obligatorio única y exclusivamente a aquellos tipos penales a través de los cuales se busca reforzar la lucha contra la corrupción en la contratación pública y proteger los intereses financieros de la Unión, por entender que la lucha contra estos delitos - y no el resto - se integra en el objetivo global de optimización de recursos en las compras públicas $^{597}$. En este caso, la especial corresponsabilidad de las prohibiciones de contratar en la aplicación de la Estrategia de Seguridad Interior por su componente de prevención de la delincuencia, podría limitarse al catálogo de prohibiciones de contratar de carácter facultativo para los Estados miembros, e incluso quedar circunscrita por razón de especialidad como ocurría, por ejemplo, con las prohibiciones de contratar en los sectores de la seguridad y defensa por delitos de terrorismo o delito ligado a actividades terroristas (artículo 39.1.d) de la Directiva 2009/81/CE).

Una tercera opción es superar la división entre motivos de exclusión obligatorios y facultativos derivados de una previa sentencia condenatoria por la comisión de ciertos delitos para centrar la atención en aquellos comportamientos

${ }^{596}$ DOUE L 168, de 30 de junio de 2009.

${ }^{597}$ La Resolución del Parlamento Europeo, de 25 de octubre de 2011, sobre la modernización de la contratación pública, señala en su apartado 44 que "la lucha contra la corrupción y el favoritismo es uno de los objetivos de las Directivas" [P7_TA (2011) 0454]. Al mismo tenor responde el Dictamen del CESE sobre el Libro Verde de la Comisión al manifestar que "uno de los objetivos de las directivas consiste en combatir el favoritismo, del fraude y la corrupción", apartados 1.14 y 6.1 (DOUE C 318, de 29 de octubre de 2011) y el documento de trabajo de los servicios de la Comisión sobre las Propuestas de Directivas, SEC (2011) 1585 final, de 20 de diciembre de 2011, pág. 30. 
que quiebran los principios básicos de la contratación (principios de igualdad de trato, no discriminación y transparencia), que infringen la normativa y que imposibilitan la eficaz aplicación de las normas de la UE.

De esta manera, el elemento clave para establecer una prohibición de carácter obligatorio no sería que ciertas conductas sean punibles, sino que atenten contra el correcto desempeño de la actividad pública. En este sentido, entre las causas de exclusión de la participación en un contrato público en todos los Estados miembros, se incluirían aquellas conductas delictivas que se han revelado lesivas a los principios y objetivos de la contratación, y también aquellas otras que, sin constituir conductas típicas, tratan de evitar que los incumplimientos de la normativa otorguen desventajas competitivas para los agentes económicos que cumplen la legislación respecto a los que no la cumplen, privando de esta manera a los responsables de las infracciones del beneficio económico derivado de ellas.

A este respecto, podrían respaldarse reformas normativas destinadas a diseñar un catálogo de prohibiciones de contratar obligatorias en todos los Estados miembros que pivote sobre la idea de impedir el falseamiento de la competencia en los procedimientos de adjudicación contractual y en evitar situaciones de privilegio de unos operadores económicos frente a otros en relación con la celebración de un contrato, máxime cuando el TJUE ha identificado la apertura de los contratos públicos a la competencia como uno de los principales objetivos de las Directivas sobre contratación pública ${ }^{598}$.

Ahora bien, al margen de la valoración de estas propuestas de lege ferenday de las que serán objeto de tratamiento posterior - en este momento debemos abordar el estudio de los instrumentos normativos que en la regulación actual conducen a una prohibición de carácter obligatorio ${ }^{599}$. Estos instrumentos

\footnotetext{
${ }^{598}$ Así se ha manifestado en sus sentencias de 11 de mayo de 2006, Carbotermo y Consorzio Alisei, C-340/04, apartado 58; de 13 de diciembre de 2007, Bayerischer Rundfunk y otros, C-337/06, apartado 39; de 23 de diciembre de 2009, CoNISMa, C-305/08, apartado 37; de 10 de octubre de 2013, Swm Costruzioni, C-94/12, apartado 34; de 10 de julio de 2014, Consorzio Stabile Libor Lavori Pubblici, C-358/12, apartado 29 y de 18 de diciembre de 2014, Data Medical Service, C-568/13, apartado 34 .

${ }^{599}$ Estos actos estaban regulados en el anterior artículo 34.2 TUE que enumeraba y definía, en términos generales, los distintos tipos de instrumentos que podían ser
} 
centran su atención en la calificación de las conductas que, como infracciones penales, deben ser objeto de incriminación y sanción por parte de los derechos nacionales. Sus definiciones son las que seguidamente trataremos, por cuanto suponen una mejor comprensión de los comportamientos que configuran una prohibición de contratar obligatoria, y el examen de sus deficiencias y lagunas nos permitirán plantear recomendaciones de mejora.

\section{IV.2. Delitos relativos a la participación en una organi- zación delictiva}

Las imprecisiones respecto de los tipos delictivos relacionados con una organización delictiva se salvan en la actual normativa contractual con la remisión a la definición recogida en la Decisión marco 2008/841/JAI del Consejo, de 24 de octubre de 2008, relativa a la lucha contra la delincuencia organizada ${ }^{600}$.

Así, de conformidad con lo establecido en el artículo 57.1.a) de la Directiva 2014/24/UE:

"Los poderes adjudicadores excluirán a un operador económico de la participación en un procedimiento de contratación cuando hayan determinado mediante la comprobación a que se refieren los artículos 59, 60 y 61, o tengan constancia de algún otro modo de que dicho operador económico ha sido condenado mediante sentencia firme por:

a) participación en una organización delictiva, tal como se define en

utilizados por el Consejo "para la consecución de los objetivos de la Unión". Entre estos mecanismos, que se enumeraban en sus letras a) a d), figuraban las posiciones comunes, las decisiones marco y los convenios, sin que se estableciera "una distinción en cuanto al tipo de actos que pueden adoptarse en función de la materia", y sin que tampoco se señalase "un orden de prelación entre los diferentes instrumentos (...) de modo que no cabe descartar que el Consejo pueda escoger entre varios instrumentos para regular una misma materia, sin perjuicio de los límites impuestos por la naturaleza del instrumento elegido", tal y como señala la STJCE de 3 de mayo de 2007, Advocaten voor de Wereld, C-303/05, apartados 36 y 37.

${ }^{600}$ DOUE L 300, de 11 de noviembre de 2008. 
el artículo 2 de la Decisión marco 2008/841/JAI del Consejo"601.

Esta disposición es el resultado de la preocupación europea por la criminalidad organizada y plantea un enfoque común en la lucha contra este fenómeno que trasciende las fronteras del Estado. Su principal objetivo consiste en proporcionar a los ciudadanos de la UE un alto grado de seguridad ante la ausencia de fronteras interiores entre los Estados miembros, ya que, la globalización económica ha ampliado las posibilidades de determinados grupos criminales que anteriormente se encontraban circunscritos a espacios geográficos más o menos limitados a acceder a una dimensión transnacional ${ }^{602}$. El planteamiento que lleva a considerar la delincuencia organizada como un hecho que altera los patrones de los comportamientos delictivos tradicionales conduce al establecimiento de una serie de criterios y características capaces de delimitar su contenido. De esta manera, la Decisión marco 2008/841/JAI, elabora un concepto estratégico relativo a qué se entiende por delincuencia organizada y fija las conductas que deben ser objeto de tipificación penal ${ }^{603}$.

${ }^{601}$ También en el artículo 57.4.a) de la Directiva 2014/23/UE («concesiones»).

${ }^{602}$ JAIME JIMÉNEZ, Ó. y CASTRO MORAL, L., "La criminalidad organizada en la Unión Europea. Estado de la cuestión y respuestas institucionales", Revista CIDOB d'Afers Internacionals, núm. 91, septiembre - octubre 2010, pág. 175. En términos parecidos se manifiesta, CARNEVALI RODRÍGUEZ, R., "La criminalidad organizada. Aproximación al Derecho penal italiano, en particular la responsabilidad de las personas jurídicas y la confiscación", Revista de Derecho Penal, núm. 33, mayo - agosto 2011, pág. 83 al señalar que "el proceso globalizador ha permitido el surgimiento de nuevas formas de criminalidad".

${ }^{603}$ Desde el año 1999 y hasta 2008, la estrategia de lucha contra la delincuencia organizada se ha definido en la UE a través de los siguientes instrumentos: En las conclusiones del Consejo Europeo extraordinario celebrado en Tampere (Finlandia) los días 15 y 16 de octubre de 1999, sobre la creación de un espacio de libertad, seguridad y justicia en la UE; en la Estrategia de la Unión Europea para el comienzo del nuevo milenio para la prevención y control de la delincuencia organizada (DOCE C 124, de 3 de mayo de 2000); a través del Programa de La Haya de noviembre de 2004; en la Comunicación de la Comisión relativa a determinadas acciones que deben emprenderse en el ámbito de la lucha contra el terrorismo y otras formas graves de delincuencia, en particular, con el fin de mejorar los intercambios de información, COM (2004) 221 final, de 29 de marzo de 2004; en la Decisión 2004/579/CE, del Consejo, de 29 de abril, por la que se aprueba en nombre de la Comunidad Europea la Convención de las Naciones Unidas contra la delincuencia organizada transnacional; en la Comunicación de la Comisión Desarrollo de un concepto estratégico para 
Habida cuenta de la remisión normativa que hacen las nuevas Directivas se incorporará a las causas de exclusión algunas formas de participación que no habían sido previstas en la Acción común 98/733/JAI pero que, con una formulación casi idéntica, figuran en la Convención de las Naciones Unidas contra la delincuencia organizada transnacional ${ }^{604}$.

A pesar de la actualización normativa a la luz de las nuevas Directivas, volvemos a insistir en la idea de que las dificultades de concreción respecto de las remisiones normativas, debiera compeler al legislador europeo a valorar la conveniencia de recoger las conductas que constituyen delitos vinculados a la participación en un grupo delictivo organizado y cuya condena por sentencia judicial firme van a ocasionar una futura prohibición de contratar, optando por abandonar los reenvíos en tanto que no aportan claridad al régimen aplicable

hacer frente a la delincuencia organizada, COM (2005) 232 final, de 2 de junio de 2005.También en el año 2005, se aprobó por parte de siete Estados miembros (Bélgica, Alemania, España, Francia, Luxemburgo, Países Bajos y Austria), y en principio al margen de la UE, el Tratado de Prüm, por el que se estrechaba la cooperación en materia de intercambio de información sobre terrorismo, criminalidad transfronteriza e inmigración ilegal, y que en febrero de 2007 se integró en parte en la estructura normativa de la UE a través de la Decisión 2008/615/JAI del Consejo, de 23 de junio de 2008, sobre la profundización de la cooperación transfronteriza, en particular en materia de lucha contra el terrorismo y la delincuencia transfronteriza (DOUE L 210, de 6 de agosto de 2008).

Otros instrumentos que actualizan los dispositivos de lucha contra la delincuencia organizada en la UE son la Comunicación de la Comisión al Consejo y al Parlamento Europeo sobre el papel de Eurojust y la Red Judicial Europea en el marco de la lucha contra la delincuencia organizada y contra el terrorismo en la Unión Europea, COM (2007) 644 final, de 23 de octubre de 2007, y la aprobación del Programa marco Seguridad y defensa de las libertades (2007-2013), compuesto por los dos Programas «Prevención y lucha contra la delincuencia» y «Prevención, preparación y gestión de las consecuencias del terrorismo y otros riesgos en materia de seguridad». Véase también la Resolución del Parlamento Europeo, de 25 de octubre de 2011, sobre la delincuencia organizada en la Unión Europea [P7_TA (2011) 0459].

${ }^{604}$ La Convención de las Naciones Unidas contra la delincuencia organizada transnacional (conocida como «Convención de Palermo» por la ciudad donde fue suscrita) se adoptó mediante la Resolución A/RES/55/25, de 15 de noviembre de 2000, con motivo de la $55^{\mathrm{a}}$ Asamblea General de las Naciones Unidas. Entró en vigor el 29 de septiembre de 2003 y fue celebrada, en nombre de la Comunidad Europea, mediante la Decisión 2004/579/CE, del Consejo, de 29 de abril (DOUE L 261, de 6 de agosto de 2004, la versión en castellano se encuentra publicada a partir de la pág. 100). 
y dificultan su comprensión ${ }^{605}$.

Pese a la crítica expuesta, y tomando como base lo dispuesto en la Decisión marco 2008/841/JAI del Consejo, lo esencial para hacer efectiva la prohibición de contratar es concretar el concepto y las características del término «organización delictiva» u organización criminal si atendemos a la versión inglesa. De esta manera, y a efectos de esta Decisión marco, se entiende por organización delictiva:

"una asociación estructurada de más de dos personas, establecida durante un cierto período de tiempo y que actúa de manera concertada con el fin de cometer delitos sancionables con una pena privativa de libertad o una medida de seguridad privativa de libertad de un máximo de al menos cuatro años o con una pena aún más severa, con el objetivo de obtener, directa o indirectamente, un beneficio económico u otro beneficio de orden material' ${ }^{\prime 606}$.

En atención a esta definición, podríamos haber entendido encuadradas dentro del concepto de organización delictiva a las organizaciones terroristas y, por tanto, entender ampliada la prohibición de contratar más allá de los sectores

${ }^{605}$ Otro argumento a favor son los cambios en el marco normativo, así por ejemplo, el Parlamento Europeo en su Resolución, de 25 de octubre de 2011, sobre la delincuencia organizada en la Unión Europea, pide a la Comisión que presente, antes de finales de 2013, una propuesta de Directiva que contenga una definición más concreta de la delincuencia organizada y defina mejor las características clave del fenómeno, centrándose en especial en el concepto clave de organización, y que tome en consideración también las nuevas formas de delincuencia organizada que no se contemplan en la Decisión marco 2008/841/JAI.

${ }^{606}$ En la Propuesta de Directiva del Parlamento Europeo y del Consejo sobre coordinación de los procedimientos de adjudicación de los contratos públicos de suministro, de servicios y de obras, COM (2000) 275 final, de 30 de agosto de 2000, se recogía en el artículo 46, apartado 1, letra a) una definición similar al excluir de la participación en un contrato que hubiera cometido "infracciones graves participando en las actividades de una organización delictiva, entendiendo por tal una asociación estructurada, establecida durante un cierto tiempo, y que actúe de manera concertada con el fin de obtener beneficios patrimoniales y, en su caso, de influir de manera indebida en el funcionamiento de la autoridad pública", (DOCE C 29E, de 30 de enero de 2001). A este respecto, véase lo dicho en la página 265 de esta memoria doctoral. 
de la defensa y seguridad - incluso antes de su inclusión en la nueva enumeración de prohibiciones de contratar - puesto que la Decisión marco no limita el concepto a la obtención de un beneficio patrimonial, sino que lo extiende al "objetivo de obtener, directa o indirectamente, un beneficio económico u otro beneficio de orden material", y lo cierto es que los grupos terroristas pueden participar directamente en la delincuencia organizada o mantener asociaciones con delincuentes o agrupaciones delictivas en ámbitos como el tráfico de armas y de drogas, la trata de personas, el fraude financiero, el blanqueo de capitales y la extorsión 607 .

Con respecto a los delitos relativos a la participación en una organización delictiva, el citado texto, después de acuñar la definición de organización delictiva, vincula a los Estados miembros a tipificar como delito los siguientes tipos de conducta y que son los que amparan una prohibición de contratar obligatoria:

a) la conducta de toda persona que, de manera intencionada y a sabiendas de la finalidad y actividad general de la organización delictiva o de su intención de cometer los delitos en cuestión, participe activamente en las actividades ilícitas de la organización, incluida la facilitación de información o de medios materiales, reclutando a nuevos participantes, así como en toda forma de financiación de sus actividades a sabiendas de que su participación contribuirá al logro de la finalidad delictiva de esta organización;

b) la conducta de toda persona que consista en un acuerdo con una o más

\footnotetext{
${ }^{607}$ En el sentido de considerar incluidos en la definición de criminalidad organizada a los grupos terroristas se muestra ZAFRA ESPINOSA DE LOS MONTEROS, R., "Implicaciones del Tratado de Lisboa en la lucha contra la delincuencia organizada", Revista General de Derecho Penal, núm. 14, noviembre 2010, pág. 16. Por su parte, ANGUITA OLMEDO sostiene que crimen organizado y el terrorismo tienen similares estructuras, pero que su gran diferencia radica en los fines que persiguen y en los daños que producen, puesto que "en el caso del crimen organizado sus fines son el beneficio económico que se obtiene de actos ilícitos o de negocios legales de origen ilícito y los daños, aunque pueden ser personales o físicos, son principalmente materiales y económicos", en ANGUITA OLMEDO, C., "La delincuencia organizada: Un asunto interior de la Unión Europea. Concepto, características e instrumentos para su neutralización", Revista Española de Relaciones Internacionales, núm. 2, julio 2010, págs. 155 y 156 .
} 
personas para proceder a una actividad que, de ser llevada a cabo, suponga la comisión de delitos considerados en el artículo 1, aún cuando esa persona no participe en la ejecución de la actividad.

Por último, no puede dejar de mencionarse que la vinculación de estas conductas con la contratación pública y el establecimiento de una prohibición de contratar como una de las medidas específicas para evitar la penetración de la delincuencia organizada en el sector público, ya aparecían recogidas en el Plan de Acción para luchar contra la delincuencia organizada, adoptado por el Consejo el 28 de abril de 1997 y aprobado por el Consejo Europeo de Ámsterdam en junio de $1997^{608}$, al recomendar la adopción de las medidas necesarias que permitan la exclusión de las organizaciones delictivas o de sus miembros de la participación en procedimientos de contratación pública.

Concretamente, su séptima recomendación se formulaba en los siguientes términos: "Los Estados miembros y la Comisión Europea deben velar por que, en el marco de las licitaciones públicas, la legislación aplicable prevea la posibilidad de que los concursantes que hayan perpetrado delitos relacionados con la delincuencia organizada queden excluidos de la participación en los procedimientos de licitación realizados por los Estados miembros y la Comunidad. En este sentido, debe estudiarse si es posible, y en qué condiciones, excluir a personas que estén siendo investigadas o procesadas por participación en actividades delictivas organizadas. Debe prestarse una atención específica a la posibilidad de fundamentar la exclusión en el origen ilícito de los fondos. La decisión de excluir a una persona de la participación en los procedimientos de licitación debe poder ser recurrida ante los tribunales".

Asimismo, también hay que señalar que por la especificidad que supone la presencia de la mafia en Italia ${ }^{609}$, el ordenamiento italiano, además de las listas

${ }^{608}$ DOCE C 251, de 15 de agosto de 1997.

${ }^{609}$ Utilizamos la expresión de forma genérica, si bien la idiosincrasia del fenómeno nos llevaría a precisar en el ámbito de la Isla de Sicilia la Cosa Nostra, 'Ndrangheta en Calabria, Camorra en Nápoles y Sacra Corona Unita en la región de Apulia. Según CARNEVALI RODRÍGUEZ, la palabra «mafia» se empleó por primera vez en 1865 en la relación del prefecto de Palermo Filippo Gualtiero al Ministro del Interior para referirse a una asociación ilícita, CARNEVALI RODRÍGUEZ, R., "La criminalidad organizada. Aproximación al Derecho penal (...)", op. cit., pág. 82. 
blancas a las que ya hemos hecho referencia anteriormente, prevé dos modelos - uno judicial y otro administrativo - para evitar la participación de operadores económicos vinculados a dicha organización criminal en la adjudicación de contratos públicos: en el Código penal calificándose de pena accesoria y en la legislación contractual como una prohibición de contratar específica y distinta de la condena por participar en una organización delictiva ${ }^{610}$. Así, el Decreto Legislativo núm. 163, de 12 de abril de 2006 (Codice dei contratti pubblici relativi a lavori, servizi e forniture), prevé en su artículo 38.1.b) que serán excluidos de la participación en la adjudicación contractual quienes se encuentren en alguno de los supuestos previstos en el artículo 10 de la Ley núm. 575, de 31 de mayo de 1965, relativa a las medidas contra la mafia (Disposizioni contro la mafia) ${ }^{611}$.

${ }^{610}$ En el Código penal italiano también se distingue entre la participación en una organización criminal y la participación cuando la organización delictiva es de índole mafiosa, de tal manera que por lo que se refiere a la tipificación del delito de asociación para delinquir de corte mafioso, aparece recogido en el artículo 461 bis del Código penal bajo el título «Associazione di tipo mafioso». Este artículo, entre otros aspectos, recoge que "(...) La asociación es de tipo mafioso cuando aquellos que forman parte se aprovechan de la fuerza de intimidación del vínculo asociativo y de la condición de sujeción y de silencio que deriva de la misma para cometer delitos, para adquirir de un modo directo e indirecto la gestión o el control de actividades económicas, de concesiones, de autorizaciones, contratos y servicios públicos o para obtener beneficios o ventajas indebidas para sí o para otros" "L'associazione è di tipo mafioso quando coloro che ne fanno parte si avvalgono della forza di intimidazione del vincolo associativo e della condizione di assoggettamento e di omertà che ne deriva per commettere delitti, per acquisire in modo diretto o indiretto la gestione o comunque il controllo di attività economiche, di concessioni, di autorizzazioni, appalti e servizi pubblici o per realizzare profitti o vantaggi ingiusti per sé o per altri" [Traducción propia].

${ }^{611}$ En el momento actual también habría que tener en consideración la Ley 136, de 13 de agosto de 2010, sobre normativa antimafia. Acerca de la legislación contractual italiana, puede consultarse la contribución de MARINA JALVO, B., "El Derecho de la contratación pública en Italia", a la obra colectiva Derecho de los contratos públicos en la Unión Europea y sus Estados miembros, Lex Nova, Valladolid, 2011, especialmente sus págs. 251 y 252. Igualmente de interés, CONTALDI LA GROTTERIA, C., "La dichiarazione sui requisiti di moralità professionale: ambito soggettivo e oggettivo di applicazione", ponencia presentada en el Seminario Requisiti generali di partecipazione e cause di esclusione: alcune problematiche applicative, celebrado en la Università degli Studi di Trento, el 16 de marzo de 2012, y que puede consultarse desde la página web del Osservatorio di Diritto Comunitario e Nazionale sugli Appalti Pubblici http://www.osservatorioappalti.unitn.it/ [Fecha 


\section{IV.3. Corrupción}

Constituye un lugar común afirmar que la corrupción ha existido en todos los tiempos y afecta a todas las civilizaciones, ya que la persistencia del fenómeno de la corrupción a lo largo de la historia es un hecho cierto desde la antigüedad clásica, si bien su configuración ha ido variando según épocas y culturas $^{612}$.

La amplia y compleja diversidad tipológica que puede revestir este fenómeno ha contribuido a una evidente dificultad para alcanzar una definición unánime sobre el significado del término «corrupción». Este obstáculo ni siquiera se salva con una referencia al origen etimológico del concepto, puesto que las palabras latinas corruptı̌o, corruptiōnis y el verbo rumpere que significa quebrar, romper completamente y destruir son demasiado genéricas como para hacer descansar sobre ellas una acepción inequívoca del fenómeno ${ }^{613}$. Esto es debido,

de consulta: 20 de octubre de 2015].

Sobre la cuestión contratos públicos y mafia en Italia versan las preguntas formuladas por el eurodiputado Armando COSSUTTA del Grupo Confederal de la Izquierda Unitaria Europea/Izquierda Verde Nórdica (GUE/NGL) a la Comisión a raíz de que el Ministro italiano de Infraestructuras y Transportes, Pietro LUNARDI, declarara públicamente en el año 2001 que, "por lo que se refiere a la realización del programa de grandes obras públicas anunciado por el Gobierno Berlusconi, debe tenerse en cuenta que, en la situación italiana, debe convivirse con la Mafia", en la pregunta escrita E-2663/01 (DOCE C 115E, de 16 de mayo de 2002, pág. 142) y preguntas E-3366/01 y E-0373/02 (DOCE C 205E, de 29 de agosto de 2002).

${ }^{612}$ Los primeros supuestos de corrupción conocidos datan del año 3000 A.C., y sobre ellos tratan las obras de NOONAN, J. T., Bribes, Macmillan, New York, 1984 y MALEM SEÑA, J. F., La corrupción: aspectos éticos, económicos, políticos y jurídicos, Gedisa, Barcelona, 2002. Incluso autores como Max WEBER han vinculado el origen de la corrupción con el pecado original cuando los primeros habitantes de la Tierra desobedecieron el mandato divino probando el fruto prohibido, en "La política como vocación", traducción de RUBIO LLORENTE, F., en Max Weber: El político y el científico, 9a ed., Alianza Editorial, Madrid, 1987, pág. 170. Por su parte, Hans-Jürgen KERNER y Stephan RIXEN, lo califican como el segundo oficio más viejo del mundo, citado por IGLESIAS RIO, M. Á. y MEDINA ARNÁIZ, T., "Herramientas preventivas (...)", op. cit., pág. 49.

${ }^{613}$ La dificultad por acercarnos a un concepto unívoco de corrupción es manifestada por la mayor parte de los autores que se ocupan de esta materia como acertadamente expone AMUNDSEN al enumerar las formas y clases de corrupción en Corruption. Definitions and Concepts, Chr. Michelsen Institute, Bergen, 2000. Así, y por lo que 
principalmente, a que se carece de un consenso acerca de todos los elementos que conforman este hecho delictivo, puesto que su conceptualización desde diversas perspectivas (criminológica, filosófica, sociológica, política, moral, pero también económica y jurídica) impiden una delimitación común al no resultar pacíficas cuestiones como la consideración conjunta o separada de la corrupción pública y la privada, la inclusión o no en el concepto de las prácticas clientelares y el nepotismo, o la exigencia de beneficio económico como uno de los elementos característicos de la corrupción.

El único consenso parece manifestarse en relación con su perniciosa influencia tanto en el correcto funcionamiento de las instituciones públicas, como en la alteración de los mercados privados, y ello porque aunque los efectos nocivos de la corrupción se manifiestan claramente en el ámbito económico, inciden igualmente a nivel social y político ${ }^{614}$.

a obras en lengua española se refiere, GARCÍA MEXÍA reconoce que existe una interminable polémica suscitada por el concepto de «corrupción» y que prácticamente podríamos afirmar que existen tantas nociones como autores deciden aventurarse a estudiarla, en GARCÍA MEXÍA, P., Los conflictos de intereses (... ), op. cit., págs. 57 y 62 . En parecidos términos se manifiestan SABÁN GODOY, A., El marco jurídico de la corrupción, Civitas, Madrid, 1991, pág. 13; GARZÓN VALDÉS, E., "Acerca del concepto de corrupción”, Claves de razón práctica, núm. 56, 1995, págs. 26-39, después reproducido en la obra colectiva La corrupción política, Alianza, Madrid, 1997, págs. 39 - 69; RIVERO ORTEGA, R., "Instituciones jurídico-administrativas y prevención de la corrupción", en la obra colectiva La corrupción: Aspectos jurídicos y económicos, Ratio Legis, Salamanca, 2000, pág. 41; RODRÍGUEZ-ARANA MUÑOZ, J., La dimensión ética, Dykinson, Madrid, 2001, pág. 357; ELISEO COCCIOLO, E., "Las mutaciones del concepto de corrupción. De la ambigüedad de las sociedades arcaicas a la complejidad en la época del Estado regulador y de la sociedad del riesgo", Revista de Llengua i Dret, núm. 50, 2008, págs. 17 - 51 y CASTRO CUENCA, C. G., La corrupción en la contratación (...)", op. cit., págs. 27 a 33.

${ }^{614}$ Contrariamente a lo aquí manifestado, algunos autores presentan una actitud más tolerante frente a la corrupción que justifican en que, bajo ciertas condiciones, constituye un resorte útil para activar la vida económica (pagos de engrase - grease the wheels), como es el caso de LEFF, N.H., "Economic Development through bureaucratic corruption", American Behavioral Scientist, vol. 8 (3), 1964, págs. 8-14. Por su parte, MALEM SEÑA manifiesta que la función de los "pagos de engrase" consiste en agilizar, no por la vía normativa, sino por la vía de los hechos, los trámites administrativos, en MALEM SEÑA, J., La corrupción (... ), op. cit., 2002, pág. 63.

Desde una perspectiva menos permisiva con la corrupción, debemos destacar las siguientes: MAURO, P., "Corruption and Growth", Quarterly Journal of Economics, 
El propio Parlamento Europeo ha transmitido su preocupación ante los efectos destructores de la corrupción al manifestar que ésta "influye desfavorablemente en el clima empresarial, la eficacia de los servicios públicos y la confianza de los ciudadanos en sus autoridades" 615 y que, asimismo, "socava el Estado de Derecho, conduce al uso inadecuado de los fondos de la UE proporcionados por los contribuyentes y causa distorsiones del mercado, y ha contribuido a la actual crisis económica"616 . Por ello, y ante la evidencia de numerosos casos de corrupción en el entorno europeo, desde los años noventa, ésta dejó de ser un problema esencialmente nacional y su lucha se ha configurado como uno de los retos planteados a los gobiernos desde las instancias europeas, principalmente desde la Comisión a través de distintas comunicaciones ${ }^{617}$.

vol. 110 (3), 1995, págs. 681-712; TANZI, V., "Corruption around the world: Causes, consequences, scope, and cures", International Monetary Fund. Staff Papers, núm. 45 (4), 1998, págs. 559 - 594; ROSE-ACKERMAN, S., La corrupción y los gobiernos: causas, consecuencias y reforma, Siglo XXI de España, Madrid, 2001 (traducción española de su obra Corruption and government: causes, consequences and reform, Cambridge University Press, Cambridge, 1999).

Centrados en el ámbito de la contratación pública, véase SØREIDE, T., Corruption in public procurement (...)", op. cit., 2002; CELENTANI, M. y GANUZA, J. J., "Corruption and competition in procurement", European Economic Review, vol. 46 (7), 2002, págs. 1273 - 1303; COMPTE, O. LAMBERT-MOGILIANSKY, A. y VERDIER, T., "Corruption and competition in procurement auctions", RAND Journal of Economics, vol. 36 (1), March 2005, págs. 1-15; AURIOL, E., "Corruption in procurement and public purchase", International Journal of Industrial Organization, vol. 24 (5), 2006, págs. 867 - 885; LINDSKOG, H., BREGE, S. y BREHMER, P. O., "Corruption in public procurement and private sector purchasing", Journal of Organisational Transformation and Social, vol. 7 (2), 2010, págs. 167-188 y NEU, D., EVERETT, J., y RAHAMAN, A. S., "Preventing corruption within government procurement: Constructing the disciplined and ethical subject", Critical Perspectives on Accounting, vol. 28, may 2015, págs. 49-61.

${ }^{615}$ Resolución del Parlamento Europeo, de 6 de abril de 2006, sobre la eficacia de la ayuda y la corrupción en los países en desarrollo [2005/2141 (INI)] (DOUE C 293E, de 2 de diciembre).

${ }^{616}$ Declaración del Parlamento Europeo, de 18 de mayo de 2010, sobre los esfuerzos de la Unión Europea en la lucha contra la corrupción, P7_TA (2010) 0176 (DOUE C 161E, de 31 de mayo de 2010). En su Resolución de 15 de septiembre de 2011, se insiste en la idea de que "la corrupción es un ámbito criminal de especial gravedad, con una dimensión transfronteriza y con consecuencias a través y más allá de las fronteras de la UE" [P7_TA (2011) 0388].

${ }^{617}$ Comunicación Una política de la Unión en materia de lucha contra la corrupción, 
Tal como hemos apuntado con anterioridad en este mismo Capítulo, entre las manifestaciones más evidentes del fenómeno de la corrupción se encuentra la relativa a la contratación pública en atención al elevado volumen de recursos económicos que moviliza. La frecuencia e importancia de las actuaciones corruptas en las compras públicas ha motivado la preocupación de la UE en esta materia y ha propiciado la adopción de una serie de medidas para atajar sus manifestaciones.

En este sentido, la política de la UE contra la corrupción persigue principalmente tres objetivos que vienen marcados por una finalidad protectora. El primero de ellos se centra en proteger los intereses financieros de la Unión, ya que la corrupción y otros delitos económicos representan un obstáculo a la recuperación económica por el uso inadecuado y la desviación de fondos públicos. Esta es una de las razones por la cual la primera vez que en los textos normativos de la UE aparecen relacionados corrupción y contratación pública sea en referencia a las condiciones de participación en los contratos financiados con cargo a los recursos del Fondo Europeo de Desarrollo (FED), y concretamente, como una de las cláusulas deontológicas en el Manual RELEX de instrucciones para los contratos de servicios, suministros y obras celebrados en el marco de la cooperación comunitaria en favor de terceros países, elaborado por la Comisión el 10 de noviembre de $1999^{618}$.

A esta regulación contribuye, a nuestro entender, tanto la anteriormente citada Comunicación de la Comisión del año 1997 Una política de la Unión en materia de lucha contra la corrupción, como, en el ámbito internacional, el establecimiento de las normas para la adjudicación de los contratos financiados

COM (97) 192 final, de 21 de mayo de 1997; Comunicación Una política global de la UE contra la corrupción, COM (2003) 317 final, de 28 de mayo de 2003; la Comunicación Lucha contra la corrupción en la UE, COM (2011) 308 final, de 6 de junio y el Informe Anticorrupción de la UE 2014, COM (2014) 38 final, de 3 de febrero de 2014.

${ }^{618}$ SEC (1999) 1801/2 del Servicio Común Relex. Este Manual, cuya finalidad era instaurar prácticas más coherentes y rigurosas en el conjunto de las ayudas exteriores, sin distinguir entre los diferentes programas, faculta a la Comisión a reservarse el derecho a suspender o anular la financiación de los proyectos si se descubren prácticas de corrupción de cualquier naturaleza y en cualquier etapa del procedimiento de contratación. 
con cargo a los recursos del Banco Mundial ${ }^{619}$.

En efecto, desde que en el año 1996, su entonces director James D. WOLFENSOHN pronunciara un discurso sobre lo que denominó el «cáncer de la corrupción ${ }^{620}$, esta institución incorporó directamente esta problemática a su programa de desarrollo, de tal manera que, entre otras medidas, prescribió la inhabilitación para la adjudicación de contratos financiados por el Banco Mundial de aquellos licitadores que hubieran transgredido las disposiciones sobre fraude y corrupción establecidas en el párrafo 1.16 de sus Normas sobre adquisiciones de bienes, obras y servicios distintos a los de consultoría y el párrafo 1.23 de sus Normas sobre selección de consultores ${ }^{621}$.

Así, y de conformidad con la primera de estas disposiciones y con una redacción similar para el supuesto de selección de consultores: "Es política del Banco exigir que los prestatarios (incluidos los beneficiarios de los préstamos

${ }^{619}$ Evidentemente, además de estas referencias, podríamos citar otros muchos factores que determinaron un cambio en la estrategia de lucha contra la corrupción desde la UE a partir de la década de los noventa, como, por ejemplo, la temprana normativa que Estados Unidos aprobó para tipificar como delito el soborno a funcionarios extranjeros - Foreign Corrupt Practices Act (1977) -; la Declaración de las Naciones Unidas contra la Corrupción y el Soborno en las Transacciones Comerciales Internacionales [A/RES/51/191 (1996)]; el Convenio de la OCDE relativo a la lucha contra la corrupción de agentes públicos extranjeros en las transacciones comerciales internacionales (1997); el Convenio penal sobre la corrupción (Convenio núm. 173 del Consejo de Europa), hecho en Estrasburgo, el 27 de enero de 1999 y, también, el Convenio civil sobre la corrupción (Convenio núm. 174 del Consejo de Europa), firmado en Estrasburgo, el 4 de noviembre de 1999.

${ }^{620}$ Sus palabras son reproducidas en http://www.bancomundial.org/temas/anticorrupcion/diez.htm "Seamos claros: debemos atacar el cáncer de la corrupción (... )" "Quisiera hacer hincapié en que el Grupo del Banco no tolerará la corrupción en los programas que respalda, y que estamos adoptando medidas para asegurar que nuestras propias actividades sigan ajustándose a las más elevadas normas de probidad" [Fecha de consulta: 20 de octubre de 2015].

${ }^{621} \mathrm{El}$ objetivo de estas normas es definir las políticas y los procedimientos para seleccionar, contratar y supervisar los contratos para proyectos financiados total o parcialmente con un préstamo del Banco Internacional de Reconstrucción y Fomento (BIRF), un crédito o una donación de la Asociación Internacional de Fomento (AIF) o una donación del Banco Mundial. Las versiones que manejamos son de fecha enero de 2011 y, por esa razón, pueden existir discrepancias con las versiones anteriores en cuanto a la numeración de los preceptos y respecto de las definiciones de las actuaciones constitutivas de fraude y corrupción. 
concedidos por la institución), licitantes, proveedores, contratistas y sus agentes (hayan sido declarados o no), subcontratistas, sub-consultores, proveedores de servicios o proveedores de insumos, y cualquier otro personal asociado, observen las más elevadas normas éticas durante el proceso de contrataciones y la ejecución de los contratos financiados por el Banco". A efectos del cumplimiento de esta política, el Banco:

"Rechazará toda propuesta de adjudicación si determina que el licitante seleccionado para dicha adjudicación o su personal, sus agentes y sub-consultores, subcontratistas, proveedores o sus empleados hayan participado, directa o indirectamente, en prácticas corruptas, fraudulentas, de colusión, coercitivas o de obstrucción para competir por el contrato de que se trate" (letra b);

"Declarará la adquisición viciada y anulará la porción del préstamo asignada a un contrato si en cualquier momento determina que los representantes del Prestatario o de un beneficiario de alguna parte de los fondos del préstamo han participado en prácticas corruptas, fraudulentas, de colusión, coercitivas o de obstrucción durante el proceso de adquisición o la implementación de dicho contrato, sin que el Prestatario haya adoptado medidas oportunas y apropiadas que el Banco considere satisfactorias para corregir la situación, dirigidas a dichas prácticas cuando éstas ocurran, incluyendo no haber informado al Banco oportunamente al haberse conocido dichas prácticas" (letra c);

"Sancionará a una firma o persona, en cualquier momento, de conformidad con el régimen de sanciones del Banco (debarment) ${ }^{622}$, incluyendo declarar dicha firma o persona inelegible públicamente, en forma indefinida o durante un período determinado para: (i) que se le adjudique un contrato financiado por el Banco y (ii) que se le nomine subcontratista, consultor, proveedor o proveedor de ser-

\footnotetext{
${ }^{622}$ Según señala el Apéndice 1, apartado 8, cuando se evalúen las ofertas, el prestatario debe revisar la lista de firmas e individuos sancionados y suspendidos para verificar que los licitantes son elegibles, ya que en la página web del Banco se publica la lista de las compañías declaradas culpables de prácticas corruptas http://go.worldbank.org/K3JQ3JNDC0 [Fecha de consulta: 20 de octubre de 2015].
} 
vicios de una firma que de lo contrario sería elegible para que se le adjudicara un contrato financiado por el Banco" (letra d).

Para la efectiva aplicación de estas medidas imprime contenido a la expresión «práctica corrupta» definiéndola como "el ofrecimiento, suministro, aceptación o solicitud, directa o indirectamente, de cualquier cosa de valor con el fin de influir impropiamente en la actuación de otra persona"623 e incluyendo, por tanto, las distintas modalidades típicas de la corrupción: activa y pasiva ${ }^{624}$.

El segundo propósito de la política europea contra la corrupción responde a la misma finalidad que veíamos respecto de la acción de la UE contra el crimen organizado, puesto que las medidas contra la corrupción también están encaminadas a proteger a los ciudadanos de la Unión en el ELSJ y evitar además con ello, la infiltración de la delincuencia en la economía. De hecho, hemos de recordar que el antiguo artículo 29 TUE preveía el objetivo de la Unión de ofrecer a los ciudadanos un alto grado de seguridad dentro de un espacio de libertad, seguridad y justicia mediante la "prevención y la lucha contra la delincuencia, organizada o no, en particular el terrorismo, la trata de seres humanos y los delitos contra los niños, el tráfico ilícito de drogas y de

${ }^{623}$ Para los fines de estas Normas, la palabra "persona" se refiere a un funcionario público que actúa con relación al proceso de contratación o la ejecución del contrato; y en este mismo contexto, el concepto "funcionario público" incluye a personal del Banco Mundial y a empleados de otras organizaciones que toman o revisan decisiones relativas a los contratos.

Sobre estas cuestiones, resulta obligatoria la cita a la obra de WILLIAMSELEGBE, S., Fighting corruption in public procurement: A comparative analysis of disqualification measures, Hart Publishing, Oxford, 2012 y en "The debarment of corrupt contractors from World Bank-financed contracts", Public Contract Law Journal, vol. 36 (3), 2007, que en su pág. 286, y en alusión a la política anti-corrupción del Banco Mundial, define la corrupción como el "abuso del cargo público para beneficio privado", para después pasar a describir cada una de las conductas reprochables por parte de la normativa de adquisiciones del Banco, es decir, qué se entiende por práctica corrupta, práctica fraudulenta, práctica de colusión, práctica coercitiva y práctica de obstrucción (págs. 287 y 288) y WILLIAMS, S., "World Bank introduces new measures to reduce fraud and corruption in Bank-financed projects and the administration of Bank loans", PPLR, vol. 16 (5), 2007, págs. NA152 - 157.

${ }^{624} \mathrm{El}$ Protocolo establecido sobre la base del artículo K.3 del Tratado de la Unión Europea, del Convenio relativo a la protección de los intereses financieros de las Comunidades Europeas, define jurídicamente por primera vez a nivel de la UE los conceptos de «corrupción pasiva» y «corrupción activa» en sus artículos 2 y 3 . 
armas, la corrupción y el fraude", mediante una mayor cooperación judicial, policial y aduanera y la aproximación, cuando así procediese, de las normas penales.

Asimismo, tanto en la Estrategia Europea de Seguridad titulada Una Europa segura en un mundo mejor, aprobada por el Consejo Europeo el 12 de diciembre de $2003^{625}$, como en la Estrategia de Seguridad Interior, adoptada a finales del 2010 bajo la presidencia española, la lucha contra la corrupción se presenta como una de las amenazas principales a las que se enfrenta la UE en atención a su creciente carácter transfronterizo. Además, y como ya hemos señalado, en esta última Estrategia, se incide en el «enfoque administrativo» en la lucha contra la corrupción al manifestar que "para invertir sus beneficios en la economía legal, las redes delictivas se basan en la corrupción y al hacerlo socavan la confianza en las instituciones públicas y el sistema económico"626.

El tercer objetivo es el de proteger al mercado de estas conductas punibles al tratar de garantizar una competencia justa y leal entre todos los operadores económicos; puesto que, la corrupción - y, como trataremos posteriormente, también el fraude - resultan irreconciliables con los principios que derivan del respeto a las libertades fundamentales y, en especial, con los de igualdad de trato y no discriminación. A este respecto, baste señalar que las Directivas sobre contratación pública, cada una dentro de su ámbito de actuación, tratan de asegurar unas condiciones de competencia reales entre los distintos licitadores y candidatos en la adjudicación de los contratos que lleven a cabo los poderes adjudicadores, y esta finalidad se desvirtúa ante manifestaciones propias de las prácticas corruptas ${ }^{627}$.

${ }^{625}$ La Estrategia Europea de Seguridad fue aprobada por el Consejo Europeo tras la correspondiente iniciativa de la Presidencia griega durante el Consejo informal de Ministros de Asuntos Exteriores (Kastelorizo, mayo de 2003) y las conclusiones del Consejo Europeo de Salónica de los días 19 y 20 de junio de 2003.

${ }^{626}$ Documento del Consejo 5842/2/2010, Estrategia de Seguridad Interior para la Unión Europea COM (2010) 673 final, de 22 de noviembre. Recordemos, igualmente que en el Programa de Estocolmo (2009), se insta a la Comisión a desarrollar una política de lucha contra la corrupción global y a establecer un mecanismo para evaluar la lucha contra la corrupción en todos los Estados miembros.

${ }^{627}$ Véase lo dicho en las páginas 132 y siguientes del Capítulo primero en relación con los fundamentos de las prohibiciones de contratar. También en MEDINA ARNÁIZ, T., "Las respuestas normativas (...)", op. cit., págs. 7 y 8; GIMENO 
Por ello, y como hemos señalado con anterioridad, atajar la corrupción y garantizar una mayor transparencia en la actividad económica y en los procedimientos de adjudicación contractual constituyen algunos de los cometidos del legislador europeo por cuanto evitan la distorsión de la concurrencia y velan por una mayor eficiencia en el gasto público ${ }^{628}$.

Ahora bien, a pesar de los esfuerzos normativos en esta materia, de la creación de órganos como la OLAF, y de la incorporación a las Directivas sobre contratación pública de la obligación de excluir de la participación de una licitación a cualquier candidato o licitador que haya sido condenado en sentencia firme por corrupción, el compromiso europeo por reducir este fenómeno adolece de importantes defectos. De entre todos ellos, vamos a destacar dos por su mayor vinculación con nuestro objeto de estudio: La aplicación del marco jurídico de la lucha contra la corrupción sigue siendo desigual entre los Estados miembros y la ausencia de un concepto general de qué es corrupción.

Así, la primera objeción que ha de hacerse se sustenta en el distinto nivel de compromiso político que muestran los Estados miembros ante esta problemática. Sus disparidades dificultan una acción concertada en la materia pues, si nos atenemos a los datos de ratificación de los instrumentos jurídicos internacionales contra la corrupción, comprobamos cómo algunos Estados miembros no han asumido esta responsabilidad o que algunos otros, como es el caso de España, lo han hecho tardíamente ${ }^{629}$. Es más, desde el año 2000, la Comisión en

FELIÚ, J. Ma ., "La Ley de Contratos del Sector Público: ¿una herramienta eficaz (... )", op. cit., pág. 524 y en Las reformas legales de la Ley 30/2007, de Contratos del Sector Público. Alcance y efectos prácticos, Civitas-Thomson Reuters, Cizur Menor (Navarra), 2011, quien en la pág. 147 manifiesta que la transparencia y la eficacia son los nuevos ejes sobre los que debe rediseñarse la gestión de la contratación pública, incorporando el principio de integridad "en aras a erradicar la corrupción del mercado de los contratos públicos".

${ }^{628}$ Recordemos que según los datos ofrecidos por el Informe Anticorrupción de la UE 2014, COM (2014) 38 final, de 3 de febrero de 2014, se calcula en 120.000 millones de euros anuales el coste económico que supone la corrupción para la economía de la UE.

${ }^{629}$ El Convenio penal sobre la corrupción (Convenio núm. 173 del Consejo de Europa) entró en vigor de forma general el 1 de julio de 2002 y para España el 1 de agosto de 2010 después de su ratificación publicada en el BOE núm. 182, de 28 de julio de 2010. Su Protocolo adicional (Convenio núm. 191 del Consejo de Europa) 
su Estrategia del Milenio sobre la prevención y el control de la delincuencia organizada, ya compelía a los Estados miembros a ratificar los instrumentos de lucha contra la corrupción que se habían gestado en el propio seno de la Unión ante la indiferencia de alguno de ellos en hacerlo (Recomendación núm. $27)^{630}$.

De hecho, en este momento, Alemania no ha ratificado el Convenio Penal sobre la corrupción del Consejo de Europa ${ }^{631}$; cuatro Estados miembros no han ratificado su Protocolo Adicional (Alemania, Estonia, Italia, y República Checa) $)^{632}$ y seis más no han ratificado el Convenio Civil sobre la corrupción (Alemania, Dinamarca, Irlanda, Luxemburgo, Portugal y Reino Unido). Otros cinco Estados siguen idéntico criterio respecto del Convenio de la OCDE sobre la lucha contra la corrupción de los agentes públicos extranjeros en las transacciones comerciales internacionales ${ }^{633}$ (Chipre, Letonia, Lituania, Malta, Rumanía); no obstante, estos Estados no son miembros de la OCDE y, de hecho, Bulgaria es el único Estado miembro que, sin ser parte de esta Organización, ha adoptado este Convenio.

Conforme a este Convenio, los Estados signatarios se comprometen a tomar las medidas necesarias para tipificar como delito el que: "una persona deliberadamente ofrezca, prometa o conceda cualquier beneficio indebido, pecuniario o de otra clase, directamente o mediante intermediarios, a un agente público extranjero, para ese agente o para un tercero, con el fin de que el agente actúe o se abstenga de actuar en relación con el ejercicio de funciones oficiales con el fin de conseguir o de conservar un contrato u otro beneficio irregular en la

entró en vigor el 1 de febrero de 2005 y fue ratificado por España el 17 de enero de 2011 (BOE núm. 56, de 7 de marzo de 2011). Asimismo, el Convenio civil sobre la corrupción (Convenio núm. 174 del Consejo de Europa), entró en vigor de forma general el 1 de noviembre de 2003 y para España el 1 de abril de 2010 después de su ratificación publicada en el BOE núm. 78, de 31 de marzo de 2010.

${ }^{630}$ DOCE C 124, de 3 de mayo de 2000, pág. 26.

${ }^{631}$ Otros Estados miembros como Italia y Austria lo ratificaron en el año 2013.

${ }^{632}$ Hungría y Portugal lo han ratificado en el año 2015, en los meses de febrero y marzo respectivamente.

${ }^{633} \mathrm{http}: / /$ www.oecd.org/daf/anti-bribery/oecdantibriberyconvention.htm (estado de ratificación a 21 de mayo de 2014 [Fecha de consulta: 20 de octubre de 2015]. 
realización de actividades económicas internacionales (artículo 1.1) ${ }^{634}$, y que junto a la Recomendación revisada de 2009 para reforzar la lucha contra la corrupción en las transacciones internacionales, exhorta a los países miembros a que:

"permitan que las autoridades suspendan, en grado conveniente, el acceso a los contratos públicos u otras ventajas otorgadas por los poderes públicos, incluidos los contratos de las administraciones públicas y contratos financiados con ayuda pública al desarrollo, de las empresas que hayan sido declaradas culpables de cohecho de funcionarios públicos extranjeros infringiendo su ley nacional y que, en la medida en que los países miembros apliquen a la contratación pública sanciones a las empresas que hayan sido declaradas culpables de cohecho de funcionarios públicos nacionales, dichas sanciones se apliquen del mismo modo en caso de cohecho de funcionarios públicos extranjeros ${ }^{635}$, y que "apoyen los esfuerzos del Comité de gobierno público de la OCDE en favor de la aplicación de los principios contenidos en la Recomendación del Consejo de 2008 sobre el fortalecimiento de la integridad en los contratos públicos [C(2008)105], asi como los trabajos sobre transparencia en los contratos públicos llevados a cabo en otras organizaciones internacionales gubernamentales como las Naciones Unidas, la Organización mundial de Comercio (OMC) y la Unión Europea"636.

${ }^{634}$ La redacción del artículo 1 que manejamos procede del Instrumento de ratificación por parte de España del Convenio de lucha contra la corrupción de agentes públicos extranjeros en las transacciones comerciales internacionales (BOE núm. 46, de 22 de febrero de 2002).

${ }^{635}$ En una de las notas al pie de esta misma Recomendación se hace constar que "Los sistemas de los países miembros para aplicar sanciones por el cohecho de servidores nacionales difieren en cuanto a si la determinación del cohecho se basa en una condena penal, la consignación o en un procedimiento administrativo; pero en todos los casos se fundamenta en pruebas sustanciales".

${ }^{636} \mathrm{La}$ Recomendación de la OCDE sobre el fortalecimiento de la integridad en los contratos públicos puede consultarse en: http://www.oecd.org/dataoecd/62/24/41549036.pdf (en inglés) Recommendation of the Council on Enhancing integrity in public procurement. Para complementar su lectura, véase además $O E C D$ Principles for Enhancing Integrity in Public Procurement, OECD Publishing, París, 
El segundo inconveniente surge ante la ausencia de un concepto unívoco de corrupción, ya que como hemos avanzado al principio de este epígrafe, y a pesar de las definiciones de «prácticas corruptas» a las que nos hemos venido refiriendo, no se conoce una definición uniforme y general de todos los elementos constitutivos de este fenómeno, aun cuando existe un denominador común en las distintas aproximaciones a su conceptualización que, sintetizado de forma abierta y sin pretensión agotadora, supone la utilización de potestades, a veces públicas, a veces privadas, para obtener cualquier clase de ventaja injustificada ${ }^{637}$.

La dificultad de perfilar un concepto único de corrupción que, junto a su utilidad práctica e interpretativa, pueda ser asumido con un amplio consenso, se intenta suplir en la legislación europea bien a través de la consolidada costumbre de enumerar un catálogo de indicadores y de consecuencias del mismo, o bien por remisión a otros instrumentos jurídicos.

2009.

${ }^{637} \mathrm{La}$ Comunicación sobre la Política de la Unión en materia de lucha contra la corrupción (COM (97) 192 final, de 21 de mayo de 1997, relaciona la corrupción con "los actos de abuso de poder o incorrección en el proceso de toma de decisiones cometidos por motivos indebidos". Asimismo, el artículo 2 de la Convención Civil sobre la corrupción (1999) nos ofrece una definición de corrupción limitada a efectos de dicha Convención, en la que entiende por corrupción "el hecho de solicitar, ofrecer, otorgar o aceptar, directa o indirectamente, un soborno o cualquier otra ventaja indebida o la promesa de una ventaja indebida, que afecte al ejercicio normal de una función o al comportamiento exigido al beneficiario del soborno, de la ventaja indebida o de la promesa de una ventaja indebida".

Una de las definiciones que goza de mayor aceptación respecto de la corrupción pública, y desde la perspectiva de las ciencias sociales, es la ofrecida por NYE al definir la corrupción como "aquella conducta que se desvía de los deberes normales de una función o cargo público por consideraciones privadas, pecuniarias o de estatus, o aquella que viola normas restrictivas de cierto tipo de influencias de beneficio privado", NYE, J.S., "Corruption and Political Development: A Cost-Benefit Analysis", American Political Science Review, vol. 61 (2), 1967, pág. 419, también citado por GARCÍA MEXÍA, P., Los conflictos de intereses (...), op. cit., pág. 59. Por su parte, GONZÁLEZ PÉREZ considera que la corrupción es una manifestación de la degradación de los valores morales que consiste en "la utilización de potestades públicas para intereses particulares", vinculándose con la desviación del servicio a los intereses generales, en GONZÁLEZ PÉREZ, J., Corrupción, ética y moral en las Administraciones públicas, $2^{\mathrm{a}}$ ed., Civitas, Cizur Menor (Navarra), 2014, págs. 39 a 44 y en su pág. 81. 
De esta manera, y en relación a las prohibiciones de contratar del artículo 57, apartado primero letra b), de la Directiva 2014/24/UE, se procura un significado normativo al término corrupción a través de la referencia a dos instrumentos jurídicos que se circunscriben en el ámbito de cooperación intergubernamental propio de la estructura de pilares que existía antes del Tratado de Lisboa, concretamente en el tercer pilar, y sobre los cuales recordemos la Comisión no tenía, hasta el 1 de diciembre de 2014, competencia para emprender acciones contra los Estados miembros por su falta de transposición ${ }^{638}$.

Es así que - además de la referencia a la definición de corrupción según la normativa nacional del poder adjudicador o del operador económico - quedará excluido de la participación en un procedimiento de contratación, el operador económico que haya sido condenado mediante sentencia firme por "corrupción, tal como se define en el artículo 3 del Convenio relativo a la lucha contra los actos de corrupción en los que estén implicados funcionarios de las Comunidades Europeas o de los Estados miembros de la Unión Europea y en el artículo 2, apartado 1, de la Decisión marco 2003/568/JAI del Consejo".

En virtud del artículo 3 del Convenio, de 26 de mayo de 1997, relativo a la lucha contra la corrupción en la que estén implicados funcionarios de las Comunidades Europeas o funcionarios de los Estados miembros de la Unión Europea $^{639}$, constituirá «corrupción activa»:

"el hecho intencionado de que cualquier persona prometa o dé, directamente o por medio de terceros, una ventaja de cualquier na-

${ }^{638}$ Véase del artículo 10 del Protocolo núm. 36 sobre las disposiciones transitorias del Tratado de Lisboa (DOUE C 115, de 9 de mayo de 2008, pág. 322). Recordemos que la «comunitarización» del tercer pilar tras la entrada en vigor del Tratado de Lisboa comporta la desaparición de los instrumentos propios de éste, si bien se mantiene sine die la vigencia de los mismos en tanto no sean derogados, anulados o modificados. Lo mismo ocurre con los convenios celebrados entre los Estados miembros sobre la base del TUE, según establece el artículo 9 del Protocolo núm. 36 sobre las disposiciones transitorias del Tratado de Lisboa. Desde el 1 de diciembre de 2014 - cinco años después de la entrada en vigor del Tratado - la cooperación policial y judicial en materia penal se incluye en el ordenamiento jurídico de la UE.

${ }^{639} \mathrm{El}$ Convenio relativo a la lucha contra la corrupción en la que estén implicados funcionarios de las Comunidades Europeas o funcionarios de los Estados miembros de la Unión Europea, se firmó en Bruselas el 26 de mayo de 1997 y entró en vigor el 28 de septiembre de 2005 (DOCE C 195, de 25 de junio de 1997). 
turaleza a un funcionario, para éste o para un tercero, para que cumpla o se abstenga de cumplir, de forma contraria a sus deberes oficiales, un acto propio de su función o un acto en el ejercicio de su función".

A tenor del artículo 2.1 de la Decisión marco 2003/568/JAI del Consejo, de 22 de julio de $2003^{640}$, constituirá «corrupción activa» en el sector privado:

a) prometer, ofrecer o entregar, directamente o a través de un intermediario, a una persona que desempeñe funciones directivas o laborales de cualquier tipo para una entidad del sector privado, una ventaja indebida de cualquier naturaleza para dicha persona o para un tercero, para que ésta realice o se abstenga de realizar un acto incumpliendo sus obligaciones;

b) pedir o recibir, directamente o a través de un intermediario, una ventaja indebida de cualquier naturaleza, o aceptar la promesa de tal ventaja, para sí mismo o para un tercero, cuando se desempeñen funciones directivas o laborales de cualquier tipo para una entidad del sector privado, a cambio de realizar o abstenerse de realizar un acto incumpliendo sus obligaciones.

Estas definiciones de corrupción que nos ofrece, por remisión, la Directiva sobre contratación pública tratan de salvar, de una parte, la falta de calificación europea de un tipo penal de corrupción cometido por particulares y, por otra, la ausencia de un concepto único que aglutine las diversas actividades delictivas que son consideradas como corruptas. Es por ello que, la definición de corrupción que se establece en las Directivas no es autónoma para la materia contractual, sino que se materializa a través del reenvío a instrumentos jurídicos que se incardinan en el contexto del tercer pilar, y que a nuestro entender no satisfacen las exigencias formuladas por los instrumentos jurídicos internacionales contra la corrupción a los que hemos hecho referencia ${ }^{641}$.

${ }^{640}$ Decisión marco 2003/568/JAI del Consejo, de 22 de julio de 2003, relativa a la lucha contra la corrupción en el sector privado (DOUE L 192, de 31 de julio de 2003).

${ }^{641}$ Nuestra preferencia por construir una definición de corrupción autónoma no 
En base a esta idea central, lo que queda puesto de manifiesto en este tipo de actuaciones delictivas es que el interés de quien toma las decisiones en el proceso contractual sustituye a la objetividad que sería deseable, al prevalerse de su posición para obtener alguna clase de beneficio, para sí o para un tercero, conculcando sus propios deberes y desatendiendo los intereses generales.

Ahora bien, una atinada definición de las conductas que impiden contratar con el sector público por actos de corrupción debiera contemplar las siguientes acciones: En primer lugar, la modalidad de cohecho «activo», es decir, el cometido por un particular adoptando la acción típica de prometer, ofrecer o entregar una ventaja/dádiva con la intención de resultar beneficiado por una decisión pública ${ }^{642}$; incluso, podría ampliarse el ámbito de aplicación por parte de las normativas nacionales a la participación de particulares que actúan como intermediarios en el caso del cohecho «pasivo», cuando recojan la posibilidad de participación de un extraneus en los delitos especiales ${ }^{643}$.

En segundo lugar, debiera incluir también una referencia a la corrupción «activa y pasiva» cuando se lleva a cabo en el transcurso de actividades profesionales - la conocida como corrupción en el sector privado - por tratarse de

es totalmente novedosa, pues ya ha sido manifestada con anterioridad, ni tampoco original puesto que ya se plasmaba en la Propuesta de Directiva del Parlamento Europeo y del Consejo sobre coordinación de los procedimientos de adjudicación de los contratos públicos de suministro, de servicios y de obras COM (2000) 275 final, de 30 de agosto de 2000 (DOCE C 29E, de 30 de enero de 2001).

${ }^{642} \mathrm{El}$ delito de cohecho requiere de la necesaria intervención de dos sujetos, cuyas conductas son distintas pero tendentes a la obtención de una misma finalidad. El cohecho «pasivo» es un delito especial propio, pues solamente puede ser cometido por quien tiene la condición de autoridad o funcionario público, mientras que el cohecho «activo» es un delito común, por lo cual puede ser cometido por cualquier persona. Véase RODRÍGUEZ PUERTA, M. J., El delito de cohecho: problemática jurídicopenal del soborno de funcionarios, Aranzadi, Elcano (Navarra), 1999, págs. 285 y siguientes que tratan sobre el delito de cohecho desde la perspectiva del particular que es la que nos interesa especialmente en este momento.

${ }^{643}$ Como hemos indicado en la nota anterior, en los delitos especiales no toda persona puede ser autor, sino que el tipo penal prevé exclusivamente la autoría de un sujeto activo con especial cualificación. Un «extraneuss» es el particular que participa como inductor, cooperador necesario o cómplice, en un delito especial, y debe responder criminalmente según el grado de participación en el delito (autoría por inducción o por cooperación necesaria o complicidad). 
conductas realizadas por particulares sin requerir la condición de autoridad o funcionario público. Consecuentemente con ello, los elementos de la infracción abarcaría los actos de corrupción que implicasen una distorsión de la competencia en relación con la adquisición de bienes y servicios comerciales cuando el particular promete, ofrece o entrega "a una persona del sector privado, una ventaja indebida de cualquier naturaleza para que realice o se abstenga de realizar un acto incumpliendo sus obligaciones", y también cuando pide, acepta o recibe dicha ventaja indebida "a cambio de realizar o abstenerse de realizar un acto incumpliendo sus obligaciones".

En tercer y último lugar dentro del apartado referente a la corrupción, también se debiera contemplar la modalidad de corrupción que tiene lugar con ocasión de la realización de actividades económicas internacionales, de tal manera que los Estados miembros garantizasen la aplicación de una prohibición de contratar con el sector público a aquellos operadores económicos considerados responsables de corrupción de un agente público extranjero por pretender adquirir una posición de dominio frente a sus competidores a través de la práctica del soborno ${ }^{644}$.

Por lo que respecta a esta última modalidad, es decir, la corrupción de agentes públicos extranjeros, su incorporación al catálogo de causas de exclusión resulta necesaria puesto que el pago de sobornos a funcionarios de otros Estados para obtener contratos en el transcurso de operaciones comerciales internacionales ha desatado alguno de los mayores escándalos de corrupción y fraude en la última década - como es el caso de la multinacional Siemens AG - sin que la empresa incurriera en una prohibición de contratar ${ }^{645}$. Los hechos

\footnotetext{
${ }^{644}$ En este caso, resulta que el artículo 3.4 del Convenio de la OCDE de lucha contra la corrupción de agentes públicos extranjeros en las transacciones comerciales internacionales, ya contempla que "Cada Parte estudiará la imposición de sanciones civiles o administrativas adicionales a una persona susceptible de sanción por la corrupción de un agente público extranjero", y el apartado 24 de los Comentarios a dicho Convenio prevé que "Las sanciones civiles y administrativas distintas de las multas no penales, que puedan imponerse a las personas jurídicas por un acto de corrupción de funcionarios públicos extranjeros son, entre otras: la exclusión del derecho a un beneficio o ayuda pública; la inhabilitación temporal o permanente para participar en la contratación pública o para ejercer una actividad comercial; la sumisión a supervisión judicial y la disolución judicial".
}

${ }^{645}$ En opinión de CLARK y SUPRENANT, el reconocimiento de los sobor- 
son los siguientes: Esta empresa alemana fue condenada en diciembre de 2007 por un tribunal de Múnich a una multa de 201 millones de euros por haber sobornado a funcionarios de Nigeria, Rusia y Libia para que se le adjudicaran contratos públicos en esos países, contabilizándose un total de 77 casos de soborno entre los años 2001 y $2004^{646}$.

Asimismo, en diciembre de 2008, Siemens AG llegó a un acuerdo tras declararse culpable ante un tribunal federal estadounidense y acordó pagar una multa de 450 millones de dólares al Departamento de Justicia por haber violado la Foreign Corrupt Practices Act de 1977, y otros 350 millones en concepto de sanción ante la Comisión estadounidense del mercado de Valores por haber quebrantado esta misma Ley (United States Securities and Exchange Commission $)^{647}$. Entre los sobornos más relevantes que había llevado a cabo esta

nos y el pago en multas por valor de casi mil trescientos millones de euros (1.600 millones de dólares) impuestos por parte de las autoridades alemanas y estadounidenses trataron de evitar una condena que hubiera conducido a una prohibición de contratar en atención a lo dispuesto en el artículo 45 de la Directiva 2004/18/CE. En CLARK, P. y SUPRENANT J. A., "Siemens - Potential Interplay of FCPA Charges and Mandatory Debarment under the $\mathrm{Pu}$ blic Procurement Directive of the European Union", comunicación presentada en el 23rd Annual National Institute on White Collar Crime, celebrado en San Francisco, el 4 de marzo de 2009 http://www.cadwalader.com/assets/article/030409ABASiemensPotentialInterplay.pdf [Fecha de consulta: 20 de octubre de 2015].

Para completar esta información, hay que destacar, sin embargo, que Siemens y el Banco Mundial acordaron un pacto por el cual la filial de Siemens AG, Siemens Rusia, fue suspendida de actividades por un plazo de cuatro años en relación con las infracciones previas al año 2007, por la realización de prácticas corruptas en un proyecto de transporte financiado por el Banco en Rusia, concretamente el Proyecto de Transporte Urbano de Moscú, y una exclusión voluntaria para Siemens AG y sus filiares por dos años de todas las licitaciones que llevara a cabo el Banco Mundial.

${ }^{646}$ Sobre estos hechos, puede consultarse BENITO SÁNCHEZ, D., El delito de corrupción en las transacciones comerciales (...), op. cit., pág. 24; CLARK, P. y SUPRENANT, J. A., "Siemens - Potential Interplay of FCPA Charges and Mandatory Debarment (...)", op. cit. y en el documento de trabajo elaborado por CORRUPTION WATCH "Creating effective corporate sanctions: debarment under EU procurement laws and its impact on enforcing overseas Corruption offences", marzo 2010, http://hawleyfeinstein.files.wordpress.com/2010/02/debarmentas-a-corporate-sanction-the-issues.pdf [Fecha de consulta: 20 de octubre de 2015].

${ }^{647}$ Securities and Exchange Commission v. Siemens Aktiengesellschaft, Civil Ac- 
empresa destacaba el pago de 40 millones de dólares a funcionarios en Argentina para garantizarse la adjudicación de un millonario contrato cuyo objeto contractual era la expedición de documentos de identidad; más de 16 millones de dólares a funcionarios de Venezuela para lograr los contratos de construcción de las líneas de metro en las ciudades de Maracaibo y Valencia; 5 millones de dólares al hijo del primer ministro de Bangladesh para la adjudicación de un contrato de telefonía móvil y cerca de 2 millones de dólares al gobierno de Saddam Hussein dentro del marco del programa «oil-for-food» (petróleo por alimentos).

Tras el conocimiento de estos hechos, se formularon distintas preguntas al Parlamento Europeo por parte de algunos eurodiputados que, por lo general, trataban de esclarecer responsabilidades habida cuenta de que también se abrigaban sospechas de sobornos en contratos públicos con financiación comunitaria $^{648}$. De entre todas las preguntas, vamos a destacar una de ellas referida

tion SEC Litigation Release. No. 20829 (December 15, 2008]: "Siemens has offered to pay a total of $\$ 1.6$ billion in disgorgement and fines, which is the largest amount a company has ever paid to resolve corruption-related charges. Siemens has agreed to pay 350millionindisgorgementtotheSEC.Inrelatedactions, Siemenswillpaya 450 million criminal fine to the U.S. Department of Justice and a fine of $€ 395$ million (approximately $€ 569$ million) to the Office of the Prosecutor General in Munich, Germany. Siemens previously paid a fine of $€ 201$ million (approximately $\$ 285$ million) to the Munich Prosecutor in October 2007". http://www.sec.gov/litigation/litreleases/2008/lr20829.htm [Fecha de consulta: 20 de octubre de 2015].

${ }^{648}$ Pregunta parlamentaria E-5822/06 (EL) de Dimitrios PAPADIMOULIS (GUE/NGL) formulada a la Comisión, el 10 de enero de 2007, en el asunto «Cajas negras» de Siemens; Pregunta E-4139/08 (EL) de Dimitrios PAPADIMOULIS (GUE/NGL) formulada a la Comisión, el 21 de julio de 2008, en el asunto $\mathrm{Ca}$ so «fondos negros» de Siemens y obras con cofinanciación comunitaria; Preguntas E-4224/08 y E-4294/08 (EL) de Stavros LAMBRINIDIS (PSE), Stavros ARNAOUTAKIS (PSE), Maria Eleni KOPPA (PSE), Maria MATSOUKA (PSE), Katerina BATZELI (PSE), Costas BOTOPOULOS (PSE), Anni PODIMATA (PSE) y Evangelia TZAMPAZI (PSE) formuladas al Consejo y a la Comisión el 23 y el 25 de julio de 2008, en el asunto El caso Siemens y el mecanismo europeo de control contra la corrupción; Pregunta parlamentaria E-000745/11 (EL) de Michail TREMOPOULOS (Verts/ALE) a la Comisión, planteada el 7 de febrero de 2011, en el asunto Esclarecimiento del escándalo de Siemens en Grecia; Pregunta E-001910/11 (EL) Ioannis A. TSOUKALAS (PPE) a la Comisión el 8 de marzo de 2011, en el caso Actividades empresariales ilegales gales por parte de Siemens AG y legislación europea. 
a la aplicación de la Directiva 2004/18/CE en Grecia y los «fondos secretos» de Siemens ${ }^{649}$.

En esta pregunta, el europarlamentario PAPADIMOULIS vinculaba el pago de sobornos por parte de Siemens con las causas de prohibición de contratar, tanto en referencia al apartado primero del artículo 45 - que trata expresamente la condena por corrupción - como al apartado segundo por el cual "podrá ser excluido de la participación en el contrato todo operador económico: d) que haya cometido una falta grave en materia profesional, que pueda ser comprobada por cualquier medio que los poderes adjudicadores puedan justificar". Después de señalar que "se ha reconocido, y en consecuencia constatado, que la empresa en cuestión sobornó con fondos secretos a partidos políticos y a otros responsables para obtener ventajas sobre las otras empresas competidoras en la obtención de contratos de obras o suministros del sector público y de las empresas públicas", el eurodiputado planteaba si este artículo 45, párrafo 2, letra d) de la Directiva 2004/18/CE, podría aplicarse en el caso de Siemens e imponer, por tanto, su exclusión de los procedimientos de adjudicación contractual y en caso afirmativo, ¿en qué condiciones?.

A nuestro entender, la respuesta dada por la Comisión elude pronunciarse expresamente sobre los aspectos sustantivos de la cuestión, puesto que centra su atención en los elementos propios de las garantías procesales vinculadas a la aplicación de la prohibición de contratar. Así, la Comisión después de referirse a las disposiciones que posibilitan la exclusión de los procedimientos de adjudicación, indica que ante el supuesto del artículo 45.2.d) de la Directiva 2004/18/CE, y debido a la falta de una definición de "falta profesional grave", deberán ser las normas nacionales las encargadas de especificar el contenido y alcance de las obligaciones en cuestión y las condiciones para su cumplimiento. En el supuesto de que un Estado miembro decida incluir en su normativa la posibilidad de excluir a una persona física o jurídica acusada de corrupción de las licitaciones públicas por la comisión de una falta profesional grave, deberá prever recursos eficaces contra dicha decisión en atención a las obligaciones impuestas en las Directivas 89/665/CEE, 92/13/CEE y 2007/66/CE («Directivas

\footnotetext{
${ }^{649}$ Pregunta parlamentaria P-4219/08 planteada por Dimitrios PAPADIMOULIS (GUE/NGL) a la Comisión, el 18 de julio de 2008 (DOUE C 40, de 18 de febrero de 2009).
} 
de recursos»), así como atender a los derechos procesales recogidos en la Carta de los Derechos Fundamentales de la Unión Europea y en el Convenio para la Protección de los Derechos Humanos y de las Libertades Fundamentales.

Estas referencias normativas ofrecen una aclaración respecto de la exigencia de seguridad jurídica derivada de la aplicación de una prohibición de contratar, y como tal serán tratadas en un momento posterior de esta memoria doctoral; sin embargo, hemos de destacar que la Comisión en esta respuesta no establece reglas básicas de actuación ante un supuesto de corrupción, ni imprime contenido a la prohibición obligatoria de excluir a un operador económico condenado por actuaciones corruptas, al ampararse en el manto de la soberanía normativa nacional para determinar los comportamientos propios de la corrupción activa y pasiva.

Esta falta de concreción puede suponer un refugio para la no aplicación de estas prohibiciones, y por ello, nuestra propuesta de fijar los conceptos básicos que configuren los presupuestos de hecho de una prohibición de contratar pretendía garantizar su aplicación ante las divergencias existentes en las normativas contractuales de los Estados miembros frente a los supuestos de prohibiciones de contratar de carácter obligatorio.

Sin embargo - y tal como hemos indicado - la actual reforma de las Directivas de la Unión no ha avanzado en esta dirección y opta por mantener la práctica de las remisiones normativas y no referirse a la dimensión internacional de este fenómeno. No obstante, y a pesar de no ofrecer un concepto autónomo de corrupción ajustado al nuevo modelo de competencias penales de la Unión, las nuevas Directivas sobre contratación pública, añaden al panorama normativo contractual una importante novedad, puesto que en lo que atañe a la causa de prohibición de contratar obligatoria por corrupción, además de remitirse a los instrumentos jurídicos de la UE, se refieren a la corrupción "tal y como se define en la legislación nacional del poder adjudicador o del operador económico", lo que podría permitir ampliar los supuestos prohibitivos, aunque de una manera imprecisa a priori y sin salvar las dificultades de definición a las que nos estamos refiriendo. 


\section{IV.4. Fraude}

El tercero de los ámbitos delictivos susceptibles de amparar una prohibición de contratar de carácter obligatorio para los Estados miembros es el referido al fraude, de tal manera que el artículo 57.1.c) de la Directiva 2014/24/UE y el artículo 38.4.c) de la Directiva 2014/23/UE («concesiones»), requieren que sea excluido de la participación en un contrato público, cualquier operador económico que haya sido condenado mediante sentencia firme por fraude en el marco del artículo 1 del Convenio sobre la protección de los intereses financieros de las Comunidades Europeas ${ }^{650}$.

Dado que el fraude tampoco es un concepto unívoco en los sistemas jurídicos de los Estados miembros, las Directivas de 2014 ofrecen una definición practicable de fraude en un contexto penal - que no administrativo ${ }^{651}-$, de tal manera que lo define como cualquier acción u omisión intencionada relativa tanto a los ingresos como a los gastos del presupuesto de la Comunidad que

${ }^{650}$ Se trata del Convenio relativo a la protección de los intereses financieros de las Comunidades Europeas, que se suscribió en Bruselas el 26 de julio de 1995, sobre la base del artículo K.3 del TUE, y que entró en vigor el 17 de octubre de 2002 (DOCE C 316, de 27 de noviembre de 1995, pág. 49).

${ }^{651}$ En el contexto administrativo de protección de los intereses financieros se habla de irregularidades y no propiamente de fraudes, de tal manera que una irregularidad es considerada toda infracción de una disposición de la UE por un operador económico que tiene, o tendría, el efecto de perjudicar los intereses financieros de la UE, mientras que el fraude es una irregularidad cometida intencionalmente que constituye una infracción penal. Véase la STJUE de 21 de diciembre de 2011, Chambre de commerce et d'industrie de l'Indre, C-465/10, apartado 43.

En el ámbito administrativo resultan de aplicación el Reglamento (CE, Euratom) 2988/95 del Consejo, de 18 de diciembre de 1995, relativo a la protección de los intereses financieros de las Comunidades Europeas, que evita el concepto de fraude y establece normas generales sobre las comprobaciones a realizar, y las medidas administrativas y sanciones a aplicar por la Comisión en relación con las irregularidades que afecten a los intereses financieros de las Comunidades Europeas (DOCE L 312, de 23 de diciembre de 1995); el Reglamento (Euratom, CE) 2185/96 del Consejo, de 11 de noviembre de 1996, relativo a los controles y verificaciones in situ que realiza la Comisión para la protección de los intereses financieros de las Comunidades Europeas contra los fraudes e irregularidades (DOCE L 292, de 15 de noviembre de 1996), y el Reglamento (CE) 1073/1999 del Parlamento Europeo y del Consejo, de 25 de mayo de 1999, relativo a las investigaciones efectuadas por la Oficina Europea de Lucha contra el Fraude (DOCE L 136, de 31 de mayo de 1999). 
tenga como resultado la mala aplicación, el incorrecto uso o la disminución ilegal o inapropiada de tales ingresos o gastos.

Esta definición se induce del tenor literal del citado artículo 1 que señala que: "A efectos del presente Convenio será constitutivo de fraude que afecta a los intereses financieros de las Comunidades Europeas

a) en materia de gastos, cualquier acción u omisión intencionada relativa: - a la utilización o a la presentación de declaraciones o de documentos falsos, inexactos o incompletos, que tengan por efecto la percepción o la retención indebida de fondos precedentes del presupuesto general de las Comunidades Europeas o de los presupuestos administrados por las Comunidades Europeas o por su cuenta;

- al incumplimiento de una obligación expresa de comunicar una información, que tenga el mismo efecto;

- al desvío de esos mismos fondos con otros fines distintos de aquellos para los que fueron concedidos en un principio; b) en materia de ingresos, cualquier acción u omisión intencionada relativa:

- a la utilización o a la presentación de declaraciones o de documentos falsos, inexactos o incompletos, que tengan por efecto la disminución ilegal de los recursos del presupuesto general de las Comunidades Europeas o de los presupuestos administrados por las Comunidades Europeas o por su cuenta;

- al incumplimiento de una obligación expresa de comunicar una información, que tenga el mismo efecto;

- al desvío de un derecho obtenido legalmente, que tenga el mismo efecto".

Este Convenio (1995) «Convenio PIF» ${ }^{652}$, junto con sus protocolos de acompañamiento («instrumentos $\mathrm{PIF} »$ ), son los primeros instrumentos adoptados en el seno del tercer pilar con la finalidad de establecer una base común para la

${ }^{652}$ El Primer Protocolo, establecido por Acto del Consejo de 27 de septiembre de 1996 (DOCE C 313, de 23 de octubre); el Protocolo de 29 de noviembre de 1996, relativo a la interpretación, con carácter prejudicial, por el Tribunal de Justicia de las Comunidades Europeas, del Convenio sobre la protección de los intereses financieros de las Comunidades Europeas (DOCE C 151, de 20 de mayo de 1997), y el Segundo Protocolo de 19 de junio de 1997 (DOCE C 221, de 19 de julio de 1997). 
protección penal de los intereses financieros de las entonces todavía Comunidades Europeas y arrancan el compromiso de los Estados miembros de estatuir en sus ordenamientos nacionales como hechos punibles las acciones defraudatorias en perjuicio de los intereses financieros de la UE tanto en materia de ingresos (delito fiscal - delito contra la Hacienda pública) como en materia de gastos (fraude de subvenciones) ${ }^{653}$.

Asimismo, y además de contribuir a la protección de las finanzas europeas perfilando los elementos penales del fraude, aborda otras cuestiones referidas a la delincuencia económica $y$, de esta manera, aboga por combatir el flagelo de la corrupción y el blanqueo de capitales al objeto de proteger también los intereses financieros de la Unión. Es así que, en el Primer Protocolo Adicional al Convenio (1996) ${ }^{654}$ se establecen las primeras obligaciones para los Estados miembros en materia de corrupción de funcionarios nacionales, comunitarios y de otros Estados miembros para que tipifiquen los delitos relacionados con el ejercicio de funciones públicas en general y en materia de corrupción en particular (artículos 2 a 5). Estos artículos, al considerar que "los intereses financieros de las Comunidades Europeas pueden verse afectados o amenazados por otras infracciones penales, en especial las constituidas por actos de corrupción cometidos por o respecto de funcionarios nacionales o comunitarios responsables de la percepción, la gestión o el desembolso de los fondos comunitarios sometidos a su control", obligan a los Estados miembros a castigar penalmente la corrupción activa y pasiva con sanciones eficaces, proporcionadas y disuasorias cuando causen o puedan causar perjuicio a los intereses financieros de la Unión ${ }^{655}$.

${ }^{653}$ FERRÉ OLIVÉ, J. C., "Corrupción y fraude de subvenciones", en la obra colectiva Fraude de subvenciones comunitarias y corrupción Vol. I (Delitos financieros, fraude y corrupción en Europa), Ed. Universidad de Salamanca, Salamanca, 2002, págs. 11 - 26, y en la misma obra GÓMEZ RIVERO, C., "La malversación de fondos comunitarios: los artículos 306 y 628 del Código Penal español”, págs. 97 - 109.

${ }^{654}$ Protocolo establecido sobre la base del artículo K .3 del Tratado de la Unión Europea, del Convenio relativo a la protección de los intereses financieros de las Comunidades Europeas, de 27 de septiembre de 1996 (DOCE C 313, de 23 de octubre de 1996).

${ }^{655} \mathrm{El}$ artículo 2.1 señala que, a efectos de este Protocolo, "constituirá corrupción pasiva el hecho intencionado de que un funcionario, directamente o por medio de terceros, solicite o reciba ventajas de cualquier naturaleza, para sí mismo o para 
Por su parte, el Segundo Protocolo del Convenio relativo a la protección de los intereses financieros de las Comunidades Europeas (1997) - por lo que a esta memoria doctoral interesa - contiene disposiciones referidas, en primer lugar, al blanqueo de capitales acordándose su tipificación como delito en todos los Estados miembros (artículo 2). En segundo lugar, se alude a la responsabilidad jurídica de las personas jurídicas previendo que todas ellas puedan ser consideradas jurídicamente responsables por las infracciones de fraude, corrupción y blanqueo de capitales (artículos 3 y 4) y, por último, reclama explícitamente a la Comisión que coopere con los Estados miembros, tanto facilitando asistencia técnica y operativa (artículo 7.1) como participando en el intercambio de información "para facilitar la aclaración de los hechos y para garantizar una acción eficaz contra el fraude, la corrupción activa y pasiva y el blanqueo de capitales" (artículo 7.2) ${ }^{656}$.

Aunque estas disposiciones avanzaban en la vía de lograr la armonización de las legislaciones penales de los Estados miembros, la existencia de sistemas jurídicos diferentes y la tardanza en la ratificación de los citados instrumentos por parte de los Estados miembros ${ }^{657}$, ponen de nuevo de relieve los problemas

un tercero, o el hecho de aceptar la promesa de tales ventajas, por cumplir o no cumplir, de forma contraria a sus deberes oficiales, un acto propio de su función o un acto en el ejercicio de su función, que cause o pueda causar perjuicio a los intereses financieros de las Comunidades Europeas".

Asimismo, y de conformidad con el artículo 3.1 "constituirá corrupción activa el hecho intencionado de que cualquier persona prometa o dé, directamente o por medio de terceros, una ventaja de cualquier naturaleza a un funcionario, para éste o para un tercero, para que cumpla o se abstenga de cumplir, de forma contraria a sus deberes oficiales, un acto propio de su función o un acto en el ejercicio de su función que cause o pueda causar perjuicio a los intereses financieros de las Comunidades Europeas".

${ }^{656}$ El Segundo Protocolo al Convenio relativo a la protección de los intereses financieros de las Comunidades Europeas fue establecido por Acto del Consejo de 19 de junio de 1997 y entró en vigor el 19 de mayo de 2009 (DOCE C 221, de 19 de julio de 1997).

${ }^{657} \mathrm{Al}$ tratarse de instrumentos propios del tercer pilar, su efectiva vigencia estaba supeditada a su ratificación por parte de los Estados miembros y, ante este lapso, la entrada en vigor del Convenio IPF se demoró siete años, aunque finalmente fue ratificado por los entonces 15 Estados miembros el 17 de octubre de 2002.

A este respecto, procede recordar nuevamente que sobre los sectores del antiguo tercer pilar, la Comisión no tenía competencia para emprender acciones contra los 
que conllevan las divergencias en la definición de las actividades que constituyen las acciones típicas del fraude, la corrupción y cualquier otra actividad ilegal que dañe los intereses financieros de la Unión Se dificultan los intercambios de información y la cooperación tanto en el ámbito administrativo como en el judicial respecto de la comisión de estas conductas delictivas, lo que repercute también en la aplicación de las prohibiciones de contratar amparadas en esos comportamientos.

Estas dificultades se intentaron salvar con dos iniciativas, que también perseguían combatir el fraude en la adjudicación de contratos públicos: la redacción del llamado Corpus Juris, un compendio de estudios comparados elaborados por expertos en Derecho penal y procesal penal de todos los Estados miembros realizado a petición del Parlamento y bajo los auspicios de la Comisión ${ }^{658}$ y con la iniciativa de la República Federal de Alemania con vistas a la adopción de una Decisión marco del Consejo relativa a la protección penal contra los comportamientos fraudulentos y de competencia desleal en la adjudicación de contratos públicos en el mercado interior $(2000)^{659}$.

El Corpus Juris de disposiciones penales en materia de protección de los intereses financieros de la Unión Europea - en sus versiones del 1997 y 2000 - persigue sintetizar una serie de principios rectores relacionados con la protección, en vía penal, de los intereses financieros de la Unión con el objetivo

Estados miembros por su falta de transposición hasta el 1 de diciembre de 2014 (véase el artículo 10, apartados 1 y 3, del Protocolo sobre las disposiciones transitorias).

${ }^{658}$ Este estudio fue realizado desde noviembre de 1995 hasta junio de 1996 por un grupo de expertos bajo la dirección de la Sra. Mireille DELMAS-MARTY. El resultado de sus trabajos se dio a conocer en la obra Corpus Juris portant dispositions pénales pour la protection des intérêts financiers de l'Union européenne - introducing penal provisions for the purpose of the financial interest of the European Union, Economica, Paris, 1997.

La última reunión del Grupo de expertos para la revisión y mejora de los resultados de este trabajo tuvo lugar en Florencia en mayo de 1999 y, por esa razón, la versión del texto revisado se conoce con el nombre de Corpus Juris 2000 («versión de Florencia»). Esta versión se puede consultar en la edición a cargo de BACIGALUPO ZAPATER, E. y SILVA CASTAÑO, $\mathrm{M}^{\mathrm{a}}$ L., Un Derecho Penal para Europa: Corpus Juris 2000: Un modelo para la protección penal de bienes jurídicos comunitarios, Dykinson, Madrid, 2004.

${ }^{659}$ DOCE C 253, de 4 de septiembre de 2000, págs. 3-5. 
de crear un espacio judicial europeo y proceder a la unificación del sistema jurídico penal dentro de las fronteras de la $\mathrm{UE}^{660}$.

Este estudio está organizado en treinta y cinco artículos a partir de seis principios básicos y se divide en dos partes: una de Derecho penal material (artículos 1 a 17) y otra que recoge disposiciones de carácter procesal penal (artículos 18 a 35). En lo que al Derecho penal material se refiere, y más concretamente respecto de los delitos que se recogen, se llega a la afirmación de que tales conductas deben ser merecedoras de sanción penal por parte de todos los Estados miembros. Entre las incriminaciones previstas, una de ellas se refiere expresamente a la contratación pública, y así se define como infracción penal el fraude que ha sido cometido con ocasión de un procedimiento de adjudicación contractual ${ }^{661}$.

En efecto, el artículo 2, apartado primero, del Corpus Juris 2000 («versión de Florencia») regula el fraude en concursos y subastas públicas y establece que:

"Constituirá infracción penal la presentación, en un procedimiento de adjudicación regido por el derecho comunitario, de una oferta basada en un acuerdo realizado para restringir la competencia y destinado a conseguir de la autoridad competente la aceptación de una oferta determinada"662.

${ }^{660}$ Sobre la creación de un espacio jurídico y judicial europeo para la protección de los intereses financieros de la Unión Europea versaba la Resolución del Parlamento Europeo, de 12 de junio de 1997 (DOCE C 200, de 30 de junio de 1997, pág. 157).

${ }^{661}$ Debemos señalar que las versiones lingüísticas del Corpus Juris no coinciden totalmente entre sí, pues la versión en castellano se refiere a los fraudes de concursos y subastas públicas, la versión alemana alude a Ausschreibungsbetrug, la inglesa a market-rigging y, por último, la francesa a fraude en matière de passation de marchés.

${ }^{662}$ Esta redacción proviene de la versión reformada de Florencia (2000) y ha sido extraída de la obra Un Derecho Penal para Europa: Corpus Juris 2000 (...), op. cit., pág. 24 y el texto en inglés puede consultarse en la obra coordinada por FABIÁN CAPARRÓS, E., La corrupción: aspectos jurídicos y económicos, Ratio Legis, Salamanca, 2000, y más concretamente en su pág. 178. En el texto del Corpus de 1997, este artículo 2 tenía el siguiente tenor: "Constituirá delito el fraude cometido con ocasión de un procedimiento de adjudicación contractual cuando del mismo se pueda derivar un perjuicio para los intereses financieros de la Comunidad. Se con- 
Pretende, por tanto, que todos los Estados miembros dispongan de prescripciones similares en sus normas penales, no exigiendo que la conducta típica se concrete en un resultado, sino que basta que sea susceptible de perjudicar los intereses financieros por suponer una restricción a la libre competencia al mediar artificios en la licitación ${ }^{663}$. Como señala VALLS PRIETO, se intenta "evitar que se lleguen a producir peligrosas tentaciones y de proteger a los

siderará fraude cualquier acuerdo secreto con los demás concurrentes respecto a las ofertas, o la amenaza, promesa o engaño a los mismos, o el cohecho con funcionario encargado de la adjudicación". Una traducción de la versión en lengua italiana, realizada por Nicolás GARCÍA RIVAS, puede consultarse en la Revista Penal, núm. 3, 1999, págs. 87 y siguientes, quien se refiere al fraude en materia de concesiones en vez de contratos.

${ }^{663}$ En España no solamente se tipifican como delitos los acuerdos fraudulentos celebrados entre un funcionario y los particulares, sino también determinados acuerdos realizados entre estos últimos mediante el delito de alteración de precios en concursos y subastas públicas del artículo 262 Código Penal. Para este delito, si se perpetrara en el ámbito de un concurso o subasta convocados por las Administraciones o entes públicos, se prevé "la pena de inhabilitación especial que comprenderá, en todo caso, el derecho a contratar con las Administraciones públicas por un período de tres a cinco años". Respecto a la confusión que aqueja a la delimitación del bien jurídico protegido con este tipo delictivo, véase, BEATO VIBORA, M., "Protección penal de concursos y subastas de (...), op. cit., págs. 174 a 178, y SOTO NIETO, F., "Alteración de precios en concursos y subastas públicas", Diario La Ley, núm. 4502, de 18 de marzo de 1998, pág. 2. Por su parte, EIRANOVA ENCINAS, sostiene que "su bien jurídico, en un sentido concreto, es la correcta formación de los precios en los concursos y subastas públicas (...). Lo que implica, a su vez, la protección de la libre concurrencia, la igualdad de oportunidades y la transparencia", en EIRANOVA ENCINAS, E., "La alteración de los precios en concursos y subastas «públicos»", Diario La Ley, núm. 4436, de 11 de diciembre de 1997, pág. 3.

En el resto de países de la UE, la mayoría de Estados tipifican el fraude en la adjudicación contractual a través del delito de cohecho y estafa, sin embargo, nos encontramos con excepciones importantes como en el caso francés que consagra el delito de favoritisme, el delito de favoritism anglosajón, la turbata libertà dagli incanti y la astensione dagli incanti italiana y el artículo 298 del Código Penal alemán (StGB) que penaliza los acuerdos restrictivos de la competencia en licitaciones públicas. En referencia a estas figuras, LAGUERRE, A., "Concurrence, favoritisme et sanction pénale dans les marchés publics", Revue Marchés Publics, núm. 271, janvier-février 1993, págs. 26-32; ARROWSMITH, S., LINARELLI, J. y WALLACE, D., Regulating Public Procurement: National (...), op. cit., pág. 823 a 826; TIEDEMANN, K., Manual de Derecho penal económico. Parte general y especial, Tirant Lo Blanch, Valencia, 2010, págs. 303 a 308 y, especialmente, CASTRO CUENCA, C. G., La corrupción (...), op. cit., págs. 353 a 360. 
funcionarios de éstas"664.

Por su parte, en la iniciativa de Decisión marco de la República Federal de Alemania antes citada se conceptualizaban los comportamientos fraudulentos o de competencia desleal en la adjudicación de contratos públicos como "la presentación premeditada por una persona, en nombre de una empresa, de una oferta que se base en un acuerdo ilícito o práctica concertada entre empresas, con la intención de incitar al adjudicador a aceptar una oferta determinada:

a) mediante la promesa, ofrecimiento o concesión a una persona, en forma directa o indirecta, de una ventaja para sí misma o para un tercero como contrapartida a la adjudicación desleal de un contrato público, o

b) mediante cualquier otro modo de cooperación colusiva con la persona responsable de la adjudicación, o

c) con ocultación de cualquier acuerdo de ese tipo.

Asimismo, se establecía la obligación para cada Estado miembro de adaptar las medidas necesarias para que las personas jurídicas fueran consideradas responsables y pudiera imponérseles sanciones tales como medidas de prohibición temporal o permanente del ejercicio de actividades comerciales (artículo 5.1.b).

Esta propuesta se rechazó por causa de su fundamento jurídico erróneo ${ }^{665}$, pero se instaba a asumir el contenido de la iniciativa en otro instrumento más pertinente. Meses después, esta misma finalidad se pretendió cumplir con

${ }^{664}$ VALLS PRIETO, J., El fraude de subvenciones de la Unión Europea. La necesidad de un espacio europeo de normas penales, Dykinson, Madrid, 2005, pág. 193.

${ }^{665}$ La República Federal de Alemania fundamentaba su propuesta en el artículo 31.e) que se refería a las disposiciones relativas a la adopción de Decisiones marco en el Consejo en referencia a "la adopción progresiva de medidas que establezcan normas mínimas relativas a los elementos constitutivos de los delitos y a las penas en los ámbitos de la delincuencia organizada, el terrorismo y el tráfico ilícito de drogas"; sin embargo, la Comisión de Asuntos Jurídicos y Mercado Interior del Parlamento Europeo entendió que el objetivo del proyecto de Decisión marco no consistía en combatir ni la "delincuencia organizada", ni el "terrorismo", ni el "tráfico ilícito de drogas", y que por tanto, la Decisión marco en su formulación inicial carecía de fundamento jurídico. 
la enmienda número 14 que el Parlamento Europeo presentó a la Propuesta de Directiva relativa a la protección penal de los intereses financieros de la Comunidad $(2001)^{666}$.

Esta enmienda - aunque no fue aceptada por la Comisión en su propuesta modificada (2002) - proponía la incorporación en el texto de la Directiva de un artículo que tuviera el siguiente tenor:

"A efectos de la presente Directiva, constituye fraude en materia de adjudicación de concursos y subastas públicos el hecho de que, en un procedimiento de adjudicación regulado por el Derecho comunitario, se presente una oferta basada en un acuerdo para restringir la competencia y con miras a que la autoridad competente acepte una oferta determinada',667.

Tales propósitos resultaban acordes con la finalidad de las Directivas sobre contratación pública en cuanto que tratan de garantizar el respeto a una competencia leal entre todos los operadores económicos, e igualmente, respondía a los objetivos que hemos señalado en relación con los tipos delictivos anteriores, pues no en vano el fraude y la corrupción en la contratación pública "distorsionan el mercado, provocan un aumento de los precios y de las tarifas abonadas por los consumidores para la adquisición de bienes y servicios, y siembran la desconfianza con respecto a la Unión Europea"668.

${ }^{666}$ Propuesta de Directiva del Parlamento Europeo y del Consejo relativa a la protección penal de los intereses financieros de la Comunidad, COM (2001) 272 final, de 23 de mayo de 2001 (DOCE C 240E, de 28 de agosto de 2001, pág. 125), posteriormente modificada por la Comisión COM (2002) 577 final, de 16 de octubre de 2002 .

${ }^{667}$ Informe del Parlamento Europeo A5-0390/2001, de 8 de noviembre de 2001 (DOCE C 153, de 27 de junio de 2002). Esta enmienda fue rechazada por parte de la Comisión argumentando que esta incriminación no correspondía "al concepto ni al objetivo de la presente propuesta de Directiva", COM (2002) 577 final, de 16 de octubre de 2002 (DOCE C 71E, de 25 de marzo de 2003).

${ }^{668}$ Apartado 27 de la Resolución del Parlamento Europeo, de 6 de mayo de 2010, sobre la protección de los intereses financieros de las Comunidades y la lucha contra el fraude, P7_TA (2010) 0155 (DOUE C 81E, de 15 de marzo de 2011). Respecto de la 
Ahora bien, la ausencia de competencia penal por parte de la UE y la consideración del Derecho penal como la ultima ratio de intervención para proteger determinados bienes jurídicos en atención a los principios de subsidiariedad y proporcionalidad, obligaba a buscar la misma eficacia disuasiva a través de otros instrumentos distintos de la pena ${ }^{669}$. El respeto a estos principios, junto con el hecho cierto del retraso de los Estados miembros en ratificar el Convenio y los Protocolos sobre la protección de los intereses financieros de las Comunidades Europeas, forzó el interés en adoptar una normativa de carácter administrativo específicamente destinada a hacer frente al fraude contra los intereses de la Unión, sin la intervención del Derecho penal ${ }^{670}$.

El Libro Blanco sobre la reforma de la Comisión (2000) avaló estas iniciativas, movilizando al conjunto de los servicios de la Comisión, con vistas a proteger mejor los intereses financieros de las Comunidades ${ }^{671}$. Así, y en el

corrupción, la Acción común 98/742/JAI, de 22 de diciembre, ya había señalado que "la corrupción falsea la competencia leal y compromete los principios de apertura y libertad de los mercados, y, en concreto, el correcto funcionamiento del mercado interior, y es contraria a la transparencia y la apertura del comercio internacional".

${ }^{669}$ Comunicación de la Comisión Hacia una política de Derecho penal de la UE: garantizar la aplicación efectiva de las políticas de la UE mediante el Derecho penal, COM (2011) 573 final, de 20 de septiembre de 2011, pág. 10. Esta opinión es compartida por BAJO FERNÁNDEZ, M. y BACIGALUPO SAGGESE, S., Derecho penal económico, Centro de Estudios Ramón Areces, Madrid, 2001, págs. 55 y 56 y por MERCKX, D., Sanctioning Economic Crime. An integrated policy, Brussels University Press, Bruselas, 2006, págs. 137 y 138.

${ }^{670}$ En referencia a la disposición del Corpus Juris 2000 que trata sobre el fraude en concursos y subastas públicas, cabe señalar que el Parlamento Europeo en su Resolución legislativa sobre la Propuesta de Directiva relativa a la protección penal de los intereses financieros de la Comunidad, propuso la incorporación en el texto de la Directiva de un artículo con el siguiente tenor: "A efectos de la presente Directiva, constituye fraude en materia de adjudicación de concursos y subastas públicos el hecho de que, en un procedimiento de adjudicación regulado por el Derecho comunitario, se presente una oferta basada en un acuerdo para restringir la competencia y con miras a que la autoridad competente acepte una oferta determinada", A5-0390/2001, de 8 de noviembre de 2001 (DOCE C 153, de 27 de junio de 2002).

${ }^{671}$ Libro Blanco La reforma de la Comisión, COM (2000) 200 final, de 5 de abril de 2000 (apartado XXVIII). Véase lo dicho en las págs. 221 y siguientes del Capítulo segundo de esta memoria doctoral. 
marco de su política de lucha contra el fraude, la Comisión, desde entonces, viene prestando particular atención a la buena gestión financiera y ha reforzado sus sistemas de control interno para combatir el fraude también respecto de los contratos públicos ${ }^{672}$. Como prueba de ello, la Medida 74 del citado Libro Blanco (2000) versaba sobre el diseño de una base de datos sobre contratos y la Medida 94 hacía referencia al blindaje frente al fraude de los sistemas de gestión de las licitaciones incorporando el compromiso de hacer más eficaz el actual sistema de blindaje contra el fraude a través de contratos estándar, base de datos central sobre contratos y nuevos instrumentos de gestión. Estas acciones propias del Derecho administrativo fueron también objeto de tratamiento por parte de los Planes específicos enmarcados en una estrategia «antifraude» a nivel de la $\mathrm{UE}^{673}$.

En este mismo contexto, y con la intención de reforzar los métodos de lucha contra el fraude en diferentes políticas de la UE, la Propuesta de Directiva del Parlamento Europeo y del Consejo sobre coordinación de los procedimientos de adjudicación de los contratos públicos de suministro, de servicios y de obras (2000), incorporaba al texto contractual dos tipos de actuaciones diferentes relacionadas con las prohibiciones de contratar.

Por una parte, se contemplaba un mecanismo de exclusión obligatoria de aquellos licitadores y candidatos condenados por fraude "a efectos del artículo 1 del Convenio relativo a la protección de los intereses financieros de las Comunidades Europeas, establecido por Acto del Consejo de 26 de julio de 1995" (artículo 46.1.c). Por otra parte, se pretendía la ampliación de los supuestos en los que se admitiría la facultad de excluir a licitadores y candidatos. Así, esta Propuesta preveía en su artículo 46, apartado 2, letra h), la facultad -

${ }^{672}$ En la Estrategia de Lucha contra el fraude que la Comisión adoptó en el año 2000, se afirmaba que "el sector de los contratos públicos es vulnerable al fraude y a la corrupción" y que con el fin de evitar los comportamientos irregulares y reforzar el respeto de las disposiciones jurídicas, se debían acompañar las disposiciones de control administrativo con un sistema de sanciones, COM (2000) 358 final, de 28 de junio de 2000, págs. 9 y 10, y la nota al pie núm. 18.

${ }^{673}$ En su Plan de Acción 2001-2003, la Comisión se preocupaba en tutelar determinados sectores sensibles a la delincuencia económica y financiera al manifestar que "los concursos públicos constituyen un sector sensible para el cual la Comisión desea reforzar los dispositivos preventivos, tanto para sus actividades propias como para las de los Estados miembros", COM (2001) 254 final, de 15 de mayo de 2001, pág. 7. 
que no la obligación - para los Estados miembros de prohibir contratar a todo operador económico que hubiera sido juzgado, por sentencia incluso no firme, por su implicación en un fraude o actividad ilegal a tenor del antiguo artículo 280 del TCE.

Estas dos prohibiciones diferenciadas atendían a la realidad del momento en el que fueron concebidas y distinguían entre las medidas relativas al fraude en el marco comunitario, es decir propias del primer pilar, y las medidas para combatir la delincuencia fuera de dicho marco, o lo que es lo mismo, integradas en el tercer pilar bajo el método de cooperación intergubernamental ${ }^{674}$. Ello implicaba una escisión de la normativa contra el fraude que también se pretendía plasmar en la normativa contractual: una prohibición de carácter obligatorio en base al Convenio PIF - que en aquel momento todavía no había entrado en vigor -, y una prohibición facultativa para los Estados miembros que se residenciaba en el artículo 280 Tratado $\mathrm{CE}^{675}$.

En aquellos momentos, una unificación legislativa penal quedaba aún lejana $y$, tal como se puso entonces de manifiesto, jurídicamente no quedaba claro que la armonización de los derechos nacionales en esta materia pudiera hacerse a partir de una Directiva y sobre la base del pilar comunitario ${ }^{676}$. Por esa razón, la

${ }^{674}$ Recordemos que con la firma del Tratado de Ámsterdam se incluye el Título VI relativo a la cooperación policial y judicial penal, que supone la creación del tercer pilar o Pilar JAI (Justicia y Asuntos de Interior). Sobre estas cuestiones, puede consultarse PÉREZ BERNABEU, B., Los intereses financieros comunitarios: concepto y principios que informan su sistema de protección, Tesis doctoral de la Universidad de Alicante, 2005, disponible en la Biblioteca virtual del Instituto Cervantes, especialmente sus páginas 92 a 98.

${ }^{675}$ Desde la entrada en vigor del Tratado de Ámsterdam (1 de mayo de 1999), y en virtud del artículo 280, TCE la Comunidad estaba obligada, al igual que los Estados miembros, a adoptar medidas para proteger los intereses financieros comunitarios de manera eficaz y equivalente en todos los Estados miembros. Así, "la Unión y los Estados miembros combatirán el fraude y toda actividad ilegal que afecte a los intereses financieros de la Unión mediante medidas adoptadas en virtud de lo dispuesto en el presente artículo, que deberán tener un efecto disuasorio y ser capaces de ofrecer una protección eficaz en los Estados miembros y en las instituciones, órganos y organismos de la Unión".

${ }^{676}$ Estas dudas no sólo se manifestaron en relación con la propuesta de Directiva sobre contratación pública, sino también, y de una manera más contundente, en la tramitación de la Directiva relativa a la protección penal de los intereses financieros 
Propuesta modificada de la Directiva (2002) suprimió la posibilidad de excluir a un operador económico que hubiera sido condenado por fraude o cualquier otra actividad ilegal, en el sentido del artículo 280 TCE y únicamente mantuvo, hasta su redacción actual, la prohibición de carácter obligatorio por condena en sentencia firme por fraude a efectos de lo dispuesto en el Convenio PIF.

Esto no significa que no se adoptaran otro tipo de medidas relacionadas con la prevención del fraude y de las irregularidades en la adjudicación de contratos públicos, ya que en la dirección marcada por las acciones del Libro Blanco de reforma de la Comisión, se apostó por un mayor seguimiento y control de los contratistas y de las operaciones contractuales para combatir el fraude.

Estas actuaciones tuvieron plasmación en la Comunicación sobre blindaje de la legislación y de la gestión de los contratos contra el fraude (2001) que, en su apartado 2.2, calificaba la instauración de una base central de datos de contratos y contratistas como una medida de carácter esencialmente preventivo y disuasivo para comprobar, "antes de la firma de un contrato, la existencia de un contratista potencial como entidad jurídica única o, si ya figura en el registro, la fiabilidad del mismo a la vista de sus relaciones contractuales anteriores o actuales con la Comisión (pérdidas por quiebra, faltas graves, riesgos de doble financiación... ) "677, y también en el Reglamento financiero 1605/2002 del

de la Comunidad, COM (2001) 272 final, de 23 de mayo de 2001, cuando el Parlamento Europeo, en su Dictamen en primera lectura, proponía que "para lograr una protección eficaz y equivalente de los intereses financieros de la Comunidad en los Estados miembros, en el sentido del apartado 4 del artículo 280 del Tratado CE, es más conveniente un reglamento, por su carácter vinculante y su aplicación directa, que una directiva" (enmienda 1) y que "la protección de estos intereses esenciales no debe inscribirse en los debates sobre el reparto de competencias entre el primer y el tercer pilar y debe ser objeto de un enfoque comunitario" (enmienda 3), A5-0390/2001, de 8 de noviembre de 2001 (DOCE C 153, de 27 de junio de 2002).

${ }^{677}$ SEC (2001) 2029 final, de 7 de noviembre de 2001. En esta Comunicación también se manifestaba que "la base central de datos de contratos y contratistas constituirá un buen sistema de bloqueo en caso de detección de problemas: podrá informarse rápidamente de todas las cuentas del contratista en cuestión. Se dará cuenta de ello inmediatamente a todos los servicios de la Comisión, los cuales de esta manera podrán actuar rápidamente y con arreglo a las circunstancias". En la Comunicación Prevención del fraude mediante el empleo de resultados operativos: un enfoque dinámico del blindaje contra el fraude, se definió un nuevo enfoque respecto del blindaje contra el fraude de la legislación, contratos, gestión y sistemas de control, COM 
Consejo, de 25 de junio de 2002, que si bien no resultaba de aplicación a los Estados miembros, señala que "con el fin de prevenir las irregularidades, luchar contra el fraude y la corrupción y fomentar una gestión saneada y eficaz, debe excluirse de la adjudicación de contratos a aquellos candidatos o licitadores que hayan sido declarados culpables de tales actos" (considerando vigésimo quinto y artículo 93, apartado primero).

A pesar de estos avances, la aplicación de estos instrumentos de protección de los intereses financieros más allá de la soberanía territorial de los Estados miembros encuentra las mismas dificultades que hemos señalado en las prohibiciones anteriores. Así, resulta necesario concretar el alcance de los conceptos de fraude e intereses financieros y se hace indispensable la instauración de un mecanismo de intercambio de datos que cubra información más extensa y selectiva para luchar de forma eficaz contra el fraude ${ }^{678}$.

Esta situación, como asegura la Comisión Europea en su Comunicación sobre la protección de los intereses financieros de la Unión Europea a través del Derecho penal (2011), “obstaculiza una protección de Derecho penal equivalente en todo el territorio de la UE y es muy probable que conduzca a resultados diferentes en casos similares en función de las disposiciones penales nacionales aplicables" 679 .

(2007) 806 final, de 17 de diciembre de 2007.

${ }^{678}$ En el Informe de la Comisión del año 2010 sobre protección de los intereses financieros de la UE, se admite que el uso de la base central de exclusiones prevista en el artículo 95 del Reglamento financiero es todavía muy limitado, puesto que solamente cinco Estados miembros admiten estar utilizándola (Bélgica, República Checa, Malta, Austria y Polonia) y que algunos Estados miembros - como Dinamarca, Irlanda, Hungría, Eslovenia, Suecia y España - utilizan sus propias bases de datos. Asimismo, se pone de manifiesto que la causa más frecuente para la exclusión de la participación en un procedimiento de adjudicación contractual es el impago de las cotizaciones sociales e impuestos recogidas en el artículo 45.2.letras e) y f) de la Directiva 2004/18/CE, COM (2011) 595 final, de 29 de septiembre de 2011, pág. 25. En relación con el uso de la base central de exclusiones resulta también de interés los datos que aporta uno de los documentos de trabajo de la Comisión que acompaña al Informe del año 2011, sobre protección de los intereses financieros de la UE y la lucha contra el fraude, COM (408) final y SWD (2012) 228 final, de 19 de julio de 2012, págs. 4 y 5 .

${ }^{679}$ Comunicación sobre la protección de los intereses financieros de la Unión Europea a través del Derecho penal y de las investigaciones administrativas, Una política 
Por esa razón, y en la misma línea argumental de las reflexiones que venimos realizando, debiera haberse establecido una definición común para los Estados miembros de las conductas delictivas que constituyen un fraude contra los intereses financieros de la $\mathrm{UE}^{680}$, pues ha de recordarse, nuevamente, que tras la entrada en vigor del Tratado de Lisboa, la UE cuenta con una base jurídica explícita para la adopción de directivas de Derecho penal con el fin de garantizar la aplicación efectiva de las políticas de la Unión que han sido objeto de medidas de armonización (artículos 86 y 325 TFUE). Además, no lo podemos olvidar, la UE y los Estados miembros tienen la obligación de combatir el fraude y cualesquiera otras actividades ilegales que afecten a los intereses financieros de la Unión. Esta obligación se establece en el artículo 310.6 del TFUE, de conformidad con lo dispuesto en su artículo 325 que exige la adopción de medidas que sirvan de elemento disuasorio y garanticen un marco equitativo.

Este no ha sido, sin embargo, el sentido adoptado por las Directivas sobre contratación pública, aun con la novedad que supone el artículo 35 de la Directiva de concesiones, que expresamente - y bajo el título de "Lucha contra la corrupción y prevención de los conflictos de intereses" - dispone que "Los Estados miembros exigirán a los poderes adjudicadores y a las entidades adjudicadoras que tomen las medidas adecuadas para luchar contra el fraude, el favoritismo y la corrupción y prevenir, detectar y solucionar de modo efectivo los conflictos de intereses que puedan surgir en los procedimientos de adjudicación de concesiones a fin de evitar cualquier distorsión de la competencia y garantizar la transparencia del procedimiento de adjudicación y la igualdad de trato de todos los candidatos y licitadores".

para salvaguardar el dinero de los contribuyentes, COM (2011) 293 final, de 26 de mayo de 2011.

${ }^{680}$ Véase, MUÑOZ DE MORALES ROMERO, M., El legislador penal europeo (... )", op. cit., págs. 291 a 311. 


\section{IV.5. Blanqueo de capitales o financiación del terroris- mo}

Otra de las prohibiciones de contratar de carácter obligatorio que recogen las nuevas Directivas - y que también estaba prevista en el artículo 45 de la Directiva 2004/18/CE - se refiere al blanqueo de capitales cuya definición operativa nos remite al artículo 1 de la Directiva 2005/60/CE, de 26 de octubre de 2005, relativa a la prevención de la utilización del sistema financiero para el blanqueo de capitales y para la financiación del terrorismo ${ }^{681}$.

"Los poderes adjudicadores excluirán a un operador económico de la participación en un procedimiento de contratación cuando hayan determinado mediante la comprobación a que se refieren los artículos 59, 60 y 61, o tengan constancia de algún otro modo de que dicho operador económico ha sido condenado mediante sentencia firme por:

e) blanqueo de capitales o financiación del terrorismo, tal y como se definen en el artículo 1 de la Directiva 2005/60/CE del Parlamento Europeo y del Consejo" ${ }^{682}$ (artículo 57.1.e) de la Directiva 2014/24/UE y artículo 38.4.e) de la Directiva 2014/23/UE).

Esta prohibición de contratar se incorporó al elenco de exclusiones obligatorias de la Directiva 2004/18/CE como consecuencia de aceptar una de las enmiendas aprobadas por el Parlamento. Esta enmienda pretendía dar coherencia a la regulación de estas prohibiciones por la estrecha relación que existe entre el blanqueo de capitales, la corrupción y el crimen organizado, y por su consideración de instrumentos en la lucha - en este caso de carácter trans-

${ }^{681}$ DOUE L 309, de 25 de noviembre de 2005. Cabe indicarse que la Directiva 2005/60/CE será derogada por la Directiva (UE) 2015/849 del Parlamento Europeo y del Consejo, de 20 de mayo de 2015, relativa a la prevención de la utilización del sistema financiero para el blanqueo de capitales o la financiación del terrorismo (DOUE L 141, de 5 de junio de 2015), cuyo plazo de transposición a los Derechos nacionales finalizará el 26 de junio de 2017.

${ }^{682}$ En cuanto a la conjunción disyuntiva «o», que figura en este apartado, debe ser interpretada en el sentido que comprende tanto las actividades propias del blanqueo de capitales como de financiación del terrorismo. 
versal - contra distintas formas de delincuencia ${ }^{\prime 63}$ y con el mismo sentido se mantiene en la nueva regulación.

La técnica utilizada para la delimitación de este tipo delictivo vuelve a ser la remisión a otra norma jurídica que, aunque en este caso sea una Directiva y no uno de los instrumentos propios del tercer pilar, plantea de nuevo alguno de los inconvenientes que hemos visto con anterioridad respecto a la eficacia de estas prohibiciones, como es la de identificar los diversos elementos que integran las conductas punibles que habilitan la prohibición de contratar.

De conformidad con lo establecido en el artículo 1.2 de la Directiva 2005/60/CE se consideran incluidas en la definición de blanqueo de capitales las siguientes actividades realizadas intencionadamente, y ello aunque "se hayan desarrollado en el territorio de otro Estado miembro o en el de un tercer país":

a) la conversión o la transferencia de bienes, a sabiendas de que dichos bienes proceden de una actividad delictiva o de la participa-

${ }^{683}$ Enmienda núm. 80 recogida en el Informe del Parlamento Europeo, de 29 de octubre de 2001, elaborado por la Comisión de Asuntos Jurídicos y Mercado Interior siendo ponente Stefano ZAPPALÀ (A5-0378/2001). Recordemos que en este mismo documento se presentaron enmiendas a la Propuesta de la Comisión para incorporar, como prohibiciones de contratar obligatorias, los delitos relacionados con la droga y el comportamiento contrario a la competencia, fraudulento o desleal en relación con la adjudicación de contratos públicos (enmiendas núms. 81 y 83).

La relación entre estos tipos delictivos ha sido puesta de manifiesto en numerosas ocasiones por la doctrina penal, como es el caso de FABIÁN CAPARRÓS quien afirma que "el reciclaje de fondos de origen ilegal encuentra su medio habitual y alcanza su máximo nivel de desarrollo en el ámbito de la criminalidad organizada", en FABIÁN CAPARRÓS, E., El delito de blanqueo de capitales, Colex, Madrid, 1988, pág. 68. También FERRÉ OLIVÉ, J.C., "Corrupción, crimen organizado y «blanqueo» de capitales en el mercado financiero", en la obra colectiva Blanqueo de dinero y corrupción en el sistema bancario. Delitos financieros, fraude y corrupción en Europa (Vol. II), Ediciones Universidad de Salamanca, Salamanca, 2002, págs. 16 a 22 .

Asimismo, esta patente relación se manifiesta en el ámbito normativo y sirvan como ejemplo los artículos 6 (Penalización del blanqueo del producto del delito) y 7 (Medidas para combatir el blanqueo de dinero) de la Convención de las Naciones Unidas contra la Delincuencia Organizada Transnacional, hecha en Nueva York el 15 de noviembre de 2000, que trata sobre la penalización del blanqueo del producto del delito y las medidas para combatir este delito (BOE núm. 233, de 29 de septiembre de 2003). 
ción en ese tipo de actividad, con el propósito de ocultar o encubrir el origen ilícito de los bienes o de ayudar a personas que estén implicadas en dicha actividad a eludir las consecuencias jurídicas de su acto;

b) la ocultación o el encubrimiento de la naturaleza, el origen, la localización, la disposición, el movimiento o la propiedad reales de bienes o de derechos sobre esos bienes, a sabiendas de que dichos bienes proceden de una actividad delictiva o de la participación en ese tipo de actividad;

c) la adquisición, posesión o utilización de bienes, a sabiendas, en el momento de la recepción de los mismos, de que proceden de una actividad delictiva o de la participación en ese tipo de actividad;

d) la participación en alguna de las actividades mencionadas en las letras precedentes, la asociación para cometer ese tipo de actos, las tentativas de perpetrarlas y el hecho de ayudar, instigar o aconsejar a alguien para realizarlas o de facilitar su ejecución. ${ }^{684}$

Por su parte, el apartado 4 de este mismo artículo entiende por «financiación del terrorismo» "el suministro o la recogida de fondos, por cualquier medio, de forma directa o indirecta, con la intención de utilizarlos o con el conocimiento de que serán utilizados, integramente o en parte, para la comisión de cualquiera de los delitos contemplados en los artículos 1 a 4 de la Decisión marco 2002/475/JAI del Consejo, de 13 de junio de 2002, sobre la lucha contra el terrorismo".

La Directiva - cuyo núcleo central es puramente administrativo ${ }^{685}$ - nace con la intención de armonizar las legislaciones de los Estados miembros para

${ }^{684} \mathrm{El}$ tenor de estos artículos resulta casi idéntico al artículo 6, apartado primero, del Convenio núm. 141 del Consejo de Europa relativo al blanqueo, seguimiento, embargo y decomiso de los productos del delito, que fue adoptado por el Comité de Ministros de Consejo de Europa en septiembre de 1990 en Estrasburgo y abierto a la firma el 8 de noviembre de ese mismo año (BOE núm. 252, del 10 de octubre de 1998) y al ya citado artículo 6 de la Convención de las Naciones Unidas contra la Delincuencia Organizada Transnacional (BOE núm. 233, de 29 de septiembre de 2003).

${ }^{685} \mathrm{El}$ texto se centra en medidas de carácter administrativo, quizá debido a que existían objeciones jurídicas respecto del ejercicio del ius puniendi por parte de la Co- 
tutelar su sistema financiero y garantizar el correcto desenvolvimiento del mercado único, toda vez que la liberalización del movimiento de capitales y de la libre prestación de servicios financieros podía facilitar la movilidad de las actividades delictivas ${ }^{686}$. Proteger la economía contra la infiltración de las redes delictivas es otro de los propósitos de esta Directiva, puesto que trata de evitar que el beneficio económico procedente del delito regrese a los mercados lícitos ocultando el origen delictivo del producto ofreciendo a las personas y propiedades una aparente sensación de legalidad ${ }^{687}$. En este sentido, la lucha contra el blanqueo de capitales resulta un importante mecanismo para combatir otras modalidades de delincuencia grave, en especial el crimen organizado ${ }^{688}$.

munidad y de que las directivas entrasen a regular materia penal. Así se manifiestan ÁLVAREZ PASTOR, D. y EGUIDAZU PALACIOS, F., La prevención del blanqueo de capitales, Aranzadi, Pamplona, 1998, pág. 104 y ARÁNGUEZ SÁNCHEZ, C., El delito de blanqueo de capitales, Marcial Pons, Madrid, 2000, págs. 115 y 116.

${ }^{686}$ Según BLANCO CORDERO, I., El delito de blanqueo de capitales, $2^{\mathrm{a}}$ ed., Aranzadi, Cizur Menor (Navarra), 2002, págs. 117 y 118, existían otros motivos que impulsaron la aprobación de esta Directiva como fueron las tensiones entre Estados Unidos y Europa por la dispar regulación sobre esta materia, pero su estudio excede el objeto de esta memoria doctoral.

${ }^{687}$ ARÁNGUEZ SÁNCHEZ al tratar la expresión «blanqueo de capitales», señala que ésta deriva del inglés money laundering que se popularizó a finales de los años setenta en la jerga utilizada por los mafiosos norteamericanos, que ironizaban sobre la existencia de unas cadenas de lavanderías que se utilizaban para invertir el dinero procedente de la venta de la heroína colombiana, mezclándolo con fondos lícitos para encubrir su origen, en ARÁNGUEZ SÁNCHEZ, C., El delito de blanqueo (...), op. cit., pág. 23.

${ }^{688} \mathrm{El}$ afianzamiento del término «crimen organizado» tiene lugar con la finalización de la Segunda Guerra Mundial, cuando comisiones constituidas para llevar a cabo investigaciones oficiales lo refieren en sus conclusiones, en GÓMEZ DE LIAÑO FONSECA HERRERO, M., Criminalidad organizada y medios extraordinarios de investigación, Colex, Madrid, 2004, pág. 47. No obstante, con anterioridad (años setenta), según señala ZUÑIGA RODRÍGUEZ la noción de "criminalidad organizada" empezó a ser utilizada en el lenguaje de la legislación y de la jurisprudencia italiana frente a la extensión de secuestros de personas y el crecimiento de los grupos terroristas, en que se empiezan a dar regulaciones especiales, de tipo emergencial. Pero es especialmente en los años ochenta cuando la criminalidad organizada emerge como un sujeto político en el escenario italiano, en ZUÑIGA RODRÍGUEZ, L., "Criminalidad organizada, Derecho Penal y sociedad. Apuntes para el análisis", en la obra colectiva El Derecho Penal frente al desafío de la criminalidad organizada, Comares, Granada, 2006, págs. 39 - 68. También SÁNCHEZ GARCÍA DE PAZ, Mª I., La 
La aprobación de la Directiva 2005/60/CE relativa a la prevención de la utilización del sistema financiero para el blanqueo de capitales y para la financiación del terrorismo - conocida también con el sobrenombre de «tercera Directiva» - ha supuesto un paso más en el importante compromiso de los Estados miembros de la UE en la lucha contra estos delitos. De esta manera, esta Directiva mejora y actualiza el contenido de las normas anteriores, incorporando una referencia explícita a la financiación del terrorismo, y ajustándose a la revisión y ampliación de las Cuarenta Recomendaciones que hizo el Grupo de Acción Financiera Internacional sobre el blanqueo de capitales (GAFI) en junio de 2003.

Estas Recomendaciones establecen las medidas que deben adoptar los sujetos obligados, entre los que se encuentran las instituciones financieras y también empresas y profesionales no financieros (contables externos, notarios, abogados, auditores, asesores fiscales, agentes inmobiliarios, casinos de juego, etc.), para impedir el blanqueo de capitales y la financiación del terrorismo. Un aspecto esencial dentro de estas normas es la adopción de medidas de debida diligencia, como la identificación del cliente, la obtención de información sobre el propósito de la relación de negocios y el seguimiento continuo de las transacciones ${ }^{689}$.

Desde octubre de 2001, y por tanto, después de los atentados terroristas del 11 de septiembre, el GAFI incorpora a su agenda la financiación del terrorismo y formula sus Ocho Recomendaciones en esta materia dirigidas a combatir la financiación de los actos y de las organizaciones terroristas. Estas Recomendaciones también son asumidas por parte de la Directiva 2005/60/CE y se procede a emplazar dentro de su ámbito de aplicación la financiación del

criminalidad organizada. Aspectos penales, procesales, administrativos y policiales, Dykinson, Madrid, 2005, especialmente en el Capítulo dedicado a la caracterización del crimen organizado frente a otras formas de asociación para delinquir.

${ }^{689} \mathrm{El}$ GAFI es un grupo intergubernamental constituido dentro de la OCDE en 1989 y constituye el principal organismo internacional en la lucha contra el blanqueo de capitales y la financiación del terrorismo. Cuenta con 36 miembros: 34 países y 2 organizaciones internacionales. Entre sus logros se encuentran las Cuarenta Recomendaciones para combatir el blanqueo de capitales, que constituyen el conjunto de normas internacionales de referencia en la lucha contra este fenómeno. Sus recomendaciones se pueden consultar en: http://www.uif.gov.ar/documentos \%20GAFI/40rec_es.pdf [Fecha de consulta. 20 de octubre de 2015]. 
terrorismo ${ }^{690}$.

Por lo tanto, el desvío de bienes legítimos a la financiación del terrorismo se debe incluir en la definición de blanqueo de capitales y, en este sentido, resulta un acierto que las nuevas Directivas exijan a los Estados miembros recoger en sus legislaciones nacionales que una condena por delitos relacionados con la financiación del terrorismo deba conducir a una prohibición de contratar obligatoria aun fuera del ámbito de la contratación en los sectores de la defensa y seguridad, donde sí se recogía expresamente antes de la regulación del año 2014 (artículo 39.1.e) de la Directiva 2009/81/CE).

\section{IV.6. Delitos de terrorismo o ligados a actividades te- rroristas}

Con anterioridad al año 2014, el artículo 39.1.d) de la Directiva 2009/81/CE, del Parlamento Europeo y del Consejo, de 13 de julio de 2009 «Directiva sectores defensa y seguridad» ${ }^{691}$, ya había incorporado una nueva prohibición de contratar de carácter obligatorio al catálogo de exclusiones previstas en la normativa contractual y lo hizo en términos similares a la regulación actual para los sectores clásicos. Así,

\footnotetext{
${ }^{690} \mathrm{~A}$ este respecto, debe señalarse que la Decisión 2000/642/JAI, de 17 de octubre, creó las Unidades de Inteligencia Financiera (UIF) como los órganos esenciales del sistema de lucha contra el blanqueo de capitales y la financiación del terrorismo (DOCE L 271, de 24 de octubre de 2000). Asimismo, debe resaltarse la importancia de la FIU.NET que es una red informática descentralizada entre estas Unidades para el intercambio seguro de datos. Esta red fomenta la cooperación y permite a las UIF intercambiar información de manera rápida, segura y eficaz, con el objetivo de promover la lucha contra estos delitos.

${ }^{691}$ Directiva 2009/81/CE sobre coordinación de los procedimientos de adjudicación de determinados contratos de obras, de suministro y de servicios por las entidades o poderes adjudicadores en los ámbitos de la defensa y seguridad (DOUE L 216, de 20 de agosto de 2009, pág. 76). El considerando sexagésimo quinto de la Directiva 2009/81/CE manifiesta que "debe evitarse la adjudicación de contratos a operadores económicos que hayan participado en una organización delictiva o que hayan sido declarados culpables de corrupción o fraude contra los intereses financieros de las Comunidades Europeas, de blanqueo de capitales, de financiación del terrorismo o de delitos de terrorismo o ligados al terrorismo".
} 
"los poderes adjudicadores excluirán a un operados económico de la participación en un procedimiento de contratación cuando hayan determinado (...) que dicho operador económico ha sido condenado mediante sentencia firme por un

"delito de terrorismo o delito ligado a las actividades terroristas, según se definen, respectivamente, en el artículo 1 y el artículo 3 de la Decisión marco del 2002/475/JAI, o inducción, complicidad o tentativa, tal como se contemplan en el artículo 4 de la citada Decisión marco" ${ }^{\prime 62}$.

Esta Decisión marco relativa a la lucha contra el terrorismo proporciona a los Estados miembros una definición operativa de qué son actos de terrorismo ante la ausencia de un concepto unívoco y preciso del término «terrorismo» dada la diversidad de elementos que presenta el fenómeno. La falta de consenso de la comunidad internacional, como veremos seguidamente, constituye nuevamente una limitación significativa que repercute sobre la propia eficacia de las respuestas diseñadas para combatirlo desde todas las áreas de gestión pública $^{693}$.

En este sentido, conviene señalar que, aunque el terrorismo es una de las amenazas que afronta el conjunto de la comunidad internacional ante el riesgo de radicalización del fenómeno por motivos tanto religiosos como ideológi$\cos ^{694}$, éste no se ha podido delimitar conceptualmente, y tal circunstancia permite ofrecer únicamente una definición funcional del mismo por referencia

${ }^{692}$ Decisión marco 2002/475/JAI del Consejo, de 13 de junio de 2002, sobre la lucha contra el terrorismo, modificada por la Decisión marco 2008/919/JAI del Consejo, de 28 de noviembre de 2008 (DOUE L 330, de 9 de diciembre de 2008, pág. 21).

${ }^{693}$ GÓMEZ MARTÍN manifiesta que la normativa existente en la materia no resulta particularmente útil en orden a la construcción de este concepto y nos remite a ASÚA BATARRITA para la exposición de la evolución del concepto jurídico de terrorismo en el contexto internacional, GÓMEZ MARTÍN, V., "Notas para un concepto funcional de terrorismo", en la obra colectiva Terrorismo y Estado de Derecho, Iustel, Madrid, 2010, págs. 27 y nota al pie núm. 8.

${ }^{694}$ La Comunicación de la Comisión La política antiterrorista de la UE: logros principales y retos futuros, COM (2010) 386 final, de 20 de julio de 2010, manifiesta que la amenaza del terrorismo sigue siendo significativa y evoluciona constantemente procediendo no sólo del terrorismo islamista, sino también de los terroristas separatistas y anarquistas. Si bien, y como nota positiva, hay que hacer notar que Europa 
a las infracciones que constituyen un delito de terrorismo o un delito ligado a actividades terroristas ${ }^{695}$.

Sus causas e implicaciones son complejas y diversas, si bien resulta un hecho cierto que sus efectos sobre la población y las empresas actúan como factor negativo para el crecimiento económico y para favorecer un clima propicio a las inversiones. Más aun - tal y como afirma el primer considerando de la Decisión marco 2008/919/JAI - "el terrorismo constituye una de las violaciones más graves de los valores universales de la dignidad humana, la libertad, la igualdad y la solidaridad, el respeto de los derechos humanos y de las libertades fundamentales, en los que se basa la Unión Europea. También representa uno de los ataques más graves contra la democracia y el Estado de Derecho, principios que son comunes a los Estados miembros y en los que se basa la Unión Europea"696.

Distintas ramas de conocimiento conceptualizan al «terrorismo» desde sus propias perspectivas y analizan los factores que promueven su surgimiento en

no ha sido objetivo de atentados de gran envergadura desde el año 2005. En este sentido, hay que destacar que en Europa, al igual que en el resto del mundo, la conciencia de amenaza y la vulnerabilidad ante este fenómeno se puso de manifiesto tras los atentados terroristas del 11 de septiembre de 2001 (Nueva York, Washington y Pennsylvania), del 11 de marzo de 2004 (Madrid) y el 7 de julio de 2005 (Londres). Estos atentados, junto con los ataques fallidos en Alemania y Reino Unido en el verano de 2006, reforzaron el compromiso internacional para combatir el terrorismo, como por ejemplo, la adopción de las Resoluciones 1373 (2001), de 28 de septiembre de 2001, y la 1377 (2001), de 12 de noviembre, del Consejo de Seguridad de las Naciones Unidas.

${ }^{695} \mathrm{El}$ antiguo Secretario General de las Naciones Unidas Kofi ANNAN destacó, ya en el año 2005, la necesidad de establecer una definición consensuada de terrorismo que deje claro que "además de las acciones ya prohibidas por los convenios y convenciones existentes, constituye terrorismo toda acción encaminada a causar la muerte o un grave daño corporal a civiles o a no combatientes con el fin de intimidar a la población u obligar a un Gobierno o una organización internacional a hacer o dejar de hacer alguna cosa". Ésta es la definición inicialmente propuesta por el Grupo de Alto Nivel sobre las Amenazas, los Desafíos y el Cambio en su informe de 2 de diciembre de 2004 y se encuentra recogida en la Resolución del Parlamento Europeo sobre la dimensión exterior de la lucha contra el terrorismo internacional [2006/2032 (INI)] (DOUE 287E, de 29 de noviembre de 2007).

${ }^{696}$ Decisión marco 2008/919/JAI del Consejo, de 28 de noviembre (DOUE L 330, de 9 de diciembre de 2008, pág. 21). 
atención a una pluralidad de condicionamientos. Asimismo, su carácter múltiple promueve investigaciones que se centran en las consecuencias del terrorismo en distintos planos (individual, grupal, social, nacional e internacional) y también desde diversos ámbitos (político, económico, sociológico, religioso, etc.). De esta manera, y a título de ejemplo, la sociología ve al terrorismo como una modalidad de delincuencia violenta; desde el ámbito político se analiza la finalidad que el grupo terrorista pretende obtener a través de dichos actos, mientras que desde las ciencias criminológicas y penales se estudia el fenómeno por su repercusión en cuanto afecta a bienes jurídicos individuales y colectivos "hasta el punto de poner en peligro la propia estabilidad del Estado"697.

Aun con las limitaciones de conceptualización que ya se han hecho constar, la Decisión marco 2002/475/JAI, en cuanto que principal instrumento jurídico de la UE en la lucha contra el terrorismo ${ }^{698}$, presenta, con un carácter vinculante, una definición jurídica de terrorismo que los Estados miembros deberán incorporar a sus respectivos ordenamientos penales ${ }^{699}$. Así, se refiere a los delitos de terrorismo como "actos intencionados que, por su naturaleza o su contexto, pueden lesionar gravemente la integridad de un país o de una organización internacional". Este enfoque supone que los bienes jurídicos tutelados por estos delitos son diferentes de los afectados por los delitos comunes, ya que los delitos terroristas - y en este aspecto es que se recoge su intencionalidad

${ }^{697}$ PÉREZ CEPEDA, I., "Definición del terrorismo como un delito internacional", en la obra colectiva Terrorismo y Estado de Derecho, Iustel, Madrid, 2010, pág. 53.

${ }^{698} \mathrm{La}$ acción de la UE en el ámbito de la lucha contra el terrorismo debe completarse, con una referencia a la Estrategia de Lucha contra el Terrorismo adoptada por el Consejo Europeo de los días 14 y 15 de diciembre de 2005, que se basa en cuatro ejes: prevenir, proteger, perseguir y responder, Véase, el Documento 14469/4/05 REV 4, de 30 de noviembre de 2005, The European Union Counter-Terrorism Strategy y la Estrategia para luchar contra la radicalización y la captación de terroristas, de la misma fecha que la anterior, pero revisada en noviembre de 2008 (CS/2008/15175).

${ }^{699}$ Con anterioridad, la Posición Común 2001/931/PESC, de 27 de diciembre de 2001, sobre la aplicación de medidas específicas de lucha contra el terrorismo, ya había ofrecido una definición de terrorismo en este mismo sentido. De tal manera que, los «actos terroristas» se definían como los actos intencionados que pueden dañar seriamente a un país u organización internacional intimidando a su población, imponiendo toda clase de dificultades, y desestabilizando o destruyendo sus estructuras fundamentales, constitucionales, sociales y económicas (artículo 1.3) (DOCE L 344, de 28 de diciembre de 2001, pág. 93). 
delictiva - van dirigidos a socavar las estructuras políticas y económicas del Estado $^{700}$.

Además, la definición de delito de terrorismo recogida en su artículo 1 se completa con una referencia a los elementos objetivos de las conductas típicas enumerando una serie de delitos calificados como terroristas y con una mención a los elementos teleológicos que orientan la conducta delictiva de sus autores.

De acuerdo con este artículo, se considerarán delitos de terrorismo la comisión de los hechos que a continuación se indican, siempre en ellos concurran alguna de las siguientes circunstancias alternativas: "intimidar gravemente a una población; obligar indebidamente a los poderes públicos o a una organización internacional a realizar un acto o a abstenerse de hacerlo; o desestabilizar gravemente o destruir las estructuras fundamentales políticas, constitucionales, económicas o sociales de un país o de una organización internacional"701

\footnotetext{
${ }^{700}$ Según manifiesta GARCÍA RIVAS, "la definición de delito terrorista que establece el art. 1 de la Decisión Marco de 13 de junio de 2002 es diferente de la adoptada en otros instrumentos jurídicos internacionales, como el Convenio general para la represión del terrorismo de 2005 del Consejo de Europa y el Proyecto de Convenio general sobre terrorismo de Naciones Unidas. Al margen de la inoportunidad de cualquier divergencia en este campo, la definición de la Decisión Marco contiene un elemento objetivo de difícil catalogación que exige la aptitud de la conducta para lesionar a un país o a una organización internacional, exigencia que impediría calificar como delito terrorista prácticamente todas las acciones del terrorismo islamista", en la introducción de su artículo "La tipificación "europea" del delito terrorista en la Decisión Marco de 2002: análisis y perspectivas", Revista General de Derecho Penal, núm. 4, noviembre 2005, págs. 1- 27.
}

${ }^{701}$ Muy crítico con estas finalidades se muestra GÓMEZ MARTÍN para quien "obligar indebidamente a los poderes públicos o a una organización internacional a realizar un acto o abstenerse de hacerlo resulta excesivamente amplia, ya que permitiría tratar como supuestos de terrorismo supuestos que deben quedar al margen de dicho ámbito", como por ejemplo, un motín penitenciario provocado con el objetivo de forzar al gobierno de un país a aceptar una determinada concesión. Asimismo, critica que el carácter alternativo de las finalidades típicas pudiera provocar que pueda ser calificado de terrorista un acto que no persiga atemorizar a la colectividad, en GÓMEZ MARTÍN, V., "Notas para un concepto funcional (...)", op. cit., págs. 28 y 29.

También ASÚA BATARRITA menciona que esta definición sería también aplicable "a quienes atenten contra regímenes dictatoriales", porque no señala que la desestabilización deba ser de las bases de un orden democrático, base común de la Unión, en ASÚA BATARRITA, A., "Concepto jurídico de terrorismo (...)", op. cit. 
a) atentados contra la vida de una persona que puedan tener resultado de muerte;

b) atentados graves contra la integridad física de una persona;

c) secuestro o toma de rehenes;

d) destrucciones masivas en instalaciones gubernamentales o públicas, sistemas de transporte, infraestructuras, incluidos los sistemas informáticos, plataformas fijas emplazadas en la plataforma continental, lugares públicos o propiedades privadas, que puedan poner en peligro vidas humanas o producir un gran perjuicio económico;

e) apoderamiento ilícito de aeronaves y de buques o de otros medios de transporte colectivo o de mercancías;

f) fabricación, tenencia, adquisición, transporte, suministro o utilización de armas de fuego, explosivos, armas nucleares, biológicas y químicas e investigación y desarrollo de armas biológicas y químicas;

g) liberación de sustancias peligrosas, o provocación de incendios, inundaciones o explosiones cuyo efecto sea poner en peligro vidas humanas;

h) perturbación o interrupción del suministro de agua, electricidad u otro recurso natural fundamental cuyo efecto sea poner en peligro vidas humanas;

Esta misma línea crítica es seguida por DE CASTILLO CODES, E., "La proyección internacional del terrorismo", Revista de Derecho Penal, núm. $32,1^{\circ}$ cuatrimestre 2011, págs. 62 y 63, para quien el terrorismo viene siendo definido por un sector doctrinal como una estrategia política articulada a través del uso de la violencia, por parte de un grupo organizado con el objetivo de crear en un sector de la población una sensación de terror e inseguridad, facilitando la consecución de sus pretensiones. Así, y según este autor, "la actividad terrorista aglutinaría como elementos inseparables, la violencia y las amenazas, pues la violencia sin amenazas corresponde al contexto de la guerra, mientras que unas amenazas sin violencia se quedan en el ámbito de la propaganda". Sobre los elementos objetivos y subjetivos en los delitos denominados de terrorismo, véase también MATA Y MARTÍN, R., "Unión Europea y armonización legislativa en materia antiterrorista", en la obra colectiva El proceso penal en la Unión Europea: Garantías esenciales / Criminal proceedings in the European Union: essential safeguards, Lex Nova, Valladolid, 2008, especialmente sus págs. 341 a 343. 
i) amenaza de ejercer cualesquiera de las conductas enumeradas en las letras a) a h).

Mediante esta definición se acotan los actos susceptibles de ser considerados delitos de terrorismo por parte de los Estados miembros, se delimitan los delitos a los que serán de aplicación las medidas específicas de cooperación policial y judicial o la intervención de su financiación. Por lo que a esta memoria doctoral interesa, también se concretan las conductas delictivas cuya condena por sentencia judicial conllevan la exclusión obligatoria del licitador o candidato en un procedimiento de adjudicación contractual tanto en los sectores de la defensa y seguridad ${ }^{702}$, como en las actuales Directivas en materia de contratación (artículo 57.1.d) de la Directiva 2014/24/UE y artículo 38.4.d) de la Directiva 2014/23/UE («concesiones»).

Respecto de la segunda remisión para la aplicación de una prohibición de contratar, es decir, una condena por un «delito ligado a actividades terroristas», y a tenor de lo dispuesto en el artículo 3.2 de la citada Decisión marco, en este concepto estarían comprendidos los siguientes actos dolosos:

a) provocación a la comisión de un delito de terrorismo, que incluye la distribución o difusión pública, por cualquier medio, de mensajes destinados a inducir a la comisión de cualesquiera de los delitos citados anteriormente, cuando dicha conducta independientemente de que promueva o no directamente la comisión de delitos de terrorismo, conlleve el riesgo de comisión de uno o algunos de dichos delitos ${ }^{703}$;

\footnotetext{
${ }^{702}$ No obstante, hay que hacer constar que en la Propuesta de Directiva «sectores defensa y seguridad» (2007), pese a recoger estas mismas remisiones normativas para concretar las prohibiciones de contratar de carácter obligatorio, se adoptaba un concepto de terrorismo autónomo y adecuado a las características específicas de los contratos de defensa y seguridad, si bien su similitud con las conductas que hemos señalado eran más que evidentes. Véase, la Propuesta de Directiva sobre coordinación de los procedimientos de adjudicación de determinados contratos públicos de obras, de suministro y de servicios en los ámbitos de la defensa y la seguridad, COM (2007) 766 final, de 5 de diciembre de 2007. GEORGOPOULOS, A., "The New Defence Procurement Directive Enters into Force", PPLR, vol. 19 (1), 2010, NA1-3 y LAZO VITORIA, X., "Los contratos públicos sobre defensa y seguridad en el mercado europeo", RVAP, núm. 82, 2008, págs. 99 - 124.

${ }^{703}$ Según el artículo 3.1.a) de la Decisión marco 2002/475/JAI, después de su mo-
} 
b) captación de terroristas, que requiere la petición a otra persona de que cometa cualesquiera de los delitos enumerados con anterioridad o que asuma la dirección de un grupo terrorista o participe en las actividades de un grupo terrorista, incluido el suministro de información o medios materiales, o mediante cualquier forma de financiación de sus actividades, con conocimiento de que esa participación contribuirá a las actividades delictivas del grupo terrorista ${ }^{704}$;

c) adiestramiento de terroristas, considerándose como tal el impartir instrucciones sobre la fabricación o el uso de explosivos, armas de fuego $u$ otras armas o sustancias nocivas o peligrosas, o sobre otros métodos o técnicas específicos, con el fin de cometer cualesquiera de los citados delitos de terrorismo, a sabiendas de que las enseñanzas impartidas se utilizarán para dichos fines ${ }^{705}$;

dificación por parte de la Decisión marco 2008/919/JAI. En opinión de BERNAL DEL CASTILLO, esta modificación "propone la incorporación o reforma de delitos que se adapten a las nuevas amenazas que proceden de las nuevas formas de atentar en el ámbito terrorista y, aunque no se diga expresamente, son propias del llamado terrorismo ideológico islamista: captación y adoctrinamiento de miembros por medios educativos o ideológicos, entrenamiento, financiación de grupos autónomos y en general difusión de materiales que podrían inducir a personas a cometer actos terroristas", BERNAL DEL CASTILLO, J., "Una visión crítica del nuevo delito de provocación al terrorismo del artículo 579.1", Revista de Derecho Penal, núm. 33, $2^{\circ}$ cuatrimestre 2011 , pág. 67.

${ }^{704} \mathrm{El}$ artículo 3.1.b) de la Decisión marco 2002/475/JAI, es el que ofrece la definición de «captación de terroristas», tras su modificación del año 2008. En este sentido, la Resolución 1624 (2005) del Consejo de Seguridad de las Naciones Unidas pedía a los Estados que adoptasen las medidas necesarias y apropiadas de acuerdo con sus obligaciones de Derecho Internacional, para prohibir por ley la inducción a la comisión de actos terroristas y para impedirlos. El informe del Secretario General de la ONU Unidos contra el terrorismo: recomendaciones para una estrategia mundial de lucha contra el terrorismo, de 27 de abril de 2006, considera esta Resolución como la base para tipificar la inducción a la comisión de atentados y a la captación de terroristas.

${ }^{705}$ La Estrategia global de las Naciones Unidas contra el terrorismo, aprobada el 8 de septiembre de 2006 (A/RES/60/288), afirma que los Estados miembros de la ONU han decidido estudiar los medios para coordinar los esfuerzos internacionales y regionales para combatir el terrorismo en todas sus formas y manifestaciones en Internet http://www.un.org/spanish/terrorism/strategy-resolution.shtml En el considerando cuarto de la Decisión marco 2008/919/JAI ya se ponía de manifiesto que 
d) hurto o robo con agravantes cometido con el fin de cometer cualesquiera de los delitos de terrorismo enumerados anteriormente;

e) chantaje con el fin de cometer cualesquiera de los delitos de terrorismo enumerados anteriormente;

f) libramiento de documentos administrativos falsos con el fin de cometer cualesquiera de los delitos de terrorismo, excepto el de amenazas, y el delito de participación en las actividades de un grupo terrorista, incluido el suministro de información o medios materiales, o mediante cualquier forma de financiación de sus actividades, con conocimiento de que esa participación contribuirá a las actividades delictivas del grupo terroris$t a^{706}$.

El catálogo de conductas punibles que conducen a una prohibición de contratar obligatoria se completa con la referencia a las diferentes formas de participación en la imputación de un delito, es decir, alude a la inducción, complicidad o tentativa, tal como se contemplan en el artículo 4 de la citada Decisión marco. En virtud de este artículo, los Estados miembros adoptarán las medidas necesarias para tipificar como delitos la complicidad para cometer un delito de terrorismo, un delito relativo a un grupo terrorista o un delito ligado a una actividad terrorista; la inducción a la comisión de uno de estos delitos y, en la mayoría de los casos, la tentativa de cometer cualesquiera de ellos ${ }^{707}$.

"Internet se utiliza para inspirar y movilizar a redes terroristas locales e individuos en Europa y también sirve de fuente de información sobre medios y métodos terroristas, funcionando por lo tanto como un "campo de entrenamiento virtual". Por ello, las actividades de provocación a la comisión de delitos de terrorismo, la captación y el adiestramiento de terroristas se han multiplicado con un coste y unos riesgos muy bajos".

${ }^{706}$ Se trata concretamente del delito relativo a un grupo terrorista recogido en el artículo 2, apartado 2, letra b) de la Decisión marco 2002/475/JAI.

${ }^{707}$ Los apartados tercero y cuarto del artículo 4 de la Decisión marco 2002/475/JAI indican que "los Estados miembros adoptarán las medidas necesarias para tipificar como delito la tentativa de cometer cualesquiera de los delitos citados en el artículo 1 , apartado 1, y el artículo 3, apartado 2, letras d) a f), excepto la tenencia mencionada en el artículo 1, apartado 1, letra f), y el delito contemplado en el artículo 1, apartado 1, letra i)"; y que "podrán decidir adoptar las medidas necesarias para tipificar como delito la tentativa de cometer cualesquiera de los delitos contemplados en el artículo 3 , apartado 2 , letras b) y c)". 
Las prohibiciones de contratar obligatorias que se plasman en estas remisiones legislativas - junto con la mención expresa a la Directiva 2005/60/CE en el apartado referido al blanqueo de capitales y financiación del terrorismo - participan del comentado objetivo de prevenir y luchar contra las amenazas directas para la seguridad y para el bienestar ciudadano en el ELSJ, y específicamente por lo que se refiere a los ámbitos de la defensa y seguridad, en la prevención y represión del terrorismo y su financiación como una de las distintas medidas para garantizar la coherencia y la complementariedad de los aspectos interiores y exteriores en la seguridad de la $\mathrm{UE}^{708}$.

En este sentido, hay que reseñar que los esfuerzos de la UE por establecer un marco normativo eficiente frente al fenómeno terrorista - y en general contra toda clase de delincuencia transfronteriza - ha llevado a que las actuales Directivas contemplen este motivo de exclusión de los procedimientos de adjudicación contractual más allá de los contratos incluidos en el ámbito de aplicación de la Directiva 2009/81/CE («sectores defensa y seguridad»). La opción del legislador europeo en incluir esta causa al elenco de prohibiciones de contratar de carácter obligatorio en todos los sectores pudiera ser cuestionada por una falta de especialidad sin que, de igual manera, se incorporen a este catálogo el resto de «delitos europeos» como son el tráfico ilícito de drogas, la falsificación de medios de pago o la delincuencia informática.

Ahora bien, lo que no ofrece lugar a dudas es que este "nuevo" motivo

${ }^{708} \mathrm{El}$ artículo 8 de la Decisión marco 2002/475/JAI, con el fin de castigar los actos terroristas de una manera amplia, contempla asimismo la imposición de sanciones a las personas jurídicas al señalar que "todos los Estados miembros adoptarán las medidas necesarias para que toda persona jurídica a la que se haya declarado responsable con arreglo al artículo 7 sea sancionada con penas efectivas, proporcionadas y disuasorias, que incluirán multas de carácter penal o administrativo y, en su caso, otras sanciones, en particular a) medidas de exclusión del disfrute de ventajas o ayudas públicas; b) medidas de prohibición temporal o permanente del desempeño de actividades comerciales".

Asimismo, en la Directiva para la contratación pública en los sectores de la defensa y seguridad, también se prevé, aunque con un carácter potestativo, que pueda ser excluido de la participación en el contrato todo operador económico en caso de haber sido condenado por la violación de la legislación vigente en materia de exportación de equipos de defensa y/o seguridad sensibles y cuando hubiera cometido una falta grave en materia profesional por vulnerar las obligaciones con respecto a la seguridad de la información o a la seguridad de abastecimiento con motivo de un contrato anterior (artículo 39.2.c) y d) de la Directiva 2009/81/CE). 
de exclusión pueden contribuir a vencer algunas de las dificultades prácticas, y también jurídicas, para la consideración de las prohibiciones de contratar como un eficaz mecanismo para garantizar la integridad en los procedimientos de adjudicación, tal y como sugiere el Libro Verde sobre la modernización de la política de contratación pública de la UE (2011) ${ }^{709}$.

Como ha manifestado REVENGA SÁNCHEZ, la respuesta europea al terrorismo ha ocasionado un repunte de los problemas jurídicos derivados del compromiso por el respeto a los derechos humanos y el dilema que afecta al equilibrio entre libertad y seguridad ${ }^{710}$ referido, por ejemplo, a la transmisión e intercambio de información respecto de las condenas penales por delitos de terrorismo ${ }^{711}$ o a la inclusión de ciudadanos en el registro de personas y entidades vinculadas con el terrorismo - las conocidas como «listas negras ${ }^{712}$.

${ }^{709} \mathrm{COM}$ (2011) 15 final, de 27 de enero de 2011, en su pág. 56.

${ }^{710}$ REVENGA SÁNCHEZ, M., "Protección "multinivel" de los derechos fundamentales y lucha contra el terrorismo a escala europea: a propósito de las listas negras y otras anomalías de la Unión", RVAP, núm. 82 (II), septiembre - diciembre 2008 (Ejemplar dedicado a: La tutela multinivel de los Derechos Fundamentales), pág. 240 quien sostiene que "la lucha europea contra el terrorismo viene siendo en los últimos años un laboratorio que pone a prueba las complejidades de un sistema de protección de los derechos a múltiples bandas".

${ }^{711}$ La Decisión del Consejo 2005/671/JAI, de 20 de septiembre de 2005, establece que los Estados miembros transmitirán información a Europol y Eurojust referente a investigaciones, procesamientos y condenas penales correspondientes a delitos de terrorismo (DOUE L 253, de 29 de septiembre de 2005, pág. 22).

${ }^{712}$ Reglamento (CE) 2580/2001 del Consejo, de 27 de diciembre de 2001, sobre medidas restrictivas específicas dirigidas a determinadas personas y entidades con el fin de luchar contra el terrorismo (DOCE L 344, de 28 de diciembre de 2001) y el Reglamento de Ejecución (UE) 687/2011 del Consejo, de 18 de julio de 2011, por el que se aplica el artículo 2, apartado 3, del Reglamento (CE) 2580/2001 sobre medidas restrictivas específicas dirigidas a determinadas personas y entidades con el fin de luchar contra el terrorismo y se derogan los Reglamentos de Ejecución (UE) 610/2010 y (UE) 83/2011 (DOUE L 188, de 19 de julio).

Sobre la problemática de las listas negras puede consultarse, entre otros, BENGOETXEA CABALLERO, J., "Las listas negras: un agujero negro (...) op.cit., págs. 27 - 47 y BLANCO CORDERO, I., "Derechos Humanos y terrorismo: las listas negras de sospechosos de actividades terroristas", en la obra colectiva El proceso penal en la Unión Europea (...), op. cit., págs. 306 - 335 y NIETO MARTÍN, A., "Kadi (STJCE de 3 de septiembre de 2008) y sus consecuencias para el Derecho penal del Consejo de Seguridad de Naciones Unidas y el Derecho penal de la Unión 
Estas listas, aplicadas al ámbito de la contratación pública, plantean el problema común de su dudosa compatibilidad con derechos fundamentales como el derecho a la tutela judicial, ya que no se contemplaba procedimiento alguno - ni judicial, ni administrativo - para engrosar estas listas, y tampoco se señalaba un procedimiento que permitiera ex post a los afectados revisar dicha inclusión $^{713}$.

A estos inconvenientes habría que añadir además el problema que se suscita en el tratamiento de los datos personales con arreglo a los principios y normas en materia de protección de datos ${ }^{714}$, y el refuerzo de los mecanismos necesarios

Europea", en la obra colectiva Terrorismo y Estado (...), op. cit., págs. 575 - 600.

${ }^{713}$ Recordemos que la Comunicación de la Comisión La contratación pública en la Unión Europea (1998) abogaba por combatir la corrupción en los procedimientos de adjudicación contractual a través de un sistema de «listas negras» que impidiera la adjudicación de contratos públicos a aquellos operadores económicos que hubieran cometido un delito relacionado con la corrupción y evitar con ello el empleo incorrecto del peculio público, COM (1998) 143, de 11 de marzo de 1998, págs. 25 y siguientes.

Sobre esta materia resulta de gran interés y utilidad la consulta del Informe del Relator Especial sobre la promoción y la protección de los derechos humanos y las libertades fundamentales en la lucha contra el terrorismo para la ONU, Sr. Martin SCHEININ (E/CN.4/2006/98, de 28 de diciembre de 2005), el Informe del Comité de Asuntos Jurídicos de la Asamblea Parlamentaria del Consejo de Europa redactado por el Sr. Dick MARTY, sobre la cuestión de las listas negras del Consejo de Seguridad de la ONU y de la UE, que dio lugar a la Resolución de 23 de enero de 2008 y que considera que los procedimientos utilizados por el Consejo de Seguridad de las Naciones Unidas y la Unión Europea para elaborar las listas negras de individuos y grupos supuestamente vinculados al terrorismo violan derechos básicos y son "completamente arbitrarios". En consecuencia, sus miembros insisten en que estos procedimientos deben ser revisados "para preservar la credibilidad de la lucha internacional contra el terrorismo". También resultan esclarecedoras las conclusiones del Abogado General Sr. POAIRES MADURO presentadas el 16 de enero de 2008, en el asunto Kadi y Al Barakaat International Foundation/Consejo y Comisión, C-402/05P, y las conclusiones de la Abogado General Sra. Eleanor SHARPSTON, presentadas el 14 de julio de 2011, Asunto C-27/09P, República Francesa contra People's Mojahedin Organization of Iran, respecto del derecho de defensa y la protección efectiva de la seguridad nacional (apartados 225 y siguientes).

${ }^{714}$ La Decisión marco 2008/977/JAI del Consejo, de 27 de noviembre de 2008, relativa a la protección de datos personales tratados en el marco de la cooperación policial y judicial en materia penal, se aplica únicamente a los datos recogidos o tratados por las autoridades competentes para la prevención, la investigación, la 
para garantizar una cooperación transfronteriza efectiva. Todos estos aspectos serán objeto de tratamiento en el siguiente capítulo de esta memoria doctoral, ya que consideramos oportuno finalizar el bloque de estudio correspondiente a las Directivas de la UE exponiendo las dificultades prácticas a las que se enfrentan las prohibiciones de contratar cuando pretenden actuar como un eficaz instrumento al servicio de objetivos secundarios en la contratación pública y que se refieren tanto a los mecanismos para garantizar la efectividad de dichas prohibiciones, como a la excepción en su aplicación a través de las llamadas medidas autocorrectoras o de «self-cleaning».

\section{IV.7. Trabajo infantil y otras formas de trata de seres humanos}

Otra de las novedades que presenta la nueva regulación de las prohibiciones de contratar de carácter obligatorio para los Estados miembros se refiere a la incorporación de un nuevo comportamiento delictivo al catálogo de los motivos de exclusión de las Directivas de 2014. De esta manera,

"los poderes adjudicadores excluirán a un operados económico de la participación en un procedimiento de contratación cuando hayan determinado (...) que dicho operador económico ha sido condenado mediante sentencia firme por:

trabajo infantil y otras formas de trata de seres humanos, tal como se definen en el artículo 2 de la Directiva 2011/36/UE del

detección o el enjuiciamiento de infracciones penales y la ejecución de sanciones penales (DOUE L 350, de 30 de diciembre de 2008).

La preocupación por conseguir un nivel suficiente de protección de los datos también se reflejó en el acuerdo de cooperación firmado por siete Estados miembros (Alemania, Austria, Bélgica, Países Bajos, Luxemburgo, Francia y España), el 27 de mayo de 2005, en Prüm (Alemania) - conocido como Tratado de Prüm - por el que se estrechaba la cooperación en materia de intercambio de información sobre terrorismo, criminalidad transfronteriza e inmigración ilegal. Este Tratado fue ratificado por España el 18 de julio de 2006 (BOE núm. 307, de 25 de diciembre de 2006) y en febrero de 2007 se integró en la estructura normativa de la UE a través de la Decisión 2008/615/JAI del Consejo, de 23 de junio de 2008, sobre la profundización de la cooperación transfronteriza, en particular en materia de lucha contra el terrorismo y la delincuencia transfronteriza (DOUE L 210, de 6 de agosto de 2008). 
Parlamento Europeo y del Consejo (artículo 57.1.f) de la Directiva 2014/24/UE y artículo 38.4.f) de la Directiva 2014/23/UE («concesiones»).

Antes de analizar esta novedosa prohibición de contratar, consideramos necesario efectuar una serie de consideraciones previas que nos ayuden a evaluar esta disposición. Así en primer lugar, la incorporación de este delito tuvo lugar con ocasión de la Posición del Parlamento Europeo, aprobada en primera lectura el 15 de enero de 2014, al aceptar una serie de enmiendas que trataban sobre este particular ${ }^{715}$. Ahora bien, a nuestro entender, su redacción no resulta lo suficientemente clara para establecer si recoge bajo un solo comportamiento la protección a los menores de edad como sujetos pasivos del delito de trata de seres humanos - por el uso de la conjunción copulativa «y»- o si su objetivo es regular separadamente ambos fenómenos (por una parte el trabajo infantil y, por otra, la trata de seres humanos) atendiendo a sus características respectivas con lo cual hubiera resultado más conveniente el uso de la conjunción disyuntiva $\ll \mathrm{O} »$.

En segundo lugar, a pesar de esta dificultad entendemos que se trata de un único comportamiento punible por dos razones: (i) la abolición del trabajo infantil es lo suficientemente importante como para haber sido objeto de regulación independiente en una nueva prohibición de contratar que cumpliera con el cometido de "cerrar puertas" a la infiltración de la delincuencia en la economía legal en línea con lo establecido en alguno de los convenios fundamentales de la Organización Internacional del Trabajo $(\mathrm{OIT})^{716}$ y en los documentos de la

${ }^{715}$ La enmienda 168 de la Posición del Parlamento en primera lectura tenía el siguiente tenor: "participación en los casos de explotación y trata de seres humanos, asi como de trabajo infantil, contemplados en la Directiva 2011/36/UE del Parlamento Europeo y del Consejo, de 5 de abril de 2011, relativa a la prevención y lucha contra la trata de seres humanos y a la protección de las víctimas". La Comisión de Empleo y Asuntos Sociales planteó también una enmienda que se refería a la "trata de seres humanos, utilización de trabajo infantil u otros crímenes contra los derechos humanos".

${ }^{716}$ El Convenio OIT núm. 138 sobre la edad mínima y el Convenio sobre la prohibición de las peores formas de trabajo infantil y la acción inmediata para su eliminación (núm .182). Estos convenios se contemplan en los Anexos de las Directivas (Anexo X de la Directiva 2014/23/UE; Anexo X de la Directiva 2014/24/UE y Anexo XIV de la Directiva 2014/25/UE). 
Comisión que versan sobre esta materia ${ }^{717}$; y (ii) la trata de seres humanos es también uno de los denominados «delitos europeos» (artículo 83 TFUE) y, en este sentido, la nueva política de seguridad de la UE pone especial énfasis en centrar su atención en las redes delictivas que "aprovechan las vulnerabilidades de las personas que buscan protección o mejores oportunidades económicas y son responsables de la pérdida de vidas en aras de un beneficio económico"718. Con ello nos gustaría pensar que se incorpora a esta dimensión de lucha contra la delincuencia transfronteriza: el tráfico ilícito de migrantes, la explotación sexual y los quebrantamientos de derechos humanos que pueden darse en las cadenas de suministro, como el trabajo infantil o el trabajo forzoso.

En cualquier caso, el acierto de esta nueva prohibición de contratar está fuera de toda duda por cuanto - a nuestro parecer - se incorpora a la regulación contractual una dimensión ética hasta ahora ignorada ${ }^{719}$. El tráfico de seres humanos y su explotación en los países de destino forma parte de una industria transnacional flagrante e ignominiosa - la denominada "esclavitud del siglo XXI" - que se manifiesta tanto en el ámbito de la explotación sexual, como en la realización de trabajos forzados mediante mano de obra sin apenas retribución y que nos aproxima a una espuria realidad que no cuenta con cifras oficiales ${ }^{720}$,

${ }^{717}$ Documentos de trabajo de los servicios de la Comisión Europea Combating Child Labour (Combatiendo el trabajo infantil), SEC (2010) 37 final, de 14 de enero de 2010 y Trade and worst forms of child labour (El comercio y las peores formas de trabajo infantil), SWD (2013) 173, de 30 de abril de 2013.

${ }^{718}$ En la Agenda Europea de Seguridad 2015 se incluyen prioridades tales como incluir la lucha contra la delincuencia organizada transnacional y el terrorismo, el tráfico ilícito de migrantes, la trata de seres humanos y la ciberdelincuencia, COM (2015) 185 final, de 28 de abril de 2015.

${ }^{719} \mathrm{Al}$ referirnos a la «compra ética» resaltamos aquellos supuestos en los cuales los elementos a valorar tienen que ver con el cumplimiento de estándares éticos establecidos en las convenciones internacionales sobre condiciones laborales dignas, salarios mínimos, derechos de los trabajadores, lucha contra el trabajo infantil, abolición del trabajo forzoso.

${ }^{720} \mathrm{Ni}$ siquiera la Oficina de las Naciones Unidas contra la Droga y el Delito se aventura a ofrecer cifras exactas en su Informe mundial sobre la trata de personas 2014. Los datos que nos ofrece la Unión Europea son del número de condenas: 1.534 en el año 2008, 1.445 en el 2009 y 1.144 en el año 2010, Estrategia de la UE para la erradicación de la trata de seres humanos (2012 - 2016), COM (2012) 286 final, de 19 de junio de 2012, pág. 10. 
pero que afecta a importantes sectores económicos (la construcción, el servicio doméstico, la agricultura, los talleres clandestinos de confección y el sector servicios en general) $)^{721}$.

Ahora bien, como la trata de seres humanos puede enfocarse desde diferentes perspectivas, conviene centrar nuestro objeto de estudio. Así pues, (i) puede estudiarse desde la protección de las víctimas, a través de la visión tuitiva propia de cualquier derecho humano ${ }^{722}$; (ii) puede verse también bajo la necesidad de incriminar tales conductas, aportando soluciones penales; (iii) también puede abordarse desde la necesaria defensa de los intereses estatales, poniendo límites y controles a la inmigración irregular; (iv) asimismo, cabe analizar el tema desde el creciente y siempre lucrativo negocio del tráfico de órganos y la explotación sexual y, por último, (v) en la faceta que ahora nos interesa, abordamos esta cuestión atendiendo al control de esas actividades laborales cuyo entramado es considerado delictivo por su naturaleza esclavista (explotación laboral). Lo que en todo momento ha de quedar claro - por mucha conexión que exista entre ellos - es que una cosa es el tráfico ilícito de inmigrantes y la inmigración clandestina (ajeno a este análisis) y otra, la trata de seres humanos que se aprovecha de la explotación de una persona en el país de destino.

Perfilada la conducta a analizar, no podemos olvidar que se trata de una amenaza creciente y muy presente en el Espacio Europeo, habiéndose convertido ya en una realidad internacional que se nutre, de forma casi ilimitada, de los

${ }^{721}$ ABAD CASTELOS, M., "El tráfico ilícito de migrantes y la trata de personas en el marco de la lucha contra la delincuencia organizada transnacional", Seminario sobre cooperación y lucha contra la delincuencia organizada en el espacio iberoamericano, Centro de Estudios Iberoamericanos (CEIB) y Universidad Rey Juan Carlos, abril 2010. Por su parte, BELSEN, P., COCK, M. y MEHRAN, F., OIT Minimum estimate of forced labour in the World, Geneva, 2005, hablan de 12,3 millones de personas que en el mundo realizan trabajos forzados.

${ }^{722}$ VILLACAMPA ESTIARTE destaca que con la adopción de la Directiva 2011/36/UE relativa a la prevención y la lucha contra la trata de seres humanos ha supuesto la asunción del paradigma victimocéntrico en la lucha contra el fenómeno de la trata de seres humanos por parte de la Unión Europea, VILLACAMPA ESTIARTE, C., "La nueva Directiva europea relativa a la prevención y la lucha contra la trata de seres humanos y la protección de las víctimas. ¿Cambio de rumbo de la política de la Unión en materia de trata de seres humanos?", en Revista Electrónica de Ciencia Penal y Criminología, núm. 13-14, 2011, págs. 14 - 52. 
crecientes flujos migratorios hacia Europa, sustentados por las redes criminales y que genera beneficios por valor de varios miles de millones de euros ${ }^{723}$. Así, desde la UE hace más de una década que se viene considerando la necesidad de adoptar una definición común de los elementos que integran esta conducta delictiva, así como de incorporar sanciones penales ${ }^{724}$. No obstante, conviene precisar que los diferentes instrumentos europeos que configuran el actual marco legislativo, no distinguen entre modalidades de trata, a diferencia de lo que sucede con la normativa española, que regula específicamente los tipos penales atendiendo a las diferencias de explotación (la explotación sexual, el trabajo o los servicios forzosos, la mendicidad, las actividades delictivas o la extracción de órganos) $)^{725}$.

La Directiva 2011/36/UE establece por vez primera en la regulación europea una serie de normas mínimas comunes ante las infracciones relacionadas con la trata de personas, entendiendo que estas conductas configuran uno de los delitos más graves a escala internacional ${ }^{726}$. Esta norma proporciona un enfoque generalista, basado en la protección integral de los derechos huma-

${ }^{723}$ Véase lo dicho por GARCÍA COSO, E., "Los avances de la Unión Europea contra el crimen organizado, tráfico de personas e inmigración ilegal", Instituto Universitario de Investigación sobre seguridad interior (UISI-UNED), Madrid, mayo 2004; PÉREZ ALONSO, J., Tráfico de personas e inmigración ilegal: un estudio sociológico, internacional y jurídico-penal, Tirant lo Blanch, Valencia, 2008.

${ }^{724}$ En el año 2000, se firmaron en Palermo dos Protocolos que complementan la Convención de Naciones Unidas contra la delincuencia organizada transnacional (Resolución 55/25 de la Asamblea General, de 15 de noviembre de 2000): el Protocolo para prevenir, reprimir y sancionar la trata de personas, especialmente mujeres y niños; y el Protocolo contra el tráfico ilícito de inmigrantes por tierra, mar y aire. Un lustro después se firmó en Varsovia el Convenio del Consejo de Europa sobre la lucha contra la trata de seres humanos (núm. 197) que entró en vigor el 1 de febrero de 2008 y que no ha sido ratificado por la República Checa. Para completar la perspectiva, el artículo 5, apartado 3, de la Carta de los Derechos Fundamentales de la Unión Europea dispone que se prohíbe la trata de seres humanos.

${ }^{725}$ VILLACAMPA ESTIARTE, C., El delito de trata de seres humanos. Una incriminación dictada desde el Derecho Internacional, Thomson-Reuters Aranzadi, Cizur Menor (Navarra), 2011.

${ }^{726}$ Directiva 2011/36/UE del Parlamento Europeo y del Consejo, de 5 de abril de 2011, relativa a la prevención y lucha contra la trata de seres humanos y a la protección de las víctimas y por la que se sustituye la Decisión marco 2002/629/JAI del Consejo (DOUE L 101, de 15 de abril de 2011). 
nos, aunque dando prioridad reguladora a la persecución de los traficantes. Para ello, anima a la armonización de las normativas internas - tal y como ya había hecho la Decisión marco 2002/629/JAI - mediante normas penales, tanto sustantivas como de naturaleza procesal ${ }^{727}$. Y para hacerlo, se apoya en dos Decisiones del Consejo que buscan promover la cooperación entre los Estados parte $^{728}$.

De esta manera, respecto a la prevención y lucha contra la trata, se ha impuesto un cambio de estrategia desde las instituciones europeas basado en la cooperación interestatal, amparada en la constatación de que las políticas económicas vigentes toleran, cuando no amparan, determinados comportamientos empresariales que se benefician de la situación de vulnerabilidad en que se encuentran ciertos colectivos. Para ello, se ha empezado por comprobar que la mera incriminación de las conductas tipificadas es insuficiente para luchar contra un fenómeno criminal transnacional, que proporciona innumerables beneficios a particulares y organizaciones ${ }^{729}$. La respuesta no debe ser sólo penal sino también económica, permitiendo no sólo la erradicación de los negocios nacidos de la trata (introduciendo sanciones como la confiscación de las ganancias), sino impidiendo cualquier tipo de contratación ad futurum con las entidades del sector público.

Conforme a lo dispuesto en el artículo 2 de la Directiva 2011/36/UE - que

\footnotetext{
${ }^{727}$ Hasta la entrada en vigor del Tratado de Lisboa (2009), las medidas adoptadas respecto a la inmigración clandestina eran competencia de la Unión - materia integrada en el primer pilar - mientras que las relativas a la trata de personas formaban parte del Espacio de Libertad, Seguridad y Justicia, e integraban el tercer pilar, por eso su regulación mediante el instrumento de la Decisión marco.

${ }^{728}$ Decisiones 2006/618/CE y 2006/619/CE, del Consejo, de 24 de julio de 2006 relativas a la celebración, en nombre de la Comunidad Europea, del Protocolo para prevenir, reprimir y sancionar la trata de personas, especialmente mujeres y niños, que complementan la Convención de las Naciones Unidas contra la delincuencia en lo que se refiere a las disposiciones del Protocolo, en la medida en que éstas entran en el ámbito de aplicación de los artículos 179 y 181 A del Tratado constitutivo de la Comunidad Europea (DOUE L núm. 262, de 22 de septiembre de 2006).

${ }^{729}$ La estimación de los beneficios mundiales anuales obtenidos mediante la explotación de las víctimas de trabajo forzoso asciende a 31. 600 millones de dólares según señala la Comunicación de la Comisión Estrategia de la UE para la erradicación de la trata de seres humanos (2012 - 2016), pág. 2.
} 
recoge las conductas relacionadas con la trata de seres humanos que habilitan la prohibición de contratar obligatoria - son punibles los siguientes comportamientos:

"La captación, el transporte, el traslado, la acogida o la recepción de personas, incluido el intercambio o la transferencia de control sobre estas personas, mediante la amenaza o el uso de la fuerza u otras formas de coacción, el rapto, el fraude, el engaño, el abuso de poder o de una situación de vulnerabilidad, o mediante la entrega o recepción de pagos o beneficios para lograr el consentimiento de una persona que posea el control sobre otra persona, con el fin de explotarla".

Ciertamente, y como conclusión de todo lo expuesto, podemos hablar de una incipiente tendencia desde las instituciones europeas a profundizar en la trata de personas desde la perspectiva del traficante, de ese empleador sin escrúpulos al que a partir de las Directivas de 2014 puede prohibírsele acceder a la contratación pública con un carácter obligatorio en todos los Estados miembros, una vez que ha sido condenado por tales conductas delictivas.

\section{El impago de impuestos y cotizaciones a la seguridad social}

La elusión del pago de impuestos o de cotizaciones a la seguridad social se configuran en las nuevas Directivas como conductas reprochables que conducen a una prohibición de contratar de carácter obligatorio a nivel de la Unión Europea, siempre que el impago haya quedado acreditado "en una resolución judicial o administrativa firme y vinculante, según las disposiciones legales del país en el que esté establecido el operador económico o las del Estado miembro del poder adjudicador" (artículo 57.2 primer párrafo de la Directiva 2014/24/UE y artículo 38.5 primer párrafo de la Directiva 2014/23/UE («concesiones»).

Si no hubiera tal constancia formal, pero el poder adjudicador puede demostrar el incumplimiento del operador económico respecto de sus obligaciones fiscales o con la seguridad social también se prevé su posible exclusión de la 
participación en un procedimiento de contratación, aunque con un carácter de prohibición de contratar facultativa para los Estados miembros (al igual que ya se contemplaba en la Directiva $2004 / 18 / \mathrm{CE})^{730}$.

Este cambio de naturaleza - de potestativa a obligatoria - cuando el impago se establece mediante una resolución definitiva denota, a nuestro entender, un mayor interés en el cumplimiento de la normativa fiscal y la prevención de la evasión fiscal y, sobre todo, un mayor respeto por las decisiones - administrativas o judiciales - adoptadas al margen de la regulación contractual, pero que suponen un descrédito del operador económico al quedar en entredicho su fiabilidad. No obstante, en cualquier caso - con o sin resolución judicial o administrativa que lo acredite - parece claro que "su exclusión del procedimiento de licitación pretende prevenir distorsiones de la competencia: se trata de evitar que, en detrimento del interés general, «ovejas negras» que, por ejemplo, no paguen sus impuestos y cotizaciones a la seguridad social, acaben presentado ofertas más ventajosas que sus competidores y que de esa manera consigan contratos públicos usando métodos desleales, máxime cuando esos contratos se financian normalmente con ingresos fiscales"731.

Ahora bien, aunque será objeto de tratamiento posterior al analizar los supuestos de inaplicación de las prohibiciones de contratar, es necesario destacar en este momento que, al igual que la nueva regulación incrementa su rigor de exigencia en cuanto a considerar no hallarse al corriente en el cumplimiento de las obligaciones tributarias o de seguridad social como causa de exclusión obligatoria, las nuevas Directivas también incorporan distintas circunstancias de inaplicación de esta prohibición que sólo encuentran fundamento bien en allanar mediante excepciones el camino de regreso hacia la legalidad de los operadores económicos incumplidores ${ }^{732}$, bien en atender a razones de propor-

\footnotetext{
${ }^{730}$ Recordemos que de criterios de justicia material respecto de estas prohibiciones hablaba GOSÁLBEZ PEQUEÑO en tanto que con el cumplimiento de estas obligaciones se contribuye al sostenimiento de los gastos públicos, GOSÁLBEZ PEQUEÑO, H., El contratista de la Administración (... ), op. cit., pág. 381.

${ }^{731}$ Son las palabras ya citadas de la Abogado General Sra. KOKOT presentadas, el 15 de abril de 2010, en el asunto Bâtiments y Ponts Construction, C-74/09, apartado 50 .

${ }^{732} \mathrm{El}$ artículo 57.2 in fine de la Directiva 2014/24/UE es del siguiente tenor: "El presente apartado dejará de aplicarse una vez que el operador económico haya cum-
} 
cionalidad $^{733}$.

Asumido lo anterior, no podemos olvidar tampoco que los órganos de contratación no son los encargados de velar por el cumplimiento de las obligaciones tributarias o con la Seguridad Social, sino que su papel ha de limitarse al ejercicio de un mero control formal que se ejerce sobre la base de la documentación expedida por otros órganos, sin que la legislación contractual pueda imponer requerimientos respecto de su contenido, más allá de la posible exigencia de un modelo de declaración responsable.

En el supuesto de existir una sentencia firme o una resolución administrativa definitiva que acredita el incumplimiento de las obligaciones del operador económico relativas al pago de las cotizaciones de la seguridad social o el pago de impuestos, el órgano de contratación debe excluir del procedimiento de adjudicación a dicho candidato o licitador, máxime cuando al tratarse de una sentencia firma o resolución administrativa definitiva no estamos ante un supuesto de deudas aplazadas, fraccionadas o que se hubiera acordado su suspensión, ya que en todos estos supuestos - y aunque el pago no sea efectivo - se entiende que el operador económico se encuentra al corriente de sus obligaciones.

\section{La regulación de las prohibiciones de carácter obligatorio en los Estados miembros}

Dado que este capítulo se ha centrado en las prohibiciones de carácter obligatorio para los Estados miembros - y puesto que aún no ha finalizado el plazo para la transposición de las Directivas de 2014 - hemos considerado conveniente finalizar este apartado presentando cómo los Estados miembros

plido sus obligaciones de pago o celebrado un acuerdo vinculante con vistas al pago de los impuestos o las cotizaciones a la seguridad social que adeude, incluidos en su caso los intereses acumulados o las multas impuestas".

${ }^{733}$ Conforme al artículo 57.3 segundo párrafo de la Directiva 2014/24/UE "Los Estados miembros podrán también establecer una excepción a la exclusión obligatoria prevista en el apartado 2 cuando tal exclusión resulte claramente desproporcionada, en particular cuando las cantidades adeudadas en concepto de impuestos o cotizaciones a la seguridad social sean reducidas". 
han transpuesto formalmente el artículo 45.1 de la Directiva 2004/18/CE a su Derecho interno, con el fin de comprobar si los legisladores nacionales han cumplido satisfactoriamente con dichas exigencias.

Para ello hemos acudido a la normativa contractual de los 28 Estados miembros y hemos contado con la inestimable ayuda de diversos expertos que nos han facilitado el manejo de las fuentes documentales en los distintos Estados y su pertinente traducción ${ }^{734}$; sin embargo, hay que hacer constar que, a

${ }^{734}$ Citamos, pues a Pierre DEVOLVÉ (Francia) Martin TRYBUS (Reino Unido), Gustavo PIGA (Italia), Regine ROSENKRANZ (Alemania), Georg WINTER (Austria), Thomas THYBO LARSEN (Dinamarca), Zuzana KRAJCOVICOVÁ (Eslovaquia), Andrea SUNDSTRAND y Ammar KHAN (Suecia), Billy NOONE (Irlanda), Johanna LÄHDE (Finlandia), M. MICHAEL (Chipre), Andrius MEIŽENIS (Lituania), Panayotis GLAVINIS (Grecia), Thomas van DOORN (Países Bajos), Evelin KARINDI-KASK (Estonia), Ágnes JUHÁSZ y Janos MAROSI (Hungría).

A este respecto también han resultado de utilidad las siguientes aportaciones doctrinales: TRYBUS, M., "The morning after the deadline: the State of implementation of the new EC Public Procurement Directives in the Member States on 1st February 2006", PPLR, vol. 15 (3), 2006, NA 82-89; la documentación preparada por Andrea RENDA para el Parlamento Europeo The Public Procurement Directives: Transposition in the EU Member States, Bruselas, mayo 2006 (IP/A/IMCO/0F/2006-071); TRYBUS, M. y MEDINA, T., "Unfinished Business: The State of Implementation of the New EC Public Procurement Directives in the Member States on February 1, 2007", PPLR, vol. 16 (4), 2007, NA89-NA97; ZUCCOLOTTO, S., (Ed.) Public Procurement in Europe, Istituto Poligrafico e Zecca Dello Stato - Public Procurement Network (PPN), 2003; BIANCHI, T. y GUIDI, V. E., The comparative survey on the National Public Procurement systems across the PPN, Istituto Poligrafico e Zecca Dello Stato - Public Procurement Network, 2010, disponible desde http://www.publicprocurementnetwork.org/; SIGMA, documento de trabajo núm. 45, Public Procurement in EU Member States - The Regulation of Contract Below the EU Thresholds and in Areas not Covered by the Detailed Rules of the EU Directives, OECD Publishing, GOV/SIGMA(2010)1/REV1, 27 de mayo; SIGMA, documento de trabajo núm. 47, Centralised Purchasing Systems in the European Union, OECD Publishing, GOV/SIGMA (2010) 3/REV1, de 17 de enero de 2011. Asimismo, se ha recurrido al documento de trabajo de los servicios de la Comisión Evaluation Report: Impact and Effectiveness of EU Public Procurement Legislation (Part 2), SEC (2011) 853 final, de 27 de junio de 2011.

Más recientemente, la obra colectiva dirigida por SÁNCHEZ MORÓN, M., Derecho de los contratos públicos en la Unión Europea y sus Estados miembros (...), op. cit., en especial las contribuciones de HUERGO LORA (Alemania), GARCÍA LUENGO (Austria), DEL OLMO ALONSO (Bélgica), MESTRE DELGADO (España), MENÉNDEZ SEBASTIÁN (Francia), SIMOU (Grecia), MEDINA ARNÁIZ (Hungría), DESDENTADO DAROCA (Irlanda), MARINA JALVO (Italia), GA- 
lo largo de lo que resta de capítulo, no se efectúan valoraciones respecto del contenido de dicha normativa más allá de afirmar la existencia de diferencias significativas respecto de los criterios adoptados para definir las conductas delictivas que originan una prohibición de contratar de carácter obligatorio, lo cual, como ya hemos señalado con anterioridad, dificulta aún más su aplicación transfronteriza ante la falta de un criterio común de delimitación ${ }^{735}$.

Igualmente hay que señalar que tampoco se incorporan referencias a la Directiva 2009/81/CE, de 13 de julio de 2009, sobre coordinación de los procedimientos de adjudicación de determinados contratos de obras, de servicios por las entidades en los ámbitos de la defensa y seguridad, por razones de su contenido, puesto que las prohibiciones de contratar obligatorias que se contemplan en el artículo 39.1 de esta Directiva recogen las mismas prohibiciones que el artículo 45.1 de la Directiva 2004/18/CE y únicamente difieren respecto del delito de terrorismo o delito ligado a las actividades terroristas (letra d) - que en el momento actual ya está incorporado a la nueva regulación y que se recogía en las normas contractuales de distintos Estados miembros (por ejemplo, Francia y Eslovaquia).

Asimismo - y aunque hemos aludido a ellas a lo largo del texto de esta memoria doctoral - no se recoge la totalidad de las disposiciones adoptadas en los Estados miembros para ajustarse a lo dispuesto en las nuevas Directivas. En este sentido, hemos de destacar que: (i) Reino Unido y Francia ya han notificado medidas de transposición que modifican por completo su anterior regulación contractual (Public Contracts Regulations 2015 y Ordonnance $n^{o}$ 2015-899, du 23 juillet 2015 relative aux marchés publics); (ii) que en Hungría, la Ley 2015 CXLIII, de 22 de septiembre, sobre contratación pública, entrará en vigor el 1 de noviembre de 2015; (iii) que Portugal ha adaptado su legislación

LLEGO CÓRCOLES (Países Bajos), LAZO VITORIA (Polonia), MORENO MOLINA (Portugal), NIETO GARRIDO (Reino Unido) y GARCÍA-ANDRADE GÓMEZ (Suecia).

${ }^{735}$ Véase lo dicho en las páginas 341 - 343 de este mismo capítulo al referirnos a la clasificación de los Estados miembros en cuatro grupos distinguiendo si éstos habían acudido a la normativa de la Unión o a sus propios Códigos penales para referirse a los conceptos de fraude, corrupción, blanqueo de capitales y crimen organizado que, recordemos, eran las conductas delictivas que amparaban una prohibición de contratar de carácter obligatoria de conformidad con el artículo 45 de la Directiva 2004/18/CE. 
referente al uso de las plataformas electrónicas de contratación mediante la Ley 96/2015, de 17 de agosto $^{736}$; (iv) que Italia, Austria, Irlanda, Malta, República Checa y España ${ }^{737}$ han modificado recientemente su regulación con un distinto grado de adaptación a las nuevas Directivas y (v) que Polonia (marzo 2015), Alemania (agosto 2015) y Bulgaria (agosto 2015) tienen muy adelantados los proyectos de ley por los que transponen a sus derechos nacionales las Directivas de 2014.

${ }^{736}$ Lei n. ${ }^{\circ}$ 96/2015, Regula a disponibilização e a utilização das plataformas eletrónicas de contratação pública e transpõe o artigo $29 .^{\circ}$ da Diretiva 2014/23/UE, o artigo $22 .^{\circ}$ e o anexo IV da Diretiva 2014/24/UE e o artigo $40 .^{\circ}$ e o anexo V da Diretiva 2014/25/CE, do Parlamento Europeu e do Conselho, de 26 de fevereiro de 2014, revogando o Decreto-Lei n. ${ }^{\circ}$ 143-A/2008, de 25 de julho (Diário da República n. ${ }^{\circ}$ 159/2015, Série I de 17 de agosto de 2015)

${ }^{737} \mathrm{El}$ artículo 60 del TRLCSP sobre las prohibiciones de contratar ha sido modificado por la Disposición final novena de la Ley 40/2015, de 1 de octubre, de Régimen Jurídico del Sector Público (BOE núm. 236, de 2 de octubre de 2015). 
Tabla 5: La transposición del artículo 45.1 de la Directiva 2004/18/CE respecto de las causas de prohibición de contratar obligatorias en los 28 Estados miembros.

\section{Alemania}

\section{Normas sobre la adjudicación de contratos públicos}

- Ley contra las prácticas restrictivas de la competencia (Gesetz gegen Wettbewerbsbeschänkungen) GWB - Parte IV

- Reglamento sobre la adjudicación de contratos públicos (Verordnungüber die Vergabe Äuffentlicher Aufträge (Vergabeverordnung- VgV)

- Reglamento para la adjudicación de contratos de obras públicas (Vergabeund Vertragsordnung für Bauleistungen) VOB/A 2006

- Reglamento de adjudicación de los contratos públicos de suministros y servicios (Verdingungsordnung für Leistungen) VOL/A 2006

- Reglamento para la contratación de servicios profesionales (Verdingungsordnung für Freiberufliche Leistungen VOF)

\section{Causas de exclusión obligatorias (Teilnehmer am Wettbewerb - Auss- chlusskriterien)}

$\S 6$ bis Nr. 1 VOB/A; $\S 6.4$ Nr. 2 VOL/A; $\S 11$ Abs. 1 VOF

(1) Una empresa/contratista/candidato será excluida/o de la participación en un procedimiento de contratación por falta de seriedad, si el poder adjudicador llega a tener conocimiento de que una persona cuyo comportamiento se ha de imputar a la empresa, está condenada en sentencia firme por:

a) $\S 129$ (creación de asociaciones criminales), 129a (creación de asociaciones terroristas), 129b (asociaciones criminales y terroristas en el extranjero) del Código Penal;

b) §261 del Código Penal (blanqueo de capitales, ocultación de valores patrimoniales obtenidos ilícitamente);

c) §263 del Código Penal (fraude), en caso de que el delito atente contra el presupuesto de las Comunidades Europeas o contra presupuestos que son administrados por las Comunidades Europeas o en su nombre (por orden, por encargo);

d) §264 del Código Penal (fraude de subvenciones), en caso de que el delito atente contra el presupuesto de las Comunidades Europeas o contra pre- 
supuestos que son administrados por las Comunidades Europeas o en su nombre (por orden, por encargo);

e) $§ 334$ del Código Penal (soborno/cohecho/corrupción), también en relación con el artículo 2 de la Ley de soborno de las Comunidades Europeas; parágrafo 2, apartado 1 del Convenio de la OCDE de lucha contra la corrupción de agentes públicos extranjeros en las transacciones comerciales internacionales; artículo 7 apartado 2, cifra 10 de la Cuarta Ley modificadora del Derecho Penal y el artículo 2 de la Ley sobre la suspensión de la prescripción de la persecución y la equiparación de los jueces y empleados del Tribunal Internacional de Crímenes de Guerra;

f) $\S 2$, apartado 2 de la Ley contra el soborno internacional (soborno de delegados extranjeros en el contexto del tráfico comercial internacional);

g) $§ 370$ de la Ordenanza tributaria, también en relación con el artículo 12 de la Ley de realización de las organizaciones comunes de mercado y de los pagos directos (MOG), en cuanto el delito atente contra el presupuesto de las Comunidades Europeas o contra aquel gestionado por las Comunidades Europeas o en su mandato;

La violación de estas disposiciones se equipara a las infracciones contra las normas penales correspondientes de otros Estados. El comportamiento de una persona que esté condenada ejecutoriamente, podrá atribuirse a una empresa si la persona ha actuado con su propia responsabilidad en la gestión de los negocios, o si concurre una culpa por falta de vigilancia u organización, conforme con el artículo 130 de la Ley de infracciones al orden administrativo, de una persona en cuanto al comportamiento de otra persona que actúa para la empresa y está condenada ejecutoriamente.

\section{Austria}

\section{Normas sobre la adjudicación de contratos públicos}

- Ley Federal de adjudicación de contratos públicos 2006 - BverG 2006 (Bundesvergabegesetz 2006)

\section{Causas de exclusión obligatorias (Ausschlussgründe)}

Sobre los operadores económicos que hay que excluir de la participación en el procedimiento de contratación 
$\S 68$. (1) Sin perjuicio de lo dispuesto en los apartados 2 y 3 , el poder adjudicador excluirá a los operadores económicos de la participación en el procedimiento de contratación si: 1 . El poder adjudicador tiene conocimiento de una condena ejecutoria contra ellos o - en caso de tratarse de personas jurídicas, sociedades personales del Derecho mercantil, sociedades de lucro o comunidades de trabajo registradas - contra las personas físicas encargadas de la gestión de los negocios de dichas entidades y a las que les afecta uno de los siguientes hechos:

- Participación en una organización criminal (artículo 278a StGB [Código penal];

- Corrupción - Soborno (artículos 302, 307, 308, 310 StGB [Código penal]);

- Competencia desleal (artículo 10 UWG [Ley Federal contra la competencia desleal];

- Fraude (artículos 146 y ss. StGB [Código penal]);

- Gestión desleal (artículo 153 StGB [Código penal]);

- Aceptación de regalos (artículo 153 a StGB [Código penal],

- Fraude de subvenciones (artículo 153 b StGB [Código penal]);

- Blanqueo de dinero (artículo 165 StGB [Código penal]) o un tipo penal análogo según la normativa del país donde el empresario tiene su domicilio;

\section{Bélgica}

\section{Normas sobre la adjudicación de contratos públicos}

- Ley de 15 de junio de 2006, sobre los procedimientos de adjudicación de contratos públicos y de ciertos contratos de suministros, obras y servicios (modificada en mayo 2014)

- Ley de 16 de junio de 2006, relativa a la información a los candidatos y licitadores y sobre los mecanismos de recursos contra la adjudicación de contratos públicos

- Circular de 21 de junio de 2010, sobre deontología y conflicto de intereses en materia de contratos públicos

- Real Decreto de 15 de julio de 2011, relativo a la adjudicación de contratos en los sectores clásicos (versión de 7 de febrero de 2014)

- Arrêté royal du 14 janvier 2013 établissant les règles générales déxécution des marchés publics et des concessions de travaux publics 
Causas de exclusión obligatorias (Droit dáccès et sélection qualitative)

Artículo 20.1. 2 de la Ley de 15 de junio de 2006 y artículo 61 del Real Decreto de 15 de julio de 2011

El Rey determina las reglas en materia del derecho de acceso a la contratación así como los criterios de selección cualitativa de los candidatos o licitadores.

Salvo por exigencias imperativas de interés general, se excluye de la participación en todo contrato público al candidato o licitador que es objeto de una condena por sentencia judicial firme, de la que tiene conocimiento el órgano de contratación, por su participación en una organización criminal, corrupción, fraude o blanqueo de capitales.

El Rey podrá derogar estas prohibiciones para contratos inferiores al umbral económico que se fije.

\section{Bulgaria}

\section{Normas sobre la adjudicación de contratos públicos}

- Ley de Contratación Pública de 2004

\section{Causas de exclusión obligatorias}

Artículo 47(1) primer párrafo (modificado SG 37, de 1 de julio de 2006)

El órgano de contratación deberá excluir de la participación en la adjudicación de un contrato público al candidato o licitador que es condenado a una pena efectiva, salvo en caso de rehabilitación, por:

a) Delitos contra el sistema financiero, fiscales o de seguridad social, incluyendo el blanqueo de capitales de los artículos 253 - 260 del Código penal;

b) Corrupción de los artículos 301 - 307 del Código Penal;

c) Participación en una organización criminal con arreglo a los artículos 321 y 321.a) del Código penal;

d) Delitos contra la propiedad en virtud de los artículos 194 - 217 del Código penal; 
e) Delitos contra la economía con arreglo a los artículos 219 - 252 del Código penal.

\section{Croacia}

Normas sobre la adjudicación de contratos públicos

- Ley de Contratación Pública (Zakon o javnoj nabavi) Gaceta Oficial 90/11, modificada en julio de 2013 (Gaceta 83/13)

\section{Motivos obligatorios de la exclusión de los candidatos y licitadores}

\section{Artículo 67}

El poder adjudicador deberá excluir de la participación de un contrato público al candidato o licitador:

1. Si el operador economico y/o la persona autorizada con poderes de representación legal ha sido condenado por sentencia judicial firme por uno o más de los siguientes hechos delictivos: asociación delictiva, aceptación de sobornos en las actividades empresariales, ofrecimiento de sobornos en las actividades empresariales, abuso de la posición oficial, intercesión ilegal, aceptación de un soborno, ofrecimiento de un soborno, fraude, fraude informático, fraude en los negocios, ocultación fraudulenta de dinero, u otro delito similar de conformidad con las disposiciones del país en el cual esté establecido

\section{Chipre}

Normas sobre la adjudicación de contratos públicos

- Ley 12 (I)/2006, de 17 de febrero de 2006, sobre la coordinación de los procedimientos de adjudicación de los contratos de suministros, obras y servicios y otros temas relacionados (versión Ley 176(I) 2011)

\section{Causas de exclusión obligatorias}

Artículo 51.1 Ley 12 (I)/2006 
Quedará excluido de la participación en un contrato público cualquier candidato o licitador que haya sido condenado mediante sentencia firme, de la que tiene conocimiento el poder adjudicador, por uno o varios de los motivos que a continuación se enumeran:

a) participación en una organización delictiva, tal y como se define en el apartado 1 del artículo 2 de la Acción Común 98/773/JAI del Consejo;

b) corrupción, tal y como se define, respectivamente, en el artículo 3 del acto del Consejo de 26 de mayo de 1997 y en el apartado 1 del artículo 3 de la Acción Común 98/742/JAI del Consejo;

c) fraude, según el artículo 1 del Convenio relativo a la protección de los intereses financieros de las Comunidades Europeas;

d) blanqueo de capitales, tal y como se define en el artículo 1 de la Directiva 91/308/CEE del Consejo, de 10 de junio de 1991, relativa a la prevención de la utilización del sistema financiero para el blanqueo de capitales.

(... ) Los órganos de contratación podrán establecer una excepción a la obligación del párrafo primero por razones imperiosas de interés general.

\section{Dinamarca}

\section{Normas sobre la adjudicación de contratos públicos}

- Orden Ministerial núm. 712, de 15 de junio de 2011, relativa a los procedimientos de adjudicación de los contratos públicos de obras, de suministro y de servicios (deroga la Orden Ministerial núm. 937, de 16 de septiembre de 2004)

\section{Causas de exclusión obligatorias (Afvisning og udelukkelse)}

$\S 10$ (BEK núm. 712)

Párrafo primero. De la participación en un procedimiento de contratación se excluirá al candidato o licitador que fuera condenado por sentencia firme conocida por las entidades contratantes por una o más causas de las mencionadas en el artículo 45.1 de la Directiva sobre contratación pública.

Párrafo segundo. En la Directiva, estas causas son:

1) Ayudar e incitar a un delito conforme al $\S 23$ del Código penal, en el cual 
la determinación de la pena se lleva a cabo bajo el §81, nr. 3 del Código penal;

2) Delito de corrupción activa de funcionarios públicos en el extranjero, de conformidad con el $§ 122$ del Código penal y el delito de corrupción en las relaciones jurídicas privadas según el §299 nr. 2 del Código penal;

3) Delito de fraude de la UE, conforme al §289.a del Código penal;

4) Delito de blanqueo de capitales en el sentido del §290.a del Código penal.

Párrafo tercero. La aplicación de los párrafos 1 y 2 podrá ser suspendida por un interés público superior.

\section{Eslovaquia}

\section{Normas sobre la adjudicación de contratos públicos}

- Ley de Adjudicaciones Públicas 25/2006, de 14 de diciembre de 2005 (últimas modificaciones Zákon č. 95/2013 Z y Zákon č. 28/2013)

\section{Causas de exclusión obligatorias}

Las causas de exclusión se recogen bajo el epígrafe general de «situación personal»

Artículo 26.1 Zákon č. 25/2006 Z.

(1) Podrán participar en la adjudicación de contratos públicos quienes reúnan las condiciones de participación respecto de su situación personal

a) Que ni el mismo, ni uno de sus organismos de derecho público o un miembro de su organización haya sido condenado por delito de corrupción, por delito por un perjuicio a los intereses financieros de las Comunidades Europeas, por un delito de blanqueo de actividades delictivas, por un delito de pertenencia, conspiración o apoyo a una organización criminal o a un grupo terrorista (...);

(2) Los licitadores o candidatos acreditará las condiciones de participación en virtud de párrafo 1 (a) por un extracto del registro de antecedentes penales no mayor de tres meses. 


\section{Eslovenia}

\section{Normas sobre la adjudicación de contratos públicos}

- Texto refundido de la Ley de Contratación Pública, de 1 de febrero de 2013 (Zakon o javnem naročanju (uradno prečiščeno besedilo)/ZJN-2UPB5 Uradni list RS, št. 12/2013

\section{Capacidad básica del candidato o licitador}

Artículo 42

(1) La entidad adjudicadora excluirá de la adjudicación del contrato público a todos aquellos candidatos o licitadores y a sus representantes legales, en caso de persona jurídica, que hayan sido condenados por la comisión de los siguientes delitos, tal y como se definen en el Código Penal (KZ):

Aceptación de sobornos en las elecciones (artículo 157); Fraude (artículo 211); Restricción de la competencia (artículo 225); Quiebras fraudulentas (artículo 226); Daño a los acreedores (artículo 227); Fraude en los negocios (artículo 228); Fraude a los intereses financieros de la Unión (artículo 229); Engaño en la adquisición y el uso de préstamos o ventajas (artículo 230); Engaño en las transacciones de valores (artículo 231); Estafa (artículo 232); Uso no autorizado de marcas (artículo 233); Uso no autorizado de invenciones y patentes (artículo 234); Falsificación o destrucción de documentos de la empresa (artículo 235); Divulgación de secreto comercial (artículo 236); Información privilegiada (artículo 238); Abuso del mercado (artículo 239); Abuso de poder en las actividades económicas (artículo 240); Aceptación de regalos - dádivas (artículo 241); Ofrecimiento de regalos - dádivas (artículo 242); Falsificación de moneda (artículo 243); Blanqueo de capitales (artículo 245); Abuso en los medios de pago no monetarios (artículo 246); Uso de medios falsificados de pago (artículo 247); Construcción, adquisición y disposición de instalaciones para la falsificación (artículo 248); Evasión fiscal (artículo 249); Tráfico ilícito (artículo 250); Divulgación de información clasificada (artículo 260); Sobornos (artículos 261 y 262); Recepción y ofrecimiento de regalos por una intermediación ilegal (artículos 263 y 264); Participación en una asociación criminal (artículo 294). 


\section{España}

\section{Normas sobre la adjudicación de contratos públicos}

- Real Decreto Legislativo 3/2011, de 14 de noviembre, por el que se aprueba el Texto refundido de la Ley de Contratos del Sector (con los cambios previstos en la Ley 40/2015)

\section{Prohibiciones de contratar}

Artículo 60

1. No podrán contratar con las entidades previstas en el artículo 3 de la presente Ley con los efectos establecidos en el artículo 61 bis, las personas en quienes concurra alguna de las siguientes circunstancias:

a) Haber sido condenadas mediante sentencia firme por delitos de terrorismo, constitución o integración de una organización o grupo criminal, asociación ilícita, financiación ilegal de los partidos políticos, trata de seres humanos, corrupción en los negocios, tráfico de influencias, cohecho, prevaricación, fraudes, negociaciones y actividades prohibidas a los funcionarios, delitos contra la Hacienda Pública y la Seguridad Social, delitos contra los derechos de los trabajadores, malversación, blanqueo de capitales, delitos relativos a la ordenación del territorio y el urbanismo, la protección del patrimonio histórico y el medio ambiente, o a la pena de inhabilitación especial para el ejercicio de profesión, oficio, industria o comercio.

La prohibición de contratar alcanzará a las personas jurídicas que sean declaradas penalmente responsables, y a aquéllas cuyos administradores o representantes, lo sean de hecho o de derecho, vigente su cargo o representación y hasta su cese, se encontraran en la situación mencionada en este apartado.

\section{Estonia}

Normas sobre la adjudicación de contratos públicos

- Ley de Contratación Pública Riigihangete Seadus (RTI, 23.02.2011, 42)

\section{Causas de exclusión obligatorias}

$\S 38$. Exclusion of the tenderer and candidate from the procurement procedure 
(1). El poder adjudicador no podrá celebrar contratos públicos y deberá excluir del procedimiento de adjudicación en cualquier momento al licitador o candidato:

1. Que él o su representante legal haya sido condenado por sentencia firme por participar en una organización criminal o pertenecer a la misma; por violación de los requisitos de la contratación pública; por la comisión de delitos relacionados con la falta de ética profesional; por fraude o blanqueo de capitales, siempre que los datos sobre la pena no hayan sido cancelados de acuerdo con la Ley del Registro de Antecedentes o la pena sea válida de acuerdo con la normativa de su país de residencia o establecimiento.

\section{Finlandia}

Normas sobre la adjudicación de contratos públicos

- Ley de Contratación Pública 348/2007, de 30 de marzo (Lag om offentlig upphandling - Laki julkisista hankinnoista)

Exclusion from the competition of candidates and tenderers convicted of certain offences (Uteslutning av anbudssÃ̈kande och anbudsgivare som gjort sig skyldiga till vissa brot)

$\S 53$ (1) El poder adjudicador deberá excluir del procedimiento de adjudicación contractual al candidato o licitador si ha tenido conocimiento que este licitador o candidato o bien cualquier persona con poderes de representación, decisión o control sobre ellos, han sido condenados por sentencia judicial firme por uno o más de los siguientes delitos:

1. Participación en una organización dedicada a actividades delictivas según el Capítulo 17 del Código penal de Finlandia;

2. Corrupción según el Cap. 16 §13, corrupción grave según el Capítulo 16 $\S 14$, corrupción en el sector industrial según Capítulo $30 § 7$;

3. Fraude fiscal según Cap. $29 § 1$ y 2, fraude relacionado con la recepción de una subvención conforme al Cap. $29 \S 5$, fraude grave relacionado con la recepción de una subvención según Cap. 29 §6, abuso o uso impropio de una subvención según Cap. $29 \S 7$;

4. Blanqueo de capitales conforme al Cap. 32 §6, así como grave blanqueo de capitales según Cap. $32 \S 7$; 
5. Por discriminación laboral recogido en el Capítulo $43 \S 6$ del Código penal.

(2) El poder adjudicador deberá excluir del procedimiento de adjudicación contractual al candidato o licitador si ha sido condenado por sentencia judicial firme en otro Estado por idénticos delitos de los señalados en el párrafo primero. En relación con los Estados miembros los delitos que implican una exclusión obligatoria están especificados en las siguientes reglas y convenios:

1. Participación en una organización delictiva, tal y como se define en el apartado 1 del artículo 2 de la Acción Común 98/733/JAI del Consejo, relativa a la tipificación penal de la participación en una organización delictiva en los Estados miembros de la Unión Europea;

2. Corrupción, tal y como se define en el artículo 3 del acto del Consejo de 26 de mayo de 1997, por el que se establece, sobre la base de la letra c) del apartado 2 del artículo K .3 del Tratado de la Unión Europea, el Convenio relativo a la lucha contra los actos de corrupción en los que estén implicados funcionarios de las Comunidades Europeas o de los Estados miembros de la Unión Europea, o en la Decisión marco 2003/568/JAI del Consejo, de 22 de julio de 2003, relativa a la lucha contra la corrupción en el sector privado;

3. Fraude, según el artículo 1 del Convenio relativo a la protección de los intereses financieros de las Comunidades Europeas;

4. Blanqueo de capitales, tal y como se define en el artículo 1 de la Directiva 91/308/CEE del Consejo, de 10 de junio de 1991, relativa a la prevención de la utilización del sistema financiero para el blanqueo de capitales.

(3) Podrá establecerse una excepción respecto de la exclusión de la participación en un procedimiento de adjudicación contractual al candidato o licitador que ha sido condenado por alguna de las causas contempladas en esta sección por necesidades imperativas de interés general, o bajo la condición de que el condenado ya no tiene posiciones de responsabilidad en la empresa que ha presentado su oferta.

\section{Francia}

\section{Normas sobre la adjudicación de contratos públicos}

- Código de Contratos Públicos 2006, aprobado por Decreto 2006-975, de 1 
de agosto de 2006 (Code des Marchés Publics) todavía en vigor (artículo 43) Interdictions de soumissionner

- Ordenanza 2015-899, de 23 de julio de 2015, sobre contratación pública (Ordonnance $n^{\circ}$ 2015-899 du 23 juillet 2015 relative aux marchés publics)

\section{Interdictions de soumissionner}

Artículo 45 (Interdictions de soumissionner obligatoires et générales)

Serán excluidos del procedimiento de adjudicación contractual:

1. Las personas que han sido objeto de una condena por sentencia judicial firme por alguna de los delitos previstos en los artículos 222-34 a 222-40, 313-1, 313-3, 314-1, 324-1, 324-5, 324-6, 421-1 a 421-2-4, 421-5, 432-10, 432-11, 432-12 a 432-16, 433-1, 433-2, 434-9, 434-9-1, 435-3, 435-4, 435-9, 435-10, 441-1 a 441-7, 441-9, 445-1 a 445-2-1 ou 450-1 del Código penal; por las infracciones previstas en los artículos 1741 a 1743, 1746 o 1747 del Código tributario o - para los contratos que no se refieran al ámbito de la seguridad y defensa - en los artículos 225-4-1 y 225-4-7 del Código penal, o el encubrimiento de esos delitos, así como por delitos equivalentes bajo la legislación de otro Estado miembro de la Unión Europea.

2. Las personas que no han cumplido con sus obligaciones fiscales o sociales o no han pagado impuestos, tasas, contribuciones y cotizaciones exigibles por vía reglamentaria.

\section{Grecia}

Normas sobre la adjudicación de contratos públicos

- Decreto Presidencial 60/2007, sobre la contratación en el sector público ( $\Phi$ EK 64/A/16.03.2007) con las modificaciones acaecidas por el Decreto Presidencial 118/2007

- Ley codificadora 3669/2008, de 4 de junio, de los contratos de obras públicas

\section{Causas de exclusión (Situación personal del candidato o licitador)}

Artículo 43 Decreto Presidencial 60/2007 y artículo 144 de la Ley 3669/2008 
Se excluye del contrato al candidato o licitador que haya sido condenado por sentencia judicial firme, conocida por el poder adjudicador, por una o más de las siguientes causas:

a) La participación en una organización delictiva, tal como se define en el artículo 2, apartado 1 de la Acción común 98/733/JAI del Consejo;

b) Corrupción, tal y como se define en el artículo 3 del acto del Consejo de 26 de mayo de 1997 y en el artículo 3, apartado 1 de la Acción común 98/742/JAI del Consejo;

c) Fraude, según el artículo 1 del Convenio relativo a la protección de los intereses financieros de las Comunidades Europeas;

d) Blanqueo de capitales, tal y como se define en el artículo 1 de la Directiva 91/308/CEE del Consejo, de 10 de junio de 1991, relativa a la prevención de la utilización del sistema financiero para el blanqueo de capitales.

\section{Hungría}

\section{Normas sobre la adjudicación de contratos públicos}

- Ley de Contratación Pública CVIII (2011. évi). En vigor hasta el 1 de noviembre de 2015

- Ley 2015 CXLIII, de 22 de septiembre, sobre contratación pública

\section{Causas de exclusión obligatorias (Kizáró okok) Artículo 56 KBT}

1. Los siguientes operadores económicos están excluidos de la participación en un procedimiento de adjudicación como licitadores, candidatos o subcontratista, y no pueden contribuir a la certificación de idoneidad porque:

h) De conformidad con el Código Penal húngaro han sido condenados por su participación en una organización delictiva - incluyendo la comisión de delitos dentro de dicha organización delictiva, por soborno-corrupción, por corrupción en las transacciones internacionales, por comportamientos que han causado perjuicios a los intereses financieros de las Comunidades, siempre y cuando hayan sido condenados por sentencia firme con fuerza de cosa juzgada y mientras que los antecedentes penales no hayan sido cancelados

A tenor del artículo 60.3 KBT, y en relación a estos mismos tipos delictivos, en el caso de licitadores establecidos en otros Estados miembros, la prohibición 
de contratar se hará efectiva por su participación en una organización delictiva, tal y como se define en el apartado 1 del artículo 2 de la Acción Común 98/733/JAI del Consejo, por corrupción tal y como se define, respectivamente, en el artículo 3 del Acto del Consejo, de 26 de mayo de 1997, y en el apartado 1 del artículo 3 de la Acción Común 98/742/JAI del Consejo, por fraude, según el artículo 1 del Convenio relativo a la protección de los intereses financieros de las Comunidades Europeas, y por blanqueo de capitales, tal y como se define en el artículo 1 de la Directiva 91/308/CEE del Consejo, de 10 de junio de 1991, relativa a la prevención de la utilización del sistema financiero para el blanqueo de capitales;

\section{Irlanda}

Normas sobre la adjudicación de contratos públicos

- Reglamento sobre la adjudicación de contratos de los poderes adjudicadores - SI 329 de 2006 (Award of Public AuthoritiesâĂŹContracts) Public Sector Procurement Regulations

Causas de exclusión obligatorias (Criteria for qualitative selection - Exclusion of certain persons from being considered for awards of public contracts)

Artículo 53 (1) Regulations 329/2006

(1) Al considerar si debe o no adjudicar un contrato público, el poder adjudicador deberá excluir de esta consideración a cualquier persona que haya sido condenado mediante sentencia firme, de la que tenga conocimiento el poder adjudicador, por un delito relacionado con:

a) Participación en una organización delictiva, o

b) Corrupción, o

c) Fraude, o

d) Blanqueo de capitales 


\section{Italia}

\section{Normas sobre la adjudicación de contratos públicos}

- Código de Contratos Públicos, aprobado por el Decreto Legislativo No. 163, de 12 de abril de 2006 (Codice dei contratti pubblici relativi a lavori, servizi e forniture)

- Reglamento de desarrollo núm. 207, de 5 de octubre de 2010 (Regolamento attuativo ed esecutivo del Codice dei contratti pubblici)

\section{Causas de exclusión (Requisiti di ordine generale)}

Artículo 38.1.b) y c) Codice dei contratti pubblici relativi a lavori, servizi e forniture (modificado por el artículo 4, apartado 2, letra b) del Decreto ley núm. 70, de 13 de mayo de 2011, Prime disposizioni urgenti per léconomia).

Quedan excluidos de la participación en los procedimientos de licitación para la adjudicación de concesiones y contratos de obras, de suministro y servicio, así como de ser subcontratista y de no poder formalizar estos contratos:

b) Contra los que se sustancien los procedimientos para la aplicación de las medidas preventivas del artículo 3 de la Ley 1423, de 27 de diciembre de 1956 [Ley de medidas preventivas para la seguridad y para garantizar la moralidad pública], o de cualquier causa impeditiva prevista en el artículo 10 de la Ley 575, de 31 de mayo de 1965 [Disposiciones contra la mafia]; la exclusión y la descalificación será efectiva cuando esté pendiente de procedimiento contra el titular o el director técnico si se trata de una empresa individual; el socio o el director técnico si se trata de una empresa colectiva; el socio limitado o el director técnico si se trata de una sociedad limitada; los directores generales con facultades de representación, el director técnico o el socio mayoritario en caso de una sociedad con menos de cuatro miembros en de otro tipo de sociedad;

c) Los que han sido condenados con fuerza de cosa juzgada irrevocable por graves delitos contra el Estado y la comunidad por delitos contra la moralidad profesional; o debido a una sentencia judicial firme por uno o más delitos relativos a la participación en una organización criminal, corrupción, fraude, blanqueo de capitales, según se define en la legislación comunitaria mencionada en el artículo 45.1 de la Directiva 2004/18/CE. La exclusión y la descalificación se lleva a cabo respecto del: el titular o el director técnico si se trata de una empresa individual; el socio o el 
director técnico si se trata de una empresa colectiva; el socio limitado o el director técnico si se trata de una sociedad limitada, los directores generales con facultades de representación, el director técnico o el socio mayoritario en caso de una sociedad con menos de cuatro miembros en de otro tipo de sociedad o consorcio. En cualquier caso, la exclusión y la prohibición también serán efectivas cuando estos sujetos han cesado de su cargo en el año anterior de la fecha de la sentencia si la empresa no demuestra que ha habido una disociación completa y eficaz respecto de la conducta punible. La exclusión y la prohibición no será posible cuando se despenalice el delito, cuando exista una rehabilitación o cuando el delito fuera declarado extinguido después de la condena o en caso de revocación de la sentencia.

\section{Letonia}

Normas sobre la adjudicación de contratos públicos

- Ley de Contratación Pública, aprobada el 6 de abril de 2006 (Publisko iepirkumu likums) La redacción vigente es del 1 de agosto de 2011

\section{Causas de exclusión obligatorias (Kandidātu un pretendentu izslēgšanas} noteikumi)

Artículo 39 (1)

El órgano de contratación excluirá de la participación en un procedimiento de adjudicación de contratación pública y no considerará la propuesta

(1) del candidato o licitador, o de la persona que tenga el derecho de representación, de toma de decisiones o los derechos de supervisión, cuando ha sido encontrado culpable por sentencia judicial firme por corrupción, por actividades financieras fraudulentas, blanqueo de capitales o participación en una organización criminal.

\section{Lituania}

Normas sobre la adjudicación de contratos públicos

- Ley de Contratación Pública No. I-1491, de 13 de agosto de 1996, que fue ampliamente reformada en el año 2005 por la Ley Núm. X-471, de 22 
de diciembre (Lietuvos Respublikos viešujų pirkimų ìstatymo pakeitimo istatymas) La última modificación en esta materia ha tenido lugar en virtud de la Ley XI-1494, de 21 de junio de 2011

\section{Causas de exclusión obligatorias (Conditions Prohibiting or Limi- ting Suppliers' Participation in Procurement Procedure)}

Artículo 33.1

El poder adjudicador deberá rechazar toda oferta o propuesta si el proveedor persona física, o el licitador o candidato persona jurídica, asociación o gerente con poderes de representación, ha sido condenado en los últimos 5 años por sentencia firme por alguno de los delitos recogidos en el artículo 45.1 de la Directiva 2004/18/CE, sobre coordinación de los procedimientos de adjudicación de los contratos públicos de obras, suministro y servicios: participación en una organización delictiva, corrupción, soborno, cohecho, fraude, evasión de impuestos, blanqueo de capitales.

\section{Luxemburgo}

Normas sobre la adjudicación de contratos públicos

- Ley sobre contratos públicos, de 25 de junio de 2009 (Loi du 25 juin 2009 sur les marchés publics)

- Reglamento de ejecución (Règlement grand-ducal du 3 août 2009 portant exécution de la loi du 25 juin 2009)

Causas de exclusión obligatorias (Situation personnelle du candidat ou du soumissionnaire)

Artículo 222 del Reglamento de ejecución de la Ley sobre contratos públicos

Quedará excluido de la participación en un contrato público cualquier candidato o licitador que haya sido condenado mediante sentencia firme, de la que tiene conocimiento el poder adjudicador, por uno o varios de los motivos que a continuación se enumeran:

a) Delitos de los artículos 322 a 324 ter del Código Penal relativos a la participación en una organización criminal;

b) Delitos de los artículos 246 a 249 del Código Penal relativos a la corrupción; 
c) Delitos de los artículos 496-1 a 496-4 del Código Penal relativos al fraude y la estafa;

d) Delitos del artículo 506-1 del Código Penal relativo al blanqueo de capitales o al artículo 8-1 de la Ley modificada de 19 de febrero de 1973 relativa a la venta de sustancias medicinales y la lucha contra la toxicomanía.

(...) las pruebas justificativas de no estar incursos en estas situaciones se referirán a las personas físicas o jurídicas, incluidos los directores de empresa correspondiente o cualquier otra persona con poder de representación, decisión o control sobre el candidato o licitador.

\section{Malta}

Normas sobre la adjudicación de contratos públicos

- Reglamento de Contratos Públicos, aprobado por Aviso Legal 296/2010, de 1 de junio de 2010 (Subsidiary Legislation 174.04), modificación Act XXV of 2014

\section{Causas de exclusión obligatorias (Qualitative selection criteria)}

Artículo 50 (4)

Quedará excluido de la participación en un contrato público cualquier candidato o licitador que haya sido condenado mediante sentencia firme, de la que tiene conocimiento el poder adjudicador, por uno o varios de los motivos que a continuación se enumeran:

a) participación en una organización delictiva, tal y como se define en el apartado 1 del artículo 2 de la Acción Común 98/773/JAI del Consejo;

b) corrupción, tal y como se define, respectivamente, en el artículo 3 del acto del Consejo de 26 de mayo de 1997 y en el apartado 1 del artículo 3 de la Acción Común 98/742/JAI del Consejo;

c) fraude, según el artículo 1 del Convenio relativo a la protección de los intereses financieros de las Comunidades Europeas;

d) blanqueo de capitales, tal y como se define en el artículo 1 de la Directiva 91/308/CEE del Consejo, de 10 de junio de 1991, relativa a la prevención de la utilización del sistema financiero para el blanqueo de capitales. 
El Director de Contratos podrá autorizar una excepción a la aplicación de esta regulación por necesidades imperativas de interés general. (....)

Atendiendo a la legislación nacional del Estado miembro donde los candidatos o licitadores estén establecidos, las pruebas de no estar incursos en prohibición de contratar se referirán a personas físicas y jurídicas, incluyendo si es el caso, a los directores de empresa y cualquier persona que tenga facultades de representación, decisión o control en relación con el candidato o licitador.

(5) El Director de Contratos (Director of Contracts) tendrá la autoridad para implementar una lista negra (mechanism for the black listing) de operadores económicos.

\section{Países Bajos}

\section{Normas sobre la adjudicación de contratos públicos}

- Ley marco de reglas europeas sobre la contratación pública (Raamwet EEG-voorschriften aanbestedingen)

- Decreto de 16 de julio de 2005, por el que se establece las normas relativas a los procedimientos para la adjudicación de contratos públicos de obras, suministros y servicios Besluit aanbestedingsregels voor overheidsopdrachten (BAO) vigente hasta el 1 abril 2013 - Article 2.87, Public Procurement Act (Aanbestedingswet) 2012

\section{Causas de exclusión obligatorias (§12. Uitsluiting, selectie en gun- ning)}

\section{Artículo $45 \mathrm{BAO}$}

1. Un poder adjudicador deberá rechazar de la participación en un contrato público a cualquier candidato o licitador condenado por sentencia definitiva en virtud de los artículos 140 (participación en una organización criminal), 177 (delitos contra la autoridad pública), 177a, (sobornos), 178 (tráfico de influencias), 225, 226, 227, 227.a), 227.b) (falsedades), 323.a) (fraude a los intereses de las Comunidades Europeas), 328ter segundo párrafo (fraude funcionarial), 416, 417, 417bis, 420bis, 420ter o 420quater (blanqueo de capitales) del Código Penal.

2. Se podrá establecer una excepción a esta obligación por necesidades 
imperativas de interés general.

\section{Polonia}

\section{Normas sobre la adjudicación de contratos públicos}

- Ley de Contratación Pública, de 29 de enero de 2004 (Prawo zamówień publicznych). Su texto consolidado es de 2011

\section{Causas de exclusión obligatorias}

Artículo 24.1 (apartados 4 a 8)

1. Deberá ser excluido del procedimiento de adjudicación contractual:

Las personas físicas/las uniones registradas/las asociaciones profesionales/las sociedades limitadas o en comandita/las personas jurídicas cuyos representantes/: han sido válidamente condenadas por un delito cometido en relación con un procedimiento de adjudicación contractual, delito contra los derechos de los trabajadores, delitos contra el medio ambiente, por corrupción, por un delito contra el orden económico o por cualquier otro delito cometido con el fin de obtener beneficios económicos, así como por fraude o por participación en una organización criminal.

(9) Las entidades colectivas respecto de las cuales un tribunal ha emitido una decisión de prohibir contratar en virtud de las disposiciones relativas a la responsabilidad penal de las entidades colectivas.

Artículo 24.4. La oferta de un operador económico excluido se considerará rechazada.

\section{Portugal}

Normas sobre la adjudicación de contratos públicos

- Decreto Ley 18/2008, de 29 de enero de 2008, que aprueba el Código dos Contratos Públicos, modificado por el Decreto Ley 278/2009, de 2 de octubre (texto consolidado)

\section{Impedimentos (Artigo 55)}




\section{Artículo 55}

No podrán ser candidatos o licitadores, ni integrar una agrupación de los mismos, las entidades que:

i) Hayan sido condenadas por sentencia judicial por alguno de los siguientes delitos, mientras no se haya producido su rehabilitación, en el caso de tratarse de personas físicas, o, en el caso de tratarse de personas jurídicas, que hayan sido condenados por los mismos los titulares de la órganos sociales de administración, de dirección o gestión de las mismas y se encuentren en el ejercicio de sus funciones, en tanto no se haya producido su rehabilitación:

i.) participación en una organización delictiva, tal y como se define en el apartado 1 del artículo 2 de la Acción Común 98/773/JAI del Consejo;

ii.) corrupción, tal y como se define, respectivamente, en el artículo 3 del acto del Consejo de 26 de mayo de 1997 y en el apartado 1 del artículo 3 de la Acción Común 98/742/JAI del Consejo;

iii.) fraude, según el artículo 1 del Convenio relativo a la protección de los intereses financieros de las Comunidades Europeas;

iv.) blanqueo de capitales, tal y como se define en el artículo 1 de la Directiva 91/308/CEE del Consejo, de 10 de junio de 1991, relativa a la prevención de la utilización del sistema financiero para el blanqueo de capitales.

\section{Reino Unido}

\section{Normas sobre la adjudicación de contratos públicos}

- Reglamento de Contratos Públicos - Public Contracts Regulations 2006 (SI 2006/5)

- Escocia tiene una legislación propia: Scottish Statutory Instruments SSI 2006/1

- Reglamento de Contratos Públicos febrero 2015 - The Public Contract Regulations 2015 (SI 102/2015)

\section{Causas de exclusión obligatorias (Criteria for the rejection of eco- nomic operators)}

Artículo 23 The Public Contracts Regulations 2006

(1) Con sujeción a lo dispuesto en el párrafo segundo y de conformidad con esta regulación, la entidad adjudicadora deberá considerar inelegible y no 
seleccionará al operador económico cuando el poder adjudicador tenga noticias que el operador económico o sus directores u otra persona que ostente su representación o tenga poder de decisión sobre el mismo, hayan sido condenados por alguno de los siguientes delitos:

(a) Conspiración en el sentido del artículo 1 de la Ley Penal de 1977 cuando la conspiración se refiere a la participación en una organización delictiva, como se define en el artículo 2(1) de la Acción Común 98/733/JAI del Consejo;

(b) Corrupción con el significado de la sección primera de la Ley de Prácticas corruptas de los organismos públicos 1889, o en la sección primera de la Ley de Prevención de la corrupción de 1906;

(c) Por un delito de soborno;

(d) Fraude, en el cual el delito se refiere al fraude que afecta a los intereses de las Comunidades Europeas tal como se define en el artículo 1 del Convenio relativo a la protección de los intereses financieros de las Comunidades Europeas, con el significado de:

i. Delito de fraude a la Hacienda,

ii. Delito de conspiración para defraudar,

iii. Fraude o robo, en el sentido de la Ley del Robo de 1968 y de 1978, iv. Operaciones fraudulentas en el sentido del artículo 458 de la Ley de Sociedades de 1985,

v. Defraudación aduanera, en el sentido de la Ley de Aduanas e Impuestos especiales de 1997, y de la Ley del Impuesto sobre el Valor Añadido de 1994;

vi. Un delito en relación con los impuestos de la Unión Europea en el sentido del artículo 71 de la Ley de Justicia Penal de 1993,

vii. La destrucción, la alteración y ocultación de los documentos o por adquirir una garantía de valor en el sentido del artículo 20 de la Ley del Robo de 1968.

(e) blanqueo de capitales, con el significado de la Regulación sobre el blanqueo de capitales del 2003 (S.I. 2003/3075);

(f) Por cualquier otro delito con el significado del artículo 45.1 de la Directiva sobre sectores clásicos tal como se define en la legislación nacional de cualquier Estado.

(2) En cualquier caso, cuando un operador económico o sus directores o cualquier otra persona con poderes de representación, decisión o control ha sido condenado por alguno de los delitos recogidos en el párrafo primero, el poder 
adjudicador puede excepcionar esta prohibición si existen razones imperiosas de interés general que lo justifiquen en relación a los operadores económicos.

\section{República Checa}

\section{Normas sobre la adjudicación de contratos públicos}

- Ley 137/2006, de 14 de marzo, de Contratos Públicos (Zákon č. 137/2006 Sb., o veřejných zakázkách), modificada por la Ley 40/2015 (Act No. $40 / 2015)$

\section{Causas de exclusión obligatorias}

\section{$\S 53$ Basic Qualifications Prerequisites}

(1) Los requisitos previos básicos que tiene que tener el operador económico para poder contratar son:

a) Que no haya sido condenado en una sentencia judicial firme por un delito de participación en un grupo de crimen organizado, por un delito de participación o complicidad en actividades delictivas, por blanqueo de capitales, por cohecho, por aceptar sobornos, por fraude incluyendo los supuestos de preparación y tentativa para cometer el delito. Este prerrequisito deberá ser cumplido por la organización y por cada uno de los miembros de la misma en caso de tratarse de una persona jurídica; en caso de una oferta o solicitud de participación presentada por una organización extranjera, el prerrequisito debe cumplirse por los operadores económicos en relación con el territorio de la República Checa y del país de establecimiento y residencia de los mismos.

j) Que no esté inscrito en una lista negra de operadores económicos que tengan prohibido participar en la ejecución de contratos públicos.

\section{Rumanía}

Normas sobre la adjudicación de contratos públicos

- Ordenanza Gubernamental de Urgencia 34/2006, de 19 de abril, relativa a la adjudicación de contratos públicos, contratos de concesión de obras 
y de servicios (Ordonant̨ă de Urgenţă GEO no. 34/2006) cuya última modificación se ha llevado a cabo por GEO 51/2014

\section{Situaţia personală a candidatului sau a ofertantului}

Artículo 180

El órgano de contratación tiene la obligación de excluir del procedimiento de adjudicación contractual al licitador/candidato del cual tenga conocimiento que en los últimos cinco años ha sido condenado por sentencia judicial firme por haber participado en las actividades de una organización criminal, por corrupción, por fraude y/o por blanqueo de capitales.

\section{Suecia}

Normas sobre la adjudicación de contratos públicos

- Ley de Contratación pública (2007:1091), de 22 de noviembre de 2007 Lag om offentlig upphandling (LOU), modificada por (2014:474)

Capítulo 10 Exclusión de proveedores/operadores económicos - Uteslutning av leverantörer

Circunstancias que darán lugar a la exclusión de los proveedores

$1 \oint E l$ poder adjudicador deberá excluir de la participación en un contrato público al proveedor si conociera que éste ha sido condenado por sentencia judicial firme por alguno de los delitos que incluyen:

1. Delito al que se refiere el artículo 2 de la Decisión marco 2008/841/JAI, relativa a la lucha contra la delincuencia organizada;

2. Corrupción, tal y como se define en el artículo 3 del acto del Consejo de 26 de mayo de 1997, por el que se establece, sobre la base de la letra c) del apartado 2 del artículo K .3 del Tratado de la Unión Europea, y en el artículo 3.1 de la Acción Común de 22 de diciembre de 1998, adoptada por el Consejo sobre la base del artículo K .3 del Tratado de la Unión Europea, sobre corrupción en el sector privado (98/742/JAI);

3. Fraude, según el artículo 1 del Convenio establecido sobre la base del artículo K .3 del Tratado de la Unión Europea, relativo a la protección de los intereses financieros de las Comunidades Europeas; 
4. Blanqueo de capitales, tal y como se define en el artículo 1 de la Directiva 91/308/CEE del Consejo, de 10 de junio de 1991, relativa a la prevención de la utilización del sistema financiero para el blanqueo de capitales, en su versión modificada por la Directiva 2001/97/CE del Parlamento Europeo y del Consejo.

Si el proveedor es una persona jurídica, deberá ser excluida si el representante de la persona jurídica ha sido condenada por alguno de esos delitos.

Si existe una causa justificada para suponer que un proveedor debe ser excluido de conformidad con las circunstancias del primer párrafo, la autoridad contratante podrá solicitar que el proveedor demuestre que no hay motivos para la exclusión. Su hubieran razones especiales, un poder adjudicador podrá renunciar a la exclusión del proveedor que haya sido condenado por un delito de conformidad con el primer párrafo.

\section{La consideración de aspectos sociales y medioambientales entre las prohibiciones de contratar. Algunas propuestas de lege ferenda}

Este epígrafe se asienta sobre la idea - ya manifestada - que la contratación pública constituye un importante instrumento de política económica y puede contribuir a la consecución de otros objetivos públicos, a los que anteriormente nos hemos referido con los calificativos de secundarios, en virtud del potencial de sinergia de los fondos destinados a las compras del sector público ${ }^{738}$.

\section{VII.1. Cuestiones previas}

La visión instrumental de las adquisiciones públicas nos conduce a hablar de la utilización de la contratación con el fin de afianzar comportamientos empresariales beneficiosos para el interés general sin que, necesariamente, estén

${ }^{738}$ Véase lo dicho en las páginas 170 a 175 de esta memoria doctoral y las referencias bibliográficas allí citadas. 
conectados con la directa satisfacción funcional del contrato ${ }^{739}$. A pesar de este loable propósito, el uso de la contratación pública como instrumento para promover el cumplimiento de finalidades de carácter más generalistas dependerá de lo que establezca el propio ordenamiento jurídico y de la intención política en incorporar estos objetivos a las compras públicas.

Tampoco podemos desconocer que han existido - y existen todavía - voces discordantes con la idea de tener en consideración aspectos sociales y medioambientales en la contratación, al entender que la normativa contractual no es el lugar adecuado para imponer obligaciones a los contratistas en el ámbito, por ejemplo, de la lucha contra la exclusión social, la perspectiva de género o la protección medioambiental ${ }^{740}$. Para ilustrar esta disconformidad valgan

${ }^{739}$ MESTRE DELGADO constataba la existencia de un interés público al emplear mecanismos de refuerzo - o fomento - para forzar a los empresarios al cumplimiento de previsiones contempladas en normativas sectoriales, en MESTRE DELGADO, J. F., "Contratos públicos y políticas de protección social y medioambiental", $R E A L$, núm. 291, enero - abril 2003, pág. 707. RODRÍGUEZ ESCANCIANO defendía que "aun cuando la contratación pública no está diseñada para que sea un medio de fomento directo ni de control específico de medidas sociales, la verdad es que puede tener un extraordinario poder de conformación social sobre el tejido empresarial", en RODRÍGUEZ ESCANCIANO, S., Un paso adelante en la protección de los derechos laborales de las personas con discapacidad: el nuevo sistema de contratación pública, Cermi- Cinca, Madrid, 2008, pág. 15 y en Cláusulas Sociales y Licitación Pública: Análisis jurídico, Instituto Andaluz de Administración Pública, Sevilla, 2009, pág. 21.

${ }^{740}$ Algunas de esas críticas las encontramos en URÍA FERNÁNDEZ, F., "Apuntes para una reforma de la legislación sobre Contratos de las Administraciones Públicas", $R A P$, núm. 165, septiembre - diciembre 2004, especialmente en la pág. 323 donde sostiene que la inclusión de cláusulas sociales "amenazaría con desvirtuar los fines de la propia contratación pública, al ponerla exclusivamente al servicio de otras políticas públicas, relevantes, sin duda, pero que, en principio, le son ajenas".

Asimismo, hay que señalar que en el Documento que recoge una síntesis de estas respuestas a las preguntas que la Comisión había formulado acerca de la utilización estratégica de la contratación para lograr objetivos políticos de la Estrategia Europa 2020, un número importante de ellas - procedentes especialmente del mundo empresarial -, se oponen al fomento una «contratación pública social»o «contratación verde». Otras partes interesadas - como en el caso de las organizaciones de la sociedad civil - se muestran, sin embargo, muy favorables a este uso estratégico de la contratación y abogaban por cambios de la legislación en esta línea. Puede consultarse el Evaluation Report (Part 1), SEC (2011) 853 final, de 27 de junio, págs. 74 a 83. 
como ejemplos el Informe y Conclusiones de la Comisión de expertos para el estudio y diagnóstico de la situación de la contratación pública en España, que manifestaba que "existen en la actualidad mecanismos jurídicos alternativos - o complementarios, si prefiere decirse así - para estimular o desincentivar determinadas conductas desde el punto de vista social o medioambiental"741 o el más reciente Informe de la CNMC sobre el Anteproyecto de la Ley de Contratos del Sector Público que considera que la contratación pública no es el instrumento correcto para el cumplimiento de los objetivos sociales comunes incluidos en las Directivas y es por ello que concluye que "debe valorarse con elevado rigor la introducción de objetivos secundarios que, aunque bienintencionados, pueden amenazar los objetivos primarios de la contratación pública incrementando el coste de los contribuyentes y de los usuarios" $" 742$.

Con todo, estas críticas se ven amortiguadas en la medida en que se ha ido aceptando, primero por parte del TJUE ${ }^{743}$ y después por la propia normativa de la Unión (Directivas 2004/17/CE y 2004/18/CE), que la contratación pública puede coadyuvar a alcanzar ciertos objetivos de interés general haciendo uso del potencial de sinergia de los fondos destinados a las compras del sector público, si bien desde la búsqueda del necesario equilibrio que no desnaturalice los objetivos propios de la normativa contractual, ni quiebre los principios que rigen la adjudicación contractual, en especial, los principios de igualdad de trato, transparencia y no discriminación ${ }^{744}$.

${ }^{741}$ Informe y Conclusiones de la Comisión de expertos para el estudio y diagnóstico de la situación de la contratación pública en España, Ministerio de Hacienda, Madrid, 2004, pág. 147.

${ }^{742}$ Informe de 16 de julio de 2015 (IPN/CNMC/010/15).

${ }^{743}$ Sentencias del Tribunal de Justicia de 20 de septiembre de 1988, Gebroeders Beentjes, C-31/87; de 20 de marzo de 1990, Du Pont de Nemours Italiana, C-21/88; de 11 de julio de 1991, Laboratori Bruneau, C-351/88; de 17 de septiembre de 2002, Concordia Bus Finland, C-513/99, apartado 69; de 4 de diciembre de 2003, EVN y Wienstrom, C-448/01, apartado 33. A este respecto, MEDINA ARNÁIZ, T., "La contratación pública socialmente responsable (...), op. cit., págs. 213 - 240.

${ }^{744}$ Son numerosos los estudios que han tratado sobre la integración de los aspectos sociales y medioambientales en las distintas fases de la adjudicación contractual. A título de ejemplo, vamos a citar alguno de ellos NIJHOLT, H., "Environmental Provisions in Public Procurement Directive 2004/18/EC", International Construction Law Review, vol. 21 (3), 2004, págs. 268 - 290; BRUUN, N. y BERCUSSON, 
Teniendo en cuenta estas consideraciones previas, no abordaremos el análisis de las consideraciones sociales y medioambientales en la contratación públi-

B., "Labour Law Aspects of Public Procurement in the EU", en la obra colectiva editada por NIELSEN, R. y TREUMER, S., The New EU Public Procurement Directives, Djøf Publishing, Copenhague, 2005, pág. 97; JACOB, M., "Peut-on introduire le critère social dans la commande publique et comment s'y prendre?", Contrats Publics, núm. 50 (número especial dedicado a los aspectos sociales en la contratación pública Du bon usage des aspects sociaux), décembre 2005, págs. 42 45; LINDITCH, F., "Critères sociaux: vers un guide des achats socioresponsables", Contrats et Marchés publics, núm. 7, juillet 2008; ARROWSMITH, S. y KUNZLIK, P., "EC regulation of public procurement", en la obra colectiva Social and Environmental Policies (...), op. cit., págs. 55 - 107; KUNZLIK, P., "The procurement of green energy", en la misma obra Social and Environmental Policies (...), op. cit., págs. 369 - 407; PALMUJOKI, A., PARIKKA-ALHOLA, K. y EKROOS, A., "Green public procurement: Analysis on the use of environmental criteria in contracts", Review of European Community and International Environmental Law, vol. 19 (2), 2010, págs. 250 - 262; CARANTA, R., "Sustainable Public Procurement in the EU", en la obra colectiva The Law of Green and Social Procurement in Europe, Djøf Publishing, Copenhague, 2010, págs. 15 - 51; FEJØ, J., "Social and Environmental Policies in EU Public Procurement Law", en la obra colectiva EU Public Procurement Law: An Introduction, EU-Asia Inter University Network, Nottingham, 2010, págs. 298 - 338; BRAMMER, S. y WALKER, H., "Sustainable procurement in the public sector: an international comparative study", International Journal of Operations 83 Production Management, vol. 31 (4), 2011, págs. 452 - 476 y CARANTA, R., "Sustainable Procurement", en la obra colectiva EU Public Contract Law: Public Procurement and beyond, Bruylant, Brussels, 2014, págs. 165 - 190.

En relación con la incorporación de aspectos sociales y medioambientales desde la doctrina española - además de las obras ya citadas - puede consultarse, con carácter general, VÈRNIA TRILLO, S., "La inclusión de las cláusulas sociales en la contratación pública", RArAP, núm. 20, junio 2002, págs. 429 - 453; GOSÁLBEZ PEQUEÑO, H., “¿Cláusulas sociales en la selección de los contratistas de las Administraciones públicas españolas?", Justicia Administrativa, núm. 20, julio 2003, págs. 27 - 67; BLÁZQUEZ ROMÁN, J. A. y RAMÍREZ HORTELANO, P., "Las cláusulas sociales en la contratación administrativa", Contratación Administrativa Práctica, núm. 42, mayo 2005, págs. 39 - 48; MOLINA NAVARRETE, C., "Relaciones laborales, política de empleo y compra pública socialmente responsable: las cláusulas sociales en la Ley 30/2007, de 30 de octubre, de Contratos del Sector Público", Revista de Trabajo y Seguridad Social, CEF, núm. 302, 2008, págs. 3 - 64; FERNÁNDEZ DE GATTA SÁNCHEZ, D., "El régimen de la incorporación de criterios ambientales en la contratación del sector público: su plasmación en las nuevas Leyes sobre contratación pública de 2007", Contratación Administrativa Práctica, núm. 80, noviembre 2008, y del mismo autor "La integración de aspectos medioambientales en la contratación pública", en la obra colectiva Derecho ambiental y transformaciones de la actividad de las Administraciones públicas, Atelier, Barcelona, 2010, págs. 123 - 159; 
ca, puesto que excede el objeto de nuestro estudio. Únicamente vamos a centrar nuestra atención en los aspectos sociales y medioambientales referidos a los criterios de selección cualitativa del contratista; es decir, en aquellos criterios que están vinculados a la apreciación de la aptitud de los licitadores y candidatos para ejecutar el contrato y que pueden justificar su exclusión de la participación en una licitación pública.

\section{VII.2. Las prohibiciones de contratar por incumplimien- to de las obligaciones en materia medioambien- tal, social o laboral en las nuevas Directivas}

Las razones que nos llevan a abordar este estudio son múltiples y atienden al pasado, al presente y quizá a una futura «quinta generación» de Directivas. En primer lugar, y aludiendo a fechas pretéritas, porque - aunque no viesen la luz en los términos propuestos - en el proceso de elaboración de la Directiva 2004/18/CE ya hemos destacado cómo se habían planteado incorporar al texto prohibiciones de contratar por motivos relacionados con la vulneración de los convenios internacionales en materia laboral, por incumplimiento de la normativa relativa a la protección del empleo y por daños causados al medio ambiente. En esta idea, es preciso recordar que el Dictamen del Co-

MELERO ALONSO, E., "La promoción del medio ambiente a través de la contratación pública: análisis de las cláusulas ambientales", Revista de derecho urbanístico y medio ambiente, núm. 260, septiembre-octubre 2010, págs. 165 - 203; OLLER RUBERT, M., "La inclusión de cláusulas ambientales en la contratación pública", Revista Catalana de Dret Ambiental, núm. 1, 2010, págs. 1-34; VILLALBA PÉREZ, F., "La dimensión social de la contratación pública. El sector de la discapacidad en la Ley de Contratos del Sector Público", en la obra colectiva Administración Local. Estudios en homenaje a Ángel Ballesteros, La Ley - El Consultor de los Ayuntamientos, Las Rozas (Madrid), 2011, págs. 219 - 262; GALLEGO CÓRCOLES, I., "Cláusulas sociales, contratación pública y jurisprudencia del TJUE", Contratación Administrativa Práctica, núm. 133, noviembre 2011; RAMOS PÉREZ-OLIVARES, A., La regulación de las cláusulas sociales en los contratos del sector público tras el Real Decreto legislativo 3/2011, La Ley, Las Rozas (Madrid), 2012; CASARES MARCOS, A., "Comercio justo y fomento de la contratación pública socialmente responsable", Contratación Administrativa Práctica, núm. 123, enero - febrero 2013 y las distintas aportaciones al libro colectivo dirigido por PERNAS GARCÍA, J.J. Contratación pública estratégica, Thomson-Aranzadi, Cizur Menor (Navarra), 2013. 
mité Económico y Social ya proponía que el texto de la Directiva recogiese expresamente que se podía "excluir a un licitador en caso de infracción grave probada de la legislación social o medioambiental" (apartado 4.9.3) ${ }^{745}$, y que el Dictamen del Parlamento Europeo, adoptado en primera lectura, abogaba por incluir en el apartado primero del artículo 46, relativo a las exclusiones de carácter obligatorio, una prohibición de contratar por incumplimiento de los convenios colectivos y otras normas y leyes en materia laboral y social ${ }^{746}$.

El segundo motivo atiende a lo dispuesto en las nuevas Directivas. Entre sus objetivos declarados se encuentran (i) fomentar la utilización más eficiente de los fondos públicos; (ii) permitir que los poderes adjudicadores empleen la contratación en apoyo de objetivos sociales comunes y (iii) aprovechar plenamente las posibilidades que ofrece la contratación pública para alcanzar los objetivos fijados en la Estrategia Europa 2020 ${ }^{747}$; sin embargo, a nuestro entender este objetivo no está bien resuelto por lo que se refiere a las prohibiciones de contratar.

En esta materia resulta un avance evidente la obligación para los Estados miembros de tomar "las medidas pertinentes para garantizar que, en la ejecución de contratos públicos/concesiones, los operadores económicos cumplen las obligaciones aplicables en materia medioambiental, social o laboral establecidas en el Derecho de la Unión, el Derecho nacional, los convenios colectivos o por las disposiciones de Derecho internacional medioambiental, social y laboral" (artículo 30.3 de la Directiva 2014/23/UE («concesiones»); artículo 18.2 de la Directiva 2014/24/UE y artículo 36.2 de la Directiva 2014/25/UE («sectores especiales»).

Para ello las Directivas establecen en sus anexos una relación de convenios internacionales cuyo respeto se exige en la fase de ejecución del contrato y que, por lo que al ámbito social y laboral se refiere, coincide con los ocho

${ }^{745}$ Dictamen del Comité Económico y Social, de 26 de abril de 2001 (DOCE C 193, de 10 de julio de 2001).

${ }^{746}$ Dictamen del Parlamento Europeo, adoptado en primera lectura el 17 de enero de 2002 (DOCE C 271E, de 7 de noviembre de 2002, pág. 176).

${ }^{747}$ Considerando tercero de la Directiva de concesiones; considerando centésimo vigésimo tercero de la Directiva 2014/24/UE y considerando centésimo de la Directiva 2014/25/UE («sectores especiales»). 
convenios declarados "fundamentales" por la Organización Internacional del Trabajo OIT. Éstos abarcan los temas que son considerados como principios y derechos esenciales en el ámbito del trabajo: la libertad de asociación y la libertad sindical, y el reconocimiento efectivo del derecho de negociación colectiva; la eliminación de todas las formas de trabajo forzoso u obligatorio; la abolición efectiva del trabajo infantil; y la eliminación de la discriminación en materia de empleo y ocupación ${ }^{748}$.

- Convenio OIT núm. 87 sobre la libertad sindical y la protección del derecho de sindicación (1948);

- Convenio OIT núm. 98 sobre el derecho de sindicación y de negociación colectiva (1949);

- Convenio OIT núm. 29 sobre el trabajo forzoso (1930);

- Convenio OIT núm. 105 sobre la abolición del trabajo forzoso (1957);

- Convenio OIT núm. 138 sobre la edad mínima (1973)

- Convenio OIT núm. 111 sobre la discriminación (empleo y ocupación) (1958);

- Convenio OIT núm. 100 sobre igualdad de remuneración (1951);

\footnotetext{
${ }^{748}$ No aparece, sin embargo, el Convenio núm. 94 relativo a las cláusulas de trabajo en los contratos celebrados por las autoridades públicas, que fue adoptado en 1949 por la OIT. En la página web de la OIT puede consultarse un interesante trabajo titulado Estudio general sobre las cláusulas de trabajo en los contratos celebrados por las autoridades públicas. La dimensión social de la contratación pública, publicado en 2008 y relativo al Convenio OIT (núm. 94) y a la Recomendación (núm. 84), en el que se pregunta retóricamente "cómo es posible que la norma internacional de trabajo de la OIT aplicable a la contratación pública, único instrumento universal de carácter vinculante y de aplicación sistemáticamente controlada, parece haber perdido parte de su protagonismo", más aun en el contexto europeo pues la transposición de la Directivas de la UE a las legislaciones nacionales ha derivado en la consecuencia de que dejara de figurar en la legislación contractual la obligación de insertar cláusulas de trabajo tal y como exige el Convenio OIT núm. 94. En este sentido, véase RODRÍGUEZ-PIÑERO BRAVO-FERRER, M., "Contratación pública y condiciones de trabajo", Relaciones Laborales, núm. 4, febrero - marzo 2008, págs. $1-16$.
} 
- Convenio OIT núm. 182 sobre las peores formas de trabajo infantil (1999).

Ahora bien, a pesar del reconocimiento que supone vincular estos convenios a la contratación pública, y previéndose la posibilidad de poder exigir a licitadores y candidatos un compromiso con los derechos laborales a lo largo de la cadena de producción que sea verificable (como condición de ejecución contractual), no logramos entender por qué este mismo rigor no se ha aplicado para impedir contratar con aquel operador económico que incumple los citados convenios.

En efecto, las nuevas Directivas sobre contratación pública al amparo de no considerar apropiado "imponer a la contratación unos requisitos medioambientales y sociales de carácter general y obligatorio"749, establecen la posibilidad de excluir de la adjudicación de un contrato público a los operadores económicos que han incumplido las obligaciones medioambientales o sociales. De esta manera, "los poderes adjudicadores podrán excluir a un operador económico de la participación en un procedimiento de contratación, por sí mismos o a petición de los Estados miembros, en cualquiera de las siguientes situaciones:

a) cuando el poder adjudicador pueda demostrar por cualquier medio apropiado que se han incumplido obligaciones aplicables en virtud del artículo 18, apartado 2 (en el caso de la Directiva 2014/24/UE) o del artículo 30, apartado 3 (en el supuesto de la Directiva de concesiones).

\section{VII.3. Nuestra propuesta de lege ferenda: dotar de un carácter obligatorio a estas prohibiciones de con- tratar}

Cuestionamos la conveniencia de la inclusión de estas prohibiciones de contratar con un carácter facultativo para los Estados miembros en base a cinco consideraciones:

(1) Al instituirse con un carácter facultativo, los Estados miembros disponen - como ya hemos advertido - de un amplio margen de apreciación

\footnotetext{
${ }^{749}$ Considerando centésimo de la de la Directiva 2014/25/UE («sectores especiales»).
} 
para decidir si incorporan, o no, estas prohibiciones de contratar a sus normativas contractuales ${ }^{750}$ y ello supone puntos de partida diferentes respecto de las de carácter obligatorio;

(2) Al resultar opcionales, no está garantizada una aplicación uniforme de estas prohibiciones en toda la Unión restándose, por tanto, eficacia disuasoria a su consideración como instrumento garante de obligaciones sociales, laborales y medioambientales;

(3) Aunque su carácter potestativo no tiene por qué obstaculizar una contratación transfronteriza, estamos en condiciones de afirmar que dificulta el conocimiento de los requisitos para contratar en los Estados miembros ante la diversidad de regulaciones que surgen respecto de estas prohibiciones de contratar;

(4) También porque resulta una contradicción que la protección del medio ambiente pueda avalar - por razones imperiosas de interés general - una excepción a una prohibición de contratar obligatoria ${ }^{751}$, y sin embargo, ese mismo interés general no quede garantizado mediante la exclusión de la licitación pública de quienes han causado un impacto negativo sobre el medioambiente.

(5) Además de ello, su carácter facultativo contrasta con los objetivos sobre desarrollo sostenible impuestos desde la UE.

El objetivo de promover una recuperación económica sostenible se ha ido incorporando a la mayor parte de las políticas de la Unión y así, a través de la Estrategia revisada para un Desarrollo Sostenible ${ }^{752}$ y de la Estrategia Europa

${ }^{750}$ En este sentido, véanse las sentencias del Tribunal de Justicia de 9 de febrero de 2006, La Cascina y otros, C-226/04 y C-228/04, apartados 21 a 23 y de 19 de mayo de 2009, Assitur, C-538/07, apartado 23.

${ }^{751}$ Véase el artículo 57.3 de la Directiva 2014/24/UE y el artículo 37.6 de la Directiva 2014/23/UE («concesiones»).

${ }^{752}$ En 2001, el Consejo Europeo de Gotemburgo aprobó la Estrategia de Desarrollo Sostenible de la UE, COM (2001) 264 final, de 15 de abril de 2001. En el año 2006 se revisó la Estrategia para un desarrollo sostenible por medio de la decisión sobre la Revisión de la Estrategia de la Unión Europea para un desarrollo sostenible Estrategia revisada, COM (2005) 658 final, de 13 de diciembre, aprobada por el 
2020, se ha apostado por estimular el crecimiento económico sobre la base de una economía innovadora, competitiva y medioambientalmente eficaz, o lo que es lo mismo, que proteja y mejore el medio ambiente a la vez que promueve la igualdad y la cohesión social.

Las prioridades de la Unión que tratan de situar a la UE en la senda de un crecimiento sostenible se han formulado a la luz de los preceptos del Tratado de Lisboa (2009), de las previsiones recogidas en el TFUE y del artículo 3 del TUE que aborda de manera transversal la cohesión económica, social y territorial $^{753}$. En este mismo sentido, han de destacarse los artículos 9, 10 y 11 TFUE que exigen que la lucha contra la exclusión social, contra toda clase

Consejo Europeo los días 15 y 16 de junio de 2006 (Doc. 10633/1/06, Rev1). En 2009, la Comisión completó la revisión en su Comunicación titulada Incorporación del desarrollo sostenible en las políticas de la UE: Informe de 2009 sobre la estrategia de la Unión Europea para el desarrollo sostenible, COM (2009) 400 final, de 24 de julio.

La expresión «desarrollo sostenible» ha tenido gran acogida en los textos relativos a la protección ambiental desde que en el año 1987 se formulara la definición de desarrollo sostenible por parte del Informe Nuestro Futuro Común (Our Common Future) elaborado por la Comisión Mundial para el Medio Ambiente y el Desarrollo de la Asamblea General de las Naciones Unidas, más conocido como Informe Brundtland por el nombre de la Primera ministra noruega que presidió la Comisión. En este Informe se definía el desarrollo sostenible como aquel que garantiza las necesidades del presente sin comprometer las posibilidades de las generaciones futuras para satisfacer sus propias necesidades. Sobre estos conceptos y su incorporación al Derecho, puede consultarse la colaboración de ALENZA GARCÍA, J. F., "Desarrollo sostenible", en la obra colectiva Los principios jurídicos del Derecho Administrativo, La Ley, Las Rozas (Madrid), 2010, págs. 1387 - 1426 y el Informe de seguimiento de EUROSTAT sobre Estrategia de Desarrollo Sostenible de la UE en 2011 (Monitoring Report of the EU Sustainable Development Strategy). Más centrado en el ámbito de la contratación pública, PREUSS, L., "Addressing sustainable development through public procurement: the case of local government", Supply Chain Management, vol. 14 (3), 2009, págs. 213 - 223 y ARROWSMITH, S., "Horizontal Policies in Public Procurement: A Taxonomy", Journal of Public Procurement, vol. 10 (2), 2010, págs. $149-186$.

${ }^{753}$ Conforme a este artículo 3.3 TUE "La Unión establecerá un mercado interior. Obrará en pro del desarrollo sostenible de Europa basado en un crecimiento económico equilibrado y en la estabilidad de los precios, en una economía social de mercado altamente competitiva, tendente al pleno empleo y al progreso social, y en un nivel elevado de protección y mejora de la calidad del medio ambiente. Asimismo, promoverá el progreso científico y técnico. La Unión combatirá la exclusión social y la discriminación (...)". 
de discriminación y la protección del medio ambiente se integren en todas las políticas y actividades de la Unión con objeto de fomentar un desarrollo sostenible.

Con arreglo al artículo 9 TFUE, la Unión deberá tener "en cuenta las exigencias relacionadas con la promoción de un nivel de empleo elevado, con la garantía de una protección social adecuada, con la lucha contra la exclusión social y con un nivel elevado de educación, formación y protección de la salud humana". Este mandato social encuentra una plasmación aún más certera en el artículo 31 de la Carta de los Derechos Fundamentales, texto que ahora forma parte del Derecho originario de la Unión, y donde se proclama que "todo trabajador tiene derecho a trabajar en condiciones que respeten su salud, su seguridad y su dignidad".

Nuestra propuesta de lege ferenda parte de una idea clara: el respeto por la legislación en vigor debiera ser un requisito inexcusable y, por tanto, obligatorio para poder contratar con el sector público, de tal manera que, las ventajas competitivas de los licitadores y candidatos en el procedimiento contractual no resulten del incumplimiento de la norma, sino del reconocimiento y valoración de un comportamiento responsable, fiable y honesto.

En base a esta propuesta, que vela por la complementariedad en todas las acciones de la UE, se debiera contemplar una causa de exclusión obligatoria en este sentido y exigir a los poderes adjudicadores que se asegurasen de que el adjudicatario de un contrato público - y a un distinto nivel probatorio también los licitadores y candidatos - respetan la legislación sociolaboral y las normas ambientales cumpliendo las obligaciones exigidas tanto a nivel internacional, a nivel europeo, como por parte del Estado en que están establecidos o en el que se va a realizar la prestación contractual ${ }^{754}$.

\footnotetext{
${ }^{754}$ En este mismo sentido, el Comité Económico y Social Europeo (CESE), en su Dictamen de 26 de abril de 2012, entre sus propuestas de enmienda manifestaba que debieran contemplarse expresamente entre las prohibiciones de contratar que los candidatos o licitadores "puedan ser excluidos cuando no cumplan la normativa nacional de cada Estado miembro, según el caso, en materia social, laboral o medioambiental y los convenios colectivos vigentes en el lugar de perfeccionamiento de la obra, el servicio o el suministro. En todo caso el CESE considera que estas exclusiones por dichos motivos deberían ser obligatorias" (DOUE C 191, de 29 de junio de 2012, pág. 84).
} 
$\mathrm{Al}$ actuar a nivel europeo se evitarían problemas de armonización causados por las diferentes regulaciones en esta materia, puesto que, en el momento actual, las obligaciones nacionales para participar en un procedimiento de adjudicación contractual por causas relacionadas con aspectos sociales o medioambientales no atienden a exigencias mínimas que deban ser respetadas por igual en todos los Estados miembros. Es así que, como consecuencia del amplio margen de discrecionalidad que los Estados miembros tienen en el establecimiento y configuración de estos motivos de exclusión, las normativas nacionales pudieran no contemplar en su regulación contractual una prohibición de contratar vinculada al incumplimiento de la normativa en materia sociolaboral y medioambiental, aun cuando se tratasen de obligaciones establecidas en convenios internacionales ${ }^{755}$.

En atención a este hecho, entendemos que la formulación de la medida propuesta no contraviene el principio de subsidiariedad por cuanto que es preciso actuar a escala de la Unión para alcanzar los objetivos fijados y su eficacia es mayor que si se llevase a cabo a nivel nacional, tal como exige el artículo 5 TUE ${ }^{756}$.

En la búsqueda de sinergias de la que partimos, consideramos que no es aceptable que accedan a la contratación pública aquellos operadores económicos respecto de los que ha quedado acreditado que no respetan los derechos laborales recogidos en los convenios fundamentales de la OIT y/o en los convenios internacionales y europeos relativos a los derechos sociales e individuales. Tampoco quienes vulneran el principio de no discriminación en el trabajo, no

\footnotetext{
${ }^{755}$ En el Dictamen del Comité Económico y Social Europeo sobre el tema «Acciones clave con vistas a un Acta del Mercado Único II», citado anteriormente, ya se hacía constar que "es necesario que los Convenios de la OIT ratificados y los derechos humanos sean respetados por todas las partes, tanto los Estados miembros como los terceros países", (DOUE C 299, de 4 de octubre de 2012, pág. 169).

${ }^{756} \mathrm{El}$ principio de subsidiariedad implica que, en aquellos ámbitos en los que no tienen una competencia exclusiva, la Unión Europea debe acreditar que puede actuar mejor que los Estados miembros por separado. De acuerdo con el artículo 5.3 del TUE "la Unión intervendrá sólo en caso de que, y en la medida en que, los objetivos de la acción pretendida no puedan ser alcanzados de manera suficiente por los Estados miembros, ni a nivel central ni a nivel regional y local, sino que puedan alcanzarse mejor, debido a la dimensión o a los efectos de la acción pretendida, a escala de la Unión".
} 
garantizan la igualdad de género, no cumplen con sus obligaciones de pago a sus trabajadores y a sus subcontratistas, quienes incumplen normas sobre accesibilidad para las personas con discapacidad o quienes recurren al trabajo no declarado o a la evasión fiscal. Asimismo, y a nuestro juicio, no debieran contratar con el sector público aquellos que han provocado daños al medio ambiente o han vulnerado la normativa protectora del medio ambiente (el denominado delito ecológico), y no sólo por el desvalor que conlleva estas conductas, sino también por el incremento de costes que supone para el erario público la recuperación - si es que ello es posible - del equilibrio de los sistemas naturales.

Ante estas conductas reprobables resulta necesario articular una acción integral de lucha a escala de la UE desde la combinación de distintas medidas con el fin de garantizar su carácter efectivo, proporcionado y disuasorio (sanciones administrativas, establecimiento de responsabilidad penal, y también prohibiciones de contratar).

El argumento que sostiene esta propuesta atiende, igualmente, a uno de los fundamentos de las prohibiciones de contratar, cual es el de preservar el interés público. En este sentido, este objetivo no se limita a proteger los intereses ínsitos en la contratación, sino que transciende de ellos al tratar de potenciar el factor disuasorio de las prohibiciones induciendo un comportamiento respetuoso con el resto del ordenamiento jurídico. Su finalidad es esencialmente preventiva dado que están previstas al objeto de garantizar el cumplimiento de las obligaciones establecidas en las normas y evitar que se reitere su incumplimiento.

De esta forma, aludimos a un doble objetivo de interés general: en primer lugar, a mejorar el cumplimiento de las normas de contenido medioambiental, social y laboral y, por tanto, a velar por el respeto de ciertos derechos amparados en principios y estrategias capitales para la UE; y, en segundo, a preservar la competencia en el proceso contractual garantizando que los operadores económicos que participan en el procedimiento lo hagan en condiciones de igualdad y sin poner en peligro los logros sociales y medioambientales de la $\mathrm{UE}$.

Así pues, los operadores económicos incumplidores no podrían hacer valer en el procedimiento de adjudicación la ventaja económica que supone no asumir sus obligaciones legales en detrimento de sus competidores cumplidores. 
Entendemos que no puede obtenerse la selección objetiva del contratista bajo la consideración de la oferta económicamente más ventajosa, si entre los licitadores y candidatos no se traba una honesta competencia desde la observancia de las normas.

En el marco de las reflexiones que venimos realizando, mantenemos la idea de que la obligatoriedad de estas prohibiciones de contratar puede contribuir significativamente a la aplicación de las políticas europeas esenciales para el desarrollo y el crecimiento de la economía europea. Pero es que, además, creemos que puede reforzar el Estado de Derecho al incitar a los operadores económicos a cumplir con lo fijado por el ordenamiento jurídico ante el efecto disuasorio que supondría la aplicación de estas nuevas disposiciones y a potenciar, con ello, la confianza de los operadores económicos respetuosos con las normas. De esta manera, nos parece un instrumento adecuado para garantizar un entorno competitivo, incrementar la observancia de la normativa y multiplicar las posibilidades de lograr una contratación pública responsable. 



\section{Capítulo cuarto}

\section{LA DELIMITACIÓN EN LA APLICACIÓN DE LAS PROHIBICIONES DE CONTRATAR}

\section{Planteamiento de la cuestión}

El estudio de cualquier institución jurídica requiere de una delimitación de su ámbito de aplicación y ésta es la pretensión de este capítulo. Los elementos que determinan la aplicabilidad de las disposiciones de las Directivas en materia de contratación pública son tres. En primer término, el elemento subjetivo referido a los sujetos a quienes les resulta de aplicación la normativa contractual; en segundo lugar, el elemento objetivo que comprende los negocios jurídicos sometidos a las normas de adjudicación contractual; y en último término, los umbrales económicos del contrato, puesto que las Directivas, con sus exigencias de procedimiento, no rigen para todo contrato público, sino que, para su aplicación, el contravalor económico de cada contrato debe alcanzar un determinado umbral, al presumir (presunción «iuris tantum») que por encima de estos umbrales existe un interés comercial transfronterizo que justifica la imposición de ciertas obligaciones: (i) publicidad europea, (ii) transparencia en los procedimientos de contratación, (iii) equivalencia de las especificaciones técnicas, (iv) homologación de las aptitudes de los contratistas y, por último, (v) objetividad en los criterios de adjudicación.

Los primeros epígrafes de este capítulo tratan sobre estos extremos, si bien centrados únicamente en aquellos aspectos que resultan de interés para la materia objeto de nuestro estudio. Con un carácter más específico, vamos a re- 
ferirnos también al resto de elementos que condicionan la aplicación de las prohibiciones de contratar y que versan, por una parte, sobre el análisis de las disposiciones que delimitan su alcance temporal y espacial y, por otro, sobre aquellos aspectos formales y procedimentales que determinan su nacimiento al mundo jurídico, prestando especial atención a los medios de los que disponen los poderes adjudicadores para comprobar la existencia de un motivo de exclusión y las pruebas presentadas por el operador económico para evidenciar que no está incurso en una prohibición de contratar.

El último de los epígrafes de este capítulo - y que pone fin a esta memoria doctoral - versa sobre los diferentes supuestos de excepción a la aplicación de una prohibición de contratar (derogación y/o rehabilitación). Su análisis centra una parte importante de este capítulo no sólo por la novedad que supone su reconocimiento normativo por parte de las Directivas sobre contratación, sino porque entendemos que el estudio de las prohibiciones de contratar debe completarse, necesariamente, con el análisis de los supuestos en los que no van a resultar de aplicación. Entre todos estos supuestos vamos a destacar, por su transcendencia práctica, las medidas autocorrectoras, de autolimpieza o de «self-cleaning» ${ }^{757}$ mediante las cuales los operadores económicos van a recuperar la posibilidad de participar en la adjudicación de un contrato aun cuando concurra en ellos una prohibición de contratar.

\section{El elemento subjetivo en las prohibiciones de contratar}

El ámbito subjetivo de aplicación de la normativa sobre contratación pública constituye uno de los aspectos decisivos en su regulación, pues determina los sujetos que resultan obligados a respetar en la celebración de sus contratos las disposiciones de la normativa sobre contratación pública, por lo que las contrataciones que lleven a cabo van a quedar sometidas a un régimen más

${ }^{757} \mathrm{La}$ incorporación al texto de este anglicismo deriva de la conveniencia de recoger como préstamo lingüístico la expresión utilizada en la mayor parte de la doctrina tanto de lengua inglesa, como no - al referirse a esta materia, aunque lo cierto es que el término self-cleaning deriva de la traducción del vocablo alemán «Selbstreinigung». 
formalista y riguroso que el propio de la contratación privada ${ }^{758}$.

En este sentido, es importante destacar que los Estados miembros deben fijar el alcance de las obligaciones de las Directivas en función de un concepto autónomo al de Administración pública que es el de «poder adjudicador». Como tendremos ocasión de analizar posteriormente, este concepto de poder adjudicador es más amplio que el propio de Administración pública y ello resulta de la falta de competencia en la materia autoorganizativa que tiene la Unión Europea para imponer las formas jurídicas que pueden revestir las Administraciones públicas en cada uno de los Estados miembros ${ }^{759}$. Al no poder concretar el ámbito subjetivo de aplicación de las Directivas mediante la referencia a una categoría concreta de sujetos - más allá de las menciones hechas al Estado y a los entes territoriales - conceptúa los sujetos obligados en atención a un criterio funcional sin atender a la calificación jurídica que tengan en cada Estado ${ }^{760}$.

${ }^{758}$ Antes de la aprobación del vigente TRLCSP, el tema del ámbito subjetivo de aplicación de la legislación contractual ya había despertado el interés de la doctrina española. A título de ejemplo, baste señalar las obras de NOGUERA DE LA MUELA, B., El ámbito subjetivo de aplicación de la nueva Ley de Contratos de las Administraciones Públicas (Real Decreto legislativo 2/2000, de 16 de junio, por el que se aprueba su Texto Refundido), Atelier, Barcelona, 2000; PAREJO ALFONSO, L., "El ámbito subjetivo de aplicación de la Ley de Contratación del Sector Público", Documentación administrativa, núm. 274-275, enero-agosto 2006, pág. 11-43; CHINCHILLA MARÍN, C., "La nueva Ley de contratos del sector público: ámbito de aplicación y otras cuestiones novedosas", RVAP, núm. 79, septiembre-diciembre 2007, págs. 41-70 y PLEITE GUADAMILLAS, F., El ámbito de aplicación subjetiva de la Ley de Contratos del Sector Público. Claves para la clasificación de los poderes adjudicadores, La Ley, Las Rozas (Madrid), 2010.

${ }^{759}$ Véase lo dicho por MORENO MOLINA, J. A., "La Administración Pública comunitaria y el proceso hacia la formación de un Derecho administrativo europeo común", RAP, núm. 148, enero - abril 1999, págs. 341 - 358 y DÍEZ SASTRE, S., "Formas y estructuras organizativas de la Administración de los contratos públicos en el mercado interior", en la obra colectiva Observatorio de los contratos públicos 2014, Thomson-Reuters Aranzadi, Cizur Menor (Navarra) 2015, págs. 61 - 87.

${ }^{760}$ Según nos recuerda la jurisprudencia del TJUE, el estatuto de Derecho privado de una entidad no constituye un criterio que pueda excluir su calificación como organismo de Derecho público y, por tanto, de entidad adjudicadora (sentencias de 15 de mayo de 2003, Comisión/España, C-214/00, apartado 55 y de 16 de octubre de 2003, Comisión/España, C-283/00, apartado 74). 
De esta manera, las Directivas sobre contratación pública pretenden delimitar su ámbito de aplicación de un modo lo bastante amplio como para garantizar que las normas impuestas en materia de adjudicación de contratos públicos se aplican al conjunto de entidades que aun cuando no forman parte de la Administración Pública están, sin embargo, controladas por ella, principalmente mediante su financiación o el control de su gestión. Con la incorporación de este concepto a la normativa contractual, se intenta poner fin al fenómeno conocido como «huida del Derecho administrativo» trayendo de vuelta al Derecho público contractual a aquellas personificaciones jurídico-privadas, tanto de carácter mercantil (sociedades mercantiles) como de naturaleza civil (fundaciones) que llevan a cabo funciones administrativas en régimen de Derecho privado ${ }^{761}$. Tales entes, al adoptar una forma jurídico-privada de personificación, constituían la manifestación más clara de la huida del ámbito de la contratación pública, puesto que, amparadas en un subterfugio de tipo nominal, pretendían eludir la aplicación de la normativa contractual pública ${ }^{762}$.

${ }^{761}$ Sobre esta materia, resultan de interés SALA ARQUER, J. M., "Huida al Derecho privado y huida del Derecho", REDA, núm. 75, julio - septiembre 1992, págs. 399 - 416; DEL SAZ CORDERO, S., "La huida del Derecho administrativo: últimas manifestaciones. Aplausos y críticas", RAP, núm. 133 enero - abril 1994, págs. 57 98; MARTÍN-RETORTILLO BAQUER, S., "Reflexiones sobre la "huida" del Derecho administrativo", RAP, núm. 140 mayo - agosto 1996, págs. 25 - 67; MARTÍNEZ LÓPEZ-MUÑIZ, J. L., “¿Sociedades públicas para construir y contratar obras públicas? (A propósito de algunas innovaciones de la Ley de acompañamiento de los Presupuestos del Estado para 1997)", RAP, núm. 144 septiembre - diciembre 1997, págs. 45 - 73 y AMOEDO SOUTO, C., TRAGSA. Medios propios de la Administración y huida del Derecho administrativo, Atelier, Barcelona, 2004.

${ }^{762}$ En esta materia resultan de obligada referencia las ya citadas sentencias condenatorias a España de 15 de mayo de 2003, Comisión/España, C-214/00; de 16 de octubre de 2003, Comisión/España, C-283/00 y de 13 de enero de 2005, Comisión/España, C-84/03 que afirmaban que la normativa española sobre contratación pública era contraria a la regulación europea. El motivo era haber omitido de esta regulación a determinadas entidades que amparándose en un estatuto de Derecho privado, pretendían evitar los procedimientos y formas de adjudicación públicos, aun cuando sí cumplían los requisitos necesarios para ser considerados poderes adjudicadores. Sobre esta materia, GARCÍA DE ENTERRÍA, E., "El Tribunal de Justicia de las Comunidades Europeas constata y censura dos graves quiebras de nuestro Derecho Administrativo en materia de entes sujetos al derecho público y de medidas cautelares Contencioso-Administrativas. Sentencia Comisión c. España, C-214/00, de 15 de mayo de 2003", REDA, núm. 119, julio - septiembre 2003, págs. 471 487; del mismo autor "Una nueva sentencia del Tribunal de Justicia de las Comu- 
Ahora bien, nuestro objeto de estudio nos obliga a analizar los elementos subjetivos de las prohibiciones de contratar, distinguiendo de una parte qué sujetos se someten a la normativa contractual como órganos de contratación y, por tanto, van a impedir el acceso a la contratación a quienes incurran en una causa de prohibición de contratar; y de otra, quienes pueden llegar a ser contratistas. Este análisis parte de las siguientes premisas:

- Para estar en presencia de un contrato público una de las partes de la relación contractual debe ser, necesariamente, una entidad del sector público (poder adjudicador o entidad adjudicadora);

- Además de ello, en el contrato deben concurrir dos voluntades autónomas que representen intereses jurídicos distintos, puesto que de no ser así podríamos estar en presencia de una relación «doméstica» que queda al margen de la aplicación de la normativa contractual. En efecto, esta excepción a las adjudicaciones de contratos denominadas «in house», está justificada por la circunstancia de que una autoridad pública que es un poder adjudicador tiene la posibilidad de realizar las tareas de interés público que le corresponden con sus propios medios administrativos, técnicos y de cualquier otro tipo, sin verse obligada a recurrir a entidades externas y ajenas a sus servicios. La jurisprudencia del TJUE viene admitiendo que un poder adjudicador está dispensado de la incoación de un procedimiento de adjudicación de un contrato público siempre que ejerza sobre el adjudicatario un «control análogo» al que ejerce sobre sus propios servicios y que tal entidad realice la parte esencial de su actividad con el poder adjudicador - o poderes adjudicadores - que la controlan $^{763}$.

nidades Europeas sobre la sumisión a las normas comunitarias sobre contratación pública de las sociedades de titularidad de las Administraciones Públicas", REDA núm. 120, octubre - diciembre 2003, págs. 667 - 677; DÍAZ LEMA, J. M., "Contratos públicos y derecho español. Comentario urgente a la STJCE 15 de mayo 2003", Actualidad Administrativa, vol. 35, septiembre 2003, págs. 843 - 856; NOGUERA DE LA MUELA, B., "Consecuencias de la Sentencia del TJUE de 15 de mayo de 2003 Comisión/España en el ordenamiento jurídico español", RAAP, núm. 53, enero - marzo 2004, págs. 17 - 46 y GIMENO FELIÚ, J. Ma ., "El nuevo ámbito subjetivo de aplicación de la Ley de Contratos del Sector Público: luces y sombras", RAP, núm. 176, mayo - agosto 2008, págs. 9 - 54.

${ }^{763}$ Véanse, las sentencias de 18 de noviembre de 1999, Teckal, C-107/98, aparta- 
- La obligación - o en su caso la posibilidad - de excluir a un operador económico de la participación en un procedimiento de adjudicación corresponde bien a los poderes adjudicadores (artículo 57 de la Directiva 2014/24/UE), bien a las entidades adjudicadoras en el supuesto de la contratación en los sectores del agua, la energía, los transportes y las telecomunicaciones y con distinto régimen si son a su vez - o no - poder adjudicador (artículo 80 de la Directiva 2014/25/UE («sectores especiales» $)^{764}$, bien a los poderes adjudicadores y entidades adjudicadoras (artículo 38 de la Directiva 2014/23/UE («concesiones») ${ }^{765}$.

do 50; de 11 de enero de 2005, Stadt Halle y RPL Lochau, C-26/03, apartado 49; de 13 de octubre de 2005, Parking Brixen, C-458/03, apartado 62; de 11 de mayo de 2006, Carbotermo y Consorzio Alisei, C-340/04, apartado 33; de 19 de abril de 2007, Asemfo, C-295/05, apartado 55; de 13 de noviembre de 2008, Coditel Brabant, C-324/07, apartado 27; de 10 de septiembre de 2009, Sea, C- 573/07, apartado 40; de 29 de noviembre de 2012, Econord, C-182/11 y C-183/11, apartado 25 y de 8 de mayo de 2014, Universität Hamburg, C-15/13, apartado 25. Sobre esta materia resultan de obligada referencia SOSA WAGNER y FUERTES LÓPEZ, M., "¿Pueden los contratos quedar en casa? La polémica europea sobre la contratación in house", Diario La Ley, núm. 6715, 17 de mayo de 2007, págs. 1669-1680; BERNAL BLAY, M. Á., "Un paso en falso en la interpretación del criterio del control análogo al de los propios servicios en las relaciones in house", REDA, núm. 137, enero-marzo 2008, págs. 115-138; PERNAS GARCÍA, J.J., Las operaciones in house y el Derecho comunitario de contratos públicos. Análisis de la jurisprudencia del TJCE, Iustel, Madrid, 2008 y VILALTA REIXACH, M., La encomienda de gestión. Entre la eficacia administrativa y la contratación pública, Aranzadi, Cizur Menor (Navarra), 2012, especialmente págs. 313-376.

${ }^{764} \mathrm{El}$ artículo 80.1 segundo párrafo es del siguiente tenor: "Cuando la entidad adjudicadora sea un poder adjudicador, esos criterios y normas incluirán los motivos de exclusión enumerados en el artículo 57, apartados 1 y 2, de la Directiva 2014/24/UE, en las condiciones que se estipulan en dicho artículo".

${ }^{765}$ En el supuesto de la Directiva de concesiones, y tal como veremos, las prohibiciones de contratar de carácter obligatorio también se limitan al supuesto de entidades adjudicadoras que sean "autoridades estatales, regionales o locales, los organismos de Derecho público y las asociaciones constituidas por una o varios de tales autoridades u organismos de Derecho público" (artículo 7, apartado 1, letra a) en la Directiva 2014/23/UE («concesiones»). 


\section{II.1. Los poderes adjudicadores}

Como ya hemos señalado, el elemento clave en la delimitación del ámbito subjetivo de aplicación de la normativa de contratos públicos es el concepto de poder adjudicador. Así pues, las Directivas sobre contratación pública establecen la obligación de aplicar sus disposiciones a quienes revisten la condición de poderes adjudicadores con independencia de su estatuto jurídico (público o privado); es decir, "el Estado, las autoridades regionales o locales, los organismos de Derecho público o las asociaciones formadas por uno o varios de dichos poderes o uno o varios de dichos organismos de Derecho público" (artículo 2.1.1) de la Directiva 2014/24/UE).

Este concepto - y con mayor detalle el concepto de «organismo de Derecho público» - ha sido objeto de una reiterada jurisprudencia del Tribunal de Justicia que, a través de distintas sentencias, ha ido aclarando el ámbito de aplicación ratione personae de las Directivas desde una interpretación funcional y no formal de estos conceptos ${ }^{766}$. Esta jurisprudencia ha sido asumida por el legislador europeo y, de esta manera, las Directivas precisan la definición de organismo de Derecho público desde el cumplimiento acumulativo de tres requisitos:

a) Que se haya creado específicamente para satisfacer necesidades de interés general que no tengan carácter industrial o mercantil;

b) Que esté dotado de personalidad jurídica propia, y

c) Que esté financiado mayoritariamente por el Estado, las autoridades regionales o locales, u otros organismos de Derecho público, o cuya gestión esté sujeta a la supervisión de dichas autoridades u organismos, o que tenga un órgano de administración, de dirección o de supervisión, en

\footnotetext{
${ }^{766}$ Sobre esta materia, GIMENO FELIÚ, J. Ma ., "La necesaria interpretación subjetivo-funcional del concepto de poder adjudicador en la contratación pública", $R A P$, núm. 151, enero - abril 2000, págs. 425 - 439 y del mismo autor "Los sujetos contratantes: alcance del concepto poder adjudicador", Cuadernos de Derecho Local, núm. 12, 2006, págs. 50 - 78 y MONTOYA MARTÍN, E., "La reciente jurisprudencia del Tribunal de Justicia de la Unión Europea acerca del concepto de "poder adjudicador" en las Directivas de la contratación pública, servicios, suministros y obras", RAAP, núm. 41, enero - abril 2001, págs. 121 - 154.
} 
el que más de la mitad de los miembros sean nombrados por el Estado, las autoridades regionales o locales, u otros organismos de Derecho público $^{767}$.

En efecto, para que un organismo pueda ser considerado «poder adjudicador», debe atenderse a las características del órgano que contrata - y no a su denominación - de tal manera que deben concurrir en él los requisitos $\operatorname{citados}^{768}$.

Por lo que a nuestra materia interesa, serán los poderes adjudicadores quienes tengan la obligación de excluir del procedimiento de adjudicación a los operadores económicos incursos en una causa de prohibición de contratar preceptiva y ello, con independencia del sector en el que actúen, puesto que la coherencia del sistema requiere aplicar de manera obligatoria dicha prohibición aunque se actúe en uno de los sectores especiales o se adjudique una concesión.

\section{II.2. Las entidades adjudicadoras}

El otro concepto que alude al ámbito subjetivo de aplicación de la normativa contractual es el de «entidad contratante» y a él se refieren tanto la Directiva 2014/23/UE sobre concesiones, como la Directiva 2014/25/UE, relativa a la contratación por entidades que operan en los sectores del agua, la energía, los

\footnotetext{
${ }^{767}$ Así pues, un organismo que opera en condiciones normales de mercado, tiene ánimo de lucro y soporta las pérdidas derivadas del ejercicio de su actividad no debe ser considerado un «organismo de Derecho público» (considerando décimo de la Directiva 2014/24/UE). Sobre el carácter acumulativo de estos requisitos, véanse las sentencias de 15 de enero de 1998, Mannesmann Anlagenbau Austria y otros, C44/96, apartado 21; de 10 de noviembre de 1998, BFI Holding, C-360/96, apartado 29; de 10 de mayo de 2001, Agorà, C-223/99 y C-260/99, apartado 26; de 13 de diciembre de 2007, Bayerischer Rundfunk y otros, C- 337/06, apartado 48; de 10 de abril de 2008, Ing. Aigner, C-393/06, apartado 36, así como de 12 de septiembre de 2013, IVD, C-526/11, apartado 23.

${ }^{768}$ Hay que hacer notar, que en los anexos de las Directivas, se identifican, para cada Estado miembro, los organismos de Derecho público y categorías de organismos que a juicio del legislador europeo deben calificarse como tales, si bien no existe una presunción iuris et de iure de que dichos organismos constituyen un «organismo de Derecho público» en el sentido de las Directivas, como bien señala la STJUE de 12 de septiembre de 2013, IVD, C-526/11, apartado 18.
} 
transportes y los servicios postales.

La especialidad del ámbito subjetivo de estas Directivas deriva de la diversidad del estatuto jurídico de las entidades que operan en estos sectores, ya que gran parte de las entidades que prestan sus servicios en los sectores señalados son empresas privadas beneficiarias de derechos especiales o exclusivos expedidos por una autoridad competente de un Estado miembro, por lo que las obligaciones de las Directivas se proyectan tanto sobre entidades públicas como privadas.

De esta manera, bajo el concepto de entidades contratantes se encuentran comprendidas, además de los «poderes adjudicadores»-caracterizados de igual manera que hemos indicado con anterioridad - las empresas públicas a quienes se ha encomendado el desarrollo de alguna de las actividades propias de estas Directivas y las empresas privadas que disfrutan de derechos exclusivos o especiales. En estos supuestos siempre que estas empresas realicen alguna de las funciones relacionadas con las actividades propias de los sectores de la producción, transporte o distribución de agua, de gas o combustible para calefacción, de electricidad, del sector de los servicios de transportes, de los servicios postales, de la prospección y extracción de petróleo, gas, carbón y otros combustibles sólidos, y la puesta a disposición de terminales de transportes (en el supuesto de los «sectores especiales») o - en el caso de las concesiones - las entidades que desarrollan una actividad recogida en el Anexo II de la Directiva 2014/23/UE y adjudican una concesión para la realización de una de estas actividades.

Con ello, se prescinde del estatuto jurídico del órgano de contratación, para obligar a las empresas que operan en estos sectores a modificar sus prácticas contractuales imponiéndoles adoptar un sistema de contratación basado en los principios de publicidad y concurrencia ${ }^{769}$. De esta manera, el elemento

\footnotetext{
${ }^{769}$ Recordemos que LÓPEZ-IBOR MAYOR y GIMENO FELIÚ califican de capital importancia esta regulación en cuanto suponen la aplicación de procedimientos públicos no sólo a Administraciones públicas, sino también a empresas privadas que ejercen actividades en alguno de los campos comprendidos en las mismas, en "Los denominados sectores excluidos: agua, transporte, energía y telecomunicaciones (Disposición adicional undécima LCAP)", en la obra colectiva Comentario a la Ley de Contratos de las Administraciones Públicas, $2^{\mathrm{a}}$ ed., Thomson-Civitas, Madrid, 2004, pág. 1678. También se refiere a estas singularidades, TORRICELLI, S.,
} 
decisivo en la aplicación de la Ley no reside en la cualidad de la entidad que adjudica el contrato, sino en la naturaleza de la actividad sobre la que recae el ámbito objetivo de aplicación de las citadas Directivas. Habida cuenta de estas singularidades, las normas reguladoras de la contratación en estos sectores no pueden aplicarse a estas empresas sin acomodarlas a sus características y, por lo que a las prohibiciones de contratar respecta, sin tener en consideración que pueden ser empresas privadas las que tengan que ponerlas en práctica. Así pues, las Directivas 2014/24/UE y 2014/25/UE establecen un distinto sistema dependiendo de si se trata de una prohibición de contratar obligatoria o facultativa.

En el supuesto de prohibiciones de contratar obligatorias, éstas deberán aplicarse, en todo caso, por las entidades adjudicadoras "cuando la entidad adjudicadora sea un poder adjudicador" o - como prescribe la Directiva de concesiones - cuando se trate de "autoridades estatales, regionales o locales, los organismos de Derecho público y las asociaciones constituidas por una o varios de tales autoridades u organismos de Derecho público", en alusión al artículo 7, apartado 1, letra a) de esta misma Directiva. El resto de entidades adjudicadoras que no sean poderes adjudicadores, es decir empresas públicas o empresas privadas que gozan de derechos exclusivos o especiales, "podrán excluir a un operador económico de la participación en un procedimiento de adjudicación de concesión cuando tengan conocimiento de que dicho operador económico ha sido objeto de una condena mediante sentencia firme" por los hechos delictivos constitutivos de una prohibición de carácter obligatorio (artículo 38.4 in fine de la Directiva 2014/23/UE («concesiones»).

Si se trata de prohibiciones de contratar facultativas, se prevé una regulación más abierta, de tal modo que las entidades adjudicadoras - sean poderes adjudicadores, empresas públicas o empresas privadas que funcionan sobre la base de derechos especiales o exclusivos - "podrán excluir, o los Estados miembros podrán pedirles que excluyan, de la participación en un procedimiento de adjudicación de concesión" a cualquier operador económico si se da cualquiera de las situaciones previstas en el artículo 38.7 de la Directiva 2014/23/UE.

"Utilities Procurement", en la obra colectiva EU Public Contract Law (...), op. cit., págs. $222-248$. 


\section{II.3. El concepto de «operador económico»}

Tal como hemos señalado desde las primeras páginas de esta memoria doctoral, la selección del contratista exige la observancia de determinadas formalidades y requisitos a la hora de elegir a la persona, física o jurídica, más idónea para ejecutar las prestaciones demandadas por una entidad del sector público ${ }^{770}$. Entre estos requisitos se encuentra la capacidad, la solvencia y la ausencia de prohibiciones de contratar, de tal manera que aquel operador económico incurso en alguno de los supuestos de prohibición de contratar será - o podrá ser - excluido de la participación en el procedimiento de adjudicación contractual $^{771}$.

En este sentido, y tal como reconoce la jurisprudencia del Tribunal de Justicia, "puede licitar o presentarse como candidato toda persona o entidad que, a la vista de los requisitos previstos en un anuncio de licitación, se considere apta para garantizar la ejecución del contrato público, con independencia de que su estatuto jurídico sea público o privado y de si opera sistemáticamente en el mercado o si sólo interviene con carácter ocasional"772.

De la interpretación amplia del concepto de «operador económico» que lleva a cabo el TJUE vamos a extraer una serie de notas:

(i) El Derecho de la Unión Europea no emplea - como sí hace el TRLCSP el concepto de empresario para referirse a la persona física o jurídica que

\footnotetext{
${ }^{770}$ En ocasiones se utiliza el término «cocontratante» como sinónimo de la "otra parte contratante". Sirvan como ejemplos de lo dicho las sentencias de 28 de enero de 2015, Kolassa, C-375/13, apartado 33 y de 18 de julio de 2007, Comisión/Alemania, C-503/04, apartado 36 .

${ }^{771}$ Recordemos nuevamente que aquellos que optan a la condición de contratista público no ostentan, sin embargo, un verdadero derecho subjetivo a ser contratistas y lo único que pueden hacer valer, para con respecto a los demás sujetos, es su derecho a participar en los procedimientos de adjudicación - no a que se les adjudique el contrato - y siempre que cumplan con los requisitos de capacidad, solvencia y ausencia de prohibiciones de contratar que la normativa contractual exige a quien quiere contratar con una entidad del sector público.
}

${ }^{772}$ Sentencias del TJUE de 23 de diciembre de 2009, CoNISMa, C-305/08, apartado 42 y de 18 de diciembre de 2014, Data Medical Service, C-568/13, apartado 35. 
va a contratar con una entidad pública ${ }^{773}$. Ello, en parte, es debido a que cualquier sujeto habilitado para ofrecer servicios en el mercado a título oneroso - aunque sea de manera ocasional y sin el carácter de empresa - puede participar en un procedimiento de adjudicación, siempre que no esté incurso en una prohibición de contratar. (STJUE de 6 de octubre de 2015, Consorci Sanitari del Maresme, C-203/14, apartado 35);

(ii) El concepto de operador económico no excluye a las entidades que no persigan principalmente un ánimo de lucro, incluso a las entidades que carezcan de ánimo de lucro (STJUE de 11 de diciembre de 2014, Azienda sanitaria locale, C-113/13, apartado 27);

(iii) El concepto de operador económico incluye también a las Administraciones públicas que pueden, por tanto, participar en licitaciones públicas en la medida en que estén habilitadas para ofrecer servicios en el mercado a título oneroso (STJUE de 6 de octubre de 2015, Consorci Sanitari del Maresme, C-203/14, apartado 39); es decir, cabe afirmar que ya se han superado las dudas iniciales sobre la posibilidad de que otra entidad pública distinta de la contratante pudiera participar, en régimen de concurrencia, con otros operadores económicos en uno de los contratos convocados por aquéllat ${ }^{774}$;

(iv) Las normas de la Unión Europea no exigen que la persona que celebra

${ }^{773}$ El Consejo de Estado en su Dictamen núm. 1270/1993, de 1 de diciembre, relativo al Anteproyecto de la Ley de Contratos de las Administraciones Públicas, ya trató este aspecto de la regulación española manifestando su preferencia por el término contratista y no admitiendo "en ningún caso, es el uso indistinto de las palabras "empresario" y "empresa" que son conceptos jurídicos diferentes".

${ }^{774}$ En nuestro país, la Junta Consultiva de Contratación Administrativa del Estado en distintos informes de los años noventa - entre otros en los Informes 39/96, de 22 de julio de 1996, 12/97, de 20 de marzo de 1997 y 42/98, de 16 de diciembre de 1998 - se refería a este particular indicando las dificultades que suscitaba la aplicación de la legislación de contratos a otros entes públicos y que "se manifiestan en una serie de normas como las relativas a la acreditación de no hallarse incurso el organismo en prohibiciones de contratar, al cumplimiento de obligaciones fiscales y de Seguridad Social, a la clasificación, y al régimen de garantías", determinando que las relaciones de contenido contractual entre estos organismos debían instrumentarse normalmente a través de la vía de colaboración y sólo excepcionalmente a través de verdaderos y propios contratos. 
un contrato con un poder adjudicador o entidad adjudicadora sea capaz de realizar la prestación pactada directamente con sus propios recursos, puesto que puede basarse en las capacidades de otras entidades ${ }^{775}$ y también acudir a la subcontratación ${ }^{776}$ (STJUE de 10 de octubre de 2013, Swm Costruzioni, C-94/12, apartados 33 a 35);

(v) En el concepto de operador económico se debe, asimismo, incluir a las uniones temporales de empresarios, las cuales en su totalidad, como unidades económicas autónomas, deben cumplir el requisito de la ausencia de prohibiciones de contratar, pero que no están obligadas a asumir una forma jurídica determinada para poder participar en un procedimiento de adjudicación ${ }^{777}$ (STJUE de 18 de diciembre de 2007, Frigerio Luigi \&6 $C$, C-357/06, apartado 25).

\section{II.4. El subcontratista}

Una de las novedades que hemos destacado de las nuevas Directivas es que ya no se limitan a regular la fase de preparación y adjudicación contractual, sino que incorporan a sus articulados la totalidad de las fases de la contratación pública y, por tanto, también recogen previsiones específicas respecto de la modificación de los contratos, su resolución y la subcontratación.

\footnotetext{
${ }^{775}$ No es necesario que el licitador tenga la propiedad de los medios técnicos, económicos o financieros, sino sólo que sea capaz de acreditar que dispondrá de ellos durante la ejecución del contrato, aunque pertenezcan a un tercero, en GALLEGO CÓRCOLES, I., "El recurso a las capacidades de otras entidades (...)", op. cit., págs. 195 - 235. Véanse, en este sentido, las sentencias del TJUE de 2 de diciembre de 1999, Holst Italia, C-176/98, apartado 29; de 18 de marzo de 2004, Siemens y ARGE Telekom, C-314/01, apartado 43 y de 10 de octubre de 2013, Swm Costruzioni, C-94/12, apartados 33 y 35.

${ }^{776}$ Sobre este particular, véase las conclusiones del Abogado General Sr. WATHELET presentadas el 4 de junio de 2015, en el asunto Ostas celtnieks, C-234/14, apartado 38 .

${ }^{777}$ En este sentido, el artículo 19.2 de la Directiva 2014/24/UE establece claramente esta posibilidad cuando dispone que "las agrupaciones de operadores económicos, incluidas las asociaciones temporales, pueden participar en procedimientos de contratación", añadiendo posteriormente que "los poderes adjudicadores no les exigirán que tengan una forma jurídica específica para presentar una oferta o una solicitud de participación".
} 
En este sentido, creemos de interés referirnos a la figura del subcontratista entendido como aquel operador económico que es propuesto por el contratista principal para ejecutar una parte de un contrato, ya que a pesar de no tener una relación jurídica directa con el poder adjudicador y quedar únicamente obligado frente al contratista, debe cumplir con una serie de requisitos que afectan directamente a la correcta ejecución del contrato ${ }^{778}$. Uno de estos requisitos se refiere a no estar incurso en una prohibición de contratar.

De esta manera, la regulación de la subcontratación en las nuevas Directivas prevé - en absoluta coherencia con las disposiciones aplicables al contratista principal - que los poderes adjudicadores "verifiquen que los subcontratistas no se encuentran en ninguna de las situaciones en las que se justificaría la exclusión de operadores económicos" (considerando centésimo quinto de la Directiva 2014/24/UE). En este sentido - y es importante que sea destacado - no es el poder adjudicador quien debe o puede excluir de la relación contractual al subcontratista que incurre en un supuesto de prohibición de contratar ${ }^{779}$. Los poderes adjudicadores pueden comprobar si existen o no motivos para la exclusión - no en vano tiene acceso a los registros y a las bases de datos que contienen esa información - pero entendemos que al no tener una relación directa con el subcontratista sólo podrán exigir su sustitución o, en su caso, no autorizar la subcontratación en aquellos casos en los que medie una causa de prohibición de contratar en el subcontratista.

${ }^{778}$ Sobre esta materia resultan de interés las referencias a FUERTES LÓPEZ, M., "La deficiente regulación de la subcontratación en los contratos de las Administraciones Públicas", REDA, núm. 109, enero - marzo 2001, págs. 61 - 73 y BLANCO LÓPEZ, F., "La subcontratación administrativa. Ejercicio de la acción directa del artículo 1597 del Código Civil”, RArAP, núm. 38, 2011, págs. 221 - 258.

${ }^{779}$ En la legislación italiana, el artículo 38.1.b) y c) Codice dei contratti pubblici relativi a lavori, servizi e forniture contempla expresamente en la relación de causas de prohibición de contratar que tampoco pueden ser subcontratista quienes incurran en alguno de los motivos previstos en este Código. Asimismo, en Hungría - el ya derogado artículo 61 de la Ley CXXIX de 2003, relativa a adjudicación de contratos públicos - establecía que el órgano de contratación está facultado para establecer en el anuncio de licitación que los licitadores, los subcontratistas que ejecuten más del $10 \%$ del valor del contrato y las entidades proveedoras de recursos externos, serán excluidos del procedimiento de adjudicación si en ellos concurre una prohibición de contratar y, por ello, tanto el licitador como el subcontratista con quien se va a concertar la realización de más de un $10 \%$ del valor del contrato, debían acreditar no estar incursos en una prohibición de contratar. 
Así pues, en el caso de que el subcontratista estuviera incurso en un supuesto de prohibición de contratar obligatorio, el poder adjudicador exigirá al candidato o licitador que sustituya a dicho subcontratista. Si por el contrario el motivo de exclusión fuera facultativo, las Directivas disponen que se pueda solicitar al contratista principal su sustitución (considerando centésimo quinto de la Directiva 2014/24/UE en relación con su artículo 71.6.b) y considerando septuagésimo segundo en relación con su artículo 42.4.b) de la Directiva 2014/23/UE («concesiones»). En este contexto, serán los Estados miembros los competentes para precisar las condiciones de ejecución de estas exigencias, pudiéndose limitar los supuestos de aplicación respecto de determinados tipos de contratos o determinadas categorías de poderes adjudicadores u operadores económicos o a partir de ciertos importes.

Ahora bien, en nuestra opinión, no es admisible que por la vía de la subcontratación se llegara a ejecutar un contrato público por parte de un operador económico que nunca hubiera podido resultar contratista principal por estar incurso en una prohibición de contratar obligatoria. La pretendida defensa del interés general y de los fondos públicos no quedaría garantizada si además resultara posible efectuar pagos directos a los subcontratistas.

\section{El elemento objetivo de las prohibiciones de contratar}

La aplicabilidad de las disposiciones de las Directivas está sujeta también a varios requisitos que se refieren a su ámbito objetivo, en particular por lo que se refiere al valor económico y a la naturaleza de los contratos de que se trata, puesto que - como seguidamente analizaremos - no todas las relaciones convencionales establecidas por los poderes adjudicadores o por las entidades adjudicadoras van a ser consideradas contratos públicos sometidos a la regulación contractual europea.

En este sentido, el considerando cuarto de la Directiva 2014/24/UE manifiesta que "las normas de la Unión sobre contratación pública no tienen por objetivo regular todas las formas de desembolso de fondos públicos, sino únicamente aquellas destinadas a la adquisición de obras, suministros o servicios 
prestados mediante un contrato público" ${ }^{780}$. Asimismo, la Directiva sobre concesiones establece que se aplicará a la adjudicación de las concesiones de obras o servicios que lleven a cabo los poderes adjudicadores y las entidades adjudicadoras cuando éstas superen determinados umbrales económicos ${ }^{781}$.

\section{III.1. Los contratos públicos y los negocios y contratos excluidos de la aplicación de las Directivas}

Se considera un contrato público el contrato oneroso celebrado por escrito entre uno o varios operadores económicos y uno o varios poderes adjudicadores, cuyo objeto sea la ejecución de obras, el suministro de productos o la prestación de servicios (artículo 2.1.5 de la Directiva 2014/24/UE).

En atención a estos requisitos, para admitir la existencia de un contrato público es necesario, en primer lugar, que éste haya sido acordado entre una entidad del sector público - sea un poder adjudicador o una entidad adjudicadora - y un operador económico. En segundo lugar, que el acuerdo tenga un carácter oneroso, lo cual implica satisfacer una contraprestación por la prestación que debe realizar el contratista, haciendo referencia a la reciprocidad en

\footnotetext{
${ }^{780} \mathrm{El}$ contrato de gestión de servicios públicos está ausente de la regulación europea. Sobre esta materia, LAVILLA RUBIRA, J. J., "El contrato de gestión de servicios públicos en el Texto Refundido de la Ley de Contratos de las Administraciones Públicas", en la obra colectiva Comentario a la Ley de contratos de las Administraciones públicas, $2^{\mathrm{a}}$ ed., Thomson - Civitas, Madrid, 2004, págs. 943 980 .

${ }^{781}$ La Directiva 2014/23/UE se refiere, según dispone su artículo 1, a las concesiones, incluyéndose en este concepto tanto las concesiones de obras, definidas legalmente como "un contrato a título oneroso celebrado por escrito, en virtud del cual uno o más poderes o entidades adjudicadores confían la ejecución de obras a uno o más operadores económicos, cuya contrapartida es bien el derecho a explotar las obras objeto del contrato únicamente, o este mismo derecho en conjunción con un pago", como las concesiones de servicios, definidas como "un contrato a título oneroso celebrado por escrito, en virtud del cual uno o más poderes o entidades adjudicadores confían la prestación y la gestión de servicios distintos de la ejecución de las obras contempladas en la letra a) a uno o más operadores económicos, cuya contrapartida es bien el derecho a explotar los servicios objeto del contrato únicamente, o este mismo derecho en conjunción con un pago" (artículo 1.1. letras a) y b).
} 
forma de intercambio material de prestaciones y sin que necesariamente deba tratarse de contraprestaciones monetarias ${ }^{782}$.

Por lo que a esta memoria doctoral interesa, la calificación jurídica de una operación como contrato público tiene como consecuencia que le van a resultar de aplicación los motivos de prohibición de contratar. Si por el contrario, por razón de su naturaleza, el contrato está excluido de la aplicación de las reglas de adjudicación pública, la deducción lógica a la que podemos llegar es que no se le puede aplicar las prohibiciones de contratar en tanto que forman parte de esa regulación que no le resulta de aplicación.

En efecto, la normativa contractual también delimita su ámbito objetivo de aplicación de una manera negativa, es decir, mencionando expresamente los negocios jurídicos y contratos excluidos de someterse a su disciplina ${ }^{783}$. Así pues, las propias Directivas contemplan una serie de supuestos heterogéneos que, a pesar de constituir relaciones de carácter convencional, están excluidos de la aplicación de la regulación contractual y se disciplinan por su normativa propia $^{784}$.

${ }^{782} \mathrm{El}$ concepto de onerosidad se ha interpretado ampliamente por el TJUE. Este concepto abarca todo tipo de obligación asumida por el poder adjudicador como contrapartida a la ejecución del contrato y aun cuando la retribución se limite al reembolso de los gastos soportados por la prestación del servicio pactado. En este sentido, pueden consultarse las sentencias del TJUE de 12 de julio de 2001, Ordine degli Architetti delle province di Milano e Lodi y otros, «Scala de Milán», C-399/98, apartado 77; de 19 de diciembre de 2012, Ordine degli Ingegneri della Provincia di Lecce y otros, C-159/11, apartado 29 y de 11 de diciembre de 2014, Azienda sanitaria locale, C-113/13, apartado 37.

${ }^{783}$ Hay que recordar, sin embargo, que incluso para los contratos que no están comprendidos en el ámbito de aplicación de las Directivas, el Tribunal de Justicia ha declarado que los Estados miembros deben respetar los principios de no discriminación y transparencia en virtud del Derecho primario. Véanse, a título de ejemplo, las sentencias de 7 de diciembre de 2000, Telaustria y Telefonadress, C-324/98, apartado 62; de 13 de octubre de 2005, Parking Brixen, C-458/03, apartados 48 y 49; de 21 de julio de 2005, Coname, C-231/03, apartado 17; de 6 de abril de 2006, ANAV, C-410/04, apartado 21; de 15 de mayo de 2008, SECAP y Santorso, C-147/06 y C-148/06, apartado 19 y 15 de octubre de 2009, Acoset, C-196/08, apartado 49.

${ }^{784}$ En el supuesto de la legislación española, el ejemplo más claro de lo dicho se produce en el ámbito de la legislación patrimonial y, más concretamente, respecto de las autorizaciones y concesiones sobre bienes de dominio público y los contratos de explotación de bienes patrimoniales (artículo 4 TRLCSP). Esto no significa que 


\section{III.2. Los umbrales económicos en la contratación}

Las Directivas sobre contratación pública, con sus estrictas exigencias de procedimiento, no son aplicables a todo contrato. Para que las disposiciones de las Directivas sean aplicables, los contratos deben superar los umbrales económicos que se fijan en ellas, puesto que el legislador de la Unión parte de la presunción de que los contratos que no superan ciertas cuantías no presentan a priori un interés transfronterizo que pueda justificar que su adjudicación se produzca mediante un procedimiento de licitación. De esta manera, el valor económico del contrato divide la normativa sobre contratación pública en dos clases: por encima del umbral que se han de observar las disposiciones específicas de las Directivas, y por debajo de él ${ }^{785}$.

Los procedimientos especiales y rigurosos establecidos por las Directivas se aplican únicamente a aquellos contratos cuyo valor sobrepasan los umbrales previstos (5.186.000 euros en los contratos públicos de obras - 134.000 euros, en los contratos públicos de suministro y de servicios adjudicados por autoridades, órganos y organismos estatales - 207.000 euros, en los contratos públicos de suministro y de servicios adjudicados por poderes adjudicadores subcentrales) ${ }^{786}$.

la exclusión sea total y ello debido a que - aunque conforme a los artículos 4.1.p) y o) del TRLCSP, los contratos sometidos a la legislación patrimonial están excluidos de sus reglas de adjudicación y ejecución - la Ley 33/2003, de 3 de noviembre, del Patrimonio de las Administraciones Públicas en un juego de remisiones normativas nos devuelve a las normas comunes sobre los procedimientos de contratación contenidas en los distintos apartados del articulado del TRLCSP, en lo que pudieran resultar aplicables con carácter supletorio.

${ }^{785}$ En este sentido, se manifestaba la Abogado General Sra. TRSTENJAK en sus conclusiones presentadas el 23 de mayo de 2012 en el asunto Azienda Sanitaria, C159/11, apartado 35. Véase también la Comunicación interpretativa de la Comisión sobre el Derecho comunitario aplicable en la adjudicación de contratos no cubiertos o sólo parcialmente cubiertos por las Directivas sobre contratación pública (DOUE C 179, de 1 de agosto de 2006), impugnada sin éxito en el asunto en que recayó la sentencia de 20 de mayo de 2010, Alemania/Comisión, T-258/06.

${ }^{786}$ Los umbrales aplicables, así como su contravalor en las monedas nacionales de los Estados miembros cuya moneda no es el euro, se revisan cada dos años y son aprobadas mediante Reglamento de la Comisión. Los umbrales hoy en vigor se actualizaron por parte del Reglamento (UE) 1336/2013, de 13 de diciembre, aunque hay que indicar que la próxima revisión tendrá lugar en diciembre y estarán en vigor 
Por debajo de estos umbrales, es cierto que los contratos no están sometidos a los procedimientos previstos por las normas comunitarias, pero según reiterada jurisprudencia del Tribunal de Justicia, los poderes adjudicadores - y la normativa contractual de los Estados miembros - deben respetar las normas fundamentales del Tratado y los principios cardinales de la contratación ${ }^{787}$. Los principios generales de igualdad de trato y no discriminación por razón de la nacionalidad, consagrados en el Derecho primario de la Unión, de los que se derivan la obligación de transparencia y la consiguiente exigencia de una publicidad adecuada, son aplicables a los contratos que revisten un interés para las empresas de otros Estados miembros, es decir, que tienen un interés transfronterizo cierto que deberá apreciarse casuísticamente ${ }^{788}$.

Respecto de los contratos que superan los umbrales económicos ya citados no existen dudas sobre la aplicación de las prohibiciones de contratar. Por debajo de ellos, no se aplican los artículos de las Directivas referidos a las prohibiciones y habría que estar a lo dispuesto en la normativa nacional que tratara la regulación de los contratos por debajo de los umbrales ${ }^{789}$. Ahora

a partir del 1 de enero de 2016 .

${ }^{787}$ Además de la jurisprudencia citada en la nota 783 , vamos a referirnos a la jurisprudencia reciente del Tribunal que aborda esta cuestión como, por ejemplo, la sentencia de 11 de diciembre de 2014, Azienda sanitaria locale, C-113/13, apartado 46; de 16 de abril de 2015, Enterprise Focused Solutions, C-278/14, apartado 15 y de 22 de octubre de 2015, Impresa Edilux y SICEF, C-425/14, apartado 19.

${ }^{788}$ MORENO MOLINA. J. A., "El sometimiento de todos los contratos públicos a los principios generales de contratación", en la obra colectiva Liber amicorum Tomás-Ramón Fernández, Civitas - Thomson, Pamplona, 2012, págs. 3429 - 3454; TREUMER, S., "Cross-border Interest and Application of EU Law Principles in the Public Procurement Context at National Level", en la obra colectiva Outside the EU Procurement Directives - Inside the Treaty, Djøf Publishing, Copenhague, 2012, págs. 335 - 357; en la misma obra COMBA, M., y RICHETTO, S., "Minor contracts: Outside the Directives and Outside the Treaties? Comparative analysis on public procurement below the thresholds in Europe", págs. 359 - 372 y DRAGOS, D. y VORNICU, R., "Public Procurement below Thresholds in the European Union", EPPL, vol. 3, 2015, págs. $187-206$.

${ }^{789}$ STJUE de 22 de octubre de 2015, Impresa Edilux y SICEF, C-425/14, apartado 19. En la legislación española la regulación se recoge en el mismo texto, pero con un régimen diferenciado para los «contratos sujetos a regulación armonizada», conocidos como contratos SARA. Sobre esta regulación, MORENO MOLINA, J.A., "Un mundo para Sara. Una nueva categoría en el Derecho español de la contratación 
bien, entendemos que esta regulación pudiera establecer una menor exigencia probatoria al operador económico sobre la ausencia de prohibiciones de contratar, pero que el requisito de no estar incurso en una prohibición de contratar es exigible en todo caso, puesto que de no ser así se vulneraría uno de los principios cardinales en la contratación pública, el principio de igualdad que - como hemos señalado - es aplicable aunque los contratos no estén comprendidos en el ámbito de aplicación de las Directivas ${ }^{790}$.

\section{La delimitación temporal de las prohibicio- nes de contratar}

El análisis de las prohibiciones de contratar debe efectuarse también sobre la base de un criterio temporal que tome en consideración el factor tiempo para corroborar la existencia de una prohibición de contratar, pero también para fijar el momento a partir del cual una prohibición despliega efectos y para determinar su duración. En este epígrafe vamos a abordar estas cuestiones haciendo constar que las nuevas Directivas inciden de una manera más detallada en este aspecto de las prohibiciones de contratar.

\section{IV.1. La apreciación de las prohibiciones de contratar}

El cumplimiento de los requisitos para poder contratar se aprecia por parte de los poderes adjudicadores antes de la adjudicación del contrato. El artículo 56.1.b) de la Directiva 2014/24/UE establece que la adjudicación de los con-

pública: los contratos sujetos a regulación armonizada", $R A P$, núm. 178, enero abril 2009, págs. 175 - 213.

${ }^{790}$ Empleando distintos argumentos, pero llegando a la misma conclusión, la JCCA del Estado, en su Informe 1/09, de 25 de septiembre, ha manifestado que "la limitación de exigencia de requisitos de aptitud a la capacidad de obrar y al título habilitante ha de entenderse en el sentido de que no es preciso acreditar documentalmente más que la una y el otro. Sin embargo, evidentemente, si la empresa adjudicataria se encuentra en prohibición de contratar y esta circunstancia es del conocimiento del órgano de contratación debe ser tenida en cuenta", de tal manera que "en los contratos menores es plenamente exigible el requisito de no estar incurso en prohibición de contratar". 
tratos se realizará sobre la base de los criterios de adjudicación que hayan sido fijados por el poder adjudicador, pero después de comprobar que la oferta ha sido presentada por un licitador que no está incurso en prohibición de contratar. De esta forma, se advierte que - desde un punto de vista temporal - la apreciación de la ausencia de prohibiciones de contratar es anterior a la adjudicación y, lógicamente, posterior al plazo de finalización de presentación de ofertas.

Al vencimiento del plazo fijado para solicitar la participación en un procedimiento de adjudicación o, en el caso de un procedimiento abierto, del plazo fijado para presentar la oferta, el operador económico debe cumplir con el requisito de no incurrir en prohibición de contratar. Ahora bien, las nuevas Directivas prevén una excepción a esta regla general. En efecto, respecto de la prohibición de contratar por incumplimiento de las obligaciones de pago de impuestos o cotizaciones a la seguridad social, se prevé que los Estados miembros puedan establecer una excepción si advierten como desproporcionado el poco plazo que el operador económico ha tenido para cumplir con sus obligaciones por haber "sido informado del importe exacto adeudado (...) en un momento tal que no le dejara posibilidad de tomar medidas como las previstas en el apartado 2, párrafo tercero" que se refieren al pago o a celebrar un acuerdo vinculante con vistas al pago (artículo 57.3 segundo párrafo de la Directiva 2014/24/UE y artículo 38.6 párrafo segundo de la Directiva 2014/23/UE («concesiones») $)^{791}$.

Otra de las novedades de la nueva regulación afecta al momento de valorar la ausencia de prohibiciones de contratar. La exigencia de no incurrir en una prohibición de contratar ha de ir referida inexorablemente al lapso temporal anterior a la adjudicación del contrato, pero nos habíamos cuestionado calificar a las prohibiciones de contratar como impedimentos para poder participar de la licitación porque un operador económico incurso en prohibición de contratar puede, de hecho, participar en un procedimiento de adjudicación ${ }^{792}$. Las nuevas Directivas ofrecen la posibilidad - en el procedimiento abierto - de examinar las

\footnotetext{
${ }^{791}$ Este aspecto de las nuevas Directivas será objeto de tratamiento posterior en este mismo capítulo al tratar los supuestos de excepción a la aplicación de las prohibiciones de contratar.

${ }^{792}$ Nos remitimos a lo dicho en las páginas 79 y 80 de esta memoria doctoral.
} 
ofertas económicas antes de comprobar la inexistencia de motivos de exclusión, con lo cual se está permitiendo participar en la licitación, presentar ofertas y "competir" en el procedimiento al licitador incurso en prohibición de contratar y que, por esa razón, no podría llegar a ser contratista (artículo 56.2 de la Directiva 2014/24/UE).

\section{IV.2. El momento a partir del cual la prohibición de contratar despliega efectos jurídicos}

Como cualquier otra medida administrativa, la exclusión de un operador económico del procedimiento de adjudicación deberá producir efectos jurídicos una vez que se declare mediante resolución administrativa y ésta sea firme en vía administrativa o judicial tras la interposición de los recursos pertinentes. Ahora bien, para determinar el momento a partir del cual una prohibición de contratar despliega efectos jurídicos es necesario distinguir entre todas las causas de prohibición de contratar y, más concretamente, diferenciar (i) si el presupuesto fáctico que habilita la prohibición de contratar exige una previa sentencia o resolución administrativa firme como sucede en los supuestos de prohibición de contratar de carácter obligatorio ${ }^{793}$, o si (ii) no existe una sentencia o resolución administrativa que acredite la existencia del motivo de exclusión.

Por lo que se refiere al último de estos supuestos, es decir a los casos de prohibición de contratar que traen causa del conocimiento que tiene el poder adjudicador - "por cualquier medio adecuado" o "por indicios suficientemente plausibles" - de los hechos que permiten la imposición de una prohibición de contratar, será necesario un previo y específico procedimiento administrativo que declare la prohibición ${ }^{794}$. De esta manera, en el desarrollo de este pro-

${ }^{793}$ GOSÁLBEZ PEQUEÑO trataba sobre el carácter declarativo o constitutivo de las declaraciones de las prohibiciones de contratar distinguiendo los supuestos de apreciación automática por parte de los órganos de contratación de aquellos otros que requerían un procedimiento administrativo, GOSÁLBEZ PEQUEÑO, H., El contratista (...), op. cit., págs. 259 a 263.

${ }^{794}$ Por ejemplo en los supuestos de prohibición de contratar por haber cometido "una falta profesional grave que pone en entredicho su integridad", por haber "llegado a acuerdos con otros operadores económicos destinados a falsear la competencia", 
cedimiento se deberá dar audiencia al operador económico para que no vea frustrado su derecho de defensa contra una medida que le resulta desfavorable. En este mismo sentido, a este procedimiento le son aplicables todas las garantías de cualquier procedimiento sancionador por cuanto la declaración de una prohibición de contratar afecta negativamente a los derechos e intereses del operador, aun no tratándose de una sanción ${ }^{795}$.

En segundo lugar, por lo que respecta a los supuestos de prohibición de contratar que requieren una previa sentencia o resolución administrativa firme, hemos de detenernos a examinar los efectos de esas resoluciones administrativas sancionadoras y sentencias condenatorias en el ámbito contractual. Cabe indicarse que en todos estos supuestos nos encontramos ante una limitación a la posibilidad de resultar contratista derivada de una previa condena penal o sanción administrativa, pero que no tiene por qué tener un tratamiento común en todos los Estados miembros, ya que las formas de aplicar dicha prohibición pueden variar de unos Estados a otros, máxime cuando se trata del ejercicio de una competencia nacional, en atención a lo dispuesto en los artículos 57.7 de la Directiva 2014/24/UE y artículo 38.10 de la Directiva 2014/23/UE.

Por tanto, de conformidad con los Derechos nacionales, la prohibición de contratar podría: (i) imponerse en un procedimiento administrativo que se incoara teniendo como presupuesto la condena o la resolución administrativa sancionadora; (ii) ser impuesta como pena por parte de los tribunales de justicia, o (iii) ser impuesta como sanción por los órganos con competencia sancionadora $^{796}$.

por incumplimiento de sus obligaciones laborales, sociales o medioambientales o por el incumplimiento de sus obligaciones en lo referente al pago de impuestos o cotizaciones a la seguridad social cuando no existe una sentencia o resolución administrativa que así lo acredite.

${ }^{795}$ Desde los primeros epígrafes de esta memoria doctoral venimos sosteniendo que las prohibiciones de contratar no participan del concepto de sanciones administrativas, si bien al tratarse de actos limitativos de derechos deben aplicárseles ciertos principios y garantías propios del procedimiento sancionador (STS de 30 de enero de 2007, RJ 2007\830 y STS de 31 de mayo de 2007, RJ 2007\5402).

${ }^{796}$ Estas posibilidades han sido analizadas en la obra colectiva dirigida por WHITE, S., Procurement and organised crime: an EU wide study, Institute of Advanced Legal Studies, Londres, 2000 y en la Comunicación de la Comisión sobre Penas privativas de derechos impuestas por condenas penales en la Unión Europea, COM (2006) 73 
Estas posibilidades nos presentan dos escenarios posibles respecto de su aplicación por parte de los órganos de contratación y de los efectos que produce: El primer escenario es aquel en el cual la sentencia o resolución administrativa sancionadora se pronuncia sobre la prohibición, su duración y ámbito de aplicación; y el segundo de los escenarios evidencia una resolución administrativa o sentencia firme que no realiza pronunciamiento alguno respecto de la prohibición de contratar.

\section{A. Primer escenario. La sentencia o resolución administrativa san- cionadora contiene un pronunciamiento expreso sobre la prohi- bición de contratar}

En este caso, la apreciación y aplicación deben ser automáticas por parte de los poderes adjudicadores ${ }^{797}$, ya que entendemos que éstos únicamente tienen que adoptar las medidas necesarias para ejecutar lo dispuesto en la sentencia o en la resolución administrativa quedando vinculado por lo allí expuesto y durante el período que se indique. Por tanto, la actividad del órgano de contratación para definir el alcance de la prohibición debe ajustarse a lo resuelto en la correspondiente sentencia o resolución, aunque fuera necesaria una resolución que declarase su existencia.

En atención a esa vinculación, las Directivas disponen, por una parte, que los operadores económicos que hayan sido excluidos por sentencia firme de la participación en procedimientos de contratación o de adjudicación de concesiones no tendrán derecho a acogerse a la posibilidad de rehabilitación mediante la aplicación de medidas autocorrectoras "durante el período de exclusión resultante de dicha sentencia en el Estado miembro en el que la sentencia sea ejecutiva" ${ }^{\prime 78} \mathrm{y}$, por otra, que debe respetarse la duración de la exclusión fijada

final, de 21 de febrero de 2006.

${ }^{797} \mathrm{El}$ artículo 61.2 del TRLCSP es elocuente en esta materia al señalar que " $L a$ prohibición de contratar por las causas previstas en las letras a) y b) del apartado 1 del artículo anterior se apreciará directamente por los órganos de contratación, cuando la sentencia o la resolución administrativa se hubiera pronunciado expresamente sobre su alcance y duración, subsistiendo durante el plazo señalado en las mismas".

${ }^{798}$ Artículo 57.6 in fine de la Directiva 2014/24/UE y artículo 38.9 in fine de la 
en la sentencia, ya que únicamente prevé plazos máximos de la prohibición de contratar "cuando una sentencia firme no haya establecido el período de exclusión". No obstante, y a pesar de este utópico escenario, la realidad nos muestra distintos problemas que siquiera brevemente creemos de interés reseñar:

1) La primera cuestión que a efectos prácticos se plantea, y que al mismo tiempo constituye el principal elemento a los efectos de aplicar las previsiones contenidas en una sentencia o resolución administrativa, es la relativa a su conocimiento, puesto que, si el órgano de contratación no tiene conocimiento de su existencia difícilmente va a poder aplicarlas.

Es por ello que se insiste en la puesta en común y en el necesario intercambio de información ${ }^{799}$, en el acceso a la información relativa a las empresas, en la obligación de conectar todos los registros, en mejorar la calidad de los intercambios de información sobre condenas ${ }^{800}$, en la obligación de publicar las sentencias ${ }^{801}$, e incluso - tal como veremos -

Directiva 2014/23/UE («concesiones»). Respecto de la aplicación de estas medidas y, más en concreto, sobre la visión crítica de esta disposición tratan las páginas 556 y 557 de esta memoria doctoral.

${ }^{799} \mathrm{El}$ artículo 61.3 del TRLCSP se refiere a ello cuando dispone que "el órgano judicial o administrativo del que emane la sentencia o resolución administrativa deberá remitir de oficio testimonio de aquélla o copia de ésta a la Junta Consultiva de Contratación Administrativa del Estado, sin perjuicio de que por parte de éste órgano, de tener conocimiento de su existencia y no habiendo recibido el citado testimonio de la sentencia o copia de la resolución administrativa, pueda solicitarlos al órgano del que emanaron", si bien no deja de ser una obligación jurídica carente de sanción.

${ }^{800}$ Decisión Marco 2008/315/JAI del Consejo, de 26 de febrero de 2009, relativa a la organización y al contenido del intercambio de información de los registros de antecedentes penales entre los Estados miembros (DOUE L 93, de 7 de abril de 2009).

${ }^{801} \mathrm{El}$ artículo 288 del Código penal español para los delitos relativos a la propiedad intelectual e industrial y, contra el mercado y los consumidores, establece la obligación de publicar la sentencia en los periódicos oficiales y la posibilidad de que el juez o tribunal ordene su reproducción total o parcial en cualquier otro medio informativo. Asimismo, la Ley Orgánica 10/2015, de 10 de septiembre, por la que se regula el acceso y publicidad de determinada información contenida en las sentencias dictadas en materia de fraude fiscal, en su Exposición de motivos nos recuerda que "en el caso concreto de los delitos relacionados con la defraudación fiscal, frente al interés 
se ha avanzado en la aplicación de mecanismos para que los órganos de contratación tengan conocimiento de las prohibiciones de contratar ${ }^{802}$.

2) En el supuesto de conocimiento posterior de esa sentencia o resolución con pronunciamiento expreso sobre la prohibición por parte del poder adjudicador $^{803}$, se plantean los efectos que ello causa en un contrato ya adjudicado a quien incurre en una causa de prohibición de contra$\operatorname{tar}^{804}$. En términos estrictos de legalidad, el artículo 73 de la Directiva 2014/24/UE prevé la posibilidad de rescisión del contrato si el contratista hubiera estado, en el momento de la adjudicación del contrato, en una de las situaciones de prohibición de contratar obligatoria y, por lo tanto, hubiera debido ser excluido del procedimiento de contratación. En el ordenamiento español la adjudicación del contrato a personas que se hallen incursas en alguna de las causas de prohibición de contratar, es causa de nulidad de derecho administrativo ${ }^{805}$. En este sentido, la nulidad de la

del condenado, se alza el interés público" (BOE núm. 218, de 11 de septiembre de 2015).

${ }^{802}$ En tal sentido, cabe señalarse nuevamente que las Directivas no contemplan disposiciones con respecto a la puesta en práctica de la publicación de "listas negras" - blacklists - de empresas excluidas como se prevé en algunos Estados miembros o en organismos como el Banco Mundial (véase lo dicho en la página 167 de esta memoria doctoral).

${ }^{803}$ Presuponemos que el operador económico sí que conoce el contenido de la sentencia condenatoria o de la resolución sancionadora, pero que aun así "ha retenido dicha información" e incluso pudiera haber realizado "declaraciones falsas al proporcionar la información exigida para verificar la inexistencia de motivos de exclusión" que son otras de las causas de prohibición de contratar contempladas en las Directivas. A nuestro entender, en caso de conocerse la sentencia o la resolución con posterioridad a la adjudicación del contrato, estos hechos de cierta "deslealtad" quiebran la confianza legítima de las partes contratantes respecto de mantener los efectos del contrato (pacta sunt servanda).

${ }^{804}$ En atención a lo dispuesto en el novedoso artículo 61 bis apartado 3 del TRLCSP "Las prohibiciones de contratar contempladas en las letras a) y b) del apartado primero del artículo 60 producirán efectos desde la fecha en que devinieron firmes la sentencia o la resolución administrativa en los casos en que aquélla o ésta se hubieran pronunciado sobre el alcance y la duración de la prohibición".

${ }^{805}$ La legislación contractual comprende una serie de normas que disciplina el régimen de validez de los contratos, es decir, un conjunto de reglas que establecen cuándo un contrato es contrario al ordenamiento jurídico (Directiva 2007/66/CE 
adjudicación del contrato tendría lugar a través de la revisión de oficio o vía recurso, y una vez declarada formalmente, se tendría que privar de eficacia al contrato entrando éste en fase inmediata de liquidación (al menos, eso sí, que ello produjese un grave trastorno al servicio público). Entendemos, por todo ello, que el órgano de contratación estaría obligado a resolver el contrato ya celebrado ${ }^{806}$.

3) Por otra parte habría que destacar que la propia sentencia o resolución administrativa no siempre delimita el contenido específico de la prohibición. Es decir, puede ocurrir que únicamente se limiten a indicar que se impone la pena o la sanción administrativa de prohibición de contratar, pero no especifiquen el alcance de dicha pena o sanción al caso concreto, lo que obliga al poder adjudicador bien a solicitar posteriormente aclaraciones al tribunal sentenciador o al órgano sancionador respecto de su aplicación $^{807}$, o bien, entender que la falta de concreción supone que la prohibición de contratar deberá determinarse en un procedimiento posterior instruido al efecto (lo que nos lleva al segundo escenario posible).

4) Otra cuestión de interés, pero que excede el objeto de este trabajo, es el

«Directiva recursos»). Por lo que respecta al TRLCSP, su artículo 31 indica, entre otras cuestiones, que los contratos "serán inválidos cuando lo sea alguno de sus actos preparatorios o el de adjudicación, por concurrir en los mismos alguna de las causas de derecho administrativo". En esta materia resulta de interés, GALLEGO CÓRCOLES, I., "Contratos públicos y régimen «cualificado» de invalidez: supuestos especiales y cuestión de nulidad", en la obra colectiva Observatorio de Contratos Públicos 2010, Civitas - Thomson Reuters, Cizur Menor (Navarra), 2011, págs. 259 318 , quien nos conduce por la regulación de otros Estados miembros en esta materia.

${ }^{806}$ Aunque los efectos de la declaración de invalidez de la adjudicación de un contrato se determine con arreglo a los ordenamientos internos de los Estados miembros, éstos se encuentran obligados a poner fin a los contratos cuya adjudicación haya infringido las normas de la Unión Europea (STJUE de 18 de julio de 2007, Comisión/Alemania, C-503/04). No obstante, y aun cuando la legislación así lo prevea, la anulación del contrato no siempre resulta posible, y tal como desarrolla AYMERICH CANO, supone todavía un problema pendiente, AYMERICH CANO, C., Un problema pendiente: La anulación de los contratos administrativos afectados por actos de corrupción, Thomson Aranzadi, Cizur Menor (Navarra), 2015.

${ }^{807}$ Cuando se trata de una sentencia que dispone la inhabilitación especial para profesión, oficio, industria o comercio existe la obligación de que dicha inhabilitación se concrete expresa y motivadamente en la sentencia (artículo 45 del Código penal). 
análisis de los efectos que producen las medidas de gracia y rehabilitación o reparación en el ámbito contractual. Nos referimos más concretamente a la extinción de la responsabilidad criminal en el supuesto de concesión de un indulto ${ }^{808}$ o de la rehabilitación en el caso de las sanciones administrativas, ya que tienen como consecuencia la extinción en todo o en parte de la pena o sanción impuesta, lo que posibilita dejar de cumplir la prohibición que aún no ha dado comienzo o dejar de cumplir la ya iniciada $^{809}$.

\section{B. Segundo escenario. La sentencia o resolución administrativa guar- da silencio respecto de la prohibición de contratar}

La falta de un pronunciamiento expreso en la sentencia condenatoria o en la resolución sancionadora sobre la aplicación de una prohibición de contratar

\footnotetext{
${ }^{808}$ Según recoge la Ley de 18 de junio de 1870 , de reglas para el ejercicio de la gracia de indulto, "El indulto de la pena principal llevará consigo el de las accesorias que con ella se hubiesen impuesto al penado, a excepción de las de inhabilitación para cargos públicos y derechos políticos (...) las cuales no se tendrán por comprendidas si de ellas no se hubiese hecho mención especial en la concesión". Este es un supuesto completamente distinto al que trataremos en el último de los epígrafes de esta memoria doctoral sobre las medidas de cumplimiento y su repercusión en cuanto a evitar la aplicación de una prohibición de contratar.

${ }^{809}$ Es el caso del artículo 55.c) del Código dos Contratos Públicos de Portugal que tiene el siguiente tenor: "Não podem ser candidatos, concorrentes ou integrar qualquer agrupamento, as entidades que: c) Tenham sido objeto de aplicação de sanção administrativa por falta grave em matéria profissional, se entretanto não tiver ocorrido a sua reabilitação".

También, por ejemplo, del artículo 117 de la Ley 3/1998, de 27 de febrero, General de Protección del Medio Ambiente del País Vasco, que dispone que "Las empresas que hayan sido sancionadas por faltas graves y muy graves derivadas del incumplimiento de la legislación medioambiental no podrán contratar ni obtener subvenciones de las Administraciones públicas hasta no haber ejecutado las medidas correctoras pertinentes y haber satisfecho la sanción", o de la más reciente Ley balear 2/2014, de 25 de marzo, de ordenación y uso del suelo, que después de indicar que la comisión de infracciones urbanísticas muy graves está sancionada con la "prohibición de contratar obras con la administración pública correspondiente", señala que estas sanciones quedarán sin efecto "si, antes de que transcurran los plazos que se prevén, las personas infractoras proceden voluntariamente a reponer la realidad física o jurídica alterada, o bien acceden a la legalización de la construcción o el uso" (artículo 177.5).
} 
supone, evidentemente, que no cabe hablar de una apreciación directa por parte del poder adjudicador, ni de un despliegue de efectos inmediato.

$\mathrm{Su}$ falta de pronunciamiento expreso puede obedecer a distintos motivos más allá del olvido en su imposición:

(i) en el caso de las personas jurídicas - y siempre que la legislación penal interna prevea su punibilidad - hemos señalado que el legislador puede dejar al arbitrio judicial la decisión sobre qué pena imponer y que ésta se contemple con un carácter potestativo para jueces y tribunales, como sucede en el caso del artículo 66 bis del Código penal español;

(ii) también puede deberse a que algunas de las figuras delictivas contempladas en la legislación contractual no señalen la posibilidad de imposición de la pena de prohibición de contratar a la persona jurídica, no existiendo, por tanto, una correspondencia entre normativas ${ }^{810}$;

(iii) asimismo, puede que tampoco exista relación cuando se trate de la imposición de sanciones en distintos sectores de actividad administrativa. En nuestra opinión, lo deseable en términos de coherencia normativa es que, si el Estado miembro decide, por ejemplo, que el incumplimiento de determinadas obligaciones sea causa de prohibición de contratar, exista reciprocidad en ese concreto ámbito de actividad sectorial, de tal manera que su infracción también se sancione con la prohibición de contratar ${ }^{811}$; e igualmente a contrario sensu, es decir, que si en sectores concretos de actividad administrativa se prevé la sanción de prohibición de contratar

\footnotetext{
${ }^{810}$ Es el caso, por ejemplo, de los delitos relativos a la protección del patrimonio histórico (artículos 321 a 324 del Código penal) o del artículo 318 del mismo texto relativo a los delitos contra los derechos de los trabajadores que tampoco está incluido en el catálogo de delitos de los que pueden ser responsables las personas jurídicas, si bien este último artículo prevé que la autoridad judicial pueda decretar alguna o algunas de las medidas previstas en el artículo 129 del Código entre las que se contempla la posibilidad de imponer la prohibición de contratar.

${ }^{811} \mathrm{El}$ supuesto más claro es que si en la normativa contractual del Estado miembro se prevé una prohibición de contratar por haberse incumplido las obligaciones aplicables en materia medioambiental, social, laboral o de defensa de la competencia, en esos sectores se contemplase, asimismo, la sanción de prohibición de contratar, pues entendemos que con este modo de actuar, el ordenamiento gana en previsibilidad y en seguridad jurídica.
} 
derivada del incumplimiento de dicha legislación, esta prohibición tenga de alguna manera reflejo en la normativa contractual $^{812}$.

Ahora bien, cualquiera que sea el motivo del silencio, el hecho de que en la condena no se señale la pena de prohibición de contratar o, en su caso, de inhabilitación especial no supone que la persona (física o jurídica) condenada o sancionada no esté incursa en un supuesto de prohibición de contratar según la normativa contractual. Son cuestiones distintas, por un lado, la referida a las causas que legalmente constituyen la prohibición de contratar y, por otro, la relativa al procedimiento que ha de seguirse para la declaración de su existencia y aplicación.

En efecto, el requisito sustantivo para imponer la prohibición de contratar es la condena penal firme y/o la sanción administrativa igualmente firme, pero su alcance y duración se deberá declarar - como hemos señalado para el resto de prohibiciones de contratar - tras un procedimiento administrativo instruido al efecto en el que se observen las garantías necesarias para su imposición.

\footnotetext{
${ }^{812}$ Ponemos como ejemplo los supuestos que presentábamos en las primeras páginas de esta memoria doctoral en sectores como patrimonio, turismo, consumidores y usuarios), pues comprobamos que la gran mayoría de estas prohibiciones no tienen acomodo en la legislación contractual y sin que exista - a modo de cierre del sistema - una prohibición que comprenda el "estar afectado por una prohibición de contratar impuesta en virtud de sanción administrativa firme/o de sentencia judicial firme", como sí sucede, por ejemplo en la legislación francesa respecto de la pena de exclusión. Así el artículo 45.4.c) Ordonnance $\mathrm{n}^{\mathrm{o}}$ 2015-899 du 23 juillet 2015 relative aux marchés publics prescribe que "Sont exclues de la procédure de passation des marchés publics : 4. Les personnes qui: c) Ont été condamnées au titre du $5^{\circ}$ de l'article 131-39 du code pénal ou qui sont des personnes physiques condamnées à une peine d'exclusion des marchés publics" o como sucede en el caso del artículo $60.1 \mathrm{f}$ ) del TRLCSP respecto de "estar afectado por una prohibición de contratar impuesta en virtud de sanción administrativa firme, con arreglo a lo previsto en la Ley 38/2003, de 17 de noviembre, General de Subvenciones, o en la Ley 58/2003, de 17 de diciembre, General Tributaria".
} 


\section{IV.3. La prescripción de la acción para la imposición de la prohibición de contratar}

Las prohibiciones de contratar, con independencia que su naturaleza sea obligatoria o facultativa, debieran tener un plazo de prescripción para su imposición por aplicación del principio de seguridad jurídica ${ }^{813}$. La prescripción supone una garantía para al operador económico al saber que transcurrido un determinado plazo (el que disponga la normativa) sin que tenga conocimiento del comienzo de un procedimiento de declaración de la prohibición de contratar ya no puede ejercercitarse la acción para su imposición.

Ahora bien, las nuevas Directivas más allá de establecer la posibilidad de rescisión de los contratos cuando el contratista hubiera estado, en el momento de la adjudicación del contrato, incurso en una prohibición de contratar obligatoria o de excluir al operador económico "en cualquier momento durante el proceso" si resulta que igualmente se encuentra en una situación de prohibición obligatoria ${ }^{814}$, no señalan un plazo dentro del cual los poderes adjudicadores pueden dar comienzo al procedimiento de declaración de la prohibición de contratar.

Podríamos sostener que el inicio del cómputo del plazo de prescripción (dies a quo) debiera ser: (i) bien la fecha en que la sentencia o la resolución administrativa hubiera adquirido firmeza, (ii) bien la fecha en la que se hubiera producido la conducta que ha dado origen a la prohibición de contratar o desde la comisión de la infracción. Sin embargo, más allá de esta "hipotética" certeza no existe en las Directivas un régimen prescriptivo que aporte seguridad jurídica respecto del día final o sobre las posibilidades de interrupción de dicho plazo de prescripción ${ }^{815}$.

\footnotetext{
${ }^{813}$ Así se ha manifestado nuestro TS en sus sentencias de 7 de noviembre de 2006 (RJ 2006 \9055) y de 30 de abril de 2014 (RJ 2014\2685).

${ }^{814}$ Se trata de los artículos 73.b) de la Directiva 2014/24/UE y 38.8 de la Directiva 2014/23/UE «concesiones».

${ }^{815}$ Entendemos - aun cuando no sea aplicable - que el plazo no debiera ser inferior a cuatro años por ser éste el plazo de prescripción previsto en el artículo 3, apartado 1, párrafo primero, del Reglamento (CE, Euratom) 2988/95 del Consejo, de 18 de diciembre de 1995, que resulta aplicable a las irregularidades que perjudiquen los intereses financieros de la Unión.
} 


\section{IV.4. La duración de las prohibiciones de contratar}

Las nuevas Directivas remiten a la normativa nacional y a las sentencias que declaren la prohibición de contratar (entendemos que también - aunque no se diga - a las resoluciones firmes) la regulación jurídica sobre la duración máxima de las prohibiciones de contratar y, en el caso de no establecerse dicha duración, señalan un plazo supletorio.

Así pues, de conformidad con el tenor del artículo 37.7 de la Directiva 2014/24/UE y del artículo 38.10 de la Directiva 2014/23/UE («concesiones»), la duración de la prohibición de contratar cuando una sentencia firme no haya establecido otro período de exclusión:

- No podrá exceder de cinco años a partir de la fecha de la condena por sentencia firme en los supuestos contemplados como prohibiciones obligatorias por participación en una organización delictiva, corrupción, fraude, blanqueo de capitales o financiación del terrorismo, delitos de terrorismo o ligados a actividades terroristas y trabajo infantil y otras formas de trata de seres humanos;

- Ni podrá exceder de tres años a partir de la fecha del hecho relevante en los casos de prohibiciones de contratar facultativas para los Estados miembros.

Estas previsiones aportan seguridad jurídica en tanto que evitan la "muerte civil" del operador económico que incurre en un supuesto de prohibición de contratar, a la vez que los operadores económicos pueden conocer con mayor concreción los efectos de su actuación; de esta manera, la fijación del máximo período de exclusión coincidiría con su comportamiento doloso o de mala fe y, muy especialmente, con unos mayores daños y perjuicios causados a los intereses públicos.

No se fija, sin embargo, un período de exclusión para el supuesto de incumplimiento de las obligaciones referentes al pago de impuestos o cotizaciones a la seguridad social. En este caso, entendemos que el silencio del legislador europeo puede deberse a la regulación de los distintos supuestos de "derogación" de esta prohibición que hace difícil que cualquier operador económico esté excluido durante mucho tiempo de un procedimiento de adjudicación por 
esta causa, ya que la prohibición "dejará de aplicarse una vez que el operador económico haya cumplido sus obligaciones de pago o celebrado un acuerdo vinculante con vistas al pago de los impuestos o las cotizaciones a la seguridad social que adeude, incluidos en su caso los intereses acumulados o las multas impuestas" (artículo 57.2 in fine de la Directiva 2014/24/UE y artículo 38.5 in fine de la Directiva 2014/23/UE («concesiones»).

Tampoco se señala un período mínimo de duración de la prohibición de contratar, ni existen reglas que lo determinen más allá de manifestar la poca entidad del daño causado al interés general con la conducta del operador económico. En el caso español, la prohibición de contratar de menor duración publicada en el BOE fue de un mes y un día ${ }^{816}$.

\section{IV.5. Las prohibiciones sobrevenidas: su incidencia en el contrato}

La situación por la cual el contratista - no el candidato o licitador - incurre en un supuesto de prohibición de contratar no se contempla en las Directivas sobre contratación pública, es decir, no se prevé como afecta a un contrato ya formalizado una causa de prohibición de contratar sobrevenida.

Hemos señalado, de una parte, que el requisito de no incurrir en ninguna causa de prohibición de contratar debe cumplirse, en todo caso, en el momento de presentación de las proposiciones u ofertas y que debe mantenerse hasta el momento de la adjudicación del contrato. Por otra, que si el contrato se hubiera adjudicado a un operador incurso - en el momento de la adjudicación - en un supuesto de prohibición de contratar, cabe la resolución del contrato durante toda su vigencia, pues la causa de prohibición de contratar existía desde un inicio y dicho operador económico "hubiera debido ser excluido del procedimiento

\footnotetext{
${ }^{816}$ Resolución de 1 de septiembre de 2005, de la Dirección General de Patrimonio del Estado, por la que se hace pública la declaración de la prohibición de contratar de D. Santiago Santana Cazorla (BOE núm. 223, de 17 de septiembre de 2005, corrección de errores de 20 de septiembre). Otras prohibiciones de corta duración han sido de dos meses a la empresa Thyssenkrupp Elevadores S.L a la que se refiere la STS de 18 de marzo de 2015 (RJ 2015 $\backslash 2796$ ) o de tres meses a D. Miquel Boixadera Vilajosana (BOE núm. 7, de 8 de enero de 1998) y a D. Mariano Pastrana de la Calle (BOE núm. 192, de 9 de agosto de 2010).
} 
de contratación" (artículo 73.b de la Directiva 2014/24/UE). Ahora bien, si el contratista se encuentra en una de las situaciones de prohibición de contratar después de adjudicado el contrato, las Directivas de la Unión no contemplan las consecuencias de tal situación.

No obstante, entendemos que dependiendo de los supuestos y siempre que ello no afectara al servicio público, debiera aplicarse el régimen jurídico de la resolución del contrato tan pronto como se produzca esta situación, pues de lo contrario, el contratista podría incurrir en los supuestos de prohibición de contratar sin ninguna consecuencia jurídica (piénsese en una situación de incumplimiento de sus obligaciones laborales con sus trabajadores, o de impago de impuestos o con la seguridad social).

\section{La delimitación espacial de las prohibicio- nes de contratar}

Resulta evidente que el Derecho de la Unión, como cualquier otro ordenamiento jurídico, debe desplegar efectos sobre un territorio que, en este caso, debiera ser el territorio de los 28 Estados miembros y sobre los - aproximadamente - 300.000 órganos de contratación existentes en toda la UE ${ }^{817}$. Ahora bien, la política sobre contratación pública no está completamente armonizada, siendo uno de los ejemplos más claros de lo dicho las prohibiciones de contratar facultativas. Como ya hemos señalado, en esta materia no se contempla una aplicación uniforme de las causas de exclusión a escala europea, en la medida en que "los Estados miembros están facultados para no aplicar en absoluto dichas causas de exclusión (...) o bien para integrarlas en la normativa nacional con un grado de rigor que podría variar según el caso, en función de consideraciones de carácter jurídico, económico o social que prevalezcan en el plano nacional" $" 818$.

${ }^{817}$ Según datos publicados en el año 2013 por la Comisión, en todo el territorio de la Unión hay entre 250.000 y 300.000 órganos de contratación. Contratación pública electrónica de extremo a extremo para modernizar la administración pública, COM (2013) 453 final de 26 de junio de 2013, pág. 8 nota al pie 23.

${ }^{818}$ Así se manifiesta el Tribunal de Justicia en sus sentencias de 9 de febrero de 2006, La Cascina y otros, C-226/04 y C-228/04, apartados 21 a 23; de 19 de mayo 
En base a ello, en este epígrafe nos vamos a centrar en dos aspectos: El primero se refiere a la posibilidad de que los Estados miembros requieran a los poderes adjudicadores de otro Estado miembro para que excluyan del procedimiento de licitación a un operador económico incurso en una prohibición de contratar facultativa. El segundo alude al reconocimiento mutuo de las resoluciones judiciales como presupuesto para que una prohibición de contratar impuesta en un Estado miembro surta efectos más allá de sus fronteras.

No obstante, vamos a dejar fuera de nuestro análisis un aspecto silenciado por las Directivas de la Unión, pero que evidentemente tiene efectos prácticos importantes para los operadores económicos y es el reconocimiento de una prohibición de contratar más allá de las fronteras de la Unión. Tampoco existe un planteamiento uniforme en esta materia ${ }^{819}$, aun cuando a nuestro entender, pudiera haberse considerado el reconocimiento de las prohibiciones de contratar de operadores económicos europeos en países del Acuerdo sobre el Espacio Económico Europeo y del Acuerdo de la Organización Mundial del Comercio sobre Contratación Pública o en otros acuerdos internacionales que vinculen a la Unión y a sus Estados miembros ${ }^{820}$.

de 2009, Assitur, C-538/07, apartado 23; de 13 de diciembre de 2012, Forposta SA, C-465/1; de 10 de julio de 2014, Consorzio Stabile, C-358/12, apartado 36 y de 22 de octubre de 2015, Impresa Edilux y SICEF, C-425/14, apartado 26.

${ }^{819}$ Véase PRIESS, H-J., "The Rules on Exclusion and Self-Cleaning (...)", op. cit., pág. 114.

${ }^{820}$ En la Lista del Banco Mundial de empresas inhabilitadas para contratar encontramos numerosos ejemplos de empresas con sede social en algún Estado miembro, sin que ello - en principio - tenga efectos en el territorio de la Unión, aunque sea una clara evidencia de falta de fiabilidad. Las últimas que aparecen en dicha base de datos son de Finlandia (septiembre 2015); de Grecia (septiembre 2015), de Austria (agosto 2015); de Suecia (julio 2015); de España (julio 2015); de Francia (junio 2015) y de Bélgica (junio 2015). http://web.worldbank.org/external/default/main?contentMDK=20942264\&menuPK=2242627\&pagePK=64148989\&piPK=51391669\&theSitePK=2242580 [Fecha de consulta: 24 de octubre de 2015]. 


\section{V.1. La petición de exclusión realizada desde otro Es- tado miembro}

En su configuración actual - y como otra de las novedades que presentan las Directivas de 2014 - se posibilita que a petición de un Estado miembro un poder adjudicador o una entidad adjudicadora puedan excluir a un operador económico por una causa de prohibición de contratar facultativa, que entendemos, aunque no se diga, que es obligatoria en la legislación del Estado "peticionario" y que afecta a sus nacionales:

"Los poderes adjudicadores podrán excluir a un operador económico de la participación en un procedimiento de contratación, por sí mismos o a petición de los Estados miembros, en cualquiera de las siguientes situaciones" (artículo 57.4 de la Directiva 2014/24/UE) [el subrayado es nuestro].

"Los poderes adjudicadores o entidades adjudicadoras podrán excluir, o los Estados miembros podrán pedirles que excluyan, de la participación en un procedimiento de adjudicación de concesión a cualquier operador económico si se da cualquiera de las siguientes situaciones" (artículo 38.7 de la Directiva 2014/23/UE) [el subrayado es nuestro].

\section{V.2. El reconocimiento de resoluciones judiciales en ma- teria penal}

Hemos sostenido que las prohibiciones de contratar obligatorias pueden resultar un importante instrumento para luchar contra ciertas manifestaciones de prácticas ilícitas en la contratación pública. Ahora bien, para combatir la delincuencia en el espacio de la Unión es preciso avanzar hacia el denominado Espacio Único de Justicia Penal; la libre circulación de personas - y, también, de delincuentes - en territorio europeo, ha de tener como límite la lucha transnacional contra el delito. Uno de los primeros textos en reflejar esta preo- 
cupación fue el Convenio sobre asistencia judicial en materia penal ${ }^{821}$, tras pasar por los filtros previos de los Programas de La Haya y Estocolmo.

La cooperación judicial se sustenta en dos pilares básicos: (i) la armonización legislativa, procurando la mayor sintonía normativa ante la ausencia de textos unificados y (ii) el reconocimiento y, en su caso, posterior ejecución de resoluciones judiciales (artículo 82 del TFUE para las resoluciones penales). Bajo el punto de vista normativo, no es hasta el año 2008 que las Decisiones marco de la Unión se centran en el reconocimiento mutuo de resoluciones judiciales en materia penal ${ }^{822}$, aunque ya en el año 2000 - y por lo que a esta memoria doctoral interesa - ya se había planteado la inhabilitación de determinados sujetos para desempeñar un cargo público, ejercer una profesión o poder contratar con las entidades del sector público, al entender que la prohibición de realizar determinadas actividades profesionales o concurrir a licitaciones debía garantizarse y tutelarse para preservar el buen funcionamiento del mercado interior, lo que exigía el reconocimiento de la sentencia condenatoria en toda la Unión ${ }^{823}$.

La propia Comunicación no vio otro recurso mejor que la creación de un registro específico de inhabilitaciones que incorporara los datos personales de los operadores económicos, las actividades prohibidas y la duración de la medida impuesta. De esta forma, se recogían, tanto las resoluciones firmes como

${ }^{821}$ Convenio de asistencia judicial en materia penal entre los Estados miembros de la Unión Europea, hecho en Bruselas el 29 de mayo de 2000 y publicado en el DOUE L 197, de 12 de julio de 2000 y en el BOE núm. 247, de 15 de octubre de 2003.

${ }^{822}$ Se trata de la Decisión marco 2008/909/JAI, de 27 de noviembre de 2008, relativa a la aplicación del principio de reconocimiento mutuo de sentencias en materia penal por las que se imponen penas u otras medidas privativas de libertad a efectos de su ejecución en la Unión Europea (DOUE L 327, de 5 de diciembre); de la Decisión marco 2008/947/JAI del Consejo, relativa a la aplicación del principio de reconocimiento mutuo de sentencias y resoluciones de libertad vigilada con miras a la vigilancia de las medidas de libertad vigilada y las penas sustitutivas (DOUE L 337, de 16 de diciembre) y de la Decisión marco 2008/978/JAI, de 18 de diciembre de 2008, relativa al exhorto europeo de obtención de pruebas destinadas a procedimientos penales (DOUE L 350, de 30 de diciembre).

${ }^{823}$ Comunicación de la Comisión al Consejo y al Parlamento europeo sobre reconocimiento mutuo de resoluciones firmes en materia penal, COM (2000) 495 final, de 26 de julio de 2000 . 
las simplemente dictadas que emanaran de cualquier Estado miembro y que debían ser tenidas en cuenta en todo el espacio europeo mediante el acceso a esa base de datos.

Este objetivo, loable desde el punto de visto ético, imprescindible desde el punto de vista económico, exigible desde el punto de vista político y factible desde el punto de vista práctico a través de la utilización de medios electrónicos, no ha sido todavía implementado ${ }^{824}$. El transcurso de tres lustros sin haberse adoptado una sola iniciativa en este sentido, nos instala en un escepticismo que duda de que en un futuro inmediato pueda ser creado el citado registro.

Pese a la hipertrofia legislativa que la Unión parece mostrar a favor del reconocimiento mutuo de resoluciones judiciales, lo cierto es que los hechos muestran la ausencia de una Directiva que ampare la creación de una base de datos judicial y policial europea, que impida la impunidad en los demás Estados miembros del operador económico condenado por sentencia judicial firme por alguno de los delitos que suponen una prohibición de contratar de carácter obligatorio en toda la Unión y que posibilite en cada país el conocimiento actualizado de las circunstancias procesales que rodean a un licitador o candidato que ha incurrido en alguna prohibición de contratar.

La única referencia a una base de datos de estas características la encontramos en el ámbito del Reglamento financiero con la creación de una base de datos de exclusión de las personas jurídicas o físicas de las que se sospecha representan un riesgo para los intereses financieros de la Unión ${ }^{825}$, aunque cabe indicarse que recientemente se ha cuestionado la atribución de competencias

\footnotetext{
${ }^{824}$ No obstante, y con un carácter más general se ha instaurado un sistema de información europeo de antecedentes penales (European Criminal Records Information System) que se remonta a una iniciativa belga de 2004 que perseguía inhabilitar a los delincuentes condenados por delitos sexuales para trabajar con niños en otros Estados miembros. Decisión 2009/316/JAI del Consejo, de 6 de abril de 2009, por la que se establece el Sistema Europeo de Información de Antecedentes Penales (ECRIS) en aplicación del artículo 11 de la Decisión Marco 2009/315/JAI (DOUE L 93, de 7 de abril de 2009).

${ }^{825}$ La base de datos central de exclusión de la que trataba el artículo 95 del derogado Reglamento financiero 1605/2002, fue creada por el Reglamento (CE, Euratom) 1302/2008 de la Comisión, de 17 de diciembre de 2008, relativo a la base de datos central de exclusión (DOUE L 344, de 20 de diciembre).
} 
a la Comisión - en virtud del Derecho primario o del Derecho derivado - para diseñar, crear y gestionar una base de datos de estas características por los efectos que produce fuera del ámbito de la propia Comisión ${ }^{826}$.

Estas cuestiones nos conducen a tratar seguidamente sobre el intercambio de información acerca de las prohibiciones de contratar.

\section{El intercambio de información acerca de las prohibiciones de contratar}

La aplicación de las prohibiciones de contratar requiere que los poderes y entidades adjudicadoras conozcan las distintas resoluciones administrativas y sentencias judiciales firmes que declaren su existencia, así como tener conocimiento de los hechos que configuran una prohibición de carácter facultativo, puesto que de no ser así, este instrumento normativo se quedaría únicamente en un mero recurso fallido ${ }^{827}$. De esta manera - y al margen de la propia declaración del operador económico y de su aportación de documentos justificativos de la ausencia de prohibiciones - para articular un sistema que permita dar a conocer, con un elevado grado de certidumbre, que el candidato o licitador no se encuentra incurso en una prohibición de contratar, resulta necesario un intercambio de información en esta materia entre todos los Estados miembros y - a mayores - entre todos los poderes y entidades adjudicadoras ubicadas en la Unión (considerando centésimo vigésimo octavo de la Directiva 2014/24/UE).

Para lograr este conocimiento transfronterizo, además de la base de datos central de exclusión a la que nos hemos referido, se ha avanzado en una serie

\footnotetext{
${ }^{826}$ Sentencia del Tribunal General de 22 de abril de 2015, Planet/Comisión, T320/09 que tenía por objeto la anulación de las decisiones de la OLAF por las cuales se solicitó la inclusión de Planet en el sistema de alerta rápida mediante la activación de la alerta W1a, y, posteriormente, de la alerta W1b, que se activan cuando sus investigaciones en una fase temprana le induzcan a pensar que probablemente existan fraudes.

${ }^{827}$ Hemos tratado de ello en diferentes ocasiones entre las que vamos a destacar MEDINA ARNÁIZ, T., "Las respuestas normativas al fenómeno de la corrupción (...)", op. cit., y en "Instrumentos jurídicos frente a la corrupción en la contratación pública (...)", op. cit., págs. $299-344$.
} 
de instrumentos que refuerzan la cooperación administrativa en el intercambio de información y que apuestan por la reducción de trámites y de documentos a aportar por los interesados para probar su capacidad para contratar ${ }^{828}$.

Estos instrumentos se basan, principalmente, en las nuevas tecnologías a través de herramientas informáticas que facilitan este proceso, como por ejemplo, la posible ampliación del Sistema de Información del Mercado Interior (IMI) para gestionar el intercambio de información entre Estados miembros en lo relativo a las compras públicas; la base de datos e-Certis que reúne modelos de certificados nacionales utilizados para la contratación pública transfronteriza o la posibilidad de que el poder adjudicador acceda directamente a una base de datos nacional de cualquier Estado miembro que pueda consultarse de forma gratuita, como registro nacional de contratación pública, un expediente virtual de la empresa, un sistema de almacenamiento electrónico de documentos o un sistema de precalificación (artículo 59.5 de la Directiva 2014/24/UE).

\section{VI.1. El Sistema de Información del Mercado Interior (IMI)}

Relacionado directamente con la Directiva de Servicios - la Directiva 2006/123/CE, de 12 de diciembre de 2006, relativa a los servicios en el mercado interior - las Directivas sobre contratación pública se cuestionan la posibilidad de que el Sistema de Información del Mercado Interior (IMI) pueda servir de utilidad para el intercambio de información requerida desde la regulación contractual (artículo 86.3 de la Directiva 2014/24/UE) ${ }^{829}$.

\footnotetext{
${ }^{828} \mathrm{La}$ lucha contra las organizaciones delictivas que operan en varios países de la Unión requiere también el intercambio de información y la cooperación entre las autoridades judiciales y, por ello, 26 Estados miembros utilizan el anteriormente citado Sistema Europeo de Información de Antecedentes Penales (ECRIS) que permite el intercambio de información sobre antecedentes penales de los ciudadanos de la UE.

${ }^{829} \mathrm{El}$ vínculo entre ambas normativas ha sido destacado por GIMENO FELIÚ, J. $\mathrm{M}^{\mathrm{a}}$., "Directiva de servicios y contratación pública. Hacia la simplificación", RArAP, núm. monográfico XII, 2010, págs. 409 - 443; SANMARTÍN MORA, A., "Contratación pública y Directiva Servicios. Hacia la simplificación administrativa", ponencia presentada al Seminario sobre Contratación Pública celebrado en Formigal en septiembre de 2010 y MEDINA ARNÁIZ, T., "Impacto sobre la Administración autonómica en cuanto a la simplificación de los trámites a los prestadores de servi-
} 
El Sistema IMI es una aplicación electrónica en línea, segura, multilingüe y reutilizable, desarrollada por la Comisión que tiene por objeto facilitar la cooperación administrativa y la asistencia mutua entre los Estados miembros, con el fin de garantizar el buen funcionamiento del mercado único ${ }^{830}$. Para ello, proporciona una herramienta de intercambio de información que incluye determinados datos personales entre las Administraciones nacionales y los Estados del Espacio Económico Europeo (EEE), es decir, los Estados miembros de la UE más Noruega, Islandia y Liechtenstein. Una de sus grandes ventajas es que consigue eliminar los principales obstáculos a la cooperación, por ejemplo, la incertidumbre respecto de a quién dirigirse, las barreras lingüísticas, las diferencias de cultura administrativa y de prácticas de trabajo, y la falta de procedimientos de cooperación establecidos, puesto que el sistema ayuda a sus usuarios a encontrar la autoridad adecuada con la que deben ponerse en contacto en otro país; a comunicarse con ella mediante un conjunto de preguntas y respuestas estándar pre-traducidas y a comprobar el estado de su solicitud de información gracias a un mecanismo de seguimiento ${ }^{831}$.

\section{VI.2. El depósito de certificados en línea (e-Certis)}

Se trata de un sistema electrónico de documentos en el que se recogen los certificados y declaraciones que con más frecuencia se exigen a los operadores para participar en un procedimiento de adjudicación estableciéndose los criterios de equivalencia entre los Estados miembros para favorecer una

cio", en el libro colectivo Colección de Estudios del Consejo Económico y Social de Castilla y León, núm. 13, dedicado al Impacto de la transposición de la Directiva de Servicios en Castilla y León, 2010, págs. 425 - 453.

${ }^{830}$ Reglamento UE 1024/2012, del Parlamento Europeo y del Consejo, de 25 de octubre de 2012, relativo a la cooperación administrativa a través del Sistema de Información del Mercado Interior y por el que se deroga la Decisión 2008/49/CE de la Comisión ("Reglamento IMI") (DOUE L 316, de 14 de noviembre de 2012).

${ }^{831}$ Acerca de la estructura del IMI en España puede consultarse la página web del Ministerio de Hacienda y Administraciones Públicas http://www.seap.minhap.gob.es/web/areas/sistema_IMI.html [Fecha de consulta: 24 de octubre de 2015]. Sobre esta materia GONZÁLEZ BUSTOS, Ma . Á., "La efectividad del sistema de información del mercado interior en la cooperación entre los Estados miembros", Revista General de Derecho Europeo, núm. 24, 2011. 
contratación transfronteriza (artículo 61 de la Directiva 2014/24/UE) ${ }^{832}$.

Con este instrumento se pretende, por una parte, aportar claridad y seguridad jurídica al operador económico en lo que se refiere a los certificados y declaraciones y otros medios de prueba que puedan exigir los Estados miembros para acreditar su aptitud para ser contratista (certificados para participar en licitaciones públicas) y, por otra, a los operadores en tanto que proporciona información sobre listas de operadores acreditados y sistemas de clasificación). Para que el sistema funcione y pueda servir a los fines encomendados es necesario que la información esté actualizada y los documentos accesibles, por esa razón, la Directiva 2014/24/UE señala que "los Estados miembros velarán por que la información sobre certificados y otros tipos de pruebas documentales introducida en e-Certis establecida por la Comisión se mantenga constantemente actualizada" y que "cada Estado miembro publicará en el depósito de certificados en línea e-Certis la lista completa y actualizada de las bases de datos que contengan información de interés sobre los operadores económicos y que puedan ser consultadas por los poderes adjudicadores de los demás Estados miembros" (artículo 59.6 de la Directiva 2014/24/UE).

\section{VI.3. La base de datos central de exclusión y los siste- mas de alerta}

Con el fin de luchar contra el fraude y proteger los intereses financieros de la Unión, el derogado Reglamento financiero 1605/2002, de 25 de junio de 2002, aplicable al presupuesto general de las Comunidades Europeas, preveía la creación y gestión, por parte de la Comisión, de una base central de exclusión con el objetivo de aplicar eficazmente las prohibiciones de contratar mediante un sistema de alertas que ofrecía información detallada de aquellos candidatos y licitadores que estaban incursos en alguna de las prohibiciones de contratar

\footnotetext{
${ }^{832}$ Puede consultarse en:
}

http://ec.europa.eu/markt/ecertis/login.do?selectedLanguage=es [Fecha de consulta: 24 de octubre de 2015]. Incluye información de los 28 Estados miembros, de Turquía (como Estado candidato a ingresar en la UE) y de los tres Estados de EEE (Islandia, Liechtenstein y Noruega). 
establecidas en el propio Reglamento ${ }^{833}$.

Esta base de datos central de exclusión no era de libre acceso, puesto que se limitaba - bajo ciertas condiciones - a las instituciones de la Unión, a las autoridades u organismos de ejecución que gestionaban fondos públicos mediante gestión compartida y a los organismos públicos nacionales de los Estados miembros que gestionaran fondos mediante gestión centralizada indirecta. Se accedía a los datos de terceros (candidatos, licitadores, contratistas, proveedores, prestadores de servicios y sus respectivos subcontratistas) y la información - mediante un sistema de alarmas - servía para constatar que la persona con la que se pretendía contratar representaba un riesgo para los intereses financieros de la Unión. Los diferentes tipos de alarmas permitían identificar el nivel de riesgo asociado a un operador económico en función de categorías que iban desde el W1, que corresponde al nivel de riesgo más bajo, al W5, correspondiente al nivel de riesgo más elevado, bien porque de las investigaciones en cursos se inducía a pensar que probablemente existiera un fraude (activación de la alerta W1a), bien porque efectivamente el operador económico estaba incurso en un supuesto de prohibición de contratar (alerta W5) ${ }^{834}$.

Ahora bien, los problemas jurídicos que plantea esta base de datos son

${ }^{833}$ Reglamento (CE, Euratom) 1302/2008 de la Comisión, de 17 de diciembre de 2008, relativo a la base de datos central de exclusión (DOUE L 344, de 20 de diciembre).

${ }^{834}$ Los artículos 10 a 14 de la Decisión 2008/969/CE, Euratom, de 16 de diciembre de 2008, relativa al sistema de alerta rápida para uso de los ordenadores de la Comisión y de las agencias ejecutivas, definen las alertas. De este modo, la alerta W1b significa que las investigaciones en curso de la OLAF o del sistema de auditoría interna les inducen a pensar que probablemente habría que registrar las constataciones finales de errores administrativos graves o de fraudes. La alerta W2 implica que se han constatado errores administrativos graves o fraude. La alerta W3 significa que se ha notificado una orden de embargo al contable, en determinadas circunstancias, o que un procedimiento judicial por errores administrativos graves o fraude está en curso. La alerta W4 implica que la Comisión ha emitido órdenes de cobro por importe superior a una determinada cantidad y cuyo pago tenga un retraso importante. Por último, las alertas W5 se registran en relación con las personas que se encuentran en una situación de exclusión, bien debido a las alertas de exclusión a las que se refiere el artículo 10, apartados 1 a 3, del Reglamento 1302/2008 (alerta W5a), bien porque estas personas son objeto de restricciones financieras vinculadas a la Política Exterior y de Seguridad Común (PESC) (alerta W5b) (DOUE L344, de 20 de diciembre de 2008). 
parecidos a los que ya hemos hecho referencia al tratar sobre las «listas negras». Así, la Decisión 2008/969/CE, relativa al sistema de alerta rápida, no establece ningún derecho para las personas jurídicas y físicas a ser informadas, y mucho menos oídas, antes de su inscripción en el Sistema de alerta rápida (SAR) mediante cualquier tipo de alerta. Ciertamente, un operador económico que, por una razón u otra, es informado de su inscripción en dicho sistema puede, con arreglo al artículo 8, apartado 2, letra b), de la Decisión 2008/969/CE, solicitar la rectificación de los datos que le afectan, pero la decisión de proceder a tal rectificación es discrecional y no sometida a control.

En el momento actual, el Reglamento financiero en vigor (Reglamento UE, Euratom 966/2012, de 25 de octubre de 2012 también prescribe que la información contenida en el sistema de alertas de exclusión se centralizará en una base de datos creada por la Comisión y gestionada desde el respeto a la protección de datos de carácter personal (artículo 108). En este sentido, aunque la Decisión 2008/969/CE no se aplica desde el 1 de julio de 2015, el objetivo del nuevo sistema de alerta es esencialmente el mismo, esto es, la circulación de información restringida por medio de un registro de las alertas referente a las personas que puedan representar un riesgo para los intereses financieros.

De esta manera, y conforme al artículo 9 de la Decisión de la Comisión, de 13 de noviembre de 2014, relativa al sistema de alerta rápida para uso de los ordenadores de la Comisión y de las agencias ejecutivas, las alertas se clasifican en dos tipos:

a) «alertas de verificación», cuando se sospeche o se haya constatado que una persona ha cometido un fraude, un acto de corrupción o cualquier otra actividad ilegal que afecte a los intereses financieros de la Unión, errores o irregularidades sustanciales, falta profesional o incumplimiento grave del contrato; y

b) «alertas de exclusión», cuando una persona sea excluida con arreglo a los motivos previstos en el artículos 106, apartado 1 y en el artículo 109, apartado 1, del Reglamento (UE, Euratom) 966/2012.

No obstante, y a pesar de constituir una importante herramienta para el intercambio de información en esta materia, la Comisión admite que el uso de 
esta base central de exclusión es todavía muy limitado en los Estados miembros, puesto que solamente cinco Estados miembros admiten estar utilizándola (Bélgica, República Checa, Malta, Austria y Polonia) y que algunos Estados miembros - como Dinamarca, Irlanda, Hungría, Eslovenia, Suecia y España utilizan sus propias bases de datos ${ }^{835}$.

\section{La simplificación en los medios de prueba de no estar incurso en una prohibición de contratar}

La exigencia de reducir las cargas administrativas que soporta el operador económico en la tramitación de un procedimiento de adjudicación nos llevará seguidamente a tratar el tema de la simplificación documental sobre la inexistencia de motivos de prohibición de contratar y, con un mayor detalle, sobre el Documento europeo único de contratación.

El objetivo de reducir las cargas administrativas y burocráticas ha sido una constante desde que se aprobaran las primeras iniciativas europeas para la simplificación administrativa con el fin de garantizar a las empresas europeas mayores posibilidades de competir en un entorno mundial altamente competitivo $^{836}$. Aunque se han dado pasos en la mejora del marco normativo a fin

\footnotetext{
${ }^{835}$ En relación con el uso de la base central de exclusión resulta también de interés los datos que aporta uno de los documentos de trabajo de la Comisión que acompaña al Informe del año 2011, sobre protección de los intereses financieros de la UE y la lucha contra el fraude, COM (408) final y SWD (2012) 228 final, de 19 de julio de 2012, págs. 4 y 5. Otros Estados miembros, como es el caso de Italia, está trabajando en un proyecto propio - el Proyecto CAPACI - del acrónimo de Creation of automated procedures against criminal infiltration in public contracts (Creación de procedimientos automatizados contra la infiltración delictiva en la contratación pública).

${ }^{836}$ Sobre las primeras iniciativas europeas para la simplificación administrativa, resultan de interés VILLAREJO GALENDE, H., "Simplificación administrativa al servicio del Mercado Interior Europeo", en la obra colectiva Libro Marrón: Retos y oportunidades para la transposición de la Directiva de Servicios, Círculo de Empresarios, Madrid, 2009, págs. 433 - 495 y CANALS AMETLLER, D., "Simplificación administrativa y Directiva de Servicios: Objetivos, medios e incidencias", RArAP, Monográfico XII dedicado a El impacto de la Directiva Bolkestein y la reforma de
} 
de simplificar el acervo comunitario y reducir su volumen, las principales medidas para legislar mejor en el ámbito europeo se recogen en dos documentos: el Plan de Acción Simplificar y mejorar el marco regulador de $2002^{837}$, y el Acuerdo Interinstitucional Legislar mejor, adoptado por el Parlamento Europeo, el Consejo y la Comisión en diciembre de 2003, que nos lleva a hablar del Programa Better Regulation ${ }^{838}$.

En este contexto de mejora regulatoria, la Comisión puso en marcha en enero de 2007 el Programa de Acción para la reducción de las cargas administrativas en la Unión Europea con el objetivo global de reducir un $25 \%$ de las cargas administrativas innecesarias que recaen sobre las empresas, a más tardar en el año 2012. Este Programa focalizaba su atención en trece áreas prioritarias, una de las cuales era la contratación pública para tratar de favorecer el acceso de las pymes a la compra pública y evitar, de esta manera, que pudieran verse disuadidas por la burocracia y por cargas administrativas desproporcionadas.

En este mismo sentido, se anuncian una serie de nuevas iniciativas - como parte del programa de trabajo de la Comisión para el año 2016 - a fin de proponer un formulario estándar de datos para resolver las dificultades con que tropiezan las pymes ante la necesidad de cumplimentar documentación "de contratación pública larga y compleja" 839 .

los servicios en el Derecho administrativo, 2010, págs. 297 - 335.

${ }^{837}$ El Plan de acción Simplificar y mejorar el marco regulador, COM (2002) 278 final, de 5 de junio de 2002 fue actualizado y completado con la Comunicación Legislar mejor para potenciar el crecimiento y el empleo en la Unión Europea, COM (2005) 97, de 16 de marzo de 2005, que considera que la simplificación debe ser una acción prioritaria para la UE.

${ }^{838}$ Sobre el Plan «Legislar mejor» - Better regulation - puede consultarse la Comunicación de la Comisión Análisis estratégico del programa «Legislar mejor» en la Unión Europea, COM (2006) 689 final, de 14 de noviembre de 2006.

${ }^{839}$ Comunicación de la Comisión Legislar mejor para obtener mejores resultados Un programa de la UE, COM (2015), 215 final, de 19 de mayo de 2015, pág. 11. 


\section{VII.1. Las previsiones sobre simplificación administra- tiva y la apuesta por reducir la carga burocrática en las nuevas Directivas}

En el apartado anterior, hemos podido comprobar cómo la UE dispone de programas específicos para establecer medidas encaminadas a reducir la burocracia para las empresas. En este momento, analizaremos en qué medida este objetivo resulta de aplicación también a la tramitación contractual, máxime cuando "muchos operadores económicos, y en concreto las PYME, consideran que un obstáculo importante para su participación en la contratación pública son las cargas administrativas que conlleva la obligación de presentar un número sustancial de certificados u otros documentos relacionados con los criterios de exclusión y de selección" (considerando octogésimo cuarto de la Directiva 2014/24/UE).

El nuevo marco jurídico incluye elementos de simplificación en tres aspectos: El primero de ellos lo hemos abordado con anterioridad y trata de vencer los obstáculos generados por la burocracia probatoria entre distintos Estados miembros creando mecanismos para el intercambio de información que refuerce la cooperación administrativa en esta materia. Esta cooperación comporta la posibilidad de consultar por parte de los poderes adjudicadores de cada Estado miembro el contenido de la documentación referente a un operador económico accediendo directamente a las bases de datos pertinentes (depósito de certificados en línea (e-Certis), expedientes virtuales de la empresa o un sistema de precalificación).

El segundo de los aspectos de simplificación se refiere a la no exigencia por parte de los poderes adjudicadores de información que sigue siendo válida y que ya posean de anteriores procedimientos de contratación. Así pues, los operadores económicos no estarán obligados a presentar documentos justificativos $\mathrm{u}$ otras pruebas documentales cuando el poder adjudicador que haya adjudicado el contrato o celebrado el acuerdo marco ya posea dicha documentación y en caso de que el poder adjudicador tenga la posibilidad de obtener los certificados o la información pertinente accediendo directamente a una base de datos nacional de cualquier Estado miembro de la Unión Europea (artículo 59.5 de la Directiva 2014/24/UE). 
En tercer lugar, la mayor apuesta de la Directiva sobre contratación pública en favor de la simplificación de los requisitos documentales en los procedimientos de contratación es la aceptación del «documento europeo único de contratación» que sirve como prueba preliminar para acreditar el cumplimiento de las condiciones de aptitud para contratar de un operador económico (artículo 59 de la Directiva 2014/24/UE). Dado que este documento está llamado a desempeñar un papel esencial en la simplificación documental, vamos a proceder a su análisis de una manera más detallada.

\section{VII.2. El documento europeo único de contratación}

El documento europeo único de contratación consiste en una declaración responsable del propio operador económico - en sustitución de los certificados expedidos por las autoridades públicas o por terceros - y que sirve como prueba preliminar en el procedimiento de adjudicación para acreditar el cumplimiento de su capacidad para contratar y la ausencia de prohibiciones de contratar. Su objetivo es reducir las cargas administrativas que conlleva la obligación de presentar un número importante de certificados u otros documentos relacionados con los criterios de exclusión y de selección.

\section{A. Su configuración}

Se trata de un documento normalizado, en formato electrónico y reutilizable con plena eficacia frente a todos los poderes adjudicadores de todos los Estados miembros, que pretende una mayor simplificación, en beneficio tanto de los operadores económicos como de los poderes y las entidades adjudicadores, mediante la sustitución de las diversas declaraciones nacionales de los interesados por un formulario normalizado establecido a nivel europeo y que esté disponible en todas las lenguas oficiales de la Unión.

Su regulación la encontramos en el artículo 59 de la Directiva 2014/24/UE y, aunque este artículo no tiene correspondencia en la Directiva 2014/23/UE («concesiones»), ni en la Directiva 2014/25/UE («sectores especiales»), entendemos que esta ausencia no supone ningún obstáculo para que este documento sea utilizado por los operadores económicos que concurran a la adjudicación 
de un contrato de concesión o a un contrato en los sectores especiales, ya que en ambas disposiciones se señala también la necesidad de que los operadores económicos acrediten la ausencia de prohibiciones de contratar en términos similares a lo dispuesto en la Directiva 2014/24/UE. Del mismo modo, cabría pensar en la posibilidad de extender su uso a la adjudicación de los contratos públicos en los ámbitos de la defensa y la seguridad, puesto que la Directiva 2009/81/CE señala en su artículo 39 la obligación de excluir a un operador económico en el que concurran las causas que en dicho precepto se relacionan, y que prácticamente coinciden con las incluidas en el artículo 55.1 de la Directiva $^{840}$.

\section{B. Su contenido}

Su contenido atiende a cuatro bloques de información en tanto que se prevé que la declaración formal del operador económico indique: (i) que no le son de aplicación las causas de prohibición de contratar; (ii) que se cumplen los criterios de selección pertinentes; (iii) que, cuando se requiera por parte del poder adjudicador, se facilitará la documentación acreditativa y (iv) que la información facilitada es exacta y veraz siendo conocedor de las consecuencias que conlleva una falsa declaración.

Ahora bien, a nuestro entender, debiera haberse previsto también que en el documento europeo único de contratación el operador económico pudiera hacer constar las medidas que ha adoptado - y que viene adoptando - para evitar infracciones del ordenamiento jurídico o para comprometerse a su cumplimiento (por ejemplo, programas de cumplimiento (compliance), códigos internos de comportamiento ético o la adopción de pactos de integridad) que pudieran evidenciar una mayor fiabilidad en ese operador económico ${ }^{841}$.

\footnotetext{
${ }^{840}$ No resultan completamente coincidentes puesto que la Directiva 2009/81/CE no contempla los nuevos supuestos de prohibición de contratar obligatorios por condena judicial en relación con el trabajo infantil y otras formas de trata de seres humanos o por incumplimiento de las obligaciones de pago de impuestos o cotizaciones a la seguridad social.

${ }^{841}$ En el borrador de Reglamento de ejecución de la Comisión sobre el documento europeo de contratación tampoco se hace referencia a la posibilidad de incorporar este tipo de información.
} 
En atención a estos bloques de información, el documento europeo único de contratación contendría las siguientes secciones:

Parte I. Información sobre el poder adjudicador y el procedimiento de contratación.

Parte II. Información sobre el operador económico

Parte III. Criterios de exclusión - prohibiciones de contratar:

A: Motivos referidos a condenas penales (su aplicación es obligatoria en virtud del artículo 57.1 de la Directiva 2014/24/UE).

B: Motivos referidos al pago de impuestos o pago de cotizaciones a la seguridad social (su aplicación hemos señalado que también es obligatoria en virtud del artículo 57.2 de la Directiva 2014/24/UE en caso de resolución firme y vinculante. Cabe señalar que la legislación nacional de algunos Estados miembros puede establecer la obligatoriedad de la exclusión también cuando la resolución no sea firme y vinculante).

C: Diversos motivos de exclusión previstos en el artículo 57.4 de la Directiva 2014/24/UE (se trata de las prohibiciones de contratar facultativas para los Estados miembros, si bien ya hemos señalado que los Estados miembros pueden imponer a sus poderes adjudicadores la obligación de aplicar estos motivos de exclusión).

D: Otros motivos de exclusión, no previstos en la Directiva 2014/24/UE y que sean compatibles con el Derecho de la Unión y con la jurisprudencia del TJUE.

Parte IV. Criterios de selección: Distinguiendo entre a) Idoneidad; b) Solvencia económica y financiera; c) Capacidad técnica y profesional y d) Sistemas de aseguramiento de la calidad y normas de gestión medioambiental

Parte V. Reducción del número de candidatos cualificados.

Parte VI. Declaraciones finales. En las que el operador económico declara que la información que ha facilitado en exacta y veraz; que consiente que el poder adjudicador acceda a los documentos justificativos de dicha 
información y que puede aportar dichos documentos cuando lo requiera el poder adjudicador

Parte VII. Reutilización del DEUC. Declaración de exactitud permanente Fecha, lugar y firma(s): $[\ldots \ldots]$

En nuestra opinión, una de las principales virtudes de este instrumento es su eficacia frente a cualquier poder adjudicador de cualquier Estado miembro. Ello implica un reconocimiento mutuo de los sistemas de certificación, así como una confianza en los procedimientos que se establezcan para certificar los contenidos del documento. Otra ventaja es la prohibición de solicitar la presentación de originales, copias compulsadas o traducciones juradas de la documentación proveniente de otros Estados y aceptar, por ello, los documentos emitidos por la autoridad competente de otro Estado miembro. No hacerlo supondría una carga administrativa adicional para los operadores económicos originarios de otros Estados miembros que les colocaría en una situación de desventaja competitiva contraria al ejercicio efectivo de las citadas libertades fundamentales y que no haría posible la apertura de los contratos públicos a la mayor participación de operadores económicos en todo el mercado interior.

\section{Los supuestos de inaplicación de una prohi- bición de contratar}

Desde el inicio de esta memoria doctoral venimos manteniendo que la nueva regulación europea sobre contratación pública pretende establecer un marco coherente y ajustado a la previsión de conjugar la normativa contractual con otras políticas de la UE, de tal manera que las compras públicas puedan contribuir al cumplimiento de otros objetivos de interés general, entre los que se encuentran la lucha contra la corrupción y distintas formas de delincuencia económica.

En este contexto, hemos señalado que uno de los mecanismos utilizados por el legislador ha sido el establecimiento de una serie de prohibiciones de contratar que excluyan del procedimiento de adjudicación a aquellas personas o entidades que han dado pruebas de carecer de los requisitos de idoneidad 
y fiabilidad que se exigen al futuro contratista por encontrarse incursos en determinadas situaciones. Ahora bien, al tiempo que fijaba el establecimiento de prohibiciones de contratar de carácter obligatorio - y como cierre del sistema -, el legislador europeo, desde el año 2004, ha venido modulando sus efectos a través de la posibilidad de excepcionar su aplicación por razones de interés general ${ }^{842}$.

Es así que, el Derecho de la Unión autoriza a los Estados miembros a establecer excepciones a dichas exclusiones en determinadas circunstancias para compatibilizar los objetivos de las prohibiciones de contratar con la garantía del principio de concurrencia que preside la tramitación contractual. De esta manera, las nuevas Directivas incorporan a sus articulados una mayor flexibilización respecto a las reglas de selección del contratista al tomar en consideración situaciones específicas de los operadores económicos y cumplen formalmente con la exigencia de seguridad jurídica al recoger en sus textos ejemplos claros y precisos de los motivos de excepción en la aplicación de las prohibiciones de contratar.

La vigente regulación ha establecido cinco grupos de excepciones supeditados al cumplimiento de ciertas condiciones y que distingue los supuestos según se trate de derogar prohibiciones de contratar obligatorias o facultativas para los Estados miembros ${ }^{843}$. Estas excepciones son las siguientes: (1) las derivadas de la existencia de razones imperiosas de interés general; (2) las que atienden a motivos económicos; (3) las que se basan en un juicio de proporcionalidad; (4) aquellas vinculadas a la regularización tributaria y (5) aquellas relacionadas con el comportamiento del candidato o licitador a través de la puesta en

\footnotetext{
${ }^{842}$ En este sentido, podemos apuntar que en las primeras Directivas sobre contratación pública (concretamente, las de «primera y segunda generación») no se establecía la posibilidad de excepcionar la aplicación de las prohibiciones de contratar, ya que éstas se preveían con un carácter voluntario para los Estados miembros. La incorporación de las prohibiciones de contratar obligatorias en el año 2004 supone, por tanto, el inicio de la posibilidad de excepcionar su aplicación.

${ }^{843}$ Las referencias normativas van a hacerse, principalmente, al artículo 57 de la Directiva 2014/24/UE («sectores clásicos»), si bien, y como ya hemos manifestado en distintas ocasiones, también tienen reflejo en el artículo 38 de la Directiva 2014/23/UE, de 26 de febrero de 2014, relativa a la adjudicación de contratos de concesión («concesiones») y en los considerandos centésimo quinto y séptimo de la Directiva 2014/25/UE («sectores especiales»).
} 
práctica de medidas autocorrectoras.

Estos supuestos de inaplicación van a ser objeto de estudio en los epígrafes siguientes. Dado que, en último extremo, todas ellas suponen una flexibilización respecto de la obligatoriedad de excluir de las compras públicas a los operadores económicos "deshonestos", nos centraremos en analizar si éstas responden - o no - a las exigencias de resultar excepcionales y objetivamente justificadas ${ }^{844}$.

En nuestra opinión, estas derogaciones deben interpretarse restrictivamente $y$, sobre todo, ser aplicadas en términos de proporcionalidad, puesto que entendemos que el hecho de hacer valer excepciones generales contravendría los objetivos que se pretenden alcanzar con las prohibiciones de contratar, al despojarlas de todo efecto disuasorio y, lo que valoramos más grave, pudiendo producir efectos adversos para los candidatos y licitadores cumplidores en el sentido de entender que el cumplimiento constituye para ellos una desventaja en el mercado público. Dicho esto, también hemos de adelantar que su incorporación al texto de las Directivas introduce un elemento modulador que creemos positivo al permitir no aplicar las prohibiciones de contratar cuando confluyan otros intereses y/o teniendo en consideración situaciones particulares de los operadores económicos.

\section{VIII.1. La excepción derivada de la existencia de razo- nes imperiosas de interés general}

De la lectura de los apartados primero y segundo, párrafo primero, del artículo 57 de la Directiva 2014/24/UE se infiere la obligatoriedad para los poderes adjudicadores de excluir de la participación en un procedimiento de adjudicación a los operadores económicos que se encuentren en alguno de los supuestos contemplados en ellos, es decir, que hayan sido condenados por sentencia firme por determinados delitos o que hayan incumplido con el pago de

\footnotetext{
${ }^{844}$ De la jurisprudencia del Tribunal de Justicia se desprende que las exenciones, derogaciones o excepciones a una norma de alcance general prevista en la normativa de la Unión deben interpretarse de forma restrictiva. En ese sentido se manifiestan las sentencias de 23 de marzo de 2006, Honyvem Informazioni Commerciali, C-465/04, apartado 24; de 5 de octubre de 2004, Pfeiffer y otros, C-397/01 a C-403/01, apartado 52 y el Abogado General Sr. P. MENGOZZI en sus conclusiones, presentadas el 17 de marzo de 2015, en el asunto Surmačs, C-127/14, apartado 32.
} 
impuestos o cotizaciones a la seguridad social.

Esta obligación general y, en principio, incondicional de exclusión queda sin efecto cuando de la ponderación de intereses en juego se aprecia la existencia de un interés superior en atención a las necesidades a cubrir por el contrato que aconseja derogar la prohibición de contratar.

En este sentido, el artículo 57.3 de la citada Directiva señala que:

"Los Estados miembros podrán establecer una excepción a la exclusión obligatoria prevista en los apartados 1 y 2, con carácter excepcional, por razones imperiosas de interés general como la salud pública o la protección del medio ambiente".

La Directiva 2004/18/CE ya contemplaba expresamente la posibilidad de derogar una prohibición de contratar de carácter obligatorio ante la existencia de una causa de interés público que lo justificara, de tal manera que los Estados miembros pudieran "establecer una excepción respecto a la obligación contemplada en el párrafo primero por necesidades imperativas de interés general" (artículo 45.1) ${ }^{845}$.

Ambas disposiciones están redactadas en términos similares ${ }^{846}$, si bien la Directiva 2004/18/CE no recogía un catálogo de supuestos incluidos en la excepción, ni establecía pautas interpretativas de qué se entendía por "necesidades imperativas de interés general". Ante esta imprecisión, los Estados miembros gozaban de un amplio margen de maniobra para la apreciación de las causas de excepción, si bien, esto no significaba - ni significa ahora - que dispusieran de total libertad para sortear las prohibiciones de carácter obligatorio.

Los supuestos que amparaban una eventual excepción se debían limitar a aquéllos que estuvieran justificados por motivos de interés general, es decir, que no persiguen exclusivamente fines individuales, sino intereses de toda la

\footnotetext{
${ }^{845}$ Con una redacción idéntica, el artículo 39.1, tercer apartado de la Directiva 2009/81/CE del Parlamento Europeo y del Consejo, de 13 de julio de 2009 («sectores defensa y seguridad»).

${ }^{846} \mathrm{La}$ referencia al carácter «imperioso» de ese interés parece endurecer, sin embargo, el rigor a la hora de introducir excepciones en la aplicación de las prohibiciones.
} 
colectividad $^{847}$. Sobre la base de dicha interpretación restrictiva, algunos autores venían manifestado que las razones justificativas que se podían invocar estaban vinculadas a la protección de la salud, a la seguridad nacional, a la defensa y a la provisión de ciertos bienes imprescindibles que no podían ser suministrados por ningún otro operador económico ${ }^{848}$.

Con argumentos límite, el Comité de las Regiones en su Dictamen sobre las Propuestas de Directivas del año 2000 se preguntaba qué sucedería cuando se trate de adquirir una mercancía que solamente pudiera facilitar un proveedor condenado por corrupción, o cuando resulte enormemente costoso cambiar de proveedor para evitar estar circunstancia. Es más, planteaba los problemas que suponía llevar los efectos de las prohibiciones de contratar hasta el último extremo en el supuesto de la adjudicación de un medicamento único y vital que no puede ser suministrado por ningún otro proveedor ${ }^{849}$. Un ejemplo similar fue expuesto por la Comisión también en la tramitación de la Directiva 2004/18/CE al referirse a enfermedades muy graves para cuya cura los únicos medicamentos disponibles provendrían de un operador económico que se en-

${ }^{847}$ En este momento, y sin entrar en mayores consideraciones, nos referimos únicamente a una definición coloquial de interés general entendido en beneficio de la comunidad, es decir, un interés fundamental para la sociedad sin estimar situaciones particulares.

${ }^{848}$ Véase, KRAMER, R., "Awarding Contracts to Suspended and Debarred Firms: Are Stricter Rules Necessary?", Public Contract Law Journal, vol. 34 (3), 2005, pág. 541; WILLIAMS, S., "The Mandatory Exclusions for Corruption (...)", op. cit., pág. 727; MEDINA ARNÁIZ, T., "Grounds for Exclusion (...)", op. cit., pág. 344; ARROWSMITH, S., PRIESS, H.J. y FRITON, P., "Self-Cleaning as a Defence to Exclusions for Misconduct - an Emerging Concept in EC Public Procurement Law?", Public Procurement Law Review, vol. 18 (6), 2009, pág. 263.

En el Reino Unido, la guía interpretativa elaborada por la Office of Government Commerce planteaba que las excepciones sólo podían aplicarse ante circunstancias excepcionales como, por ejemplo, en caso de emergencia nacional, OGC Guidance on the Mandatory Exclusion of Economic Operators, Londres, 2010, pág. 8.

${ }^{849}$ Dictamen del Comité de las Regiones, de 13 de diciembre de 2000, sobre las Propuestas de Directivas del Parlamento Europeo y del Consejo, sobre coordinación de los procedimientos de adjudicación de los contratos públicos de suministro, de servicios y de obras; y sobre coordinación de los procedimientos de adjudicación de contratos en los sectores del agua, de la energía y de los transportes (DOCE C 144, de 16 de mayo de 2001, pág. 26). 
contrara entre los casos de exclusión previstos en la normativa contractual ${ }^{850}$.

Alguno de estos supuestos de excepción han quedado refrendados por lo dispuesto en las nuevas Directivas. En este sentido, resultan reveladores el considerando centésimo de la Directiva 2014/24/UE y el considerando centésimo quinto de la Directiva 2014/25/UE («sectores especiales») que, si bien no tienen efectos jurídicos vinculantes, aclaran las intenciones del legislador por cuanto:

“(...) los Estados miembros deben poder establecer excepciones a dichas exclusiones obligatorias en circunstancias excepcionales, cuando necesidades imperativas de interés general hagan indispensable la adjudicación de un contrato. Ello podría ocurrir, por ejemplo, cuando vacunas o equipos de emergencia que se requieran urgentemente solo puedan adquirirse a un operador económico al que se aplique alguna de las razones obligatorias de exclusión".

A la luz del conjunto de las consideraciones precedentes, los Estados miembros disponen de una amplia potestad discrecional para definir lo que consideran circunstancias excepcionales que justifican no aplicar una prohibición de contratar de carácter obligatorio ${ }^{851}$. Ahora bien, pese a este margen de apreciación, las nuevas Directivas exigen, de una parte, que dichas excepciones estén justificadas por «razones imperiosas de interés general»y, por otra, que se refieran a circunstancias excepcionales a fin de no privar de eficacia a las prohibiciones de contratar.

La expresión «razones imperiosas de interés general», ya ha sido interpretada por el Tribunal de Justicia en distintas sentencias con ocasión del examen

${ }^{850}$ Comunicación de la Comisión al Parlamento Europeo con arreglo al párrafo segundo del apartado 2 del artículo 251 del Tratado CE acerca de la Posición Común adoptada por el Consejo con vistas a la adopción de una Directiva del Parlamento Europeo y del Consejo sobre coordinación de los procedimientos de adjudicación de los contratos públicos de obras, de suministros y de servicios, (SEC 2003/366 final, de 25 de marzo de 2003).

${ }^{851}$ Recordemos que la naturaleza obligatoria es doble. Por una parte, para los Estados miembros que deben recoger estas causas de prohibición de contratar en sus normativas nacionales y, por otra, para los órganos de contratación que deben aplicarlas. 
de los artículos 49 y 56 TFUE - antiguos artículos 43 y 49 del Tratado CE avalando restricciones a la libertad de establecimiento y la libre prestación de servicios $^{852}$.

Esta misma jurisprudencia también puede ser de utilidad para la materia que nos ocupa por dos razones: la primera es que se acepta que el concepto «razones imperiosas de interés general» comprende, al menos, algunos de los siguientes ámbitos: orden público, la seguridad pública, la salud pública, la protección del medio ambiente y la propiedad intelectual e industrial ${ }^{853}$; y, la segunda es porque - en sentido negativo - nos indica que los motivos económicos no pueden invocarse como razones imperiosas de interés general que puedan justificar la no aplicación de una prohibición de contratar ${ }^{854}$.

${ }^{852}$ Según reiterada jurisprudencia, las restricciones a estas libertades que sean aplicables sin discriminación por razón de nacionalidad pueden estar justificadas por razones imperiosas de interés general, siempre que sean adecuadas para garantizar la realización del objetivo que persiguen y no vayan más allá de lo que es necesario para alcanzar dicho objetivo. Véase a título de ejemplo, y entre muchas otras, las sentencias de 11 de marzo de 2010, Attanasio Group, C-384/08, apartado 50; de 10 de marzo de 2009, Hartlauer, C-169/07, apartado 44; de 19 de mayo de 2009, Apothekerkammer des Saarlandes y otros, C-171/07 y C-172/07, apartado 25; y de 1 de junio de 2010, Blanco Pérez y Chao Gómez, C-570/07 y C-571/07, apartado 94.

${ }^{853}$ Nos estamos refiriendo únicamente a alguno de los ámbitos que nos pueden interesar por razón de la materia tratada; sin embargo, en el considerando cuadragésimo de la Directiva 2006/123/CE del Parlamento Europeo y del Consejo, de 12 de diciembre de 2006, sobre los servicios en el mercado interior, podemos encontrar todas las referencias reconocidas por la jurisprudencia del TJUE como «razones imperiosas de interés general». Además de las que hemos indicado, aluden también a: la protección civil, la preservación del equilibrio financiero del régimen de seguridad social, la protección de los consumidores, de los destinatarios de servicios y de los trabajadores, las exigencias de la buena fe en las transacciones comerciales, la lucha contra el fraude, la protección del entorno urbano, la sanidad animal, la conservación del patrimonio histórico y artístico nacional y los objetivos de la política social y cultural.

${ }^{854}$ De una reiterada jurisprudencia del TJUE "se desprende que los motivos de carácter meramente económico no pueden constituir razones imperiosas de interés general capaces de justificar una restricción a una libertad fundamental garantizada por el Tratado", apartado 48 de la sentencia del Tribunal de Justicia de 27 de marzo de 2014, Ulrike Elfriede, C-322/13. En el mismo sentido, la sentencia de 17 de marzo de 2005, Kranemann, C-109/04, apartado 34 y la de 15 de abril de 2010, CIBA, C96/08, apartado 48 . 
La protección de la salud pública y del medio ambiente no plantea dudas interpretativas, puesto que ha sido el propio legislador europeo quien les ha atribuido la condición habilitadora para fundamentar la exclusión. Este mismo criterio ha sido acogido por el Reino Unido al transponer a su normativa nacional la Directiva 2014/24/UE. A tenor del artículo 57 (6) de Public Contracts Regulations 2015:

"Exceptions to mandatory exclusion

A contracting authority may disregard any of the prohibitions imposed by paragraphs (1) to (3), on an exceptional basis, for overriding reasons relating to the public interest such as public health or protection of the environment".

"Un poder adjudicador puede ignorar cualquiera de las prohibiciones impuestas por los párrafos 1 a 3, con carácter excepcional, por razones imperiosas de interés general como la salud pública o la protección del medio ambiente" [Traducción propia].

No obstante, y dado que las Directivas no establecen una lista exhaustiva y taxativa de los supuestos comprendidos bajo la consideración de excepciones - más allá de los ejemplos citados - entendemos que un Estado miembro que ejerza la facultad de derogar una prohibición de carácter obligatorio podría vincular la excepción a cualquiera de los ámbitos considerados de interés general por la jurisprudencia europea. Y, diríamos más, con especial énfasis en aquellos relacionados con el orden, la seguridad y la moralidad pública, la vida humana y animal y la conservación de las especies vegetales, ya que, según expone el considerando cuadragésimo primero de la Directiva 2014/24/UE, ninguna disposición en la presente Directiva debe impedir la imposición o ejecución de medidas necesarias para proteger estos ámbitos ${ }^{855}$.

De esta forma, la existencia de razones imperiosas de interés general no se agota en los objetivos generales vinculados a la protección de la salud y del medio ambiente, si bien podemos entender que son los que mejor ejemplifican

${ }^{855}$ En este sentido se manifiesta también el considerando quincuagésimo noveno de la Directiva 2014/23/UE («concesiones»). 
la función de beneficio a la colectividad ${ }^{856}$.

Ahora bien, desde una perspectiva pragmática, el interés último reside en garantizar la prestación objeto del contrato; es decir, en posibilitar su realización aun cuando el único operador económico que puede llevarlo a cabo esté incurso en una prohibición de contratar (como, por ejemplo, provisión de vacunas o equipos de emergencia, de salvamento, de extinción de incendios, recogida y eliminación de residuos tóxicos que se requieran urgentemente $)^{857}$. Este hecho nos lleva a tratar del procedimiento negociado sin previa publicación, pues los mismos supuestos que posibilitan acudir a un procedimiento negociado sin publicidad podrían servir de guía para la regulación de esta materia por parte de los Estados miembros tras adaptar su aplicación a las exigencias del artículo 57.3 de la Directiva 2014/24/UE y del artículo 38.6 de la Directiva 2014/23/UE.

Tal como prevé la normativa contractual, el procedimiento negociado sin publicación previa es un procedimiento excepcional por cuanto al tener un carácter no competitivo, debe utilizarse únicamente en circunstancias muy delimitadas y sólo si concurre alguna de las causas previstas con carácter tasado en las Directivas ${ }^{858}$ (artículo 32 de la Directiva 2014/24/UE y artículo 50 de

${ }^{856} \mathrm{El}$ TJUE ha declarado en distintas ocasiones que la salud y la vida de las personas ocupan el primer puesto entre los bienes e intereses protegidos por la normativa europea. Véase, por ejemplo, las sentencias de 11 de diciembre de 2014, Azienda sanitaria locale, C- 113/13, apartados 56 y 57, de 13 de febrero de 2014, SokollSeebacher, C-367/12, apartado 26 con cita en la sentencia de 1 de junio de 2010, Blanco Pérez y Chao Gómez, C-570/07 y C-571/07, apartado 44.

${ }^{857}$ Hay que hacer notar, sin embargo, que, con arreglo al artículo 10, letra h), de la Directiva 2014/24/UE, esta Directiva no es aplicable a ciertos contratos de servicios y, en particular, a los contratos públicos de servicios de defensa civil y protección civil.

${ }^{858}$ A tenor de la sentencia del TJUE de 11 de septiembre de 2014, Fastweb, C-19/13, apartado 49 "procede recordar que sólo cabe recurrir al procedimiento negociado en las circunstancias descritas con carácter exhaustivo en los artículos 30 y 31 de la Directiva 2004/18, y que este procedimiento tiene, en relación con los procedimientos abierto y restringido, carácter excepcional". En esta materia, resulta obligada la referencia a GALLEGO CÓRCOLES, I., "Los procedimientos de adjudicación en la nueva Directiva sobre contratación pública", en la obra colectiva Observatorio de los contratos públicos 2013, Thomson Reuters-Aranzadi, Cizur Menor (Navarra), 2014, págs. 165 - 232, y especialmente las páginas 217 a 229. 
la Directiva 2014/25/UE«sectores especiales»).

Entre estas circunstancias excepcionales cabe citar "la práctica imposibilidad técnica de que otro operador económico alcance los resultados necesarios, o la necesidad de utilizar conocimientos técnicos, herramientas o medios específicos que únicamente estén a disposición de un único operador económico" (considerando quincuagésimo de la Directiva 2014/24/UE y considerando sexagésimo primero de la Directiva 2014/25/UE).

Por lo que se refiere a los supuestos que se deben tomar en consideración para acudir a un procedimiento negociado sin publicidad nos interesa destacar dos: el primero se fija en que las prestaciones contractuales sólo puedan ser proporcionadas por un operador económico; y el segundo, en caso de adquisiciones de suministros y servicios en condiciones especialmente ventajosas para el poder adjudicador, que será objeto de tratamiento en el siguiente epígrafe.

Respecto del primero de estos supuestos, cabe señalar que se permite acudir a un procedimiento negociado sin publicación de un anuncio de licitación cuando por razones técnicas o artísticas o por cualquier otra razón relacionada con la protección de derechos de propiedad o industrial, el contrato sólo puede encomendarse a un operador económico determinado (artículo 32.2.b) Directiva 2014/24/UE). En tal sentido, puede entenderse que el hecho objetivo de que un único operador económico pueda ejecutar el contrato, también sería causa suficiente para justificar la derogación de una prohibición de contratar.

Así lo ha valorado también la legislación francesa que, de manera novedosa respecto del Código de Contratos Públicos 2006 (Code des marchés publics) - que no contemplaba excepción alguna - recoge ahora esta posibilidad de derogación.

El artículo 47 de la Ordenanza 2015-899, de 23 de julio de 2015, sobre contratación pública (cuya entrada en vigor se fijará a más tardar el 1 de abril de 2016) ${ }^{859}$, señala los supuestos de "Derogación justificada en el interés general" (Dérogation justifiée par l'intérêt général). De tal manera que:

"Les acheteurs peuvent, à titre exceptionnel, autoriser un opéra-

${ }^{859}$ Artículo 103 de l'Ordonnance no 2015-899, du 23 juillet 2015 (JORF no 169 du 24 juillet 2015). 
teur économique qui serait dans un cas d'interdiction de soumissionner prévu aux articles 45 et 46 à participer à la procédure de passation du marché public, à condition que cela soit justifié par des raisons impérieuses d'intér êt général, que le marché public en cause ne puisse être confié qu'à ce seul opérateur économique et qu'un jugement définitif d'une juridiction d'un Etat membre de l'Union européenne n'exclut pas expressément l'opérateur concerné des marchés publics".

"Los órganos de contratación podrán, excepcionalmente, autorizar que un operador económico incurso en un supuesto de prohibición de licitar previsto en los artículos 45 y 46 pueda participar en un procedimiento de contratación, siempre que esté justificado por razones de interés general, que el contrato público en cuestión no pueda ser confiado más que a un único operador económico y que una sentencia firme de un tribunal de un Estado miembro no excluya expresamente a ese operador concreto de la contratación pública" [Traducción propia].

En nuestra opinión, la derogación de las prohibiciones de contratar por razones de interés general debería superar la distinción entre prohibiciones de contratar obligatorias (apartados 1 y 2, párrafo primero del artículo 57 de la Directiva 2014/24/UE) y potestativas para los Estados miembros (apartado 4 del mismo artículo), puesto que la finalidad de la derogación supera las razones que han llevado al legislador europeo a establecer esta distinción. Y en todo caso, sería preceptivo insistir en los controles de adecuación, necesidad y proporcionalidad, en el supuesto en que el Estado miembro optara por contemplar esta excepción en su legislación ${ }^{860}$.

El fundamento de no limitarse a las prohibiciones de carácter obligatorio lo basamos en dos argumentos: Primero, las situaciones "de interés general"

\footnotetext{
${ }^{860}$ Es preciso recordar a este respecto que, según jurisprudencia reiterada, los Estados miembros disponen de cierto margen de apreciación para no aplicar las causas de exclusión potestativas o bien integrarlas en la normativa nacional con un grado de rigor que podría variar según el caso, en función de consideraciones de carácter jurídico, económico o social que prevalezcan en el plano nacional. Véase las sentencias de 9 de febrero de 2006, Cascina, C-226/04 y C-228/04; de 16 de diciembre de 2008, Michaniki, C-213/07 y de 23 de diciembre de 2009, Serrantoni, C-376/08.
} 
y de carácter excepcional que avalan la excepción no distinguen situaciones; es decir, respecto de la protección de la salud que se ha puesto como ejemplo, resulta indiferente si el único proveedor que puede suministrar las vacunas contra una enfermedad ha sido condenado por corrupción o ha cometido una falta profesional grave que pone en entredicho su integridad. Sin embargo, para actuar conforme a derecho, sería necesario que la normativa permitiera al órgano de contratación aplicar dicha excepción en el segundo de los supuestos citados $^{861}$.

El segundo razonamiento trae causa de la transposición de los motivos de exclusión facultativos a los derechos nacionales, puesto que ya hemos advertido que la mayor parte de las prohibiciones de contratar establecidas con carácter potestativo para los Estados miembros han sido recogidas en sus legislaciones internas en el momento de la transposición de la Directiva 2004/18/CE [Tabla 5]. Respecto de la Directiva 2014/24/UE existe un estudio que avanza que Austria, Chipre, Estonia, Lituania y Eslovaquia transpondrán a sus derechos nacionales todos los motivos de prohibición de contratar y que Polonia los transpondrá algunos como obligatorios y otros como no obligatorios ${ }^{862}$. El Reino Unido también distingue entre los obligatorios (mandatory exclusions) y los facultativos para los poderes adjudicadores (discretionary exclusions) ${ }^{863}$. Ahora bien, una vez que se convierten en obligatorias para los órganos de contratación nacionales, debiera poder preverse su derogación bajo los parámetros que hemos expuesto, y así debería recogerse en las legislaciones internas.

Estas mismas conclusiones intermedias son aplicables al resto de supuestos de derogación que se refieren también - y en exclusiva - a una prohibición de contratar de carácter obligatorio.

Con mayores dudas interpretativas, abordamos el segundo de los supuestos

\footnotetext{
${ }^{861}$ Esta conclusión no debe cuestionarse aun cuando, en este concreto ejemplo, se podría acudir a un procedimiento negociado sin publicidad sobre la base de la protección de derechos exclusivos.

${ }^{862}$ Public Procurement Network Italian Presidency 2014: Comparative survey on the transposition of the new EU Public Procurement package, 2014, pág. 16 que puede consultarse en: http://www.publicprocurementnetwork.org/docs/ItalianPresidency/documento \%206.pdf [Fecha de consulta: 15 de octubre de 2015].

${ }^{863}$ Artículos 57 (1) y (8) Public Contracts Regulations 2015.
} 
que habilita una nueva derogación de una prohibición y que hemos vinculado a causas de tipo económico.

\section{VIII.2. Las excepciones por motivos económicos}

El artículo 32.3.d) de la Directiva 2014/24/UE permite la utilización del procedimiento negociado sin publicidad respecto de los contratos públicos de suministro "cuando se trate de la compra de suministros o servicios en condiciones especialmente ventajosas, ya sea a un proveedor que cese definitivamente su actividad comercial ya sea a un administrador en un procedimiento de insolvencia o en virtud de un convenio con los acreedores o de un procedimiento de la misma naturaleza existente en las disposiciones legales o reglamentarias nacionales" $" 864$.

Esta modalidad "enmascara" una derogación tácita de una prohibición de contratar - potestativa para los Estados miembros -, ya que establece expresamente la posibilidad de adjudicar un contrato público a un proveedor sometido a un procedimiento de insolvencia o liquidación, cuando éstas son las situaciones que pueden habilitar la exclusión de un operador económico de la participación en un procedimiento de contratación (artículo 57.4.b) de la Directiva 2014/24/UE) y que también tiene su propia causa de excepción en el artículo 57, apartado cuarto in fine.

“ (...) los Estados miembros podrán exigir o prever la posibilidad de que el poder adjudicador no excluya a un operador económico que se encuentre en una de las situaciones contempladas en dicha letra si ha comprobado que ese operador económico va a estar en condiciones de ejecutar el contrato, teniendo en cuenta las normas y medidas nacionales aplicables en materia de continuación de la actividad empresarial en caso de producirse una de las situaciones contempladas en la letra b)".

${ }^{864}$ Acertadamente GALLEGO CÓRCOLES destapa el error técnico de este artículo al ampliar este supuesto a los contratos de servicios cuando el apartado d) se refiere a los contratos de suministro. GALLEGO CÓRCOLES, I., "Los procedimientos de adjudicación (...)", op. cit., pág. 226 
De esta forma, podemos señalar dos excepciones por motivos económicos: (i) La primera derivada de aplicar un mecanismo de «segunda oportunidad»a favor de la continuidad de la actividad empresarial donde el elemento a tener cuenta es que el operador económico - aun encontrándose en un procedimiento de insolvencia o liquidación - ofrezca garantías de poder ejecutar el contrato; y la segunda (ii) la derogación tácita a la que nos hemos referido para compras de suministros o servicios en condiciones especialmente ventajosas para el órgano de contratación.

\section{A. Una «segunda oportunidad» para los empresarios en situación de quiebra y/o insolvencia}

Este primer supuesto de excepción insta a los Estados miembros a contemplar la posibilidad de "rescatar" de la prohibición de contratar a empresas viables, a pesar de estar en dificultades financieras, evitando así el automatismo de la exclusión y facilitando que el poder adjudicador valore las garantías que se aportan para la correcta ejecución del contrato y no se deje guiar únicamente por la situación nominal en la que se encuentra el operador económico.

Esta excepción por motivos económicos debemos contemplarla inserta en la política de promoción de una cultura a favor de la reestructuración de las empresas y de garantizar una «segunda oportunidad» después de un fracaso empresarial, máxime si entendemos que el impedir contratar con el sector público puede obstaculizar las perspectivas de reestructurar la actividad mercantil de cualquier operador económico y tendría consecuencias nefastas para los propios acreedores y los trabajadores de la empresa ${ }^{865}$.

Por todo ello, con el fin de facilitar la supervivencia de las empresas, se

\footnotetext{
${ }^{865}$ En la Recomendación 2014/135/UE de la Comisión, de 12 de marzo de 2014, sobre un nuevo enfoque frente a la insolvencia y el fracaso empresarial se insta a los Estados miembros a que pongan en marcha procedimientos de reestructuración temprana y disposiciones de «segunda oportunidad» (DOUE L 74, de 14 de marzo de 2014). Véase también el estudio elaborado para la Dirección General de Mercado Interior, Industria, Emprendimiento y PYMES de la Comisión Europea sobre quiebra y segunda oportunidad para los empresarios honrados 'Bankruptcy and second chance for honest bankrupt Entrepreneurs'(2014) en: $\quad$ http://ec.europa.eu/enterprise/newsroom/cf/itemdetail.cfm?item_id=7962\&lang $=$ en [Fecha de consulta: 15 de octubre de 2015].
} 
prevé esta nueva causa de excepción de una prohibición de contratar orientada al rescate empresarial de quienes están afectados por una situación de quiebra, insolvencia o liquidación.

\section{B. Compras de suministros en condiciones especialmente ventajo- sas para el órgano de contratación}

En el segundo supuesto que hemos contemplado, el motivo de la medida viene amparado también prima facie por razones de carácter económico, pues entendemos que los objetivos que subyacen en la opción del legislador se vinculan a la adquisición de suministros cuyo precio de compra es considerablemente más bajo que el habitual del mercado. En estas circunstancias ventajosas económicamente para el órgano de contratación, se posibilita prescindir de la aplicación de una prohibición de contratar, aun cuando hemos sostenido que - según se deduce de la jurisprudencia del TJUE - los motivos económicos no podían ser tenidos en cuenta como razones imperiosas de interés general para justificar esta excepción ${ }^{866}$.

Dejando aparte la evidente contradicción que suponen los preceptos citados con la jurisprudencia europea, lo cierto es que esta derogación tácita de una prohibición de contratar parece gozar de presunción de conformidad con los objetivos del Derecho europeo sobre contratos públicos a tenor de lo dispuesto en los ya citados artículos sobre el procedimiento negociado y en el Reglamento Financiero (Reglamento (UE, Euratom) 966/2012, del Parlamento Europeo y del Consejo, de 25 de octubre de 2012, sobre las normas financieras aplicables al presupuesto general de la Unión) ${ }^{867}$.

Entre las disposiciones del Reglamento financiero que regulan la contratación pública - aun cuando no obligan a los Estados miembros ${ }^{868}$ - destacamos

\footnotetext{
${ }^{866}$ Sentencia del Tribunal de Justicia de 27 de marzo de 2014, Ulrike Elfriede, C$322 / 13$, apartado 48, con cita expresa en la sentencia de 15 de abril de 2010, CIBA, C-96/08.
}

${ }^{867}$ DOUE L 298, de 26 de octubre de 2012.

${ }^{868}$ Hemos tratado de ello en MEDINA ARNÁIZ, T., "Las disposiciones financieras de la Unión Europea y su aplicación a la contratación pública: especial referencia al nuevo Reglamento Financiero y sus normas de desarrollo", en la obra colectiva 
el artículo 106 relativo a los criterios de exclusión aplicables a la participación en procedimientos de contratación pública, que recoge un total de seis causas de prohibición de contratar y tres supuestos de excepción de estas prohibiciones.

Este precepto contempla todas las prohibiciones con un carácter obligatorio para las instituciones, órganos y organismos de la Unión y, como ya hemos señalado en esta memoria doctoral, comprenden las siguientes circunstancias: a) el estar incurso en un procedimiento de quiebra, liquidación, intervención judicial o concurso de acreedores, cese de actividad o en cualquier otra situación similar; b) la condena firme por cualquier delito que afecte a su ética profesional; c) la comisión de una falta profesional grave; d) no estar al corriente en el pago de las cuotas de la seguridad social o en el pago de impuestos; e) la condena firme por fraude, corrupción, participación en una organización delictiva, blanqueo de capitales o cualquier otra actividad ilegal que suponga un perjuicio para los intereses financieros de la Unión; y f) por la imposición de una sanción administrativa.

Los supuestos de excepción de estas prohibiciones no mencionan las «razones imperiosas de interés general», pero con alusión constante a la proporcionalidad en cuanto a su aplicación ${ }^{869}$, recoge el primero de los supuestos de derogación que hemos tratado; es decir, cuando "el contrato solo pueda ser adjudicado, por razones técnicas o artísticas o por motivos relacionados con la protección de derechos exclusivos, a un operador económico determinado" (artículo 106.2 del Reglamento financiero). Asimismo, como tendremos ocasión de precisar más adelante, contempla la adopción por parte del operador económico de medidas de "auto-limpieza" y, por lo que ahora nos interesa, establece que las prohibiciones contenidas en las letras a) a d):

"no serán de aplicación a las compras de suministros en condiciones particularmente ventajosas, bien a un proveedor en cese defi-

Observatorio de contratos públicos 2012, Thomson Reuters, Cizur Menor (Navarra), 2013, págs. 165 - 194.

${ }^{869}$ En especial en el artículo 142 del Reglamento Delegado (UE) 1268/2012 de la Comisión, de 29 de octubre de 2012, sobre las normas de desarrollo del Reglamento Financiero, respecto de la aplicación de los criterios de exclusión y su duración (DOUE L 362, de 31 de diciembre). 
nitivo de actividad empresarial o bien a síndicos o administradores judiciales de una quiebra, mediante un concurso de acreedores o como consecuencia de un procedimiento similar con arreglo al Derecho nacional" (artículo 106.1 párrafo segundo).

De esta disposición se desprende que el legislador de la Unión admite implícitamente la legalidad de la medida que, aun teniendo un claro motivo económico, permite excepcionar una prohibición de contratar. Así, un objetivo que podría a priori ser incompatible con la jurisprudencia clásica del Tribunal de Justicia, al mismo tiempo podría considerarse apropiado como resultado de la aplicación de un criterio finalista del propio procedimiento de adjudicación contractual: la búsqueda de la oferta económicamente más ventajosa ${ }^{870}$.

Ahora bien, si esta excepción constituye una medida idónea para garantizar este objetivo, el legislador europeo debiera haber optado por incorporar en las Directivas sobre contratación pública los supuestos de derogación referidos a motivos económicos que permitirían ponderar la no aplicación de una prohibición de contratar a la vista de los beneficios obtenidos de ello, y no dejar relegada esta posibilidad a la utilización del procedimiento negociado sin publicidad. En cualquier caso, y por coherencia expositiva, se impone la conclusión parcial de que sería necesario validar jurídicamente esta derogación tácita en los artículos referidos a los motivos de exclusión

\section{VIII.3. Excepciones que superan el juicio de proporcio- nalidad}

Con arreglo al artículo 57.3 párrafo segundo de la Directiva 2014/24/UE,

"Los Estados miembros podrán también establecer una excepción a la exclusión obligatoria prevista en el apartado 2 cuando tal exclusión resulte cla-

\footnotetext{
${ }^{870}$ Sobre la necesaria reformulación de los criterios de interés económico como límite a las libertades fundamentales de la Unión, se manifiesta ARROWSMITH, S., "Rethinking the approach to economic justifications under the EU's free movement rules", Current Legal Problems 2015, que se puede consultar en http://www.nottingham.ac.uk/pprg/publications/index.aspx [Fecha de consulta: 15 de octubre de 2015].
} 
ramente desproporcionada (...)"871. Esta exclusión obligatoria se refiere tanto al supuesto de impago de las obligaciones tributarias como con la seguridad social.

La exigibilidad en el cumplimiento de las obligaciones tributarias y con la seguridad social se ha configurado tradicionalmente como requisito previo para contratar con los poderes adjudicadores, de modo que el incumplimiento de estas obligaciones aparece desde las primeras Directivas sobre contratación pública como motivo de exclusión del procedimiento de adjudicación (artículos 23.e) y f) de la Directiva 71/305/CEE y artículo 20.e) y f) de la Directiva $77 / 62 / \mathrm{CEE})$.

El objetivo perseguido con estas prohibiciones de contratar era - y es todavía - "garantizar la fiabilidad, la diligencia y la seriedad del licitador, así como el comportamiento adecuado de éste hacia sus asalariados" $" 872$, a la vez que aportan un valor añadido a la lucha contra el fraude y la evasión fiscal, al convertirse en un estímulo para estar al corriente en el pago de estas obligaciones.

Como ya hemos indicado con anterioridad, las nuevas Directivas han venido

\footnotetext{
${ }^{871}$ Esta excepción no aparecía recogida en el artículo 55 de la Propuesta de Directiva sobre contratación pública, COM (2011) 896 final, de 20 de diciembre de 2011. Su incorporación al texto de la Directiva tiene lugar en dos momentos procedimentales distintos en atención a los dos supuestos de falta de proporción que contempla este artículo: i) por razón de las cuantías, debemos acudir al Texto transaccional de la Presidencia/versión consolidada, de 24 de julio de 2012; y ii) por una cuestión temporal, al resultado del Dictamen de Primera lectura del Parlamento Europeo, de 15 de enero de 2014.

${ }^{872}$ Apartado 32 de la sentencia del TJUE de 10 de julio de 2014, Consorzio Stabile, C-358/12. Especialmente significativas a este respecto resultan las ya citadas conclusiones de la Abogado General Sra. KOKOT presentadas, el 15 de abril de 2010, en el asunto Bâtiments y Ponts Construction, C-74/09, apartado 50 “(...) se trata de evitar que, en detrimento del interés general, «ovejas negras» que, por ejemplo, no paguen sus impuestos y cotizaciones a la seguridad social, acaben presentado ofertas más ventajosas que sus competidores y que de esa manera consigan contratos públicos usando métodos desleales, máxime cuando esos contratos se financian normalmente con ingresos fiscales". De criterios de justicia material respecto de estas prohibiciones hablaba GOSÁLBEZ PEQUEÑO en tanto que con el cumplimiento de estas obligaciones se contribuye al sostenimiento de los gastos públicos, GOSÁLBEZ PEQUEÑO, H., El contratista de la Administración (...), op. cit., pág. 381.
} 
a aportar un mayor rigor respecto a la exigencia de comportamientos acordes con los deberes económicos de cualquier ciudadano en la medida que obligan a los Estados miembros a incorporar a sus legislaciones nacionales como causas de prohibición de contratar el incumplimiento de los mismos ${ }^{873}$. Estas prohibiciones conllevan para los poderes adjudicadores una obligación absoluta de excluir a los operadores económicos cuando exista una resolución judicial o administrativa firme y vinculante que acredite el incumplimiento ${ }^{874}$.

Ahora bien, las Directivas a la vez que imponen esa obligación permiten a los Estados miembros que excepcionen su aplicación bien por «razones imperiosas de interés general» (artículo 57.3 primer párrafo de la Directiva 2014/24/UE ya tratado) o que se pronuncien respecto de la proporcionalidad de la medida posibilitando su excepción ante determinadas circunstancias. Así pues, en atención a las desfavorables consecuencias que para la competencia se podrían derivar de una interpretación estricta de la norma por impedir acudir a la licitación a todo aquel que no estuviera al corriente de sus obligaciones relativas al pago de impuestos o cotizaciones de la seguridad social, la Directiva plantea esta novedosa excepción, no prevista en las Directivas del año 2004, que pretende que la prohibición de contratar no comprometa - sin que se aprecien razones de peso - el objetivo de la apertura a la concurrencia ${ }^{875}$.

No obstante, el margen de apreciación de que disponen los Estados miembros no es ilimitado, ya que se encuentra delimitado por los mismos artículos que supeditan la derogación de la prohibición de contratar a que ésta "resulte

\footnotetext{
${ }^{873} \mathrm{El}$ considerando centésimo quinto de la Directiva 2014/25/UE es del siguiente tenor: "El impago de impuestos o cotizaciones a la seguridad social también debe ser sancionado con la exclusión obligatoria a nivel de la Unión".

${ }^{874}$ Cabe señalar que el artículo 57.2, segundo apartado, de la Directiva 2014/24/UE también contempla una prohibición de contratar respecto de estos mismos incumplimientos, pero en este caso, potestativa para los poderes adjudicadores - "podrán excluir" - cuando "pueda demostrar por cualquier medio adecuado que el operador económico ha incumplido sus obligaciones en lo referente al pago de impuestos o cotizaciones a la seguridad social."

${ }^{875}$ En este sentido, volvemos a recordar que uno de los objetivos de las normas de la Unión en materia de contratos públicos es la apertura a la competencia lo más amplia posible, tal como señala el TJUE en sus sentencias de 13 de diciembre de 2007, Bayerischer Rundfunk y otros, C-337/06, apartado 39 y de 23 de diciembre de 2009, CoNISMa, C-305/08, apartado 37.
} 
claramente desproporcionada" (artículo 57.3 párrafo segundo de la Directiva 2014/24/UE y artículo 38.6 párrafo segundo de la Directiva 2014/23/UE («concesiones»).

Conforme a dicha exigencia, las circunstancias referidas en las Directivas que no guardan una relación de proporción con los objetivos pretendidos por la norma son dos:

Primera. Cuando las cantidades adeudadas por el candidato o licitador sean de poca entidad, o lo que es lo mismo, que se hayan dejado de abonar "pequeñas cantidades", según los términos utilizados por la Directiva 2014/23/UE.

El elemento central de estos preceptos radica en flexibilizar el criterio de exclusión contemplado en las Directivas con un carácter obligatorio a tenor de los importes de la deuda pendiente. Parece, pues, acorde a un análisis de proporcionalidad que desde la legislación contractual se ofrezca la posibilidad de valorar la gravedad del incumplimiento, aunque sea desde un punto de vista cuantitativo y, lo que entendemos más importante, se otorgue un trato diferente a quienes tienen deudas de escasa relevancia, que en ningún caso comprometen el sostenimiento de los gastos públicos, frente a quienes - llevado al extremo se consideran grandes defraudadores (con negocios ficticios, dinero en paraísos fiscales, etc.).

Esta línea de análisis es la que se ha desarrollado en el asunto Consorzio Stabile ${ }^{876}$, conforme a la cual el TJUE entiende ajustado a las disposiciones europeas una normativa que obliga a los órganos de contratación a excluir del procedimiento de adjudicación de un contrato de obras a un licitador responsable de una infracción en materia de pago de cotizaciones de seguridad social si la diferencia entre las cantidades adeudadas y las abonadas es de un importe superior, a la vez, a 100 euros y al $5 \%$ de las cantidades adeudadas ${ }^{877}$. A sensu

${ }^{876}$ STJUE de 10 de julio de 2014, Consorzio Stabile, C-358/12. La normativa cuestionada es el Decreto Legislativo núm.163, de 12 de abril de 2006, por el que se aprueba en Italia el Codice dei contratti pubblici relativi a lavori, servizi e forniture in attuazione delle direttive 2004/17/CE e 2004/18/CE.

${ }^{877} \mathrm{El}$ artículo 38, apartado 2, del Código italiano de los contratos públicos define el criterio de gravedad de las infracciones a las normas aplicables en materia de pago de cotizaciones a los organismos de seguridad social. En esencia, señala que, a efectos del artículo 38, apartado 1, letra i), del mismo Decreto Legislativo se consideran graves 
contrario tendríamos que entender que por debajo de esas cuantías el licitador no podría ser excluido del procedimiento al considerar que no ha cometido una infracción grave que conlleve aparejada una prohibición de contratar.

El Tribunal de Justicia resuelve en esta sentencia la petición de decisión prejudicial planteada por el Tribunale Amministrativo Regionale per la Lombardia respecto del Código de Contratos Públicos italiano partiendo del siguiente hecho: El artículo 45, apartado 2, letra e), de la Directiva 2004/18/CE permitía a los Estados miembros excluir de la participación en un contrato público a los operadores económicos que no estuvieran al corriente de sus obligaciones relativas al pago de las cotizaciones de seguridad social, pero no establecía una cantidad mínima de retrasos de cotizaciones. De ahí que, la prohibición de contratar operaba sea cual fuese el importe adeudado y sin tener en cuenta la gravedad de la infracción.

Ante esta realidad normativa, el TJUE manifiesta que la fijación, en la legislación nacional, de un umbral preciso de exclusión "garantiza no sólo la igualdad de trato de los licitadores sino también la seguridad jurídica, principio cuyo cumplimiento constituye un requisito de la proporcionalidad de una medida restrictiva" (apartado 34, de la sentencia de 10 de julio de 2014, Consorzio Stabile, C-358/12).

En esta línea de cuantificar las cantidades por debajo de las cuales no se considera que el operador económico haya incumplido sus obligaciones fiscales o con la seguridad social, tenemos que referirnos a la legislación de Lituania y Letonia $^{878}$.

En Lituania, la Ley de Contratación Pública No. I-1491, de 13 de agosto

las infracciones que impiden la expedición del Documento único de regularidad en materia de contribuciones sociales y considera grave una infracción en materia de cotizaciones, comprobada de forma definitiva, cuando su cuantía supera el importe de 100 euros y es además superior al $5 \%$ de la diferencia entre las cantidades adeudadas y las abonadas en cada período de pago o cotización.

${ }^{878}$ Dejamos fuera de este análisis la normativa del Reino Unido, pues si bien el artículo 57 (7) de la Public Contracts Regulations 2015 contempla también la posibilidad de derogar esta misma prohibición de contratar, lo hace en idénticos términos que las Directivas; es decir, sin aportar una cuantía concreta más allá de indicar que se trate de cantidades menores "where only minor amounts of taxes or social security contributions are unpaid". 
de 1996, ha sido ampliamente modificada en dos ocasiones distintas con el fin de transponer al Derecho lituano las Directivas sobre contratación pública (las del año 2004, y ahora las que hemos denominado de «cuarta generación»). La última de esas modificaciones - Ley No. XII-1768, de 9 de junio de 2015 nos ofrece una versión consolidada de la legislación contractual, que por lo que respecta al artículo 33 que trata sobre las condiciones para prohibir o restringir la participación de proveedores en el procedimiento de adjudicación establece, con efectos a partir del 1 de enero del 2016, que:

Artículo 33.1. "El órgano de contratación deberá rechazar las solicitudes y propuestas, si un proveedor:

2) No ha cumplido con las obligaciones relativas a los impuestos, incluidas las contribuciones de seguridad social, en el país donde está registrado o en el país del poder adjudicador. El proveedor se considerará que ha cumplido con las obligaciones relativas a impuestos, incluyendo las contribuciones a la seguridad social si la cantidad pendiente de pago es menor de 50 euros". [Traducción proz.com].

En Letonia, la regulación que transpuso la Directiva 2004/18/CE, la Ley de Contratos Públicos, de 6 de abril de 2006 [Publisko iepirkumu likums] ha sido modificada en octubre de 2014 para incorporar al derecho letón algunas de las novedades previstas en la Directiva 2014/24/UE. Por lo que se refiere a las causas de exclusión obligatorias por el impago de impuestos o cotizaciones a la seguridad social, el artículo 39.1 en diferentes apartados dispone que:

"El poder adjudicador excluirá de la participación en un procedimiento de contratación a los licitadores o candidatos en cualquiera de los siguientes supuestos: (...)

1. c) haber sido condenado por sentencia judicial firme por impago de impuestos o pagos similares.

5. Cuando conste en la base de datos de los servicios de rentas del Estado en la fecha de última actualización antes de la publicación de la licitación o en el día en que se adopta la decisión de compra en el supuesto que no se necesitar publicación, que el licitador tiene en 
Letonia o en el Estado en que esté registrado o tenga su residencia habitual, deudas por impago de impuestos, incluyendo atrasos de pago de seguridad social en alguno de los países, por más de 150 euros" [Traducción proz.com].

Así pues, y a sensu contrario, podemos interpretar que si las deudas no superan la cuantía de 150 euros, el licitador o candidato no debiera resultar excluido del procedimiento de adjudicación contractual.

La segunda de las circunstancias que el legislador europeo considera "claramente desproporcionada" en relación con las consecuencias derivadas del incumplimiento de las obligaciones tributarias y con la seguridad social, tiene lugar cuando el operador económico no ha dispuesto de tiempo material suficiente para regularizar su situación por haber conocido los importes exactos adeudados "antes del vencimiento del plazo fijado para solicitar la participación o, en el caso de los procedimientos abiertos, del plazo fijado para presentar su oferta". Es decir, antes de la finalización del plazo para la presentación de la documentación acreditativa sobre la inexistencia de motivos de exclusión y del cumplimiento de los criterios de selección, o antes de que el poder adjudicador tuviera acceso a dicha información por otros medios.

Esta cuestión nos permite, por una parte, volver a referirnos a la importancia del momento en el que se deben cumplir los criterios de selección cualitativa; y por otra, aludir a la opción político criminal del legislador europeo a favor de la regularización. Esta opción supone hacer abstracción de la exigencia de fiabilidad y seriedad en el licitador o candidato, y dejar de aplicar una prohibición de contratar cuando - con posterioridad al reproche que conlleva una resolución firme y vinculante - éste ha procedido al pago de las cantidades adeudadas "incluidos en su caso los intereses acumulados o las multas impuestas" (Artículo 57, apartado 2 in fine de la Directiva 2014/24/UE que será tratado seguidamente) $)^{879}$.

Respecto del momento del cumplimiento de los criterios de selección cua-

${ }^{879}$ Como hemos indicado anteriormente, esta excepción tampoco aparecía en el artículo 55 de la Propuesta de Directiva sobre contratación pública, COM (2011) 896 final, de 20 de diciembre de 2011. Se incorporó al texto de la Directiva en virtud del Dictamen de Primera lectura del Parlamento Europeo, de 15 de enero de 2014. 
litativa, esta excepción a la prohibición de contratar parece presentar como claramente desproporcionado el hecho de que los plazos para la participación y la presentación de ofertas no permitan tener en consideración la imposibilidad del operador económico para cumplir con la regularización de su situación por la improrrogabilidad de aquellos, dado que cuando se le informa "del importe exacto adeudado", el cumplimiento resultaba imposible por falta de tiempo ${ }^{880}$.

A pesar de su reflejo legal, creemos que su calificación de desproporcionada resulta excesiva, en tanto que el operador económico: i) conoce perfectamente que las deudas no fueron atendidas en el periodo voluntario de pago; y ii) que en el procedimiento judicial o administrativo que ha finalizado con la resolución firme que acredita el incumplimiento, tiene acceso a los datos referentes a sus deudas, cuenta con medios de defensa para hacer valer sus intereses y la oportunidad de cumplir sus obligaciones. Incluso, tras la resolución, tendría la posibilidad de solicitar un aplazamiento en el pago y considerarse, así, al corriente en sus obligaciones tributarias o con la seguridad social.

Entendemos, por ello, que lo que al legislador europeo le resulta verdaderamente proporcionado es poder utilizar cualquier posible mecanismo disuasorio para evitar los fraudes y las evasiones fiscales, puesto que con la posibilidad de derogar la prohibición de contratar únicamente se persigue que se cumpla con el pago adeudado a las autoridades tributarias y de seguridad social.

Este mismo argumento, es predicable de la siguiente excepción.

\footnotetext{
${ }^{880}$ Recordemos que el Tribunal de Justicia ha señalado que las Directivas no se oponen a que los datos relativos a la oferta puedan corregirse o completarse de manera puntual o para subsanar errores materiales manifiestos (sentencia de 29 de marzo de 2012, Slovensko y otros, C-599/10, apartado 40), pero siempre que se refiera a información cuya "anterioridad con respecto al término del plazo de presentación de candidaturas sea objetivamente verificable" (sentencia de 10 de octubre de 2013, Manova, C-336/12, apartado 39). Las omisiones que no sean meramente formales no pueden subsanarse "cualquiera que sea la forma, tras la expiración del plazo concedido para la presentación de las ofertas", sentencia de 6 de noviembre de 2014, Cartiera dell'Adda, C-42/13, apartado 45.
} 


\section{VIII.4. El levantamiento de la prohibición con moti- vo de la regularización tributaria del operador económico "incumplidor"}

Este supuesto de derogación de una prohibición de contratar tiene por objeto la regularización de la situación tributaria del licitador o candidato, ya que, según disponen las Directivas, la prohibición de contratar

“(...) dejará de aplicarse, si el operador económico ha cumplido sus obligaciones mediante el pago o mediante un acuerdo vinculante con vistas al pago de los impuestos o las cotizaciones a la seguridad social adeudadas, cuando así proceda con los intereses devengados o las sanciones impuestas." (Artículo 57.2. in fine de la Directiva 2014/24/UE y artículo 38.5 tercer párrafo de la Directiva $2014 / 23 / \mathrm{UE})$.

Como ya hemos apuntado previamente, esta derogación - que a diferencia del resto nos parece que es de carácter imperativo dado los términos en los que se encuentra redactada - encuentra justificación en la opción política del legislador por facilitar el "retorno a la legalidad" 881 de aquellos incumplidores tributarios o con la seguridad social, de tal suerte que, al regularizar su situación neutralizan el desvalor de su conducta anterior y evitan la aplicación de una prohibición de contratar futura ${ }^{882}$.

Así pues, estos preceptos dan a conocer a los operadores económicos la práctica que deben seguir si quieren evitar una de las consecuencias jurídicas que deriva de su incumplimiento - la prohibición de contratar - y busca, con

\footnotetext{
${ }^{881}$ La expresión «retorno a la legalidad», la tomamos prestada de la Ley Orgánica 7/2012, de 27 de diciembre, por la que se modifica la Ley Orgánica 10/1995, de 23 de noviembre, del Código Penal en materia de transparencia y lucha contra el fraude fiscal y en la Seguridad Social (BOE núm. 312, de 28 de diciembre de 2012).

${ }^{882}$ Esta derogación de la prohibición de contratar se incorporó al texto de la Directiva 2014/24/UE en virtud del Texto transaccional de la Presidencia, de 30 de noviembre de 2012, puesto que, al igual que hemos señalado con el resto de excepciones, tampoco aparecía en la Propuesta de Directiva COM, (2011) 896 final, de 20 de diciembre de 2011.
} 
ello, potenciar un efecto motivador a favor de la observancia de las obligaciones fiscales y con la seguridad social, aunque el cumplimiento sea posterior a la comisión del hecho defraudatorio. En todo caso, el "beneficio" que para el operador económico supone la no aplicación de la prohibición de contratar está supeditado a la condición de pagar la cantidad debida, incluidos recargos, intereses de demora y posibles multas ${ }^{883}$.

Esta derogación - más allá de pasar o no por el tamiz de la proporcionalidad - hemos de enmarcarla dentro del objetivo de la tutela de los intereses financieros de la Unión y de los Estados miembros. Por tanto, los mismos argumentos que nos llevaban a justificar la existencia de las prohibiciones de contratar obligatorias (la protección del erario público frente a distintas formas de delincuencia ${ }^{884}$ ) son los que nos llevan a justificar esta medida y, de manera más evidente si cabe, los que fundamentan el último grupo de excepciones a las prohibiciones de contratar.

Ahora bien, lo anterior no obsta para que, dejando al margen la importancia que tiene salvaguardar los intereses financieros y garantizar la recaudación, pasemos por alto el que con estas medidas se equipara al contribuyente cumplidor con aquel otro que no lo ha sido. En la persecución de tales objetivos se descuida la pretendida búsqueda de un contratista fiable y serio y se priman razones de economía al rebajar las exigencias de honestidad de quien va

\footnotetext{
${ }^{883}$ Resulta de interés los comentarios efectuados por el Abogado del Estado en el caso que dio lugar a la STC 276/2000, de 16 de noviembre de 2000, sobre el devengo de recargos tras el vencimiento del periodo de pago. Entendía el Abogado del Estado que quien hace un ingreso en aplicación del derogado artículo 61.2 de la Ley General Tributaria, "hace uso de un derecho propio de ajustar el tiempo de pago a sus conveniencias; realiza, efectivamente, una actividad lícita que resulta más onerosa que si el pago se hubiera efectuado en tiempo, pero que, a diferencia de las infracciones tributarias, no da lugar a otras sanciones complementarias como es la prohibición de contratar".

${ }^{884} \mathrm{~A}$ este respecto, recordemos lo dicho por la Comisión en la Comunicación $L a$ Estrategia de Seguridad Interior de la UE en acción al indicar que, desde un enfoque administrativo, debieran desarrollarse políticas "por las que los órganos administrativos y reguladores responsables de la concesión de licencias, autorizaciones, contratos públicos y subvenciones se comprometan a proteger la economía contra la infiltración de las redes delictivas", COM (2010) 673 final, de 22 de noviembre de 2010, pág. 6.
} 
a contratar con una entidad pública ${ }^{885}$.

En la búsqueda de la eficiencia económica del mercado, las nuevas Directivas sobre contratación pública instrumentalizan las prohibiciones de contratar como una "amenaza" para los operadores económicos incumplidores reforzando, de esta manera, sus efectos intimidatorios, y sin que ciertamente se pretenda con ello asegurar una mejor y más adecuada selección del contratista. De una parte se incorporan nuevas causas de prohibición de contratar obligatorias (por delitos de terrorismo, trata de seres humanos, delitos contra la hacienda pública y la seguridad social) ${ }^{886}$, y de otra, se configura un régimen favorable a su derogación sobre la base del cumplimiento ${ }^{887}$.

\section{VIII.5. La excepción a la aplicación de las prohibiciones de contratar a través de las medidas de «self- cleaning»}

Las vigentes Directivas sobre contratación pública también prevén la posibilidad de excepcionar la aplicación de una prohibición de contratar - sin distinguir entre obligatorias y potestativas - a través de las llamadas medidas autocorrectoras, de autolimpieza o de «self-cleaning» ${ }^{888}$ (artículo 57.6 de

\footnotetext{
${ }^{885}$ Nos referimos a la honestidad en clara alusión a la expresión "licitadores deshonestos" utilizada por la Comisión en el Libro Verde sobre la modernización del mercado europeo de la contratación pública, COM (2011) 15 final, de 27 de enero de 2011.
}

${ }^{886}$ En el Informe anual de la Comisión sobre Protección de los intereses financieros de la Unión Europea - Lucha contra el fraude 2013, COM (2014), 474 final, de 17 de julio, pág. 30 se señalaba que "se han revisado las Directivas sobre contratación pública a fin de añadir medidas tendentes a prevenir, detectar y subsanar el fraude".

${ }^{887}$ Sobre esta materia, resulta de interés NIETO MARTÍN, A., "De la ética Pública al Public Compliance: sobre la prevención de la corrupción en las Administraciones públicas", en la obra colectiva Public Compliance: Prevención de la corrupción en Administraciones públicas y partidos políticos, Ediciones de la Universidad de Castilla-La Mancha, Cuenca, 2014, págs. 17 - 42.

${ }^{888} \mathrm{La}$ incorporación al texto de este anglicismo deriva de la conveniencia de recoger como préstamo lingüístico la expresión utilizada en la mayor parte de la doctrina tanto de lengua inglesa, como no - al referirse a esta materia, aunque lo cierto es que 
la Directiva 2014/24/UE («sectores clásicos») y artículo 38.9 de la Directiva 2014/23/UE («concesiones») ${ }^{889}$.

De esta manera, y en atención al principio de proporcionalidad que exige que las prohibiciones no excedan de lo que resulta apropiado y necesario para lograr los objetivos propuestos por las Directivas, se contempla la posibilidad de eximir de su aplicación a través del establecimiento de medidas de autocorrección cuando los candidatos o licitadores en los que concurre un motivo de exclusión han adoptado mecanismos eficaces para corregir las consecuencias de su inadecuado comportamiento e impedir de manera efectiva que éste se vuelva a repetir.

"Todo operador económico que se encuentre en alguna de las situaciones contempladas en los apartados 1 y 4 podrá presentar pruebas de que las medidas adoptadas por él son suficientes para demostrar su fiabilidad pese a la existencia de un motivo de exclusión pertinente. Si dichas pruebas se consideran suficientes, el operador económico de que se trate no quedará excluido del procedimiento de contratación.

A tal efecto, el operador económico deberá demostrar que ha pagado o se ha comprometido a pagar la indemnización correspondiente por cualquier daño causado por la infracción penal o la falta, que ha aclarado los hechos y circunstancias de manera exhaustiva colaborando activamente con las autoridades investigadoras y que ha adoptado medidas técnicas, organizativas y de personal concretas, apropiadas para evitar nuevas infracciones penales o faltas" (primer y segundo párrafos del artículo 57.6 de la Directiva 2014/24/UE).

el término self-cleaning deriva de la traducción del vocablo alemán «Selbstreinigung».

${ }^{889}$ En la Directiva 2014/25/UE, relativa a la contratación por entidades que operan en los sectores del agua, la energía, los transportes y los servicios postales, no se recoge un precepto similar, si bien su considerando centésimo séptimo señala que "cuando las entidades adjudicadoras estén obligadas a aplicar u opten por aplicar los criterios de exclusión mencionados, deben aplicar lo dispuesto en la Directiva 2014/24/UE en lo que respecta a la posibilidad de que los operadores económicos adopten medidas de cumplimiento encaminadas a reparar las consecuencias de las infracciones penales o las faltas y a prevenir eficazmente nuevos casos de conducta indebida". 
El análisis de estas medidas constituye el objeto de este último epígrafe del capítulo, toda vez que su regulación no está exenta de elementos controvertidos al presentar dificultades interpretativas y plantear interrogantes respecto de cuestiones tan importantes como son: (i) la justificación de la nueva regulación; (ii) cuál es el momento en el que los operadores económicos deben adoptar estas medidas para reparar las consecuencias de las infracciones que han cometido; (ii) quién es el órgano competente para su apreciación y valoración o (iii) si se trata - o no - de un derecho que tiene el operador económico.

Con afán de contribuir a la discusión en esta novedosa materia, procederemos ahora a examinar el contenido normativo de las Directivas y el alcance de la «rehabilitación» ${ }^{890}$ prevista en el citado apartado sexto del artículo 57 de Directiva 2014/24/UE. A este respecto, el estudio de estas medidas nos llevará a acotar el concepto de self-cleaning y a presentar el contexto en el que éstas se inscriben.

En dicho contexto tendremos que referirnos a los programas de cumplimiento (compliance), a los códigos internos de comportamiento ético y a la adopción de pactos de integridad como instrumentos para desarrollar una cultura de respeto de la legalidad que se incardinan en un nuevo modelo de entender la responsabilidad penal de las personas jurídicas (modelo de «palos y zanahorias» en el que se combina la presión sobre las empresas incumplidoras (palo, en este caso en forma de prohibición) con el apoyo para aquéllas que demuestran su compromiso con el cumplimiento (zanahoria) ${ }^{891}$. Estas prácticas

${ }^{890} \mathrm{Al}$ hablar de rehabilitación nos referimos al hecho de reponer al operador económico en la posibilidad de participar en un procedimiento de adjudicación contractual.

${ }^{891}$ Véanse los trabajos de BERNAL BLAY, M. Á., "Los efectos de los programas de compliance en la contratación pública", Comunicación presentada en el X Congreso de la Asociación Española de Profesores de Derecho Administrativo y publicada en la obra colectiva Las nuevas Directivas de contratación pública, Thomson - Aranzadi, Cizur Menor (Navarra), 2015, págs. 413 a 424 y de GÓMEZ-JARA DÍEZ, C., "Responsabilidad penal de las personas jurídicas y contratación pública (...), op. cit., y del mismo autor "La responsabilidad penal de las personas jurídicas en el ámbito público: ¿hacia los Compliance Programs anti-corrupción como exigencias legales de contratación pública?", en la obra colectiva La gestión de los Fondos Públicos: Control y responsabilidades, Thomson - Aranzadi, Cizur Menor (Navarra), 2013, especialmente pág. 1247 al reivindicar que "el programa de cumplimiento sea una exigencia legal para poder contratar con la Administración de tal manera que 
comparten propósito con las medidas de self-cleaning en cuanto incorporan a la contratación una opción de política criminal para lograr uno de los objetivos perseguidos con las prohibiciones de contratar, esto es, promover la integridad, pero sin la pérdida de competitividad que supone tener que excluir a ciertos operadores económicos de los procedimientos de adjudicación.

Como trataremos seguidamente, éste es uno de los argumentos principales esgrimidos por quienes defienden la inclusión de estas medidas de corrección en la normativa contractual, pues frente al deber legal que supone para el órgano de contratación la exclusión de un licitador o candidato que se encuentra incurso en una situación de prohibición de contratar, entienden que deben arbitrarse vías que permitan excepciones a la misma si se muestran garantías suficientes respecto de la implementación de un modelo de organización, gestión y control idóneo para la prevención de delitos y conductas contrarias a la norma ${ }^{892}$.

En todo caso, el reconocimiento legal de estas pautas de conducta redefine el alcance, e incluso el fundamento de las prohibiciones de contratar, puesto que la adopción por parte del operador económico de medidas para reparar y prevenir en el futuro comportamientos inapropiados no se contemplan como criterios de atenuación de responsabilidad en un procedimiento de declaración de la prohibición de contratar (por ejemplo para determinar su duración) ${ }^{893}$, sino como exención, ya que "cuando estas medidas ofrezcan garantías suficientes, se debe dejar de excluir por estos motivos al operador económico de que se trate" (considerando centésimo segundo de la Directiva 2014/24/UE).

No obstante, del debate respecto de su aceptación, señalamos que existe una cierta tensión que se refleja en dos posiciones opuestas bajo las cuales se presentan quienes defienden un distinto tratamiento para los operadores

las empresas que no cuenten con el mismo se vean impedidas en la contratación".

${ }^{892}$ Entre otros, ARROWSMITH, S., PRIESS, H.-J. y FRITON, P., "Self-Cleaning as a Defence to Exclusions for Misconduct (...)", op. cit., y HJELMENG, E. y SØREIDE T., "Debarment in public procurement: rationales and realization", en la obra colectiva Integrity and Efficiency in Sustainable Public Contracts, Bruylant, Bruselas, 2014, págs. 215 - 232.

${ }^{893}$ Distinta opinión parecen manifestar HJELMENG, E. y SØREIDE T., en las conclusiones de su trabajo al sostener que "the revised PPD addresses firms' opportunity to avoid or reduce debarment through self-cleaning initiatives", en "Debarment in public procurement (...)", op. cit., pág. 232. 
económicos cumplidores y para quienes han vulnerado la normativa y después pretenden remediar las consecuencias jurídicas negativas derivadas de dicho incumplimiento y quienes abogan por propiciar la redención de los infractores ${ }^{894}$. En cualquier caso, prescindiendo de las posibles dudas sobre la necesidad o, incluso, conveniencia en su regulación - que insistimos, han sido resueltas por las propias Directivas al recoger expresamente las medidas de self-cleaning en su articulado - lo cierto es que éstas responden, si bien mínimamente, a la exigencia de seguridad jurídica que precisan las excepciones en términos de legalidad. El análisis de su regulación actual se aborda en los siguientes apartados.

\section{A. Las medidas de self-cleaning son «viejas conocidas» de la legis- lación contractual}

Hemos indicado que una de las novedades que se incorpora al articulado de las nuevas Directivas sobre contratación pública ha sido el reconocimiento legal a la posibilidad de los licitadores y candidatos de demostrar su fiabilidad aun encontrándose incursos en alguna de las situaciones habilitadoras de una prohibición de contratar.

A pesar de esta aseveración, lo cierto es que resulta excesivo adjetivar de novedosa esta excepción por tres motivos. El primero es que el Comité de las Regiones ya aludía a ellas en su Dictamen sobre las Propuestas de Directivas del año 2000 al recomendar que se debían analizar con detalle las consecuencias que para la aplicación de una prohibición de contratar supone que "los agentes económicos hayan introducido en sus empresas, por ejemplo, medidas de prevención idóneas, o hayan despedido de inmediato a los directivos que cometieron estos delitos sin la complicidad del agente económico en cuestión" $" 895$.

\footnotetext{
${ }^{894}$ Reunión del Grupo de Expertos de interesados en materia de contratación pública (25 de febrero de 2013) http://ec.europa.eu/internal_market/publicprocurement/docs/expert-group/130225_minutes_en.pdf [Fecha de consulta: 15 de octubre de 2015].

${ }^{895}$ Dictamen del Comité de las Regiones, de 13 de diciembre de 2000, sobre las Propuestas de Directivas del Parlamento Europeo y del Consejo, sobre coordinación de los procedimientos de adjudicación de los contratos públicos de suministro, de servicios y de obras; y sobre coordinación de los procedimientos de adjudicación de contratos en los sectores del agua, de la energía y de los transportes (DOCE C 144, de 16 de mayo de 2001, pág. 26).
} 
La segunda de las razones es que, con base en el artículo 45 de la Directiva 2004/18/CE, algunos Estados miembros ya habían recogido en sus normativas contractuales la posibilidad de excepcionar las prohibiciones de contratar cuando del comportamiento del candidato o licitador quedasen "disipadas las dudas" relacionadas con su honestidad profesional, su solvencia y su fiabilidad $^{896}$. Los Estados miembros que con anterioridad a la nueva regulación europea ya contemplaban la posibilidad de excepcionar la aplicación de una prohibición de contratar eran Austria, Alemania y, en menor medida, Italia ${ }^{897}$.

El tercer motivo también es de carácter normativo, puesto que las medidas de self-cleaning aparecen recogidas en las disposiciones que regulan la contratación pública de las instituciones y los órganos de la Unión. De esta manera, el artículo 106, apartado 1, último párrafo del ya citado Reglamento financiero (Reglamento (UE, Euratom) 966/2012) dispone que la prohibición de contratar aneja a condenas penales firmes "no será de aplicación si los candidatos o licitadores pueden demostrar que se han adoptado medidas adecuadas contra las personas con poderes de representación, decisión o control sobre ellos que estén sometidas a una sentencia a tenor del párrafo primero, letras b) o e)".

A la vista del precepto transcrito, se prevé la derogación de la prohibición para con respecto a las personas jurídicas sobre la base de la prueba documental aportada por el candidato o licitador, destinada a acreditar que se han adoptado las "medidas adecuadas" contra las personas con poderes de representación, decisión o control que han cometido dichas infracciones. Ahora bien, el Reglamento financiero no señala cuáles son esas medidas adecuadas, tam-

\footnotetext{
${ }^{896} \mathrm{El}$ Libro Verde sobre la modernización del mercado europeo de la contratación pública, avalaba esta posibilidad al indicar que "el artículo 45 permite a los Estados miembros tener en cuenta las medidas autocorrectoras (...). Sin embargo, no hay normas uniformes al respecto, aunque en algunos Estados miembros los poderes adjudicadores tienen en cuenta de todas formas las medidas tomadas por los operadores económicos para corregir la situación de exclusión", COM (2011) 15 final, de 27 de enero de 2011, pág. 57.

${ }^{897}$ Sobre la regulación de las medidas de 'self cleaning' en estos Estados miembros, puede consultarse la obra colectiva Self-Cleaning in Public Procurement Law, Ed. Carl Heymans, Colonia, 2009, y más en concreto, REIDLINGER, A., DENK, S. y STEINBACH, H., "Austria", págs. 33 - 50; PRIESS, H.-J., PÜNDER, H. y STEIN, R., "Alemania", págs. 51 - 100 y CLARICH, M. y GIORDANO, C.F., "Italia", págs. $101-117$.
} 
poco desarrolla los aspectos procedimentales, ni establece las reglas para su aplicación ${ }^{898}$.

Con la finalidad de delimitar más certeramente el contenido de los motivos de exclusión y también su excepción, el artículo 142 del Reglamento (UE) 1268/2012 $2^{899}$ titulado «Aplicación de los criterios de exclusión y duración de la exclusión», prevé que:

"Para determinar la duración de la exclusión y garantizar el cumplimiento del principio de proporcionalidad, la institución responsable tendrá en cuenta, en particular, la gravedad de los hechos, incluidas las repercusiones en los intereses financieros y la imagen de la Unión y el tiempo transcurrido, la duración y reiteración de la infracción y la intención o el grado de negligencia de la entidad en cuestión y las medidas tomadas por esta entidad para poner remedio a la situación".

Con arreglo a este artículo, las medidas de self-cleaning se tendrán en cuenta para decidir sobre la imposición de la prohibición de contratar y sobre su duración, e invocan la autorregulación en tanto que produce efectos jurídicos que los poderes públicos asumen o toman en consideración ${ }^{900}$. No obstante lo

${ }^{898}$ En este sentido, resultará de interés analizar la sentencia que tiene su origen en el recurso interpuesto el 19 de junio de 2015, en el asunto T-320/15, Impresa Costruzioni Giuseppe Maltauro/Comisión, basado en la falta de examen de la prueba documental aportada por Impresa Costruzioni Giuseppe Maltauro SpA durante la fase de instrucción del procedimiento de exclusión, destinada a acreditar que se habían adoptado las «medidas adecuadas» respecto de las actividades ilegales imputadas a un antiguo consejero delegado (DOUE C 254, de 3 de agosto de 2015).

${ }^{899}$ Reglamento Delegado (UE) 1268/2012 de la Comisión, de 29 de octubre de 2012, sobre las normas de desarrollo del Reglamento financiero, respecto de la aplicación de los criterios de exclusión y su duración (DOUE L 362, de 31 de diciembre).

${ }^{900}$ DARNACULLETA I GARDELLA, M., "La autorregulación y sus fórmulas (... )", op. cit., pág. 666 señala que "la utilización instrumental de la autorregulación por parte de los poderes públicos podría reportar incontables ventajas, especialmente en un contexto de progresiva responsabilización de los sujetos y organizaciones privadas respecto de la satisfacción de tradicionales fines públicos". Por su parte, GIRALDES GUTIÉRREZ apunta los Códigos de Buenas Prácticas como un instrumento de autorregulación, si bien señala que la autorregulación "puede conocer 
dicho, la regulación explicitada en el Reglamento financiero y sus normas de desarrollo adolece de concreción puesto que, insistimos en ello, no clarifican algunos conceptos y nociones clave para garantizar una cierta seguridad jurídica, ni determinan los instrumentos y medidas que deben habilitar la derogación de una prohibición de contratar ${ }^{901}$.

\section{B. Las acciones del operador económico que posibilitan su "reha- bilitación" en la participación en un procedimiento de adjudi- cación}

Con el fin de aportar seguridad jurídica, claridad expositiva y previsibilidad para las partes, las nuevas Directivas de contratación al incorporar las medidas de auto-limpieza a su articulado, establecen pautas respecto de las acciones que debe acometer un operador económico para participar en un procedimiento de contratación "pese a la existencia de un motivo de exclusión".

Estos requerimientos se formulan atendiendo a la experiencia acumulada en Austria y Alemania que, como hemos señalado, ya tenían reconocidos mecanismos de self-cleaning en la contratación pública con anterioridad al año $2014^{902}$. Su pretensión es la de establecer un régimen mínimo común en toda la UE que favorezca el objetivo de la prevención de irregularidades en la contratación pública mediante la adopción de mecanismos de autorregulación interna por parte de los operadores económicos, pues no en vano, recordemos que una de las razones principales para admitir las medidas de autocorrección está en forzar una cultura empresarial a favor del cumplimiento y contribuir con ello

una pluralidad de formas e instrumentos cuyos contornos se dejan en manos de las partes", en GIRALDES GUTIÉRREZ, L. S., "La autorregulación en el ámbito de la contratación pública. Análisis de las posibilidades de utilización que ofrece el nuevo marco jurídico comunitario y nacional", REDA, núm. 168, enero - marzo 2015, pág. 338.

${ }^{901}$ En la Propuesta de Reglamento por el que se modifica el Reglamento financiero para adaptar sus normas a las referentes a la contratación pública que se recogen en las nuevas Directivas, tampoco se concretan estos aspectos, COM (2014) 358 final, de 18 de junio de 2014 .

${ }^{902}$ PRIESS, H-J., "The rules on exclusion and self-cleaning under the 2014 Public Procurement Directive", Public Procurement Law Review, vol. 23(3), 2014, pág. 121. 
al objetivo de mantener la integridad y evitar distorsiones de la competencia en los procedimientos de adjudicación.

Así pues, la opción legislativa consiste en incentivar a aquellos licitadores o candidatos que adopten un papel activo en la prevención de comportamientos irregulares eximiéndolos de una de las consecuencias jurídicas de su conducta ímproba: la no participación en un procedimiento de adjudicación contractual.

Conforme a lo recogido en el artículo 57, apartado 6, párrafo segundo de la Directiva 2014/24/UE, el operador económico para no quedar excluido del procedimiento de adjudicación deberá demostrar:

- Que ha pagado o se ha comprometido a pagar la indemnización correspondiente por cualquier daño causado por la infracción penal o la falta;

- Que ha aclarado los hechos y circunstancias de manera exhaustiva colaborando activamente con las autoridades investigadoras y,

- Que ha adoptado medidas técnicas, organizativas y de personal concretas, apropiadas para evitar nuevas infracciones penales o faltas.

Del tenor literal de este párrafo se infiere tanto la imperatividad de las medidas a adoptar por el operador económico, como su carácter acumulativo. Ahora bien, conviene reseñar que su concurrencia no determina sin más la rehabilitación del candidato o licitador, ya que la decisión de no exclusión se evaluará "teniendo en cuenta la gravedad y las circunstancias particulares de la infracción penal o la falta" (artículo 57.6, párrafo tercero de la Directiva 2014/24/UE).

De cualquier modo, la recuperación de la fiabilidad operará si, al inicio del procedimiento de "rehabilitación", el operador económico puede demostrar que ha cumplido con las siguientes condiciones ${ }^{903}$ :

\section{B.1. Indemnización por los daños causados}

${ }^{903}$ Todas estas medidas han sido analizadas por PÜNDER, H., PRIESS, H.-J. y ARROWSMITH, S., Self-Cleaning in Public Procurement Law, Ed. Carl Heymans, Colonia, 2009, págs. $4-6$. 
Entre las medidas a adoptar por parte del operador económico se encuentra la de compensar el daño que ha infligido su comportamiento a través del pago de la indemnización que corresponda, por lo que parece sobreentenderse que la reparación que se requiere es únicamente de tipo pecuniario ${ }^{904}$. La idea que subyace es que se asuman las responsabilidades por los daños ocasionados, a la vez que se muestra cierto arrepentimiento por sus acciones que evite que éstas se vuelvan a cometer en el futuro.

Debemos destacar, no obstante, que la medida se limita a establecer una compensación por el daño causado y no contiene elementos que vayan más allá de este objetivo, como podrían ser restablecer la situación anterior (imaginemos daños medioambientales) o la recuperación de los beneficios obtenidos por la comisión de ciertos tipos delictivos. Por consiguiente, esta primera medida es únicamente de tipo compensatorio y no de reparación o restitución.

\section{B.2. Colaboración con el esclarecimiento de los hechos}

De esta acción se desprende la exigencia de un deber de cooperación activa en los procesos de investigación para esclarecer los hechos reprobables y depurar las posibles responsabilidades. En este caso, - y salvando las diferencias - la finalidad perseguida es similar a la pretendida con las declaraciones realizadas en el marco de un programa de clemencia por el cual se recompensa a las empresas involucradas en cárteles secretos que deciden poner fin a su participación y cooperan en la investigación de este tipo de prácticas ilegales.

Desde esta perspectiva, se trata de aportar elementos de prueba (documentos, declaraciones o informaciones) que ayuden a constatar una infracción del ordenamiento jurídico y que muestren la intención del operador económico en colaborar para que no vuelvan a repetirse.

\footnotetext{
${ }^{904}$ PRIESS, H.-J., PÜNDER, H. y STEIN, R., apuntan la existencia en Alemania de otro tipo de medidas compensatorias - aunque sean la excepción - y para ello ponen el ejemplo de la inserción de anuncios en los medios de comunicación, PRIESS, H.-J., PÜNDER, H. y STEIN, R., "Alemania (... )", op. cit., pág. 77.
} 


\title{
B.3. Adopción de medidas técnicas, organizativas y de personal
}

El sistema de self-cleaning tiene dos pilares fundamentales: que se corrijan las consecuencias de las infracciones penales o las faltas que el operador económico haya cometido, y evitar la continuidad de las conductas ilícitas. De esta manera, el operador económico podría ver rehabilitada su fiabilidad siempre que haya satisfecho una serie de condiciones.

Para una correcta interpretación de estas condiciones, debemos acudir al considerando centésimo segundo de la Directiva 2014/24/UE que indica que:

\begin{abstract}
“(.. ) podría tratarse de medidas que afecten al personal y la organización, como la ruptura de todos los vínculos con las personas u organizaciones que participaran en las conductas ilícitas, medidas adecuadas de reorganización del personal, implantación de sistemas de información y control, creación de una estructura de auditoría interna para supervisar el cumplimiento y adopción de normas internas de responsabilidad e indemnización".
\end{abstract}

Sin perjuicio de otros posibles modos de proceder, este considerando ejemplifica algunas posibles acciones del operador económico - pensado principalmente en una persona jurídica - para evitar su exclusión del procedimiento de adjudicación y distingue las medidas estructurales y de organización de las medidas referidas al personal. De modo sintético, vamos a seguir esta misma distinción.

\section{- Medidas técnicas y organizativas}

Hemos apuntado que lo que interesa al legislador es estimular al máximo la implementación de mecanismos de previsión y de prevención de actividades ilícitas. Por esa razón, adquiere mayor importancia la organización de un sistema preventivo y obligatorio de control del riesgo jurídico que vendría dado por los programas de cumplimiento - compliance program - (a modo de zanahoria) $)^{905}$.

\footnotetext{
${ }^{905}$ Puede resultar de gran interés la consulta a la numerosa bibliografía existente sobre la responsabilidad penal de las personas jurídicas y la importancia que están adquiriendo los sistemas de prevención de delitos o Corporate Compliance pa-
} 
En este sentido, sabemos que el operador económico no está obligado a verificar una «autolimpieza» después de estar incurso en cualquiera de las causas de exclusión, pero si se quiere impedir la aplicación de la prohibición de contratar, deberá demostrar que ha diseñado e implementado un programa de prevención de delitos o de cumplimiento normativo. Su objetivo es detectar y prevenir la perpetración de delitos o infracciones ad futurum realizados en el ámbito de su actividad o, por lo menos, reducir el riesgo de su comisión ${ }^{906}$.

La propia Directiva parece apuntar que resultan insuficientes las operaciones de simple mejora de la imagen empresarial, requiriéndose que dicho sistema sea adecuado para prevenir y/o descubrir las infracciones del ordenamiento jurídico que pudieran cometerse bajo la cobertura de la persona jurídica. El hecho de que la empresa se dote de un código de conducta/pacto de integridad/programa de cumplimiento puede, por tanto, no ser suficiente, ya que se exige el establecimiento de un sistema de cauces disciplinarios que sancione el incumplimiento de las medidas de prevención ${ }^{907}$.

ra atenuar e, incluso, exonerar de responsabilidad penal a las personas jurídicas. Ello tendría virtualidad, incluso para impedir la condena penal habilitadora de una prohibición de contratar. A título de ejemplo, puede consultarse NIETO MARTÍN, A., La responsabilidad penal de las personas jurídicas: Un modelo legislativo, Iustel, Madrid, 2008; BACIGALUPO ZAPATER, E., Compliance y Derecho Penal, Aranzadi, Cizur Menor (Navarra), 2011.

${ }^{906}$ En el Capítulo tercero de esta memoria doctoral ya hemos aludido al caso de la empresa alemana Siemens que sorteó una prohibición de contratar tras llegar a un acuerdo con el Banco Mundial y declararse culpable del pago de sobornos para obtener ventajas sobre las otras empresas competidoras en la obtención de contratos en el extranjero. Acordó pagar una multa y a partir de este momento (año 2008) elaboró un Plan Anticorrupción y lanzó su Iniciativa de Integridad que ha servido de modelo para otras empresas http://w5.siemens.com/spain/web/es/home/corporacion/compliance/Documents/BCG_ES.pdf [Fecha de consulta: 15 de octubre de 2015].

${ }^{907}$ En el Decálogo de reglas para prevenir la corrupción en los contratos públicos, GIMENO FELIÚ señalaba certeramente que "la integridad y su prevención no debe abordarse de marera unidireccional", que el sector empresarial debía dar un paso al frente en esta misma dirección. Es así que "Los medios de "legal compliance" pueden ayudar a la necesaria revalorización social del concepto de ética empresarial así como la puesta en valor de la responsabilidad corporativa", publicado en el Observatorio de Contratación Pública (12 de noviembre de 2014). http://www.obcp.es/ [Fecha de consulta: 15 de octubre de 2015]. 
En este sentido, se requiere instituir un sistema de control interno encarnado en la figura de un supervisor (compliance officer) que tenga encomendadas funciones de verificación del cumplimiento de las medidas de prevención. No se ve, sin embargo, la necesidad de articular un sistema de denuncias internas en las empresas (mecanismos de whistleblowing), si bien su implantación puede ser un indicativo del compromiso empresarial con la erradicación de las irregularidades en la empresa ${ }^{908}$.

En este mismo apartado - y aunque no se mencione por parte de la Directiva -también pudiera resultar de interés implementar acciones formativas con respecto al cumplimiento normativo y, por lo que nos interesa, con respecto a la legislación penal, de contratación pública y de defensa de la competencia ${ }^{909}$.

\section{- Medidas relativas al personal}

La responsabilidad penal de las personas jurídicas resulta exigible siempre que se constate la comisión de un delito por quien ostente cargos o funciones sometidas a la jerarquía empresarial. Dado que, como ya hemos señalado, la persona jurídica puede devenir responsable de la infracción penal - y, por tanto excluida del procedimiento de contratación - como consecuencia de su vinculación con el individuo que la comete, la Directiva exige que se adopten medidas respecto de su continuidad en la empresa, de tal manera que el operador económico/persona jurídica debe garantizar que todas las personas que han participado en el delito o en la infracción se desvinculan de ella y no puede ejercer influencia alguna en su gestión.

El artículo 57.1 in fine de la Directiva 2014/24/UE establece que "la obligación de excluir a un operador económico se aplicará también cuando el conde-

\footnotetext{
${ }^{908} \mathrm{La}$ denuncia de irregularidades se diseña como un mecanismo adicional para que los empleados informen de malas conductas de manera interna a través de un canal específico. El sistema permitiría la denuncia de "comportamientos, acciones o hechos que puedan constituir violaciones tanto de las normas internas de la compañía como de las leyes, normativas o códigos éticos" que rigen su actividad. Sobre esta materia, resulta de interés RAGUÉS I VALLÉS, R., Whistleblowing. Una aproximación desde el Derecho Penal, Marcial Pons, Madrid, 2013.

${ }^{909}$ PÁLENÍKOVÁ, L., "Corruption in public tenders. Concept of self-cleaning", Anali Pravnog fakulteta Univerziteta u Zenici (Annals of the Faculty of Law - University of Zenica), vol. 9, 2012, pág. 279 y ANDERSEN, S.M., Self-cleaning $i$ det nye anskaffelsesdirektivet, Master Thesis, University of Oslo, 2014, pág. 7
} 
nado mediante sentencia firme sea un miembro del órgano de administración, de dirección o de vigilancia del operador económico o tenga poderes de representación, decisión o control en el mismo".

En virtud de lo expuesto, el cese o dimisión de estos sujetos puede liberar a la persona jurídica de la prohibición de contratar. Obsérvese que como presupuesto para atribuir responsabilidad penal a la persona jurídica es necesario que la vigencia del cargo o representación se refiera al momento de la actuación penada; y que para quedar exonerada de la prohibición de contratar como una de las consecuencias del delito - será necesario el cese de los administradores o representantes una vez concluido el proceso penal y después de la sentencia condenatoria.

En la regulación española, y a pesar del sentido gramatical, se ha interpretado que se exonera a la persona jurídica de la prohibición de contratar si el cargo o representación no está vigente en el momento de la comisión del delito $^{910}$. Así:

"La prohibición de contratar alcanza a las personas jurídicas cuyos administradores o representantes, vigente su cargo o representación, se encuentren en la situación mencionada por actuaciones realizadas en nombre o a beneficio de dichas personas jurídicas, o en las que concurran las condiciones, cualidades o relaciones que requiera la correspondiente figura de delito para ser sujeto activo del mismo" 911 (artículo 60.1.a) TRLCSP). [El subrayado es nuestro].

${ }^{910}$ Tanto en las sentencias del TS de 4 de octubre de 2005 (RJ 2005\8752), como en la 11 de noviembre de 2003 (RJ 2003\8060) se advertía "del peor derecho a los contratistas individuales frente a las personas jurídicas" y de una diversidad de tratamiento jurídico, que no se justifica, entre los empresarios individuales y las personas jurídicas, "toda vez que para aquéllos una vez declarada la suspensión o la prohibición de contratar perduraría por todo el tiempo marcado, mientras que para las personas jurídicas (para actuaciones de sus administradores o representantes), la prohibición, o la suspensión, desaparecerían una vez que cesaran en sus cargos, lo que proporcionaría a aquéllos una mejor condición, sin que haya razón objetiva alguna que justifique esa diversidad de tratamiento".

${ }^{911}$ Esta previsión se incorporó a la legislación contractual española con ocasión de la aprobación de la Ley 9/1996, de 15 de enero, de medidas extraordinarias, excepcionales y urgentes de abastecimiento de aguas como consecuencia de la persistencia 


\section{El ámbito de aplicación de las medidas de self-cleaning}

La posibilidad de que los operadores económicos adopten medidas de autolimpieza y recuperar así el derecho a participar en un procedimiento de adjudicación contractual no se prevé para todas las causas de prohibición de contratar, antes al contrario, se circunscribe a las recogidas en los apartados 1 y 4 del artículo 57 de la Directiva 2014/24/UE ${ }^{912}$. Es preciso, pues, examinar su ámbito de aplicación y lo haremos desde una perspectiva negativa.

En primer lugar, se observa que quedan al margen los supuestos de incumplimiento de las obligaciones tributarias o cotizaciones a la seguridad social que, como hemos visto, cuentan con su propio sistema de corrección al reconocerse por el legislador europeo la no aplicación de una prohibición de contratar cuando el candidato o licitador efectúe el pago de sus obligaciones o celebre "un acuerdo vinculante con vistas al pago de los impuestos o las cotizaciones a la seguridad social que adeude, incluidos en su caso los intereses acumulados o las multas impuestas" (artículo 57.2 párrafo tercero de la Directiva 2014/24/UE).

En segundo lugar, somos de la opinión que no todas las situaciones previstas en el apartado cuarto del artículo 57, es decir las «prohibiciones de contratar de carácter facultativo», son susceptibles de encajar en la posibilidad de que el operador económico presente pruebas que demuestren su fiabilidad. A pesar de la declaración genérica del artículo 57.6 primer párrafo en favor de tal facultad, entendemos que las medidas de self-cleaning están pensadas, principalmente,

de la sequía, que modificaba en este aspecto el apartado a) del artículo 20 de la Ley 13/1995, de 18 de mayo, de Contratos de las Administraciones Públicas. En aquel momento, desde los medios de comunicación se apuntaba la posibilidad de que se designaran "cabezas de turco" de segunda fila para eliminar responsabilidades de las empresas (Noticia de El País de 30 de noviembre de 1995, pág. 53) e incluso, el Abogado del Estado en la contestación a la demanda en el caso que dio lugar a la citada STS de 4 de octubre de 2005 indicaba que el cese en la condición de administrador de quien es condenado "constituye una clara evidencia de la intención torticera de la empresa adjudicataria de evitar con dicho cese (...) incurrir en la prohibición para contratar «ex» art. 20.a) de la LCAP".

${ }^{912}$ También en los apartados 4 y 7 del artículo 38 de la Directiva 2014/23/UE («concesiones»). En la Propuesta de Directiva sobre contratación pública en todos los motivos de exclusión se contemplaban la posibilidad de aplicar medidas de selfcleaning, COM (2011) 896 final, de 20 de diciembre. 
para remediar la exclusión del candidato o licitador del procedimiento de adjudicación cuando ésta proviene de una condena penal, de una sanción administrativa o de una resolución administrativa previa. El propio considerando centésimo segundo parece así confirmarlo al referirse a la adopción de medidas de cumplimiento "destinadas a reparar las consecuencias de las infracciones penales o las faltas que hayan cometido y a prevenir eficazmente que vuelvan a producirse conductas ilícitas".

No obstante ello, conviene analizar también los siguientes motivos de exclusión: (i) los que surgen por la existencia de un conflicto de intereses o por la participación previa de los operadores económicos en la preparación del contrato; (ii) los que derivan de las pruebas e indicios de los que dispone el poder adjudicador ( se basan en falsedades. Queda al margen la referencia a las causas económicas y financieras, puesto que ya hemos comentado que la misma Directiva 2014/24/UE - al margen de las medidas de self-cleaning - prevé la posibilidad de que el poder adjudicador no excluya a un operador económico que se encuentre en una situación de insolvencia o liquidación, si ha comprobado que ese operador económico va a estar en condiciones de ejecutar el contrato (artículo 57.4 in fine).

En lo que se refiere a los conflictos de intereses y la participación previa en la preparación del contrato, la prohibición de contratar se establece como última opción, es decir, cuando no existen otros mecanismos menos restrictivos para garantizar la imparcialidad en la elección del contratista ${ }^{913}$. En base a ello, entendemos que si existieran medidas alternativas se hubieran utilizado antes de llegar a declarar una prohibición de contratar y ya no tendría sentido hablar de «auto-limpieza».

En el supuesto de que sea el poder adjudicador el que demuestre los incumplimientos habilitadores de una prohibición de contratar sin que exista una condena o una sanción previa (letras a), c) y d) del artículo 57.4), parece un contrasentido que sea este mismo órgano - si así se determina en la legislación nacional - el que evalúe las pruebas aportadas por el operador económico pa-

\footnotetext{
${ }^{913}$ En este sentido, las Directivas exigen que el poder adjudicador tome las medidas adecuadas para prevenir, detectar y poder remedio a estos conflictos (artículos 24 y 41 de la Directiva 2014/24/UE).
} 
ra su "rehabilitación" posterior" ${ }^{914}$. Entendemos que el poder adjudicador no puede sustraerse de su previa valoración y actuará de conformidad con sus propias apreciaciones fácticas. La única excepción a lo dicho podría producirse con ocasión de contemplar la no aplicación de una prohibición de contratar a aquellas empresas que se hayan beneficiado del programa de clemencia previsto en la normativa de defensa de la competencia.

Por último, aceptar la derogación de una prohibición de contratar basada en la información engañosa aportada por el operador económico conllevaría entrar en una hipotética permanente falta de confianza, puesto que no se trata de un olvido ${ }^{915}$. La necesidad de avanzar en la descarga burocrática que supone la aceptación de una declaración responsable por parte del licitador o candidato respecto del cumplimiento de los requisitos para contratar se basa en la confianza en los operadores económicos. A una mayor confianza del órgano de contratación debiera corresponder un mayor compromiso a favor de la lealtad documental por parte del operador económico, de tal manera que si ésta quiebra se fractura el equilibrio de esta ecuación ${ }^{916}$.

La aceptación de una posterior - vamos a denominarla así - declaración de arrepentimiento para renovar la confianza perdida ante el descubrimiento de la información "capciosa"917, sería como primar la inacción del poder adjudicador

\footnotetext{
${ }^{914}$ Recordemos que las causas de prohibición de contratar del apartado 4 son de carácter dispositivo para los Estados miembros, pero que en atención al tenor literal de esta norma también resultan potestativos para los poderes adjudicadores que podrán - o no - excluir de la participación en un procedimiento de contratación a quienes se encuentren incurso en alguna de las circunstancias referenciadas.
}

${ }^{915} \mathrm{El}$ artículo 57.4.letra i) de la Directiva 2014/24/UE dispone que "los poderes adjudicadores podrán excluir a un operador económico de la participación en un procedimiento de contratación (...) cuando el operador económico haya intentado (....) proporcionar negligentemente información engañosa que pueda tener una influencia importante en las decisiones relativas a la exclusión, selección o adjudicación".

${ }^{916}$ Es necesario hacer constar que no estamos tratando los supuestos de falsificación documental o de manipulación de certificados que se acreditan mediante sentencia judicial o resolución administrativa firme.

${ }^{917}$ Utilizamos el adjetivo capcioso, porque lo cierto es que, aunque la Directiva nos hable de negligencia y no de dolo, las distintas versiones lingüísticas de este artículo nos aportan una variedad de términos que denotan en todos los casos la intencionalidad del operador económico en falsear los requisitos o en ocultar los impedi- 
ante un ataque directo a su confianza. Aun suponiendo que esta declaración de arrepentimiento pueda estimarse, lo cierto es que pone de manifiesto una desnaturalización del objetivo de la declaración responsable del licitador o candidato $^{918}$.

Por último, una tercera excepción a la aplicación general de las medidas de self-cleaning para todos los supuestos de prohibición de contratar la encontramos en el último párrafo del artículo 57.6 de la Directiva 2014/24/UE al disponer que:

Los operadores económicos que hayan sido excluidos por sentencia firme de la participación en procedimientos de contratación o de adjudicación de concesiones no tendrán derecho a acogerse a la posibilidad prevista en el presente apartado durante el período de exclusión resultante de dicha sentencia en el Estado miembro en el que la sentencia sea ejecutiva.

El tenor literal de este precepto nos lleva a tratar dos cuestiones. La primera se refiere a la preeminencia de la inhabilitación penal frente a la prohibición de contratar administrativa, y la segunda alude al principio de reconocimiento mutuo de las resoluciones judiciales.

Por lo que se refiere a las penas privativas o restrictivas de derechos, ya se ha puesto de relieve en esta memoria doctoral que, aunque los efectos son similares, debemos distinguir la pena de prohibición de contratar impuesta por los tribunales de justicia y la prohibición de contratar establecida desde

mentos para poder contratar. Estos términos son los siguientes: misleading information (inglés); informações erróneas (portugués); informazioni fuorvianti (italiano); irreführende Informationen (alemán); informations trompeuses (francés); informatii false (rumano).

${ }^{918}$ Sobre la declaración responsable tratan las páginas - de esta memoria doctoral en referencia al Documento europeo único de contratación y, en ellas, ya señalábamos la importancia de establecer por parte del órgano de contratación un modelo de documento en el que, además de autorizar al órgano de contratación a recabar cuanta información fuera necesaria para comprobar la veracidad de las declaraciones realizadas, el licitador o candidato asumiera expresamente las consecuencias que pudieran derivarse de la inexactitud o falsedad de los datos aportados. 
órganos administrativos por aplicación de la normativa contractual ${ }^{919}$.

Las penas de inhabilitación en el supuesto de las personas físicas y la pena de prohibición de contratar para las personas jurídicas se establecen como respuesta punitiva a la comisión de determinadas conductas delictivas ${ }^{920}$, mientras que las prohibiciones de contratar son medidas diseñadas desde la regulación administrativa para proporcionar un incentivo adicional a favor del cumplimiento normativo y contractual y que se aplican tanto a personas físicas como jurídicas. Es cierto que una serie de supuestos de prohibición de contratar se vinculan a la condena del operador económico mediante sentencia judicial firme, pero ésta, necesariamente, no tiene porqué llevar aparejada una pena de inhabilitación ${ }^{921}$.

Por esa razón, este precepto contempla el hecho de que si existe una inhabilitación por sentencia judicial del operador económico, éste no puede pretender su rehabilitación ante los órganos administrativos del Estado que la impone durante el período de exclusión que resulta de dicha sentencia. Salvando las diferencias entre instituciones jurídicas, podemos afirmar que no es posible "un indulto" en tanto que no cabe la injerencia del poder ejecutivo en la actuación

${ }^{919}$ Recordemos que en el Estudio Procurement and organised crime: an EU wide study, se presentaban las diferencias entre Estados miembros respecto de los órganos con competencia para poder excluir a un operador económico de la contratación pública y diferenciaban tres mecanismos: a) sólo a través de resoluciones judiciales; b) por parte de órganos administrativos y c) mediante una variedad de procedimientos posibles, en WHITE, S. (Ed.), Procurement and organised crime: an EU wide study, Institute of Advanced Legal Studies, Londres, 2000, pág. 16.

${ }^{920}$ A título de ejemplo, vamos a remitirnos al Código penal francés que expresamente contemplan estas penas en su articulado. Así, el artículo 131-6, apartados 11 y 15, se refieren a l'interdiction d'exercer une activité professionnelle, une profession commerciale ou industrielle para las personas físicas y el artículo 131-39, apartado 5, contempla para las personas jurídicas "L'exclusion des marchés publics à titre définitif ou pour une durée de cinq ans au plus". El legislador español también prevé la pena de prohibición de contratar en el catálogo de penas susceptibles de ser impuestas a las personas jurídicas (artículo 33.7.f) del Código penal). Hemos tratado de ello en las páginas 112 y siguientes de esta memoria doctoral.

${ }^{921}$ Ya ha sido destacado en otro apartado de esta memoria doctoral, pero la práctica nos muestra que son muy pocas las ocasiones en las que la sentencia condenatoria dota de contenido específico a la pena de inhabilitación profesional y se limitan a hacer una declaración sobre su existencia. 
del poder judicial.

En consecuencia, el alcance de las medidas de self-cleaning en la contratación pública se circunscribe a las prohibiciones establecidas en procedimientos administrativos, aunque éstas puedan derivar de una previa condena penal, puesto que los poderes adjudicadores estarán vinculados a lo acordado en la sentencia condenatoria, dada la situación de hegemonía de lo dispuesto por los tribunales penales sobre otras manifestaciones del Derecho y que nadie, sin que medie una medida de gracia, puede sustraerse de acatar las resoluciones judiciales.

La segunda cuestión a tratar versa sobre los efectos de una condena de inhabilitación impuesta en un Estado miembro y su reconocimiento por el resto de Estados. Ya se ha indicado que el principio de reconocimiento mutuo de las resoluciones judiciales se apoya en la equivalencia y confianza entre los Estados miembros y supone que, una vez adoptada una resolución por una autoridad judicial de un Estado miembro, ésta será automáticamente aceptada y reconocida en los demás Estados y surtirá en ellos similares efectos al del Estado en que se adoptó ${ }^{922}$.

Ahora bien, de los propios términos de la disposición citada, resulta que la propia Directiva es la que limita el reconocimiento de la sentencia, de tal manera que la inhabilitación judicial únicamente va a surtir efectos "en el Estado miembro en el que la sentencia sea ejecutiva”. Por lo que ahora nos interesa, esta aseveración nos lleva a concluir que la sentencia de inhabilitación sólo tiene efectos en el Estado que la impone, aun cuando a nuestro entender agotada la acción penal en un Estado miembro, los demás no debieran ignorar este hecho ${ }^{923}$. Al negar la recíproca aceptación de las resoluciones judiciales,

\footnotetext{
${ }^{922}$ Resultan de escasa operatividad práctica alguna de las consideraciones recogidas en el Libro Blanco relativo al intercambio de información sobre condenas penales y al efecto de éstas en la Unión Europea, COM (2005) 10 final, de 25 de enero de 2005 o en la Comunicación de la Comisión sobre el reconocimiento recíproco de las resoluciones judiciales en materia penal y el fortalecimiento de la confianza mutua entre los Estados miembros, COM (2005) 195 final, de 19 de mayo de 2005.

${ }^{923}$ Con acierto, GUTIÉRREZ CASTAÑEDA advierte que el proceso de establecimiento del sistema de reconocimiento mutuo de resoluciones ha experimentado escasos avances reales que vayan más allá de señalar la necesidad de su implantación. GUTIÉRREZ CASTAÑEDA, A., Las penas privativas de derechos (...), op.
} 
nada impide que un inhabilitado judicial para ser contratista (por ejemplo, en Francia que expresamente reconoce la pena de prohibición de contratar a las personas jurídicas por la comisión de ciertos delitos) pudiera hacer uso de los mecanismos de self-cleaning para poder licitar en otro Estado miembro y, una vez verificada su aptitud para ejecutar el contrato, llegar incluso a ser contratista si presenta la oferta económicamente más ventajosa ${ }^{924}$.

De esta manera, a la dificultad ya manifestada de reconocer una prohibición de contratar más allá de las fronteras nacionales, se añade ahora la de cuestionar su eficacia aun cuando haya sido impuesta por los tribunales de justicia. No se trata de caer en comentarios populistas favorables a una idea represora de las prohibiciones de contratar, pero sí en dar a entender que aun no reconociéndose responsabilidad penal a las personas jurídicas en todos los Estados miembros, las disposiciones de las Directivas sobre contratación pública - al aplicarse tanto a las personas físicas como jurídicas - debieran ayudar a crear un verdadero espacio de justicia más allá de las fronteras nacionales.

\section{Un posible procedimiento de "rehabilitación"}

La adopción de medidas de cumplimiento por parte del licitador o candidato puede suponer el restablecimiento de la confianza perdida por haber incurrido éste en una causa de prohibición de contratar. Ahora bien, existe el riesgo de considerar que la mera formalización de estas medidas constituye un salvoconducto para eludir la exclusión del procedimiento de contratación, cuando en realidad no es así. Es preciso el desarrollo de un procedimiento administrativo, al final del cual se dicta el acuerdo que declara o deniega la "rehabilitación" del operador económico, y por tanto, se le admite o no a tomar parte en un procedimiento de contratación ${ }^{925}$.

cit., págs. 249 y 250.

${ }^{924}$ Recordemos que con la aceptación de las medidas de self-cleaning la persona jurídica quedaría "liberada" de la prohibición si ha adoptado y ejecutado eficazmente un modelo de organización y gestión que resulte adecuado para prevenir delitos o para reducir de forma significativa el riesgo de su comisión.

${ }^{925}$ Recordemos que al hablar de rehabilitación nos referimos al hecho de restituir al operador económico en la posibilidad de participar en un procedimiento de adjudicación contractual. 
A este respecto, la Directiva encomienda a los Estados miembros la evaluación de las medidas de self-cleaning y, tal como señala el ya citado considerando centésimo segundo de la Directiva 2014/24/UE, deja “a los Estados miembros que determinen las condiciones exactas de fondo y de procedimiento aplicables en dichos casos" ${ }^{\prime 26}$.

A pesar de ser los Estados miembros quienes ostentan la competencia tanto para establecer un posible procedimiento de rehabilitación como para determinar cuál va a ser el órgano encargado de su apreciación, encontramos en la Directiva elementos de armonización que anticipan una cierta uniformidad en cuanto a su plasmación en los ordenamientos jurídicos nacionales.

Entre estos elementos vamos a destacar los siguientes:

- El levantamiento de la prohibición de contratar se debe sustanciar a través de un procedimiento administrativo que finalice con un acto en el que se acuerda - o no - la admisión del operador económico en el procedimiento de contratación;

- El procedimiento se iniciará a instancia de parte. Entendemos que se trata de un procedimiento a instancia de parte interesada, y no de oficio, por dos razones. El operador económico es quien está interesado en evitar el efecto negativo que conlleva su exclusión del procedimiento de licitación y, en segundo lugar, porque el poder adjudicador está obligado a la exclusión del operador económico cuando existe una resolución por la que se acuerda la prohibición de contratar. Sólo puede excepcionar su aplicación cuando el ordenamiento jurídico lo posibilita y atendiendo a las condiciones estipuladas;

- Es al operador económico a quien le corresponde demostrar que ha adoptado medidas de cumplimiento, o lo que es lo mismo, la carga de la prueba acerca de la existencia de determinados estándares de prevención de irregularidades recae en el candidato o licitador;

- Para una valoración positiva de tales medidas, las pruebas aportadas por el operador económico deben ofrecer "garantías suficientes" de que cier-

${ }^{926}$ También el considerando septuagésimo primero de la Directiva 2014/23/UE («concesiones»). 
tamente contribuyen a esclarecer conductas irregulares pasadas, reparar sus consecuencias y a prevenir otras futuras ${ }^{927}$. En este sentido, como ya se ha indicado anteriormente, no es suficiente la adopción formal de programas de cumplimiento/pactos de integridad/códigos éticos, sino que se requiere garantizar un verdadero compromiso hacia conductas intachables que, en último extremo, sirvan para recuperar la credibilidad en el operador económico;

- Sin entrar, por el momento, a analizar quién debe ser el órgano que valore estas pruebas, cabe indicarse que la Directiva obliga a su evaluación "teniendo en cuenta la gravedad y las circunstancias particulares de la infracción penal o la falta" (artículo 57.6, párrafo tercero de la Directiva 2014/24/UE);

- Los derechos del operador económico en este procedimiento se garantizan a través de la exigencia de motivación de la resolución por la cual se desestima la pretensión de admisión realizada por el operador económico. Se entiende, entonces que las pruebas aportadas no han sido adecuadas para proceder a su rehabilitación, ya que de ofrecer garantías suficientes "se debe dejar de excluir al operador económico de que se trate" tal como se desprende del considerando centésimo segundo de la Directiva $2014 / 24 / \mathrm{UE}^{928}$.

Así pues, las cuestiones a examinar respecto de este procedimiento serán las relativas al régimen jurídico aplicable a la solicitud del operador económico sobre la aceptación de sus medidas de self-cleaning determinando: (i) el momento en el que debe iniciarse el procedimiento, (ii) la documentación a presentar,

\footnotetext{
${ }^{927}$ Volvemos a señalar que, en nuestra opinión, la incorporación de estas medidas a la normativa contractual obedece a consideraciones fundamentalmente utilitaristas y de oportunidad política en favor de incentivar conductas acordes con la promoción del cumplimiento normativo y la lucha contra la delincuencia económica. Si no cumplen esa función, su razón de ser quedaría en entredicho.

${ }^{928}$ Insistimos en la idea, ya manifestada, de que los considerandos de una Directiva carecen en sí mismos de valor jurídico vinculante, pero contribuyen a la interpretación de la norma, como bien señala el TJUE en sus sentencias de 19 de junio de 2014, Karen Millen Fashions, C-345/13, apartado 31 y de 11 de abril de 2013, Oreste Della Rocca, C-290/12, apartado 38.
} 
(iii) el órgano que entendemos competente para resolver y, por último, (iv) los efectos de la resolución. No obstante, conviene recordar que, las Directivas no contienen previsiones expresas ordenadoras de ningún procedimiento, sino que son los Estados miembros los que tienen que determinar las condiciones de aplicación de estos preceptos. Por esa razón, entendemos que un adecuado análisis de este apartado aconseja acudir también a la legislación de alguno de los Estados miembros que ya tiene regulada esta materia en su normativa interna.

\section{D.1. Inicio del procedimiento}

La solicitud de rehabilitación es de carácter voluntario para el operador económico y trata de evitar una situación desfavorable que afecta a su no admisibilidad en un procedimiento de adjudicación contractual. Es, por tanto, el operador económico cuestionado quien debe solicitar el inicio del procedimiento.

Respecto de cuándo dar inicio al procedimiento se pueden valorar distintas opciones, aunque todas ellas pasan por la condición previa de "la existencia de un motivo de exclusión" en el operador económico, tal como exige el artículo 57.6 de la Directiva 2014/24/UE.

No obstante, advertida la existencia de un motivo de exclusión, tendremos que diferenciar si el operador económico ha sido, o no, declarado incurso en prohibición de contratar y, en este sentido, si la declaración de prohibición de contratar requiere un procedimiento específico determinando su existencia, alcance y duración ${ }^{929}$ o si se aprecia de forma automática por parte del órgano de contratación (por ejemplo, si está afectado por una incompatibilidad).

Como ya hemos tenido ocasión de señalar con anterioridad, si el operador económico no ha sido declarado incurso en prohibición de contratar, aunque

\footnotetext{
${ }^{929} \mathrm{No}$ es el caso de la prohibición de contratar impuesta como pena por una sentencia judicial firme que establezca la duración de la pena de inhabilitación, ya que la Directiva expresamente señala que "Los operadores económicos que hayan sido excluidos por sentencia firme de la participación en procedimientos de contratación o de adjudicación de concesiones no tendrán derecho a acogerse a la posibilidad prevista en el presente apartado durante el período de exclusión resultante de dicha sentencia en el Estado miembro en el que la sentencia sea ejecutiva".
} 
concurra en él un motivo de exclusión de los previstos en los apartados 1 y 4 del artículo 57 de la Directiva 2014/24/UE, puede seguir contratando con cualquier entidad del sector público ${ }^{930}$, puesto que en puridad, la imposibilidad de contratar con una entidad del sector público deriva de la declaración de una prohibición de contratar que es la consecuencia de hallarse el operador económico en alguna de las circunstancias previstas en la normativa contractual $^{931}$.

Si éste ha sido declarado incurso en prohibición de contratar, el poder adjudicador está obligado a aplicarla y, por tanto, a excluir al operador económico del procedimiento de adjudicación. En este supuesto, entendemos que notificada al operador económico la resolución por la cual se le excluye de un procedimiento de adjudicación concreto, éste podría recurrirla (recurso contra el acuerdo de exclusión) y al interponer el recurso instando la anulación de la exclusión, podría solicitar subsidiariamente su rehabilitación en atención a las pruebas de self-cleaning que aportase.

A pesar de esta posibilidad, otra opción nos lleva a pensar que la rehabilitación debiera solicitarse antes de que surta efecto la resolución por la que se declara la prohibición de contratar; es decir, con ocasión del procedimiento de su declaración - y ante el órgano que tenga atribuida la competencia para adoptar la resolución y, de esta manera, impedir que despliegue efectos jurídicos ${ }^{932}$.

${ }^{930}$ En la STS de 18 de mayo de 2011 (RJ 2011 \4440), se hacía constar que "la prohibición de contratar ha de imponerse con sumo cuidado tras un exquisito procedimiento administrativo y en función, estrictamente, del resultado, adecuadamente ponderado, que arrojen las pruebas practicadas, ya que no es dable admitir que la Administración pueda ejercitar una potestad, que afecta a la capacidad de una empresa para intervenir en la contratación pública, y que le priva por tanto de un derecho, a su libre decisión y sin una prueba objetivamente convincente" (FJ 6).

${ }^{931}$ A nuestro juicio, y tal como ya hemos indicado, ésta es una de las mayores burlas del sistema en cuanto a resultar una verdadera " arma poderosa para castigar y también, en cierta medidas, impedir los comportamientos empresariales ilícitos" (Libro Verde sobre la modernización del mercado europeo de la contratación pública, COM (2011) 15 final, de 27 de enero de 2011, pág. 56). Si las entidades del sector público no dan inicio a los procedimientos de declaración de prohibición de contratar no surtirán efectos, aunque los licitadores o candidatos incurran en causas de prohibición de contratar, y en último extremo, éstas resultaran inoperativas.

${ }^{932}$ En el caso de la legislación española, el artículo 61 bis, apartado 3 del TRLCSP 


\section{D.2. La documentación a aportar por parte del operador económico}

La rehabilitación debe solicitarse en base a las pruebas objetivas que pueda aportar el operador económico para demostrar de forma suficiente, inequívoca y convincente su fiabilidad enervando de este modo la presunción en contra que deriva de la existencia de una causa de prohibición de contratar. Para determinar cuál es la documentación a presentar tenemos que partir de lo dispuesto en la propia Directiva cuando señala que éstas han de ser "suficientes para demostrar su fiabilidad" y que, a tal efecto como prueba pertinente "el operador económico deberá demostrar que ha pagado o se ha comprometido a pagar la indemnización correspondiente por cualquier daño causado por la infracción penal o la falta, que ha aclarado los hechos y circunstancias de manera exhaustiva colaborando activamente con las autoridades investigadoras y que ha adoptado medidas técnicas, organizativas y de personal concretas, apropiadas para evitar nuevas infracciones penales o faltas" (artículo 57.6 párrafo tercero de la Directiva 2014/24/UE).

En ese supuesto, la carga de la prueba recae en el operador económico quien ha de demostrar que ha cumplido con las condiciones expuestas. No obstante - y puesto que el precepto citado guarda silencio a este respecto - no vemos inconveniente para que el operador económico aporte, a mayores, otras pruebas adicionales para cumplir la carga de la prueba que recae sobre él ${ }^{933}$.

Una vez presentada la solicitud junto con las pruebas documentales, el efecto inmediato debiera ser la suspensión de la prohibición de contratar - en el supuesto de que ésta se hubiera declarado - hasta que se produzca el correspondiente pronunciamiento sobre la rehabilitación del operador económico,

dispone que "las prohibiciones de contratar contempladas en las letras a) y b) del apartado primero del artículo 60 producirán efectos desde la fecha en que devinieron firmes la sentencia o la resolución administrativa en los casos en que aquélla o ésta se hubieran pronunciado sobre el alcance y la duración de la prohibición. En el resto de supuestos, los efectos se producirán desde la fecha de inscripción en el registro correspondiente".

${ }^{933}$ En un momento anterio, hemos advertido de la posibilidad de que en el formulario normalizado del Documento europeo único de contratación se registrase toda la información relacionada con los operadores económicos en situación de exclusión, pero también las medidas de cumplimiento adoptados por éstos, con el fin de aportar información suficiente al órgano de contratación para que valore si contratar con ese licitador o candidato supone - o no - un riesgo para los intereses públicos. 
para evitar así un perjuicio irreparable como consecuencia de su inmediata aplicación ${ }^{934}$.

\section{D.3. La valoración de las pruebas aportadas}

Las valoración positiva de las pruebas que han sido aportadas al procedimiento de rehabilitación debe basarse en si éstas presentan garantías suficientes para recobrar la confianza perdida, puesto que la Directiva estipula que cuando las medidas de cumplimiento "ofrezcan garantías suficientes", se debe dejar de excluir al operador económico de que se trate (artículo 57.6 párrafo primero de la Directiva 2014/24/UE).

A nuestro juicio, el órgano que tiene que resolver cuenta con un margen de apreciación suficiente para permitirle actuar con la flexibilidad necesaria según las circunstancias de cada caso y atendiendo siempre a la conveniencia para el interés público. No obstante, la admisión de esta facultad discrecionalidad se encuentra limitada ante la necesidad de tener en cuenta, en todo caso, "la gravedad y las circunstancias particulares de la infracción penal o la falta", tal como preceptúa la propia Directiva.

Venimos afirmando que las medidas de self-cleaning pretenden reestablecer la fiabilidad de un operador económico, y en este sentido, el legislador entiende - con buen criterio - que la evaluación no debe hacerse en abstracto, sino en relación directa con la conducta que se pretende rectificar. De esta manera, se incorporan a la valoración elementos de equidad como son la gravedad de los hechos y las circunstancias en las que las conductas reprochables fueron cometidas, atendiendo en último extremo, a la magnitud del perjuicio causado a los intereses generales y al erario público.

Pese a no mencionarse en el texto de la Directiva, creemos que también se tendrían que tener en cuenta otros factores que pudieran ser los siguientes: (i) el lapso de tiempo transcurrido entre la realización de las conductas habilitadoras de la prohibición de contratar y el momento en el que se van a aplicar. No se trata, sin embargo, únicamente de una cuestión de iter temporal, ya que, evidentemente, pueden discurrir varios años hasta llegar a una

\footnotetext{
${ }^{934}$ Pensemos, por ejemplo, que en el caso español, han existido prohibiciones de contratar con una duración de un mes y un día.
} 
sentencia judicial firme, se trata de valorar - como ha hecho la jurisprudencia alemana - si en ese tiempo se han vuelto a llevar a cabo conductas irregulares o si se ha vuelto a delinquir ${ }^{935}$ y/o (ii) el carácter reincidente de la actuación infractora, ya que este supuesto el operador económico manifiesta una falta de compromiso con la legalidad difícil de superar con medidas de self-cleaning.

\section{D.4. El órgano que entendemos competente para valorar las prue- bas y resolver el procedimiento}

La Directiva 2014/24/UE otorga a los Estados miembros la competencia para determinar el órgano encargado de evaluar si las medidas aportadas por el operador económico son - o no - adecuadas y también para resolver el que hemos calificado como supuesto procedimiento de rehabilitación. En particular, dispone que sean los Estados miembros quienes decidan "si desean dejar que sean los poderes adjudicadores particulares los que realicen las evaluaciones pertinentes o si prefieren confiar dicho cometido a otras autoridades a un nivel centralizado o descentralizado" (considerando centésimo segundo de la Directiva 2014/24/UE).

Corresponde, por tanto, al ordenamiento jurídico interno de cada Estado miembro designar dicho órgano siendo dos las posibilidades previstas por la normativa: que sea el propio órgano de contratación o que sea un órgano distinto que actúe a un nivel centralizado o descentralizado.

Cualquiera de las dos opciones puede resultar conforme a Derecho, si bien la determinación del órgano más idóneo dependerá, en su caso, de si se ha llevado a cabo la declaración de la prohibición de contratar - ya que en ese caso entendemos que el órgano competente para su declaración debe ser el competente para su levantamiento - y, sobre todo, de los efectos que se pretenden

${ }^{935}$ PRIESS, H.-J., PÜNDER, H. y STEIN, R., "Alemania (...)", op. cit., págs. 84 y 85. En opinión de estos autores, cuanto más tiempo haya transcurrido y siempre que se han adoptado medidas de corrección, menos razonable sería excluir al operador económico. MAJTAN, R., "The self-cleaning dilemma: Reconciling competing objectives of procurement processes", George Washington International Law Review, vol. 46 (2), 2013, pág. 310 también se muestra favorable al diseño de un marco más flexible en el que se atienda, por ejemplo, a si el operador económico ha tenido tiempo suficiente para eliminar las circunstancias dentro de la organización que llevaron a la concurrencia del motivo de exclusión. 
conseguir. Es decir, si la rehabilitación se pretende para tomar parte en un procedimiento de adjudicación determinado - como parece deducirse del tenor literal de la Directiva y hemos sosteniendo en aseveraciones previas ${ }^{936}$-, el órgano competente para la valoración de las pruebas debiera ser el órgano de contratación, porque es él quien está en mejor disposición para una valoración en términos de riesgos si se admite ese operador económico a la concreta licitación. Por otra parte, si el «levantamiento» de la prohibición se pretende con un alcance general, es decir, para todos los contratos a los que quiera presentarse el operador incurso en una causa de prohibición de contratar, podemos defender - como hace BERNAL BLAY - que sean otras autoridades las que realicen las evaluaciones pertinentes con extensión de efectos en sus resoluciones, puesto que, en ese caso, un efecto general y no contradictorio no lo garantizan los órganos de contratación ${ }^{937}$.

La mayoría de los Estados miembros no contemplaban todavía medidas de self-cleaning en sus legislaciones nacionales ${ }^{938}$, pero del análisis de las regulaciones ya existentes se deduce una preferencia porque sean los órganos de

${ }^{936}$ Artículo 57.6 párrafo primero de la Directiva 2014/24/UE “(...) Si dichas pruebas se consideran suficientes, el operador económico de que se trate no quedará excluido del procedimiento de contratación" o en el considerando centésimo segundo de esta misma Directiva "Los operadores económicos deben tener la posibilidad de solicitar que se examinen las medidas de cumplimiento adoptadas con vistas a su posible admisión en el procedimiento de contratación" (el subrayado es nuestro).

${ }^{937}$ BERNAL BLAY se decanta porque esta competencia recaiga en un "órgano especializado y con jurisdicción en todo el territorio nacional", y en el caso de transposición al Derecho español sostiene que sería una función a atribuir a la Junta Consultiva de Contratación Administrativa del Estado que debería desarrollar su labor en colaboración con las Juntas Consultivas autonómicas, en BERNAL BLAY, M. Á., "Los efectos de los programas (... )", op. cit., pág. 420.

${ }^{938}$ Éste va a ser uno de los cambios más importantes que se produzcan en las normativas contractuales de los Estados miembros, pero mientras las Directivas se transponen a los derechos nacionales cabe referirse a Austria, Alemania y, en menor medida Italia, como recogen los trabajos de ARROWSMITH, S., PRIESS, H.-J. y FRITON, P., "Self-Cleaning as a Defence to (...)", op. cit., y PÜNDER, H., PRIESS, H.-J. y ARROWSMITH, S., SelfCleaning in Public (...), op. cit. Sobre la regulación en el resto de Estados miembros puede consultarse en http://www.publicprocurementnetwork.org/docs/ItalianPresidency/documento \%206.pdf (2014) [Fecha de consulta: 15 de octubre de 2015]. 
contratación los encargados de valorar las medidas aportadas por el operador económico para reestablecer su confianza. Entre estas regulaciones nacionales vamos a destacar, por su desarrollo normativo, las referidas a Austria, Alemania, Reino Unido y Francia.

- La Ley Federal austriaca de contratación pública (Bundesvergabegesetz 2006) Versión consolidada BVergG-Novelle 2015 (BGBl. II Nr. $292 / 2014)$

§73. Beurteilung der beruflichen Zuverlässigkeit

(1) Der Auftraggeber hat der Beurteilung der Zuverlässigkeit des Unternehmers insbesondere die gemäß $\S 72$ Abs. 2 verlangten Nachweise und die gemäß $\S 72$ Abs. 1 zweiter Satz eingeholte Auskunft zugrunde zu legen. Ergibt sich aus diesen Bescheinigungen, dass ein rechtskräftiges Urteil im Sinne des $\S 68$ Abs. 1 Z 1 oder 4 vorliegt oder stellt der Auftraggeber aufgrund dieser Bescheinigungen eine Verfehlung im Sinne des $\S 68$ Abs. 1 Z 5 nachweislich fest oder erlangt der Auftraggeber auf andere Weise von einem solchen Urteil oder einer solchen Verfehlung nachweislich Kenntnis, so ist bei diesem Unternehmer die geforderte Zuverlässigkeit nicht gegeben, es sei denn, er macht glaubhaft, dass er trotz dieses Umstandes zuverlässig ist.

(2) Zur Glaubhaftmachung im Sinne des Abs. 1 zweiter Satz letzter Halbsatz hat der Unternehmer darzulegen, dass er konkrete technische, organisatorische oder personelle Maßnahmen getroffen hat, die geeignet sind, das nochmalige Setzen der betreffenden strafbaren Handlungen bzw. Verfehlungen zu verhindern. Als derartige Maßnahmen gelten etwa

1. die Einführung eines qualitativ hochwertigen Berichts- und Kontrollwesens,

2. die Einschaltung eines Organs der inneren Revision zur regelmäßigen Überprüfung der Einhaltung der maßgeblichen Vorschriften,

3. die Einführung von internen Haftungs- und Schadenersatzregelungen zur Einhaltung der maßgeblichen Vorschriften. 
(3) Der Auftraggeber hat das Vorbringen des Unternehmers zu prüfen und bei der Beurteilung der Zuverlässigkeit die vom Unternehmer gesetzten Maßnahmen in ein Verhältnis zur Anzahl und zur Schwere der begangenen strafbaren Handlungen bzw. Verfehlungen zu setzen. Bei der Beurteilung der Schwere der rechtskräftigen Bestrafung gemäß $§ 28$ Abs. 1 Z 1 AuslBG ist insbesondere die Zahl der illegal beschäftigten Arbeitnehmer und die Dauer der illegalen Beschäftigung zu berücksichtigen. Liegen mehr als zwei rechtskräftige Bestrafungen gemäß $\S 28$ Abs. 1 Z 1 AuslBG vor oder erfolgten zwei rechtskräftige Bestrafungen gemäß $§ 28$ Abs. $1 \mathrm{Z} 1$ AuslBG in kurzen Zeitabständen, ist ein strengerer Maßstab anzulegen.

\section{Artículo 73 Apreciación de la fiabilidad profesional}

(1) El poder adjudicador deberá apreciar la fiabilidad del empresario de conformidad con los documentos justificativos y las pruebas presentadas según establece el artículo 72 apartado 2 y artículo 72 apartado 1. Si de estas certificaciones se deduce la existencia de una sentencia judicial firme en el sentido del artículo 68 párrafos 1 y 4, o de una resolución administrativa en el sentido del artículo 68 párrafos 1 y 5 , o tiene conocimiento de una mala conducta probada por otras vías, no se le dará la fiabilidad solicitada, salvo que el empresario haga creíble que a pesar de esas circunstancias sí que es fiable.

(2) Para hacerlo creíble en el sentido del párrafo primero última segunda frase, el empresario tiene que demostrar que ha tomado medidas técnicas, organizativas, y de personal que sean adecuadas para impedir que vuelvan a darse los anteriores comportamientos punibles o sancionables. Se pueden considerar como tales medidas:

1. La introducción de un sistema cualitativo de información y control de alto valor,

2. La creación de un órgano de control interno para la verificación periódica del cumplimiento de las disposiciones pertinentes,

3. La introducción de regulaciones internas de responsabilidad y reparación de daños para el mantenimiento de las prescripciones impuestas. 
(3) El poder adjudicador tiene que examinar las pruebas que el empresario presente y establecer en la valoración la fiabilidad de las medidas adoptadas. Para la evaluación de la fiabilidad debe tenerse en cuenta el número y la gravedad de los comportamientos punibles o infracciones cometidas y sus circunstancias. Para la apreciación de la gravedad de la sanción firme impuesta de conformidad con el artículo 28 apartado 1 número 1 de la Ley relativa a la contratación de trabajadores extranjeros AuslBG (Ausländerbeschäftigungsgesetz), se tendrá en cuenta el número de los trabajadores ilegalmente contratados y la duración de la contratación ilegal. Si concurren más de dos sanciones firmes según el artículo 28 apartado 1 número 1 AuslBG, o bien dos sanciones pero en un corto periodo de tiempo, se tendrá que imponer un nivel más estricto de exigencia.

[Traducción propia]

\section{- Ley alemana contra las prácticas restrictivas de la competencia} (Gesetz gegen Wettbewerbsbeschränkungen, GWB). La normativa alemana sobre contratación pública se completa con lo dispuesto en la Parte Cuarta de la Ley contra las prácticas restrictivas de la competencia que prevé un artículo sobre las medidas de self-cleaning (Proyecto de Ley del 8 de julio de 2015) Gesetzesentwurf der Bundesregierung zur Modernisierung des Vergaberechts

$\S 125$ Selbstreinigung

(1) Öffentliche Auftraggeber schließen ein Unternehmen, bei dem ein Ausschlussgrund nach $\S 123$ oder $\S 124$ vorliegt, nicht von der Teilnahme an dem Vergabeverfahren aus, wenn das Unternehmen nachgewiesen hat, dass es 1. für jeden durch eine Straftat oder ein Fehlverhalten verursachten Schaden einen Ausgleich gezahlt oder sich zur Zahlung eines Ausgleichs verpflichtet hat, 2. die Tatsachen und Umstände, die mit der Straftat oder dem Fehlverhalten und dem dadurch verursachten Schaden in Zusammenhang stehen, durch eine aktive Zusammenarbeit mit den Ermittlungsbehörden und dem öffentlichen Auftraggeber umfassend geklärt hat, und 3. konkrete technische, organisatorische und personelle Maßnahmen ergriffen 
hat, die geeignet sind, weitere Straftaten oder weiteres Fehlverhalten zu vermeiden. $\S 123$ Absatz 4 Satz 2 bleibt unberührt.

(2) Öffentliche Auftraggeber bewerten die von dem Unternehmen ergriffenen Selbstreinigungsmaßnahmen und berücksichtigen dabei die Schwere und die besonderen Umstände der Straftat oder des Fehlverhaltens. Erachten die öffentlichen Auftraggeber die Selbstreinigungsmaßnahmen des Unternehmens als unzureichend, so begründen sie diese Entscheidung gegenüber dem Unternehmen.

Artículo 125 Auto-limpieza

(1) Los poderes adjudicadores no excluirán a una empresa de un procedimiento de adjudicación por las causas de los artículos 123 o 124 cuando la empresa ha acreditado que 1. por cada daño que ha causado por un delito o una infracción ha pagado una compensación o se ha obligado a un acuerdo para pagarlo, 2. ha contribuido de forma activa con las autoridades encargadas de la investigación para el esclarecimiento de los hechos y las circunstancias que han causado el daño, y 3. ha asumido medidas técnicas, organizativas y de personal que son adecuadas para evitar ulteriores delitos o infracciones. El artículo 123 apartado 4 frase 2 permanece inalterado.

(2) Los poderes adjudicadores valorarán las medidas de autolimpieza asumidas por la empresa y tendrán en consideración para ello la gravedad y las circunstancias particulares del delito o la infracción. Si los poderes adjudicadores no consideran adecuadas las medidas de autolimpieza fundamentarán la resolución frente a la empresa.

[Traducción propia]

- Reglamento de Contratos Públicos 2015 (Public Contracts Regulations SI 2015/102, febrero 2015)

Article 57 Exclusion grounds

Self-cleaning

(13) Any economic operator that is in one of the situations referred to in paragraph (1) or (8) may provide evidence to the effect that mea- 
sures taken by the economic operator are sufficient to demonstrate its reliability despite the existence of a relevant ground for exclusion.

(14) If the contracting authority considers such evidence to be sufficient, the economic operator concerned shall not be excluded from the procurement procedure.

(15) For that purpose, the economic operator shall prove that it has-

a) paid or undertaken to pay compensation in respect of any damage caused by the criminal offence or misconduct;

b) clarified the facts and circumstances in a comprehensive manner by actively collaborating with the investigating authorities; and

c) taken concrete technical, organisational and personnel measures that are appropriate to prevent further criminal offences or misconduct.

(16) The measures taken by the economic operator shall be evaluated taking into account the gravity and particular circumstances of the criminal offence or misconduct.

(17) Where the contracting authority considers such measures to be insufficient, the contracting authority shall give the economic operator a statement of the reasons for that decision.

Artículo 57 Motivos de exclusión

\section{Self-cleaning}

(13) Todo operador económico que se encuentre en alguna de las situaciones contempladas en los apartados (1) y (8) podrá presentar pruebas de que las medidas adoptadas por él son suficientes para demostrar su fiabilidad pese a la existencia de un motivo de exclusión pertinente. (14) Si el poder adjudicador considera estas pruebas suficientes, el operador económico no quedará excluido del procedimiento de contratación. (15) A tal efecto, el operador económico deberá demostrar que:

a) ha pagado o se ha comprometido a pagar la indemnización correspondiente por cualquier daño causado por la infracción penal o la falta, 
b) ha aclarado los hechos y circunstancias de manera exhaustiva colaborando activamente con las autoridades encargadas de la investigación, y

c) ha adoptado medidas técnicas, organizativas y de personal concretas, apropiadas para evitar nuevas infracciones penales o faltas.

(16) Las medidas adoptadas por los operadores económicos se evaluarán teniendo en cuenta la gravedad y las circunstancias particulares de la infracción penal o la falta.

(17) Cuando el poder adjudicador considere que las medidas son insuficientes, el poder adjudicador dará al operador económico una motivación de dicha decisión.

[Traducción propia].

- Ordenanza 2015-899, de 23 de julio de 2015, sobre contratación pública (Ordonnance $\mathrm{n}^{\circ}$ 2015-899, du 23 juillet 2015 relative aux marchés publics) que estará en vigor a partir del 1 de abril de 2016.

Article 45 Interdictions de soumissionner obligatoires et générales

Sont exclues de la procédure de passation des marchés publics : (...)

Toutefois, l'exclusion mentionnée au présent $4^{\circ}$ n'est pas applicable à la personne qui établit : (...)

- qu'elle a réglé l'ensemble des amendes et indemnités dues, qu'elle a collaboré activement avec les autorités chargées de l'enquête, qu'elle a, le cas échéant, réalisé ou engagé la régularisation de sa situation au regard de l'obligation de négociation de l'article 2242-5 du code du travail, et, enfin, qu'elle a pris des mesures concrètes de nature à prévenir la commission d'une nouvelle infraction pénale ou d'une nouvelle faute;

$5^{\circ}$ Les personnes qui font l'objet d'une mesure d'exclusion des contrats administratifs en vertu d'une décision administrative prise en application de l'article 8272-4 du code du travail. Toutefois, l'exclusion mentionnée au présent $5^{\circ}$ n'est pas applicable à la personne qui établit qu'elle a réglé l'ensemble des amendes et indemnités dues, qu'elle a collaboré activement avec les autorités chargées de l'enquête, et qu'elle a pris des mesures 
concrètes de nature à prévenir la commission d'une nouvelle infraction pénale ou d'une nouvelle faute.

Artículo 45 Prohibiciones de licitar obligatorias y generales

Son excluidos del procedimiento de adjudicación contractual: (...)

Sin embargo, la exclusión mencionada en el apartado 4 no será aplicable a la persona [operador económico] que: (...)

- ha pagado todas las multas e indemnizaciones debidas, que ha colaborado activamente con las autoridades encargadas de la investigación, que ha realizado o se ha comprometido a la regularización de su situación respecto de la obligación de negociación del artículo 2242-5 del Código de Trabajo, y, finalmente, que ha adoptado medidas concretas para prevenir la comisión de una nueva infracción penal o de una nueva falta;

$5^{\circ}$ Las personas [operadores económicos] que están sujetas a una causa de exclusión de los contratos administrativos en virtud de una resolución administrativa adoptada en aplicación del artículo 8272-4 del Código de Trabajo. Sin embargo, la exclusión mencionada en el presente apartado 5 no será aplicable a la persona [operador económico] que ha pagado todas las multas e indemnizaciones debidas, que ha colaborado activamente con las autoridades encargadas de la investigación, y que ha adoptado medidas concretas para prevenir la comisión de una nueva infracción penal o de una nueva falta. ${ }^{939}$ [Traducción propia]

${ }^{939} \mathrm{El}$ artículo 2242-5 del Código de Trabajo (en su modificación de 4 de agosto de 2014) se refiere a la obligación de negociación sobre salarios y condiciones laborales para lograr la igualdad entre mujeres y hombres en la empresa. Por su parte, el artículo 8272-4 del Código de Trabajo establece la sanción administrativa de exclusión de la participación en un contrato administrativo (mesure d'exclusion) en los supuestos de trabajo ilegal. 


\section{D.5. Los efectos de la resolución}

La facultad de apreciación con la que cuentan los órganos que deben valorar estas pruebas es el único elemento discrecional del que disponen, ya que el resto de elementos de este procedimiento debieran ser de carácter reglado. De esta forma, la terminación del procedimiento tendrá lugar - además de por desistimiento o renuncia - por resolución en la que se acuerde: (i) bien la exclusión del operador económico del procedimiento de adjudicación si las pruebas aportadas por el interesado no se estiman aptas para recuperar la fiabilidad perdida, o (ii) bien, su admisión en el procedimiento si las medidas adoptadas se consideran suficientes a tal fin, puesto que, insistimos en ello, el tenor literal de la Directiva no deja lugar a la duda al señalar que "si dichas pruebas se consideran suficientes, el operador económico de que se trate no quedará excluido del procedimiento de contratación".

Así pues, en el momento en el que se notifica al operador económico la resolución favorable a la rehabilitación de la fiabilidad, éste podría tomar parte en el procedimiento de licitación sin limitación alguna. Por el contrario, cuando la rehabilitación se deniega, la Directiva exige que el derecho del operador esté tutelado mediante la motivación de dicha decisión ${ }^{940}$.

En cuanto a esta obligación, la resolución debe motivarse haciendo referencia a las consideraciones que han llevado al órgano evaluador a juzgar que las medidas adoptadas por el operador económico resultan insuficientes para su admisión, puesto que recordemos que no es suficiente la adopción formal de programas de cumplimiento, sino que se requiere un papel activo del interesado. En este sentido, y aunque la obligación de motivación ha de distinguirse de la fundamentación de la motivación ${ }^{941}$, somos de la opinión que, además

\footnotetext{
${ }^{940}$ En otro epígrafe de este mismo capítulo nos hemos referido a la necesidad de motivar el acto por el que se declara la prohibición de contratar para permitir su control jurisdiccional. Entre otras cuestiones, hemos afirmado - siguiendo los argumentos del Tribunal General en su sentencia HESR ChemPharm, T-551/08 - que la motivación de un acto debe ser lógica y no presentar contradicciones internas que obstaculicen su buena comprensión.
}

${ }^{941}$ Así se manifiesta el TJUE en su sentencia de 29 de abril de 2004, Países Bajos/Comisión, C-159/01, apartado 65. Según su sentencia de 14 de abril de 2015, Consejo/Comisión, C-409/13, apartado 79 "Un acto lesivo está suficientemente motivado desde el momento en que se adopta en un contexto conocido por los intere- 
de cumplir formalmente con la exigencia de motivar, la resolución ha de estar fundamentada de manera adecuada para no privar al operador económico de los elementos necesarios para poder recurrir al entender que existen defectos o errores en la valoración de sus pruebas ${ }^{942}$. En efecto, atendiendo a una reiterada jurisprudencia del TJUE, la obligación de motivar un acto desfavorable tiene la finalidad, por una parte, de proporcionar al interesado una indicación suficiente sobre si el acto está bien fundado o si eventualmente adolece de algún vicio que permita impugnar su validez y, por otra parte, de permitir a éste el ejercicio de su control sobre la legalidad de la resolución y ejercer su derecho de defensa ${ }^{943}$.

En este supuesto, y tras la interposición del recurso que resulte pertinente, la tramitación se desplaza fuera de este procedimiento para residenciarse en los órganos responsables de los procedimientos de recurso (en vía administrativa o judicial).

\section{E. El derecho del operador económico a que se examinen sus me- didas de cumplimiento}

Examinados los trámites procedimentales de un hipotético procedimiento de rehabilitación, este último apartado pretende dar respuesta a las dudas que se plantean respecto de si el operador económico - al vencimiento del plazo de transposición de las Directivas a los ordenamientos nacionales ${ }^{944}$ - puede

sados".

${ }^{942}$ No queremos decir con ello que el operador económico no pueda recurrir la decisión por otros motivos como podrían ser, incluso, el incumplimiento de la obligación de motivación o la inobservancia de atender a "la gravedad y las circunstancias particulares de la infracción penal o la falta".

${ }^{943}$ A título de ejemplo, cabe señalarse las sentencias de 29 de septiembre de 2011, Elf Aquitaine/Comisión, C-521/09 P, apartado 148, y de 15 de noviembre de 2012, Consejo/Bamba, C-417/11 P, apartado 49. También las sentencias del Tribunal General de 12 de diciembre de 2014, HESR ChemPharm, T-551/08, apartado 40 y de 15 de julio de 2015, Pilkington Group/Comisión, T-462/12, apartado 21.

${ }^{944}$ Las nuevas Directivas sobre contratación deben estar incorporadas a los ordenamientos nacionales a más tardar el 18 de abril de 2016 (artículo 51.1 Directiva 2014/23/UE («concesiones»), artículo 90.1 Directiva 2014/24/UE y artículo 106.1 Directiva 2014/25/UE («sectores especiales»). 
invocar su derecho a presentar pruebas que le rehabiliten en su fiabilidad, de tal manera que pueda hacerlo valer en aquellos Estados miembros donde el legislador nacional haya guardado silencio sobre dicha posibilidad. En este sentido, y aun cuando el problema todavía no se ha producido ratione temporis ya que nos encontramos en una vacatio respecto a la transposición, puede plantear una cierta complejidad cuando se constate que las normas nacionales no son suficientes para dar cumplimiento a la obligación de resultado impuesta por la Directiva y se cuestione el efecto directo de los preceptos referidos a las medidas de self-cleaning ${ }^{945}$.

Para acometer tal labor, es preciso mencionar siquiera brevemente de una parte, el reconocimiento del principio de primacía del Derecho europeo sobre el Derecho nacional ${ }^{946}$ y, de otra, la existencia de una obligación para los órganos nacionales responsables de la transposición de una Directiva de adoptar los medios que consideren más adecuados para garantizar el efecto útil de las mismas, teniendo en cuenta el objetivo que éstas se han propuesto ${ }^{947}$.

\footnotetext{
${ }^{945}$ Debemos recordar que el artículo 288 TFUE establece que "La directiva obligará al Estado miembro destinatario en cuanto al resultado que deba conseguirse, dejando, sin embargo, a las autoridades nacionales la elección de la forma y de los medios", y que aunque las Directivas no tienen reconocido efecto jurídico, el reconocimiento de dicho efecto trae causa de la interpretación jurisprudencial que tiene por objeto solventar una patología del sistema de fuentes para que los ciudadanos puedan, en último extremo, exigir el disfrute de aquellos derechos que las Directivas les confieran en términos "precisos e incondicionales". El efecto directo del Derecho europeo fue consagrado en la sentencia de 5 de febrero de 1963, Van Gend \& Loos, 26/62 y entre los muchos autores que han tratado estos temas, puede consultarse ALONSO GARCÍA, R., Sistema Jurídico de la Unión Europea, 4. $^{\mathrm{a}}$ ed., Civitas - Thomson Reuters, Cizur Menor (Navarra), 2014, págs. 283 y siguientes.

${ }^{946}$ Son numerosas las sentencias del TJUE que se refieren a la primacía del Derecho de la Unión sobre el Derecho interno de cada uno de los Estados miembros y, entre ellas, hemos de destacar la de 15 de julio de 1964, Costa/ENEL, 6/64, en la que se declaró que el Derecho procedente de las instituciones europeas se integra en los sistemas jurídicos de los Estados miembros que están obligados a respetarlo. También, y más recientes, las sentencias de 19 de enero de 2010, Kücükdeveci, C555/07 y de 19 de noviembre de 2009, Filipiak C-314/08.

${ }^{947}$ Es preciso referirnos, con carácter general, a la jurisprudencia del TJUE que consagra el efecto directo de las Directivas cuando sus disposiciones no estén sujetas a condición alguna y sean lo suficientemente precisas, en particular a las sentencias de 19 de enero de 1982, Becker, 8/81, apartado 25; de 10 de septiembre de 2002, Kügler, C-141/00, apartado 51; de 17 de febrero de 2005, Linneweber y Akritidis,
} 
Pues bien, según hemos manifestado, las medidas de self-cleaning - aun cuando eran conocidas y aplicadas en algunos Estados miembros antes del 2014 - se incorporan por primera vez ese año a las Directivas de contratación pública y lo hacen con la expresa finalidad de permitir que los operadores económicos eviten la exclusión de la adjudicación de contratos aun cuando incurran en un supuesto de prohibición de contratar. A este respecto, según el considerando centésimo segundo de la Directiva 2014/24/UE “los operadores económicos deben tener la posibilidad de solicitar que se examinen las medidas de cumplimiento"948, y del tenor de su artículo 57.6 y del artículo 38.9 de la Directiva 2014/23/UE («concesiones») se desprende que todo operador económico que se encuentre en alguna de las situaciones de prohibición de contratar obligatorias o facultativas "podrá presentar pruebas de que las medidas adoptadas por él son suficientes para demostrar su fiabilidad" pese a la existencia de un motivo de exclusión.

A nuestro juicio, de la lectura de estos preceptos puede deducirse claramente que el legislador de la Unión pretende conferir un derecho al operador económico: el derecho a que se examinen las medidas de cumplimiento por él adoptadas con vistas a su posible admisión en el procedimiento de adjudicación ${ }^{949}$. Por consiguiente, entendemos que estas disposiciones son, desde el punto de vista de su contenido, lo suficientemente "claras, precisas e incon-

asuntos acumulados C-453/02 y C-462/02, apartado 33 y la más reciente de 16 de julio de 2015, Larentia + Minerva, asuntos acumulados C-108/14 y C-109/14, apartados 48 y 49. También la jurisprudencia en materia de contratos públicos es clara en este sentido, y en concreto en sus sentencias de 20 de septiembre de 1988, Beentjes, 31/87, apartados 40 a 44; de 22 de junio de 1989, Fratelli Costanzo, 103/88, apartados 29 a 31; de 4 de marzo de 1999, HI, C-258/97, apartados 34 a 39 y de 18 de octubre de 2001, SIAC Construction, C-19/00, apartados 35 a 45.

${ }^{948} \mathrm{El}$ considerando centésimo séptimo de la Directiva 2014/25/UE («sectores especiales») también se manifiesta en términos imperativos "Cuando las entidades adjudicadoras estén obligadas a aplicar u opten por aplicar los criterios de exclusión mencionados, deben aplicar lo dispuesto en la Directiva 2014/24/UE en lo que respecta a la posibilidad de que los operadores económicos adopten medidas de cumplimiento encaminadas a reparar las consecuencias de las infracciones penales o las faltas y a prevenir eficazmente nuevos casos de conducta indebida".

${ }^{949}$ MAJTAN, R., "The self-cleaning dilemma (...), op. cit., pág. 337 configura las medidas de autolimpieza como un derecho de quien quiere llegar a ser contratista para así evitar su inhabilitación (debarment). 
dicionales" como para poder ser invocadas por los particulares en caso de no transponerse a los ordenamientos internos, de tal manera que al vencimiento del plazo para su transposición, los operadores económicos deben tener la posibilidad de solicitar su rehabilitación al órgano que sea competente y, en caso de no admitirse dicho derecho por no contemplarse en la normativa nacional, a invocarlo ante los órganos con competencia en materia de recursos contractuales o ante los tribunales de justicia ${ }^{950}$.

Es indudable, pues, que las disposiciones citadas cumplen los criterios exigidos para generar derechos con efecto directo y, en este sentido, entendemos que antes de causar este efecto, las medidas de self-cleaning debieran recogerse en las normativas nacionales y, de este modo, evitar los inconvenientes ya advertidos ${ }^{951}$. Por lo demás, su vocación protectora respecto del operador económico "arrepentido" es coherente con el estímulo normativo a favor de la implementación de mecanismos de prevención de prácticas irregulares - como por ejemplo sucede en los programas de clemencia en materia de competencia - o de la adopción de medidas de autorregulación que incrementen los controles internos en cada organización - los llamados programas de compliance o modelos de prevención de delitos - que en el Derecho español pueden no sólo atenuar la responsabilidad penal de las personas jurídicas, sino incluso llegar a extinguirla ${ }^{952}$.

${ }^{950}$ Sobre estos aspectos, resulta de interés GIMENO FELIÚ, J. M. ${ }^{\text {. }}$, Los efectos jurídicos de las Directivas de contratación pública ante el vencimiento del plazo de transposición sin nueva Ley de Contratos Públicos. La Directiva de concesiones, Ponencia presentada en el Seminario de Contratación Pública celebrado en Formigal (septiembre 2015), quien acertadamente indica que "los preceptos de las Directivas del 2014 que sean claros, precisos e incondicionados desplegarán efectos jurídicos de obligada aplicación por los operadores jurídicos y, por ello, serán parámetro de control por parte de los órganos administrativos de recursos contractuales y la jurisdicción contencioso-administrativa".

${ }^{951}$ BERNAL BLAY, M. Á., "Los efectos de los programas (...), op. cit., págs. 416 y 417; y GÓMEZ-JARA DÍEZ, C., "Responsabilidad penal de las personas jurídicas y contratación pública (...)", op. cit., al señalar que "la Directiva puede desplegar efectos beneficiosos para los operadores económicos - si bien, el plazo de transposición a partir del cual despliega efectos directos es el 18 de abril de 2016".

${ }^{952}$ En este último supuesto, el modelo de cumplimiento previsto por la persona jurídica deberá ser implementado y ejecutado en los términos de la nueva redacción del artículo 31 bis del Código penal, en vigor desde el 1 de julio de 2015. 
No obstante, cabe advertir que el mandato del legislador europeo se incumple - por el momento y a falta de una transposición completa - por parte del legislador español. Los últimos cambios legislativos en cuanto a las prohibiciones de contratar no son suficientes para dar cumplimiento a la obligación de resultado impuesta por la Directiva, ya que no contemplan previsión alguna respecto de una posible derogación de las prohibiciones de contratar ${ }^{953}$.

En este sentido, al igual que advertíamos que la aceptación de las medidas de self-cleaning estaba animada por consideraciones fundamentalmente de oportunidad política, en el caso español - y a nuestro entender - esas mismas razones son las que aconsejan no contemplar dichas medidas en un momento en el que los escándalos de corrupción vinculados a supuestas tramas para la adjudicación irregular de contratos públicos siguen salpicando la vida política del país. La responsabilidad de cumplir con la normativa europea se obvia en favor de una supuesta regeneración democrática ${ }^{954}$, que no recoge medidas de cumplimiento para eludir una prohibición de contratar, difiriendo, de esta manera, su aplicación hasta que desde los tribunales nos obliguen a ello.

Ahora bien, no se trata únicamente de indicar una adaptación incorrecta de lo dispuesto en las Directivas sobre contratación pública, puesto que recordemos que el Derecho europeo también impone a los Estados miembros la obligación de reparar los daños causados a los particulares por no haber adaptado su Derecho interno a lo dispuesto en una Directiva ${ }^{955}$. Esta reparación

${ }^{953}$ Ante la imposible viabilidad de seguir en esta Legislatura con la tramitación de los Anteproyectos de la Ley de Contratos del Sector Público y de la Ley de contratos en los sectores del agua, la energía, los transportes y los servicios postales (abril de 2015), el legislador español ha procedido a modificar los artículos 60, 61 y a incorporar un nuevo artículo 61 bis al TRLCSP a través de la aprobación de la Ley 40/2015, de 1 de octubre, de Régimen jurídico del Sector Público, y más concretamente mediante la Disposición final novena de la citada Ley (BOE núm. 236 , de 2 de octubre de 2015).

${ }^{954}$ En el Plan de Regeneración Democrática anunciado en el Consejo de Ministros del 20 de septiembre de 2013, se nos anunciaba la aprobación de un amplio catálogo de medidas para luchar contra la corrupción y mejorar los mecanismos de respuesta y detección de que dispone el ordenamiento jurídico, entre las que se encontraban la modificación del TRLCSP para prohibir contratar con el sector público que quienes fueran condenados por prevaricación, falsedad en las cuentas de los partidos políticos o financiación ilegal, entre otros delitos.

${ }^{955}$ Además de ello, "la obligación, a cargo de los Estados miembros, de reparar los 
procederá siempre y cuando concurran tres requisitos que creemos cumplidos en el caso que nos ocupa: (i) que la Directiva atribuya derechos a los particulares; (ii) que el contenido de estos derechos pueda determinarse basándose en las disposiciones de dicha Directiva, y (iii) tercero y último, que exista una relación de causalidad entre el incumplimiento de la obligación que incumbe al Estado y el daño sufrido por las personas afectadas ${ }^{956}$.

Con estos últimos comentarios, únicamente advertimos de las posibles consecuencias que conlleva no adaptar la normativa interna a lo que consideramos obligaciones prescritas por las Directivas; sin embargo, no pretendemos adelantar acontecimientos, ya que es preciso señalar que, antes de la expiración del plazo de transposición, no cabe reprochar a los Estados miembros que no hayan adoptado las medidas necesarias para adecuar su ordenamiento jurídico a lo dispuesto en las Directivas ${ }^{957}$.

daños causados a los particulares por las violaciones de Derecho comunitario que les son imputables no puede limitarse únicamente a los daños sufridos con posterioridad a que se haya dictado una sentencia del Tribunal de Justicia en la que se declare el incumplimiento reprochado".

${ }^{956}$ Véase, en este sentido, las sentencias de 19 de noviembre de 1991, Francovich y otros, C-6/90 y C-9/90, apartado 39 y de 14 de julio de 1994, Faccini Dori, C-91/92, apartado 27.

${ }^{957}$ STJUE de 4 de julio de 2006, Adeneler y otros, C-212/04, apartados 114 y 115. 



\section{CONCLUSIONES}

El objeto de esta memoria doctoral ha sido aportar una reflexión de carácter jurídico respecto de la regulación de las prohibiciones de contratar en el ámbito del Derecho de la Unión Europea. A partir de su análisis crítico, podemos extraer distintas conclusiones que vamos a diferenciar en dos apartados: unas conclusiones generales y otras de carácter más específico que tratan sobre aspectos particulares del actual régimen jurídico.

\section{CONCLUSIONES GENERALES}

Las Directivas sobre contratación pública establecen las condiciones de participación en la adjudicación de un contrato bajo el epígrafe general de «criterios de selección cualitativa». Estos criterios regulan la aptitud del operadores económico para llegar a ser contratista sobre la base de su capacidad y de su situación personal, de tal manera que los poderes adjudicadores pueden excluir de la licitación a quienes no demuestren la idoneidad suficiente para la ejecución de la prestación demandada. Es decir, determinan quién puede y quién no puede llegar a ser contratista en atención a su capacidad, a su solvencia económica, financiera y técnica o profesional, e incluso a su honestidad, estableciendo las causas por las cuales un operador económico incurre en un supuesto de prohibición de contratar.

Con carácter general, las prohibiciones son medidas que limitan la actuación de una persona física o jurídica para la realización de ciertas actividades. Aplicadas al ámbito de la contratación pública, y desde la perspectiva del operador económico, se configuran como actos desfavorables en cuanto restringen su posibilidad de participar en un procedimiento de licitación. Pueden definirse como medidas administrativas, aplicadas por los órganos de contratación, que impiden contratar a quienes incurran en una serie de circunstancias que, a jui- 
cio del legislador, presuponen una falta de fiabilidad en el candidato o licitador o de imparcialidad para la selección del contratista. Inciden negativamente en la esfera jurídica de aquellos a quien se le imponen, pero no por ello tienen un carácter sancionador.

Hemos mantenido que - desde el ámbito contractual - su naturaleza no es sancionadora porque no se impone con un fin represivo o retributivo por la realización de una conducta que se considere administrativa o penalmente ilícita. En nuestra opinión, la consagración en el ámbito contractual público de una serie de prohibiciones legales para contratar se orientan, no al castigo del sujeto afectado por la exclusión, sino a la prevención.

Así, entendemos que su naturaleza obedece a una triple finalidad preventiva: (i) proteger a la entidad contratante de los "operadores económicos informales y deshonestos" asegurando una adecuada elección del contratista, (ii) ampliando sus fines preventivos al tráfico jurídico en general al impedir ventajas inaceptables entre operadores económicos no basadas en la oferta que presentan, a la vez que, (iii) de algún modo, con las prohibiciones de contratar se desincentiva el quebrantamiento de la legalidad vigente. Además de ello, pudieran servir de garantía a la buena gestión de los fondos públicos al reforzar las medidas para prevenir la infiltración de la delincuencia en la contratación pública (como instrumento de lucha contra la corrupción, el fraude y otras actividades ilegales).

Las nuevas Directivas de contratación pública contienen una enumeración exhaustiva de las circunstancias por las cuales un operador económico debe, en unos casos («prohibiciones de contratar obligatorias»), y puede en otros («prohibiciones de contratar facultativas») ser excluido de un procedimiento de licitación (artículo 38 de la Directiva 2014/23/UE («concesiones»), en el artículo 57 de la Directiva 2014/24/UE y en el artículo 80 de la Directiva 2014/25/UE («sectores especiales»).

Estas Directivas, que entraron en vigor el 18 de abril de 2014, deben ser transpuestas a los Derechos nacionales antes del 18 de abril de 2016. En esta fecha se hará efectiva también la derogación de las Directivas 2004/17/CE («sectores especiales») y 2004/18/CE en aquellos Estados miembros en los que no hayan entrado en vigor las medidas de transposición de las nuevas Directivas. 
Ahora bien, dado que las Directivas se aplican únicamente a aquellos contratos cuyo valor sobrepasa los umbrales económicos expresamente fijados en cada una de ellas, en esta materia resultan de especial interés las normas fundamentales y los principios generales del TFUE, en particular, los principios de igualdad de trato, de reconocimiento mutuo, de proporcionalidad y de no discriminación por razón de la nacionalidad, y a la obligación de transparencia que de ellos se deriva. Asimismo, la jurisprudencia del TJUE se nos muestra como elemento que sirve de soporte a las exigencias derivadas de las libertades garantizadas por el Tratado y son una referencia obligada para conformar el sistema de contratación pública a nivel europeo

La relación de circunstancias que, en caso de concurrir en el operador económico, constituyen un impedimento legal para poder contratar, obedece a la aplicación de estos principios y son la razón última por la cual se ha reconocido que los Estados miembros tienen la facultad de establecer, además de las causas de exclusión explícitamente recogidas en las Directivas, otras prohibiciones de contratar siempre que tengan por objeto garantizar la observancia de los principios de igualdad de trato, transparencia y proporcionalidad.

\section{CONCLUSIONES ESPECÍFICAS}

Una vez efectuadas estas reflexiones de carácter general, vamos a centrarnos en aquellos aspectos concretos que presentan las novedades en la regulación de las prohibiciones de contratar y en aquellos que, en nuestra opinión, debieran haberse regulado de distinta manera.

\section{A. LAS PROHIBICIONES DE CONTRATAR DE CARÁCTER OBLIGATORIO}

La exclusión obligatoria de los procesos de contratación pública se prevé para actuaciones que pueden ser agrupadas en dos categorías: (i) incumplimientos por parte del operador económico de sus obligaciones relacionadas con el pago de impuestos o de cotizaciones a la seguridad social establecidos por una resolución judicial o administrativa firme y vinculante; y (ii) el operador económico ha sido condenado mediante sentencia firme por alguno de los siguientes tipos delictivos: participación en una organización delictiva, corrupción, fraude, delito de terrorismo o delito ligado a las actividades terroristas, 
blanqueo de capitales o financiación del terrorismo y trabajo infantil y otras formas de trata de seres humanos.

Como importantes - y acertadas - novedades de la nueva regulación debemos destacar, en primer lugar, que se amplía el catálogo de delitos que habilitan una prohibición de contratar de carácter obligatorio a los delitos de terrorismo o delitos ligado a las actividades terroristas - aunque ya estaban recogidos en la Directiva 2009/81/CE («sectores seguridad y defensa») - y a los delitos vinculados al trabajo infantil y otras formas de trata de seres humanos. En segundo lugar, se incorpora como motivo de exclusión obligatorio que el operador económico haya quebrantado sus obligaciones fiscales y con la seguridad social; no obstante, dicho quebrantamiento debe estar acreditado por una sentencia o resolución administrativa firme, puesto que de no ser así, no se contempla como una prohibición de carácter obligatorio, aunque sí potestativa (artículo 57.2 in fine Directiva 2014/24/UE y artículo 38.5 de la Directiva 2014/23/UE («concesiones»).

Todas estas prohibiciones de contratar deben ser transpuestas en las normativas internas de los 28 Estados miembros. En este sentido, hemos destacado que Reino Unido y Francia ya han notificado medidas de transposición que modifican por completo su anterior regulación contractual (Public Contracts Regulations 2015 y Ordonnance $n^{o}$ 2015-899, du 23 juillet 2015 relative aux marchés publics). En Hungría, la Ley 2015 CXLIII, de 22 de septiembre, sobre contratación pública, entrará en vigor el 1 de noviembre de 2015; y que Italia Austria, Malta, República Checa y España han modificado recientemente su regulación con un distinto grado de adaptación a las nuevas Directivas. Así pues, aunque todavía no ha finalizado el plazo para su transposición y, por tanto, no podemos concluir cómo se va a llevar a cabo en todos los Estados, en esta memoria doctoral hemos defendido una serie de propuestas que, en nuestra opinión, hubieran aportado seguridad jurídica al texto de las Directivas.

Primera propuesta. Tras examinar cómo los Estados miembros habían transpuesto el artículo 45 apartado primero de la Directiva 2004/18/CE a su Derecho interno (Tabla 5), podemos afirmar la existencia de diferencias significativas respecto de los criterios adoptados para concretar las conductas delictivas que originan una prohibición de contratar de carácter obligatorio.

Por ello, y dado que los conceptos de corrupción, fraude, terrorismo y parti- 
cipación en una organización criminal a los que remiten las Directivas del 2014 se forjaron sobre la base jurídica del tercer pilar y éste ya está superado, quizá hubiera sido el momento de aportar una definición autónoma de estos delitos en la contratación pública. La supresión de las referencias normativas evitaría, además, la falta de concordancia entre normativas cuando se produjeran derogaciones, como ha ocurrido respecto de la Directiva 2005/60/CE («Tercera Directiva contra el blanqueo de capitales») que será derogada - aunque quede tiempo para ello - por la Directiva (UE) 2015/849 del Parlamento Europeo y del Consejo, de 20 de mayo de 2015, relativa a la prevención de la utilización del sistema financiero para el blanqueo de capitales o la financiación del terrorismo.

Segunda propuesta. Esta propuesta parte de dos premisas: La primera es que la contratación pública, además de constituir un medio de provisión de bienes y servicios, es también un poderoso instrumento jurídico al servicio de los poderes adjudicadores para el cumplimiento de objetivos de carácter secundario o no comercial. La segunda es que una de las razones argumentadas para revisar y modernizar el marco jurídico de la contratación pública ha sido incrementar la eficiencia del gasto público y "permitir que los contratantes utilicen mejor la contratación pública en apoyo de objetivos sociales comunes" (considerando segundo de la Directiva 2014/24/UE).

En base a ello, nuestra propuesta de regulación hubiera previsto que el incumplimiento de las obligaciones en materia social, laboral o medioambiental supusiera para el operador económico su exclusión obligatoria del procedimiento de adjudicación contractual - y no únicamente de carácter potestativo - de conformidad con los objetivos y prioridades previstas en la «Estrategia Europa 2020» y en favor de un desarrollo sostenible y una política de contratación pública basada en valores.

\section{B. LAS PROHIBICIONES DE CONTRATAR DE CARÁCTER FA- CULTATIVO}

Bajo la consideración de prohibiciones de contratar facultativas podemos agrupar toda una serie de conductas que pueden suponer - si así se contempla por parte de las normativas nacionales - la exclusión del procedimiento de adjudicación de un contrato público a quienes se hallen incursos en ellas 
(artículo 57.4 de la Directiva 2014/24/UE y artículo 38.4 de la Directiva de concesiones).

El carácter voluntario de las prohibiciones de contratar recogidas en estos artículos supone, en la práctica, otorgar a los Estados miembros un amplio margen de apreciación para que decidan acerca de incorporar o no, estas causas de exclusión a sus legislaciones nacionales, puesto que las Directivas del 2014 - al igual que sus antecesoras - no pretenden una aplicación uniforme de estas causas de prohibición de contratar a escala europea. Así pues, y según reiterada jurisprudencia, los Estados miembros están facultados para no aplicar en absoluto dichas causas de exclusión o bien integrarlas en la normativa nacional "con un grado de rigor que podría variar según el caso, en función de consideraciones de carácter jurídico, económico o social que prevalezcan en el plano nacional", por lo cual, la legislación de los Estados miembros es muy diversa.

El apartado referente a las prohibiciones de contratar facultativas es el que mayores novedades presenta para dar cabida a una regulación más acorde con ciertos aspectos ya tratados por el TJUE en distintas sentencias y ya establecidos en la regulación financiera (Reglamento (UE, Euratom) 966/2012, de 25 de octubre de 2012, sobre las normas financieras aplicables al Presupuesto general de la Unión).

Habida cuenta del nuevo contexto normativo, entre las conductas que pueden habilitar una prohibición de contratar por falta de idoneidad profesional suficiente, tendremos que entender incluidas las siguientes:

- Incumplimientos de las obligaciones aplicables en los ámbitos del Derecho medioambiental, social y laboral, si bien a nuestro entender - y tal como hemos manifestado - se debieran haber recogido como prohibiciones de contratar obligatorias;

- Aquellas que confirman judicialmente o en vía administrativa la infracción de las normas sobre competencia por formalizar acuerdos ilícitos entre operadores económicos a fin de proceder a un reparto del mercado o a la fijación de precios, lo que se conoce como «bid-rigging» (STJUE de 18 de diciembre de 2014, Generali-Providencia Biztositó, C-470/13);

- Deficiencias significativas o persistentes en el cumplimiento de un requi- 
sito de fondo en el marco de un contrato público anterior (STJUE de 13 de diciembre de 2012, Forposta SA, C-465/11). Se posibilita excluir a los candidatos o licitadores cuya actuación en anteriores contratos públicos haya mostrado graves deficiencias en lo que se refiere al cumplimiento de los requisitos de fondo, como la no realización de una entrega o prestación, la existencia de deficiencias significativas en el producto entregado o el servicio prestado que los hagan inutilizables para el fin perseguido, o una conducta indebida que haga dudar seriamente de la fiabilidad del operador económico (considerando centésimo primero de la Directiva 2014/24/UE y considerando 70 de la Directiva 2014/23/UE).

- Las conductas que vulneran la igualdad de oportunidades entre licitadores al disfrutar de una posición de ventaja frente al resto de sus competidores, tal como ocurre, por ejemplo, en el supuesto de un falseamiento de la competencia derivado de la participación previa de los operadores económicos en la preparación del procedimiento de contratación, y siempre que no pueda remediarse por medios menos restrictivos (STJUE de 3 de marzo de 2005, Fabricom, C-21/03 y C-34/03);

- También en el supuesto de conflicto de intereses. En este supuesto, debemos tener en cuenta que no existe una obligación absoluta de los poderes adjudicadores de excluir sistemáticamente a los operadores económicos en situación de conflicto de intereses, dado que tal exclusión no se justifica en aquellos casos en que puede probarse que tal situación no ha tenido ninguna incidencia en su comportamiento en el marco del procedimiento de licitación y que no supone un riesgo real de que surjan prácticas que puedan falsear la competencia entre los licitadores. En cambio, la exclusión de un licitador en situación de conflicto de intereses resulta indispensable cuando no se dispone de un remedio más adecuado para evitar cualquier vulneración de los principios de igualdad de trato entre los licitadores y de transparencia (STJUE de 12 de marzo de 2015, eVigilo, C-538/13 y sentencia del Tribunal General de 13 de octubre de 2015, Intrasoft International/Comisión, T-403/02);

- Cualquier incumplimiento grave de las obligaciones contractuales imputables al contratista previa apreciación del comportamiento culposo que se le imputa, puesto que el concepto de «falta grave» debe entenderse 
referido a un comportamiento que revele dolo o una negligencia de cierta gravedad por parte del operador económico en cuestión (STJUE de 13 de diciembre de 2012, Forposta SA, C-465/11). Ahora bien, aun tratándose de una competencia nacional, y en virtud del principio de seguridad jurídica, hubiera resultado de utilidad haber delimitado las conductas consideradas reprobables a la luz de la normativa europea, más allá de una referencia genérica al concepto de «falta grave profesional». La indeterminación de las Directivas respecto de las causas de prohibición de contratar por la comisión de una falta grave en materia profesional es "contagiosa" en tanto que se reproduce en algunas de las regulaciones nacionales (Bélgica y Luxemburgo). A nuestro entender, los operadores debieran conocer con exactitud el alcance de las obligaciones que se les imponen y poder así valorar sus efectos en caso de incumplimiento.

\section{LA APLICACIÓN DE LAS PROHIBICIONES DE CONTRA- TAR POR PARTE DE LOS ESTADOS MIEMBROS}

Conforme a lo dispuesto en las propias Directivas, los Estados miembros están facultados para precisar las condiciones de implementación de las prohibiciones de contratar. Sin embargo, y en la medida en que se trata de una restricción al ejercicio de los derechos de los operadores económicos, y por tanto, un acto administrativo desfavorable, el legislador europeo concreta alguno de los aspectos para su correcta aplicación.

Así pues, en este estudio nos hemos referido a los siguientes:

\section{a. La vinculación a una condena por sentencia judicial firme o reso- lución administrativa firme y vinculante}

En el caso de las prohibiciones de contratar obligatorias se exige que el operador haya "sido condenado mediante sentencia firme" o que el incumplimiento de sus obligaciones referentes al pago de impuestos o cotizaciones a la seguridad social "haya quedado establecido en una resolución judicial o administrativa firme y vinculante". En este sentido, también se prevé que en determinadas circunstancias las personas jurídicas puedan responsabilizarse de la conducta ilegal cometida por la persona física si el condenado mediante sentencia firme es "un miembro del órgano de administración, de dirección o de vigilancia del operador económico o tenga poderes de representación, decisión o control 
en el mismo". Esta previsión trata de salvar los inconvenientes que plantea la responsabilidad penal de las personas jurídicas.

Nos encontramos, por tanto, ante la privación de un derecho vinculado a una condena penal o una resolución administrativa firme y vinculante, sin que éstas tengan que contener un pronunciamiento expreso sobre la prohibición. Por ello, es necesario distinguir los supuestos en los que las sentencias o resoluciones se pronuncian sobre la prohibición y su duración, de aquellos en los que guardan silencio sobre estas cuestiones. Si existe un pronunciamiento expreso, el órgano de contratación deberá aplicarlas automáticamente y, en el segundo supuesto, podemos sostener que el órgano de contratación dispone de un cierto margen de discrecionalidad para decidir sobre la misma.

En este sentido, es preciso, por una parte, requerir a los Estados miembros a colaborar de manera más activa en el intercambio de información de condenas, y por otra, seguir avanzando en el principio de reconocimiento mutuo y ejecución de resoluciones judiciales que constituye la piedra angular de la cooperación judicial en materia penal en la Unión Europea.

\section{b. Las prohibiciones de contratar no pueden tener una duración ili- mitada}

Uno de los aciertos en la regulación actual es fijar unos plazos máximos de duración de las prohibiciones de contratar si éstos no han sido determinados por sentencia judicial. Estos plazos no excederán de tres o cinco años dependiendo de los supuestos de exclusión. Esta previsión normativa aporta seguridad jurídica en tanto que evita la "muerte civil" del operador económico, a la vez que los operadores económicos pueden conocer con mayor concreción los efectos de su actuación y actuar en consecuencia. No se fija un periodo mínimo, si bien hemos destacado - a modo de ejemplo - que en España la prohibición de contratar de menor duración publicada en el BOE fue de un mes.

\section{c. Listas negras - listas blancas}

Los mayores inconvenientes para una aplicación coherente y efectiva de estas prohibiciones se encuentran en la falta de conocimiento de los hechos, sentencias o resoluciones que habilitan una prohibición de contratar. 
Las Directivas sobre contratación pública no prevén disposiciones con respecto a la puesta en práctica de «listas negras» de empresas excluidas por corrupción o fraude, como se ha previsto por algunos Estado miembros (Malta y República Checa) y en organismos como el Banco Mundial. Sin embargo, hemos señalado que en el ámbito del Reglamento financiero, se ha creado una base de datos central en materia de exclusión que contiene información sobre los operadores económicos que se encuentran en alguna de las situaciones de prohibición de contratar previstas en la normativa financiera y de conformidad con la normativa sobre protección de datos de carácter personal.

En nuestra opinión, esta base de datos - así como las que se contemplan en los Estados miembros - son una importante herramienta para el intercambio de información sobre las prohibiciones de contratar, aunque el uso de esta base central es todavía muy limitado, puesto que únicamente cinco Estados miembros declaran estar haciendo uso de ella (Bélgica, República Checa, Malta, Austria y Polonia) y que algunos Estados miembros - como Dinamarca, Irlanda, Hungría, Eslovenia, Suecia y España - utilizan sus propias bases de datos.

Ahora bien, en la medida en que el uso de estas "listas negras" puede llegar a conculcar algún derecho fundamental del operador económico - piénsese, por ejemplo, en el derecho de defensa - consideramos apropiado un enfoque más favorable a la creación de «listas blancas». En el ámbito de la contratación pública, las «listas blancas» podrían ser consideradas como un mecanismo para que el operador económico probara su integridad - entendida como buena reputación - para con respecto al cumplimiento de las normas y a ciertos valores añadidos de responsabilidad (por ejemplo, a través de programas de cumplimiento, pactos de integridad, códigos éticos y/o de conducta).

\section{d. Simplificación de los requisitos documentales para poder licitar}

Uno de los esfuerzos actuales de la normativa contractual se concentra en simplificar los requisitos de documentación a presentar por parte de los operadores económicos interesados en la adjudicación de un contrato. No en vano, "muchos operadores económicos, y en concreto las PYMEs, consideran que un obstáculo importante para su participación en la contratación pública son las cargas administrativas que conlleva la obligación de presentar un número sustancial de certificados u otros documentos relacionados con los criterios 
de exclusión y de selección" (considerando octogésimo cuarto de la Directiva 2014/24/UE).

Así, las nuevas Directivas reducen la carga burocrática para participar en una licitación e intentan establecer mecanismos que faciliten el conocimiento de los certificados que se exigen para participar en un procedimiento de adjudicación en los distintos Estados miembros. Uno de estos instrumentos es el depósito de certificados en línea e-Certis que facilita el intercambio de certificados y demás pruebas documentales solicitadas por los poderes adjudicadores.

Otro de ellos - y en nuestra opinión el más importante - es el uso del documento europeo único de contratación que, a modo de declaración responsable del operador económico evita que éste tenga que presentar los certificados $u$ otros documentos relacionados con los criterios de exclusión. Constituye una declaración formal por la que el operador económico certifica que no se encuentra en alguna de las situaciones en las que deba o pueda ser excluido; que cumple los criterios de selección pertinentes, así como, cuando proceda, que satisface los requisitos que se hayan establecido por parte del órgano de contratación y que está en disposición de presentar los documentos que así lo acreditan "previa petición y sin demora".

Ahora bien, en la medida en que se otorga una mayor confianza al operador económico éste debiera responder de igual manera. En este sentido, las nuevas Directivas ayudan a proteger las expectativas del poder adjudicador mediante la posibilidad de excluir del procedimiento de adjudicación a aquel operador económico que: (i) ha sido declarado culpable de falsedad grave al proporcionar la información exigida para verificar la inexistencia de motivos de exclusión; (ii) ha retenido dicha información; (iii) no puede presentar los documentos justificativos requeridos; o (iv) ha proporcionado negligentemente información engañosa que pueda tener una influencia importante en las decisiones relativas a la exclusión, selección o adjudicación.

\section{LA INAPLICACIÓN DE UNA PROHIBICIÓN DE CONTRA- TAR}

El legislador europeo al tiempo que ha fijado el establecimiento de prohibiciones de contratar de carácter obligatorio - y como cierre del sistema ha venido modulando sus efectos a través de la posibilidad de excepcionar su 
aplicación. En las Directivas del año 2004 (Directiva 2004/18/CE y Directiva 2004/17/CE) la única previsión a este respecto era "por razones imperiosas de interés general".

En la vigente regulación, se autoriza a los Estados miembros a establecer excepciones a dichas prohibiciones en determinadas circunstancias para compatibilizar los objetivos de las prohibiciones de contratar con la garantía del principio de concurrencia que preside la tramitación contractual.

Así pues, las Directivas de 2014 han establecido cinco grupos de excepciones supeditados al cumplimiento de ciertas condiciones y que distingue los supuestos según se trate de derogar prohibiciones de contratar obligatorias o facultativas para los Estados miembros. Estas excepciones son las siguientes: (1) las derivadas de la existencia de razones imperiosas de interés general; (2) las que atienden a motivos económicos; (3) las que se basan en un juicio de proporcionalidad; (4) aquellas vinculadas a la regularización tributaria y (5) aquellas relacionadas con el comportamiento del candidato o licitador a través de la puesta en práctica de medidas de self-cleaning, mediante las cuales se posibilita que presente "pruebas de que las medidas adoptadas por él son suficientes para demostrar su fiabilidad pese a la existencia de un motivo de exclusión pertinente".

Por tanto, las nuevas Directivas incorporan en su articulado una mayor flexibilización respecto a las reglas de selección del contratista al tomar en consideración situaciones específicas de los operadores económicos. Estas nuevas previsiones cumplen formalmente con la exigencia de seguridad jurídica al recoger en sus textos ejemplos claros y precisos de los motivos de excepción en la aplicación de las prohibiciones de contratar.

Algunas de estas disposiciones satisfacen - a nuestro entender - los criterios exigidos para generar derechos con efecto directo y, en este sentido, consideramos que antes de causar este efecto, las medidas de self-cleaning debieran recogerse en todas las normativas nacionales, como ya resultaba posible antes del año 2014 en Austria, Alemania o Italia, y como comienza a ser una realidad en otros Estados como el Reino Unido, Francia y Hungría.

Es importante tener en cuenta que algunos de los cambios propuestos van a depender de la voluntad política de cada Estado miembro en aplicarlos, pero 
que esa voluntad tendrá que ceder frente a las previsiones que en las Directivas se recogen con el carácter de obligatorias. Respecto de las que no lo son, las legislaciones nacionales deben dictarse, en todo caso, de conformidad con el Derecho de la Unión. En nuestra opinión, en la transposición de las prohibiciones de contratar, los legisladores nacionales deben generar certeza entre los operadores económicos "honestos" que participan del respeto al Estado de Derecho y, por último, y no menos importante, deben generar estabilidad en la economía al atemperar los efectos perjudiciales que las prácticas ilícitas causan en la economía legal de un país. 


\section{CONCLUSIONS}

EU Public Procurement Directives establish the conditions for participation in tendering procedures under the general heading of 'Criteria for qualitative selection'. These criteria regulate the positive requirements to be met by candidates and tenderers, in order for them to become contractors. At the same time, they empower the contracting authorities to exclude from award procedures those contractors who fail to meet the criteria for contract execution. So, by laying down the circumstances under which certain actors may be excluded from the contract award procedure, the contracting authorities decide who can and who cannot be a contractor. They do so by examining the personal circumstances of the candidate or the tenderer, their economic and financial standing, their technical knowledge and experience, and even their reliability.

Exclusion is a disqualification that restricts an individual or a legal person from participating in certain activities. When applied to the field of public procurement, exclusion may be understood as a limitation of the right to participate freely in public procurement procedures, such that they may be defined as administrative remedies applied by contracting authorities to disqualify contractors from competing for public contracts. The grounds for exclusion from a procurement procedure and the objective of exclusion from becoming a contractor, even though it has no overtly punitive function, is the disqualification of those candidates who have incurred in a series of circumstances which, in the opinion of the legislator, either implies a lack of reliability, diligence and responsibility on the part of the economic operator or implies a lack of impartiality in the selection of the contractor.

In my opinion, the enshrinement of a series of legal exclusions from contracting in the field of public contract law is not aimed at punishing the indi- 
vidual to whom the exclusion applies, but rather at preventing the contracting authorities from contracting organizations and persons whose conduct has previously raised doubts over their trustworthiness. An acceptable contractor selection process is thereby ensured which is to the benefit of the inherent objectives of the contract. In addition, it serves to guarantee sound management of the public funds of the Union, preventing those who have contravened the regulations from contracting with public bodies and reinforcing measures to prevent the infiltration of the visible economy by criminal networks (as an instrument in the fight against corruption, fraud and other unacceptable activities; in other words, disqualification as an anti-corruption tool).

The 2014 Public Procurement Directives contain an exhaustive list of the circumstances under which a tenderer or candidate should, in some cases ('mandatory grounds for exclusion'), and can in others ('discretionary grounds for exclusion') be excluded from a bidding procedure (article 38 of the Directive 2014/23/EU ('Concessions Directive'); article 57 of the Directive 2014/24/EU ('Public Sector Directive') and article 80 of the Directive 2014/25/EU ('Utilities Directive').

The deadline for transposition of the 2014 Procurement Directives falls on April 18th 2016, by which time, Member States are required to have transposed the Directives into national law. However, given that EU Directives on Public Procurement cover only public procurement above certain thresholds, the references to the principles of the Treaty on the Functioning of the European Union (TFEU) - equal treatment, non-discrimination, mutual recognition, proportionality and transparency - and to the case-law of the Court of Justice of the European Union (CJEU) ${ }^{*}$ are of great interest.

The general principles arising from the primary Law of the Union in matters concerning the award of public contacts show us that they are the component that provides support to the requirements linked to the liberties guaranteed

\footnotetext{
${ }^{*}$ La Cascina and Others, C-226/04 and C-228/04, EU:C:2006:94; Michaniki, C-213/07, EU:C:2008:731; Assitur, C-538/07, EU:C:2009:317; Serrantoni, C-376/08, EU:C:2009:808; Bâtiments y Ponts Construction, C-74/09, EU:C:2010:431; Forposta SA, C-465/1, EU:C:2012:801; Consorzio Stabile, C-358/12, EU:C:2014:2063; Cartiera dell'Adda, C-42/13, EU:C:2014:2345; Croce Amica One Italia, C-440/13, EU:C:2014:2435; Generali-Providencia Biztositó, C-470/13, EU:C:2014:2469; and Impresa Edilux and SICEF, C-425/14..
} 
by the TFEU (the free movement of goods, freedom of establishment, and the freedom to provide services) and they are an obligatory reference for the organization of the public procurement system at a European level.

The list of circumstances which, if applicable to the tenderer or the candidate, constitute a legal obstacle to being able to contract, responds to the application of the above principles. They are the underlying reason why it has been acknowledged that the Member States have the authority to establish, in addition to the causes for exclusion that are explicitly contained in the Directives, other grounds for exclusion from contracting, provided that those grounds have as their objective to guarantee observance of the principles of equal treatment, transparency and proportionality. Having expounded these thoughts of a general nature, I shall now centre on some of the novel aspects in the regulation of the grounds for exclusion from participation in a public contract, and on those that, in my view, could have been regulated in different ways.

\section{MANDATORY EXCLUSIONS OF ECONOMIC OPERATORS}

The obligatory exclusions of the public procurement processes are foreseen for acts which may be grouped into two categories: (i) non-compliance by the economic operator with its obligations relating to the payment of taxes or social security contributions, in cases where non-compliance has been established by a final and binding judicial or administrative decision; and, (ii) the economic operator has been convicted in a final judgment for participation in a criminal organisation; corruption; fraud; terrorist offences or offences linked to terrorist activities; child labour and other forms of human trafficking.

I should in the first place highlight, as important — and successful — novelties of the new regulation, that the catalogue of offences that gives rise to mandatory grounds for exclusion has been enlarged to cover terrorist offences or offences linked to terrorist activities - although they were already covered in the Directive 2009/81/EC ('Defence and Security Directive') — and the offences linked to child labour and other forms of human trafficking. In second place, as a mandatory ground for exclusion it covers the economic operator in breach of its obligations relating to the payment of taxes or social security contributions; nevertheless, that breach should be supported by a firm judicial sentence or binding administrative decision. Were that not so, the exclusion would not be 
mandatory in nature, although it would be discretionary (article 57 (2) in fine ('Public Sector Directive').

All these exclusions from contracting should be transposed into the internal regulations of the 28 Member States (United Kingdom and France have notified the EC of legislation in transposition of the 2014 Directives; while Hungary, Italy, Austria, Malta and Spain have recently modified their legislation). Although the deadline for its transposition is not over and the way in which it will take place in all the States is, therefore, as yet unknown, I have defended a series of proposals in this doctoral thesis that, in my opinion, would have contributed greater legal certainty to the text of the Directives.

First proposal. After examining the way in which the member States have transposed article 45(1) of Directive 2004/18/EC into their internal legislation (Table 5), I can affirm the existence of significant differences with regard to the criteria adopted to specify the criminal behaviours that give rise to mandatory grounds for exclusion.

For this reason, and given that the concepts to which the 2014 Procurement Directives refer, of corruption, fraud, terrorism and participation in a criminal organisation, were constructed around the legal grounds of the third pillar, which is now consigned to the past, it would perhaps have been a good opportunity to contribute an independent definition of these public procurement offences. The supression of the normative references would, in addition, circumvent the lack of concordance between legislation following the abrogation of a law, as has taken place with regard to Directive 2005/60/EC ('Third Money Laundering Directive') which will be replaced - although there is still time for that to happen-by Directive (EU) 2015/849, of 20 May 2015, on the prevention of the use of the financial system for the purposes of money laundering or terrorist financing.

Second proposal. This proposal is based on two assumptions: the first is that public procurement, as well as constituting a means of providing goods and services, also represents a powerful legal instrument available to a contracting authority to ensure compliance with secondary or non-commercial goals. The second is that one of the reasons for revising and modernising the rules on public procurement through the adoption of the 2014 Procurement Directives has been 'to increase the efficiency of public spending $(. .$.$) and to enable$ 
procurers to make better use of public procurement in support of common societal goals' (Recital 2 'Public Sector Directive').

On that basis, my proposal for regulation would have foreseen that noncompliance with the obligations in the fields of environmental, social and labour laws would imply the mandatory — and not solely discretionary - exclusion of the economic operator from the procedure for the award of a public contract in harmony with the objectives foreseen in the 'Europe 2020 strategy for smart, sustainable and inclusive growth'.

\section{DISCRETIONARY GROUNDS FOR EXCLUSION}

Under the heading of discretionary grounds for exclusion, a series of behaviours is grouped together that can imply - if considered in this way in national legislation - exclusion from the procedure to award a public procurement contract to economic operators who have been involved in such conduct (article 57.4 'Public Sector Directive' and article 38.4 'Concessions Directive').

In the context of that case-law, the Court of Justice took account of the fact that the Member States may choose not to apply those grounds of exclusion at all or to incorporate them into national law with varying degrees of rigour according to the legal, economic and social considerations prevailing at national level. The Member States had the power to make the grounds for exclusion less onerous or more flexible (La Cascina and Others, C-226/04 and C-228/04, EU:C:2006:94 and Michaniki, C-213/07, EU:C:2008:731). Member States legislation is, in that regard, very diverse.

The section referring to discretionary grounds for exclusion is the one that presents the most novelties to fill a regulation that is more in accordance with certain aspects of well-established case-law of the CJUE and with the Financial Regulation (Regulation (EU, Euratom) 966/2012 on the financial rules applicable to the general budget of the Union).

Taking account of the new regulatory context, among the behaviours that can lead to exclusion from contracting, because of a lack of suitable professional care, they should be understood to include the following:

- Violations of environmental, social and labour laws, although in my understanding, it should have been considered a mandatory ground for 
exclusion;

- Those that confirm the infringement of laws on competitition through either legal or administrative channels, because of having entered into illegal agreements between economic operators, in order to monopolize the market or agree on collusive agreements - price fixing or 'bid-rigging' (Generali-Providencia Biztosító, C-470/13, EU:C:2014:2469). This new ground for exclusion can have a deterrent effect on the establishment of collusive agreements.

- Persistent deficiencies in the performance of earlier public contracts (Forposta SA, C-465/11 EU:C:2012:801). Major deficiencies with regard to substantive requirements, for instance, failure to deliver or to perform, significant shortcomings of the product or service delivered, making it unusable for the intended purpose, or misbehaviour that casts serious doubts on the integrity of the economic operator (recital 101 'Public Sector Directive' - recital 70 'Concessions Directive').

- Behaviours that infringe the principle of equal treatment of tenderers, when one tenderer is in an advantageous position with regard to its competitors, as happens, for example, with the distortion of competition, with the prior involvement of the economic operators in the preparation of the procurement procedure-provided that it cannot be remedied by other, less intrusive measures - Fabricom, C-21/03 and C-34/03, EU:C:2005:127).

- Moreover, under the circumstances of a conflict of interests. In such situations, the contracting authorities are under no absolute obligation to exclude tenderers systematically. Such exclusions are not justified where it can not be shown that that situation had no impact on their conduct in the context of the tender procedure, and that it entailed no actual risk of practices liable to distort competition between tenderers. On the other hand, where there is a conflict of interests, the exclusion of a tenderer is essential, especially if there is no more appropriate remedy to avoid any breach of the principles of equal treatment of tenderers and transparency (eVigilo, C-538/13, EU:C:2015:166; Intrasoft International/Commission, $\mathrm{T}-403 / 02)$. 
- Any grave non-compliance of the contractual obligations applicable to the contractor, subject to the appreciation of the negligent behavior of which it is accused, given that the concept of 'grave misconduct' should be understood as revealing culpability or negligence of a certain seriousness by the economic operator in question (Forposta SA, C-465/11 EU:C:2012:801). However, even though it is a question of national competence, and by virtue of the principle of legal certainty, it would have been useful to have defined the conduct considered reproachable in the light of the European regulation, beyond mere generic reference to the concept of 'grave professional misconduct'. The lack of clarity of the Directives with regard to the grounds for exclusion from contracting, because of having commited serious misconduct in professional matters is "contagious", in so far as it is reproduced in some of the national regulations (Belgium and Luxembourg). The economic operators should have precise knowledge of the scope of the obligations imposed upon them, and should be able to evaluate their effects in case of non-compliance.

\section{APPLICATION BY THE MEMBER STATES}

In accordance with the provisions of the Directives, Member States are empowered to define the implementing conditions of the exclusions from contracting. However, insofar as these conditions imply restrictions to the exercise of the rights of the economic operators and, therefore, amount to an administrative act with an adverse effect on their interests, the EU legislature specifies some points for their successful application.

From among these points, in this study, I refer to the following:

\section{(i) The connection with a firm judgment which has the force of res judicata-binding administrative decision that may no longer be contested}

In the case of exclusions from mandatary contracting, the economic operator has to have been "the subject of a conviction by final judgment" or one that "has been established by a judicial or administrative decision having final and binding effect". In that connection, under certain circumstances, a legal person who is not the perpetrator of an offence may nevertheless be "penalised" for the unlawful conduct of a natural person, if "the person con- 
victed by final judgment is a member of the administrative, management or supervisory body of that economic operator or has powers of representation, decision or control therein". This provision is intended to remedy the problem of the criminal liability of legal persons. We therefore find ourselves facing the privation of a right linked to a criminal conviction or a firm and binding administrative decision, without either the former or the latter having to contain a specific reference to exclusion. Nonetheless, it is necessary to distinguish the cases in which sentences on disqualification and its duration are pronounced, from those cases in which they are not pronounced. In the former, the Court's assessment of the situation and the sentence are automatically imposed on the contracting authorities, and in the latter, in which such final sentences make no pronouncement on this situation, the contracting authorities have a margin of discretion to decide the exclusion. In this sense, it is necessary, on the one hand, to require the Member States to cooperate more effectively and to exchange information with each other and, on the other hand, to continue advancing towards the principle of the mutual recognition of judgments and judicial decisions, commonly referred to as a cornerstone of judicial cooperation in criminal matters within the Union.

\section{(ii) The exclusions from contracting can not be for an unlimited period}

One of the successes of the present regulation is to set maximum deadlines on the exclusions from contracting, if they have not been delivered by a court sentence. These deadlines will not exceed three to five years, depending on the circumstances for exclusion. This regulatory provision contributes legal certainty, in so far as it avoids the "legal death" of the company/legal person, at the same time as the economic operators concerned may know without ambiguity what rights and obligations ensue from it, so that they may take steps accordingly. No minimum period is fixed, although we have highlightedby way of an example - that the shortest exclusion from contracting in Spain published in the Official State Gazette (BOE) was for one month.

\section{(iii) Blacklisting vs. White listing}

The greatest drawbacks for the effective and coherent application of these exclusions are found in the lack of knowledge of the facts/judgements and decisions that lead to an exclusion from contracting. 
Public procurement Directives foresee no regulations with regard to the implementation of 'blacklists' of firms that have been excluded because of corruption/fraud, as foreseen by some member States (Malta and the Czech Republic) and in financial institutions such as the World Bank. However, it is worth mentioning that in relation to the Financial Regulation, the EU legislature created a central database (Central Exclusion Database), complying with European regulations on the protection of personal data, which contained the details of candidates and tenderers which fall into one of many situations that calls for exclusion.

In my opinion, this database - as well as those that are functioning in the member States - are an important tool for the exchange of information on grounds for exclusion, although the use of this central database is still very limited, given that only five Member States have declared that they are currently making use of it (Belgium, Czech Republic, Malta, Austria and Poland) and that some member States - like Denmark, Ireland, Hungary, Slovenia, Sweden and Spain - use their own national exclusion databases.

In our opinion, a good alternative would be to draw up 'white lists' of companies compiled on the basis of compliance with the legal framework, which are lists of honorably sound companies that have shown high standards of integrity when participating in public tendering procedures. White listing can be considered as a means of incentivization, whereby companies eligible to participate in tendering are pre-selected, because they have demonstrated the ability to perform in a responsible manner and are willing to abide by applicable rules and regulations.

\section{(iv) Reducing the requirements for documentation}

Public procurement Directives seek to reduce the requirements that contracting authorities impose on economic operators to prove their eligibility to participate in a given procurement procedure. It is no surprise that many economic operators, and not least Small and Medium Sized Enterprises (SME), find that a major obstacle to their participation in public procurement consists in administrative burdens arising from the need to produce a substantial number of certificates or other documents related to exclusion and selection criteria (recital 84 'Classic Directive'). 
Thus, the 2014 Directives reduce the administrative burden for tenderers in different ways and are intended to establish mechanisms to facilitate knowledge of the certificates that are required to participate in an award procedure in the different Member States. One of these instruments is the e-Certis database that provides a record of national certificates used for cross-border public procurement.

Another one - in my opinion the most important and certainly the most widely applied - is the use of the European Single Procurement Document (consisting of updated self-declarations), as prima-facie evidence for selection is more widely applied. The contracting authorities accept the European Single Procurement Document as preliminary evidence that no grounds for exclusion apply to candidates and tenderers, and that they comply with the established selection criteria with regard to their suitability to pursue the professional activity, their economic and financial standing and their technical and professional ability; nonetheless, candidates of tenderers must, however, be prepared to submit the actual official documents "upon request and without delay".

However, insofar as greater confidence is granted to the economic operator, it has to reply in kind. In that regard, the Public procurement Directives aim to protect the legitimate expectations of the contracting authority through the possibility of grounds for the exclusion of candidates of tenderers which (i) have been found guilty of misrepresentation in supplying information required for participation in the contract procedure; (ii) have deliberately withheld such information; (iii) are unable to submit the supporting documentation that is required; or, (iv) have negligently provided misleading information. These exclusions on contracting are foreseen as discretionary, although in my opinion they should have been envisaged under the mandatory circumstances for exclusion, as such grounds suggest a high degree of "dishonesty and disloyalty", and a breakdown in the level of trust needed to become a contractor.

\section{DEROGATIONS}

The EU legislature, at the same time as fixing the establishment of mandatory exclusions on contracting - and as a closure of the system-has been modulating its effects through the possibility of preparing exceptions to its application. In the Directives from 2004 (Directive 2004/18/EC and Directive $2004 / 17 / E C)$, the only provision in this respect was "for overriding require- 
ments in the general interest".

In the current regulation, the member States are authorized to establish exceptions in certain circumstances to those exclusions, so as to make the objectives of the exclusions from contracting compatible with the guarantee underlying the principle of competition that underlies the contractual process.

The 2014 Directives therefore established five groups of exceptions, subject to compliance with certain conditions, that distinguish the circumstances under which it is in the hands of the Member States to repeal either mandatory or discretionary grounds for exclusions from contracting. The exceptions are as follows: (1) those arising from the existence of overriding reasons in the general interest; (2) those that refer to economic motives; (3) those based on criteria of proportionality; (4) those linked to tax regularization; and, (5) those related to the conduct of the candidate or tenderer through the implementation of self-cleaning measures, with which it is possible for an economic operator to regain its eligibility to participate in public procurement procedures, despite the existence of a relevant ground for exclusion.

Therefore, the new Directives incorporate greater flexibility with regard to the contractor selection criteria in their rules, by taking the specific situations of the economic operators into account and they provide formal compliance with the requirement of legal certainty, as they include in their texts clear and precise examples of the reasons for the exception to the application of the grounds for exclusion from contracting.

Some of these regulations comply - in my understanding - with the criteria required to generate rights with direct effect and, in this sense, I consider that before this effect is invoked, the self-cleaning measures should be included in all the national regulations, as was possible before 2014 in Austria, Germany and Italy and it is becoming so in other Member states such as the United Kingdom, France and Hungary.

It is important to note that the effects of the changes are dependent on the contracting authorities and the political will in each and every Member State, but that some of the provisions are mandatory. With regard to those that are not, the national legislations should be interpreted in accordance with European Union Law. In my view, the national legislators should, in 
the transposition of the grounds for exclusion, generate certainty among the 'honest' economic operators that participate with regard to the rule of Law in a democratic State. Finally, and no less importantly, they should generate economic stability by moderating the prejudicial effects that illegal practices cause to the visible economic sector of a country. 



\section{BIBLIOGRAFÍA}

ABRATE, S., "Il requisito della moralità professionale delle imprese negli appalti pubblici. Prassi operativa e giurisprudenza", Appalti \& Contratti, vol. 4 (8 y 9), 2009, págs. 8 - 24.

ALARCÓN SOTOMAYOR, L., Procedimiento administrativo sancionador y derechos fundamentales, Cizur Menor (Navarra), Thomson-Aranzadi, 2007.

ALBALADEJO GARCÍA, M., Derecho civil. Introducción y parte general, Tomo I, 15. ${ }^{a}$ ed., Bosch, Barcelona, 2002.

ALLAIN, Y., "The new European Directives on Public Procurement: Change or continuity?", Public Contract Law Journal, vol. 34 (3), 2006, págs. 517 - 536.

ALENZA GARCÍA, J. F., "Desarrollo sostenible", en la obra colectiva Los principios jurídicos del Derecho Administrativo, La Ley, Las Rozas (Madrid), 2010, págs. $1387-1426$.

ALONSO GARCÍA, R., "La ejecución normativa del Derecho comunitario europeo en el ordenamiento español", RAP, núm. 121, enero - abril 1991, págs. 213 243.

- Sistema Jurídico de la Unión Europea, $4^{\mathrm{a}}$ ed., Civitas - Thomson Reuters, Cizur Menor (Navarra), 2014.

ALONSO-ALEGRE, G., Manual de contratación pública socialmente responsable en relación con las personas con discapacidad, Cermi - Cinca, Madrid, 2009.

ÁLVAREZ-CIENFUEGOS SUÁREZ, J. M., "Aspectos jurídico-públicos de la subcontratación administrativa", Actualidad jurídica Aranzadi, núm. 443, junio 2000, págs. $1-5$.

ÁLVAREZ GARCÍA, F. J., "Retribución y prevención general negativa como fines de la pena", Cuadernos de Política Criminal, núm. 72, 2000, págs. 563 - 613.

- Consideraciones sobre los fines de la pena en el ordenamiento constitucional español, Comares, Granada, 2001.

ÁLVAREZ GARCÍA, V., "Las perspectivas de futuro del Derecho Público: La formación del Derecho Público europeo y la armonización de los Derechos Públicos nacionales", Revista General de Derecho Administrativo, núm. 25, octubre 2010, págs. $1-37$.

ÁLVAREZ PASTOR, D. y EGUIDAZU PALACIOS, F., La prevención del blanqueo de capitales, Aranzadi, Pamplona, 1998. 
AMIEL, R., "Favoritisme dans les marchés publics: bilan jurisprudential cinq ans après la création de cette incrimination", Revue de la concurrence et de la consommation, núm. 96, 1997, págs. 31.

AMOEDO SOUTO, C., TRAGSA. Medios propios de la Administración y huida del Derecho administrativo, Atelier - Ilustre Colegio Oficial de Veterinarios de A Coruña, Barcelona, 2004.

AMUndsen, I., Corruption. Definitions and Concepts, Chr. Michelsen Institute, Bergen, 2000.

ANDERSEN, S. M., Self-cleaning $i$ det nye anskaffelsesdirektivet. Om self-cleaning bestemmelsens innvirkning avvisningsplikten, herunder forholdet til utestengelsesperioden og dokumentasjonskrav, Master thesis, University of Oslo, 2014.

ANECHIARICO, F., "La corrupción y el control de la corrupción como impedimentos para la competitividad económica", Gestión y Política Pública, vol. XIX (2), 2010, págs. 239 - 261.

ANECHIARICO, F., y JACOBS, J. B., "Purging corruption from public contracting: the "solutions" are now part of the problem", New York Law School Law Review, vol. 40, 1995, págs. 143 - 175.

ANGUITA OLMEDO, C., "La delincuencia organizada: Un asunto interior de la Unión Europea. Concepto, características e instrumentos para su neutralización", Revista Española de Relaciones Internacionales, núm. 2, julio 2010, págs. $152-172$.

ARÁNGUEZ SÁNCHEZ, C., El delito de blanqueo de capitales, Marcial Pons, Madrid, 2000.

ARIAS MARTÍNEZ, M. A., "La libre concurrencia en la contratación administrativa", Revista Xuridica Galega, núm. 32, julio - septiembre 2001, págs. 13 24.

ARIEL REZZOAGLI, B., Corrupción y contratos públicos: una visión desde la fiscalización del Tribunal de Cuentas, Ratio Legis, Salamanca, 2005.

ARIÑO ORTIZ, G., La reforma de la Ley de Contratos del Estado, Unión Editorial, Madrid, 1984.

, "El concepto de contrato público en la CEE", Noticias CEE, núm. 21, octubre 1986, págs. 19 - 26.

- "Problemática actual de la contratación de las Administraciones públicas", en la obra colectiva coordinada por MARTÍNEZ LÓPEZ-MUÑIZ, J.L. y LAGUNA DE PAZ, J.C., Contratación pública, Marcial Pons Madrid, 1996, págs. $17-36$.

, "Estudio introductorio", en la obra colectiva Comentarios a la Ley de Contratos de las Administraciones Públicas, Granada, Comares, 2002, págs. 1 45 .

, "El enigma del contrato administrativo", RAP, núm. 172, enero - abril 2007, págs. $79-102$.

ARIÑO ORTIZ, G. (Director): Comentarios a la Ley de Contratos de las Administraciones Públicas, Comares, Granada, 2002. 
ARIÑO ORTIZ, G., DE LA CUÉTARA MARTÍNEZ, J. M., y MARTÍNEZ LÓPEZMUÑIZ, J. L., El nuevo servicio público, Marcial Pons, Madrid, 1997.

ARNOULD, J., "Secondary Policies in Public Procurement: The Innovations of the New Directives", Public Procurement Law Review, vol. 13 (4), 2004, págs. 187 - 197.

ARROWSMITH, S., "Public procurement as an instrument of policy and the impact of market liberalisation", Law Quarterly Review, núm. 111, April 1995, págs. $235-284$.

, "The Community's legal framework on public procurement: "The way forward" at last?", Common Market Law Review, vol. 36 (1), 1999, págs. 13 49 .

, "An Assessment of the New Legislative Package on Public Procurement", Common Market Law Review, vol. 41 (5), 2004, págs. 1277 - 1325.

, "The past and future evolution of EC Procurement Law: From Framework to Common Code?", Public Contract Law Journal, vol. 35 (3), 2006, págs. 337 -384 .

"Public procurement in the EU. A practitioner's guide", Common Market Law Review, vol. 45 (4), 2008, págs. 1288 - 1290.

"Application of the EC Treaty and directives to horizontal policies: a critical review", en la obra colectiva Social and Environmental Policies in EC Procurement Law. New Directives and New Directions, Cambridge University Press, Cambridge, 2009, págs. 147 - 248.

, "Horizontal Policies in Public Procurement: A Taxonomy", Journal of Public Procurement, vol. 10 (2), 2010, págs. 149 - 186.

, Public Procurement Regulation: An Introduction, EU Asia Inter University Network 2010.

, "Modernising the European Union's public procurement regime: A blueprint for real simplicity and flexibility", Public Procurement Law Review, vol. 21 (3), 2012, págs. $71-82$.

, The Law of public and utilities procurement, $3^{\mathrm{a}}$ ed., Sweet \& Maxwell, London, 2014.

-, "Rethinking the approach to economic justifications under the EU's free movement rules", Current Legal Problems 2015, que se puede consultar en http://www.nottingham.ac.uk/pprg/publications/index.aspx [Fecha de consulta: 15 de octubre de 2015].

ARROWSMITH, S. y ANDERSON R. (Eds.): The WTO Regime on Government Procurement: Challenge and Reform, Cambridge University Press, New York, 2011.

ARROWSMITH, S. y DAVIES, A., Public procurement: Global Revolution, Kluwer Law International, London, 1998.

ARROWSMith, S., LiNARELLI, J. y WALlACE, D., Regulating Public Procurement: National and International Perspectives, Kluwer Law International, The Hague (Netherlands), 2000. 
ARROWSMITH, S. y KUNZLIK, P., (Dirs.) Social and Environmental Policies in EC Procurement Law. New Directives and New Directions, Cambridge University Press, Cambridge, 2009.

ARROWSMITH, S. y KUNZLIK, P., "Public procurement and horizontal policies in EC law: general principles", en la obra colectiva de la cual son Directores Social and Environmental Policies in EC Procurement Law. New Directives and New Directions, Cambridge University Press, Cambridge, 2009, págs. 9 54.

ARROWSMITH, S., PRIESS, H.-J. y FRITON, P., "Self-Cleaning as a Defence to Exclusions for Misconduct - An Emerging Concept in EC Public Procurement Law?", Public Procurement Law Review, vol. 18 (6), 2009, págs. 257 - 282.

ARROWSMITH, S., PRIESS, H.-J. y PÜNDER, H., Self-Cleaning in Public Procurement Law, Carl Heymans, Cologne, 2009.

ARROYO ZAPATERO, L. y NIETO MARTÍN, A. (Directores), El derecho penal de la Unión Europea: situación actual y perspectivas de futuro, Ediciones de la Universidad de Castilla - La Mancha, Cuenca, 2007.

ATELJEVIC, J., y BUDAK, J.,"Corruption and public procurement: Example from Croatia", Journal of Balkan and Near Eastern Studies, vol. 12 (4), 2010, págs. $375-397$.

AURIOL, E., "Corruption in procurement and public purchase", International Journal of Industrial Organization, vol. 24 (5), September 2006, págs. 867 - 885.

ÁVILA ORIVE, J. L., Los convenios de colaboración excluidos de la Ley de Contratos de las Administraciones Públicas, Civitas, Madrid, 2002.

AYMERICH CANO, C. I., "Condicións sociais e contratación pública", Anuario da Facultade de Dereito da Universidade da Coruña, núm. 4, 2000, págs. 53 - 66. , "Un problema pendiente: la ineficacia de los contratos afectados por actos de corrupción", en la obra colectiva Las nuevas Directivas de contratación pública, Thomson Aranzadi, Cizur Menor (Navarra), 2015, págs. 291 - 303.

—_ Un problema pendiente: La anulación de los contratos administrativos afectados por actos de corrupción, Thomson Aranzadi, Cizur Menor (Navarra), 2015.

BACA ONETO, V. S., La invalidez de los contratos públicos, Thomson-Civitas, Cizur Menor (Navarra), 2006.

BACIGALUPO SAGGESE, S., La responsabilidad penal de las personas jurídicas, Bosch, Barcelona, 1998.

, "Comentario al artículo 33.7 del Código penal", en la obra colectiva dirigida por GÓMEZ TOMILLO, M., Comentarios al Código Penal, 2. ${ }^{\mathrm{a}}$ ed., Lex Nova, Valladolid, págs. $280-285$.

BACIGalupo ZAPATER, E., Compliance y Derecho Penal, Aranzadi, Cizur Menor (Navarra), 2011.

BAENA DEL ALCÁZAR, M., "Contratistas extranjeros y productos de fabricación extranjera en la legislación vigente sobre contratos de la Administración", $R A P$, núm. 57, septiembre - diciembre 1968, págs. 407 - 426. 
BALDI, M., "Il previgente regime delle cause di esclusione per reati incidenti sulla moralità professionale negli appalti di lavori e serviz, Urbanistica e appalti, vol. 11 (2), 2007, págs. $234-243$.

BALLESTEROS FERNÁNDEZ, Á., "De los requisitos para contratar con la Administración", en la obra colectiva Contratos de las Administraciones Públicas. Comentarios al Texto Refundido de la Ley (aprobado por Real Decreto Legislativo 2/2000, de 16 de junio), $3^{\mathrm{a}}$ ed., Publicaciones Abella - El Consultor de los Ayuntamientos y de los Juzgados, Madrid, 2000, págs. 219 - 287.

BALLESTEROS MOFFA, L. Á., "La selección del contratista en el sector público. Criterios reglados y discrecionales en la valoración de las ofertas", $R A P$, núm. 180, septiembre - diciembre 2009, págs. 21 - 57.

, La adjudicación de contratos en el sector público, Civitas - Thomson Reuters, Cizur Menor (Navarra), 2010.

BAÑO LEÓN, J. M., "El Derecho comunitario de los contratos públicos y su incidencia en la nueva Ley de Contratos de las Administraciones Públicas", en la obra colectiva Contratación pública, Cuadernos de Derecho Judicial. Consejo General del Poder Judicial, Madrid, 1995, págs. 33 - 49.

, "La influencia del Derecho comunitario en la interpretación de la Ley de Contratos de las Administraciones Públicas", RAP, núm. 151, enero - abril 2000, págs. $11-37$.

BARRERO RODRÍGUEZ, Ma . C., "La resolución del contrato por incumplimiento del contratista en la Ley 30/2007, de 30 de octubre, de Contratos del Sector Público", RAP, núm. 176, mayo - agosto 2008, págs. 89 - 113.

, La resolución de los contratos administrativos por incumplimiento del contratista, $2^{\mathrm{a}}$ ed., Lex Nova, Valladolid, 2011.

_, "Los efectos de la resolución de los contratos administrativos: resolución por concurso y por incumplimiento del contratista. La conveniencia de una reforma normativa", $R A P$, núm. 196, enero - abril 2015, págs. $61-95$.

BASSOLS COMA, M., "Aproximación a la normativa comunitaria europea sobre contratación administrativa", Noticias CEE, núm. 21 octubre 1986, págs. 27 -34 .

, "Contratación administrativa y ordenamiento comunitario: experiencias y perspectivas", en la obra colectiva España en la Europa comunitaria: Balance de diez años, Centro de Estudios Ramón Areces, Madrid, 1995, págs. 301 318.

BAUCELLS LLADÓS, J., "Las penas previstas para la persona jurídica en la reforma penal de 2010. Un análisis crítico", Estudios Penales y Criminológicos, vol. XXXIII 2013, págs. 175 - 218.

"Sistema de penas para la delincuencia económica en Derecho español", en la obra colectiva La delincuencia económica. Prevenir y sancionar, Tirant lo Blanch, Valencia, págs. $393-423$.

BEATO VIBORA, M., "Protección penal de concursos y subastas de naturaleza pública: El artículo 262 del Código Penal", Anuario de la Facultad de Derecho de la Universidad de Extremadura, vol. 14 - 15, 1996 - 1997, págs. 167 - 187. 
BENACCHIO, G.A., "Verso le direttive di quarta generazione", en la obra colectiva Gli appalti pubblici tra regole europee e nazionali, EGEA, Milano, 2012, págs. $3-28$.

BENACCHIO, G. A. y COZZIO, M. (Coord.), Gli appalti pubblici tra regole europee e nazionali, Egea, Milán, 2012.

BENGOETXEA CABALLERO, J., "Las listas Negras: un agujero negro en la Europa de los derechos fundamentales", Revista Vasca de Administración Pública, núm. 82 (II), septiembre - diciembre (Ejemplar dedicado a la tutela multinivel de los Derechos Fundamentales), 2008, págs. 27 - 47.

BENÍTEZ MORCILLO, G. J., El contratista en la Ley de Contratos de las Administraciones Públicas: (régimen jurídico en el Derecho comunitario europeo y en el Derecho administrativo español), Tesis doctoral manuscrita, Universidad Autónoma de Madrid, 1998.

, "Capacidad de las empresas", en la obra colectiva dirigida por ARIÑO ORTIZ, G., Comentarios a la Ley de Contratos de las Administraciones Públicas, Comares, Granada, 2003, págs. 1 - 39.

BERASATEGI, J., "La integración de la contratación pública en la Defensa de la Competencia", Gaceta jurídica de la Unión Europea y de la competencia, núm. 247, enero - febrero 2007, págs. 35 - 52.

BERCUSSON, B. y BRUUN N., "Labour law aspects of public procurement in the EU", en la obra colectiva The new EU public procurement Directives, Djøf Publishing, Copenhagen, 2005, págs. 97-116.

BERMEJO VERA, J., "Objetivos, principios y prospectiva de la política comunitaria de contratos públicos", REGAP, núm. 29, septiembre - diciembre 2001, págs. $141-163$.

, "Las prohibiciones de contratar en la Ley de Contratos del Sector Público", Revista Aragonesa de Administración Pública, núm. monográfico El Derecho de los Contratos del Sector Público, 2008, págs. 109-140.

-, Voz "prohibiciones de contratar", en la obra colectiva Diccionario de Contratación Pública, Iustel, Madrid, 2009 págs. 537 - 552.

BERMEJO VERA, J. (Director): Diccionario de Contratación Pública, Iustel, Madrid, 2009.

BERNAL BLAY, M. Á., "Hacia una contratación pública socialmente responsable: Las oportunidades de la Ley 30/2007, de 30 de octubre, de Contratos del Sector Público", Revista Aragonesa de Administración Pública, núm. monográfico X sobre el Derecho de los contratos del Sector Público, 2008, págs. 211 - 252.

, "Un paso en falso en la interpretación del criterio del control análogo al de los propios servicios en las relaciones in house", REDA, núm. 137, enero-marzo 2008, págs. 115-138.

, El contrato de concesión de obras públicas y otras técnicas "paraconcursales", Civitas - Thomson Reuters, Cizur Menor (Navarra), 2011.

, "El principio de objetividad en la contratación pública", Documentación administrativa, núm. 289, enero - abril 2011, págs. 129 - 150. 
_ "El desarrollo de políticas activas de empleo a través de los contratos públicos", en la obra colectiva dirigida por PERNAS GARCÍA, J. J., Contratación pública estratégica, Aranzadi, Cizur Menor (Navarra), 2013, págs. 161 - 186.

__ "Los efectos de los programas de compliance en la contratación pública", en la obra colectiva Las nuevas Directivas de contratación pública, Thomson - Aranzadi, Cizur Menor (Navarra), 2015, págs. 413 - 424.

BERTOK, J., "Promoting transparency and integrity in public procurement: the work of the OECD", PPLR, vol. 15 (6), 2006, págs. NA188 -194.

BESTEIRO RIVAS, J., "Comentarios al artículo 49 de la Ley de Contratos del Sector Público (Prohibiciones de contratar)", en la obra colectiva dirigida JIMÉNEZ APARICIO, E., Comentarios a la Legislación de Contratación Pública, Aranzadi - Thomson Reuters, Cizur Menor (Navarra), págs. 760 - 791.

BETH, E., Integrity in Public Procurement: Good Practice from A to Z, OCDE, Paris, 2007.

BIANCHI, T. y GUIDI, V. E., The comparative survey on the National Public Procurement systems across the PPN, Istituto Poligrafico e Zecca Dello Stato Public Procurement Network (PPN), 2010.

BICKERSTAFF, R., "The new directives' rules on e-communication mechanisms in public and utilities procurement", PPLR, vol. 13 (6), 2004, págs. $277-284$.

BJORVATN, K. y SØREIDE, T., Corruption and market reform, CMI Working Papers (WP 2003:7) Chr. Michelsen Institute, Bergen 2003.

BLANCO CORDERO, I., "La corrupción desde una perspectiva criminológica: un estudio de sus causas desde las teorías de las actividades rutinarias y de la elección racional", en la obra colectiva dirigida por PÉREZ ÁLVAREZ, F., In Serta in Memoriam Alexandri Baratta, Universidad de Salamanca, Salamanca, págs. $274-291$.

, "Derechos Humanos y terrorismo: las "listas negras" de sospechosos de actividades terroristas", en la obra colectiva dirigida por DE HOYOS SANCHO, M., El proceso penal en la Unión Europea: Garantías esenciales/Criminal proceedings in the European Union: essential safeguards, Lex Nova, Valladolid, 2008, págs. $306-335$.

-, El delito de blanqueo de capitales, $3^{\text {a }}$ ed., Aranzadi, Cizur Menor (Navarra), 2012.

, "La admisibilidad de las listas de evasores fiscales sustraídas en el extranjero como prueba para acreditar la comisión de delitos", InDret. Revista para el análisis del Derecho, vol. 3 julio 2015, págs. 1 - 34 .

BLANCO LÓPEZ, F., "La capacidad de los contratistas. Personalidad jurídica y capacidad de obrar. Solvencia económica y técnica. Clasificación empresarial", en la obra colectiva Contratación de las Administraciones públicas. Análisis práctico de la nueva normativa sobre contratación pública, Atelier, Barcelona, 2004, págs. 37 - 60.

, "La subcontratación administrativa. Ejercicio de la acción directa del artículo 1597 del Código Civil”, RArAP, núm. 38, 2011, págs. 221 - 258. 
BLÁZQUEZ ROMÁN, J. A. y RAMÍREZ HORTELANO, P., "Las cláusulas sociales en la contratación administrativa", Contratación Administrativa Práctica, núm. 42, mayo 2005, págs. 39 - 48.

BOLTON, P., "The Use of Government Procurement as an Instrument of Policy", South African Law Journal, vol. 121, 2004, págs. 619- 635.

, "The Exclusion of Contractors from Government Contract Awards", Law Democracy \& Development, vol. 10 (1), 2006, págs. 1 - 25.

, Protecting the environment through public procurement: The case of South Africa", Natural Resources Forum, vol. 32 (1), 2008, págs. 1 - 10.

BOQUERA OLIVER, J. M., "La caracterización del contrato administrativo en la reciente jurisprudencia francesa y española", $R A P$, núm. 23, mayo - agosto 1957, págs. $193-210$.

, "Influencia de la Comunidad Económica europea sobre los procedimientos de la selección de contratistas en las Administraciones nacionales", $R A P$, núm. 29, mayo - agosto 1959, págs. 415 - 426.

, La selección de contratistas. Procedimiento de selección y contrato, Instituto de Estudios Políticos, Madrid, 1963.

, "Los contratos de la Administración desde 1950 a hoy", RAP, núm. 150, septiembre - diciembre 1999, págs. 13 - 32.

BORRAJO INIESTA, I., "Las Directivas sobre contratación pública como manifestación de la libertad comunitaria de circulación", Noticias CEE, núm. 21, octubre 1986, págs. 41 - 48.

BOURGOIN, P., "Les exclusions de marchés publics", Revue Marchés Publics, núm. 208, 1985, págs. 27 - 31.

BOVIS, C., "Qualitative Selection Criteria for Enterprises Participating in the Award of Public Procurement Contracts", European Business Law Review, vol. 5 (1), 1994, págs. 9 - 12.

— EC Public Procurement Law, Longman, London, 1997.

, EC Public procurement: Case law $\&$ regulation, Oxford University Press, Oxford, 2006.

, "Developing public procurement regulation: Jurisprudence and its influence on law making", CMLR, vol. 43 (2), 2006, págs. 461-495.

, "Public procurement in the EU: Jurisprudence and conceptual directions", Common Market Law Review, vol. 49 (1), 2012, págs. 247 - 289.

_ - "The challenges of public procurement reform in the single market of the European Union", ERA Forum, vol. 14, June 2013, págs. 35 - 57.

BRÉCHON-MOULÈNES, C., "L'échec des Directives Travaux et Fournitures de 1971 et 1976", en el número especial Les marchés publics européens de la Revue Française de Droit Administratif, 1989, págs. 8 - 16

Droit des marchés publics. Exclusions (epígrafe III. 410.1), Le Moniteur, Paris, 1998. 
BROWN, A., "The Permissibility of Excluding an Economic Operator From a Tendering Procedure on the Ground that it has Previously Committed an Infringement of Competition Law: Case C-470/13 Generali-Providencia Biztosító", PPLR, vol. 24 (3), 2015, N51 - N60.

, "Beyond the pale: Breaking the rules may exclude you from tendering for public contracts", Competition Law Insight, vol. 14 (3), 2015, págs. 5 - 7.

BRUNELLI, P., Marchés publics et Union européenne: nouvelles règles communautaires, Ed. Continent Europe, Paris, 1995.

BRUUN, N. y BERCUSSON, B., "Labour Law Aspects of Public Procurement in the EU", en la obra colectiva editada por NIELSEN, R. y TREUMER, S., The New EU Public Procurement Directives, Djøf Publishing, Copenhague, 2005, págs. $97-116$.

BUEB, J. P., "Fraudes et Corruption dans les Marchés Publics", Revue du Marché Unique Européen, vol. 1, 1997, págs. 27 - 68.

BURGI, M., "La transposición de las Directivas de contratación pública en Alemania", Instituto de Derecho Local, UAM, Madrid, 2014 (con ocasión del Seminario Internacional sobre contratación pública que puede consultarse en http://www.idluam.es/images/stories/Convocatorias/Folien_ES_Martin_Burgi.pdf [Fecha de consulta: 15 de octubre de 2015].

BUSCAGLIA, E. y VAN DIJK, J., "Controlling organized crime and corruption in the public sector", Forum on Crime and Society, vol. 3 (1 y 2), December 2003, págs. 3 - 34 .

CACIAGLI, M., Clientelismo, corrupción y criminalidad organizada. Evidencias empíricas y propuestas teóricas a partir de los casos italianos, Centro de Estudios Constitucionales, Madrid, 1996.

CADEMARTORI, D., Buena administración y procedimientos de selección de contratistas: Análisis de mecanismos jurídicos e informativos para alcanzar la eficiencia en las licitaciones públicas, Tesis doctoral manuscrita presentada en la Universidad de Salamanca, 2010.

CALVO CHARRO, M., "Las uniones temporales de empresas", en la obra colectiva dirigida por GÓMEZ- FERRER MORANT, R., Comentario a la Ley de Contratos de las Administraciones Públicas, $2^{\mathrm{a}}$ ed., Thomson - Civitas, Madrid, 2004, págs. $173-197$.

CANALS AMETLLER, D., "Simplificación administrativa y Directiva de Servicios: Objetivos, medios e incidencias", RArAP, Monográfico XII dedicado a El impacto de la Directiva Bolkestein y la reforma de los servicios en el Derecho administrativo, 2010, págs. 297 - 335.

CARANTA, R., "Sustainable Public Procurement in the EU", en la obra colectiva dirigida por CARANTA, R., y TRYBUS, M., The Law of Green and Social Procurement in Europe, Djøf Publishing, Copenhagen, 2010, págs. 15 - 51.

, "Sustainable Procurement", en la obra colectiva dirigida por CARANTA, R., EDELSTAM, G., y TRYBUS, M., EU Public Contract Law: Public Procurement and beyond, Bruylant, Brussels, 2014, págs. 165 - 190.

, "The changes to Public Contract Directives and the story they tell about how EU law works", Common Market Law Review, vol. 52 (2), 2015, págs. 391 - 460 . 
CARANTA, R. y TRYBUS, M., (Eds.) The Law of Green and Social Procurement in Europe, Djøf Publishing, Copenhague, 2010.

CARBONERO GALLARDO, J. M., La adjudicación de los contratos públicos. Procedimientos para la adjudicación de los contratos administrativos y otros contratos del sector público, La Ley - El Consultor de los Ayuntamientos y de los Juzgados, Las Rozas (Madrid), 2010.

CARLÓN RUIZ, M., "Las Administraciones Públicas ante el fenómeno concursal: algunas reflexiones al hilo de la nueva Ley". RAP, núm. 164 mayo - agosto 2004, págs. $95-143$.

, "La Ley de Contratos de las Administraciones Públicas y su carácter estructurante del ordenamiento jurídico-público", en la obra colectiva Comentario a la Ley de Contratos de las Administraciones Públicas, dirigida por GÓMEZFERRER MORANT Thomson-Civitas, 2a ed., Madrid, 2004, págs. 1801 1823

, "El principio de proporcionalidad", en la obra colectiva dirigida por SANTAMARÍA PASTOR, J.A., Los principios jurídicos del Derecho Administrativo, La Ley, (Las Rozas) Madrid, 2010, págs. 203 - 230.

CARNEVALI RODRÍGUEZ, R., "La criminalidad organizada. Aproximación al Derecho penal italiano, en particular la responsabilidad de las personas jurídicas y la confiscación", Revista de Derecho Penal, núm. 33, mayo - agosto 2011.

CARRERA, S. y GEYER, F., "El Tratado de Lisboa y un Espacio de Libertad, Seguridad y Justicia: Excepcionalismo y fragmentación en la Unión Europea", Revista de Derecho Comunitario Europeo, núm. 29, enero - abril 2008, págs. $133-162$.

CARRETERO PÉREZ, A., "El contrato administrativo ante la Ley de Bases de contratos del Estado de 28-XII-1963", RAP, núm. 45, septiembre - diciembre 1964.

CASARES MARCOS, A., "Comercio justo y fomento de la contratación pública socialmente responsable", Contratación Administrativa Práctica, núm. 123, enero - febrero 2013.

CASTILLO GARCÍA, J. F., "La comunitarización del Tercer Pilar: un paso necesario para la consolidación del Espacio penal europeo", Revista General de Derecho Europeo, núm. 11, octubre 2006, págs. 1 - 49.

CASTRO CUENCA, C. G., La corrupción en la contratación pública en Europa, Ratio Legis, Salamanca, 2009.

CEA AYALA, Á., "Breves reflexiones acerca de las prohibiciones para contratar", Contratación Administrativa Práctica, núm. 67, septiembre 2007, págs. 26 40.

CECCHINI, P., Europa 1992: Una apuesta de futuro, Alianza Editorial, Madrid, 1988.

CELENTANI, M y GANUZA, J. J., "Corruption and competition in procurement", European Economic Review, núm. 46 (7) July 2002, págs. 1273 - 1303.

CERRILLO I MARTÍNEZ, A., El principio de integridad en la contratación pública. Mecanismos para la prevención de los conflictos de intereses y la lucha contra la corrupción, Aranzadi, Cizur Menor (Navarra), 2014. 
CHINCHILLA MARÍN, C., "La insolvencia del contratista de las Administraciones públicas". RVAP, núm. 69 (I) mayo - agosto 2004, págs. 33 - 88 .

, "La nueva Ley de contratos del sector público: ámbito de aplicación y otras cuestiones novedosas", RVAP, núm. 79, septiembre-diciembre 2007, págs. 4170 .

, "La jurisprudencia del TJUE sobre contratos públicos (I). Ámbito subjetivo y objetivo de aplicación de las Directivas", en la obra colectiva dirigida por SÁNCHEZ MORÓN, M., El Derecho de los contratos públicos en la Unión Europea y sus Estados miembros, Lex Nova, Valladolid, 2011, págs. 33 - 79.

CLARK, P., y SUPRENANT, J., "Siemens - Potential Interplay of FCPA Charges and Mandatory Debarment under the Public Procurement Directive of the European Union", comunicación presentada en $23^{\circ}$ Annual National Institute on White Collar Crime, San Francisco, 2009, y que puede consultarse en: http://www.cadwalader.com/assets/article/ -

030409ABASiemensPotentialInterplay.pdf [Fecha de consulta: 15 de octubre de 2015].

CLERC, E., "La mondialisation des marchés publics: Bilan et perspectives de láccord OMC sur les marchés publics", en la obra colectiva Les marchés publics à l'aube du XXIe siècle, Bruylant, Brussels, 2000, págs. 141-194.

CLIMENT BARBERÁ, J. 1986. "La selección de contratistas en los contratos de las Administraciones Públicas en el Derecho comunitario y en el Derecho español". Noticias CEE no. 21 (octubre):49 - 87.

CODINA GARCÍA-ANDRADE, X., "La doctrina de las obligaciones positivas del Tratado de Funcionamiento de la Unión Europea en la contratación pública: arquitectura constitucional europea y nuevas Directivas", Revista Española de Derecho Europeo, núm. 50, abril - junio 2014, págs. 73 - 101

, Why Manova is not Slovensko: a new balance between equal treatment of tenderers and competition?, PPLR, vol. 4, 2015.

COMBA, M., y RICHETTO, S., "Minor contracts: Outside the Directives and Outside the Treaties? Comparative analysis on public procurement below the thresholds in Europe", en la obra colectiva Outside the EU Procurement Directives - Inside the Treaty, Djøf Publishing, Copenhague, 2012, págs. 359 - 372

CONTALDI LA GROTTERIA, C., "I requisiti soggettivi di moralità professionale", en la obra colectiva coordinada por BENACCHIO, G. A. y COZZIO, M., Gli appalti pubblici tra regole europee e nazionali, Egea, Milán, 2012, págs. 181 201.

COSTA GONÇALVES, P., "Concorrência e Contratação Pública (a integração de preocupações concorrenciais na contratação pública)", en la obra colectiva Estudos em Homenagem a Miguel Galvão Telles, Volume I, Almedina, Coimbra, págs. 479-516.

COX, A. y FURLONG, P., "European procurement rules and national preference: Explaining the local sourcing of public works contracts in the EU in 1993", Journal of Construction Procurement, vol. 1 (2) 1995, págs. 87 - 99.

, "Cross-border trade and contract awards: The intellectual myopia at the heart of the EU procurement rules", European Journal of Purchasing \& Supply Management, vol. 3 (1), 1997, págs. 9 - 20. 
DARNACULLETA I GARDELlA, M., Autorregulación y derecho público: la autorregulación regulada, Marcial Pons, Madrid, 2005.

, "La autorregulación y sus fórmulas como instrumentos de regulación de la economía", en la obra colectiva dirigida por MUÑOZ MACHADO, S., y ESTEVE PARDO, J., Derecho de la regulación económica. I. Fundamentos e instituciones de la regulación, Iustel, Madrid, 2009, págs. 631 - 667.

DE LA CUÉTARA MARTÍNEZ, J. M., La actividad de la Administración, Tecnos, Madrid, 1983.

DE LA MATA BARRANCO, N., Derecho penal europeo y legislación española: Las reformas del Código penal, Tirant lo Blanch, Valencia, 2015.

DE LA QUADRA-SALCEDO, T., "Libertad de establecimiento y de servicios: ¿Reconocimiento mutuo o país de origen?", REDA, núm. 146, abril - junio 2010, págs. $221-263$.

DE QUADROS, F., Droit de l'Union européenne («European Union Law»), Bruylant, Bruselas, 2008.

DE SOLAS RAFECAS, J. Ma ; "La Ley de contratos del sector público: Dos regulaciones de naturaleza distinta en un solo texto legal", en la obra colectiva coordinada por DE LA CUÉTARA MARTÍNEZ, J.M, MARTÍNEZ LÓPEZMUÑIZ, J.L. y VILLAR ROJAS, F. J., Derecho administrativo y regulación económica. Liber Amicorum profesor Doctor Gaspar Ariño Ortiz, La Ley, Las Rozas (Madrid), 2011, págs. 493 - 520.

DEL GUAYO CASTIELLA, I., Contratos del sector público y concurso de acreedores, La Ley, Las Rozas (Madrid), 2011.

DEL OLMO ALONSO, J., "El Derecho de la contratación pública en Bélgica", en la obra colectiva dirigida por SÁNCHEZ MORÓN, M., Derecho de los contratos públicos en la Unión Europea y sus Estados miembros, Lex Nova - Thomson Reuters, Valladolid, 2011, págs. 409 - 455.

DEL SAZ CORDERO, S., "La huida del Derecho administrativo: últimas manifestaciones. Aplausos y críticas", RAP, núm .133, enero - abril 1994, págs. 57 98.

DELLA PORTA, D. y VANNUCCI, A., Corrupt exchanges: actors, resources, and mechanisms of political corruption, Walter de Gruyter, New York, 1999.

DESDENTADO DAROCA, E., "El Derecho de la contratación pública en Irlanda", en la obra colectiva dirigida por SÁNCHEZ MORÓN, M., Derecho de los contratos públicos en la Unión Europea y sus Estados miembros, Lex Nova Thomson Reuters, Valladolid, 2011, págs. $687-720$.

DI LASCIO, F., "La transposición de las nuevas Directivas de contratación pública en Italia", Instituto de Derecho Local, UAM, Madrid, 2014 (con ocasión del Seminario Internacional sobre contratación pública que puede consultarse en http://www.idluam.es/images/stories/Convocatorias/DiLasci_seminario.pdf [Fecha de consulta: 15 de octubre de 2015].

DÍAZ LEMA, J. M., "Contratos públicos y derecho español. Comentario urgente a la STJCE 15 de mayo 2003", Actualidad Administrativa, vol. 35, septiembre 2003, págs. $843-856$. 
_ , "Contratos públicos versus contratos administrativos: ¿es conveniente mantener la duplicidad de la Ley de Contratos del Sector Público?", REDA, núm. 141, enero - marzo 2009, págs. 5 - 42.

DÍEZ MORENO, F., "Las dificultades de la incorporación al ordenamiento español de las Directivas comunitarias sobre contratación de los sectores excluidos", Noticias CEE, núm. 71, diciembre 1990, págs. 49 - 63.

, Manual de Derecho de la Unión Europea, 5ª ed., Civitas-Thomson, Cizur Menor (Navarra), 2009.

DÍEZ MORENO, F. y LÓPEZ-IBOR MAYOR, V., "La contratación administrativa en la UE y el ordenamiento español", Política exterior, núm. 43 (IX), febreromarzo 1995, págs. 146-163.

DÍEZ RIPOLLÉS, J.L., "Las penas de las personas jurídicas y su determinación legal y judicial: regulación española", en la obra colectiva Estudios penales en homenaje al Profesor Rodrigo Fabio Suárez Montes, Constitutio Criminalis Carolina, Oviedo, 2013, págs. 195 - 217.

DÍEZ SASTRE, S., La tutela de los licitadores en la adjudicación de contratos públicos, Marcial Pons, Madrid, 2012.

"Formas y estructuras organizativas de la Administración de los contratos públicos en el mercado interior", en la obra colectiva dirigida por GIMENO FELIÚ, J. Ma ., Observatorio de los contratos públicos 2014, Thomson-Reuters Aranzadi, Cizur Menor (Navarra), 2015, págs. 61 - 87.

DIRICKX, N., L'influence du Droit Communautaire des marchés publics sur les éléments de définition du marché public en France, Atelier National de reproduction des thèses, Lille, 2005.

DOMíngueZ ALONSO, A. P., y MORENO MOLINA, J.A., "Contratos públicos y políticas de apoyo a las personas con discapacidad", en la obra colectiva dirigida por PERNAS GARCÍA, J.J., Contratación pública estratégica, Thomson-Aranzadi, Cizur Menor (Navarra), 2013, págs. 187 - 212.

DOMÍNGUEZ-BERRUETA DE JUAN, M. Á., "Sobre la Ley de Contratos de las Administraciones Públicas. Factores de la reforma de la normativa reguladora de la contratación pública", en la obra colectiva La contratación pública, (vol. I), Hammurabi, Buenos Aires, 2006, págs. 137 - 165.

DONAIRE VILLA, F. J., "El espacio de libertad, seguridad y justicia tras el Tratado de Lisboa: entre supranacionalidad e integración diferenciada", Revista Española de Derecho Europeo, núm. 35, julio - septiembre 2010, págs. 337 364.

DRAGOS, D., y CARANTA, R. (Eds.), Outside the EU Procurement Directives Inside the Treaty?, Djøf Publishing, Copenhagen, 2012.

DRAGOS, D. y VORNICU, R., "Public Procurement below Thresholds in the European Union", EPPL, vol. 3, 2015, págs. 187 - 206.

DREW, K., "The Challenges Facing Debarment and the European Union Public Procurement Directive", en la obra colectiva Fighting Corruption and Promoting Integrity in Public Procurement, OECD Publishing, Paris, 2005, págs. $267-276$. 
DRIJBER, B. J. y STERGIOU, H., "Public procurement law and internal market law", CMLR, vol. 46 (3), 2009, págs. $805-846$.

DURVIAUX, A. L., "Précisions relatives à la faute grave en matière professionnelle", Revue trimestrielle de droit européen, núm. 2, 2013, págs. 354 - 355.

EHLERMANN-CACHE, N., "Regulating Access to Public Procurement: Issues for Consideration", en la obra colectiva Fighting Corruption and Promoting Integrity in Public Procurement, OCDE, Paris, 2005.

EIGEN, P., Las redes de la corrupción: la sociedad civil contra los abusos de poder, Planeta, Barcelona, 2004.

ESCUIN PALOP, C., "Principios inspiradores del procedimiento de contratación pública", Contratación Administrativa Práctica, núm. 46, octubre 2005, págs. $29-41$.

ESTEVE PARDO, J., "Las prácticas de mercado como instrumento de regulación. Buenas Prácticas y Prácticas Aceptadas por el regulador", en la obra colectiva dirigida por MUÑOZ MACHADO, S., y ESTEVE PARDO, J., Derecho de la regulación económica. I. Fundamentos e instituciones de la regulación, Iustel, Madrid, 2009, págs. 669 - 683.

ESTEVES DE OLIVEIRA. R., "Os princípios gerais da contratação pública", en la obra colectiva dirigida por COSTA GONÇALVES, P., Estudos de Contratação Pública I, Coimbra Editora, Coimbra, 2008, págs. 51-113.

-, "Restrições à participação em procedimentos de contratação pública", Revista de Direito Público e Regulação, núm. 1, mayo 2009, págs. 27 - 34.

ESTORNINHO, M. J., Requiem pelo contrato administrativo, Almeida, Coimbra, 1990.

, "A transposição das Directivas 2004/17/CE e 2004/18/CE, de 31 de Março, e a elaboração de um Código de Contratos Públicos", Cadernos de Justiça Administrativa, vol. 58, 2006, págs. 10 - 20.

—, Direito Europeu dos Contratos Públicos, Almedina, Coimbra, 2006.

Curso de Direito dos Contratos Públicos - Por uma contratação pública sustentável, Almedina, Coimbra, 2012.

EVENETT, S. y HOEKMAN, B., "Government procurement: market access, transparency, and multilateral trade rules", European Journal of Political Economy, vol. 21 (1), 2005, págs. 163 - 183.

FABIÁN CAPARRÓS, E., El delito de blanqueo de capitales, Colex, Madrid, 1988.

FEIJOO SÁNCHEZ, B., Sanciones para empresas por delitos contra el medio ambiente. Presupuestos dogmáticos y criterios de imputación para la intervención del Derecho penal contra las empresas, Civitas, Madrid, 2002.

— La legitimidad de la pena estatal. Un breve recorrido por las teorías de la pena, Iustel, Madrid, 2014.

FEJØ, J., "Social and Environmental Policies in EU Public Procurement Law", en la obra colectiva dirigida por ARROWSMITH, S., EU Public Procurement Law: An Introduction, EU Asia Inter University Network, Nottingham, págs. 298 338. 
FENECH, G., La moralisation des marchés publics, Presses Universitaires de France, Col. Que sais je?, Paris, 1998.

FENELLÓS PUIGCERVER, V., "Prohibiciones de contratar", en la obra colectiva Comentarios a la Ley de Contratos de las Administraciones Públicas, Tomo II. La gestación del contrato, Comares, Granada, 2003, págs. 71 - 164.

FERESIN, E., Le cause di esclusione negli appalti pubblici, Giuffrè Editore, Milán, 2011.

FERNÁNDEZ DE GATTA SÁNCHEZ, D., "El régimen de la incorporación de criterios ambientales en la contratación del sector público: su plasmación en las nuevas Leyes sobre contratación pública de 2007", Contratación Administrativa Práctica, núm. 80, noviembre 2008.

, "La integración de aspectos medioambientales en la contratación pública", en la obra colectiva Derecho ambiental y transformaciones de la actividad de las Administraciones públicas, Atelier, Barcelona, 2010, págs. 123 - 159.

FERNÁNDEZ GARCÍA, J. F., "Contratación administrativa y libre competencia", REDA, núm. 158, abril - junio 2013, págs. 91 - 127.

FERNÁNDEZ GARCÍA, M ${ }^{\mathrm{a}}$ Y., "La nueva regulación de la contratación pública en el Derecho comunitario europeo", RAP, núm. 166, enero - abril 2005, págs. $281-320$.

FERNÁNDEZ MALLOL, A. L., "La integridad del procedimiento de contratación pública en el Derecho de la Unión Europea. El conflicto de interés y su incidencia sobre la regulación de las prohibiciones para contratar, las causas de incompatibilidad y las disposiciones sobre transparencia y buen gobierno", $R E A L A$, núm. 2 (nueva época), julio-diciembre 2014.

FERNÁNDEZ MARTín, J. Ma ; The EC Public Procurement Rules: A Critical Analysis, Clarendon Press, Oxford, 1996.

FERNÁNDEZ NAVAJAS, E., "La contratación pública en el ordenamiento comunitario", Revista Jurídica de Navarra, núm. 9, enero - junio 1990, págs. 195-208.

FERNÁNDEZ TORRES, I., "Algunas consideraciones en torno a los efectos del concurso sobre los contratos del sector público: Una perspectiva ius privatista", REDA, núm. 143, julio - septiembre 2009, págs. 493 -526.

, El concurso de las entidades del sector público y sus contratistas, Civitas Thomson Reuters, Cizur Menor (Navarra), 2015.

FERRÉ OLIVÉ, J.C., "Corrupción, crimen organizado y «blanqueo» de capitales en el mercado financiero", en la obra colectiva Blanqueo de dinero y corrupción en el sistema bancario. Delitos financieros, fraude y corrupción en Europa (Vol. II), Ediciones Universidad de Salamanca, Salamanca, 2002, págs. 13 - 23.

FERRER MAESTRO, J.J., "Los contratos públicos y el poder privado en la República romana", POTESTAS. Revista del Grupo Europeo de Investigación Histórica, núm. 2, 2009.

FLAMME, M. A., "Los contratos de obras públicas de la Administración", RAP, núm. 21, septiembre - diciembre 1956, págs. 13 - 128.

FUERTES LÓPEZ, M., El contratista y el subcontratista ante las Administraciones públicas, Marcial Pons, Madrid, 1997. 
, "Personificaciones públicas y contratos administrativos. La última doctrina del Tribunal de Justicia de las Comunidades Europeas", REALA, núm. 279, enero - abril 1999, págs. 25 - 34.

, "Los problemas de la delimitación entre los contratos administrativos y privados de las Administraciones públicas", Repertorio de Jurisprudencia Aranzadi, núm. 6, 2000, págs. 37 - 54 .

, "La deficiente regulación de la subcontratación en los contratos de las Administraciones Públicas", REDA, núm. 109, enero - marzo 2001, págs. 61 73.

GALLEGO CÓRCOLES, I., "Contratación pública electrónica", en la obra colectiva Administraciones públicas y nuevas tecnologías, Valladolid, Lex Nova, 2005, págs. $219-272$.

- "Capacidad y solvencia del empresario", en la obra colectiva Contratación del sector público local, $2^{\mathrm{a}}$ ed., La Ley - El Consultor de los Ayuntamientos, Madrid, 2010, págs. 380 - 562.

, "El derecho de la contratación pública en los Países Bajos", en la obra colectiva dirigida por SÁNCHEZ MORÓN, M., Derecho de los contratos públicos en la Unión Europea y sus Estados miembros, Lex Nova - Thomson Reuters, Valladolid, 2011, págs. $367-407$.

, "Contratos públicos y régimen «cualificado» de invalidez: supuestos especiales y cuestión de nulidad", en la obra colectiva dirigida por GIMENO FELIÚ, J. $\mathrm{M}^{\mathrm{a}}$., Observatorio de Contratos Públicos 2010, Civitas - Thomson Reuters, Cizur Menor (Navarra), 2011, págs. 259 - 318.

, "El recurso a las capacidades de otras entidades (o del intento de concretar el régimen jurídico de la integración de la solvencia mediante medios externos)", en la obra colectiva dirigida por GIMENO FELIÚ, J. Ma ${ }^{\mathrm{a}}$., Observatorio de los contratos públicos 2014, Thomson - Aranzadi, Cizur Menor (Navarra), 2015, págs. $195-235$.

-, "La prevención de la corrupción en la contratación pública", en la obra colectiva dirigida por NIETO MARTÍN, A., Public Compliance: Prevención de la corrupción en administraciones públicas y partidos políticos, Ediciones de la Universidad de Castilla La Mancha, Cuenca, 2014, págs. 61 - 92.

, "Los procedimientos de adjudicación en la nueva Directiva sobre contratación pública", en la obra colectiva dirigida por GIMENO FELIÚ, J. Ma ${ }^{\mathrm{a}}$, Observatorio de los contratos públicos 2013, Thomson Reuters-Aranzadi, Cizur Menor (Navarra), 2014, págs. 165 - 232.

, "La modificación de los contratos en la cuarta generación de Directivas sobre contratación pública", en la obra colectiva Las nuevas Directivas de contratación pública, Thomson Reuters - Aranzadi, Cizur Menor (Navarra), 2015, págs. $107-167$.

GALLIASSO, M. "L'esclusione dalla partecipazione alle gare pubbliche per grave negligenza o malafede nell'esercizio di precedenti appalti: compatibilità con l'ordinamento comunitario ed obbligo di motivazione", Il Foro amministrativo, vol. 2, 2007, págs. 636 - 643 . 
GANUZA FERNÁNDEZ, J. J., "Los sobrecostes en las obras públicas: un análisis económico del caso español", Economía Industrial, núm. 318 (Ejemplar dedicado a: Competencia y regulación de mercados), 1997, págs. $111-122$.

GARCÍA DE COCA, J. A., "Regulación comunitaria sustantiva sobre los contratos celebrados en los sectores especiales y su repercusión sobre los contratos entre empresas de titularidad privada", RVAP, núm. 59, enero - abril 2001, págs. $37-56$.

GARCÍA DE ENTERRÍA, "Dos regulaciones orgánicas de la contratación administrativa", RAP, núm. 10, enero - abril 1953, págs. 241 - 281.

, "El problema jurídico de las sanciones administrativas", REDA, núm. 10, julio - septiembre 1976, págs. 399 - 430.

, "El Tribunal de Justicia de las Comunidades Europeas constata y censura dos graves quiebras de nuestro Derecho Administrativo en materia de entes sujetos al derecho público y de medidas cautelares Contencioso-Administrativas. Sentencia Comisión c. España, C-214/00, de 15 de mayo de 2003", REDA, núm. 119, julio - septiembre 2003, págs. 471 - 487.

, "Una nueva sentencia del Tribunal de Justicia de las Comunidades Europeas sobre la sumisión a las normas comunitarias sobre contratación pública de las sociedades de titularidad de las Administraciones Públicas", REDA, núm. 120, octubre - diciembre 2003, págs. 667 - 677 .

GARCÍA LUENGO, J., "El Derecho de la contratación pública en Austria", en la obra colectiva dirigida por SÁNCHEZ MORÓN, M., Derecho de los contratos públicos en la Unión Europea y sus Estados miembros, Lex Nova - Thomson Reuters, Valladolid, 2011, págs. 457 - 501.

GARCÍA MEXÍA, P., Los conflictos de intereses y la corrupción contemporánea, Aranzadi, Elcano (Navarra), 2001.

GARCÍA-ANDRADE GÓMEZ, J., Derecho administrativo en la contratación entre privados: (sociedades, fundaciones, concesionarios y sectores excluidos), Marcial Pons, Madrid, 2005.

, "El Derecho de la contratación pública en Suecia", en la obra colectiva dirigida por SÁNCHEZ MORÓN, M., Derecho de los contratos públicos en la Unión Europea y sus Estados miembros, Lex Nova - Thomson Reuters, Valladolid, 2011, págs. $553-577$.

GEORGOPOUlOS, A., "The New Defence Procurement Directive Enters into Force", PPLR, vol. 19 (1), 2010, NA1-3.

GIL IBÁÑEZ, J.L., "La capacidad para contratar y la clasificación de los contratistas en la Ley de Contratos de las Administraciones Públicas", Actualidad Administrativa, núm. 46, diciembre 1995, págs. 845 - 879.

GIMENO FELIÚ, J. Mª ., El control de la contratación pública. Las normas comunitarias y su adaptación en España, Civitas, Madrid, 1995.

"La necesaria interpretación subjetivo-funcional del concepto de poder adjudicador en la contratación pública", $R A P$, núm. 151, enero - abril 2000, págs. $425-439$. 
, Contratos públicos: ámbito de aplicación y procedimiento de adjudicación. La incidencia de las Directivas comunitarias en el ordenamiento jurídico español, Civitas, Madrid, 2002.

, La nueva contratación pública europea y su incidencia en la legislación española. La necesaria adopción de una nueva ley de contratos públicos y propuestas de reforma, Thomson-Civitas, Madrid, 2006.

__ , "Los sujetos contratantes: alcance del concepto "poder adjudicador"", Cuadernos de Derecho Local, núm. 12, 2006, págs. 50 - 78.

, "La incorporación del Derecho comunitario al ordenamiento nacional", NUE, núm. 267, abril 2007.

, "El nuevo ámbito subjetivo de aplicación de la Ley de Contratos del Sector Público: luces y sombras", RAP, núm. 176, mayo - agosto 2008, págs. 9 - 54.

, "La Ley de Contratos del Sector Público: ¿una herramienta eficaz para garantizar la integridad?. Mecanismos de control de la corrupción en la contratación pública", REDA, núm. 147, julio - septiembre 2010, págs. 517 535.

, "Directiva de servicios y contratación pública. Hacia la simplificación", Revista Aragonesa de Administración Pública, núm. Monográfico XII, 2010, págs $409-443$.

- Novedades de la Ley de Contratos del Sector Público de 30 de octubre de 2007 en la regulación de la adjudicación de los contratos públicos, Civitas Thomson Reuters, Cizur Menor (Navarra), 2010.

, "Las nuevas Directivas - cuarta generación - en materia de contratación pública. Hacia una estrategia eficiente en compra pública", REDA, núm. 159, julio - septiembre 2013, págs. 39 - 105.

, "Compra pública estratégica", en la obra colectiva dirigida por PERNAS GARCÍA, J. J., Contratación pública estratégica, Aranzadi, Cizur Menor (Navarra), 2013, págs. $45-79$.

- El nuevo paquete legislativo comunitario sobre contratación pública. De la burocracia a la estrategia. El contrato público como herramienta del liderazgo institucional de los poderes públicos, Aranzadi - Thomson Reuters, Cizur Menor (Navarra), 2014.

, Decálogo de reglas para prevenir la corrupción en los contratos públicos, publicado en el Observatorio de Contratación Pública (12 de noviembre de 2014).

http://www.obcp.es/ .

, "El valor interpretativo de las Directivas comunitarias sobre contratación pública y del derecho pretoriano. Las opciones de transposición en España de la propuesta de reforma", en la obra colectiva dirigida por él mismo Observatorio de los contratos públicos 2014, Thomson Reuters - Aranzadi, Cizur Menor (Navarra), 2015, págs. 19 - 60.

-, "La reforma comunitaria en materia de contratos públicos y su incidencia en la legislación española. Una visión desde la perspectiva de la integridad", en la obra colectiva Las nuevas Directivas de contratación pública, Thomson Reuters - Aranzadi, Cizur Menor (Navarra), 2015, págs. 37 - 105 
- "Los efectos jurídicos de las Directivas de contratación pública ante el vencimiento del plazo de transposición sin nueva Ley de Contratos Públicos. La Directiva de concesiones", Ponencia presentada en el Seminario de Contratación Pública celebrado en Formigal (septiembre 2015).

GIRALDES GUTIÉRREZ, L. S., "La autorregulación en el ámbito de la contratación pública. Análisis de las posibilidades de utilización que ofrece el nuevo marco jurídico comunitario y nacional", REDA, núm. 168, enero - marzo 2015, págs. $315-339$.

GOHON, J.-P., Les marchés publics européens, Presses Universitaires de France, Collection Que sais-je?, núm. 2625, Paris, 1991.

GÓMEZ MARTÍN, V., "Notas para un concepto funcional de terrorismo", en la obra colectiva Terrorismo y Estado de Derecho, Iustel, Madrid, 2010.

GÓMEZ TOMILLO, M., Derecho administrativo sancionador. Parte general: teoría general y práctica del Derecho penal administrativo, $3^{\mathrm{a}}$ ed., Cizur Menor (Navarra), Thomson-Aranzadi, 2013.

—_ Introducción a la responsabilidad penal de las personas jurídicas, Aranzadi, Cizur Menor (Navarra), 2015.

GÓMEZ-JARA DÍEZ, C., "La responsabilidad penal de las personas jurídicas en el ámbito público: ¿hacia los Compliance Programs anti-corrupción como exigencias legales de contratación pública?", en la obra colectiva coordinada por GARCÉS SANAGUSTÍN, M. y PALOMAR OLMEDA, A., La gestión de los Fondos Públicos: Control y responsabilidades, Thomson - Aranzadi, Cizur Menor (Navarra), 2013, págs. 1235 - 1251.

, "Responsabilidad penal de las personas jurídicas y contratación pública. A propósito de la nueva Directiva europea sobre contratación pública", Diario La Ley, núm. 8423, 18 de noviembre de 2014.

GONZÁLEZ BUSTOS, Ma . Á., "La efectividad del sistema de información del mercado interior en la cooperación entre los Estados miembros", Revista General de Derecho Europeo, núm. 24, 2011.

GONZÁLEZ GARCÍA, J. V., "Medios propios de la Administración, colaboración interadministrativa y sometimiento a la normativa comunitaria de contratación", RAP, núm. 173, mayo - agosto 2007, págs. 217 - 237.

-, Colaboración público-privada e infraestructuras de transporte. Entre el contrato de colaboración entre el sector público y el sector privado y la atipicidad de la gestión patrimonial, Marcial Pons - CEDIT, Madrid, 2010.

, "Sustainability and Public Procurement in the Spanish Legal System", en la obra colectiva dirigida por CARANTA, R., y TRYBUS, M., The Law of Green and Social Procurement in Europe, Djøf Publishing, Copenhagen, 2010, págs. $235-257$.

GONZÁlEZ PÉREZ, J., "Ética en la Administración Pública", Anales de la Real Academia de Ciencias Morales y Políticas, núm. 73, 1996, págs. 117 - 158.

, Corrupción, ética y moral en las Administraciones públicas, Civitas, Cizur Menor (Navarra), 2006.

—., La ética en la Administración pública, 2a ed., Civitas, Madrid, 2000. 
, Corrupción, ética y moral en las Administraciones públicas, $2^{\mathrm{a}}$ ed., Thomson Reuters-Civitas, Cizur Menor (Navarra), 2014.

GONZÁLEZ SANFIEL, A. M. "Integridad en la contratación pública: Patologías al uso (a propósito del Informe de la Comisión europea sobre lucha contra la corrupción)", en la obra colectiva Las nuevas Directivas de contratación pública, Thomson Reuters-Aranzadi, Cizur Menor (Navarra), 2015, págs. 253 $-263$.

GONZÁLEZ-BERENGUER URRUTIA, J. L., "El texto articulado de la Ley de Contratos del Estado", Revista de Estudios de la Vida Local, núm. 142, julio - agosto, 1965.

GONZÁLEZ-VARAS IBÁÑEZ, S., "La contratación de las Comunidades Europeas", $R A P$, núm. 142, enero - abril 1997, págs. 195 - 223.

, "La reforma de las Directivas comunitarias de contratación pública", Revista de Derecho Comunitario Europeo, núm. 13, septiembre - diciembre 2002, págs. $961-975$.

— El contrato administrativo, Civitas, Madrid, 2003.

, "El Derecho administrativo español ante la reciente sentencia del Tribunal de Justicia de las Comunidades Europeas de 15 de mayo de 2003 en materia contractual", Revista Española de Derecho Europeo, núm. 7 2003, págs. 517 528 .

, Tratado de Derecho Administrativo. Tomo IV. El contrato administrativo, Thomson-Civitas, Cizur Menor (Navarra), 2008.

GOSÁlBEZ PEQUEÑO, H., El contratista de la Administración Pública, Marcial Pons - Cámara de Cuentas de Andalucía, Madrid, 2000.

, "El régimen jurídico de la capacidad del contratista de la Administración: las novedades introducidas por la Ley 53/1999", NUE, núm. 198, julio 2001, págs. 9 - 20.

, ¿Cláusulas sociales en la selección de los contratistas de las Administraciones públicas españolas?", Justicia Administrativa, núm. 20, julio 2003, págs. $27-67$.

GUTIÉRREZ CASTAÑEDA, A., Las penas privativas de derechos politicos y profesionales. Bases para un nuevo modelo regulatorio, Tirant lo Blanch, Valencia, 2012 .

HAMER, C. R., "Treaty Requirements for Contracts "Outside" the Procurement Directives", en la obra colectiva dirigida por CARANTA, R., EDELSTAM, G., y TRYBUS, M., EU Public Contract Law: Public Procurement and beyond, Bruylant, Brussels, 2014, págs. $191-219$.

HARTNELL, H., "Public procurement and the fight against gender discrimination in The United States", comunicación presentada en 7th Congress of the European Women Lawyers' Association (EWLA), Zürich (Suiza), 2007.

HEBLY,J., European Public Procurement: Legislative History of the Classic Directive 2004/18/EC, Kluwer Law International, Alpen aan den Rijn (The Netherlands), 2007. 
- European Public Procurement: Legislative History of the Utilities Directive 2004/17/EC, Kluwer Law International, Alpen aan den Rijn (The Netherlands), 2008.

HELLER, N., "Definiendo y midiendo la corrupción. ¿De dónde venimos, dónde estamos ahora y qué importa para el futuro?", Revista del CLAD, núm. 45, octubre 2009, págs. 5 - 30 .

HERNÁNDEZ GONZÁLEZ, F. L. "La nueva Directiva de concesiones. Un largo viaje con final esperado", en la obra colectiva Las nuevas Directivas de contratación pública, Thomson Reuters-Aranzadi, Cizur Menor (Navarra), 2015, págs. $169-237$.

HERNÁNDEZ Y FERNÁNDEZ DEL VALLE, Ma . I., "Los procedimientos de recurso en materia de adjudicación de los contratos públicos de suministros y de obras", NUE, núm. 89, 1992, págs. 43 - 50.

HERNANDO RYDINGS, M., La colaboración público privada. Fórmulas contractuales, Civitas, Madrid, 2012.

HJELMENG, E. y SØREIDE T., "Debarment in public procurement: rationales and realization", en la obra colectiva dirigida por RACCA, G. y YUKINS, Ch., Integrity and Efficiency in Sustainable Public Contracts, Bruylant, Bruselas, 2014, págs. $215-232$.

HOLLARD, V., L'exclusion des march'es publics, Chambre de commerce et d'industrie de Paris, 6 juillet 1989 (Annexe au rapport sur le projet de réforme du Code penal).

HUERGO LORA, A., "El Derecho español de contratos públicos y el Derecho comunitario", REDA, núm. 126, abril - junio 2005, págs. 217 - 246.

— Las sanciones administrativas, Iustel, Madrid, 2007.

IGLESIAS RIO, M. Á y MEDINA ARNÁIZ, T., "Herramientas preventivas en la lucha contra la corrupción en el ámbito de la Unión Europea", Revista penal, núm. 14, julio 2004, págs. $49-70$.

IRURZUN MONTORO, F., Honorabilidad como requisito para el ejercicio de profesiones financieras y otras actividades, Thomson-Civitas, Cizur Menor (Navarra), 2007.

JACOBS, J. B., y ANECHIARICO, F., "Blacklisting of Public Contractors as an Anti-Corruption and Racketeering Strategy", Criminal Justice Ethics, vol. 11 (2), 1992, págs. $64-76$.

JAIME JIMÉNEZ, Ó. y CASTRO MORAL, L., "La criminalidad organizada en la Unión Europea. Estado de la cuestión y respuestas institucionales", Revista CIDOB d'Afers Internacionals, núm. 91, septiembre - octubre 2010, págs. 173 $-194$.

JAREÑO LEAL, Á., Corrupción y delincuencia de los funcionarios en la contratación pública, Iustel, Madrid, 2011.

, El delito de negociaciones prohibidas a los funcionarios públicos, Thomson Aranzadi, Cizur Menor (Navarra), 2015.

JAREÑO LEAL, Á., (Dir.) Corrupción pública. Cuestiones de política criminal (I), Iustel, Madrid, 2014. 
JÈZE, G., Principios generales del Derecho Administrativo, Vol. IV, Teoría general de los contratos de la Administración, (Formación. Ejecución de los contratos), Depalma, Buenos Aires, 1950, (traducción de la $3^{\mathrm{a}}$ ed. francesa de Les principes généraux du droit administratif).

KAHLENBORN, W., et al. (ADELPHI), Strategic Use of Public Procurement in Europe - Final Report to the European Commission (MARKT/2010/02/C), Berlin, 2011.

KAUFMANN, D., KRAAY, A. y MASTRUZZI, M., The Worldwide Governance Indicators: A Summary of Methodology, Data and Analytical Issues, World Bank Policy Research, Working Paper núm. 5430, 2010.

KENNY, C., Measuring and Reducing the Impact of Corruption in Infrastructure, World Bank Policy Research, Working Paper núm. 4099, December 2006.

KENNY, C. y SØREIDE, T., Grand Corruption in Utilities, World Bank Policy Research, Working Paper núm. 4805, December 2008.

KRAMER, R., "Awarding Contracts to Suspended and Debarred Firms: Are Stricter Rules Necessary?", Public Contract Law Journal, vol. 34 (3), 2005, págs. 539 -552 .

KUTLINA-DIMITROVA, Z., y LAKATOS, C., Determinants of direct cross-border public procurement in EU Member States, julio 2014 en: http:// trade.ec.europa.eu/doclib/docs/2014/july/tradoc_152700.pdf [Fecha de consulta: 18 de octubre de 2015].

LAGUERRE, A., Concurrence dans les marchés publics, Berger-Levrault, Paris, 1989.

LAUBADÈRE, A., MODERNE, F. y DELVOLVÉ, P., Traité des contrats administratifs, Tomo I, LGDJ, Paris, 1983.

LAVILLA RUBIRA, J. J., "La contratación de los órganos constitucionales y de relevancia constitucional", en la obra colectiva coordinada por PENDÁS GARCÍA, B., Derecho de los contratos públicos: (estudio sistemático de la Ley 13/1995, de 18 de mayo, de contratos de las Administraciones Públicas), Praxis, Barcelona, 1995, págs. $155-188$.

, "La morosidad de la administración en la nueva ley de Contratos de las Administraciones Públicas", Noticias de la Unión Europea, núm. 136, 1996, págs. $41-48$.

, "El contrato de gestión de servicios públicos en el Texto Refundido de la Ley de Contratos de las Administraciones Públicas", en la obra colectiva Comentario a la Ley de contratos de las Administraciones públicas, $2^{\mathrm{a}}$ ed., Thomson - Civitas, Madrid, 2004, págs. 943 - 980.

LAZO VITORIA, X., "Los contratos públicos sobre defensa y seguridad en el mercado europeo", RVAP, núm. 82, 2008, págs. 99 - 124.

, "Los contratos mixtos", RAP, núm. 179, mayo - agosto 2009, págs. 143 165.

, "El Derecho de la contratación pública en Polonia", en la obra colectiva dirigida por SÁNCHEZ MORÓN, M., Derecho de los contratos públicos en la Unión Europea y sus Estados miembros, Lex Nova - Thomson Reuters, Valladolid, 2011, págs. $343-365$. 
LÓPEZ-FONT MÁRQUEZ, J. F., "La apertura de los procedimientos nacionales de adjudicación de contratos públicos a las empresas de otros Estados miembros de la Unión Europea (Sentencia de 17 de noviembre de 1993 del Tribunal de Justicia de las Comunidades Europeas)", RAP, núm. 133, enero - abril 1994, págs. $311-342$.

LÓPEZ-IBOR MAYOR y GIMENO FELIÚ "Los denominados sectores excluidos: agua, transporte, energía y telecomunicaciones (Disposición adicional undécima LCAP)", en la obra colectiva dirigida por GÓMEZ-FERRER MORANT Comentario a la Ley de Contratos de las Administraciones Públicas, $2^{\mathrm{a}}$ ed., Thomson - Civitas, Madrid, 2004, págs. 1673 - 1712.

LÓPEZ MIÑO, A., y VALCÁRCEL FERNÁNDEZ, P., "Colusión en la contratación pública (bid rigging): propuestas para combatirla eficazmente y posibilidades que ofrece la Directiva 2014/14/UE sobre contratación pública", en la obra colectiva dirigida por GIMENO FELIÚ, J. $\mathrm{M}^{\mathrm{a}}$., Observatorio de los contratos públicos 2013, Thomson-Aranzadi, Cizur Menor, 2014, págs. 425 - 487.

-, "Contracting authorities' inability to fight bid rigging in public procurement: reasons and remedies", en la obra colectiva dirigida por RACCA, G. y YUKINS, Ch., Integrity and efficiency in Sustainable public contracts. Balancing Corruptions Concerns in Public Procurement Internationally, Bryulant, Brussels, 2014, págs. 199 - 214.

LUCERO ESPINOSA, M., La licitación pública, Porrúa, México, 1993.

MAJTAN, R., "The self-cleaning dilemma: Reconciling competing objectives of procurement processes", George Washington International Law Review, vol. 46 (2), 2013, págs. 291 - 347.

MANGAS MARTÍN, A. y LIÑÁN NOGUERAS, D. J., Instituciones y Derecho de la Unión Europea, 8 ${ }^{\mathrm{a}}$ ed., Tecnos, Madrid, 2014.

MANTECA VALDELANDE, V., "El derecho a ser contratista", Contratación administrativa práctica, núm. 40, 2005, págs. 33 - 43.

MANUEL, K., Debarment and Suspension of Government Contractors: An Overview of the Law Including Recently Enacted and Proposed Amendments, Congressional Research Service, 2012, disponible en: http://www.safgc.hq.af.mil/shared/media/document/AFD-120315-091.pdf [Fecha de consulta: 15 de octubre de 2015].

MARDAS, D. y TRIANTAFYLLOU, D., "Selection criteria and the award procedure in public procurement", International Advances in Economic Research, vol. 3 (1), 1997, págs. $91-112$.

MARINA JALVO, B., "El Derecho de la contratación pública en Italia", en la obra colectiva dirigida por SÁNCHEZ MORÓN, M., Derecho de los contratos públicos en la Unión Europea y sus Estados miembros, Lex Nova - Thomson Reuters, Valladolid, 2011, págs. 235 - 288.

MARTÍNEZ FONS, D., Cláusulas sociales, libre competencia y contratación pública, Fundación Alternativas, 2009.

MARTÍN BURGOS, J. A., "El Derecho comunitario y la contratación pública. Situación y perspectivas", Gaceta Jurídica de la CEE, núm. 59, 1989, págs. 3 8 . 
MARTÍN-RETORTILLO BAQUER, L.,"Honorabilidad y buena conducta como requisitos para el ejercicio de profesiones y actividades", $R A P$, núm. 130, eneroabril 1993, págs. $23-96$.

-, "Lo público y la acción administrativa: el fantasma de la corrupción" en la obra Don Luis Jordana de Pozas, creador de ciencia administrativa, Servicio de Publicaciones de la Facultad de Derecho y Fundación BSCH, Madrid, 2000, págs. $79-91$.

MARTÍN-RETORTILLO BAQUER, S., "La institución contractual en el Derecho administrativo: en torno al problema de la igualdad de las partes", $R A P$, núm. 29, mayo - agosto 1959, págs. 59 - 102.

- El Derecho civil en la génesis del Derecho administrativo y de sus instituciones, $2^{\mathrm{a}}$ ed. ampliada, Civitas, Madrid, 1996.

"La prohibición de contratar establecida en el artículo 20 a) de la Ley de Contratos de las Administraciones Públicas", La Ley, núm. 4037, de 16 de mayo de 1996.

, "Reflexiones sobre la "huida" del Derecho administrativo", $R A P$, núm. 140, mayo - agosto 1996, págs. 25 - 67.

MARTÍNEZ LÓPEZ-MUÑIZ, J.L., "La moralidad pública como límite de las libertades públicas", en la obra colectiva Los derechos fundamentales y libertades públicas (Vol. I), XII Jornadas de Estudio sobre la Constitución, Centro de Publicaciones del Ministerio de Justicia, Madrid, 1992, págs. 1003 - 1021.

, "Examen de la contratación de los Entes Instrumentales. Estudio especial del Derecho Comunitario", en la obra colectiva dirigida por DELGADO BARRIO, J., Eficacia, discrecionalidad y control judicial en el ámbito administrativo, Cuadernos de Derecho Judicial, CGPJ, Madrid, 1994, págs. 349 - 393.

, “¿Sociedades públicas para construir y contratar obras públicas? (A propósito de algunas innovaciones de la Ley de acompañamiento de los Presupuestos del Estado para 1997)", RAP, núm. 144, septiembre-diciembre 1997, págs. 45 -73 .

, "Los beneficiarios de subvenciones", en la obra colectiva dirigida por FERNÁNDEZ FARRERES, G., Comentario a la Ley General de Subvenciones, Thomson Civitas, Cizur Menor (Navarra), 2005, págs. 155 - 223.

, "El régimen necesariamente jurídico-público de los bienes, contratos, personal y entes instrumentales de los poderes públicos", Revista General de Derecho Administrativo, núm. 27, mayo 2011.

, "El nacimiento de los contratos públicos: reflexiones sobre una equivocada transposición de la Directiva comunitaria "de recursos", $R A P$, núm. 185, mayo - agosto 2011, págs. 323-343.

MARTÍNEZ-BUJÁN PÉREZ, C., Derecho penal económico y de la empresa, Parte especial, $5^{\mathrm{a}}$ ed., Tirant lo Blanch, Valencia, 2015.

MATA Y MARTÍN, R., "Unión Europea y armonización legislativa en materia antiterrorista", en la obra colectiva El proceso penal en la Unión Europea: Garantías esenciales / Criminal proceedings in the European Union: essential safeguards, Lex Nova, Valladolid, 2008. 
MATEO SANZ, A., Manceps, redemptor, publicanus. Contribución al estudio de los contratistas públicos en Roma, Universidad de Cantabria, Santander, 1999.

MATTERA RICIGLIANO, A., El Mercado Único Europeo. Sus reglas, su funcionamiento, Civitas, Madrid, 1991.

MAURO, A., "La selezione dei partecipanti", en el volumen colectivo coordinado por GALLO, S., Le nuove direttive europee in materia di appalti e concessioni, Magglioli Editore, Santarcangelo di Romagna, 2014, págs. 119 - 169.

McCRUDDEN, C., "Using public procurement to achieve social outcomes", Natural Resources Forum, vol. 28 (4), 2004, págs. 257 - 267.

, Buying Social Justice. Equality, Government Procurement and Legal Change, Oxford University Press, Oxford, 2007.

MEDINA ARNÁIZ, T., "Grounds for exclusion in public procurement: Measures in the fight against corruption in European Union", comunicación presentada en II International Public Procurement Conference, Roma, 2006.

, "La contratación pública electrónica: balance actual de su regulación en Europa", en la obra colectiva Gobierno, Derecho y Tecnología: las actividades de los poderes públicos, Cizur Menor (Navarra), Thomson - Civitas, 2006, págs. $527-556$.

"EU Directives as an Anticorruption Measures: Excluding Corruption-Convicted Tenderers from Public Procurement Contracts", en la obra colectiva International Handbook of Public Procurement, CRC Press (Francis \& Taylor), Boca Raton, Florida, 2008.

, "Las respuestas normativas al fenómeno de la corrupción en la contratación pública", La Ley, núm. 7382, abril 2010.

, "Impacto sobre la Administración autonómica en cuanto a la simplificación de los trámites a los prestadores de servicio", en el libro colectivo Colección de Estudios del Consejo Económico y Social de Castilla y León, núm. 13, dedicado al Impacto de la transposición de la Directiva de Servicios en Castilla y León, 2010, págs. $425-453$.

, "Social Considerations in Spanish Public Procurement Law", Public Procurement Law Review, vol. 20 (2), 2011, págs. 56 - 79.

, "El Derecho de la contratación pública en Hungría", en la obra colectiva dirigida por SÁNCHEZ MORÓN, M., Derecho de los contratos públicos en la Unión Europea y sus Estados miembros, Lex Nova - Thomson Reuters, Valladolid, 2011, págs. $579-626$.

"La contratación pública socialmente responsable a través de la jurisprudencia del Tribunal de Justicia de la Unión Europea", REDA, núm. 153, enero marzo 2012, págs. 213 - 240.

-, "Las disposiciones financieras de la Unión Europea y su aplicación a la contratación pública: especial referencia al nuevo Reglamento financiero y sus normas de desarrollo", en la obra colectiva dirigida por GIMENO FELIÚ, J. $\mathrm{M}^{\mathrm{a}}$., Observatorio de contratos públicos 2012, Thomson Reuters, Cizur Menor (Navarra), 2013, págs. 165 - 194. 
, "Instrumentos jurídicos frente a la corrupción en la contratación pública: perspectiva europea y su incidencia en la legislación española", en la obra colectiva dirigida por VALCÁRCEL FERNÁNDEZ, P. y FERNÁNDEZ ACEVEDO, R., La contratación pública a debate: presente y futuro, Thomson Aranzadi, Cizur Menor (Navarra), 2014, págs. 299 - 344.

, "Los conflictos de intereses llegan a las Directivas sobre contratación pública", en la obra colectiva dirigida por GIMENO FELIÚ, J. M ${ }^{\mathrm{a}}$., Observatorio de los contratos públicos 2013, Thomson - Aranzadi, Cizur Menor (Navarra) 2014, págs. 271 - 302.

, "La regulación europea de las prohibiciones de contratar y su aplicación según la jurisprudencia del Tribunal de Justicia de la Unión Europea”, en la obra colectiva dirigida por GIMENO FELIÚ, J. M ${ }^{\mathrm{a}}$. Observatorio de Contratos públicos 2014, Thomson Reuters, Cizur Menor (Navarra), 2015, págs. 173 194.

MEDINA ARNÁIZ, T. y TRYBUS, M., "La transposición de las Directivas comunitarias sobre contratación pública en los Estados miembros", NUE, núm. 298, noviembre 2009, págs. 83 - 94.

MEILÁN GIL J.L., "La actuación contractual de la Administración Pública española. Una perspectiva histórica", $R A P$, núm. 99, septiembre - diciembre 1982, págs. 7 - 36 .

— L La estructura de los contratos públicos, Iustel, Madrid, 2008.

, "Una concepción iusadministrativista de los contratos públicos", Derecho PUCP Facultad de Derecho, núm. 66, 2011, págs. 223 - 245.

MEILÁN GIL, J. L. y AYMERICH CANO, C. I., "La contratación pública en los denominados "sectores excluidos": Consecuencias de la falta de incorporación de las Directivas de la falta de incorporación de las Directivas 93/38/CEE y 92/13/CEE al Derecho español", en la obra colectiva Competencia y sector eléctrico: un nuevo régimen jurídico, Civitas, Madrid, 1997, págs. 121-148.

MELERO ALONSO, E., "La promoción del medio ambiente a través de la contratación pública: análisis de las cláusulas ambientales", Revista de derecho urbanístico y medio ambiente, núm. 260, septiembre-octubre 2010, págs. 165 $-203$.

MELLADO RUIZ, L., "El sistema jurídico de la contratación pública en España: novedades del régimen de los contratos realizados por entes públicos de gestión de sujetos al Derecho privado". REDA, núm. 127 julio - septiembre 2005, págs. $381-415$.

, "Directiva de Servicios y simplificación administrativa: un paso adelante en la racionalización de la organización y actuación administrativas", Noticias de la Unión Europea, núm. 317 (Ejemplar dedicado a: La Directiva de Servicios y su transposición al Derecho español), 2011, págs. 73 - 86 .

MENÉNDEZ SEBASTIÁn, E. M., "Posibles medidas de fomento de la Administración: la preferencia en la contratación, las subvenciones y el distintivo de igualdad como ejemplos", en la obra colectiva La Administración promotora de la igualdad de género, Tirant lo Blanch, Valencia, 2012, págs. 269 - 307. 
, "El Derecho de la contratación pública en Francia", en la obra colectiva dirigida por SÁNCHEZ MORÓN, M., Derecho de los contratos públicos en la Unión Europea y sus Estados miembros, Lex Nova - Thomson Reuters, Valladolid, 2011, págs. $123-182$.

MERCKX, D., Sanctioning Economic Crime. An integrated policy, Brussels University Press, Bruselas, 2006.

MESTRE DELGADO, J. F., "La normativa comunitaria europea sobre contratación administrativa: una visión general", Noticias CEE, núm. 21, octubre 1986, págs. $57-62$.

, "El control de la adjudicación de los contratos públicos a tenor del Derecho comunitario europeo: Una nueva ordenación de las medidas cautelares", Noticias CEE, núm. 74, marzo 1991, págs. 35 - 40.

, "El control de la adjudicación de los contratos públicos", en la obra colectiva coordinada por BAÑO LEÓN, J. M ${ }^{\mathrm{a}}$. y CLIMENT BARBERÁ, J., Nuevas perspectivas del Régimen local. Estudios en homenaje al Profesor José $M^{a}$. Boquera Oliver, Tirant lo Blanch, Valencia, 2002, págs. 291-330.

, "Contratos públicos y políticas de protección social y medioambiental", $R E A L$, núm. 291, enero - abril 2003, págs. 705 - 730.

, "El Derecho de la contratación pública en España", en la obra colectiva dirigida por SÁNCHEZ MORÓN, M., Derecho de los contratos públicos en la Unión Europea y sus Estados miembros, Lex Nova - Thomson Reuters, Valladolid, 2011, págs. $289-342$.

MERINO MERCHÁN, J. F. y PALMA FERNÁNDEZ, J. L. "Requisitos para contratar con la Administración (I): Capacidad y solvencia", en la obra colectiva Derecho de los contratos públicos, Praxis-Wolters Kluwer, Barcelona, 1995.

MOLINA NAVARRETE, C., "Relaciones laborales, política de empleo y compra pública socialmente responsable: las cláusulas sociales en la Ley 30/2007, de 30 de octubre, de Contratos del Sector Público", Revista de Trabajo y Seguridad Social del CEF, núm. 302, 2008, págs. 3 - 64.

MONTOYA MARTÍN, E., "La reciente jurisprudencia del Tribunal de Justicia de la Unión Europea acerca del concepto de "poder adjudicador" en las Directivas de la contratación pública, servicios, suministros y obras", RAAP, núm. 41, enero - abril 2001, págs. 121 - 154.

, "La prohibición para contratar por causa de incompatibilidad. El caso de los representantes de la Administración en Cajas de Ahorro y Empresas Públicas", RAAP, núm. 48, octubre - diciembre 2002, págs. 129 - 178.

MORAN, J., POPE J. y DOIG, A., Debarment as an Anti-Corruption Means -a review report-, U4 Anti-Corruption Resource Centre, 2004.

MORELL OCAÑA, L., "Requisitos de los contratos. Capacidad y solvencia de las empresas (arts. 10 a 23 de la Ley)", en la obra colectiva Comentario a la Ley de Contratos de las Administraciones Públicas, Civitas, Madrid, 1996.

MORENO MOLINA, J. A., Contratos públicos: Derecho comunitario y Derecho español, McGraw-Hill, Madrid, 1996.

, "Las nuevas Directivas sobre contratos públicos", NUE, núm. 135, 1996, págs. $31-40$. 
"La Administración Pública comunitaria y el proceso hacia la formación de un Derecho administrativo europeo común", RAP, núm. 148, enero - abril 1999, págs. 341-358.

, "La reciente jurisprudencia del Tribunal de Justicia de las Comunidades Europeas en materia de contratos públicos", RAP, núm. 151, enero-abril 2000, págs. $319-342$.

-, "Los procedimientos de selección de contratistas y de adjudicación de los contratos", Noticias de la Unión Europea, núm. 198, julio 2001, págs. 55 - 70.

, "Reciente evolución del derecho comunitario de la contratación pública. El asunto C-214/2000 Comisión contra España", en la obra colectiva dirigida por GIMENO FELIÚ, J. Ma ., Contratación de las administraciones públicas: análisis práctico de la nueva normativa sobre contratación pública, Atelier, Barcelona, 2004, págs. 17 - 36.

- Los principios generales de la contratación de las Administraciones públicas, Bomarzo, Albacete, 2006.

, "El ámbito objetivo de aplicación de la Ley de Contratos del Sector Público", Documentación administrativa, núm. 274 - 275 (Ejemplar dedicado a "La nueva Ley de Contratos del Sector Público"), enero - agosto 2006, págs. 45 91.

Los principios generales de la contratación de las Administraciones públicas, Bomarzo, Albacete, 2006.

, "Un mundo para Sara. Una nueva categoría en el Derecho español de la contratación pública: los contratos sujetos a regulación armonizada", RAP, núm. 178, enero - abril 2009, págs. 175 - 213.

, "La influencia del Derecho Comunitario de la contratación pública en el Derecho español. Los principios generales de la contratación en el sector público", Noticias de la Unión Europea, núm. 298, noviembre 2009, págs. 7 - 19.

, La reforma de la Ley de Contratos del Sector Público en materia de recursos. Análisis de la Ley 34/2010, de 5 de agosto, La Ley, Las Rozas (Madrid), 2010.

, "El Derecho de la contratación pública en Portugal", en la obra colectiva dirigida por SÁNCHEZ MORÓN, M., Derecho de los contratos públicos en la Unión Europea y sus Estados miembros, Lex Nova - Thomson Reuters, Valladolid, 2011, págs .503- 552 .

, Derecho global de la contratación pública, Ubijus, Asociación Internacional de Derecho Administrativo, México, 2011.

, "El sometimiento de todos los contratos públicos a los principios generales de contratación", en la obra colectiva Liber amicorum Tomás-Ramón Fernández, Civitas - Thomson, Pamplona, 2012, págs. 3429 - 3454.

, "La cuarta generación de Directivas de la Unión Europea sobre contratos públicos", en la obra colectiva dirigida por GIMENO FELIÚ, J. $\mathrm{M}^{\mathrm{a}}$., Observatorio de contratos públicos 2012, Thomson Aranzadi, Cizur Menor (Navarra), 2013, págs. $115-163$.

, "La nueva Directiva sobre contratación pública y su incorporación al derecho español", Contratación Administrativa Práctica, núm. 129, 2014, págs. 16 21. 
, "La influencia del Acuerdo de Contratación Pública de la OMC sobre la Directiva 2014/24/UE", en la obra colectiva Observatorio de los Contratos Públicos 2013, Thomson-Reuters Aranzadi, Cizur Menor (Navarra), 2014, págs. 123 -164 .

-, "Relación de síntesis sobre las nuevas Directivas de contratación pública", en la obra colectiva Las nuevas Directivas de contratación pública, Thomson Reuters - Aranzadi, Cizur Menor (Navarra), 2015, págs. 21 - 34.

MOREnO MOLINA, J. A. y DOMÍNGUEZ ALONSO, A. P., "El nuevo derecho de la Unión Europea sobre contratación pública", en la obra colectiva dirigido por VALCÁRCEL FERNÁNDEZ, P. y FERNÁNDEZ ACEVEDO, R., La contratación pública a debate: presente y futuro, Civitas-Thomson, Cizur Menor (Navarra), 2014, págs. 139 - 164.

MORENO MOLINA, J.A. y PLEITE GUADAMILLAS, F., La nueva Ley de Contratos del Sector Público. Estudio sistemático, $3^{\mathrm{a}}$ ed., La Ley, Las Rozas (Madrid), 2011.

MORETTI, L., y VALBONESI, P., "Firms'Qualifications and Subcontracting in Public Procurement: An Empirical Investigation", Journal of Law, Economics E Organization, vol. 31 (3), págs. 568 - 598.

MUÑOZ DE MORALES ROMERO, M., El legislador penal europeo: Legitimidad y racionalidad, Civitas - Thomson Reuters, Cizur Menor (Navarra), 2011.

MUÑOZ MACHADO, S., Tratado de Derecho Administrativo y Derecho Público General. Tomo IV. La actividad administrativa, Iustel, Madrid, 2011.

MUÑOZ MACHADO, S., y ESTEVE PARDO, J., Derecho de la regulación económica. I. Fundamentos e instituciones de la regulación, Iustel, Madrid, 2009.

MUSACCHIO, V., "Corrupción y adjudicaciones públicas en el ámbito europeo", Revista General de Derecho Penal, núm. 19, mayo 2013.

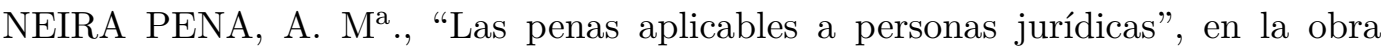
colectiva Las penas privativas de derechos y otras alternativas a la privación de libertad, Tirant lo Blanch, Valencia, 2013, págs. 393 - 426.

NEU, D., EVERETT, J., y RAHAMAN, A. S., "Preventing corruption within government procurement: Constructing the disciplined and ethical subject", Critical Perspectives on Accounting, vol. 28, may 2015, págs. 49 - 61.

NEVADO-BATALLA MORENO, P. T., "Cumplimiento de la legalidad en la nueva cultura de gestión pública: propuestas y realidades en la lucha contra la corupción", en la obra colectiva La corrupción en un mundo globalizado: análisis interdisciplinar, Ratio Legis, Salamanca, 2004, págs. 87 - 107.

NIELSEN, R. y TREUMER, S. (Eds.), The new EU Public Procurement Directives, Djøf Publishing, Copenhague, 2005.

NIETO GARCÍA, A., Corrupción en la España democrática, Ariel, Barcelona, 1997.

—, Derecho administrativo sancionador, $5^{\mathrm{a}}$ ed., Tecnos, Madrid, 2012.

NIETO MARTÍN, A., La responsabilidad penal de las personas jurídicas: Un modelo legislativo, Iustel, Madrid, 2008. 
, "La armonización del Derecho penal ante el Tratado de Lisboa y el Programa de Estocolmo", Revista General de Derecho Penal, núm. 13, mayo 2010.

, "De la Ética Pública al Public Compliance: sobre la prevención de la corrupción en las Administraciones públicas", en la obra colectiva dirigida por él mismo Public Compliance: Prevención de la corrupción en Administraciones públicas y partidos políticos, Ediciones de la Universidad de Castilla-La Mancha, Cuenca, 2014, págs. $17-42$.

NIETO MARTÍN, A., (Dir), Public Compliance: Prevención de la corrupción en Administraciones públicas y partidos políticos, Ediciones de la Universidad de Castilla-La Mancha, Cuenca, 2014.

NIETO GARRIDO, E., "El Derecho de la contratación pública en el Reino Unido", en la obra colectiva dirigida por SÁNCHEZ MORÓN, M., Derecho de los contratos públicos en la Unión Europea y sus Estados miembros, Lex Nova Thomson Reuters, Valladolid, 2011, págs. 183 - 234.

NIJHOLT, H., "Environmental Provisions in Public Procurement Directive 2004/18/EC", International Construction Law Review, vol. 21 (3), 2004, págs. 268 - 290.

NOGUEllou, R., y STELKENS, U., (Dirs) Droit comparé des Contrats Publics / Comparative Law on Public Contracts, Bruylant, Brussels, 2010.

NOGUERA DE LA MUELA, B., El ámbito subjetivo de aplicación de la nueva Ley de Contratos de las Administraciones Públicas (Real Decreto legislativo 2/2000, de 16 de junio, por el que se aprueba su Texto Refundido), Atelier, Barcelona, 2000.

, "Consecuencias de la Sentencia del TJUE de 15 de mayo de 2003 Comisión/España en el ordenamiento jurídico español", RAAP, núm. 53, enero marzo 2004, págs. 17 - 46.

NOONAN, J. T., Bribes, Macmillan, New York, 1984.

OCDE. Fighting corruption and promoting integrity in public procurement, OECD Publishing, Paris, 2005.

, Bribery in Public Procurement: Methods, Actors and Counter-Measures, OECD Publishing, Paris, 2007.

OJEDA MARÍN, A., "Contratos públicos en la Comunidad Europea: La Ley de Contratos del Estado y su adecuación al ordenamiento jurídico comunitario", $R A P$, núm. 112, enero - abril 1987, págs. 131-172.

, "Hacia un sistema de contratación pública acorde con el mercado interior", Revista de Instituciones Europeas, vol. 15 (3), septiembre - diciembre 1988, págs. $821-844$.

, "La Comunidad Europea y el GATT en el moderno sistema de contratación pública", RAP, núm. 116, mayo - agosto 1988, págs. 409 - 446.

OLAIZOLA NOGALES, I., El delito de cohecho, Tirant lo Blanch, Valencia, 1999.

OLAYA, J. "Blacklisting corrupt companies", en la obra colectiva Global Corruption Report 2005, Transparency International, Berlín, 2005, págs. 72 - 73.

OlazABAl CABRAL, M., O Concurso Público nos Contratos Administrativos, Almedina, Coimbra, 1999. 
-, "O artigo 55, alínea j), do Código dos Contratos Públicos: mais vale ser do que parecer", Revista de Contratos Públicos, núm. 1, janeiro - abril 2011, págs. $125-171$.

OLLER RUBERT, M., "El procedimiento de contratación pública como garantía de la transparencia", en la obra colectiva Derecho administrativo de la información y administración transparente, Marcial Pons, Madrid, 2010.

- El régimen de contratación de los poderes adjudicatarios que no son Administración Pública, Reus, Madrid, 2013.

ORDÓÑEZ SOLÍS, D., La contratación pública en la Unión Europea, Aranzadi, Cizur Menor (Navarra), 2002.

, "Las nuevas Directivas sobre la contratación pública en la Unión Europea: renovación formativa y experiencia judicial", REDE, núm. 18, abril - junio 2006, págs. $153-204$.

, "La lucha europea contra el fraude en la gestión de fondos y contra la corrupción en la contratación pública", Gaceta jurídica de la Unión Europea y de la competencia, núm. 16, julio - agosto 2010, págs. 7 - 29.

PÁLENÍKOVÁ, L., "Corruption in public tenders. Concept of self-cleaning", Anali Pravnog fakulteta Univerziteta u Zenici (Annals of the Faculty of Law University of Zenica), vol. 9, 2012.

PARAdA VÁZquez, R., Derecho Administrativo. Parte general, Tomo I, $19^{\mathrm{a}}$ ed., Marcial Pons, Madrid, 2012.

PAREJO ALFONSO, L., "El ámbito subjetivo de aplicación de la Ley de Contratación del Sector Público", Documentación administrativa, núm. 274-275, enero-agosto 2006, pág. 11-43.

PASSARELLI, G., "Criteri di selezione qualitativa nelle procedure di aggiudicazione degli appalti pubblici: la Corte di giustizia delimita la nozione di errore grave in materia professionale", Diritto pubblico comparato ed europeo, vol. 2, 2013 págs . $713-724$.

PEMÁN GAVÍN, I., "Dificultades para la delimitación sustantiva del concepto de sanción. Pautas para un replanteamiento de la cuestión", Revista Aragonesa de Administración Pública, núm. 14, 1999, págs. 131 - 202.

PÉREZ BERNABEU, B., Los intereses financieros comunitarios: concepto y principios que informan su sistema de protección, Tesis doctoral de la Universidad de Alicante, 2005, disponible en la Biblioteca virtual del Instituto Cervantes.

PÉREZ CEPEDA, I., "Definición del terrorismo como un delito internacional", en la obra colectiva, dirigida por SERRANO-PIEDECASAS, J. R. y DEMETRIO CRESPO, E., Terrorismo y Estado de Derecho, Iustel, Madrid, 2010, págs. 53 -80 .

PÉREZ MARÍN, M ${ }^{\mathrm{a}}$ A., La lucha contra la criminalidad en la Unión Europea. El camino hacia la jurisdicción penal común, Atelier, Barcelona, 2013.

PERNAS GARCÍA, J. J., Las operaciones in house y el Derecho comunitario de contratos públicos. Análisis de la jurisprudencia del TJCE, Iustel, Madrid, 2008. 
—, Contratación pública verde, La Ley, Las Rozas (Madrid), 2011.

, "Contratación pública y eficiencia energética", en la obra colectiva Contratación pública estratégica, Aranzadi, Cizur Menor (Navarra), 2013, págs. 283 -328 .

PERNAS GARCÍA, J. J. (Director), Contratación pública estratégica, Aranzadi, Cizur Menor (Navarra), 2013.

PETERSEN, Z., "Refining the Rules on the Distinction between Selection and Award criteria - Evropaïky Dynamiki v Commission (T-589/08)", PPLR, vol. 20 (6), 2011, págs. NA246 - 249.

PIGA, G., "A fighting chance against corruption in public procurement?", en la obra colectiva editada por ROSE-ACKERMAN, S. y SØREIDE, T., International Handbook on the economics of corruption, $2^{\mathrm{a}}$ ed., Edward Elgar, Northampton, 2011, págs. $141-184$.

PIÑAR MAÑAS, J. L., "El sistema de garantías para la efectiva implantación de la apertura de la contratación pública comunitaria", en la obra colectiva coordinada por MARTÍN-RETORTILLO BAQUER, L., La protección jurídica del ciudadano. Estudios en homenaje al profesor Jesús González Pérez, Civitas, Madrid, 1993, págs. 773 - 796 .

, "El Derecho comunitario como marco de referencia del Derecho español de contratos públicos", en la obra colectiva dirigida por GÓMEZ-FERRER MORANT, R., Comentario a la Ley de Contratos de las Administraciones Públicas, $2^{\text {a }}$ ed., Thomson - Civitas, Madrid, 2004, págs. 27 - 79.

, "Origen y fundamentos del Derecho europeo de contratos públicos", en la obra colectiva dirigida por CASSAGNE, J.C., y RIVERO YSERN, E., La contratación pública, (vol. I), Hammurabi, Buenos Aires, 2006, págs. 275 319.

PIÑAR MAÑAS, J. L. y HERNÁNDEZ CORCHETE, J. A., "El contrato de obras en el ámbito de los sectores excluidos", en la obra colectiva dirigida por LÓPEZIBOR MAYOR, La contratación pública en los llamados sectores excluidos. Agua, Energía, Transportes, Telecomunicaciones, Civitas, Madrid, 1997, págs.

PISELLI, E., "The scope for excluding providers who have committed criminal offences under the EU Procurement Directives", Public Procurement Law Review, vol. 9 (6), 2000, págs. $267-286$.

PLEITE GUADAMILLAS, F., El ámbito de aplicación subjetiva de la Ley de Contratos del Sector Público. Claves para la clasificación de los poderes adjudicadores, La Ley, Las Rozas (Madrid), 2010.

POPE, J., "Public Procurement: Where the Public and Private Sectors Do Business", en la obra colectiva TI Sourcebook 2000. Confronting Corruption: The Elements of a National Integrity System, Transparency International, Washington, 2000, págs. $205-220$.

PREUSS, L., "Addressing sustainable development through public procurement: the case of local government", Supply Chain Management, vol. 14 (3), 2009, págs. $213-223$. 
PRICEWATERHOUSECOOPERS y ECORYS, Identifying and Reducing Corruption in Public Procurement in the EU - Development of a methodology to estimate the direct costs of corruption and other elements for an EU-evaluation mechanism in the area of anti-corruption, de 30 de junio de 2013.

PRIESS, H-J., "The Rules on Exclusion and Self-Cleaning under the 2014 Public Procurement Directive", Public Procurement Law Review, vol. 23 (3), 2014, págs. $112-123$.

PRIETO ÁLVAREZ, T., La dignidad de la persona: núcleo de la moralidad y el orden público, límite al ejercicio de libertades públicas, Thomson-Civitas, Cizur Menor (Navarra), 2005.

PÜNDER, H., PRIESS, H.-J. y ARROWSMITH, S., Self-Cleaning in Public Procurement Law, Ed. Carl Heymans, Colonia, 2009.

PUNZÓN MORALEDA, J. y PUERTA SEGUIDO, F., "Procesos concursales y contratación pública", REDA, núm. 161, enero-marzo 2014, págs. 223-259.

PUNZÓN MORALEDA, J. y SÁNCHEZ RODRÍGUEZ, F., "El uso de las nuevas tecnologías en la Administración Pública: la contratación pública electrónica prevista en la Directiva 2004/18/CE", REDETI, núm. 24, septiembre diciembre 2005, págs. $63-96$.

, La utilización de medios electrónicos, informáticos y telemáticos en la Ley 30/2007, de Contratos del Sector Público, La Ley, Madrid, 2009.

QUINTERO OLIVARES, G., (Dir.) Comentario a la reforma penal de 2015, Thomson Reuters, Cizur Menor (Navarra), 2015.

RACCA, G. y YUKINS, Ch., (Eds.) Integrity and efficiency in Sustainable public contracts. Balancing Corruptions Concerns in Public Procurement Internationally, Bryulant, Brussels, 2014.

RAGUÉS I VALLÉS, R., Whistleblowing. Una aproximación desde el Derecho Penal, Marcial Pons, Madrid, 2013.

RAMBØLL MANAGEMENT, Cross-border public procurement above EU thresholds, mayo 2011.

RAMOS PÉREZ-OLIVARES, A., La regulación de las cláusulas sociales en los contratos del sector público tras el Real Decreto legislativo 3/2011, La Ley, Las Rozas (Madrid), 2012.

, "Las consecuencias de la declaración de concurso de acreedores de licitadores y contratistas públicos", Contratación Administrativa Práctica, núm. 121, septiembre - diciembre 2012.

RAMOS VÁZQUEZ, J. A., "La pena de inhabilitación especial para profesión, oficio, industria o comercio", en la obra colectiva Las penas privativas de derechos y otras alternativas a la privación de libertad, Tirant lo Blanch, Valencia, 2013, págs. $115-128$.

, "Las «especiales» inhabilitaciones especiales en el Código Penal", Diario La Ley, núm. de 9 de enero de 2013, págs. 1 - 9 .

RAZQUIN LIZARRAGA, J. A., "El sistema especial de recursos en la contratación pública tras la reforma de la Ley de Contratos del Sector Público", Revista General de Derecho Administrativo, núm. 25, octubre 2010. 
RAZQUÍN LIZARRAGA, M. Mª, Contratos públicos y Derecho comunitario, Aranzadi, Pamplona, 1996.

"La jurisprudencia del Tribunal de Justicia de las Comunidades Europeas sobre contratación pública", Justicia Administrativa, núm. 6, 2000, págs. 5 32 .

, "Selección de contratistas y adjudicación de contratos: (con especial referencia a la Administración local)", REALA, núm. 306, 2008, págs. 31 - 66.

-, "La contratación de las administraciones públicas y de los demás entes del sector público. Novedades. Procedimientos de adjudicación", RVAP, núm. 80, 2008, págs. 163 - 198.

, "La Ley de Contratos del Sector Público: balance crítico, aplicación y novedades, en especial para los entes locales", $R A P, 186$, septiembre - diciembre 2011, págs. $53-89$.

— La confidencialidad de los datos empresariales en poder de las Administraciones públicas, Iustel, Madrid, 2013.

__ , "Las nuevas Directivas sobre contratación pública de 2014: aspectos clave y propuestas para su transposición en España", RAP, núm. 196, enero - abril 2015, págs. $97-135$.

REBOLLO PUIG, M., "La invalidez de los contratos administrativos", Noticias de la Unión Europea, núm. 136, 1996, págs. 95 - 105.

—_ "El contenido de las sanciones", Justicia Administrativa, número extraordinario de dedicado a las Infracciones, sanciones y procedimiento administrativo sancionador, 2001, págs. $151-206$

, "Los entes institucionales de la Junta de Andalucía y su utilización como medio propio", RAP, núm. 161, mayo - agosto 2003, págs. 359-393.

REVENGA SÁNCHEZ, M., "Protección "multinivel" de los derechos fundamentales y lucha contra el terrorismo a escala europea: a propósito de las listas negras y otras anomalías de la Unión", RVAP, núm. 82 (II), septiembre - diciembre 2008 (Ejemplar dedicado a: La tutela multinivel de los Derechos Fundamentales), págs.. $235-252$.

RIVERO ORTEGA, R., "Corrupción y contratos públicos: las respuestas europeas y latinoamericana", en la obra colectiva La corrupción en un mundo globalizado: Análisis interdisciplinar, Ratio Legis, Salamanca, 2004, págs. 109 -125.

, "¿Es necesaria una revisión del régimen de los contratos administrativos en España?", REDA, núm. 121, enero - marzo 2004, págs. 25 - 47.

, La necesaria innovación en las instituciones administrativas. Organización, procedimiento, función pública, contratos administrativos y regulación, INAP, Madrid, 2012.

RODRÍGUEZ-ARANA MUÑOZ, J., "El procedimiento de adjudicación de los contratos de obras públicas en el Derecho Comunitario (El caso Gebroeders Beentjes Bve/Estado de los Países Bajos de 20 de septiembre de 1988)", Noticias CEE, núm. 65, junio 1990, págs. 133 - 138.

El buen gobierno y la buena administración de instituciones públicas, Thomson Aranzadi, Cizur Menor (Navarra), 2006. 
, "Los principios del Derecho global de la contratación pública", Revista Derecho PUCP, núm. 66, 2011, págs. 29 - 54

, "Los principios del Derecho global de la contratación pública", en la obra colectiva coordinada por DE LA CUÉTARA MARTÍNEZ, J.M., MARTÍNEZ LÓPEZ-MUÑIZ, J.L. y VILLAR ROJAS, F. J., Derecho administrativo y regulación económica. Liber Amicorum profesor Doctor Gaspar Ariño Ortiz, La Ley, Las Rozas (Madrid), 2011, págs. 431 - 456.

Interés general, Derecho Administrativo y Estado de bienestar, Iustel, Madrid, 2012.

"La contratación del sector público como política pública", en la obra colectiva dirigida por PERNAS GARCÍA, J. J., Contratación pública estratégica, Aranzadi, Cizur Menor (Navarra), 2013, págs. 31 - 44.

RODRÍGUEZ ESCANCIANO, S., Âžit Un paso adelante en la protección de los derechos laborales de las personas con discapacidad: el nuevo sistema de contratación pública, CERMI- CINCA, Madrid, 2008.

, "Trabajo y exclusión social en el nuevo sistema de contratación del sector público", Revista de Trabajo y Seguridad Social CEF, núm. 305 -306, 2008, págs. 3 - 64 .

—_ Cláusulas Sociales y Licitación Pública: Análisis jurídico, Instituto Andaluz de Administración Pública, Sevilla, 2009.

RODRÍGUEZ-PIÑERO BRAVO-FERRER, M., "Contratación pública y condiciones de trabajo", Relaciones Laborales, núm. 4, febrero - marzo 2008, págs. 1 -16 .

ROSE-ACKERMAN, S., "Corruption and the Global Economy", en la obra colectiva Corruption and Integrity Improvement Initiatives in Developing Countries, United Nations Programme Development, New York, 1998.

Corruption and government: causes, consequences, and reform, Cambridge University Press, Cambridge, 1999.

, "Corruption and Conflicts of Interest", en la obra colectiva Corruption and Conflicts of Interest. A Comparative Law Approach, Edward Elgar Publishing, United Kingdom, 2014, págs. 3 - 11.

RUIZ DE CASTAÑEDA DE LA LLAVE, A., "La nomenclatura CPV en la contratación", en la obra colectiva Administración Local. Estudios en homenaje a Ángel Ballesteros, La Ley - El Consultor de los Ayuntamientos, Las Rozas (Madrid), 2011, págs. $197-204$.

RUIZ DE CASTAÑEDA DE LA LLAVE, A. y BERNAL BLAY, M. Á., "La contratación pública y el Derecho comunitario. Cuestiones pendientes", en la obra colectiva dirigida por GIMENO FELIÚ, J. $\mathrm{M}^{\mathrm{a}}$., Observatorio de los contratos públicos 2010, Thomson Reuters-Aranzadi, Cizur Menor (Navarra), 2011, págs. $23-41$.

RUIZ OJEDA, A., (Dir.) Derecho de la contratación pública y regulada. Comentario sistemático y concordado de la legislación vigente, Thomson - Civitas, Madrid, 2004. 
RUIZ OJEDA, A., "Algunos problemas de regulación de mercados en el ámbito de la contratación de obras públicas", NUE, núm. 219, abril 2003.

SAITTA,F.,"Moralità professionale e partecipazione alle gare (Note a margine dell'art. 12, comma 1, lett. b), d. lgs. n. 157 del 1995", Rivista trimestrale degli appalti, vol. 1, 2004, págs. 229-247.

SALA ARQUER, J. M., "Huida al Derecho privado y huida del Derecho", REDA, núm. 75, julio - septiembre 1992, págs. 399 - 416.

-, "Requisitos para contratar con la administración (II): clasificación y registro de contratistas", en la obra colectiva coordinada por PENDÁS GARCÍA, B., Derecho de los contratos públicos: (estudio sistemático de la Ley 13/1995, de 18 de mayo, de contratos de las Administraciones Públicas), Praxis, Barcelona, 1995 , págs. $345-362$.

, "La prohibición de contratar prevista en el art. 20.a) de la nueva Ley de Contratos de las Administraciones Públicas", en la obra colectiva Estudios sobre el ordenamiento jurídico español. Libro conmemorativo del $X$ aniversario de la Facultad de Derecho, Universidad de Burgos, Burgos, 1996, págs. 637 654.

, "La empresa mixta como modo de gestión de los servicios públicos en la nueva Ley de Contratos de las Administraciones Públicas", REDA, núm. 90, abril - junio 1996, págs. 233 - 244.

SAMANIEGO BORDIÚ, G., "La normativa comunitaria de los contratos de las empresas que actúan en los sectores del agua, la energía, los transportes y las telecomunicaciones", REDA, núm. 71, julio - septiembre 1991, págs. 357 374.

SÁNCHEZ GRAELLS, A., Public Procurement and the EU Competition Rules, $2^{\mathrm{a}}$ ed., Hart Publishing, Oxford, 2014.

, "Exclusion, Qualitative Selection and Short-Listing in the New Public Sector Procurement Directive 2014/24", en la obra colectiva Modernising Public Procurement: The New Directive, DJØF Publishing, Copenhague, 2014, págs. $97-129$.

, "Prevention and deterrence of bid rigging: a look from the new EU directive on public procurement", en la obra colectiva Integrity and Efficiency in Sustainable Public Contracts, Bruylant, Brussels, 2014, págs. 171 - 198.

-, "The Continuing Relevance of the General Principles of EU Public Procurement Law After the Adoption of the 2014 Concessions Directive", EPPL, vol. 10 (3), 2015, págs. 130 - 139.

SÁNCHEZ MORÓN, M., "La corrupción y los problemas del control de las Administraciones públicas", en la obra colectiva La corrupción política, Alianza Editorial, Madrid, 1997, págs. 189 - 210.

SÁNCHEZ MORÓN, M., (Dir.), Derecho de los contratos públicos en la Unión Europea y sus Estados miembros, Lex Nova - Thomson Reuters, Valladolid, 2011.

, Public procurement in the European Union and its Member States, Lex Nova

- Thomson Reuters, Valladolid, 2012. 
SANMARTÍN MORA, A., "Contratación pública y Directiva Servicios. Hacia la simplificación administrativa", ponencia presentada al Seminario sobre Contratación Pública celebrado en Formigal en septiembre de 2010

SANTAMARÍA PASTOR, J.A., "La constante e interminable reforma de la normativa sobre contratación pública", REDA, núm. 159, julio - septiembre 2013, págs. $25-38$.

SANTÍAS VIADA, J. A., "La normativa comunitaria sobre contratación pública en el período 1985-1990", Noticias CEE, núm. 75, abril 1991, págs. $67-77$.

SANTÍAS VIADA, J. A., LÓPEZ BLANCO, C. y SANTAMARÍA DE PAREDES CASTILlO, V., El Derecho comunitario de la contratación pública, Escuela de Hacienda Pública, Madrid, 1991.

SARMIENTO RAMÍREZ-ESCUDERO, D., "Un paso más en la constitucionalización del Tercer Pilar de la Unión Europea: La sentencia Maria Pupino y el efecto directo de las Decisiones Marco", Revista Electrónica de Estudios Internacionales, núm. 10, 2005, págs. 1 - 32 .

SASTRE BECEIRO, M., "Efectos de la falta de capacidad, solvencia y de las prohibiciones de contratar", en la obra colectiva dirigida por ARIÑO ORTÍZ, G., Comentarios a la Ley de Contratos de las Administraciones Públicas. Tomo II. La gestión del contrato, Comares, Granada, 2003, págs. 165 - 168.

SCHOONER, S., "Desiderata: Objectives for a System of Government Contract Law", Public Procurement Law Review, vol. 11 (2), 2002, págs. 103 - 110.

, "The Paper Tiger Stirs: Rethinking Suspension and Debarment", Public Procurement Law Review, vol. 13 (5), 2004, págs. 211 - 217.

SEMPLE, A., A Practical Guide to Public Procuremnt, Oxford University Press, 2015.

SEMPLE, A. y ANDRECKA, M., "Classification, Conflicts of Interest and Change of Contractor: A Critical Look at the Public Sector Procurement Directive", $E P P L$, vol. 10 (3), 2015, págs. $171-186$.

SHAW, S. A., "Access to Information: The Key Challenge to a Credible Suspension and Debarment Programme", PPLR, vol. 13 (5), 2004, págs. 230 - 234.

SIMOU, S., "El Derecho de la contratación pública en Grecia", en la obra colectiva dirigida por SÁNCHEZ MORÓN, M., Derecho de los contratos públicos en la Unión Europea y sus Estados miembros, Lex Nova - Thomson Reuters, Valladolid, 2011, págs. $627-685$.

SIGMA, Public Procurement in EU Member States - The Regulation of Contract Below the EU Thresholds and in Areas not Covered by the Detailed Rules of the EU Directives, Documento de Trabajo núm. 45, 2010.

- Collusion and Corruption in Public Procurement, octubre 2010.

—, Use of Official Automatic Exclusion Lists in Public Procurement, julio 2013. http://sigmaweb.org/publications/Brief24_ExclusionListsinPP_2013.pdf [Fecha de consulta: 25 de octubre de 2015].

SMITH, S., "EU: Forposta SA, ABC Direct Contact sp. z o.o. v Poczta Polska SA (C-465/11) - exclusion on the grounds of grave professional misconduct", PPLR, vol. 22 (3), 2013, págs. N57-NA60. 
"eVigilo: dealing with bias and conflicts of interest, time limits for making a claim and acceptability of allegedly abstract award criteria", PPLR, vol. (4), págs. NA104-NA108.

SØREIDE, T., Corruption in public procurement: causes, consequences and cures, Chr. Michelsen Institute, Bergen, 2002.

, "Grey Zones and Corruption in Public Procurement: Issues for Consideration", en la obra colectiva Fighting Corruption and Promoting Integrity in Public Procurement, OECD Publishing, París, 2005, págs. 51 - 57.

, Risks of Corruption and Collusion in the Awarding of Concession Contracts, European Parliament's Committee on Internal Market and Consumer Protection, Bruselas, 2012.

SOSA WAGNER, F., El contrato público de suministro, 2a ed., Civitas, Madrid, 2003.

, "El empleo de "los recursos propios" por las Administraciones locales", en la obra colectiva coordinada por COSCULLUELA MONTANER, L., Estudios de Derecho público económico. Libro homenaje al Prof. Dr. D. Sebastián MartínRetortillo, Civitas, Madrid, 2003, págs. 1309 - 1342.

, "El contrato de gestión de servicios públicos y los problemas de contratación in house", Revista Española de la Función Consultiva, núm. 8, julio - diciembre 2007, págs. 175 - 190.

SOSA WAGNER, F. y FUERTES LÓPEZ, M., "¿Pueden los contratos quedar en casa?. La polémica europea sobre la contratación in house", Diario La Ley, núm. 6715, 17 de mayo de 2007, págs. 1669 -1680.

, "La Ley de Contratos del Sector Público y el murciélago", Actualidad jurídica Aranzadi, núm. 743, 17 de enero 2008.

SPAGNOLO, G., "Reputation, Competition, and Entry in Procurement", Stockholm Institute of Transition Economics, Working Paper núm. 14, 2012, disponible en: http://ssrn.com/abstract=1988818 [Fecha de consulta: 15 de octubre de 2015].

STAPENHURST, F. y LANGSETH, P., "The role of the public administration in fighting corruption", The International Journal of Public Sector Management, vol. 10 (5), 1997, págs. $311-330$.

STEINICKE, M., "Qualification and Shortlisting", en la obra colectiva dirigida por CARANTA, R., EDELSTAM, G., y TRYBUS, M., EU Public Contract Law: Public Procurement and beyond, Bruylant, Brussels, 2014, págs. 105 - 123.

STROMBOM, D., "Corruption in Procurement", Economic Perspectives, vol. 3 (5) 1998, págs. $22-26$.

SUAY RINCÓN, J., Sanciones administrativas, Publicaciones del Real Colegio de España, Bolonia, 1989.

TANZI, V. y DAVOODI, H., Corruption, Public Investment, and Growth, IMF Working Papers 97/139, 1997.

, "Corrupción, inversión pública y crecimiento", Gestión y Análisis de Políticas Públicas, núm. 21, mayo - agosto, 2001, págs. 73 - 82. 
TÁTRAI, T., "Ethical public procurement", ERA Forum, vol. 14, June 2013, págs. $59-68$.

TELGEN, J., HARLAND, Ch., y KNIGHT, L., "Public procurement in perspective", en la obra colectiva coordinada por KNIGHT, L., et al., Public Procurement: International Cases and Commentary, Routledge, London, 2007.

THAI, K. V. (Ed.), International Handbook of Public Procurement, CRC Press (Francis \& Taylor), Boca Raton, 2008.

TORRICELLI, S., Libertà economiche europee e regime del provvedimento amministrativo nazionale, Maggioli Editore, Santarcangelo di Romagna, 2013.

_, "L'autorità di vigilanza sui contratti pubblici in Italia", en la obra colectiva dirigido por VALCÁRCEL FERNÁNDEZ, P. y FERNÁNDEZ ACEVEDO, R., La contratación pública a debate: presente y futuro, Civitas-Thomson, Cizur Menor (Navarra), 2014, págs. 493-510.

-, "Utilities Procurement", en la obra colectiva dirigida por CARANTA, R., EDELSTAM, G., y TRYBUS, M., EU Public Contract Law: Public Procurement and beyond, Bruylant, Bruselas, 2014, págs. $222-248$.

TREPTE, P. A., Public Procurement in the EU: a Practitioner's Guide, Oxford University Press, Oxford, 2007.

TREUMER, S., "The Distinction between Selection and Award Criteria in EC Public Procurement Law: A Rule without Exception?", PPLR, vol. 18 (3), 2009, págs. $103-111$.

, "Cross-border Interest and Application of EU Law Principles in the Public Procurement Context at National Level", en la obra colectiva Outside the EU Procurement Directives - Inside the Treaty, Djøf Publishing, Copenhague, 2012, págs. $335-357$

-, "Evolution of the EU Public Procurement Regime: The New Public Procurement Directive", en la obra colectiva Modernising Public Procurement. The New Directive, Djøf Publishing, Copenhagen, 2014, pág. 9.

TRYBUS, M., "The morning after the deadline: the State of implementation of the new EC Public Procurement Directives in the Member States on 1st February 2006", PPLR, vol. 15 (3), 2006, NA 82-89.

TRYBUS, M. y MEDINA, T., "Unfinished Business: The State of Implementation of the New EC Public Procurement Directives in the Member States on February 1, 2007", PPLR, vol. 16(4), 2007, págs. NA89 - NA97.

TRUYOL Y SERRA, A., La integración europea: análisis histórico-institucional con textos y documentos. Génesis y desarrollo de la Comunidad Europea (19511979), Tecnos, Madrid, 1999.

TURPIN, C., "Public contracts in the EEC", CMLR, vol. 9 (4) November, 1972, págs. $411-424$.

URÍA FERNÁNDEZ, F., "Apuntes para una reforma de la legislación sobre Contratos de las Administraciones Públicas", RAP, núm. 165, septiembre - diciembre 2004, págs. $297-325$. 
VÁLCARCEL FERNÁNDEZ, P., "Un paso de gigante hacia una contratación pública ambientalmente sostenible: La obligación de comprar vehículos de transporte por carretera limpios y energéticamente eficientes", Contratación Administrativa Práctica, núm. 112, octubre 2011, págs. 48 - 57.

, "Impulso decisivo en la consolidación de una contratación pública responsable. Contratos verdes: de la posibilidad a la obligación", Actualidad Jurídica Ambiental, núm. 3, marzo 2011, págs. 1-11.

, "Promoción de la igualdad de género a través de la contratación pública", en la obra colectiva dirigida por PERNAS GARCÍA, J. J., Contratación pública estratégica, Aranzadi, Cizur Menor (Navarra), 2013, págs. 329 - 368.

VALCÁRCEL FERNÁNDEZ, P. y FERNÁNDEZ ACEVEDO, R., La contratación pública a debate: presente y futuro, Thomson - Aranzadi, Cizur Menor (Navarra), 2014.

VALEIJE ÁLVAREZ, I., El tratamiento penal de la corrupción del funcionario. El delito de cohecho, Editoriales de Derecho Reunidas, Madrid, 1996.

, "Delito de cohecho activo (artículo 424)", en la obra colectiva Comentarios a la Reforma de Código Penal de 2015, 2a ed., Tirant lo Blanch, Valencia, 2015, págs. $1172-1176$.

, "Tráfico de influencias (arts. 428 y ss.)", en la obra colectiva Comentarios a la Reforma de Código Penal de 2015, 2ª ed., Tirant lo Blanch, Valencia, 2015, págs. 1194 a 1203.

VARA ARRIBAS, G., "Novedades en el Debate Europeo sobre la Contratación Pública", Revista Española de Derecho Europeo, núm. 26, 2008, págs. 115 $-150$.

VÁZQUEZ MATILLA, F. J., "La corrupción una barrera a la eficiencia e integridad en la compra pública", Opinión publicada en el Observatorio de Contratación Pública, 10 de diciembre de 2012. http://www.obcp.es/

VÈRNIA TRILLO, S., "La inclusión de las cláusulas sociales en la contratación pública", RArAP, núm. 20, junio 2002, págs. 429 - 453.

VERVAELE, J. A., "La europeización del Derecho penal y la dimensión penal de la integración europea", Revista Penal, núm. 15, enero 2005, págs. 169 - 183.

VIANA, C., Os Princípios Comunitários na Contratação Pública, Coimbra Editora, Coimbra, 2007.

, "A qualificação dos operadores económicos nos procedimentos de contratação pública", en la obra colectiva dirigida por COSTA GONÇALVES, P., Estudos de Contratação Pública II, Coimbra Editora, Coimbra, 2010, págs. $153-196$.

, "A jurisprudência "principialista" do Tribunal de Justiça da União Europeia relativa à contratação pública", en la obra colectiva coordinada por SILVEIRA, A., Direito da União Europeia e Transnacionalidade - Acção Jean Monnet, Quid Iuris, Lisboa, 2010, págs. 63 - 84.

, "Contratación pública electrónica: La experiencia portuguesa", en la obra colectiva dirigida por GIMENO FELIÚ, J. Ma ., Observatorio de Contratos públicos 2014, Thomson Reuters, Cizur Menor (Navarra), 2015, págs. 279 294. 
VICENTE BLANCO, D. J. y RIVERO ORTEGA, R., Impacto de la transposición de la Directiva de Servicios en Castilla y León, Colección de Estudios del Consejo Económico y Social de Castilla y León, núm. 13, Valladolid, 2010.

VICENTE LÓPEZ, C., La contratación administrativa. Condiciones generales y eficacia, Comares, Granada, 1996.

VIEIRA QUINTA NOVA, A.R. A Exclusão de Operadores Económicos à Luz da Nova Directiva sobre Contratos Públicos - o artigo $57^{\circ} n^{\circ} 4,1^{\circ}$ parágrafo, alínea g), Publicações CEDIPRE Online - 22, Coimbra, 2014. http://www.fd.uc.pt/cedipre/publicacoes/online/public_22.pdf [Fecha de consulta: 15 de octubre de 2015].

VILALTA REIXACH, M., La encomienda de gestión. Entre la eficacia administrativa y la contratación pública, Aranzadi, Cizur Menor (Navarra), 2012.

VILLACAMPA ESTIARTE, C., El delito de trata de seres humanos. Una incriminación dictada desde el Derecho Internacional, Thomson-Reuters Aranzadi, Cizur Menor (Navarra), 2011.

- "La nueva Directiva europea relativa a la prevención y la lucha contra la trata de seres humanos y la protección de las víctimas. ¿Cambio de rumbo de la política de la Unión en materia de trata de seres humanos?", Revista Electrónica de Ciencia Penal y Criminología, núm. 13-14, 2011, págs. 14 - 52.

, "Trata de seres humanos y delincuencia organizada. Conexión entre ambos fenómenos criminales y su plasmación jurídico-penal", InDret. Revista para el análisis del Derecho, enero 2012.

VILLALBA PÉREZ, F., "La dimensión social de la contratación pública. El sector de la discapacidad en la Ley de Contratos del Sector Público", en la obra colectiva Administración Local. Estudios en homenaje a Ángel Ballesteros, La Ley - El Consultor de los Ayuntamientos, Las Rozas (Madrid) 2011, págs. 219 -262 .

- La contratación de las sociedades en manos de las Administraciones públicas. Principios de publicidad y concurrencia: fundamentos de su publificación, Tirant lo Blanch, Valencia, 2003.

VILlaR PALASÍ, J.L. y VILlaR EZCURRA, J. L., Principios de Derecho Administrativo. Tomo III. Contratación Administrativa, Servicio de publicaciones de la Universidad Complutense de Madrid, Madrid, 1983.

VILLAREJO GALENDE, H., "Simplificación administrativa al servicio del Mercado Interior Europeo", en el Libro Marrón: Retos y oportunidades para la transposición de la Directiva de Servicios, Círculo de Empresarios, Madrid, 2009, págs. $433-495$.

, "Simplificación administrativa al servicio del Mercado Interior Europeo", en la obra colectiva Libro Marrón: Retos y oportunidades para la transposición de la Directiva de Servicios, Círculo de Empresarios, Madrid, 2009, págs. 433 - 495.

VILLORIA MENDIETA, M., "Corrupción: la amarga verdad", en el Informe sobre la Democracia en España 2010. La erosión de la confianza y el bienestar. Contra la desafección ciudadana, Marcial Pons - Fundación Alternativas, Madrid, 2010, págs. $81-105$. 
, "La ética pública y los códigos de conductas administrativos vs. corrupción y escándalos políticos", en la obra colectiva El derecho a una buena administración y la ética pública, Tirant lo Blanch, Valencia, 2011, págs. 179 202.

VILLORIA, M. y JIMÉNEZ, F., “¿Cuánta corrupción hay en España?. Los problemas metodológicos de la medición de corrupción", Revista de Estudios Políticos, núm. 156, abril - junio 2012, págs. 13 - 47.

VINYOLES I CASTELLS, M., La adjudicación de los contratos públicos: la nueva Ley de Contratos de las Administraciones Públicas y normativa comunitaria, Civitas, Madrid, 1995.

VIVARELLI, M. G., "Il fenomeno della corruzione negli appalti pubblici", Rivista trimestrale degli appalti, núm. fasc. 2, 2009, págs. 351 - 364.

WAINWRIGHT, R., "Marchés publics - Refonte des Directives", Revue du Marché Commun et de l'Union Européenne, vol. 449, juin 2001, págs. 394 - 399.

WEYEMBERGH, A., "Approximation of criminal laws, the Constitutional Treaty and the Hague Programme", CMLR, vol. 42 (6), 2005, págs. 1567 - 1597.

WHITE, S., "Exclusion of tenderers in the European Union: The only way forward against procurement fraud?", en la obra colectiva Fighting Corruption and Promoting Integrity in Public Procurement, OECD Publishing, Paris, 2005, págs. 251-254.

WHITE, S., (Dir) Procurement and organised crime: an EU wide study, Institute of Advanced Legal Studies, Londres, 2000.

WIDMER, M. y DELBOS, M., "El nuevo acuerdo sobre la contratación pública del GATT", en la obra colectiva dirigida por LÓPEZ-IBOR MAYOR, La contratación pública en los llamados sectores excluidos. Agua, Energía, Transportes y Telecomunicaciones, Civitas, Madrid, 1997, págs. 383 - 403.

WILLIAMS, S., "The mandatory exclusions for corruption in the new EC Procurement Directives", European Law Review, vol. 31 (5), October 2006, págs. 711 -734 .

, "Coordinating public procurement to support EU objectives - a first step? The case of exclusions for serious criminal offences", en la obra colectiva editada por ARROWSMITH, S. y KUNZLIK, P., Social and Environmental Policies in EC Procurement Law, Cambridge University Press, Cambridge, 2009, págs. $479-498$.

WILliamS-ELEGBE, S., Fighting Corruption in Public Procurement: A Comparative Analysis of Disqualification Measures, Hart Publishing, Oxford, 2012.

ZAFRA ESPINOSA DE LOS MONTEROS, R., "Implicaciones del Tratado de Lisboa en la lucha contra la delincuencia organizada", Revista General de Derecho Penal, núm. 14, noviembre 2010.

ZÚÑIGA RODRÍGUEZ, L., Bases para un modelo de imputación de responsabilidad penal a las personas jurídicas, $3^{\mathrm{a}}$ ed., Aranzadi, Cizur Menor (Navarra), 2009. 
Escrito en $\mathrm{AT}_{\mathrm{EX}} 2_{\varepsilon}$ empleando la aplicación MiKTeX 2.9 para ejecutar pdfLATEX.

Esta Memoria se depositó ante la Comisión de Doctorado de la Universidad de Burgos el miércoles 28 de octubre de 2015. 